\title{
FICCIONES DE LA PUERTORRIQUEÑIDAD
}

(Construcciones discursivas de las identidades nacionales en la obra de Edgardo Rodríguez Juliá y Manuel Ramos Otero)

\section{TESIS DE DOCTORADO}

Directora: Profesora Susana E. Zanetti

Doctoranda: Lic. Carolina Sancholuz

Carrera: Doctorado en Letras/ Facultad de Humanidades y Ciencias de la Educación/ Universidad Nacional de La Plata Mayo de 2005 


\section{FICCIONES DE LA PUERTORRIQUEÑIDAD}

\section{ÍNDICE}

Introducción

pp. I-VII

\section{Capítulo I}

"Puerto Rico en el mapa cultural caribeño y latinoamericano"

pp. 1-51

I. 1 Relecturas del Caribe: de los planteos de Édouard Glissant y Antonio Benítez Rojo al "Archipiélago de fronteras externas" de Ana Pizarro

I. 2.Puerto Rico como "discurso antillano", "isla que se repite", $30-51$ "archipiélago de fronteras externas"

pp.

\section{Capítulo II}

"Una nación de tinta y papel: cultura, literatura e identidad nacional en Puerto Rico en el siglo XX"

pp. 52-103

II. 1 Los intelectuales de la Generación del Treinta, Insularismo y la fundación de una escritura de la identidad puertorriqueña

pp. 60-69

II. 2 Colonialismo y crisis del modelo populista en El puertorriqueño dócil de René Marqués

pp. $69-80$

II. 3 Nuevas miradas: ampliación de la "familia puertorriqueña" en El país de cuatro pisos de José Luis González

pp. $80-88$

II. 4 Pliegues y repliegues del verbo bregar en la historia cultural puertorriqueña moderna: El arte de bregar. Ensayos, de Arcadio Díaz Quiñones

pp.89-103

\section{Capítulo III}

"Dilemas de la puertorriqueñidad: sobre las crónicas de actualidad de Edgardo Rodríguez Juliá"

pp. 104-196

III. 1 Crónicas escatológicas de Puerto Rico. Sobre

Las tribulaciones de Jonás, El entierro de Cortijo

y Una noche con Iris Chacón

pp. 113-196

III.1.1 Crónicas de entierros

pp. 113-126

III. 1. 2 Barroco caribeño y fúnebre

III.1.3 Rituales escatológicos: el cuerpo de la nación

pp. 126-142 en Una noche con Iris Chacón

pp. 143-157 
III. 2 Topografía y memoria: sobre las crónicas

"El Cerro Maravilla (octubre-noviembre de 1983)" y

El cruce de la Bahía de Guánica

III. 3 De la iconoteca familiar a la iconoteca social.

pp. $158-174$

Notas sobre la relación escritura y fotografía en Puertorriqueños

(Álbum de la Sagrada Familia puertorriqueña a partir de 1898)

pp. $175-196$

\section{Capítulo IV}

"Fábulas de la puertorriqueñidad: invenciones, versiones

y visiones del siglo XVIII en La renuncia del héroe Baltasar,

La noche oscura del Niño Avilés, El Camino de Yyaloide y

Campeche o los diablejos de la melancolía de E. Rodríguez Juliá" pp. 197- 306

IV.1 Biografías infames, héroes apócrifos, archivos alterados y

falsos historiadores en La renuncia del héroe Baltasar

pp. 201-222

IV.1.2 El (anti)héroe Baltasar o la conciliación imposible

pp. $208-216$

IV.1.3 "Historiadores de papel": potens imaginatio

de la otra historia

IV.2 La noche oscura del Niño Avilés

pp. $216-223$

o la poética de la desmesura

pp. 224-277

IV.2.1 De la proliferación

pp. $224-238$

VI.2.2 La proliferación espacial: ciudades invisibles, territorios de la utopía, lugares de sueños y pesadillas, sitios de la memoria y el olvido en La noche oscura del Niño Avilés

pp. 239-273

IV.2.3. El Niño Avilés, historia de una mirada

pp. $273-277$

IV.3.1 Campeche o los diablejos de la melancolía: bocetos y

estampas de la identidad puertorriqueña

pp. 277-287

IV. 3. 2 El niño monstruo: del cuadro a la novela

pp. 281-287

Breve visita a la galería de retratos de Campeche

pp. $288-290$

IV. 4 La ruta del desvarío: El camino de Yyaloide o

la antinovela de formación

pp. 291-306

\section{Capítulo V}

"Puerto Rico en Nueva York: escritura, desplazamiento y sujetos migrantes en los cuentos de Manuel Ramos Otero"

pp. $307-360$

V.1 Subjetividades desplazadas, cuerpos en movimiento:

los sujetos migrantes en los cuentos de Manuel Ramos Otero

pp. 316-347

V.2 Contar, recontar, descontar: poéticas del cuento,

la enfermedad y la muerte

pp. $348-360$ 
A manera de epílogo

pp. $361-370$

BIBIBLIOGRAFÍA

pp. 371-389 


\title{
Introducción
}

"Los escritores contemporáneos en Puerto Rico, desde una pluralidad de enfoques nos acercamos a nuestra historia para narrar el tiempo escondido que, como un hermano desconocido y ausente, se presenta de pronto en nuestra vida y nos sorprende, tanto por su gran parecido a nosotros como por lo maravilloso e inesperado de su sola existencia."

\section{Magalí García Ramis, La ciudad que me habita}

\begin{abstract}
“¿Somos latinoamericanos o norteamericanos? ¿Seremos estado de la unión, estado libre asociado o país independiente? ¿Base nuclear y militar, o puente conciliador entre las dos culturas? ¿Cordero pascual del escudo de los Reyes Católicos o chivito estofado de San Juan Bautista? ¿Piragua de papel en aguas de piringa o peñón de Gibraltar perdido en el Caribe? ¿Gallito kirikikí guapetón o veleta vertiginosa, que cuando apunta hacia el sur nos dirige hacia el norte y cuando apunta hacia el norte nos dirige hacia el sur? ¿Paraíso del perito político o del perito lingüístico?
\end{abstract}

Rosario Ferré, "Memorias de Maldito amor"

Obsesión, recurrencia o asedio constante, lo cierto es que la pregunta por la identidad cultural puertorriqueña se ha formulado en el pasado y se sigue formulando en la actual literatura de un país que, como lo condensa sagazmente Juan Gelpí, ha creado una literatura nacional a pesar de no haberse constituido como nación independiente ${ }^{1}$. Si tal interrogante se repite con insistencia a lo largo del pasado siglo XX, sus respuestas en cambio se articulan desde la pluralidad de enfoques que señala Magalí García Ramis en el epígrafe, aunque en ellas se pueda percibir también una preocupación común que se fundamenta en la condición colonial vigente hoy en día en la isla, estrechamente vinculada al problema de la identidad nacional. Como sabemos, Puerto Rico fue primero colonia de España; luego de la Guerra Hispanoamericana de 1898, el pequeño pero estratégico país fue cedido a los Estados Unidos, hegemonía que se reforzó en 1952 a través de la creación del Estado Libre Asociado, estatuto político actual

1 Gelpí, Juan (1993). Literatura y paternalismo en Puerto Rico, San Juan, Editorial de la Universidad de Puerto Rico. 
de la isla. Por ello mismo y a contramarcha de los acercamientos teóricos que proponen el desmantelamiento de la idea de la nación mediante conceptos tales como globalización, transnacionalización, postnacionalidad ${ }^{2}$, en Puerto Rico la pregunta por la identidad nacional sigue generando todavía discusiones, debates, polémicas y, desde el eje de la producción literaria, articulando diversas "ficciones de la puertorriqueñidad", algunas de las cuales procuro analizar en mi trabajo.

A lo largo de este estudio me centro particularmente en la compleja relación entre nacionalismo y representación literaria atendiendo a la construcción discursiva y textual de un imaginario de lo puertorriqueño que, en este caso, implica asimismo considerar el peculiar contexto histórico colonial del país. La sugerente reflexión de Homi Bhabha en torno al par nación/narración ${ }^{3}$, donde propone una construcción cultural de la nacionalidad como una forma narrativa con determinadas estrategias textuales, desplazamientos metafóricos, subtextos y estratagemas figurativas, abre una interesante vía de abordaje a la hora de pensar un relato de la nacionalidad puertorriqueña. Pero creo también que ceñirlo solo a su carácter simbólico o de constructo textual entraña el riesgo de negarle su sentido histórico. Procuro situar a Puerto Rico como un lugar de complejas construcciones de identidades en un mapa más vasto y heterogéneo: el territorio caribeño en primer lugar y América Latina en una pertenencia más amplia. Así, en

\footnotetext{
${ }^{2}$ La idea de "fragmentación de la nación" ha sido trabajada especialmente desde el campo de los estudios poscoloniales. Véase al respecto Chatterjee, Partha (1993). The Nation and its Fragments. Colonial and Poscolonial Histories, Princeton, Princeton University Press. Entre los críticos latinoamericanos se han ocupado de la cuestión de la nación y la globalización véanse los trabajos de: García Canclini, Néstor (1995). Consumidores y ciudadanos. Conflictos culturales de la globalización, México, Grijalbo; Achugar, Hugo (1996). "Repensando la heterogeneidad latinoamericana (A propósito de lugares, paisajes y territorios)", Revista Iberoamericana, vol. LXII, núms. 176-177, julio- diciembre; VV.AA., Moraña, Mabel (ed., 2000). Nuevas perspectivas desde/sobre América Latina, Santiago de Chile, Cuarto Propio/Instituto Internacional de Literatura Iberoamericana; Grínor Rojo, Alicia Salomone y Claudia Zapata (2003).’Postcolonialidad y nación: algunos aspectos de la discusión teórica", en: Castillo, A., Muzzopappa, E., Salomone A., Urrejola, B. Y Zapata, C. (editoras). Nación, Estado y cultura en América Latina, Ediciones de la Facultad de Filosofía y Humanidades, Universidad de Chile, 2003. Si bien tengo en cuenta estas discusiones no constituyen el centro de análisis de mi acercamiento a la literatura puertorriqueña, como se verá a lo largo de la tesis.

3 Bhabha, Homi (1990). "Narrating the Nation", en el libro que también compila: Nation and Narration, Londres, Routledge, pp. 1-7. Véase también del mismo autor "Diseminación. El tiempo, el relato y los márgenes de la nación moderna", en: El lugar de la cultura, traducción de César Aira, Buenos Aires, Manantial, 2002, pp. 175-207.
} 
el capítulo I "Puerto Rico en el mapa cultural caribeño y latinoamericano" me detengo en la conformación cultural del Caribe, destacando su complejidad y diversidad pero también intentando aprehender, a partir de distintas miradas críticas, los trazos comunes que permiten articular lo múltiple en una red, atravesada por hilos tales como la historia de la colonización, el esclavismo, la economía de plantación, la dependencia económica, las migraciones, entre otros. Se analizan especialmente tres perspectivas críticas sobre la cuestión: Les discours antillais (1981) del escritor martiniqués Édouard Glissant, La isla que se repite. El Caribe y la perspectiva posmoderna (1989) del escritor cubano Antonio Benítez Rojo, y el ensayo de la escritora chilena Ana Pizarro con el cual abre y titula una colección de textos críticos sobre el Caribe que también compila, "El archipiélago de fronteras externas" (2002), donde provee una profunda y actualizada relectura del espacio antillano desde el Cono Sur. A partir de estos enfoques me concentro en el contexto histórico y cultural particular de Puerto Rico en el Caribe, como país que no ha logrado el estatuto de estado-nación, y qué implicancias conlleva el mantenimiento de una situación colonial respecto de sus manifestaciones culturales y literarias.

En el capítulo II, "Una nación de tinta y papel: cultura, literatura e identidad nacional en Puerto Rico en el siglo XX", doy cuenta del interrogante sobre la identidad puertorriqueña a través de la formación de un incipiente pero moderno campo intelectual en Puerto Rico en las primeras décadas del siglo XX, en cuyas instituciones, agentes y discursos se gestó un relato de y para la nación, articulado a través de una retórica, imágenes, tópicos y metáforas que es posible rastrear aún en textos puertorriqueños contemporáneos, aunque con importantes cuestionamientos y redefiniciones. Con este fin analizo un conjunto de ensayos que responden de muy diversa manera a la pregunta sobre la identidad nacional en Puerto Rico. Publicados en diferentes coyunturas histórico-políticas del país mantienen, sin embargo, un vínculo entre sí: la asunción y defensa de posiciones anticolonialistas. Se trata de Insularismo (1934) de Antonio S. Pedreira; El puertorriqueño dócil (1960) de René Marqués; El país de cuatro pisos (1980) de José Luis González, y El arte de bregar (2000) de Arcadio Díaz Quiñones. El 
ensayo de Pedreira, considerado unánimemente por la crítica como texto fundante y modelo retórico de una escritura de lo nacional, provee imágenes y tópicos acerca de la puertorriqueñidad que fueron posteriormente citados, a veces repetidos, en otras ocasiones redefinidos y también impugnados por un número importante de escritores e intelectuales del país. Dos de sus metáforas rectoras la nación como la gran familia puertorriqueña y la insularidad- son fuertemente cuestionadas en la narrativa de los autores centrales cuyas ficciones de la puertorriqueñidad pretendo indagar: Edgardo Rodríguez Juliá ${ }^{4}$ y Manuel Ramos Otero ${ }^{5}$.

Ambos escritores coinciden en comenzar a publicar a comienzos de la década de los años setenta, en un momento de intensa ruptura cultural en las letras puertorriqueñas, como lo testimonia la novela de Luis Rafael Sánchez, La guaracha del Macho Camacho (1976), obra que proyectó de manera significativa la rica literatura puertorriqueña hacia el ámbito latinoamericano ${ }^{6}$. Asimismo tanto Rodríguez Juliá como Ramos Otero se reconocen marcados por el peso histórico

\footnotetext{
${ }^{4}$ Edgardo Rodríguez Juliá nació en Río Piedras, el 9 de octubre de 1946. Pasó sus niñez en Aguas Buenas, espacio revisitado en varias de sus crónicas. Se inicia en la literatura desde la adolescencia, a través de las escritura de cuentos que según su opinión no publicará jamás, por ser muy malos. Su primera novela, La renuncia del héroe Baltasar, editada en 1974 provocó una importante reacción de la crítica, que lo señala desde entonces como una de las voces más originales de la actual literatura de sus país, y que su segunda novela, la monumental La noche oscura del Niño Avilés (1984) vino a confirmar. Pero sin dudas el género que lo volvió un escritor popular y también controvertido en Puerto Rico fue la crónica. En este sentido desde Las tribulaciones de Jonás de 1981 hasta Caribeños del año 2002 no ha dejado de publicar sus llamadas "crónicas de actualidad" tanto en libros como en los principales periódicos de la isla. Actualmente se desempeña como catedrático de la Universidad de Puerto Rico. El detalle de su vasta producción literaria se consigna en la Bibliografía.

${ }^{5}$ Manuel Ramos Otero nació en Manatí, en 1948 y falleció en 1990, víctima del sida. Gran parte de su vida transcurrió en al ciudad de Nueva York, donde se traslada en el año 1968 y desde donde escribe toda su producción literaria, atravesada por un marcado sentido de desarraigo y tránsito, como se verá a través del análisis de sus cuentos. Cursó estudios de cine en la School of Visual Arts de Nueva York y dirección teatral en el Lee Strasberg Theather Institute. Realizó una maestría en literatura latinoamericana en la Universidad de Nueva York, donde cursó estudios doctorales hasta su muerte. Se destacó fundamentalmente como cuentista y poeta. Tiene sin embargo una inhallable novela de corte experimental publicada en 1976 bajo el título La novelabingo. Varios de sus cuentos fueron premiados en certámenes literarios en Puerto Rico. El detalle de su obra literaria se consigna en la Bibliografía.

${ }^{6}$ La guaracha del Macho Camacho se publicó por primera vez en Buenos Aires, por Ediciones de la Flor, en un gesto de osada ampliación cultural que desafiaba no solo las limitaciones de las leyes de mercado sino también la desfavorable coyuntura de nuestro país, en el momento en que comenzaba su peor dictadura militar.
} 
que tuvo en Puerto Rico el desarrollo del Partido Popular Democrático liderado por Luis Muñoz Marín, responsable en gran parte del establecimiento del Estado Libre Asociado. Sus historias vitales y textuales están atravesadas por la utopía populista pero también fuertemente signadas por su fracaso, una de cuyas consecuencias más dramáticas lo constituye la emigración forzada de miles de puertorriqueños a Nueva York desde 1952. En este sentido me interesó particularmente analizar los diferentes lugares de enunciación postulados por cada autor, ya que mientras Rodríguez Juliá escribe desde la Isla, Ramos Otero en cambio lo hace desde Nueva York, cuestión que plantea entonces la ampliación de las fronteras nacionales a la hora de pensar qué textos forman parte de la literatura puertorriqueña actual.

El análisis de la obra de Edgardo Rodríguez Juliá focaliza en la peculiar conformación del género crónica, modalidad que aparece contaminada por otros géneros como la novela y el ensayo, aspectos estudiados en el capítulo III "Dilemas de la puertorriqueñidad: sobre las crónicas de actualidad de Edgardo Rodríguez Juliá". Entre los temas especialmente trabajados rápidamente consigno: la construcción de la historia de la dependencia colonial de Puerto Rico; los mitos de origen y fundación de la identidad puertorriqueña; la particular configuración de una compleja imagen de escritor, dada la multiplicidad de lugares de enunciación que adopta el narrador; la apelación a los usos populares de la lengua, sobre todo a partir de las inflexiones entre oralidad urbana y escritura, y, de manera pormenorizada, la relación entre texto, imágenes pictóricas y fotografías, diversos soportes de los cuales se vale el autor para dar cuenta de las relaciones entre relato y memoria en la historia cultural puertorriqueña. En el capítulo IV, "Fábulas de la puertorriqueñidad: invenciones, versiones y visiones del siglo XVIII en La renuncia del héroe Baltasar, La noche oscura del Niño Avilés, El Camino de Yyaloide y Campeche o los diablejos de la melancolía de E. Rodríguez Juliá", me ocupo sobre todo de la datación temporal que recrea como marco histórico el siglo XVIII en Puerto Rico, época propuesta como origen y fundación de la nacionalidad puertorriqueña. La reconstrucción del pasado se lleva a cabo mediante la incorporación e intersección de archivos, crónicas y documentos, 
reales, apócrifos e inventados, en un relato de los hechos dado por la multiplicación de narradores con muy diversos roles. El autor utiliza la imitación y la parodia al remedar el lenguaje arcaizante y el estilo de las crónicas coloniales dieciochescas, período representado por el concepto barroco de la tensión. La evocación de un siglo de la razón pero también de monstruos, pesadillas y destrucción -más allá de sus falsificaciones y ambigüedades explícitas- manifiesta también otra particularidad: se vuelve al XVIII para leer y buscar en el pasado una explicación, casi siempre insatisfactoria, del presente colonial puertorriqueño. En uno y otro momento resultan imprescindibles los aportes de los sectores negros y mulatos en la conformación histórica y cultural del país, donde el modelo del cimarronaje adquiere particular peso. Las ficciones del siglo XVIII de Edgardo Rodríguez Juliá ponen el acento en los conflictos derivados del esclavismo, sobre todo a través de metáforas corporales y eróticas que procuran recuperar un cuerpo maltratado por la explotación esclavista y ocultado como estigma en el futuro.

El capítulo V "Puerto Rico en Nueva York: escritura, desplazamiento y sujetos migrantes en los cuentos de Manuel Ramos Otero" se plantea el problema de la construcción de un imaginario nacional puertorriqueño pero desde la perspectiva del sujeto emigrado, teniendo en cuenta el contexto histórico de las emigraciones masivas puertorriqueñas a los Estados Unidos antes señalado. Hay en sus textos variados desplazamientos que entrañan el viaje paradigmático del emigrado puertorriqueño entre Puerto Rico y Nueva York, en un entorno de diásporas de diversos personajes errantes que se destacan por su alteridad cultural, étnica, lingüística. Emigrantes desposeídos, solitarios, signados por la pérdida, por la desintegración de la propia subjetividad, para quienes la reconstrucción de la identidad implica la negociación de los dos espacios (allá/aquí) y la posibilidad de disipar la amenaza de la ruptura del flujo migratorio para crear e imaginar nuevas continuidades. Asimismo en varias ocasiones se interceptan y coinciden la figura del migrante y la del escritor. Quien se traslada narra, oficiando de "cuentero", como veremos a partir de algunos análisis 
específicos de determinados relatos, caracterizados por un subrayado gesto autorreflexivo.

Desde propuestas de escritura muy diferentes entre sí, Edgardo Rodríguez Juliá y Manuel Ramos Otero también exploran y responden al interrogante obsesivo sobre la identidad puertorriqueña, negada e ignorada en términos legales, pero sumamente compleja y heterogénea en otros sentidos -social, cultural, afectivo, literario. Sus obras forman parte de un profuso conjunto de voces $^{7}$ que desafían por su volumen el pequeño espacio insular y se instalan en la comunidad puertorriqueña en Nueva York. Lamentablemente si la producción literaria de Puerto Rico es escasamente conocida en nuestro ámbito local en gran parte se debe los intereses económicos del mercado editorial que, hoy en día, está regido por empresas multinacionales. Celebro entonces un sello de nuestro país como Ediciones de la Flor que se preocupó por dar a conocer parte de este intenso movimiento literario ${ }^{8}$.

\footnotetext{
${ }^{7}$ Nombro algunos escritores que forman parte de la nueva literatura puertorriqueña: Luis Rafael Sánchez, Rosario Ferré, Tomás López Ramírez, Olga Nolla, Magali García Ramis, Edgardo Sanabria Santaliz, Luis López Nieves, Ana Lydia Vega, Juan Antonio Ramos, Tato Laviera, Vanessa Droz, Piri Thomas, etcétera.

${ }^{8}$ Ediciones de la Flor publicó también a Ana Lidia Vega, Edgardo Sanabria-Santaliz, además de Luis Rafael Sánchez. Por otra parte Editorial Sudamericana, antes de que fuera comprada por una empresa multinacional, promovía una colección llamada Narrativas Latinoamericanas donde publicó en 1992 Maldito amor de Rosario Ferré.
} 


\title{
I. Puerto Rico en el mapa cultural caribeño y latinoamericano
}

\begin{abstract}
"Se ha dicho que el Caribe es el tercer mundo del tercer mundo. Si ello es así, Puerto Rico se sitúa en la marginalidad más extrema de estas tierras marginales, países a medio hacer, según Naipaul, donde el colonialismo no ha cesado a pesar de la independencia y sus variados disfraces. Una vez colonia de España, ahora colonia de Estados Unidos, el país de Hostos y Betances reclama su derecho al ámbito cultural latinoamericano, a la vez que se asimila económicamente al american way of life".
\end{abstract}

Edgardo Rodríguez Juliá

El epígrafe de Rodríguez Juliá9 ${ }^{9}$ uno de los narradores actuales más destacados de Puerto Rico, revela una fisura que atraviesa no solo a su país natal sino al espacio caribeño: una historia compartida, violentamente marcada por diversos colonialismos, y por otra parte, una voluntad de afirmar una pertenencia cultural propia, más próxima en su planteo al concepto de la heterogeneidad cultural latinoamericana profundamente pensado por Cornejo Polar $^{10}$. Como señala Marcia Rivera: "Los caribeños consideran su cultura su más preciado bien; tal vez de lo único que realmente se sienten ser dueños." ${ }^{11}$ Si el espacio caribeño ha suscitado una serie de imágenes idílicas, construidas por la publicidad -una de las formas del colonialismo contemporáneo- donde el acento se ha puesto en la naturaleza exuberante de sus territorios, las playas de aguas cálidas y transparentes, los cuerpos bronceados y ociosos de cara al sol, lo que no revela la iconografía publicitaria es justamente el lado oscuro que

\footnotetext{
${ }^{9}$ Rodríguez Juliá, Edgardo (1984). "Tradición y utopía en el barroco caribeño", en: Caribeños, San Juan, Instituto de Cultura Puertorriqueña, 2002, pp. 65-73.

${ }^{10}$ Me refiero aquí al concepto de heterogeneidad cultural postulado por Antonio Cornejo Polar en su libro Escribir en el aire. Si bien Cornejo Polar reflexiona sobre el área andina y especialmente sobre la cuestión del indigenismo, su concepto de heterogeneidad permite dar cuenta de los "procesos de producción de literaturas en las que se intersectan conflictivamente dos o más universos socio-culturales". En el caso del área cultural caribeña hay diversas intersecciones culturales muy complejas y el concepto de heterogeneidad permite acercarse al problema de la construcción de las identidades de manera crítica, destacando justamente lo complejo, plural, heterogéneo y conflictivo de la cuestión. Véase Cornejo Polar, Antonio (1994). Escribir en el aire. Ensayo sobre la heterogeneidad socio-cultural en las literaturas andinas, Lima, Horizonte, particularmente la Introducción, pp. 11-24.

${ }^{11}$ Rivera, Marcia (1992). "Ebullición del ser: los movimientos culturales puertorriqueños y la producción femenina en plástica, poesía y narrativa", ponencia leída en las I Jornadas de Arte, Literatura y Medios. Masculino/Femenino: las marcas del género, Facultad de Filosofía y Letras, UBA, 1992. (Mimeo. Reproduzco la cita gracias a la gentileza de su autora).
} 
descubre el epígrafe: tercer mundo, marginalidad, contrastes profundos, riesgos de la asimilación, pérdidas.

Me interesa aproximarme al Caribe destacando su complejidad y diversidad pero también intentando aprehender, a partir de distintas miradas críticas, los trazos comunes que permiten articular lo múltiple en una red, atravesada por hilos tales como la historia de la colonización, el esclavismo, la economía de plantación, la dependencia económica, las migraciones, entre otros. En este heterogéneo mapa cultural caribeño y latinoamericano, Puerto Rico se caracteriza por constituir un lugar de complejas construcciones de identidades, resultado de la experiencia colonial española hasta fines del siglo XIX. Si bien dominante ella no fue homogénea, ya que hubo una fuerte presencia de culturas africanas, a la que se sumaron las inmigraciones de corsos, franceses, catalanes e ingleses del siglo XIX, y a partir de 1898, al finalizar la Guerra Hispanoamericana, la dominación norteamericana. Esta última, reforzada desde 1952 con la creación del Estado Libre Asociado (ELA), promovió la consolidación de la doble ciudadanía (norteamericana y puertorriqueña), las dos lenguas (español e inglés) y las dos banderas. Fue el inicio de una etapa que Arcadio Díaz Quiñones caracteriza como la "nueva era de conciliación del Estado Libre Asociado", en la que "...muchos hablaban no de la nacionalidad, sino de la personalidad puertorriqueña. Se quería una historia que uniera y no dividiera: una historia no conflictiva del pueblo puertorriqueño". ${ }^{12}$ Me centraré en este capítulo inicial en el análisis de tres perspectivas críticas sobre el Caribe, para detenerme luego en Puerto Rico y su lugar en el mapa cultural antillano y latinoamericano.

\section{I.1 Relecturas del Caribe: de los planteos de Édouard Glissant y Antonio Benítez Rojo al "Archipiélago de fronteras externas" de Ana Pizarro}

Ana Pizarro, en un ensayo publicado en 1985, se formulaba la siguiente pregunta: "¿Existe una relación que pueda justificar, desde el punto de vista

\footnotetext{
${ }^{12}$ Díaz Quiñones, Arcadio (1993). "La vida inclemente", en: La memoria rota, Río Piedras, Ediciones Huracán, pp. 27-28.
} 
literario, considerar al Caribe en América Latina?"13 Su trabajo daba cuenta de una intervención crítica que promovía la integración del territorio caribeño al espacio latinoamericano, señalando la importancia de resaltar características que numerosos acercamientos al Caribe no han dejado de indicar: su heterogeneidad, su pluralidad lingüística, sus hibridaciones y sincretismos religiosos, su transculturación, sus cruces y mezclas étnicas, sus complicados procesos de colonización, luchas independentistas, colonialismos y neocolonialismos.

El Caribe integrado a América Latina es una idea que comienza a imponerse desde los años sesenta del siglo XX, especialmente a partir del efecto que produjo en la región la Revolución Cubana. Sin embargo, como destaca Pizarro, hubo un primer proceso fundamental en la cultura antillana que hizo que varios intelectuales volvieran su mirada hacia este espacio: el movimiento de la Negritud, iniciado hacia los años treinta del siglo XX, y que tuvo como figuras destacadas al poeta africano Léopold Sédar Senghor, al martiniqueño Aimé Césaire, al guyanés León Gontran Damas y al haitiano René Depestre. En la década del cuarenta ensayos canónicos comenzaron a reflexionar acerca de los procesos históricos y culturales del Caribe, como podemos advertir en el célebre texto de Fernando Ortiz Contrapunteo cubano del tabaco y del azúcar (1940) ${ }^{14}$, inicio de un abordaje cultural que incluye al mundo antillano a pesar del peso de lo nacional cubano, y en el libro de Germán Arciniegas, Biografía del Caribe $(1945)^{15}$, pionero en su planteo de una unidad de América Latina con el Caribe. Peau noire, masques blancs (1952) ${ }^{16}$ del médico psiquiatra de la Martinica Frantz Fanon ${ }^{17}$, en su proyecto de

\footnotetext{
${ }^{13}$ Pizarro, Ana (1985). "La noción de literatura latinoamericana y del Caribe como problema historiográfico", en: Pizarro, Ana (org.). La literatura latinoamericana como proceso, Buenos Aires, Centro Editor de América Latina, pp. 132-144. Las reflexiones de Ana Pizarro son un aporte fundamental acerca de los estudios sobre el Caribe en el Cono Sur.

${ }^{14}$ Ortiz, Fernando (1978). Contrapunteo cubano del tabaco y del azúcar, Caracas, Biblioteca Ayacucho. (Primera edición 1940).

${ }^{15}$ Arciniegas, Germán (1959). Biografía del Caribe, Buenos Aires, Sudamericana, séptima edición. (Primera edición 1945)

${ }^{16}$ Fanon, Frantz (1952). Peau noire, masques blancs, París, Seuil.

${ }^{17}$ Las reflexiones de Fanon sobre las relaciones entre blancos y negros y las problemáticas de los procesos de descolonización en Africa, en buena medida por su militancia en la liberación de Argelia, lo constituyó en uno de los mentores intelectuales de generaciones revolucionarias en los años sesenta en América Latina y África. La importancia de sus aportes puede comprobarse en la cantidad de veces que es analizado, releído y glosado por teóricos del llamado
} 
comprender la "psicopatología del negro", revela crudamente la alienación y otros trastornos mentales sufridos por los sujetos colonizados, al colocar en primer plano el problema de la alteridad y la asimilación del negro de las Antillas a los valores culturales del colonizador.

No pretendo realizar aquí una revisión historiográfica completa acerca del concepto y la compleja construcción cultural del Caribe ${ }^{18}$, sino tan solo señalar algunos antecedentes que preceden una sostenida reflexión sobre la cuestión, y sobre los cuales vuelven su mirada importantes ensayos que marcaron una nueva etapa en el pensamiento e indagación sobre el espacio caribeño: me refiero a Le discours antillais ${ }^{19}$ (1981) del escritor martiniqueño Édouard Glissant y a La isla que se repite. El Caribe y la perspectiva posmoderna $^{20}$ (1989) del escritor cubano Antonio Benítez Rojo. Ambos proponen interesantes cruces teóricos que les permiten vincular la reflexión sobre el espacio caribeño con conceptos provenientes de los estudios literarios, culturales, filosóficos, científicos, además de pensar nuevas categorías de análisis. Más reciente (2002) resulta el aporte del ensayo de Ana Pizarro con el cual abre y titula una colección de textos críticos sobre el Caribe que también compila, "El archipiélago de fronteras externas"21, donde provee una profunda y actualizada relectura del territorio antillano desde el Cono Sur.

Édouard Glissant es autor de una obra, amplia y diversa, que abarca géneros variados como la poesía, la novela, las piezas teatrales y el ensayo, todas ellas enmarcadas y atravesadas por el espacio y paisaje antillanos. En la formación intelectual de Glissant tuvieron un enorme peso los gestores de la

pensamiento poscolonial, como podemos notar en el ensayo que le dedica Homi Bhabha y en los comentarios y análisis de Edward Said. Véase Bhabha, Homi (1994), "Interrogar la identidad. Frantz Fanon y la prerrogativa poscolonial", en: El lugar de la cultura, Buenos Aires, Manantial, 2002, pp. 61-89, y Edward Said (1996), Cultura e imperialismo, Barcelona, Anagrama.

${ }^{18}$ Para ampliar esta cuestión remito a los ensayos de Pizarro, Ana (1985), "La noción de literatura latinoamericana y del Caribe como problema historiográfico", ed. cit., y "El archipiélago de fronteras externas" en: Pizarro, Ana (comp.) (2002). El archipiélago de fronteras externas, Santiago, Editorial de la Universidad de Santiago de Chile, pp. 15-31. La revista Casa de las Américas número 36-37, año 1966, recoge variados ensayos sobre la identidad cultural y la historia del Caribe.

${ }^{19}$ Glissant, Édouard (1997). Le discours antillais, París, Éditions Gallimard (primera edición 1981).

${ }^{20}$ Benítez Rojo, Antonio (1996). La isla que se repite. El Caribe y la perspectiva posmoderna, Hanover, Ediciones del Norte, segunda edición.

${ }^{21}$ Pizarro, Ana (comp.) (2002). "El archipiélago de fronteras externas" en: El archipiélago de fronteras externas, ed. cit., pp. 15-31. 
noción de negritud, como Aimé Césaire, Léopold Senghor, Frantz Fanon. Sin embargo, toma distancia, particularmente de la posición de Césaire $^{22}$, al observar que el concepto de negritud corría el riesgo desviarse de la realidad caribeña para apelar a otro lugar, el retorno a África, y por tanto, cristalizarse en una noción de identidad esencialista, de "raíz única". Acuerda con JeanPaul Sartre ${ }^{23}$ al afirmar que la negritud es un momento de lucha, que cumplió su objetivo de contestación y afirmación de una identidad. Inspirado por las ideas de Gilles Deleuze y Félix Guattari ${ }^{24}$, prefiere pensar la identidad como "rizoma": "Raíz múltiple, extendida en redes en la tierra o en el aire, sin que ningún tronco intervenga como predador irremediable". ${ }^{25}$ Como señala Eurídice Figueiredo: "Tanto la palabra poética de Césaire como expresión de la negritud, como la obra práctico-teórica de Fanon, con su actuación revolucionaria en Argelia, son para Glissant una desviación necesaria. La etapa siguiente es la vuelta a lo real antillano." ${ }^{26}$ Al concepto de negritud, Glissant responde y complementa con las nociones de "antillanidad", "creolización"27 y "poética de la relación".

El concepto de antillanidad fue forjado hacia fines de los años sesenta y nació de una constatación, con la cual también abre su ensayo Le discours antillais: la sociedad antillana está enferma. Ella sufre la experiencia de una política de colonización "exitosa", y las comillas indican la mirada crítica sobre esta noción, ya que el éxito está de parte de la acción metropolitana mientras su colonia, Martinica, y el sujeto martiniqués, corren el riesgo de la pérdida de la identidad. La antillanidad entraña la idea de una unidad antillana como reconquista cultural e identitaria, que implica no solo al sujeto martiniqués sino

\footnotetext{
${ }^{22}$ Es importante destacar que René Depestre, en su ensayo publicado en 1980, Bonjour et adieu à la négritude, si bien hace un balance positivo del concepto de la negritud también critica su esencialismo implícito. Para Depestre, Césaire devolvió a sus compatriotas el África que les fuera confiscada y el orgullo de ser negros. Véase Depestre, René (1980). Bonjour et adieu à la négritude, París, Robert Laffont. Publicado también en La Habana, Cuadernos Casa de las Américas, Nro. 29, 1986.

${ }^{23}$ Sartre, Jean-Paul (1948). "Orphée Noir". Préface de: Léopold Sedar Senghor (org.), Anthologie de la nouvelle poésie nègre et malgache de langue françese, París, Quadrige/PUF.

${ }^{24}$ Deleuze, Gilles y Guattari, Félix (1977). Rizoma, Valencia, Pre-Textos.

${ }^{25}$ Glissant, Édouard (1990). Poétique de la relation, París, Gallimard, p. 235.

${ }^{26}$ Figueiredo, Eurídice (2002). "Construcciones identitarias: Aimé Césaire, Édouard Glissant y Patrick Chamoiseau", en: Pizarro, Ana (comp.). El archipiélago de fronteras externas, ed.cit., p. 38.

${ }^{27}$ El término "creolización" también puede hallarse traducido como "criollización".
} 
que incluye al sujeto caribeño. Glissant la piensa como una voluntad de reconstituir los desgarros sociales, de llenar los blancos de la memoria colectiva y de establecer relaciones fuera del modelo metropolitano. "No se repara la desgracia con palabras", -explica Glissant-, "pero las palabras refuerzan la memoria que flaquea, la obligan a una permanencia agitada que nos endurece." ${ }^{28}$ El objetivo de Glissant es poner en escena lo "real antillano" a través de la historia común de la plantación azucarera, a la que caracterizaron la compartimentación social, el color de la piel, la herencia africana y la lengua créole. Afirma la especificidad de las Antillas en su diversidad, su pluralidad de lenguas y de historias. Por lo tanto la Antillanidad se propone como la construcción de una identidad abierta y plural.

Respecto del concepto de creolización Glissant señala: "Yo Ilamo creolización a los contactos culturales en un lugar dado del mundo, que no se producen por un simple mestizaje sino que son resultado de relaciones imprevisibles." 29 La noción de creolización guarda estrecha relación con lo que Glissant explica como "mundo-caos", caracterizado no tanto por el desorden sino por la imprevisibilidad. Para el autor el mestizaje se puede prever no así la creolización. Si bien en la raíz de la palabra creolización encontramos tanto la noción de créole, lengua oral que se formó por la mezcla de las lenguas africanas y el francés, como también el concepto de lo criollo como lo nacido en América, el fenómeno de la creolización que va más del plano lingüístico y territorial; se trata de un fenómeno cultural que le permite a Glissant observar vínculos en un marco espacial amplio, un "arco caribeño" que se prolonga desde el nordeste brasileño, las Guyanas, la costa colombiana, el sur de México y las Antillas, y todavía más, según desarrolla el autor: "La creolización no permite comprender sino más bien intentar aprehender lo que pasa en el mundo. Intentar penetrar y descubrir la creolización del mundo, es comenzar a luchar contra la estandarización generalizada que alcanza a la economía, a lo

\footnotetext{
${ }^{28}$ Glissant, Édouard. Conferencia inaugural pronunciada en el Carrefour de litteratures européenes, el 4 de noviembre de 1993, L'Espace culturel, Écrivains français d'outre-mer, Internet, Páginas Web/Ecrivains français d'outre-mer (L'Espace Culturel).htm

${ }^{29}$ Entrevista a Édouard Glissant, "Nous sommes tous des créoles" , por Thierry Clermont y Odette Casamayor, Revista Régards, enero de 1998. Publicada en Internet, Páginas Web/France 3 en ligne. Un siècle d'écrivains.htm.
} 
social, a la cultura..." ${ }^{\text {30 }}$ Desde esta perspectiva la creolización sería un fenómeno religador que propone pensar las relaciones respetando las diferencias frente a los riesgos de la estandarización que promueve la globalización, como "una manera permanente de luchar contra esa suerte de depredador invisible que es la mundialización." ${ }^{31}$

Donde Édouard Glissant sistematiza y expone sus reflexiones sostenidas a lo largo de varios años es en su ensayo Le discours antillais (1981), al cual se podría caracterizar como "suma" en el sentido literal de adición, por cuanto una rápida mirada a la estructura y composición del libro nos muestra sus diversas partes: cuatro libros, cada uno de ellos dividido en distintos ítems, pero además con poemas, discursos, notas periodísticas, entrevistas, tablas, cronologías, documentos, proclamas, anexos, glosario intercalados. Es suma también en su sentido de totalidad, aunque como una totalidad abierta, no cerrada, que genera la posibilidad de nuevas adiciones, si pensamos como tal un posterior texto suyo, sugestivamente llamado Traité $d u$ Tout-Monde (1997). El propio Glissant en una de las partes de las Introducciones (la introducción se divide en once partes, de allí que el autor utilice el plural) describe su método de trabajo, acorde con la estructura plural del libro: "La intención en este trabajo fue acumular en todos los niveles.(...) La acumulación es la técnica más apropiada para el develamiento de una realidad que se disemina." ${ }^{32}$ La travesía intelectual es vista como una suerte de itinerario geográfico que en su caso propone una aproximación crítica al modo de contacto entre pueblos y culturas, partiendo de su espacio natal, Martinica. Glissant reclama para su propuesta el "derecho a la opacidad" en oposición a la racionalidad occidental que ha impuesto el principio universal de la transparencia:

"La transparencia ya no parece ser el fondo del espejo en que la humanidad occidental reflejaba el mundo a su imagen: al fondo del espejo hay ahora opacidad, un légamo entero depositado por pueblos, légamo fértil pero a decir verdad incierto, inexplorado aún hoy día y la

\footnotetext{
${ }^{30}$ Entrevista a Édouard Glissant, "Nous sommes tous des créoles" , por Thierry Clermont y Odette Casamayor, Revista Régards, enero de 1998. Publicada en Internet, Páginas Web/France 3 en ligne. Un siècle d'écrivains.htm

${ }^{31}$ Ibid.

${ }^{32}$ Glissant, Édouard (1997). Le discours antillais, ed. cit., p. 17.
} 
mayoría de las veces negado o insultado, cuya insistente presencia no podemos dejar de advertir." 33

Esta perspectiva le permite articular el esfuerzo intelectual con sus repeticiones, pensadas como ritmos, con sus momentos contradictorios, sus imperfecciones necesarias, las exigencias de una formulación limitada a veces por el esquematismo, frecuentemente oscurecida por su objeto mismo. El acento está puesto en las diversas formas de encontrar relaciones, vínculos, enlaces, nudos, tramas, como formas de contacto entre pueblos y culturas, en una perspectiva a la que llama Poética de la Relación.

Uno de los problemas que centran su reflexión es el de la extinción de la memoria colectiva y la consecuente desaparición del sujeto martiniqueño, el problema de la pérdida de la identidad cultural de su pueblo. Este peligro tiene su origen en la "exitosa" acción colonizadora por parte de Francia, en tanto la colonización francesa de las Antillas promovió la asimilación del colonizado. Se favoreció la formación de una pseudo-élite, la de los grandes colonos, llamados bekés, quienes renunciaron a inscribirse dentro de los marcos de una producción nacional de la Martinica y más bien fueron persuadidos de participar de la "Gran Patria" (la metrópolis). En 1946 se produjo el proceso de departamentalización y las Antillas francesas fueron declaradas "Departamentos de ultramar", proceso por el cual sus habitantes fueron reconocidos como ciudadanos franceses. Para Glissant la departamentalización condujo a las Antillas a negarse en tanto colectividad, a fin de conquistar una "ilusoria igualdad individual."34

La colonización del Caribe tendió a dividir una región, habitada en su mayoría por africanos, en tierras inglesas, francesas, holandesas, españolas, convirtiendo en extranjeros a quienes no lo eran. La fuerza del concepto de la negritud entre los intelectuales antillanos respondió para Glissant a la necesidad de referirse a una raíz común, de reencontrar la unidad a pesar de la diseminación. Este movimiento sirvió para que en la actualidad el antillano no reniegue más la parte africana de su identidad, aunque tampoco, por reacción,

\footnotetext{
${ }^{33}$ Cita de Glissant tomada del artículo de Curtius, Anny Dominique (2002). "Unidad en la diversidad en el Caribe: religiones y espacio literario", en: Pizarro, Ana (2002, comp.). El archipiélago de fronteras externas, ed. cit., p. 94.

${ }^{34}$ Glissant, Édouard (1997). Le discours antillais, ed.cit., p. 24.
} 
haya que sostenerla como la exclusiva: Glissant propone la idea de un "devenir antillano" en estrecha relación con el concepto de antillanidad explicado antes. Para el autor la idea de la unidad antillana es la de una reconquista cultural: "ella nos reinstala en la verdad de nuestro ser, ella milita por nuestra emancipación." ${ }^{35}$

La reconquista cultural antillana no puede hacerse al margen de la historia, y en la historia del Caribe es innegable el peso del esclavismo y la trata. A partir del par de conceptos retour/détour $r^{36}$ y sus sutiles diferencias Glissant explica el esclavismo como instancia histórica y sus derivas en el presente. El análisis se centra en la operación de la trata, del tráfico esclavista, y allí reside una enorme diferencia histórica entre un pueblo que logra su continuidad en otro espacio, que mantiene su identidad, y una población que se transforma en un espacio diferente en "otro" pueblo, esto es cuando la población no ha logrado continuar colectivamente las técnicas de existencia o supervivencia materiales y espirituales que practicaba antes de su traslado. Pero estas técnicas no desaparecen sino que subsisten como trazos o bajo la forma de pulsiones e impulsos. De allí que la primera pulsión de una población trasplantada que no está segura de mantener en el lugar de su traslado el antiguo orden de sus valores sea la del Retorno (Retour) a África: "El Retorno es la obsesión de lo Uno: no hay que cambiar el ser." ${ }^{137}$ Sin embargo, las poblaciones trasladadas por la trata no pudieron mantener por mucho tiempo la pulsión del Retorno, que cederá a medida que el recuerdo de la tierra ancestral se difumine. Así, para poder atenuar este imposible retour, es necesario un détour, un desvío, que debe ser nutrido por el retour, pero ya no a la tierra africana, sino a la tierra nativa del Caribe.

En Martinica, donde la población trasladada se constituyó en Pueblo ${ }^{38}$, la comunidad intentó exorcizar el Retorno imposible por lo que Glissant denomina una "práctica del Desvío". El rodeo, la vuelta, el desvío, es el último recurso de una población en la cual la dominación del Otro está oculta bajo el mejor de los

\footnotetext{
${ }^{35}$ Ibid., p. 26.

${ }^{36}$ Glissant, Édouard.(1997) "12. Le retour et le détour", Ibid., p. 40. Se puede traducir " retour" como retorno y "détour" como vuelta, rodeo, desvío.

${ }^{37}$ Ibid., p. 44.

${ }^{38} \mathrm{Se}$ respetan las mayúsculas utilizadas por el autor.
} 
camuflajes, el de la asimilación, donde la materialidad de la dominación no es directamente visible.

¿Dónde percibe Glissant la constitución de prácticas culturales del Détour? Especialmente en la lengua créole: "primera geografía del Desvío, y que solamente en Haití escapó a esta finalidad original". ${ }^{39}$ Glissant se inscribe en una concepción que le asigna dimensión política a la lengua. Valiéndose de conceptos trabajados por el lingüista Michel Benamou, señala que el esclavo confisca la lengua que el amo le ha impuesto. El lenguaje, apropiado a las exigencias del trabajo, es impulsado al extremo de su simplificación. El créole, sería así la lengua que, en su estructura y en su poética, asumiría a fondo lo irrisorio de su génesis, en el sentido en que los lingüistas han marcado que la sintaxis créole tradicional imita voluntariamente la lengua del niño. Empujada hasta ese punto, una práctica de la infantilización no es inocente, hay un voluntario camuflaje de la lengua como estrategia de resistencia. La consecuencia en el presente de esta práctica es el problema de la diglosia permanente que se ve todavía hoy en las Antillas, a pesar de señalarse y subrayarse la evidencia de la creatividad créole. En cambio, el créole haitiano, superó más rápido el détour, por la razón histórica que asumió al créole como lengua de responsabilidad productiva de la nación haitiana. Para Glissant el sincretismo religioso también constituye un avatar ostensible de la práctica del Desvío, como puede verse en ritos brasileros, en el Vudú, en las prácticas campesinas de Martinica. La diferencia radica en que, mientras en Brasil, en Haití, estas estrategias sincréticas poseen en la creencia colectiva un contenido positivo, en Martinica en cambio, poseen un trazo negativo, en tanto colocan a quienes practican estas creencias en el lugar del otro. De allí que el discurso de la creencia popular llame a estas prácticas en Martinica, aún hoy, I'oreille de I'Autre ${ }^{40}$ (la oreja -como escucha- de lo Otro).

Pero donde Glissant percibe con mayor énfasis una de las manifestaciones más ostensibles de la necesidad del détour ${ }^{41}$ por parte de una

\footnotetext{
${ }^{39}$ Glissant, Édouard (1997). "12. Le retour et le détour", Le discours antillais, ed.cit., p. 49.

${ }^{40}$ Ibid., p. 52.

${ }^{41}$ Los intelectuales antillanos han puesto en escena la necesidad de este Desvío y entre los ejemplos analizados por Glissant se destaca el "sueño africano" del jamaiquino Marcus Garvey, quien en los Estados Unidos enciende la pasión de los negros norteamericanos. También la asunción universal del sufrimiento negro en la teoría (o la poética) antillana de la Negritud, que
} 
sociedad amenazada por la pérdida de la identidad, se encuentra en el movimiento de emigración de poblaciones antillanas hacia Francia. Allí los emigrados antillanos se descubren a sí mismos como diferentes y toman conciencia de su antillanidad, la cual no deja de ser dramática porque coloca a los individuos emigrados ante una situación muy compleja de alienación ${ }^{42}$ que ya estaba presente en el propio lugar natal. En Martinica por ejemplo, a partir sobre todo del proceso de Departamentalización, que había promovido la "igualdad" de ciudadanía del sujeto martiniqués con el francés metropolitano, se practicó una política de asimilación que portaba en sí misma la alienación ${ }^{43}$. Glissant advierte con dramatismo que la conciencia de alienación recién cobró peso a partir de los movimientos emigratorios hacia la metrópolis.

También destaca el problema de la dependencia económica con la metrópolis, lo que conlleva al estancamiento y la pérdida de las formas de producción locales, regionales, que sólo volvieron a ser fuente económica importante durante la Segunda Guerra Mundial. Lo que no se fabrica se importa, se reemplaza la noción de producción por la de servicios, que favorece a una pequeña franja de la burocracia de funcionarios de Martinica. Señala Glissant que la política de asimilación económica precede a la asimilación política y cultural. Hay, por lo tanto, un consumo pasivo o una adopción acrítica de productos metropolitanos, desde periódicos, literatura, teatro, hasta programas de radio y TV. Glissant habla de una "pulsión mimética" que coloca al sujeto martiniqués en la posición de una comunidad alienada y amenazada

representa, para Glissant, un aspecto sublimado del Desvío. La necesidad histórica de reivindicar para los pueblos mezclados de las pequeñas Antillas la "parte africana" de su ser, largo tiempo menospreciada, expulsada, negada por la ideología dominante, es en sí misma suficiente para justificar el movimiento antillano de la Negritud. Esta reivindicación asume Aimé Césaire en su teoría de la Negritud, la cual a su vez se reencuentra con los movimientos de liberación de las culturas africanas; así el libro de Césaire, Cahier d'un retour au pays natal fue igualmente popular en Senegal y en la Martinica. El ejemplo más significativo del Desvío lo percibe Glissant en la obra de Frantz Fanon, a quien considera entre los intelectuales antillanos francófonos como el único que pasó al acto, a través de su adhesión a la causa de Argelia.

${ }^{42}$ Esta alienación ya había sido advertida por Aimé Césaire y Frantz Fanon. Ambos recuerdan una escena de la educación recibida en la infancia, muy significativa respecto de las relaciones entre colonizadores y colonizados, ya que la educación suministrada en la colonia era idéntica a la de la metrópolis,. En las clases de historia debían repetir la frase: "Nuestros ancestros los Galos". Véase Bhabha, Homi (1994), "Interrogar la identidad. Frantz Fanon y la prerrogativa poscolonial", en: El lugar de la cultura, ed. cit., pp. 61-89.

${ }^{43} \mathrm{Se}$ evocan varios ejemplos de esta alienación, algunos parecen menores pero son muy significativos, como el hecho de que Martinica se rija por la demarcación de estaciones europea, y se hable de invierno, verano, etc. en el Caribe. 
por la disolución: "La pulsión mimética es posiblemente una de las formas de violencia más extremas que se pueden imponer a un pueblo, ya que ella supone un consentimiento (e incluso, el goce) de la mímesis." ${ }^{44}$ En el análisis del colonialismo vivido y sufrido por el pueblo de la Martinica se destacan los aspectos negativos de la situación: pérdida, erosión de la identidad cultural, improductividad, asimilación económica, política y cultural, alienación, diglosia, "afrancesamiento" (francisation) visible sobre todo a partir de 1946, emigración a la metrópolis, entre otros de los problemas señalados.

¿Cuáles son, sin embargo, las alternativas de descolonización que se pueden plantear frente a las cuestiones enunciadas? Glissant apuesta a la reconstrucción de una identidad cultural antillana abierta y plural, y encuentra en la literatura la posibilidad de desarrollo de la misma. En este sentido apunta muy especialmente a la cultura popular, particularmente a través de su expresión oral, y en el caso de la Martinica, a través de la revalorización del créole. Propone promover su explosión creadora, en oposición a la política de neutralización de la cultura oficial que reduce el créole, reactivando sus contenidos populares y su tradición oral. El proyecto literario propuesto y puesto en práctica por Glissant, como bien lo explica Eurídice Figueiredo, implica una concepción del narrador como un "nosotros", que es a su vez chroniqueur, auteur, deparleur. "Él es anónimo, está inmerso en la multitud, al escuchar y transmitir la palabra de los otros. Hace circular la palabra al pasar la voz a otros narradores."45 Hay un intento de lograr una síntesis entre la escritura y el habla: "Evoco una síntesis, síntesis de la sintaxis escrita y de la rítmica hablada, de lo adquirido de la escritura y del reflejo oral, de la soledad de la escritura y de la participación en el canto común..." ${ }^{46}$ Esta síntesis, designada como oraliteratura, implica por parte de Glissant una operación de hibridación del francés, ya que para dar cuenta de la rítmica del créole, de su entonación, mezcla la lengua metropolitana con palabras, proverbios, dichos, refranes criollos, desmontando la sintaxis de la lengua escrita.

Sin embargo advierte el riesgo de que su literatura sea colocada en el casillero de lo exótico o de lo criollo:

\footnotetext{
${ }^{44}$ Glissant, Édouard (1997)."16. La dépossession", Le discours antillais, ed.cit., p. 105.

${ }^{45}$ Figueiredo, Eurídice (2002). "Construcciones identitarias: Aimé Césaire, Édouard Glissant y Patrick Chamoiseau", ed. cit., p. 41.

${ }^{46}$ Glissant, Édouard (1997). Le discours antillais, ed. cit., p. 450.
} 
"Para mí la criollización no es el criollismo: es, por ejemplo, generar un lenguaje que teja las poéticas, quizás opuestas, del créole y de la lengua francesa. ¿Qué es lo que yo llamo poética? El contador de historias criollo se sirve de procedimientos que no pertenecen al espíritu de la lengua francesa, que le son incluso opuestos; los procedimientos de la repetición, insistencia, circularidad. Las prácticas del listado (...) la acumulación precisamente como procedimiento retórico, todo eso me parece mucho más importante desde el punto de vista de la definición de un lenguaje nuevo." ${ }^{47}$

Según Glissant, habría entre los diversos escritores del Caribe, independientemente de la lengua hablada, un lenguaje común. Nicolás Guillén, Derek Walcott, V.S. Naipaul y él mismo, entre otros, harían una utilización semejante de las lenguas occidentales, moldeándolas según sus necesidades de expresión. Coinciden en tanto pueden inscribirse en la "poética de la relación" como pensamiento de archipiélago, apertura a la complejidad de lo diverso, ruptura con cualquier esencialismo o pensamiento de sistema para dar cuenta de la fragilidad de las construcciones identitarias, siempre en constante mutación, en una multiplicidad de posibilidades combinatorias.

"Creemos en el advenimiento de los países pequeños" ${ }^{48}$ señala Glissant, relacionados entre sí, en este caso por la trama de la antillanidad. Aunque tampoco deja de advertir acerca de los problemas que la amenazan: la "balcanización" de las islas, el aprendizaje de lenguas de comunicación diferentes y muchas veces opuestas (la querella del francés, del inglésamericano, del español), los cordones umbilicales que mantienen a las islas bajo el dominio de las metrópolis, la presencia de inquietantes y poderosos vecinos, como los Estados Unidos:

"La historia del Caribe es una historia balcanizada, donde la islas a pesar de su proximidad han estado separadas por los colonizadores y sus lenguas. Pero a pesar de estas diferencias los escritores caribeños tienen estilos coincidentes porque el barroco hispánico marcó toda la estructura del lenguaje, la forma de contar. El Caribe está descubriendo eso y que la diferencia de idioma no es una barrera." ${ }^{49}$

\footnotetext{
${ }^{47}$ Glissant, Édouard (1997). Traité du Tout-Monde, París, Gallimard, , p. 121.

${ }^{48}$ Glissant, Édouard . "L’idée Martinique", Le discours antillais, op.cit., p. 307.

${ }^{49}$ Entrevista a Édouard Glissant, en el marco del ciclo de conferencias Literatura y destierro, organizado por la Casa refugio de escritores Citlatéptl, ciudad de México, publicado en la revista on line ¿Cómo cambiar el mundo?, Internet, www.francia.org.mx, año 1999.
} 
Consideremos ahora al escritor cubano Antonio Benítez Rojo, cuentista, novelista y ensayista, quien publica en 1989 su importante ensayo La isla que se repite. El Caribe y la perspectiva posmoderna, dedicado a Fernando Ortiz. Este reconocimiento implica también una vinculación entre ambos ensayistas por el peso que cobra tanto en uno como en otro el territorio cubano. Si bien Benítez Rojo realiza en la introducción y en el capítulo primero un intento de aprehender lo caribeño y caracterizarlo a partir de ciertos ejes comunes que atraviesan el área, una buena parte de su ensayo se detiene en autores de su isla natal, como Nicolás Guillén, Fernando Ortiz, Alejo Carpentier. En el caso de Bartolomé de las Casas, a pesar del origen hispánico, focaliza especialmente su intervención respecto de la introducción de esclavos negros en La Española, es decir, se remonta al origen del sistema esclavista en Cuba. La inclusión de un escritor del Caribe de habla inglesa, cuya novela transcurre en la selva de Guyana como Wilson Harris, le permite la comparación con Carpentier, especialmente con su novela Los pasos perdidos, anterior a la de Harris. ${ }^{50}$ Las dos obras de ficción de autores no cubanos que elige analizar, Los panamañes de la colombiana Fanny Buitrago y La noche oscura del Niño Avilés de Edgardo Rodríguez Juliá posibilitan leer vínculos entre estas ficciones y su concepción del Caribe como "isla que se repite", en tanto ambas novelas participarían de una común historia caribeña a través del sistema de la plantación y de las prácticas de sublevación del cimarronaje, regularidades que se "repiten", no de la misma manera sino con sus especificidades y diferenciaciones. Benítez Rojo explora la categoría de la repetición diferencial al aproximar su conceptualización sobre el Caribe a la teoría científica del Caos:

"(...) dentro de la fluidez sociocultural que presenta el archipiélago Caribe, dentro de su turbulencia historiográfica y su ruido etnológico y lingüístico, dentro de su generalizada inestabilidad de vértigo y huracán, pueden percibirse los contornos de una isla que se repite a sí misma, desplegándose y bifurcándose hasta alcanzar los mares y tierras del globo, a la vez que dibuja mapas multidisciplinarios de insospechados diseños. He destacado la palabra repite porque deseo darle el sentido un tanto paradójico en el que suele aparecer en el discurso de Caos, donde

\footnotetext{
${ }^{50}$ Benítez Rojo analiza de Wilson Harris Palace of the Peacok, Londres, Faber\&Faber, 1960. De Alejo Carpentier, Los pasos perdidos, Madrid, Cátedra, 1985, originalmente publicada en 1953.
} 
toda repetición es una práctica que entraña necesariamente una diferencia..." ${ }^{51}$

Por otra parte y como lo indica el subtítulo de su ensayo "El Caribe y la perspectiva posmoderna", Benítez Rojo explicita sus vinculaciones con conceptos y autores del posestructuralismo y del posmodernismo filosófico. La noción de diferencia no solo se la provee la teoría del Caos sino también Jacques Derrida ${ }^{52}$; cita profusamente a Gilles Deleuze y Félix Guattari ${ }^{53}$ como así también a Jean-François Lyotard y su libro La condición posmoderna ${ }^{54}$. El ensayista invita a realizar, por ejemplo, una lectura "posmoderna" del Contrapunteo cubano del tabaco y el azúcar de Fernando Ortiz. Su justificación respecto de la adopción de esta perspectiva reside en su propuesta de relectura, no solo de Ortiz, sino de las diversas conceptualizaciones del espacio caribeño. El ensayo de Ortiz puede leerse desde una perspectiva posmoderna según Benítez Rojo porque desmitifica el concepto de autor como voz autorizada: Ortiz da sus propias opiniones sobre el "Contrapunteo" como un texto que se sabe insuficiente de antemano, no a través de notas o prefacios firmados sino desde el interior del ensayo mismo. Se cuestiona el concepto de unidad al aludirse al "vastísimo archivo heteróclito del cual emerge su ensayo" 55 , a contrapelo de otros de corte positivista con los que se lo compara, como por ejemplo Azúcar y población en las Antillas (1927) de Ramiro Guerra y Sánchez. Para Benítez Rojo la noción misma de "contrapunteo" permite desmantelar las rígidas oposiciones binarias, así los contrastes entre el azúcar y el tabaco entrañan múltiples matices, encuentros y desencuentros acordes con las dinámicas de lo caribeño. Si las nociones de modernidad y posmodernidad implican un marco de referencia occidental, el Contrapunteo, y éste como metonimia del Caribe, lo hacen estallar al hacer ingresar y coexistir lo occidental, moderno y posmoderno, con lo no occidental

\footnotetext{
${ }^{51}$ Benítez Rojo, Antonio (1996). "Introducción", La isla que se repite. El Caribe y la perspectiva posmoderna, Hanover, Ediciones del Norte, (primera edición 1989),p. iv.

${ }_{52}$ Derrida, Jacques (1989). La escritura y la diferencia, Barcelona, Anthropos.

${ }^{53}$ Deleuze, Gilles y Guattari, Félix (1988). Mil mesetas. Capitalismo y esquizofrenia, Valencia, Pre-textos.

${ }^{54}$ Lyotard, Jean-François (1989). La condición posmoderna, Madrid, Cátedra.

${ }^{55}$ Benítez Rojo, Antonio (1996). La isla que se repite. El Caribe y la perspectiva posmoderna, ed.cit., p. 157.

${ }^{55}$ Ibid., p. 160.
} 
y premoderno: liturgias afrocubanas, herencias taínas, polirritmia, formas culturales de los pueblos de mar. Benítez Rojo invita a leer el ensayo de Fernando Ortiz desde una perspectiva posmoderna y en esa invitación nos sugiere especularmente un modo de acercarnos a su propio ensayo:

"Entonces, ¿cómo leer el Contrapunteo? Mi sugerencia sería: leerlo como un texto dialógico y acéntrico en cuyo pluralismo de voces y de ritmos no sólo se dejan escuchar las más variadas disciplinas y las ideologías más irreconciliables, sino también enunciados que corresponden a dos formas muy diferentes de conocimiento, de saber. Yo diría del Contrapunteo que es un texto que tiene mucho de la promiscuidad propia de las cosmogonías paganas, pero que no descarta el monismo teológico, y esto en el sentido que lo significa el culto de la Regla Kimbisa del Santo Cristo del Buen Viaje, propio de Cuba, que da cabida a Cristo, a la Virgen y a los Santos católicos, sin relegar a un segundo plano al nganga del congo, al nkisi del abakuá, el oricha del lucumí." 56

En el análisis que Benítez Rojo propone sobre el culto cubano de la Virgen de la Caridad del Cobre es donde se vislumbra con mayor énfasis la apuesta crítica del ensayista. Como señala el autor, a pesar de ser una expresión religioso-cultural sincrética varias veces estudiada, su enfoque pretende desmontar, deconstruir las diversas lecturas e interpretaciones sobre este culto particular. Se remonta a sus orígenes, espaciales y temporales (el Cobre, cerca de Santiago de Cuba; 1605) y señala la especial intersección de tres tradiciones que se funden finalmente en una misma imagen. Confluyen en la Virgen la procedencia aborigen taína, la deidad Atabey o Atabex; la procedencia africana yoruba, la deidad Ochún, y la Virgen de Illescas, de España. Ahora bien, al analizar a su vez cada una de estas procedencias Benítez Rojo encuentra en ellas nuevos sincretismos. En Atabey se funden la deidad taína mencionada y Orehu, madre de las aguas entre los arahuacos de la Guayana. Esto implica un itinerario que permite vincular lo insular con lo continental, Cuba con las cuencas del Orinoco y del Amazonas, a través de la epopeya de los aborígenes caribes: "...la grandiosa epopeya arahuaca: la partida de la cuenca amazónica, la ascensión del Orinoco, la llegada a la costa 
caribeña, el poblamiento minucioso del arco antillano hasta llegar a Cuba, el encuentro aún oscuro con los mayas de Yucatán..." ${ }^{57}$

Al analizar la imagen de Nuestra Señora venerada en el Cobre concluye que se trata de la fusión de dos estampas distintas de la Virgen María. Remontando la procedencia europea del culto, Benítez Rojo advierte que la devoción a la Virgen es un desvío no previsto por los Doctores de la Iglesia Romana, desvío que se inicia en el medioevo, en Bizancio, desde donde se habría infiltrado subrepticiamente en Europa. Respecto de los orígenes africanos, también ellos son múltiples; Ochún adquiere plurales formas y significaciones:

"Ochún, en tanto objeto sincrético, es tan vertiginoso como su baile voluptuoso de pañuelos dorados. Tradicionalmente es la Señora de los Ríos, pero algunos de sus avatares la relacionan con las bahías y las orillas del mar. (...) también la vemos como una vieja hechicera que se alimenta de carroña y como el oricha de la muerte. ${ }^{58}$

Si las primeras lecturas del culto intentaron nacionalizarlo, criollizarlo como resultado de los mestizajes que la Conquista produjo en el territorio cubano, la propuesta de Benítez Rojo implica transnacionalizar el culto, verlo como epítome de múltiples cruces, muchos de ellos imprevistos e imprevisibles en el espacio del Caribe. Para el autor la noción misma de mestizaje es inviable en el análisis, no solo de este culto en particular, sino de las diversas formas y manifestaciones culturales del Caribe en general, porque el mestizaje implicaría una solución "positivista" y "logocéntrica"59 que pretende resolver en una síntesis complejos factores diferenciales. Su lectura e interpretación del culto no pretende echar por tierra las anteriores sino sumarle una perspectiva diferente, más abarcadora:

\footnotetext{
${ }^{57}$ Benítez Rojo, Antonio (1996). "Introducción", en: La isla que se repite. El Caribe y la perspectiva posmoderna, ed.cit., p. xviii.

${ }^{50}$ Ibid., p. xx.

51 "El elogio del mestizaje, la solución del mestizaje, no es originaria de África ni de Indoamérica ni de ningún pueblo del mar. Se trata de un argumento positivista y logocéntrico, un argumento que ve en el blanqueamiento biológico, económico y cultural de la sociedad caribeña una serie de pasos sucesivos hacia el 'progreso', y por lo tanto se refiere a la conquista, a la esclavitud, la neocolonización y la dependencia." Ibid., xxvi.
} 
"El culto de la Virgen de la Caridad del Cobre puede ser leído como un culto cubano, pero también puede ser releído -una lectura no niega a la otra- como un texto del meta-archipiélago, una cita o confluencia de flujos marinos que conecta al Níger con el Mississippi, al Mar de la China con el Orinoco, al Partenón con un despacho de frituras en una callejuela de Paramaribo."60

¿Qué implica la noción de meta-archipiélago? Algo que se sugiere en el párrafo recién citado, posee efectos desterritorializadores y de descentramiento, "tiene la virtud de carecer de límites y de centro."61 Benítez Rojo compara el meta-archipiélago caribeño, al cual considera como el "último de los grandes meta-archipiélagos" con la Hélade, en tanto ambos se constituyeron como un mar histórico-económico principal y crearon una cultura original a partir de la fundición y refundición de diversos componentes etnológicos, cultura a la cual el ensayista caracteriza como "acuática", fluyente, sinuosa, como las corrientes marinas, que conectan en cierta manera lo que parece remoto y apartado:

"Así el Caribe desborda con creces su propio mar, y su última Thule puede hallarse a la vez en Cádiz o Sevilla, en un suburbio de Bombay, en las bajas y rumorosas riberas del Gambia, en una fonda cantonesa hacia 1850, en un templo de Bali, en un ennegrecido muelle de Bristol, en un molino de viento junto al Zuyder Zee, en un almacén de Burdeos en los tiempos de Colbert, en una discoteca de Manhattan y en la saudade existencial de una vieja canción portuguesa. Entonces, ¿qué es lo que se repite? Tropismos, series de tropismos, de movimientos en una dirección aproximada, digamos la imprevista relación entre un gesto danzario y la voluta barroca de una verja colonial."62

El concepto de meta-archipiélago entraña también la posibilidad de pensar el espacio caribeño como un territorio que trasciende la formación de archipiélago tradicional con la cual se percibe al Caribe, ya que no se limita a lo insular sino que abarca relaciones con el continente americano y extracontinentales a través de los diversos movimientos migratorios que

\footnotetext{
${ }^{60}$ Benítez Rojo, Antonio (1996). "Introducción", en: La isla que se repite. El Caribe y la perspectiva posmoderna, ed.cit, p. xxi.

${ }^{61}$ Ibid., p. v.

${ }^{62}$ Ibid., p. v.
} 
vincularon las Antillas con África, Asia y Europa. También supone una ponderación particular de la temporalidad que se manifiesta a través de conceptos tales como cambio, tránsito, retorno, flujos, puesto que la complejidad del meta-archipiélago Caribe "atraviesa la cronología de las grandes contingencias de la historia universal."63 Para poder dar cuenta del funcionamiento del meta-archipiélago Benítez Rojo adopta el concepto de máquina de Deleuze y Guattari ${ }^{64}$, como un dispositivo compuesto de máquinas más pequeñas que se eslabonan unas a otras, con continuidades e interrupciones del flujo que las conecta. Esta metáfora le permite explorar los complejos acoplamientos históricos entre culturas supuestamente aisladas, como se vio a través del ejemplo de la Virgen de la Caridad del Cobre, como así también pensar el colonialismo en términos de una poderosa "máquina económica", cuando se detiene en el análisis del sistema de la flota a través del cual se enriqueció la metrópolis. El ensayista describe la flota justamente en los términos propuestos por los pensadores franceses:

"Era una máquina integrada por una máquina naval, una máquina militar, una máquina burocrática, una máquina política, una máquina legal, una máquina religiosa, en fin, por todo un descomunal parque de máquinas que no vale la pena continuar identificando. Lo único que importa aquí es que era una máquina caribeña; una máquina instalada en el mar Caribe y acoplada al Atlántico y el Pacífico."65

El sistema o máquina de la flota es el que posibilitó la implementación y ejecución del sistema o máquina colonial, que a su vez generó una máquina "que se repite" hasta el presente y que constituye uno de los ejes fundamentales que atraviesa todo el espacio antillano: el sistema de plantación. Benítez Rojo dedica la primera parte de su ensayo a analizar e historizar el paso del sistema de plantación a la sociedad de Plantación. Destaca mediante

${ }^{63}$ Benítez Rojo, Antonio (1996). "Introducción", en: La isla que se repite. El Caribe y la perspectiva posmoderna, ed. cit., p. vi.

${ }^{64}$ Benítez Rojo no explicita la fuente pero el libro en el cual Gilles Deleuze y Félix Guattari explican la noción de máquina es El Anti-Edipo: capitalismo y esquizofrenia. A partir del concepto de máquina deseante de Sigmund Freud los autores intentan complementar la perspectiva psicoanalítica con el análisis de la máquina social, a la cual analizan a su vez a través del encadenamiento de tres máquinas: la máquina salvaje, la máquina bárbara o despótica y la máquina capitalista. Véase Deleuze, G. Y Guattari, F. (1985) El Anti-Edipo: capitalismo y esquizofrenia, Buenos Aires, Paidós.

${ }^{65}$ Benítez Rojo, Antonio (1996). "Introducción", en: La isla que se repite. El Caribe y la perspectiva posmoderna, ed. cit., pp. ix y $\mathrm{x}$. 
el uso de las mayúsculas una diferenciación entre ambos estadios. Para poder distinguirlos se vale de un conocido ensayo, extensamente citado, de Sidney W. Mintz publicado en 1966, "The Caribbean as a Socio-Cultural Area"66. Para este autor la gran mayoría de las naciones caribeñas presentan estructuras económicas paralelas entre sí, que fueron determinadas por un mismo fenómeno concurrente: la plantación, lo que lo lleva a pensar el Caribe en términos de "societal area": "...considerando que sus sociedades comparten probablemente muchos más rasgos socio-estructurales que culturales." $67 \mathrm{Si}$ bien la plantación resulta entonces un eslabón imprescindible para estudiar el área caribeña, lo que le interesa especialmente a Benítez Rojo es destacar cómo se desarrolló el proceso que va de lo socio-estructural a lo cultural, de la economía de plantación al discurso de la Plantación. Ello implica detenerse en la emergencia de la cultura criolla, la incidencia del sistema esclavista en tanto "contribuyó mucho más a africanizar la cultura criolla"68, en el peso de la cultura cimarrona, así como en el desarrollo del sistema económico, social y cultural del ingenio, las economías de monocultivo, la llamada sacarocracia, los vastos contingentes de trabajadores contratados provenientes de Asia e India, todos factores complejos y heterogéneos que fue posible reunir a través del sistema de la plantación. Apelando a la comparación con el ámbito de las ciencias, mediante los aportes de la geometría fractal sumado al concepto de máquina, Benítez Rojo llega a la siguiente conclusión:

"Como hemos visto, la Plantación se repitió en la cuenca del Caribe presentando rasgos diferenciadores en cada isla, en cada tramo de la costa, en cada bloque colonial. Sin embargo -como viera Mintzestas diferencias, lejos de negar la existencia de una sociedad pancaribeña, la hacen posible en la medida en que un sistema de ecuaciones fractales o una galaxia lo es. Las distintas máquinas azucareras, instaladas aquí y allá a lo largo de los siglos, pueden verse también como una gran máquina de máquinas en continua transformación tecnológica. Su implacable carácter territorializador la hizo -la hace aún- avanzar en extensión y profundidad por los predios de la naturaleza, triturando bosques, sorbiendo ríos, desalojando a otros cultivos y aniquilando la fauna y la flora autóctona. Al mismo tiempo,

\footnotetext{
${ }^{66}$ Mintz, Sidney W. (1966). "The Caribbean as a Socio-Cultural Area", Cahiers d'Histoire Mondiale, IX, 4, pp. 912-937.

${ }^{67}$ Mintz, Sidney W. (1966), citado por Benítez Rojo, Antonio (1996). Parte I, "La sociedad", en: La isla que se repite. El Caribe y la perspectiva posmoderna, ed.cit., p. 8.

${ }^{68}$ Ibid. , p.49.
} 
desde su puesta en marcha, esta poderosa máquina ha intentado sistemáticamente moldear a su modo y conveniencia las esferas políticas, económicas, sociales y culturales del país, hasta convertirlo en sugar island. "69

Mintz busca una forma de "caribeñidad" no en el ámbito cultural, al cual percibe muy diversificado, sino en patrones económico-sociales. En parte Benítez Rojo adhiere a esta perspectiva -de allí que se detenga pormenorizadamente en el funcionamiento de la "máquina" plantación- pero busca aprehender los elementos que permitan destacar una regularidad común especialmente en la cuestión cultural, que desafíe a su vez el riesgo de la aculturación que implica la Plantación. Para ello se vale del texto de un viajero francés, Pierre Labat $^{70}$, quien en sus crónicas de viaje a las Antillas describe un baile popular llamado calenda, bailado por diversos sectores sociales, negros esclavos y libertos, mulatos, criollos blancos, visitantes extranjeros. La cita de la crónica permite a Benítez Rojo destacar un elemento estructurante y repetitivo, el ritmo:

"¿Qué es lo que Labat señala como una regularidad común a todo el Caribe? Un elemento: ritmo. Es el ritmo lo que, en sus palabras, hace a los caribeños estar 'en un mismo bote', más allá de las separaciones impuestas por la 'nacionalidad' y la 'raza'; es el ritmo -no una expresión cultural específica- lo que confiere 'caribeñidad'. " 71

Para Benítez Rojo las regularidades que muestra la cultura del Caribe constituyen una performance que intenta "releer y reescribir la marcha de la

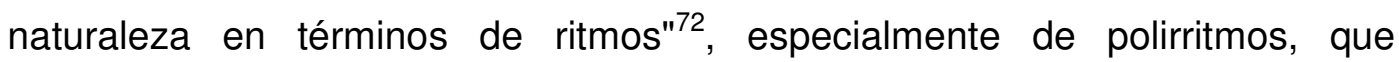

\footnotetext{
${ }^{69}$ Benítez Rojo, Antonio (1996). La isla que se repite. El Caribe y la perspectiva posmoderna, ed. cit., p.51.

${ }^{70}$ Benítez Rojo cita de P. Labat su crónica Nouveaux voyages aux isles de l'Amérique (Antilles) 1693-1705, pero no acude directamente a la fuente sino que extrae el fragmento del libro de Knight, Franklin (1978). The Caribbean. The Genesis of a Fragmented Nationalism, Nueva York, Oxford University.

${ }^{71}$ Benítez Rojo, Antonio (1996). Parte I, "La sociedad", en: La isla que se repite. El Caribe y la perspectiva posmoderna, ed. cit., p.55 (cursivas y entrecomillados del autor).

${ }_{72}^{7}$ Ibid., "Introducción", p. xxiii.

${ }^{65}$ Benítez Rojo, Antonio (1996). Parte I "La sociedad", en: La isla que se repite. El Caribe y la perspectiva posmoderna, ed. cit., p. 65.

66 "El mundo caribeño está saturado de mensajes -'language games', diría Lyotard- emitidos en cinco idiomas europeos (español, inglés, francés, holandés, portugués), sin contar los aborígenes
} 
preceden a la música e incluso a la misma percusión. Si, como he comentado antes, el ensayista había caracterizado el espacio caribeño en términos de meta-archipiélago y de máquina, la regularidad cultural del ritmo es pensada paralelamente como meta-ritmo, en el sentido en que puede manifestarse por vía de cualquier sistema de signos, tales como la música, el lenguaje, el arte, la danza e incluso formas de caminar, expresiones corporales, deportes.

Tomando en cuenta las cronologías que indican los viajes de Labat a las Antillas, fechados entre 1693 y 1705, Benítez Rojo formula una hipótesis general que luego apoyará valiéndose de los argumentos de Fernando Ortiz, Alejo Carpentier y Leópold Senghor. Para el autor, al menos desde el siglo $\mathrm{XVII}$, es posible reconocer en el Caribe ritmos comunes, que obedecen a un tipo de percusión polirrítimica y polimétrica muy diferente de las formas percusivas europeas y cuya característica más destacada es la imposibilidad de ser pautada según la notación musical convencional. El ritmo caribeño poseería esta particular condición de irreductibilidad. Serviría, sin embargo, de vehículo para una instancia performativa que permite una catarsis de la violencia histórica, social, étnica, económica que ha atravesado y aún atraviesa al Caribe, en tanto procura reunir lo caribeño, africano, europeo, asiático e indoamericano a la vez, aunque no en términos de unidad, síntesis, mestizaje o sincretismo sino como "caos de diferencias y repeticiones, de combinaciones y permutaciones". ${ }^{73}$

La noción de ritmo, como una regularidad que reúne lo diverso, conduce al autor a preguntarse acerca de las condiciones de posibilidad de una literatura caribeña, partiendo de una constatación básica: el plurilingüismo antillano ${ }^{74}$. Advierte que en una primera instancia se podría pensar que no existe una literatura caribeña sino literaturas locales, escritas desde los distintos bloques lingüísticos del Caribe. Sin embargo rechaza esta mirada y vuelve a la noción de meta-archipiélago: "No hay centros ni bordes, pero hay dinámicas comunes que se expresan de modo más o menos regular dentro del

que, junto con los diferentes dialectos locales (surimantongo, papiamento, créole, etc.), dificultan enormemente la comunicación de un extremo a otro de su ámbito." "Introducción", en: Ibid., p. ii. 
caos..." ${ }^{75}$ ¿Cuál sería entonces la regularidad que permite vincular las literaturas locales del Caribe, a pesar de su plurilingüismo? Para poder responder a esta pregunta retoma el concepto de polirritmia y de performance. El escritor caribeño se caracterizaría como un performer cuyos textos ponen en escena un continuo "estado de fuga", un "desplazamiento metonímico hacia las formas escénicas, rituales y mitológicas" ${ }^{176}$, un juego polirrítmico multiétnico cuya síntesis resulta imposible. La literatura caribeña, como antes se atribuyó al ritmo, "involucra un deseo de no violencia." ${ }^{77}$ :

"La literatura del Caribe puede leerse como un texto mestizo, pero también como un flujo de textos en fuga en intensa diferenciación consigo mismos y dentro de cuya compleja coexistencia hay vagas regularidades, por lo general paradójicas. El poema y la novela del Caribe no son solo proyectos para ironizar un conjunto de valores tenidos por universales; son, también, proyectos que comunican su propia turbulencia, su propio choque y vacío, el arremolinado black hole de violencia social producido por la encomienda, la plantación, la servidumbre del coolie y del hindú; esto es, su propia Otredad, su asimetría periférica con respecto a Occidente. ${ }^{78}$

El texto caribeño entonces no puede desgarrarse de la sociedad multiétnica que lo produce y de la cultura supersincrética de donde emerge según señala Benítez Rojo; plantea el problema de la identidad del sujeto antillano pero en términos de la imposibilidad de poder asumir una identidad estable. Se articula con múltiples expresiones populares como el mito, la música, la danza, el teatro, el canto, que imprimen su especial huella en la superficie textual y por ello confluye con la expresión más popular del Caribe, el carnaval, "...la gran fiesta del Caribe que se dispersa a través de los más variados sistemas de signos: música, canto, baile, mito, lenguaje, comida, vestimenta, expresión corporal."${ }^{79}$ En el epílogo del ensayo el autor reafirma su

\footnotetext{
${ }^{75}$ Benítez Rojo, Antonio (1996). "Introducción", en: La isla que se repite. El Caribe y la perspectiva posmoderna, ed. cit., p. xxii.

${ }^{77}$ Ibid.,p. xxiv.

${ }^{77}$ Ibid., p. xxxiii.

${ }^{78}$ Ibid., p. xxxv.
}

${ }^{79}$ Benítez Rojo, Antonio (1996). "Introducción", en: La isla que se repite. El Caribe y la perspectiva posmoderna, ed. cit., p. xxxviii. 
elección de la perspectiva posmoderna como la vía de acceso para analizar la cuestión de la caribeñidad. A pesar de señalar también sus insuficiencias considera que la óptica posmoderna "tiene la virtud de ser la única que se dirige al juego de las paradojas y las acentricidades, de los flujos y los desplazamientos; es decir, provee posibilidades muy a tono con los rasgos que definen el Caribe." ${ }^{80}$

Es indudable que tanto el ensayo de Édouard Glissant como el de Benítez Rojo intervinieron de manera significativa en lo que se refiere a nuevos abordajes y aproximaciones críticas al Caribe. La isla que se repite, escrito originalmente en castellano, luego traducido al inglés y promovido desde los departamentos de estudios culturales del mundo académico norteamericano donde se desempeña Benítez Rojo desde su exilio de Cuba en 1980, tuvo una mayor difusión y recepción en el campo de los estudios latinoamericanistas actuales. En cambio Le discours antillais no ha sido traducido aún a nuestra lengua y su difusión en inglés comenzó hacia fines de los ochenta ${ }^{81}$, cuando Glissant aceptó el cargo de Profesor Honorario del Doctorado en literatura francófona, primero en la Universidad de Louisiana y luego en CUNY, la Universidad de la ciudad de Nueva York.

Ambos autores coinciden en subrayar la complejidad cultural del Caribe y promueven miradas críticas novedosas y abiertas a diálogos interdisciplinarios. Destacan con particular énfasis el peso del esclavismo y la trata como una instancia ineludible para la aprehensión y comprensión de la cultura caribeña. Proponen una nueva concepción del espacio antillano que corroe conceptos tradicionales de insularidad y aislamiento, para enfatizar más bien los vínculos y religaciones entre el archipiélago y el continente americano. Revisan y analizan complicadas construcciones culturales que atañen tanto a lo sectores letrados como a los sectores populares. Podríamos seguir trazando vínculos entre ambas perspectivas aunque prefiero señalar también las divergencias, para deslindar los aportes diferenciales de cada ensayo. Es muy

\footnotetext{
${ }^{80}$ Benítez Rojo, Antonio (1996). "Último comentario", en: Ibid., p. 315.

${ }^{81}$ En 1989, el mismo año en que Benítez Rojo publica su ensayo, Michael Dash realiza una compilación del ensayo de Glissant, con el título: Caribbean Discourse: Selected Essays, editado por University Press of Virginia. Pese a la labor de difusión que provee la traducción de Dash, varios segmentos suprimidos del texto original y algunas traducciones imprecisas de términos -la más notable a mi entender es la que sustituye antillano por caribeño- privan al lector de un conocimiento más cabal de la obra de Glissant.
} 
visible el peso que cobra para cada ensayista la pertenencia y experiencia personal de lo caribeño, tanto en Glissant desde su Martinica natal como Benítez Rojo desde Cuba, como he señalado al reseñar ambos enfoques. Se nota en Le discours antillais un esfuerzo permanente en la articulación de la experiencia martiniqueña con el arco antillano en general, esfuerzo que se traduce en los conceptos de antillanidad y poética de la relación.

Se puede sostener que Benítez Rojo promueve un esfuerzo similar a través del concepto de meta-archipiélago. Con todo éste no se despliega con la misma intensidad más allá de las páginas de la Introducción de La isla que se repite. Glissant analiza con mayor rigor esta cuestión a través de las prácticas de los desplazamientos y migraciones, historizadas desde la trata hasta las migraciones más recientes sufridas en el Caribe a partir de los efectos de la descolonización. Hay mayor énfasis en destacar cómo se responde culturalmente ante prácticas políticas de aculturación, asimilación, mimetismo, que vuelven nuestra mirada hacia el problema de la situación geopolítica de los territorios caribeños, como bastiones estratégicos disputados por intereses metropolitanos, muy especialmente de los Estados Unidos en el último siglo.

Si en ambos autores encontramos un asedio constante al problema de las definiciones y construcciones identitarias caribeñas, notamos que para Glissant la cuestión de la identidad se piensa desde una reflexión atenta en advertir los riesgos que entrañan las cristalizaciones o los esencialismos excluyentes. Benítez Rojo también apela a un concepto plural de la identidad antillana, de allí que rechace con énfasis la noción de mestizaje antes apuntada. Sin embargo, en su empeño por trazar regularidades que permitan aprehender los rasgos comunes del diverso universo cultural caribeño se advierte que cae en el error que pretende eludir. Cuando intenta describir una "cierta manera" intrínsecamente caribeña cuya manifestación más clara estaría dada por la noción de ritmo su posición roza el esencialismo:

"En todo caso, resumiendo, podemos decir que el performance caribeño, incluso el acto cotidiano de caminar, no se vuelve solo hacia el performer sino que también se dirige hacia un público en busca de una catarsis carnavalesca que se propone canalizar excesos de violencia y que en última instancia ya estaba ahí. Quizás por eso las formas más naturales de la expresión cultural caribeña sean el baile y la música populares; quizás por eso los caribeños se destaquen más en los 
deportes espectaculares (el boxeo, el base-ball, el basket-ball, el cricket, la gimnasia, el campo y pista, et.) que en deportes más recogidos, más austeros, donde el espacio para el performer es menos visible (...) No es de extrañar que los caribeños sean buenos boxeadores y, también, por supuesto, buenos músicos, buenos cantantes, buenos bailadores y buenos escritores." ${ }^{182}$

La cita es por demás explícita, aunque Benítez Rojo matice su mirada al señalar los puntos de fuga que rodean los planteos acerca de la caribeñidad habla de un "locus furtivo de la caribeñidad"83-; o también cuando considera que: "Hay performers que nacieron en el Caribe, y que no son caribeños por su performance; hay otros que nacieron más acá o más allá, y sin embargo lo son. ${ }^{184}$; se distancia de esta manera de una concepción de la identidad caribeña atrapada en las redes topográficas y las categorías duras de la territorialidad.

La noción de performatividad le permite a Benítez Rojo leer una textualidad caribeña que trasciende el concepto de literatura pensado especialmente como práctica escrita, de allí que rechace nociones como autor o escritor en favor de performer. Glissant, por su parte, ya había señalado la necesidad de contemplar críticamente la noción de literatura en la cultura caribeña, para diferenciarla del concepto eurocéntrico basado excluyentemente en las concepciones de "une littérature dans I'absolu du signe écrit." ${ }^{85}$ En Le discours antillais una detallada exploración de esta cuestión la observamos en los apartados dedicados particularmente a las producciones en créole. Si bien Benítez Rojo destaca los importantes aportes de la cultura popular, sobre todo a través de los sincretismos religiosos, musicales y en fiestas como el carnaval, señala pero no indaga en qué medida estos aportes pueden notarse con singularidad en las expresiones literarias que apelan a sus vínculos con lo oral, con las particulares formas de habla del Caribe. Más bien en su mayoría los ejemplos analizados corresponden a la cultura escrita culta $^{86}$, en castellano,

\footnotetext{
${ }^{82}$ Benítez Rojo, Antonio (1996). "Introducción", en: La isla que se repite. El Caribe y la perspectiva posmoderna, ed. cit., p. xxviii. (El subrayado es mío)

${ }^{83}$ Ibid., p. xxviii.

${ }^{84}$ Ibid., p. xxxii.

${ }^{85}$ Glissant, Édouard (1997). Le discours antillais, ed. cit., p. 243.

${ }^{86}$ La noción de "literatura culta" o "circuito culto" la uso en el sentido en que los escritores trabajados por Benítez Rojo, aun aquellos que se valen de formas culturales populares como en el uso de ritmos afroamericanos del poeta Nicolás Guillén, forman parte de una literatura y
} 
salvo la excepción ya señalada de W. Harris. Con todo, los capítulos dedicados a los autores, cada uno de ellos un ensayo en sí mismo, resultan sumamente valiosos ya que proponen nuevas miradas sobre escritores que podríamos caracterizar canónicos de la literatura latinoamericana: Nicolás Guillén, Alejo Carpentier, como así también análisis de obras más recientes como en el caso de la colombiana Fanny Buitrago o en la interpretación de la novela de Edgardo Rodríguez Juliá, La noche oscura del Niño Avilés, una de las primeras lecturas críticas de rigor sobre este libro.

Para finalizar este itinerario de lecturas y miradas críticas sobre el Caribe quiero considerar brevemente otro aporte a la cuestión: el ensayo "El archipiélago de fronteras externas" de Ana Pizarro. La autora se vale de las reflexiones de Benítez Rojo y de Glissant para destacar que tanto ella como quienes participan del volumen que compila comparten una idea ampliada de lo que se entiende por "culturas del Caribe":

"Estamos aproximándonos a las culturas del Caribe hoy, a partir de una noción de Caribe que no se asienta en el espacio del Caribe insular solamente -el archipiélago de las Antillas- sino en una noción de la región en tanto cuenca del Caribe, esto es, incorporando los territorios que baña el mar Caribe y que diseñan un conjunto de culturas articuladas por trazos comunes ligados a una también común historia de colonización y esclavitud, centrada en la economía de plantación." ${ }^{87}$

A partir de conceptos como los de pluralidad, complejidad, sociedades en movimiento, multilingüismo, Pizarro intenta explorar una vertiente del Caribe poco conocida en América Latina: los territorios de lengua y cultura francesa, inglesa y holandesa. Estos territorios comparten rasgos que atraviesan toda la cuenca del Caribe, y que coinciden con los analizados tanto por Glissant como por Benítez Rojo: la densidad simbólica que imprimió en la cultura la trata de esclavos y el cimarronaje, núcleos que incorporaron procesos de reelaboración del imaginario africano; el peso que tuvo el movimiento de la Negritud como impulsor de una conciencia de la afroantillanidad; los reiterados asedios a la cuestión de la definición de una identidad caribeña de cultura mestiza, "criolla",

ensayística latinoamericana canónica, con amplio peso en los sectores académicos del ámbito cultural: Carpentier, Fernando Ortiz, Guillén.

${ }^{87}$ Pizarro, Ana (2002). "El archipiélago de fronteras externas", en El archipiélago de fronteras externas, ed. cit., p. 15. 
propuesta que por momentos aparece como tardía respecto del resto de los países de América Latina, pero cuyo anacronismo se explica históricamente por ser los países del Caribe los que sufrieron los procesos más lentos de descolonización. El aspecto central que le interesa destacar a Pizarro es cómo se construyó consecuentemente una literatura particular del Caribe, entre cuyos rasgos principales se destacan la voluntad implícita de la incorporación de lo popular desde el registro de diferentes voces, las propuestas de aunar los ámbitos de la literatura y la música, la revisión y puesta en crisis de los legados coloniales, el especial desarrollo de una perspectiva de género que se evidencia en un notable y cada vez más numeroso aporte de autoras.

¿Cuál sería entonces para Ana Pizarro el rasgo que le permite reunir y abordar tres espacios marcados por diferencias lingüísticas ${ }^{88}$ tan notorias? Para responder a este interrogante nos remite a un fenómeno que no solo se advierte en el Caribe, pero que se da con especial énfasis en las zonas estudiadas como una tendencia que se acentúa hacia el último y reciente fin de siglo: el fenómeno de la migración, la diáspora, los exilios. Explica la autora:

"Las transformaciones que se dan en el Caribe y a nivel internacional a partir de esa década (se refiere a la década de 1980) generan una nueva situación de enunciación: la del intelectual exílico. Ellos viven fuera del archipiélago, se han desplazado por razones económicas, políticas u otras y hablan desde un espacio que les pertenece y les es ajeno al mismo tiempo, desde un 'entre lugar', configurando así las fronteras en movimiento de un archipiélago que se expande mucho más allá de las geográficas." 89

Pizarro se vale del concepto de "entre lugar" trabajado por Homi Bhabha en su ensayo "Narrating the Nation"90. "In-between", traducido como "entre

\footnotetext{
${ }^{88} \mathrm{Me}$ resulta pertinente citar a la autora en su detallado enfoque sobre el multilingüismo antillano: "Porque como lo hemos señalado en trabajos anteriores, estamos hablando desde la perspectiva cultural, de un conjunto plural en donde se hablan en las diferentes subáreas cuatro lenguas metropolitanas: español, inglés, francés y holandés, así como, en cada sector una o más lenguas criollas, llamadas créole, para el caso francés; pidgin, para el área inglesa; papiamento para el Caribe neerlandés insular, así como el sranan para el Surinam, la principal lengua criolla hablada en este sector continental de la cultura Caribe holandesa, que accedió a su independencia recién en 1975." Pizarro, Ana (2002)."El archipiélago de fronteras externas", ed. cit., p. 15.

${ }^{89}$ Ibid., p. 24.

90 Bhabha, Homi. (1990). "Narrating the Nation" en Bhabha, Homi (comp.), Nation and Narration, Londres, Routledge, pp. 1-7. Hay una versión del ensayo en castellano con el título "Narrando la nación" en la muy buena compilación de Fernández Bravo, Alvaro (2000). La
} 
lugar", "entre medio", es una categoría que mantiene abiertas significaciones como flujo, circulación y que se resiste a atribuir un origen fijo a la idea de nación y nacionalidad. Justamente son los fenómenos de migración los que ponen en escena el "entre lugar", en tanto los desplazamientos, diásporas, nomadismos desarticulan una noción telúrica fija, territorializadora, de la identidad nacional. Dos ejemplos analizados por la autora resultan muy iluminadores de la cuestión: se trata de dos premios Nóbel, el poeta de Saint Lucia, Derek Walcott y el narrador trinitario V.S. Naipaul. Este último sale tempranamente de su Trinidad natal y, con palabras de Pizarro: "(...) forma parte del universo de los caribeños que extiende las fronteras del archipiélago a Inglaterra, los Estados Unidos y Canadá, principalmente."191 Lo que caracteriza la lengua literaria de Naipaul es lo que la autora describe como un inglés desarticulado por formas de pensamiento y de vida heterogéneos, plagado de elementos lingüísticos tan variados como formas dialectales del hindi y trinitarias, atendiendo al origen asiático del abuelo paterno del escritor y a la sociedad colonial donde nació y vivió hasta su adolescencia. A pesar de que Naipaul se ha manifestado críticamente en contra de su legado cultural por considerarlo informe y absurdo, éste, sin embargo, no deja de atravesar su obra. Por su parte Derek Walcott responde a Naipaul en su empeño por incorporar la región cultural caribeña, -pensada como ilegítima, desarraigada, mestizada por la mirada colonial y externa- a un diálogo con la cultura universal, como podemos leer en su largo poema $O_{m e r o s}{ }^{92}$, una épica de las Antillas inscripta en referencias al poeta griego. Pizarro destaca el empeño de Walcott por legitimar el universo fragmentado caribeño, como una memoria que alberga diversas diásporas, como la africana y la asiática, y que hace de ello su esplendor. Los dos escritores, de una y otra manera, le permiten a Pizarro una aproximación a su propuesta sobre cómo pensar el complejo espacio cultural caribeño:

"Es decir, la reflexión sobre la cultura que hemos querido llevar hoy es la de un Caribe que vive entre dos -por lo menos- universos

invención de la nación. Lecturas de la identidad de Herder a Homi Bhabha, Buenos Aires, Manantial, pp. 211-219.

${ }_{91}^{91}$ Pizarro, Ana (2002). "El archipiélago de fronteras externas", ed. cit., pp. 24-25.

92 Walcott, Derek. Omeros, Londres, Faber and Faber, 1990. Hay versión en castellano, corresponde a la traducción de Rivas, José Luis, Barcelona, Anagrama, 1994. 
culturales, producto de las migraciones recientes. (...) Si la historia de esta región cultural está marcada por identidades diaspóricas desde la trata de esclavos, y si los habitantes de sus islas han tenido una permanente relación de tránsito con las respectivas metrópolis, hoy, en las últimas décadas, el fenómeno de la migración masiva ha tenido, como en algunos países de América Latina, magnitudes tales que han marcado significativamente el mundo del arte, de la literatura, de la vida cotidiana. Nos encontramos entonces con un universo cultural de identidades tránsfugas, con procesos de dislocación de sujetos, saberes y lenguajes." 93

Así Ana Pizarro retoma una de sus preocupaciones constantes acerca de los estudios sobre el Caribe: su estrecha vinculación con cuestiones históricas y socioculturales que atraviesan toda América Latina, ya que en el Caribe procesos históricos que ha vivido toda América Latina se han dado de un modo particularmente intenso, si pensamos en la conquista, colonización, imperialismo y diversos colonialismos sufridos en el área, y, actualmente, en las diásporas, migraciones y desplazamientos de sus habitantes, forzadas 0 voluntarias.

\section{I.2. Puerto Rico como "discurso antillano", "isla que se repite", "archipiélago de fronteras externas"}

"Las islas surgieron del océano, primero como islotes aislados, luego los cayos se hicieron montañas y las aguas bajas, valles. Más tarde las islas se reunieron para formar una gran isla que pronto se hizo verde donde no era dorada o rojiza. Siguieron surgiendo al lado las islitas, ahora hechas cayos y la isla se convirtió en un archipiélago: una isla larga junto a una gran isla redonda rodeada de miles de islitas, islotes y hasta otras islas. Pero como la isla larga tenía una forma definida dominaba el conjunto y nadie ha visto el archipiélago, prefiriendo llamar a la isla isla y olvidarse de los miles de cayos, islotes, isletas que bordean la isla grande como coágulos de una larga herida verde. está."

Ahí está la isla, todavía surgiendo de entre el océano y el golfo: ahí

Guillermo Cabrera Infante, Vista del amanecer en el trópico

La tensión entre la insularidad como aislamiento y el archipiélago como vínculo y red que nos propone la imagen geológica y poética trazada por Cabrera Infante, nos invita a reflexionar sobre el lugar de Puerto Rico en el mapa caribeño. El proceso geológico descripto en la cita de Vista del amanecer

\footnotetext{
${ }^{93}$ Pizarro, Ana (2002). "El archipiélago de fronteras externas", ed. cit., pp. 28-29.
} 
en el trópico bien le cuadra a Puerto Rico, cuyo ámbito territorial no incluye sólo lo que comúnmente se reconoce como la Isla Grande ${ }^{94}$ sino también Vieques, Culebra, Mona, Desecheo y muchas pequeñas islas y cayos cercanos. Sin duda, Puerto Rico es parte del arco antillano que describen las propuestas de Glissant, Benítez Rojo y Pizarro. Pero esta pertenencia no tiene tanto que ver con su ubicación inequívocamente caribeña en el espacio geográfico sino más bien por compartir procesos comunes que hacen al particular contexto social, cultural e histórico antillano.

La historia de la colonización de Puerto Rico comienza con Cristóbal Colón cuando en 1493, durante su segundo viaje a las tierras que aún no se sabían americanas, le da el nombre de San Juan Bautista, redenominando un territorio cuyos pobladores nativos, los taínos ${ }^{95}$, llamaban Borinquén, según consignan los cronistas de entonces. Durante algunos años los españoles apenas incursionaron en la isla de Borinquén, hasta que en 1507 un hidalgo leonés, Juan Ponce de León, obtiene la autorización de la corona española para la colonización de la isla, ya que sabía de la posibilidad de yacimientos de oro. Entre 1508 y 1520 la isla proveyó a la metrópolis castellana con importantes rentas en oro. La explotación de la población nativa, obligada a trabajar en los yacimientos de los ríos, sumada a la exposición y contagio de enfermedades portadas por los españoles provocó que durante la década de 1520 la población taína ${ }^{96}$ se redujera notablemente en el territorio Borinquén. Borrado su nombre original, prácticamente exterminada su población aborigen, Puerto Rico, nombre con el cual se designó a la isla a partir de 1521, no quedó excluida de los procesos violentos de colonización tan bien descriptos por Glissant y Benítez Rojo, ya que la población nativa fue reemplazada por esclavos de procedencia africana.

\footnotetext{
${ }^{94}$ Puerto Rico constituye la menor de las Antillas Mayores y la superficie de la llamada Isla Grande, la porción territorial principal, es de tan solo 176 kilómetros de largo y 56 de ancho.

${ }^{95}$ Véase Gómez Acevedo, L. y Ballesteros Gaibrois, M. (1978) Culturas indígenas de Puerto Rico, Río Piedras, Editorial Antillana.

${ }^{96}$ La historiografía caribeña suele aseverar la pronta desaparición de la población aborigen, particularmente respecto de los taínos. Sin embargo estudios meticulosos sobre la historia del léxico puertorriqueño proveen información acerca de la cimarronería indígena. Manuel Alvarez Nazario afirma que: "...los indios se internaron por las serranías, distantes de los lugares donde habían padecido las penas de la esclavitud", y que por tal razón escapaban de la visibilidad de las autoridades coloniales y por lo tanto de los documentos que éstos producían. Véase Alvarez Nazario, Manuel (1982). Origen y desarrollo del español en Puerto Rico (siglos XVI y XVII), San Juan, Editorial de la Universidad de Puerto Rico, p. 27.
} 
Una vez que el oro había sido explotado y que las minas ya no proveían metálico, hacia 1530 la ciudad de San Juan de Puerto Rico insiste en la conveniencia de fomentar ingenios de azúcar para asegurar el relevo de la economía minera. Si durante los siglos XVI y XVII se establece la llamada primera era azucarera, basada en el desarrollo de los ingenios y los trapiches y sostenida a través de la explotación y la trata, en el lapso que media entre 1765 y 1823 la economía se orientó hacia el monocultivo azucarero, recrudeciéndose de la peor manera el esclavismo. Pero desde 1790 empiezan también los primeros intentos de rebeliones por parte de los esclavos, quienes, a partir de la revolución haitiana de 1804, conciben más cercana la posibilidad de la obtención de la libertad. Guillermo Baralt ${ }^{97}$ da cuenta de los principales intentos colectivos de rebelión entre los esclavos de Puerto Rico en la primera mitad del siglo XIX. Si los movimientos rebeldes esclavos sufrieron una feroz represión, hubo otras formas de resistencia, como las prácticas del cimarronaje y las fugas colectivas hacia Haitíl ${ }^{98}$, aunque también, como en el resto de las sociedades de plantación del Caribe, quienes no pudieron soportar más la opresión buscaron la salida en el suicidio.

Entre 1823 y 1837 Puerto Rico se colocó en la segunda posición, después de Cuba, como isla productora de azúcar en el Caribe. Durante estos años aumentó de manera considerable la trata, con esclavos que no solo provenían de África sino también de zonas antillanas vecinas a Puerto Rico. Recién en 1873 se resuelve la emancipación de los esclavos, pero, como señala el historiador Fernando Picó, se les imponía la condición de trabajar bajo contrato con algún patrón por el término de tres años: "En teoría tenían el derecho de libre contratación, pero en la práctica la inmensa mayoría tuvo que

\footnotetext{
${ }^{97}$ Baralt, Guillermo (1982). Esclavos rebeldes: conspiraciones y sublevaciones de esclavos en Puerto Rico (1795-1873), Río Piedras, Ediciones Huracán. Véase también Nistal Moret, Benjamín (ed.) (1984). Esclavos prófugos y cimarrones: Puerto Rico, 1770-1870, San Juan, Editorial de la Universidad de Puerto Rico.

${ }^{98}$ En 1804 Haití obtiene su independencia. La revolución haitiana tuvo la particularidad de ser la primera rebelión independentista de América Latina llevada a cabo por la población negra de la isla. Como señala Martín Lienhard respecto de la peculiaridad de esta revolución: "Na história da América escravocrata, a revoluçao haitiana foi a primeira insurreiçao escrava bemsucedida; nao se sabia ainda que seria a única." Véase Lienhard, Martin (1998). O mar e o mato. Histórias da escravidao (Congo-Angola, Brasil, Caribe), Salvador, Universidade Federal da Bahía, p. 121.
} 
optar por contratar con sus antiguos amos." ${ }^{\text {99 }}$ Si bien a mediados del siglo XIX se intentó desarrollar con desigual éxito la agricultura, no alcanzó para cambiar el sello esclavista que marca a la sociedad de la isla hasta fines del mencionado siglo. Para el sociólogo puertorriqueño Ángel Quintero Rivera ${ }^{100}$, en Puerto Rico, especialmente en el área rural, se fue configurando una formación social particular de sus pobladores alrededor del eje de "escapados"101, quienes generaron una sociedad de la contraplantación o de cimarronaje. El uso del término cimarrón se amplía, desde su perspectiva, ya que no solo incluye a los esclavos escapados de origen africano, sino también a otros fugitivos de diverso origen étnico que, por diferentes razones, optaron por el cimarronaje. Con palabras de Benítez Rojo, Puerto Rico no escapa entonces a la "isla que se repite" en todo el Caribe, primero con su sistema o "máquina" de flota cargando el oro hacia la metrópolis; luego con su sistema y sociedad de plantación y contraplantación y cimarronaje.

De todos los grupos que llegaron a Puerto Rico a finales del siglo XVIII y principios del XIX, el más numeroso e importante fue el de los africanos. Pero hubo también, como consecuencia de la posguerra napoleónica, un movimiento emigratorio alentado por España hacia sus colonias. En los años posteriores a 1815 llegaron a Puerto Rico importantes contingentes de franceses, ingleses, irlandeses, alemanes, italianos, y, en menor escala, holandeses. Muchos de ellos criollizaron sus apellidos y se integraron a la sociedad a través del comercio y el artesanado. A partir de 1820 llegan a la isla catalanes, mallorquines y canarios, y especialmente un importante sector de inmigración corsa, quienes dominaron particularmente la producción cafetalera de la zona.

\footnotetext{
${ }^{99}$ Picó, Fernando (1988). Historia general de Puerto Rico, Río Piedras, Ediciones Huracán, p. 209.

100 Véase Quintero Rivera, Ángel (1988). Patricios y plebeyos: burgueses, hacendados, artesanos y obreros. Las relaciones de clase en el Puerto Rico de cambio de siglo, Río Piedras, Ediciones Huracán, especialmente el capítulo I, pp. 22-98 y, Quintero Rivera, Ángel G. (1998). Salsa, sabor y control. Sociología de la música tropical, México, Siglo XXI Editores, especialmente capítulo 3, "El tambor camuflado: la melodización de ritmos y la etnicidad cimarroneada", pp. 201-251.

101 "Pero los escapados no fueron solamente indios, negros, esclavos y libertos, que deberían asumir una identidad personal hispana; muchos lo fueron por razones vinculadas a la turbulenta historia española del período, con sus conflictos étnicos internos contra descendientes de judíos y moros, la represiva Inquisición y sus angustiosos procedimientos de pureza de sangre..." agrega Quintero Rivera. Véase del autor Salsa, sabor y control. Sociología de la música tropical, ed. cit., p. 212.
} 
Esta última oleada se estableció en la zona montañosa de la isla, y constituyó, según José Luis González ${ }^{102}$, un sector fuertemente tradicional, hacendado, blanco, a partir del cual se cristalizó el mito identitario del "jíbaro", campesino blanco, como epítome de la puertorriqueñidad, aspecto en el cual me detendré en el próximo capítulo.

En coincidencia con los planteos acerca de los legados africanos que expresan tanto Glissant con su descripción de los procesos de creolización como Benítez Rojo, al destacar la preeminencia del ritmo en las culturas caribeñas, Ángel Quintero Rivera señala: "En el Caribe, antes del verbo fue el tambor, el ritmo y el movimiento." ${ }^{103}$ En su riguroso estudio sobre las relaciones entre la música tropical y las sociedades caribeñas destaca, por ejemplo, que en el siglo XIX se concibió a la danza como la primera música nacional de los países del Caribe hispano, composición musical que incorporó las tres principales etnias que conformaron dichos pueblos: "Las letras y melodías son principalmente de tradición española, el ritmo exhibe marcadas influencias africanas, y la utilización del güiro en su instrumentación se aduce como influencia indígena." ${ }^{104}$ Respecto de Puerto Rico analiza particularmente la bomba ${ }^{105}$ como la formación musical más identificada históricamente con la plantación esclavista y la población negra. Sostiene una tesis muy interesante respecto de cómo los elementos rítmicos ligados a las tradiciones africanas se "camuflaron" a través de un proceso de melodización de los ritmos. Para Quintero Rivera este camuflaje constituye un acto de cimarronería, ya que mantiene solapada pero viva la herencia negra. Ritmos sincopados del tipo de la guaracha, habanera, tumbao, bomba, se camuflan a través de una armonía que suena española. Ello se logra a través de la incorporación de un instrumento típicamente campesino, el cuatro, cuyo timbre evoca la española mandolina o laúd:

\footnotetext{
${ }^{102}$ González, José Luis (1982). El país de cuatro pisos y otros ensayos, Río Piedras, Ediciones Huracán, 3ra. edición. (Primera edición de 1980).

${ }^{103}$ Quintero Rivera, Ángel G. (1998). Salsa, sabor y control. Sociología de la música tropical, ed. cit., Prefacio, p. 14.

${ }^{104}$ Quintero Rivera, Ángel G. (1998). Ibid., "Ponce, la danza y lo nacional", capítulo 4, pp. 267 268.

${ }^{105}$ Véase especialmente el capítulo 3 del libro citado de Quintero Rivera, "El tambor camuflado: la melodización de ritmos y la etnicidad cimarroneada", pp. 201-251.
} 
"Con un timbre radicalmente distinto al del tambor, un timbre metálico brillante que evoca las cuerdas de la música española, el cuatro camufló en su música jextraordinariamente!, para el mundo contradictorio de la contraplantación, la vívida presencia afro de su negada constitución."106

Sin pretender realizar una reseña histórico-cultural rigurosa, tan solo quiero destacar, mediante algunos hechos y ejemplos significativos cómo Puerto Rico, a pesar de la hegemonía colonial española hasta fines del siglo XIX, compartió (y comparte) con otros pueblos antillanos la diversidad étnica, social y cultural de su sociedad, a través de complejos procesos inmigratorios que dejaron sus innegables huellas en la conformación del sector criollo de la Isla, especialmente en sus múltiples expresiones culturales. Se suman a estos procesos los complicados vaivenes del cambio de soberanía: "Como todo año emblemático, el 1898 aparece como referencia transparente, pero en realidad está rodeado de zonas oscuras en torno a cuestiones de raza, nacionalidad, religión, fronteras culturales e imperio (...)", señala Arcadio Díaz Quiñones ${ }^{107}$, en su propuesta de "repensar el 98", año en el cual Estados Unidos invadió y ocupó Puerto Rico, en el contexto histórico de la Guerra Hispanoamericana. Mediante el Tratado de París que puso fin a la guerra entre los Estados Unidos y España, ésta le cedió a su contrincante los derechos sobre Puerto Rico y las Islas Filipinas. Para Díaz Quiñones el término mismo de "guerra hispanoamericana" constituye una suerte de falacia histórica, ya que reduce un complejo proceso a un enfrentamiento binario entre el viejo imperio español y el joven norteamericano "como si solo los imperios fueran sujetos históricos"108, excluyendo del debate a los cubanos, filipinos y puertorriqueños. Pero esta exclusión no solo se da en los discursos entre imperios, sino que, señala el autor, es muy notable la exclusión de Puerto Rico de la historiografía cubana:

\footnotetext{
${ }^{106}$ Quintero Rivera, Ángel G. (1998). Salsa, sabor y control. Sociología de la música tropical, ed. cit., "El tambor camuflado: la melodización de ritmos y la etnicidad cimarroneada", p. 251. Me interesa destacar este aspecto de la presencia negra en formaciones culturales como las musicales, ya que, como veremos en el capítulo dedicado a las crónicas de actualidad de Edgardo Rodríguez Juliá, este autor explora la impronta de la música popular en la sociedad puertorriqueña en dos de sus más importantes crónicas y repone la etnicidad negra que durante el siglo XIX y principios del XX cierto sector de la intelectualidad del país tendió a negar.

${ }^{107}$ Díaz Quiñones, Arcadio (2000). "Repensar el 98", en: El arte de bregar (ensayos), San Juan, Ediciones Callejón, p. 195.

${ }^{108}$ Díaz Quiñones, Arcadio (2000). "Repensar el 98", ed. cit., p. 198.
} 
"Muchas veces el discurso histórico cubano se limita al uso de Puerto Rico para subrayar la diferencia triunfante: $\mathrm{Cuba}^{109}$, convertida en alegoría y epopeya de la nación; Puerto Rico, colonia que nunca llegó a ser estado-nación." ${ }^{110}$

Antes de la invasión norteamericana Puerto Rico había intentado, infructuosamente, obtener su independencia respecto de España, en un episodio histórico conocido como el Grito de Lares, en el año 1868. Ramón Emeterio Betances fue una de las principales figuras que ideó el intento revolucionario. Exiliado de Puerto Rico, organizó el levantamiento desde Santo Domingo, Santo Tomás y Nueva York. En contacto con independentistas cubanos planeó un alzamiento simultáneo de las dos Antillas ${ }^{111}$, pero que fracasó, entre otros motivos, como los que señala el historiador Fernando Picó ${ }^{112}$, por la escasa "estructura organizativa" y desigual nivel de conciencia política de los organizadores y ejecutantes de la rebelión, muchos de ellos hacendados extranjeros que habían adoptado a Puerto Rico como nueva patria. Hacia 1886-1887 una grave crisis financiera afectó a los países productores de monocultivos tropicales. La contracción económica reveló la falta de capacidad del gobierno español para proteger la economía de sus colonias antillanas. Un sector influyente de la sociedad criolla puertorriqueña consideró que, para evitar tales descalabros, era necesario modernizar la agricultura y las actividades industriales relacionadas, pero para poder lograrlo era indispensable que Puerto Rico tuviera cierto control sobre las decisiones a tomar. Las discusiones de los sectores liberales en torno a estas cuestiones promovieron la creación del Partido Autonomista hacia 1887, que se organizó fundamentalmente a nivel municipal. Este partido consigue a su vez que en 1897 se le conceda a Puerto Rico el estatuto autonómico. Según Arcadio Díaz

\footnotetext{
${ }^{109}$ En 1898 el ejército independentista cubano aceptó la alianza con los Estados Unidos para derrotar a los españoles. En 1902 nace la República cubana, negociada en el marco de la ocupación militar estadounidense.

${ }^{110}$ Díaz Quiñones, Arcadio (2000). "Repensar el 98", ed. cit., p. 199.

${ }^{111}$ Véase Ramos Mattei, Andrés. "Betances, Lares y el ciclo revolucionario antillano", Sin Nombre, vol. XIII, núm. 3, 1983.

${ }^{112}$ Picó, Fernando (1988). Historia general de Puerto Rico, ed. cit., pp. 177-180. El historiador señala: "Para aquilatar la importancia del Grito de Lares hay que enmarcar la revolución en el contexto de esos años. Aunque dirigido por hacendados extranjeros en dificultades económicas, el Grito de Lares representó los intereses de la mayor parte de la población. Para los esclavos, era la abolición; para los jornaleros, el fin de las libretas; para los agricultores, el cese de la expoliación por parte de los comerciantes peninsulares; para los profesionales y rentistas, la oportunidad de jugar un papel en la dirección y administración de los asuntos del país.", p. 179.
} 
Quiñones en Puerto Rico se "mitificó" por demás la autonomía concedida por España a través de la Carta Autonómica de 1897, ya que en ella no se menciona el marco cruel de la guerra de Cuba, contexto del cual no puede disociarse la firma de este acuerdo. ${ }^{113}$ La invasión norteamericana desbarató la posibilidad de que la autonomía se efectivizara. ${ }^{114}$

Desde los inicios de la ocupación norteamericana en 1898 y hasta 1900 Puerto Rico permaneció bajo el gobierno de militares estadounidenses. En esta etapa otro importante intelectual exiliado desde hacía varios años en República Dominicana, Eugenio María de Hostos, intentó vanamente movilizar la opinión pública de su país en contra de la ocupación. Desilusionado, Hostos ${ }^{115}$ regresó a Santo Domingo, donde murió en 1903. La promulgación de la Ley Foraker, aprobada en 1900 por el Congreso de Washington, favorecía los intereses de la política imperialista de los Estados Unidos de la mano del presidente William Mc Kinley. A través de la misma se concedía a los puertorriqueños una cámara de delegados electiva, pero se le yuxtaponía un consejo ejecutivo cuyos integrantes eran nombrados directamente por el presidente de los Estados Unidos. El gobernador no sería electo por los puertorriqueños, sino designado por el presidente del país invasor y ratificado por su Senado. A nivel comercial establecía el libre mercado entre los Estados Unidos y Puerto Rico, medida que revierte negativamente sobre la Isla, a partir de la expansión de la industria del azúcar desde 1900 en manos de grandes corporaciones azucareras con capital mayoritario norteamericano, quienes van paulatinamente acorralando a las centrales criollas. Se articuló una dependencia económica con los Estados

\footnotetext{
${ }^{113}$ Díaz Quiñones, Arcadio (2000). "Repensar el 98",ed. cit., p. 200. Las comillas son del autor.

${ }^{114} \mathrm{La}$ Carta Autonómica le garantizaba a Puerto Rico un parlamento insular, un gabinete propio y ayuntamientos municipales electos por el pueblo. Véase Barbosa de Rosario, Pilar (1975). El ensayo de la autonomía en Puerto Rico 1897-1898, San Juan, Imprenta Venezuela.

${ }^{115}$ Véase Hostos, Eugenio María de (1980). América: la lucha por la libertad, edición preparada y prologada por Manuel Maldonado-Denis, especialmente el apartado 5 "La lucha por la independencia de Puerto Rico", 201-249. Hostos, entre otras razones, no tuvo éxito en su arenga contra la ocupación norteamericana, en parte, por el relativo desconocimiento que había sobre su persona en Puerto Rico debido a su largo exilio, ya que casi vive toda su vida fuera del país, aunque muy vinculado a la Isla, como se puede corroborar en su correspondencia. Pero también porque gran parte de los sectores más influyentes de Puerto Rico apoyaron la ocupación norteamericana, creyendo que obtendrían más rápidamente la independencia respecto de España. Así, por ejemplo, en 1898 el Partido Autonomista sufrió una fuerte escisión; mientras un grupo se convirtió en defensor de la anexión a los Estados Unidos otro sector del partido tuvo que replantearse una nueva estrategia de liberación.
} 
Unidos en términos de lo que Tulio Halperín Donghi ${ }^{116}$ denomina el "nuevo pacto colonial", donde Estados Unidos se lanza hacia una política intervencionista, sobre todo en el Caribe y América Central, que vuelve estrechamente dependiente a la economía de estas áreas, como productoras de monocultivos (azúcar, café, tabaco) e importadoras a la fuerza de bienes manufacturados en la metrópolis. Pero el nuevo afectó no sólo las relaciones políticas y económicas sino también la vida cotidiana, a través de la implementación de nuevas políticas colonialistas en la instrucción pública y en la salud. Arcadio Díaz Quiñones señala en su lúcido ensayo "El 98: la guerra simbólica" cómo se pusieron de manifiesto las complejas relaciones entre ciencia e imperialismo en Puerto Rico, al reflexionar sobre la autobiografía del médico norteamericano que acompañó la tropas invasoras, Bailey K. Ashford, titulada sugestivamente $A$ Soldier in Science, en tanto "...exaltación de la razón positivista por un joven médico que llegó a Puerto Rico con las tropas e hizo su propia 'guerra' contra la anemia." ${ }^{117}$ Díaz Quiñones se detiene en el análisis de la "insólita visibilidad" que cobran a partir de 1898 el archipiélago de Filipinas, Cuba y Puerto Rico para el gobierno de los Estados Unidos, ya que la ocupación militar de las islas generó una iconografía y una documentación visual sin precedentes, dado el desarrollo tecnológico de las cámaras fotográficas portátiles:

"Lo que era vida cotidiana en las antiguas colonias adquiría de pronto importancia visto desde el centro del nuevo imperio. Muchos de los aspectos de la vida en Cuba, Puerto Rico y las Filipinas pasaban por el filtro de la fotografía: eran el ojo de la guerra. A la larga, el resultado fue algo complejo y decisivo: una nueva construcción cultural que implicaba una conciencia y una política determinadas de la historia." 118

También destaca en qué consiste esa "nueva construcción cultural" que ponen en escena los recientes ocupantes de la Isla a través de la innovación tecnológica de la cámara fotográfica: desde un especial y reiterado interés en las áreas de los cultivos de café, azúcar y tabaco, hasta una marcada obsesión

\footnotetext{
${ }^{116}$ Halperín Donghi, Tulio (1988). Historia contemporánea de América Latina, especialmente Quinta Parte "Madurez del orden neocolonial: 1880-1930", Buenos Aires, Alianza Editorial, segunda edición, pp. 255-321.

${ }^{117}$ Díaz Quiñones, Arcadio (2000). "Repensar el 98", ed. cit., p. 217.

118 Díaz Quiñones, Arcadio (2000). "Repensar el 98", ed. cit., p. 215.
} 
en registrar al otro con rasgos de exotismo, como observa a través de los retratos femeninos como modelos de "belleza mestiza", o la mirada sobre los contrastes sociales, herencia del colonialismo español recién depuesto:

"Simultáneamente, las imágenes destacaban el contraste entre los amplios balcones de las suntuosas residencias y las pobrísimas casas que definían las clases sociales; y también la alimentación, los mercados, las posibilidades comerciales, los niños con los vientres hinchados por las lombrices y las 'razas exóticas'. Las ausencias brillan: apenas hay fotos que representen la vida religiosa de las comunidades, o los aspectos más sangrientos de la propia guerra."119

Entre los problemas surgidos del cambio de soberanía en Puerto Rico a partir de la ocupación norteamericana, el de la ciudadanía incidió particularmente en la cuestión de la identidad. Hacia 1910 los puertorriqueños seguían siendo ciudadanos de Puerto Rico, pero tal condición carecía de un marco legal, ya que, por ejemplo, para poder salir del país necesitaban el endoso de las autoridades norteamericanas. La nueva fuerza política que había comenzado a operar hacia 1904, el Partido de la Unión de Puerto Rico, en el cual militaban importantes intelectuales del país ${ }^{120}$, intentó infructuosamente introducir enmiendas a la Ley Foraker, para finalmente aceptar una nueva ley, conocida como Ley Jones, que comenzó a regir en 1917 y que disponía conceder la ciudadanía norteamericana a todos los habitantes naturales de Puerto Rico que no la rechazaran en un lapso de seis meses. La ley acentuó la dependencia, al imponer el servicio militar obligatorio y aumentar la intervención económica del país, hechos a los cuales se sumó el inicio de la emigración ${ }^{121}$ masiva hacia los Estados Unidos, especialmente a Nueva York,

\footnotetext{
${ }^{119}$ Díaz Quiñones, Arcadio (2000). "El 98: la guerra simbólica", ed.cit., p.216.

${ }^{120}$ Entre los intelectuales militantes del Partido de la Unión se destacan varias figuras que pertenecen al sector letrado y literario del país, como Manuel Zeno Gandía, autor de la novela La charca de 1894, considerada como exponente del naturalismo en Puerto Rico y el poeta Luis Llórens Torres, unos años después celebrado como el poeta nacional de la Isla, quienes combinaron actividades políticas con las letras. Véase el excelente ensayo de Arcadio Díaz Quiñones sobre Luis Llórens Torres, donde analiza a partir de este autor la constitución del sistema literario paralelamente al sistema político-social en las primeras décadas del siglo XX en Puerto Rico, en: El almuerzo en la hierba (Llórens Torres, Palés Matos, René Marqués), Río Piedras, Ediciones Huracán, 1982, pp. 19-70.

${ }^{121}$ La reconstrucción de los primeros procesos de emigración a Nueva York se describe en un relato testimonial de uno de aquellos emigrantes, Bernardo Vega, editado por César Andreu
} 
en busca de empleo. Aunque la ley establecía cambios en la estructura política, con senadores que representaban con mayor peso a Puerto Rico, de todos modos el gobernador debía ser nombrado por el presidente de los Estados Unidos.

Si la cuestión de la ciudadanía puede analizarse como un problema de alienación cultural, ésta se ve profundizada por la obligatoriedad del uso del inglés como vehículo de enseñanza en las escuelas públicas. La campaña más fuerte en contra de la imposición del inglés fue llevada a cabo por una nueva fuerza política que comenzó como un desprendimiento disidente del Partido de la Unión, el Partido Nacionalista, entre cuyas figuras se destacó Pedro Albizu Campos. Albizu llevó a cabo una suerte de cruzada antinorteamericana, exaltando lo "hispánico-católico" en oposición al mundo protestante "anglosajón"122, por momentos con connotaciones un tanto mesiánicas, de allí que varios miembros del Partido Nacionalista ${ }^{123}$ tomaran distancia de su líder.

La controversia en torno al idioma oficial de enseñanza no disminuyó, sino que, por el contrario, se puso cada vez más de manifiesto el objetivo de lograr la americanización del pueblo puertorriqueño a través de la escuela pública, que alentaba un modelo de ciudadanía por lo menos alienante. El dominio del inglés se tornó en una cuestión del orden de la exclusión social, ya que los estudiantes que provenían de los sectores con menos contacto con la cultura norteamericana (sectores obreros, rurales, pequeños artesanos) no podían alcanzar grados académicos que requirieran un manejo fluido del inglés ${ }^{124}$. En esos mismos años se vivieron en Puerto Rico los efectos de la

Iglesias en 1977. Véase Memorias de Bernardo Vega: contribución a la historia de la comunidad puertorriqueña en Nueva York, 6ta. edición, Río Piedras, Ediciones Huracán, 2002.

${ }^{122}$ Las comillas indican los términos usados por Albizu Campos. Sobre esta figura histórica del nacionalismo puertorriqueño véase Ferrao, Luis Angel (1990), Pedro Albizu Campos y el nacionalismo puertorriqueño, Río Piedras, Editorial Cultural. Díaz Quiñones, Arcadio (1997). "Isla de quimeras: Pedreira, Palés y Albizu", en: Revista de Crítica Literaria Latinoamericana, año XXIII, núm. 45, Lima-Berkeley, 1er. Semestre, pp. 229-246. Del mismo autor "La pasión, según Albizu", en: El arte de bregar, ed. cit., pp. 88-95. Por otra parte la hispanofilia de varios sectores intelectuales de Puerto Rico en la primera mitad del siglo XX respondía a una estrategia de diferenciarse de lo norteamericano, como analizaré en el próximo capítulo a través del caso de Antonio S. Pedreira.

${ }^{123}$ Como fuerza política el Partido Nacionalista no pudo acercarse ni mantener un diálogo fluido con los sectores obreros, que brindaron su apoyo a una fuerza cada vez más creciente hacia 1930: el Partido Socialista.

${ }^{124}$ Las controversias acerca del idioma llegan hasta el presente en Puerto Rico. Muy brevemente quiero señalar algunos momentos puntuales respecto de las políticas oficiales. En 1902, 
depresión económica en los Estados Unidos, lo que agudizó el grado de dependencia con la metrópolis a través del asistencialismo y las subvenciones. Hacia 1938, en medio de una crisis política que afectó a las fuerzas partidarias del país, comienza a conformarse el Partido Popular Democrático (PPD) ${ }^{125}$, que habría de tornarse en el partido más poderoso de la Isla, y cuya hegemonía recién se resquebraja a fines de los años sesenta. La intervención de Estados Unidos en la Segunda Guerra Mundial en 1941 motivó que una importante cantidad de puertorriqueños fueran reclutados para el servicio militar norteamericano. La guerra produjo una suerte de paréntesis en las discusiones políticas internas del país, así, por ejemplo, los dirigentes del Partido Popular Democrático, entre los cuales varios alentaban la independencia, decidieron posponer hasta el fin del conflicto bélico toda consideración sobre las relaciones futuras entre Puerto Rico y los Estados Unidos.

mediante una ley, se inicia una política docente de bilingüismo que disponía que la enseñanza primaria se hiciera en español y la secundaria en inglés. En 1905 se revisa esta ley y se promueve que todos los niveles de la enseñanza se dicten en inglés y que el español pase a categoría de segunda lengua. Una nueva revisión en 1916 que se mantuvo hasta 1934 dispuso usar el español de primero a cuarto grado, luego un período bilingüe, hasta llegar finalmente a los grados superiores con el inglés como único vehículo de enseñanza. Cuando en 1948 se elige por primera vez mediante voluntad popular al gobernador de Puerto Rico, elecciones en las cuales triunfa Luis Muñoz Marín, éste dispone que se imparta la enseñanza en español en todos los niveles del sistema de instrucción pública, pero sin que se lo declare como lengua oficial. Recién en 1991, mediante Ley, se proclama al español como idioma oficial de Puerto Rico, aunque apenas dos años después, en 1993, cuando asume la gobernación de la Isla un candidato de perfil anexionista, Pedro Roselló, deroga la ley de 1991 y restablece el bilingüismo. En 1997 el Departamento de Educación dio a conocer un plan llamado "Proyecto para formar un ciudadano bilingüe", que entró en polémica con la Academia Puertorriqueña de la Lengua Española y que no se llegó a implementar. Los hechos confirman un innegable bilingüismo en Puerto Rico, complicado además por la enorme comunidad puertorriqueña que vive en los Estados Unidos y que ha dado lugar a un particular fenómeno de lenguas en contacto como el spanglish, donde inglés y español se interfieren mutuamente en diversos niveles, fonológicos, sintácticos, semánticos. Véase Revista de Estudios Hispánicos, Universidad de Puerto Rico, vol. XXVII, Núm. 1, 2000, donde se recogen varios trabajos críticos sobre las polémicas lingüísticas en Puerto Rico. Véase también Flores, Juan (1997), "Memorias (en lenguas) rotas/Broken English Memories", en: Revista de Crítica Literaria Latinoamericana, Año XXIII, nro. 45, Lima-Berkeley, 1er. Semestre; pp. 341-350.

${ }^{125}$ Véase Navas Dávila, Gerardo (editor, 1980), Cambio y desarrollo en Puerto Rico: la trasformación ideológica del Partido Popular Democrático, Río Piedras, Editorial de la Universidad de Puerto Rico. González Díaz, Emilio (1980), "Muñoz, el populismo y el ELA", Claridad (suplemento En rojo), 25-31 de julio, pp.2-3. Álvarez-Curbelo, Silvia y Rodríguez Castro, María Elena (editoras, 1993), Del nacionalismo al populismo: cultura y política en Puerto Rico, Río Piedras, Ediciones Huracán. 
Esta coyuntura dio lugar a nuevas divisiones en la política local. Luis Muñoz Marín ${ }^{126}$, principal dirigente del PPD, privilegió el problema del despegue económico del país, aprovechando la favorable circunstancia de la posguerra, como un problema más urgente que la cuestión del estatus político. Otros dirigentes, en cambio, consideraron que la independencia debía constituir la primera prioridad en la agenda política de la posguerra. Las posiciones se volvieron irreconciliables y en 1946 una escisión del PPD funda el Partido Independentista Puertorriqueño. Una enmienda a la Ley Jones, aprobada en 1947, permitió volver electivo el cargo de gobernador en Puerto Rico. El Partido Popular Democrático ganó las elecciones en 1948 y Luis Muñoz Marín ${ }^{127}$ se convirtió entonces en el primer gobernador electo de Puerto Rico. EI PPD se mantuvo en el poder ininterrumpidamente hasta 1968 y en sus largos años de hegemonía política se destacan al menos tres importantes procesos que afectaron la construcción de la nacionalidad puertorriqueña: el establecimiento del Estado Libre Asociado, las políticas económicas de industrialización y urbanización y la emigración masiva y forzada hacia los Estados Unidos.

$\mathrm{Si}$ bien en sus inicios Muñoz Marín militó en las filas del independentismo, al ganar las elecciones como gobernador su posición dio un giro con el fin de lograr un estatuto de autonomía bajo la hegemonía de Estados Unidos. Así la Convención Constituyente reunida entre 1951 y 1952, compuesta en su mayoría por miembros afiliados al PPD, y una muy escasa representación de la minoría (el Partido Independentista se abstuvo de participar), aprobó mediante un referéndum la constitución del "Estado Libre Asociado" (ELA), que comenzó a regir desde el 25 de julio de 1952, ratificándose los conceptos, por cierto paradójicos, de autogobierno y de unión permanente con los Estados Unidos. La creación y consolidación del ELA está estrechamente vinculada al proceso de industrialización fomentado por el Partido Popular Democrático, que solo podía producirse en el marco de la dependencia colonial. Apelo una vez más a las lúcidas reflexiones de Arcadio Díaz Quiñones sobre este período:

\footnotetext{
${ }^{126}$ Me detengo especialmente en la constitución del PPD y en la figura de su líder porque constituyen un imprescindible marco referencial tanto de las crónicas de Edgardo Rodríguez Juliá como de la cuentística de Ramos Otero, como se verá oportunamente a partir de los análisis propuestos entre los capítulos III y V.

${ }^{127}$ Luis Muñoz Marín gobernó interrumpidamente durante el lapso 1949-1964.
} 
"Aquel modelo de desarrollo modernizador, que decían concebido en defensa de las 'clases populares', era, en los hechos, una coalición de las clases dominantes puertorriqueñas y la hegemonía imperialista. Las clases privilegiadas puertorriqueñas renunciaron a la creación de un estado-nación, y optaron por transformarse en clases que, a la vez, han sido dominantes en la Isla y subordinadas al capitalismo y el Estado norteamericanos. La dominación política norteamericana, tan patente a pesar del flamante estatuto del Estado Libre Asociado (1952), fue aceptada, justificada y celebrada por el Partido Popular, a cambio del crecimiento industrial y de la considerable inversión de capital norteamericano."128

Pesó en esta decisión el hecho de que hacia la década de1940, la agricultura, tal como estaba organizada en Puerto Rico, basada fundamentalmente en la producción y exportación del azúcar, era incapaz de desempeñar un papel efectivo en dirección a mejorar el nivel de vida de la población. De allí que los líderes del Partido Popular Democrático, en especial su conductor, Luis Muñoz Marín, promovieran un proceso de industrialización en la Isla. Se llevó a cabo un programa de Fomento Económico, bajo el lema entusiasta de "Operación Manos a la Obra"129. Para el historiador económico James Dietz $^{130}$ el grave error de esta vía fue que terminó acentuando la dependencia con los Estados Unidos, ya que el desarrollo de la industrialización se orientó hacia fuera. Puerto Rico pasó a ser una plataforma de exportación a su principal mercado, los Estados Unidos. Por otra parte las empresas que se radicaron en la Isla se vieron más que favorecidas por exenciones impositivas, sin que estuvieran ligadas al mercado interno del país. Se establecían con el fin de producir para la exportación, y los beneficios para Puerto Rico consistían primordialmente en los empleos y ganancias que generarían. A su vez el mercado interno pasó a depender, en grado significativo, de las importaciones, desalentando la producción local y acentuando la dependencia con la metrópolis. Si la prioridad del PPD en la

\footnotetext{
${ }^{128}$ Díaz Quiñones, Arcadio (1998), "Los años sin nombre", en: La memoria rota, ed. cit., p. 121. ${ }^{129}$ Moscoso, Teodoro (1980), "Origen y desarrollo de la Operación Manos a la Obra", en: Navas Dávila, Gerardo, Cambio y desarrollo en Puerto Rico: la trasformación ideológica del Partido Popular Democrático, ed. cit., pp. 161-169.

${ }^{130}$ Dietz, James (1993), "La reinvención del subdesarrollo: errores fundamentales del proyecto de industrialización", en: Álvarez-Curbelo, Silvia y Rodríguez Castro, María Elena (editoras). Del nacionalismo al populismo: cultura y política en Puerto Rico, ed. cit., pp. 179-205.
} 
década del cuarenta se basaba en la justicia social, luego del establecimiento del Estado Libre Asociado, hubo un marcado cambio ${ }^{131}$ de rumbo dirigido al desarrollo económico y la infraestructura. Brevemente Dietz explica el fracaso de esta política alentada por el PPD:

\begin{abstract}
"Al dedicar una gran parte de sus actividades promocionales y de sus fondos a estimular la localización en Puerto Rico de los inversionistas extranjeros y a mantener la ventaja contributiva federal artificial de esa localización, Fomento y el PPD anclaron la estrategia en el éxito continuo de dicha promoción. Al no generar una estratagema central para introducir por fases una producción poseída y controlada localmente, que pudiera sustituir con el tiempo, a las empresas extranjeras, la estrategia de desarrollo recreó una economía de enclave muy parecida a la economía azucarera de la década de 1940. Sólo que ahora sería una economía de enclave manufacturera, lo que los economistas hoy día llamarían una economía de plataforma para la exportación, de la cual la mayor parte del valor agregado en la producción fluye de la economía hacia los inversionistas externos." ${ }^{132}$
\end{abstract}

Si bien el modelo propuesto tuvo una etapa aparentemente exitosa durante la década del cincuenta ${ }^{133}$, sin embargo comenzó rápidamente a revelar sus fisuras. Los empleos generados no alcanzaban para satisfacer grandes masas poblacionales que se trasladaron de los decaídos sectores rurales a las zonas urbanas, en particular a la ciudad de San Juan, donde comenzaron a crecer las urbanizaciones y barrios proletarios. Para resolver el conflictivo problema del desempleo se halló una solución no menos conflictiva:

\footnotetext{
${ }^{131}$ Al principio de la década de 1940 , cuando hacía muy poco tiempo que se había constituido como partido, el PPD tenía entre sus objetivos principales combatir la concentración latifundista y el monocultivo azucarero, promover la diversificación agrícola y las industrias manufactureras locales, para darnos una idea del giro de sus posiciones después de 1950.

${ }^{132}$ Dietz, James (1993). "La reinvención del subdesarrollo: errores fundamentales del proyecto de industrialización", ed. cit., p. 200. Sobre esta etapa véase también Rivera Medina, Eduardo y Ramírez, Rafael (1985, editores). Del cañaveral a la fábrica: Cambio social en Puerto Rico, Río Piedras, Ediciones Huracán.

${ }^{133}$ El ensayo que abre la La memoria rota de Arcadio Díaz Quiñones, titulado "La vida inclemente", en ed. cit., pp. 17-66, da cuenta de las contradicciones y fisuras del modelo desarrollista instaurado durante los años de hegemonía del PPD y de su carismático líder Luis Muñoz Marín. El título, por otra parte, rinde homenaje a un famoso bolero cuya letra dice :"La vida inclemente te separa de mí y un siglo de ausencia voy sufriendo por ti", del puertorriqueño Alfredo Gil, uno de los integrantes del famoso trío Los Panchos, que se forma en Nueva York y entre cuyos boleros se destacan los temas de los desplazamientos, la errancia, la separación, no solo de la amada sino del país natal. Más adelante volveré sobre este período a través del análisis de tres crónicas de Edgardo Rodríguez Juliá que se centran especialmente en estos años: Las tribulaciones de Jonás, El entierro de Cortijo y Puertorriqueños.
} 
una política que alentó y forzó la emigración masiva a la metrópolis, muy especialmente a la ciudad de Nueva York. Hacia fines de la década de 1960 alrededor del cuarenta por ciento de la población puertorriqueña ${ }^{134}$ había emigrado hacia los Estados Unidos. Para Luis Muñoz Marín y para la mayoría de los ideólogos del PPD el problema de Puerto Rico era la escasez de la tierra y el número elevado de la población, de allí la defensa de dos prácticas polémicas: la emigración y el control de la natalidad. Lo que no pudieron prever es que con la emigración comenzaron a darse complejas experiencias sociales y culturales que pesaron significativamente tanto en quienes se quedaron en la Isla como en los que se trasladaron a Estados Unidos, experiencias que pusieron en escena el problema de la identidad en la diáspora, muy visible en la notable difusión de la música latina y particularmente puertorriqueña en Nueva York ${ }^{135} \mathrm{y}$ en el progresivo crecimiento de las radioemisoras hispanas. Por otra parte entre emigrados e isleños se construyeron diversas formas de vinculación, lazos afectivos y culturales, a través del intercambio de fotos, cartas, encomiendas, también a través de la conservación de prácticas religiosas, como se puede notar en los festejos de santos y, con igual fuerza, la conservación de tradiciones culinarias, la cocina de platos típicos puertorriqueños. Como señala Díaz Quiñones, los emigrantes fortalecían la necesidad de conservar identidades como así también la necesidad de pensar nuevas descripciones de la identidad ${ }^{136}$.

El destacado escritor Luis Rafael Sánchez, en una aguda crónica titulada "La guagua aérea", metáfora coloquial para designar al avión en Puerto Rico, registra el viaje desgarrado de los migrantes puertorriqueños entre "downtown San Juan" y "uptown New York". A pesar del humor que impregna al texto, lo mordaz revela una mirada crítica, donde se observa que viajar para el puertorriqueño no tiene tan solo la precaria significación que le asigna el

134 Actualmente la población en la Isla es de alrededor de 3.800 .000 habitantes y aproximadamente un tercio de ese número reside en los Estados Unidos, según los datos aportados en el último plebiscito llevado a cabo en diciembre de 1998 para decidir el estatus político de Puerto Rico. La convocatoria fue alentada por el gobernador anexionista Pedro Rosselló y se volvió a votar por la vigencia del Estado Libre Asociado. Vale aclarar que no se permitió votar a los puertorriqueños con residencia en los Estados Unidos.

${ }^{135}$ Remito al importante libro de Angel Quintero Rivera, Salsa, sabor y control. Sociología de la música tropical, ed. cit., véase nota 92, y también Rondón, César Miguel (1980). El libro de la salsa, Caracas, Edición Arte.

${ }^{136}$ Díaz Quiñones, Arcadio (1998). "La vida inclemente", ed. cit., pp. 48-51. 
diccionario -traslado de un lugar a otro-, sino la más compleja del exilio, el desperdigamiento y la diáspora. Un puertorriqueño en Nueva York no tiene carta de ciudadanía norteamericana, sino que representa lo "otro", el pelo malo o "kinky", la tez oscura, lo latino. El puertorriqueño que viaja a EE.UU. para mejorar su precaria condición de vida termina añorando su tierra natal, y entonces, es "la guagua aérea", con su rápida posibilidad de traslación, la que permite el encuentro con lo propio. La cercanía del "paraíso" abona la falsa ilusión de poder regresar a él cuando se quiera, y de esta manera el viaje "se confirma como una metáfora estremecedora del ser y el existir puertorriqueños." 137

La emigración, temática que cobra singular peso en la cuentos de Ramos Otero ${ }^{138}$, comienza a volverse visible en la literatura de autores puertorriqueños a partir de fines de los cincuenta y los sesenta, por ejemplo en las ficciones de Pedro Juan Soto y José Luis González. Adquiere mayor desarrollo a partir de los años setenta, donde se destaca además el aporte a esta cuestión de un importante grupo de escritoras, entre ellas Magalí García Ramis, Rosario Ferré, Ana Lydia Vega y también las producciones literarias de los puertorriqueños que viven en Estados Unidos, escritas tanto en inglés como en español, e incluso en sus intersecciones, como pone en escena la poesía escrita en spanglish de Tato Laviera. La experiencia de la emigración y la vida en la urbe neoyorquina está indisolublemente unida a la historia de Puerto Rico, independientemente de la lengua que usen los escritores, experiencia del desgarro y la errancia que figura en la poesía de Pedro Pietri y del mencionado Laviera, en la narrativa de Piri Thomas, Nicholasa Mohr, Edwin Torres, Esmeralda Santiago, para mencionar algunos ejemplos ${ }^{139}$.

Fueron sobre todo los poetas llamados Nuyorican quienes a partir de los setenta expresaron las incongruencias existentes entre el mito del sueño

\footnotetext{
${ }^{137}$ Sánchez, Luis Rafael (1994). La guagua aérea, San Juan, Editorial Cultural, p. 7.

${ }^{138}$ Analizaré la representación del sujeto migrante puertorriqueño especialmente en cuentos de Manuel Ramos Otero, en el capítulo V .

${ }^{139}$ Textos breves (testimonios, ensayos, artículos) de varios de estos escritores figuran en el libro editado por Asela Rodríguez de Laguna (1985). Imágenes e identidades: el puertorriqueño en la literatura, Río Piedras, Ediciones Huracán, compilación de intervenciones de la conferencia del mismo nombre que el libro, llevada a cabo del 7 al 9 de abril de 1983 en Rutgers, La Universidad Estatal de New Jersey y en el Museo y la Biblioteca Pública de Newark.
} 
americano y las realidades inhóspitas que encontraban sus familias al emigrar, señala Carmen Dolores Hernández ${ }^{140}$. El término Nuyorican o cualquiera de sus variantes -Neorican, New Rican, designa tanto a los emigrados como a los hijos de emigrados, nacidos y criados en Nueva York, cuyas experiencias de vida registran el entrecruce conflictivo de dos culturas y dos lenguas muy diferentes entre sí. Así lo reconoce Miguel Algarín, editor junto a Miguel Piñero de la primera antología de poesía nuyorican ${ }^{141}$ al afirmar, refiriéndose al desafiante uso del spanglish en el discurso poético nuyorican: "Los conflictos son muchos. Los idiomas luchan por poseernos; el inglés nos quiere dominar completamente; el español también nos quiere adueñar. Nosotros, en cambio, los hemos mezclado a ambos"142. Con palabras de Walter Mignolo, las migraciones, los desplazamientos, promueven pensar la nación "despegada de los espacios geográficos", y en el caso particular de las migraciones puertorriqueñas a los Estados Unidos permiten también "imaginar Puerto Rico en Nueva York"143.

A mediados de los años sesenta el consenso que el Partido Popular Democrático había logrado durante tantos años comienza a resquebrajarse. Los movimientos estudiantiles, sindicales, de mujeres, de vecinos, de rescatadores de tierras, irrumpen en la escena política, y, en 1968 el PPD pierde las elecciones. Un año antes, en 1967, el PPD había impulsado la celebración de un plebiscito para discutir el estatus político del país. La fórmula estadolibrista obtuvo el sesenta por ciento de los votos, la estatidad recibió un apoyo del treinta y nueve por ciento y menos del uno por ciento señaló su preferencia por la idependencia. No obstante el candidato a gobernador que se impuso en 1968, Luis Ferré, fue quien propulsaba la incorporación de Puerto Rico como estado federado de la Unión norteamericana. Desde entonces la contienda electoral por la gobernación de Puerto Rico se ha visto escindida

${ }^{140}$ Hernández, Carmen Dolores (2000). "Emigración y Literatura", en: Revista de Estudios Hispánicos, Universidad de Puerto Rico, Vol. XXVII, Núm. 2, 2000.

${ }^{141}$ Algarín, Miguel y Piñero, Miguel (1975, editores). Nuyorican Poetry, New York, William Morrow \& Co., Inc.

${ }^{142}$ Algarín, Miguel (1985). "Estética nuyorican", en: Asela Rodríguez de Laguna (1985), Imágenes e identidades: el puertorriqueño en la literatura, ed. cit., p. 192.

${ }^{143}$ Mignolo, Walter (1994). "Crítica, historia y política cultural: agendas para la próxima década", en: Revista de Crítica Literaria Latinoamericana, Año XX, No. 40, Lima, 2 do. Semestre, dossier especial "Documentos de trabajo: Jornadas Andinas de Literatura Latinoamericana (JALLA), Tucumán, 1995, pp. 363-374. 
entre candidatos del Partido Nuevo Progresista, explícitamente anexionista y del Partido Popular, estadolibrista. La solución independentista no logró consenso fundamentalmente porque no diseñó un proyecto que permitiera revertir la dependencia económica de Puerto Rico con los Estados Unidos. A su vez la anexión total a los Estados Unidos convertiría a la Isla en su estado más débil, por su alta tasa de desempleo y bajos índices de crecimiento económico. El estadolibrismo, ratificado mediante la consulta popular en dos oportunidades más, en los años 1993 y 1998, sigue debatiéndose en una encrucijada compleja en el marco de las asimétricas relaciones que impone el colonialismo.

Narrados así los hechos podría interpretarse que Puerto Rico no opuso formas de resistencia a la intervención colonial norteamericana ni alentó políticas de afirmación de la identidad nacional. Por el contrario hubo a partir de los años sesenta, paralelamente al quiebre del "milagro económico" desarrollista y a la ruptura del consenso social, "una verdadera ebullición en la producción de artes plásticas, música y literatura", para expresarlo en los términos de la cientista social puertorriqueña Marcia Rivera ${ }^{144}$, con diversas y múltiples respuestas contestatarias ${ }^{145}$ desde la cultura puertorriqueña, especialmente en el ámbito de la literatura y de la música popular. Antes de estos años también hubo otras reacciones anticolonialistas desde el ámbito cultural, si pensamos, por ejemplo, en el desarrollo de una prolífica ensayística

\footnotetext{
${ }^{144}$ Rivera, Marcia (1992). "Ebullición del ser: los movimientos culturales puertorriqueños y la producción femenina en plástica, poesía y narrativa", ponencia leída en las I Jornadas de Arte, Literatura y Medios. Masculino/Femenino: las marcas del género, Facultad de Filosofía y Letras, UBA, 1992. (mimeo, gentileza de la autora, p.1)

${ }^{145}$ No dejo de tener en cuenta, aunque por razones de síntesis no puedo detenerme en este aspecto, las respuestas contestatarias de fuerzas políticas como las de los nacionalistas y los independentistas. He nombrado antes una figura emblemática como la del nacionalista Pedro Albizu Campos, quien sufrió persecuciones, exilios y largas temporadas en la cárcel, tanto en Puerto Rico como en los Estados Unidos. Hechos más recientes, muy significativos, son el llamado "Caso Maravilla", un oscuro episodio en el cual fueron asesinados dos jóvenes militantes independentistas a manos de la policía de Puerto Rico, hecho que constituye el disparador de una crónica de Rodríguez Juliá "El cerro Maravilla", sobre la cual me detendré luego. El episodio más reciente es la acción conjunta de la comunidad puertorriqueña para lograr la desmilitarización de la Isla de Vieques. Esta pequeña isla habitada por civiles fue desde la década del sesenta un desafío constante al Pentágono, ya que las operaciones de la marina fueron sistemáticamente blanco de protestas y acciones legales. Mediante actos de desobediencia civil y numerosas declaraciones apoyadas no solo por la comunidad puertorriqueña sino por organizaciones internacionales, finalmente se llegó a un acuerdo en el 2003 para la desmilitarización paulatina de la isla, proceso que actualmente se está llevando a cabo, aunque con ciertas dificultades.
} 
que se centró en el problema de la identidad nacional puertorriqueña en la primera mitad del siglo XX. Sobre ambos momentos me detengo especialmente en el próximo capítulo a través del análisis de los complejos vínculos entre cultura y nación en Puerto Rico, solo quiero adelantar, mediante una cita de Rivera, el peso de esta cuestión:

"El sentido de la identidad propia se ha sostenido firme a lo largo de más de 90 años, pese a la política estadounidense dirigida a lograr la integración total de Puerto Rico a Estados Unidos. Para muchos que se acercan a conocer a Puerto Rico, este fenómeno es realmente inusitado. Un pueblo que ha estado inmerso en la economía y en la política de otro que ostenta el poder ulterior por tantos años, raras veces sobrevive culturalmente. Y si sobrevive, su cultura pasa a ser parte del folklore, perteneciendo al ámbito del recuerdo y la nostalgia. Sin embargo en Puerto Rico la situación es muy diferente; la cultura está viva, es dinámica, se renueva y sirve de elemento de cohesión."146

Marcia Rivera, Arcadio Díaz Quiñones, Ángel Quintera Rivera, para nombrar algunos ejemplos de intelectuales puertorriqueños que han renovado con sus aportes la reflexión sobre la compleja trama cultural de Puerto Rico, coinciden al destacar el carácter cimarrón de la cultura puertorriqueña, en términos muy parecidos a los sostenidos por Édouard Glissant. Así cuando el escritor martiniqueño analiza el sentido de détour, como una práctica de desvío y rodeo, se explica entonces el modo en que los esclavos pudieron conservar importantes acervos de sus culturas originales, en la lengua, la religión, comidas, artes, economías de subsistencia, como formas del cimarronaje (marronnage ${ }^{147}$ ), prácticas de resistencia popular consuetudinaria. Pero el cimarronaje no solo se remonta a la época de la trata, sino que tales formas de resistencia cultural se siguen practicando en comunidades que sienten amenazado su sentido de la identidad, como analiza Glissant respecto de los emigrados martiniqueños en Francia. ¿Cómo no pensar entonces en la enorme comunidad puertorriqueña en los Estados Unidos, y en prácticas culturales "cimarronas" como la poesía Nuyorican? ¿Cómo no encontrar vasos comunicantes entre expresiones tales como la literatura en créole y en

\footnotetext{
${ }^{146}$ Rivera, Marcia (1992). "Ebullición del ser: los movimientos culturales puertorriqueños y la producción femenina en plástica, poesía y narrativa", ed. cit., p. 4.

${ }^{147}$ Marronnage, marron en francés provienen de la palabra cimarrón.
} 
spanglish? "Lejos de anular la cultura puertorriqueña, las comunidades puertorriqueñas de la emigración la han reactivado con gran energía y creatividad"148 ${ }^{14}$ reflexiona Arcadio Díaz Quiñones. Su análisis coincide con la perspectiva de Ana Pizarro, con quien podemos afirmar a Puerto Rico en el "archipiélago de fronteras externas", ya que el mapa del territorio puertorriqueño es a la vez preciso e inabarcable, con fronteras externas, que se ensanchan más allá de la Isla. La preocupación de Pizarro por dar cuenta del peso de las diásporas y las migraciones caribeñas en la construcción de las prácticas culturales antillanas encuentra en Puerto Rico un desgarrador y manifiesto ejemplo de las "identidades tránsfugas", del "entre-lugar" de su cultura.

"¿Cuál sería entonces la isla que se repite, Jamaica, Aruba, Puerto Rico, Guadalupe, Miami, Haití, Recife?"149 se pregunta Antonio Benítez Rojo, y notamos en los espacios nombrados un arco que trasciende los límites geográficos tradicionalmente asignados al Caribe. Miami constituye junto con Nueva York un centro urbano de asentamiento de migraciones caribeñas, particularmente cubanas. Recife, y todo el Nordeste brasileño, ha vivido la historia de la esclavitud, con estrechos vínculos con el Caribe. Por otra parte, la importancia que el escritor cubano le asigna a la noción de ritmo en la constitución de las culturas caribeñas halla en la música puertorriqueña un exponente sumamente rico para sus indagaciones, si pensamos en ritmos tales como la bomba o el desarrollo de la salsa en las comunidades latinas y especialmente caribeñas de Nueva York, cuestiones muy bien estudiadas por Ángel Quintero Rivera ${ }^{150}$. Esclavitud, economía de plantación, cimarronajes del pasado y del presente, migraciones y diásporas, colonialismo externo e interno, entrecruzamientos lingüísticos y étnicos, sincretismos religiosos y culturales, en fin varias y variadas razones que he intentado sintetizar en las páginas anteriores, confirman a Puerto Rico en el complejo mapa caribeño y latinoamericano, como isla que se repite, como archipiélago de fronteras externas, como indudable discurso antillano.

\footnotetext{
${ }^{148}$ Díaz Quiñones, Arcadio (2000). "La brega", en: El arte de bregar, ed.cit., p. 77.

${ }^{149}$ Benítez Rojo, Antonio (1989). "Introducción" en: La isla que se repite, ed. cit., p. v.

${ }^{150}$ Véase el libro antes nombrado de Ángel Quintero Rivera, Salsa, sabor y control, ed. cit., remito a nota 92 .
} 


\section{Una nación de tinta y papel: cultura, literatura e identidad nacional en Puerto Rico en el siglo XX}

"A la larga, el tema responde a un ¿cómo somos? o a un ¿qué somos? los puertorriqueños globalmente considerados. Intentamos recoger los elementos dispersos que laten en el fondo de nuestra cultura, y sorprender los puntos dominantes de nuestra psicología colectiva."

Antonio S. Pedreira

"La literatura nuestra -y esto lo digo sin la menor intención de restar mérito a su calidad- constituye una variación constante sobre el mismo tema obsesivo: la sinfonía de la identidad nacional con sus dos vertientes melódicas de la lucha antimperialista y la lucha de clases."

Ana Lydia Vega

Dos escritores y dos momentos distintos del siglo $\mathrm{XX}$, la década del treinta y los años ochenta, tensionan la cuerda de un arco que dispara una y otra vez el mismo interrogante sobre la "identidad nacional" de los puertorriqueños aunque, como propongo analizar, las respuestas sobre la cuestión difieran, y tiendan a complejizar el problema. La "obsesión" por la identidad puertorriqueña se destaca como el centro de análisis de numerosos artículos y libros de estudiosos de la cultura latinoamericana y especialmente puertorriqueña. Arcadio Díaz Quiñones, Juan Gelpí, Ángel Quintero Rivera, Julio Ramos, María Elena Rodríguez Castro, Julio Ortega, entre otros, consolidaron una bibliografía indispensable sobre el tema. ${ }^{151}$ En general, sus

\footnotetext{
${ }^{151}$ Sobre las relaciones entre identidad nacional y cultura en Puerto Rico véanse los siguientes textos de Arcadio Díaz Quiñones: El almuerzo en la hierba (Llórens Torres, Palés Matos, René Marqués), Río Piedras, Ediciones Huracán 1982; "Recordando el futuro imaginario", en Revista Sin Nombre, Vol. XIV, \#3, abril-junio de 1984, pp. 16-35; "Tomás Blanco, historia, racismo y esclavitud" en Tomás Blanco, El prejuicio racial en Puerto Rico, Río Piedras, Ediciones Huracán, 1985; La memoria rota, Río Piedras, Ediciones Huracán, 1993, y su más reciente contribución El arte de bregar. Ensayos, San Juan, Ediciones Callejón, 2000. De Juan Gelpí véase "Desorden frente a purismo: la nueva narrativa frente a René Marqués", en Literatures in Transition: The Many Voices of the Caribbean Area, Rose Minc, editora, Gaithersburg, Montclair State College \& Ediciones Hispamérica, 1982, pp. 177-187, y especialmente su libro, Literatura y paternalismo en Puerto Rico, San Juan, Editorial de la Universidad de Puerto Rico, 1993. De Rodríguez Castro, María Elena,"Las casas del porvenir: nación y narración en el ensayo puertorriqueño", en: Revista Iberoamericana, números 163-64, enero-junio de 1993, pp. 33-54, y como editora conjuntamente con Silvia Alvarez-Curbelo, Del nacionalismo al populismo: cultura y política en Puerto Rico, Río Piedras, Ediciones Huracán, 1993. De Ángel Quintero Rivera véanse Conflictos de clase y política en Puerto Rico, San Juan, HuracánCEREP, 1977, Patricios y plebeyos: burgueses, hacendados, artesanos y obreros. Las
} 
perspectivas críticas y analíticas coinciden en aprehender las complejas relaciones entre nacionalismo y cultura, especialmente en sus representaciones literarias, en el caso particular de Puerto Rico, en tanto país que no llegó a consolidarse como nación independiente ni a conformarse como estado-nación pero que, sin embargo, produce y articula una "literatura nacional", como lo afirma enfáticamente José Luis González: "Puerto Rico tiene una literatura nacional. Y eso no lo discute prácticamente nadie en Puerto Rico hoy"152. En sus trabajos señalan la problemática de la afirmación de la identidad cultural puertorriqueña ante la vigencia del colonialismo, lo cual los conduce a repensar conceptos con los cuales los historiadores y analistas del nacionalismo han descrito y definido las vinculaciones entre la constitución de los estados nacionales, los nacionalismos y las prácticas culturales.

"La nación, en el concepto actual del término, es, según se afirma, una creación relativamente reciente ( $\mathrm{y}$, en última instancia, arbitraria)" afirma el historiador Elías Palti ${ }^{153}$. En su estudio recoge los principales enfoques ${ }^{154}$ en

relaciones de clases en el Puerto Rico de cambio de siglo, Río Piedras, Ediciones Huracán, 1988 y Salsa, sabor y control. Sociología de la música tropical, México, Siglo XXI, 1998. De Julio Ortega véase Reapropiaciones (cultura y nueva escritura en Puerto Rico), Río Piedras, Editorial de la Universidad de Puerto Rico, 1991. De Julio Ramos véanse sus ensayos "Luisa Capetillo o los pliegues de la letras" y "Migratorias" incluidos en Paradojas de la letra, Caracas, eXcultura, 1996.

${ }^{152}$ González, José Luis (1989). "Puerto Rico: una nueva mirada a un nuevo país", Nuevo Texto Crítico, Nro. 3, Año II, Primer semestre, pp. 59-69.

${ }^{153}$ Palti, Elías (2002). La nación como problema. Los historiadores y la "cuestión nacional", Buenos Aires, Fondo de Cultura Económica, p. 9.

${ }^{154}$ La corriente denominada constructivista, también antigenealógica, que concibe a la nación y los nacionalismos en su carácter de recientes y "construidos" tiene entre sus principales teorizadores los siguientes autores y textos: Anderson, Benedict (1993). Comunidades imaginadas.Reflexiones sobre el origen y la difusión del nacionalismo, México, Fondo de Cultura Económica, 1era. edición en español (edición original en inglés 1983); Gellner, Ernest (1988). Naciones y nacionalismo, Madrid, Alianza Editorial (edición original en inglés 1983); Hobsbawm, Eric J. (1983). The Invention of Tradition, E.J.Hobsbawm and Terence Ranger eds., Cambridge, y del mismo autor Naciones y nacionalismo desde 1780, Barcelona, Editorial Crítica, 1991 (edición original en inglés 1990); Seton-Watson, Hugh (1977). Nations and States: an Inquiry into the Origins of Nations and the Politics of Nationalism, Londres, Methuen. Bhabha, Homi (1990). "Introduction: Narrating the Nation" y "DissemiNation: Time, Narrative and the Margins of Modern Nation", en Bhabha, Homi (comp.) Nation and Narration, Londres, Routledge; Bhabha, Homi (2002). El lugar de la cultura, Buenos Aires, Manantial, (edición original en inglés 1994); Habermas, Jürgen (1994). Identidades nacionales y posnacionales, Madrid, Tecnos; Smith, Anthony (1996). La identidad nacional, Barcelona, Trama; Breuilly, John (1990). Nacionalismo y Estado, Barcelona, Pomares. Para una revisión y puesta al día de la cuestión de los nacionalismos véanse Palti, Elías (2002). La nación como problema. Los historiadores y la "cuestión nacional", ed. cit., y Fernández Bravo, Alvaro 
torno a las cuestiones de la nacionalidad, las identidades nacionales, el nacionalismo, -desde ensayos clásicos como el de Ernest Renan, también los estudios anglosajones de Kedourie a Hobsbawn, hasta las propuestas poscoloniales como las de Homi Bhabha- y constata que en general dichos análisis coinciden en pensar a la nación como una entidad históricamente nueva, cuya construcción, "fabricación" o "invención" es relativamente reciente, básicamente a partir de las revoluciones burguesas y la consolidación de la sociedad capitalista, industrial o moderna en Occidente. Estas corrientes teóricas distinguen la constitución del nacionalismo en un sentido estricto como un principio político que requiere volver efectiva la correspondencia "natural" entre nacionalidad y estado y, en un sentido amplio, como un artefacto y sistema cultural ${ }^{155}$.

Ernest Gellner afirma la existencia de un vínculo necesario aunque no suficiente entre nacionalismo y estado: "(...) el nacionalismo sólo emerge en situaciones en las que la existencia del estado se da ya por supuesta." 156 Asimismo plantea que es "el nacionalismo el que engendra las naciones" ${ }^{157}$ y en esta perspectiva resulta fundamental el vínculo que se crea entre cultura y estado, en tanto los estados modernos articulan e imponen una ficción de homogeneidad cultural que supone la idea de nacionalidad. Por su parte Eric Hobsbawn, siguiendo los lineamientos de Gellner, puntualiza sobre el concepto de nación: "Es una entidad social sólo en la medida en que se refiere a cierta clase de estado territorial moderno, el 'estado-nación', y de nada sirve hablar de nación y nacionalidad excepto en la medida en que ambas se refieren a él." ${ }^{158}$ Destaca el elemento de "invención", de "ingeniería social" que interviene en la construcción de las naciones, pensadas como "constructos mentales", acercándose así a la definición aportada por Benedict Anderson sobre las naciones como "comunidades imaginadas", como formas de

(2000, comp.). La invención de la nación. Lecturas de la identidad de Herder a Homi Bhabha, Buenos Aires, Manantial.

${ }^{155}$ Sigo aquí la precisa formulación de Miguel Dalmaroni en su "Introducción. Identidades nacionales y representación literaria: umbrales teóricos, textos argentinos y relecturas", Dalmaroni, M. (1995, comp.), Literatura argentina y nacionalismo (Gálvez, Fogwil, Saer, Aira), La Plata, Facultad de Humanidades, Serie Estudios/Investigaciones, pp. 9-21.

${ }^{156}$ Gellner, Ernest (1988), Naciones y nacionalismo, ed. cit., p. 17.

${ }^{157}$ Ibid., p. 80.

${ }^{158}$ Hobsbawm, Eric (1991).Naciones y nacionalismo desde 1780, ed.cit., p. 18. 
identidad discursivamente construidas. La nación moderna suele representarse a sí misma como una comunidad imaginada, definida por Anderson en los siguientes términos: "Así pues, con un espíritu antropológico propongo la definición siguiente de la nación: una comunidad política imaginada como inherentemente limitada y soberana." ${ }^{159}$ Es imaginada porque aún los miembros de la nación más pequeña no conocerán jamás a la mayoría de sus compatriotas, pero en la mente de cada uno vive la imagen de su comunión. La nación se imagina limitada porque incluso la mayor de ellas tiene fronteras finitas aunque elásticas, más allá de las cuales se encuentran otras naciones, y soberana porque el concepto nació en una época en que la llustración y la Revolución estaban destruyendo la legitimidad del reino dinástico jerárquico, divinamente ordenado. Por último, se imagina como comunidad porque, independientemente de la desigualdad y la explotación que en efecto puedan prevalecer en cada caso, la nación se concibe siempre en términos de la percepción compartida de la existencia de vínculos subjetivos horizontales, como un compañerismo profundo, como "enraizado sentimiento horizontal de camaradería"160. Anderson destaca el carácter subjetivo de las identidades colectivas, subjetividad que puede engendrar que ciertas ficciones de comunidad se impongan socialmente y otras no.

Las teorías citadas aquí también señalan, además del carácter de "construcción mental" del nacionalismo en su sentido amplio, su emergencia y consolidación paralela a la aparición de la literatura como práctica discursiva y social diferenciada. Miguel Dalmaroni observa que:

"(...) junto con la delimitación estable de un territorio, la formación de una lengua y una literatura nacionales son procesos históricamente necesarios para la consolidación de las nacionalidades modernas como totalidades homogéneas que hagan las veces de matrices de la identidad social." 161

En este punto hallamos, a través de la literatura, un ejemplo de intersección entre nacionalismo y cultura, articulación compleja en la cual

\footnotetext{
159 Anderson, Benedict (1993). Comunidades imaginadas. Reflexiones sobre el origen y la difusión del nacionalismo, ed. cit., p. 23.

160 Ibid., p. 25.

${ }^{161}$ Dalmaroni, Miguel (1995). "Introducción. Identidades nacionales y representación literaria: umbrales teóricos, textos argentinos y relecturas", ed. cit., p. 13.
} 
tuvieron un rol muy importante los intelectuales, quienes, como describe Álvaro Fernández Bravo "(...) fueron quienes primero establecieron, con la ayuda de la filología, el valor de la lengua y de ciertos géneros literarios como la poesía y las leyendas populares en la definición de la identidad nacional en Europa." ${ }^{162}$ Una de las principales funciones que cumple el discurso literario en relación con la construcción de las identidades nacionales sería proveer "ficciones de homogeneidad"163, en algunos casos establecidas y sostenidas por el estado, desde los aparatos culturales y educativos oficiales (escuelas, academias de la lengua, universidades), que imponen, inculcan y controlan la constitución de las lenguas nacionales; en otros, a través de prácticas simbólicas entre las que se destaca la narración. Sobre esta cuestión Dalmaroni aclara que:

"La idea de un colectivo poblacional homogéneo y ancestral que se corresponde necesariamente con una unidad estatal es un constructo histórico imaginario que se sostiene en la invención narrativa de un pasado capaz de fundar sentido. Esto es, que la posibilidad de constitución, autoconfirmación y continuidad prospectiva de la nacionalidad moderna es posible por acción de una narratividad: un sistema de selección, concatenación e invención de los sucesos capaz de conferir sentido a la experiencia y orientarla hacia un telos comunitario." 164

Para Anderson, atento a la emergencia de un público lector amplio hacia finales del siglo XVIII, las "ficciones homogeneizadoras" que la literatura provee al nacionalismo se desenvuelven especialmente a través de las novelas y la prensa escrita, como prácticas de producción simbólica y discursiva de formas colectivas de la identidad: "Estas formas (novela y periódico)

\footnotetext{
${ }^{162}$ Fernández Bravo, Alvaro (2000, comp.) "Introducción", en: La invención de la nación. Lecturas de la identidad de Herder a Homi Bhabha, ed. cit., p. 14.

${ }^{163}$ Uso la expresión "ficciones de homogeneidad" en el sentido que le asigna Elías Palti, en tanto articulan una comunidad nacional que se vuelve dominante con la modernidad y en las cuales se pretende una homología imaginada entre nación y lengua que se repite en el nivel del imaginario en la homología entre nación y cultura, y específicamente, entre nación y literatura. Véase La nación como problema. Los historiadores y la "cuestión nacional", ed.cit., especialmente capítulo 3 "Emergencia y descomposición del discurso antigenealógico de la nación", pp. 85-129.

${ }^{164}$ Dalmaroni, Miguel (1995). "Introducción. Identidades nacionales y representación literaria: umbrales teóricos, textos argentinos y relecturas", ed. cit., pp. 13-14.
} 
proveyeron los medios técnicos necesarios para la 'representación' de la clase de comunidad imaginada que es la nación." 165

Ahora bien, estas consideraciones teóricas que brevemente he reseñado se complejizan en el caso particular de Puerto Rico, donde no es posible sostener la coincidencia entre nacionalismo y estado, y en donde es insoslayable la continuidad del colonialismo, lo que conduce a Arcadio Díaz Quiñones a cuestionarse que: "(...) la nación pensada e imaginada, paradójicamente estaría doblemente hegemonizada, por el imperio que fue y por el que es." 166 Díaz Quiñones reflexiona sobre cómo desarticular esta doble hegemonía y, citando el magnífico trabajo de Serge Gruzinski ${ }^{167}$, se pregunta cómo descolonizar el imaginario en Puerto Rico, cómo pensar la nación sin "caer en nueva exclusiones o imposibles purezas". ${ }^{168}$ Juan Gelpí, analizando los vínculos entre nacionalismo y representación literaria en la literatura puertorriqueña también puntualiza los límites de las teorizaciones sobre los nacionalismos :

"Entre las literaturas de los países latinoamericanos, la puertorriqueña parecería destacarse por varias razones. En primer lugar, porque la sustenta una contradicción aparente: el hecho que se haya creado una literatura nacional en un país que aún no se ha constituido en nación independiente." ${ }^{169}$

Gelpí, Rodríguez Castro, Díaz Quiñones sostienen que las relaciones entre los textos literarios y la prácticas que construyen el imaginario nacionalista en Puerto Rico son problemáticas, y en varias ocasiones paradójicas o contradictorias. No obstante y a pesar de no haberse constituido el país en estado-nación, hubo sin embargo una "narrativa de la identidad nacional puertorriqueña" en cual y en ciertos momentos particulares del desarrollo histórico-político del país, algunos textos se convirtieron en más

\footnotetext{
165 Anderson, Benedict (1993). Comunidades imaginadas. Reflexiones sobre el origen y la difusión del nacionalismo, ed. cit., pp. 46-47 (cursiva y comillas del autor).

${ }^{166}$ Díaz Quiñones, Arcadio (1993). La memoria rota, ed. cit., p. 143.

${ }^{167}$ Gruzinski, Serge (1991). La colonización de lo imaginario. Sociedades indígenas y occidentalización en el México español. Siglos XVI-XVIII, México, FCE.

${ }^{168}$ Díaz Quiñones, Arcadio (1993). La memoria rota, ed. cit., p. 146. Agrego esta cita en la misma página: "El deseo de pureza de un sentido único, de una identidad, de una lengua, puede llegar a ser, dejando intacto el problema colonial, una temible utopía." (cursivas del autor)

${ }^{169}$ Gelpí, Juan (1993). Literatura y paternalismo en Puerto Rico, ed.cit., p. 7.
} 
representativos que otros. Estos autores preservan en sus estudios el concepto de construcción discursiva de la nación, y también utilizan la tesis de Anderson respecto de la relación entre narratividad y nacionalismo, aunque desprendiéndola de la restricción genérica con la cual la piensa Anderson (novela, prensa periódica). Más bien destacan el hecho de la preferencia, en el caso puertorriqueño, de articular un relato de fundación de la nacionalidad a través del género ensayístico. Así lo sintetiza María Elena Rodríguez Castro:

"En este proceso el ensayo, una escritura abierta pero ordenadora, oscilante entre la voluntad de verdad de los discursos objetivos y la expresividad del arte, fue uno de los modos específicos que asumió la intervención letrada. En el espacio del intelectual sin estado, una posición que problematiza los cimientos de construcción de fuertes identidades nacionales -sus comienzos, su linaje, su sistema de autoridades y tradiciones tanto fundantes como interpretativas- se fabularon proyectos nacionales y se inauguraron los mitos y gestos que aún definen lo puertorriqueño."170

Para leer este relato de la nación puertorriqueña voy a detenerme en el análisis de un conjunto de ensayos, publicados en diferentes coyunturas políticas del país, que responden de muy diversa manera al interrogante sobre la identidad nacional en Puerto Rico. Se trata de Insularismo de Antonio S. Pedreira ${ }^{171}$, editado en 1934; El puertorriqueño dócil de René Marqués ${ }^{172}$, publicado en 1960; El país de cuatro pisos de José Luis González ${ }^{173}$, de 1980, y El arte de bregar de Arcadio Díaz Quiñones ${ }^{174}$, aparecido en el año $2000^{175}$.

\footnotetext{
${ }^{170}$ Rodríguez Castro, María Elena (1993)."Las casas del porvenir: nación y narración en el ensayo puertorriqueño", ed. cit., p. 35.

${ }^{171}$ Pedreira, Antonio S. (1970). Insularismo en: Obras de Antonio S. Pedreira, San Juan, Instituto de Cultura Puertorriqueña, p. 25 (editado originalmente en 1934).

${ }^{172}$ Marqués, René (1972). El puertorriqueño dócil. (Literatura y realidad psicológica), en: Ensayos 1953-1971, Río Piedras, Editorial Antillana, publicado originalmente en 1960, en adelante todas las referencias corresponden a esta edición.

${ }^{173}$ González, José Luis (1982). El país de cuatro pisos y otros ensayos, Río Piedras, Ediciones Huracán, tercera edición, (en adelante todas las referencias corresponden a esta edición). La primera edición de esta colección corresponde al año 1980.

${ }^{174}$ Díaz Quiñones, Arcadio (2000). El arte de bregar. Ensayos, San Juan, Ediciones Callejón, en adelante todas las referencias corresponden a esta edición.

${ }^{175}$ La selección de estos cuatro ensayos implica un recorte parcial sobre un conjunto bastante mayor de ensayos culturales y literarios puertorriqueños cuyo análisis hubiera constituido en sí mismo otra tesis. Tengo presentes, entre otros, los ensayos de Tomás Blanco Prontuario histórico de Puerto Rico (1935) y El prejuicio racial en Puerto Rico (1938); El despertar de un pueblo (1942) de Vicente Géigel Polanco; Historia de la literatura puertorriqueña (1956) de
} 
El ensayo de Pedreira, considerado unánimemente por la crítica como texto fundante y modelo retórico de una escritura de lo nacional, provee imágenes y tópicos acerca de la puertorriqueñidad que fueron posteriormente citados, a veces repetidos, en otras ocasiones redefinidos y también impugnados por un número importante de escritores e intelectuales del país ${ }^{176}$. María Elena Rodríguez Castro señala la función e importancia asignada al ensayo de Antonio S. Pedreira en el interior del campo cultural de la década del treinta y su influencia posterior a estos años:

"Insularismo codificó y prestigió no solo un entramado para la nación, también un modo de narrarla: un sistema de tópicos, imágenes y estrategias narrativas que resistieron la repetición y el desgaste de sus contenidos ideológicos excediendo las fronteras del marco letrado y alojándose permanentemente en el imaginario puertorriqueño." ${ }^{177}$

El ensayo de René Marqués fue publicado como texto contestatario en el momento de auge del desarrollismo populista. Sin embargo, a pesar de su encendido discurso crítico y su aguda ironía, en su dispositio y elocutio ${ }^{178}$ es posible hallar una continuidad respecto del modelo fuerte provisto por Insularismo. En ambos, para usar las categorías de análisis que establece Roberto González Echevarría, es posible escuchar una "voz magisterial", donde se reúnen la figura del autor y de la autoridad a través del emblema del "maestro". Al respecto vale la pena citar un pasaje de González Echevarría referido al ensayismo latinoamericano: "La figura que preside el género del ensayo es la del maestro, cuya tarea es sondear las profundidades del lenguaje

Francisco Manrique Cabrera; "La generación o sea" (1972) de Luis Rafael Sánchez; Sitio a Eros (1980) de Rosario Ferré; el conjunto de textos editado por Ana Lydia Vega, El tramo ancla; ensayos puertorriqueños de hoy (1992); La memoria rota (1993) de Arcadio Díaz Quiñones. La lista queda, de todos modos, incompleta.

${ }^{176}$ Véase el interesante análisis que propone Juan Gelpí acerca de las diversas reescrituras del clásico ensayo Insularismo no solo por otros ensayistas, comoVicente Géigel Polanco sino por escritores de las nuevas generaciones como Luis Rafael Sánchez y Edgardo Rodríguez Juliá, en géneros tales como la novela y la crónica literaria. Gelpí, Juan (1993). Literatura y paternalismo en Puerto Rico, ed.cit., especialmente el capítulo II, "Reescrituras del Clásico", pp. 17-60.

${ }^{177}$ Rodríguez Castro, María Elena (1993). "Las casas del porvenir: nación y narración en el ensayo puertorriqueño", ed. cit., pp. 35-36.

${ }^{178} \mathrm{Me}$ refiero aquí a los términos usados por Roland Barthes para la sistematización de las operaciones de la retórica que propone en su libro Investigaciones retóricas I. La antigua retórica, Buenos Aires, Editorial Buenos Aires, 1982, p. 42 y sigs. 
y la historia con el fin de articular la voz de la cultura y hacerla apta para la diseminación, esto es, convertir esta voz -pura, autóctona- en fuente de autoridad." ${ }^{179}$ La voz del "viejo y venerable maestro" de Ariel (1901) de José Enrique Rodó tan bien estudiada por González Echevarría impregna con su entonación el ensayismo cultural latinoamericano de las tres primeras décadas del siglo XX y actúa como modelo explícito en Insularismo.

La renovación y ruptura en el terreno de la ensayística la observamos en El país de cuatro pisos de José Luis González, donde, desde una abierta perspectiva marxista y afrocaribeña, abrió una polémica puerta hacia nuevos debates sobre la cultura y nación puertorriqueña. Por su parte, El arte de bregar de Arcadio Díaz Quiñones, "brega" a contrapelo de la ensayística puertorriqueña empecinada en fijar identidades y propone un recorrido múltiple y amplio por la cultura del país a través de los diversos sentidos que es posible asignar al verbo "bregar" en el contexto, no solo de la historia puertorriqueña, sino también caribeña.

\section{1 Los intelectuales de la Generación del Treinta, Insularismo y la fundación de una escritura de la identidad puertorriqueña}

Juan Gelpí, en su riguroso estudio sobre las relaciones entre el sistema literario y el "paternalismo" sociocultural puertorriqueño, se detiene particularmente en esta paradoja o contradicción aparente que he señalado un poco antes: ¿cómo se creó una literatura nacional en un país que no se ha constituido aún en nación independiente? Para poder contestar este interrogante se vale de la noción de "paternalismo" que remite a relaciones familiares altamente jerarquizadas y prácticas patriarcales que encumbran la figura del padre. Gelpí señala que en el caso de Puerto Rico se puede ver el nacionalismo cultural como manifestación de un discurso paternalista, cuya retórica remite a las relaciones familiares y su metáfora fundamental consiste

\footnotetext{
${ }^{179}$ González Echevarría, Roberto (2001). La voz de los maestros. Escritura y autoridad en la literatura latinoamericana moderna, Madrid, Verbum, p. 38. "En el seno de la tradición ensayística latinoamericana, esa figura (se refiere a la figuración del autor) ha encarnado en la figura de autoridad pedagógica del maestro, ya que, hasta hace poco, la educación, como parte de la ideología liberal sobre la que se fundan las modernas naciones latinoamericanas, era considerada como la respuesta a los problemas que sobre su propia forma de existencia y futuro enfrentaba el continente." Ibid., p. 40.
} 
en equiparar la nación con una gran familia. Este discurso paternalista emerge con fuerza especialmente entre los integrantes de la Generación del Treinta ${ }^{180}$, quienes, según demuestra Angel Quintero Rivera ${ }^{181}$, padecieron una seria crisis cultural estrechamente vinculada al hecho de que los hacendados criollos -clase de la cual los treintistas eran herederos directos- habían perdido su hegemonía a raíz de la invasión norteamericana de 1898. Para Gelpí esta pérdida de la hegemonía constituye el origen del tema "obsesivo" de este grupo de intelectuales: la búsqueda de la identidad nacional.

La Revista de las Antillas (1913-14) en las primeras décadas del siglo XX, y luego Indice, entre los años 1929 y 1931, precedieron los debates del emergente nacionalismo cultural cuya consolidación se afirma en la década del treinta. La creación de un proyecto de definición de la identidad nacional puertorriqueña se transformó en un objetivo en común, compartido por los miembros de los círculos letrados urbanos, quienes, en el marco de una nueva relación colonial, alarmados por las consecuencias tanto reales como simbólicas del cambio de soberanía, configuraron una ideología que se vehiculizó a través de la práctica literaria. Así, los letrados reunidos en la llamada Generación del Treinta, construyeron relatos unificadores y legitimadores, fundamentados en la autoridad pero también en el consenso, como destaca Gelpí, ya que: "El canon literario que crearon e impusieron en una sociedad colonial ha hecho las veces de una constitución nacional: ha compensado la inexistencia de un Estado nacional independiente." ${ }^{182}$

\footnotetext{
${ }^{180}$ Entre los nombres que se destacan como integrantes de este grupo podemos citar a escritores que ya tenían un notable reconocimiento desde las décadas del diez y del veinte, como Nemesio Canales y Luis Llórens Torres y cuyas obras circularon sobre todo en la Revista de las Antillas. Intelectuales universitarios como Concha Meléndez y Antonio S. Pedreira. Abogadosintelectuales-periodistas como el citado Canales y Miguel Guerra Mondragón; los ensayistas Tomás Blanco, Samuel R. Quiñones y Vicente Géigel Polanco. Sobre la Generación del Treinta véanse Díaz Quiñones, Arcadio (1982). El almuerzo en la hierba (Llórens Torres, Palés Matos, René Marqués), ed. cit., pp. 19-70; Rodríguez Castro, María Elena (1987-1988). "Tradición y modernidad: el intelectual puertorriqueño ante la década del treinta", Río Piedras, Boletín del Centro de Investigaciones Históricas de la Universidad de Puerto Rico, nro. 3, pp. 45-65; Fernández Valledor, Roberto (2000). "La sociedad cubana y puertorriqueña de las décadas del veinte y treinta a través de su ensayística", en: Revista de Estudios Hispánicos, Río Piedras, Universidad de Puerto Rico, vol. XXVII, Núm. 2, pp. 39-49.

181 Quintero Rivera, Angel G. (1985). "La base social de la transformación ideológica del Partido Popular en la década del 40", en Gerardo Navas Dávila, editor, Cambio y desarrollo en Puerto Rico: la trasformación ideológica del Partido Popular Democrático, Río Piedras, Editorial de la Universidad de Puerto Rico, p. 80.

${ }^{182}$ Gelpí, Juan (1993). Literatura y paternalismo en Puerto Rico, ed.cit., p. 15.
} 
Los estudios de Rodríguez Castro, Gelpí, Quintero Rivera, coinciden con la perspectiva de Arcadio Díaz Quiñones ${ }^{183}$, quien observa que, en los discursos literarios puertorriqueños de estas primeras décadas del siglo $X X$, empezó a cobrar fuerza una definición "culturalista" de la nacionalidad, que podía coexistir con la situación de dominación colonial que vivía el país. Esto es, la definición de la nación como una "cultura", al margen de la creación de un estado independiente en el ámbito específico de la política. Para Díaz Quiñones la definición de la "nación" está ligada al poder de la escritura y a los paradigmas que manejan los letrados, y por consiguiente, no puede verse como "expresión" de una realidad previamente constituida al margen de los discursos que la articulan. La retórica del nacionalismo cultural promovida por los intelectuales de la Generación del Treinta constituyó, ante una sociedad de cambios vertiginosos, una suerte de hito de permanencia y continuidad en tanto estos intelectuales se erigieron a sí mismos, con palabras de Rodríguez Castro, en "custodios de una cultura concebida como memoria colectiva", "como voz autorizada y confiable". Ante la especialización y heterogeneidad resultantes de los procesos de modernización, se presentaron "como un factor de orden y cohesión"184. Metáforas colectivas y homogeneizadoras como la ya mencionada de la "gran familia puertorriqueña"; mitos identitarios como el del jíbaro, campesino blanco de la hacienda azucarera anterior a la modernización norteamericana; sentimiento "hispanófilo" como clara reacción antinorteamericana, manifestado en las reiteradas expresiones que conciben a Puerto Rico como una porción de España en el Caribe; defensa de la "pureza" lingüística del castellano ante la cercanía "contaminante" del inglés, constituyen algunos de los principales tópicos que recorren la escritura ensayística del nacionalismo cultural puertorriqueño de aquel momento.

Antonio S. Pedreira (1899-1939), quien encarnó la figura del "intelectual universitario", modernizó y profesionalizó la historiografía y la crítica literaria en Puerto Rico, siguiendo el modelo académico aprendido en los estudios hispánicos de la Universidad de Columbia, donde había cursado sus estudios, y de su prestigioso maestro Federico de Onís. Activo colaborador de la revista

\footnotetext{
${ }^{183}$ Díaz Quiñones, Arcadio (1993). La memoria rota, ed. cit., p. 65.

${ }^{184}$ Rodríguez Castro, María Elena (1993)."Las casas del porvenir: nación y narración en el ensayo puertorriqueño", ed. cit., p. 35.
} 
Indice (1929-1931), su obra más difundida fue su ensayo Insularismo. En ella diseñó un proyecto de reforma intelectual, cuyo desafío fue, como destaca Díaz Quiñones, "(...)abolir el paradigma de la 'inferioridad' cultural que el discurso colonial postulaba para realzar la 'superioridad' imperial." 185

Juan Gelpí observa que Insularismo se leyó como un ensayo de interpretación de la historia de Puerto Rico. Erigido en uno de los clásicos de la literatura puertorriqueña, en las décadas del cuarenta, cincuenta y sesenta no se interpretó en tanto acontecimiento discursivo con una retórica y unos procedimientos literarios específicos, es decir como una escritura, según subraya Gelpí, sino como una especie de logos o voz fundadora de una "verdad" acerca de la nacionalidad puertorriqueña ${ }^{186}$. Su análisis se propone especialmente volver visibles los dispositivos retóricos y textuales del ensayo de Pedreira, entre los que se destaca un reiterado empleo del lenguaje figurado basado en el uso de metáforas. La más reconocida es la que equipara a Puerto Rico con una gran familia ${ }^{187}$, imagen que sigue modos consabidos en el marco de la ensayística y literatura latinoamericanas, como una metáfora que difumina las diferencias y tensiones étnicas, de clase, culturales, regionales, y más bien promueve una armonía artificial.

La comparación del país con una gran familia vertebra la construcción de un discurso conciliador. El ámbito de las relaciones familiares se convierte en un lugar primordial y privilegiado para cimentar una comunidad. Lo nacional y lo familiar se superponen y, por lo tanto, la familia es emblema de la nación. En Insularismo la metáfora familiar se correlaciona con el tópico de la búsqueda de una figura paterna simbólica, presente en épocas pasadas, pero ausente en el aquí y ahora de la voz enunciadora del ensayista:

\footnotetext{
${ }^{185}$ Díaz Quiñones, Arcadio (1997). "Isla de quimeras: Pedreira, Palés y Albizu", en: Revista de Crítica Literaria Latinoamericana, Año XXIII, Nro. 45, Lima-Berkeley, 1er. semestre, pp. 229246, la cita corresponde a la p. 232. Para el análisis del ensayo de Pedreira tengo presentes como bibliografía, además del artículo de Díaz Quiñones recién citado, el capítulo II de Juan Gelpí en Literatura y paternalismo, ed. cit., titulado "Reescrituras del Clasico", pp.17-60; Flores, Juan (1979). Insularismo e ideología burguesa (Nueva lectura de A.S. Pedreira), Río Piedras, Ediciones Huracán, particularmente pp. 83-90 y Rodríguez Vecchini, Hugo (1993). "Palés y Pedreira: la rumba y el rumbo de la historia", en: La Torre. Revista de la Universidad de puerto Rico, año VII, núms. 27-28, pp. 595-627; Rodríguez Castro, María Elena (1993)."Las casas del porvenir: nación y narración en el ensayo puertorriqueño", ed. cit., pp. 33-54.

${ }^{186}$ Gelpí, Juan (1993). Literatura y paternalismo en Puerto Rico, ed.cit., pp. 18-19.

${ }^{187}$ Volveré sobre el tópico de la familia puertorriqueña, especialmente a partir de su puesta en crisis en las crónicas de actualidad de Edgardo Rodríguez Juliá, en el capítulo III.
} 
"Los hombres de mi generación hemos buscado inútilmente un hombre superior a nuestras luchas intestinas, a cuya sombra acogedora y pura pudiéramos oír con claridad la voz de nuestro mito. A cada rato, en que la avaricia política nos pelotea sin videncia, esta generación en tela de juicio vuelve los ojos hacia el vacío que han debido llenar los equivalentes de Hostos, de Giner, de Rodó, de Varona, forjadores de pueblos y de conciencias". ${ }^{188}$

La ausencia del "padre", del prócer, de la figura rectora y conductora, se relaciona de manera directa con otra imagen fundamental en Insularismo: la infantilización del país. Pedreira compara los primeros tres siglos de la historia de Puerto Rico con un "período de lactancia"; el siglo XIX es el momento en que el país "niño" comienza a gatear: "Desde la falda de la nación descubridora hicimos las primeras gracias. Luego empezamos a gatear y a recibir golpes; al empezar el siglo XIX dimos, con marcada dificultad, los primeros pasos en el campo de la cultura." ${ }^{189}$ El lenguaje connotativo apela también a la retórica organicista: el país, como un niño, debe cumplir determinadas etapas de su desarrollo y crecimiento para alcanzar la adultez. Pero esta última etapa, en la visión de Pedreira, no llega a plasmarse satisfactoriamente por la interrupción, el "trauma" o "síncope" con el cual se alude y se nombra a la invasión norteamericana de 1898. Pedreira organiza una red metafórica cuya imagen central es la enfermedad. ${ }^{190}$ Así el país puede pensarse como un cuerpo enfermo, y sus males sociales como enfermedades, que necesitan curaciones radicales. En Insularismo la enfermedad se "nacionaliza" y el mal que aqueja a Puerto Rico es el colonialismo. Se representa al país como un cuerpo enfermo, caracterizado con una serie de notas negativas: es un país raquítico, anémico, agotado, abúlico, paralítico, invertebrado. La patología metafórica está unida al determinismo biológico del que se sirve el autor para presentar la formación histórica de Puerto Rico, donde se advierte una marcada reacción ante la mezcla y la heterogeneidad racial. La apelación al lenguaje científico, que puede diagnosticar la presunta enfermedad nacional, revela la existencia de un

\footnotetext{
${ }^{188}$ Pedreira, Antonio S. (1970). Insularismo, ed. cit, p. 166.

${ }^{189}$ Ibid., p. 136.

${ }^{190}$ Para un análisis de la retórica de la enfermedad y del uso de las metáforas patologizantes véase Sontag, Susan (1996). La enfermedad y sus metáforas y El sida y sus metáforas, Madrid, Taurus, p. 73.
} 
discurso, de un espacio ideológico y textual desde el cual enuncia un tipo de escritor que se posiciona como médico figurado. Pedreira diagnostica a Puerto Rico como un "país-niño", sin rumbo, lo que sugiere la necesidad de personas esclarecidas, que deseen y puedan guiar al país. Estas tienen que surgir de la juventud letrada, quien vendrá naturalmente a reemplazar a los hombres de la generación del autor. A esa juventud se le confía una importante misión: "esclarecer nuestros altos menesteres", a través de la "capacidad comprensiva, dilatación, ensanche, urbanización mental". ${ }^{191}$ Teniendo en cuenta las épocas históricas y los personajes que en ellas intervienen, el texto se escinde en dos tiempos: por un lado, un pasado y un presente marcados por la confusión, enfermedad, infantilismo e incertidumbre, y por otro, un futuro utópico, en el cual se espera que la juventud supere las luchas intestinas que han retardado el crecimiento del país- niño. Esa juventud habrá de "inyectar sanidad, sangre nueva, optimismo y alegría en el cuerpo desgastado de la sociedad". ${ }^{192}$

En el capítulo llamado "Alarde y expresión", Pedreira asume el lugar del crítico literario y traza el itinerario de las obras representativas de la literatura puertorriqueña. Una vez más, el autor acude a la metaforización patológica para describir la "larga pulmonía poética" por la que atraviesan las letras; alerta a los jóvenes escritores contra los peligros de la sensibilidad exacerbada que solo conduce a "momentos enfermizos cargados de idiotez"; respecto a las estéticas foráneas advierte acerca de los riesgos de "la transfusión de glóbulos blancos" (es decir, "importar" estéticas que debiliten las "esencias" de una literatura propia). La genealogía literaria que construye Pedreira comienza en el siglo XIX, más precisamente con la publicación en 1849 del poema El Gíbaro, de Manuel Alonso, en el cual aparece la primera mitificación del campesino blanco, figura emblemática nacional para los treintistas: "Salvando las distancias, El Gíbaro, es nuestro Poema del Cid y nuestro Martín Fierro. Si por su forma sigue tenazmente amarrado a la literatura española, por su esencia y sus fervores pertenece por entero a la cultura puertorriqueña." ${ }^{193}$

\footnotetext{
${ }^{191}$ Pedreira, Antonio S. (1970). Insularismo, ed.cit., p. 131.

192 Ibid., p. 170.

${ }^{193}$ Pedreira, Antonio S. (1970). Insularismo, ed.cit. , p. 59 (el subrayado es mío).
} 
Otros autores rescatados para formar parte de la tradición literaria nacional son el poeta Luis Llórens Torres y el novelista Manuel Zeno Gandía, quien en su obra La charca inaugura la retórica de la enfermedad antes aludida, al presentar la anemia como imagen del estancamiento colonial en las comunidades rurales. El movimiento poético vanguardista de los atalayistas se excluye del canon, como así también la producción literaria femenina ${ }^{194}$ : "Esa cosa que por ahí llaman atalayismo tiene para mí un profundo sentido experimental que solo irrita a los espíritus asustadizos." 195

En Insularismo se reelabora una nueva versión de la oposición civilización/barbarie, para reemplazarla por la sutil dicotomía civilización/cultura. Del lado de la civilización coloca el innegable progreso alcanzado en la Isla a raíz de los efectos modernizadores norteamericanos, como la industrialización incipiente, la tecnologización agraria, la expansión comercial, entre otros. Sin embargo, los avances "civilizadores" suponen también su faz negativa: el detrimento de la cultura, que según la definición de Pedreira, implica "el repertorio de condiciones que dan tono a los sucesos, y cauces a la vida de los pueblos; esa peculiar reacción ante las cosas -maneras de entender y de crearque diferencia en grupos nacionales a la humanidad."196 Para el escritor la civilización es horizontal, mientras que la cultura es vertical, espacializando jerárquicamente dos áreas, y los miembros que representan a cada una: "...diría hoy que somos más civilizados, pero ayer éramos más cultos."197,

\footnotetext{
${ }^{194}$ Este pasaje revela la misoginia del ensayista: "Nuestras mujeres dirigentes se conforman en hablar en los mítines y alcanzar algunos puestos para las asociadas. Alguna que otra flirtea con la cultura y en general son amantes de los bridge parties y se desviven por la crónica social. Cultivan unas ideas chiquititas y llevan en el vanity unas cuantas procupaciones de ocasión". Y más adelante, para que no queden dudas hacia qué sector femenino se está dirigiendo, el autor aclara: "...me refiero a las mujeres intelectuales, organizadoras, que ocupan la atención pública y están en condiciones de rendir mejores servicios a la cultura. Si éstas no logran penetrar en el riñón del pueblo y en el corazón de la isla, no deben tener a descortesía que alguien les señale deficiencias. Ruego, además, a mis lectoras, tener en cuenta que no estoy escribiendo madrigales." (Insularismo, ed.cit., pp. 110 y 111, el subrayado es mío). Es notable que a pesar de la explícita descalificación de la mujer, una intelectual de los años cincuenta como Margot Arce de Vázquez cuestiona la visión superficial que Pedreira tiene de la mujer, pero rescata la "actualidad palpitante" del ensayo. Las impugnaciones más profundas son las que llevan a cabo las escritoras, a partir de los años setenta y ochenta, entre ellas Rosario Ferré desde las páginas de la revista que dirigió entre 1972 y 1975 , Zona de carga y descarga, y Ana Lydia Vega, en su cuentística y ensayos.

${ }^{195}$ Ibid., p. 66.

${ }^{196}$ Ibid., p. 28.

${ }^{197}$ Pedreira, Antonio S. (1970). Insularismo, ed. cit., p. 88.
} 
concluye con nostalgia. Según el análisis de Pedreira la crisis cultural se manifiesta en dos instituciones principales: la escuela y la lengua. Cuando Puerto Rico pasa a ser colonia de los Estados Unidos, comienza una campaña oficial dirigida a asimilar la isla a la órbita cultural norteamericana, proceso al que se denominó el "American way of life". En 1917 se impuso unilateralmente la ciudadanía norteamericana a todos los puertorriqueños. En las instituciones educativas se implantó la enseñanza del inglés como lengua obligatoria, medida cuyos avatares analicé en el capítulo anterior. ${ }^{198}$ Mediante la imagen de la "nave al garete", el ensayista intenta representar la situación de "medianía" que aqueja al puertorriqueño, un estado de transición y desorientación al situarse en medio de dos culturas, dos lenguas, dos banderas: "¿Adónde vamos? ¿Cuál ha de ser el status definitivo de la isla? ¿Estado federal? ¿República independiente? ¿Autonomía con protectorado?" ${ }^{199}$ El bilingüismo también se puede leer como una metáfora, en este caso de la inestabilidad y fluctuaciones históricas de un pueblo, y sus consecuencias se enuncian, una vez más, desde el campo semántico de la enfermedad: "El empobrecimiento de la lengua materna degenera en gangosa tartamudez, y al cabo de los años las consecuencias tienen que ser fatales para nuestra cultura."200

Juan Gelpí observa una marcada "hispanofilia" en Pedreira, aunque no es posible hallar en Insularismo una apología del orden colonial español. Me parece más interesante la posición de Arcadio Díaz Quiñones quien observa que en la retórica y el lenguaje de Pedreira hay varios elementos tomados de la llamada "generación del 98" española, cuyos autores fueros muy frecuentados por el ensayista y que por tanto impregnan su discurso. España aparece más bien como lugar prestigioso, "origen inmemorial de la cultura"201, ya que lo hispánico le permite establecer un hilo de continuidad histórica entre el pasado y el presente, al cual define siempre en términos de "transición", "tránsito". Sin embargo el derrumbe del antimoderno régimen español era condición necesaria para la emergencia de Puerto Rico según la perspectiva de Pedreira. Al respecto señala Díaz Quiñones: "El ocaso del imperio español le permitió

\footnotetext{
${ }^{198}$ Véase la nota 116 del capítulo I.

${ }^{199}$ Pedreira, Antonio S.(1970). Insularismo, ed. cit., pp. 89-90.

${ }^{200}$ Ibid., p. 90, el subrayado es mío.

${ }^{201}$ Díaz Quiñones, Arcadio (2000). "Pedreira en la frontera", en: El arte de bregar, ed. cit., p. 100.
} 
construir la tríada España-Puerto Rico-Estados Unidos como un drama histórico en el que Puerto Rico emergiera como protagonista" ${ }^{202}$. Si apelamos a desplegar la red metafórica topográfica que impregna a Insularismo, cuando Pedreira habla de "tránsito" alude, como respuesta al no lugar entre imperios antes referido, a la negociación de un lugar propio para Puerto Rico, aunque sin desaprovechar las posibilidades de la manipulación de la cultura española y la civilización norteamericana en la conformación de los nuevos sectores intelectuales. Si hay un enemigo externo éste es el mar y la insularidad puesto que entrañan riesgos de aislamiento para el desarrollo y progreso del país; el enemigo interno son los puertorriqueños negros y mulatos, masas patologizadas en el ensayo, como así también la creciente y peligrosa presencia femenina en el ámbito público. Estos sectores son percibidos como "extraños", "invasores", y por su alteridad obstaculizan la construcción de una sociedad homogénea.

Pedreira comienza su ensayo concibiendo su reflexión sobre la cultura e historia puertorriqueñas en términos de relato de viajes, itinerario, recorrido, como un desplazamiento en el tiempo cuyo final es una apuesta al futuro. Se despide del lector en un último apartado titulado "Juventud, divino tesoro", sector en el cual se deposita la esperanza para la conformación de la puertorriqueñidad. No apela a todos los jóvenes sino especialmente a los sectores ilustrados, a los estudiantes universitarios, asumiendo una posición, como diría González Echevarría, tanto magistral como magisterial, donde, no sólo los jóvenes destinatarios explícitos, sino también los lectores del ensayo se encuentran en situación de statu pupillari:

"El recurso a la forma de diálogo es una manera de situar a la audiencia, de colocarla en una posición subordinada con respecto al hablante. Aunque ostensiblemente la forma dialógica parecería promover la dialéctica, lo que realmente posibilita es una entronización de la voz del maestro, un despliegue monofónico, un discurso, en resumen, que estratégicamente fomenta la impresión de un efecto polifónico: magister dixit, magister dicta."203

\footnotetext{
${ }^{202}$ Díaz Quiñones, Arcadio (2000). "Pedreira en la frontera", en: El arte de bregar, ed. cit., p. 101.

${ }^{203}$ González Echevarría, Roberto (2001). La voz de los maestros. Escritura y autoridad en la literatura latinoamericana moderna, ed.cit., p. 47.
} 
Para concluir este apartado y procurar dar cuenta de esta voz magistral y magisterial de Pedreira me permito incorporar el siguiente fragmento, a pesar de su extensión, con el cual se cierra Insularismo:

"Podéis pensar, jóvenes de mi tiempo que la historia comienza ahora, que sois vosotros los llamados a llenarla, a darle el contenido ideal que todo hombre puro quisiera para su patria. Si queréis ser leales con vosotros mismos y leales con las demandas del momento en que vivimos tenéis que maniobrar por todos los caminos de la historia y cifrar con esmero vuestra conducta, para que algún día caiga satisfecha en sus anales. De lo contrario seréis siempre una juventud cronológica, cargando sin remedio con vuestras arcas vacías.

Atended al divino tesoro, pues el título más alto se puede convertir en mote." 204

\section{2. Colonialismo y crisis del modelo populista en El puertorriqueño dócil de René Marqués}

Juan Gelpín ${ }^{25}$ analiza cómo los dirigentes del Partido Popular Democrático se apropiaron del ensayo de Pedreira a principios de la década del cuarenta, en el sentido de proyectar en el texto, sobre todo en la nostalgia de una figura rectora del país, la prefiguración reparadora de esa ausencia mediante el liderazgo de Luis Muñoz Marín. Para mejor comprender la continuidad retórica e ideológica de Insularismo durante la década del cuarenta se detiene en un texto que representa de manera directa la colectividad política del Partido Popular Democrático. Se trata de la colección de discursos y ensayos publicada en 1942 por Vicente Géigel Polanco, llamada El despertar de un pueblo. ${ }^{206}$ Este autor trabajó junto con Pedreira en varios proyectos literarios, siendo el más significativo la publicación de la revista Indice entre los años 1929 y 1931. En el libro de Géigel Polanco se le otorga a Luis Muñoz Marín un papel privilegiado, lo que subraya el carácter de "propaganda política" que adquiere este texto. Arcadio Díaz Quiñones destaca las principales líneas que configuran el imaginario utópico de El despertar de un pueblo:

\footnotetext{
${ }^{204}$ Pedreira, Antonio S.(1970). Insularismo, ed. cit., pp. 175-176.

${ }^{205}$ Gepí, Juan (1993). Literatura y paternalismo en Puerto Rico, ed. cit., pp. 48-49.

${ }^{206}$ Géigel Polanco, Vicente (1942). El despertar de un pueblo, San Juan, Biblioteca de Autores Puertorriqueños.
} 
"Era un tiempo adánico: el despertar de un pueblo. Con esa vieja metáfora, renovada por Vicente Géigel Polanco, se proponía la inauguración de un tiempo más feliz. Aquella utopía inspiró 'jalda arriba' grandes transformaciones materiales y sociales nada desdeñables para amplios sectores de la población puertorriqueña. El discurso histórico, literario y político alegorizaba así, hacia 1940, el advenimiento de un nuevo orden. Era la época en que las 'muchedumbres felices' despertaban y salían de su 'postración moral', a la lucha contra el adversario: las corporaciones azucareras. Todo el proceso se representaba como el movimiento de un pueblo que se movía al unísono. La historia, interrumpida por el 'tiempo muerto' se reanudaba en 1940 con el triunfo del Partido Popular Democrático."207

El optimismo populista de aquellos años, al término de los años cincuenta, sin embargo, se había eclipsado. El proyecto político del PPD comenzaba a mostrar los primeros signos de su crisis, que se manifestaron de manera clara en los años sesenta, al comprobarse que la economía de Puerto Rico prácticamente importaba todo lo que consumía, se constataban fuertes alzas en las tasas de desocupación y la política emigratoria no resolvía satisfactoriamente el problema del "exceso" de población. El carácter dependiente de la industrialización repercutió en el sesgo independentista que adquirió la obra literaria de René Marqués (1919-1979), cuyos textos más significativos fueron producidos en la década del cincuenta. Dramaturgo, novelista, cuentista, ensayista, René Marqués, considerado un autor canónico en el campo literario puertorriqueño, "...es uno de los escritores más representativos de nuestro espíritu nacional, de los más concientes de los males de la colonia" ${ }^{208}$, señalaba Nilita Vientos Gastón, directora de la prestigiosa revista Sin Nombre, en un número de homenaje al autor en el mismo año de su muerte. Su ensayo más difundido, El puertorriqueño dócil (Literatura y realidad psicológica), recibió en 1960 el Premio de Ensayo del Ateneo Puertorriqueño. Legitimado socialmente por las instituciones literarias

\footnotetext{
${ }^{207}$ Díaz Quiñones, Arcadio (1983). "Recordando el futuro imaginario...", ed.cit., p. 6. (Los subrayados son del autor)

${ }^{208}$ Véase "Homenaje a René Marqués", número especial de la revista Sin Nombre, San Juan, Puerto Rico, vol. X No. 3, octubre-diciembre de 1979. Se cita el texto de la directora de la revista, Nilita Vientós Gastón "René Marqués", pp. 9 y 10. Este volumen recoge trabajos de escritores como Luis Rafael Sánchez y trabajos de críticos como María Teresa Babín, Arcadio Díaz Quiñones, Margot Arce de Vázquez, entre otros.
} 
académicas, el texto de Marqués pone en escena la construcción de una imagen de escritor poderosa, en la que se proyecta una idea de la función social del mismo que desborda el ámbito discursivo literario y que convierte a la práctica de la escritura no solo en una estética sino también en una ética. Si en Insularismo es posible reconocer intertextos de autores tales como José Ortega y Gasset, Miguel de Unamuno, Oswald Spengler, Enrique Rodó, en El puertorriqueño dócil es muy fuerte la impronta de Jean Paul Sartre y su tesis del escritor comprometido, como así también las ideas de Albert Camus respecto a la rebeldía del intelectual. Una cita del ensayo de Marqués resulta esclarecedora para revelar el lugar asignado a la figura del escritor en la sociedad particular de su presente:

"En este sentido puede decirse que la literatura puertorriqueña durante las dos últimas décadas -anterior y posterior al Estado Libre Asociadoha sido fundamentalmente antiestadolibrista. Se comprende que así sea puesto que el escritor -rebelde con causa- jamás podrá conciliar, ni en Puerto Rico ni en sociedad alguna del mundo civilizado, su concepto ético de la libertad y la dignidad humana con la realidad antiética del colonialismo bajo cualquier nombre o circunstancia en que éste se produzca." 209

En el ensayo de Marqués el colonialismo ya no se expresa mediante una retórica de la enfermedad ni a través de un lenguaje figurado que identifica al país con un cuerpo, sino mediante una determinada "personalidad" (psíquica, espiritual) del pueblo puertorriqueño. El rasgo colectivo que identifica y responsabiliza como causa esencial del colonialismo reside en el concepto de "docilidad", característica que Marqués toma y reinterpreta de un artículo del crítico literario norteamericano Alfred Kazin, quien en su estadía como profesor visitante de la Universidad de Puerto Rico publicara un polémico artículo titulado "A critical view at Puerto Rico"210:

\footnotetext{
${ }^{209}$ Marqués, René (1972). El puertorriqueño dócil (Literatura y realidad psicológica), en: Ensayos: 1953-1971, ed.cit., pág. 171. (El subrayado es mío).

${ }^{210}$ El artículo de Kazin fue publicado en el periódico The San Juan Star a fines de febrero de 1960 y René Marqués le respondió en inglés con otro artículo, publicado en el mismo periódico el 8 d emarzo de 1960, con el título "The sound and fury of Mr. Kazin's critics". Traducido por el propio Marqués, es incorporado en su volumen Ensayos: 1953-1971, ed. cit., con el título "El ruido y la furia de los críticos del Sr. Kazin", pp. 117-130.
} 
"Tal parece que lo que algunos norteamericanos han resentido más en las declaraciones de Alfred Kazin es su afirmación de que los puertorriqueños somos dóciles. ¿Pero es que no lo somos? Va sin decirse que, como puertorriqueño, me resulta detestable tener que admitirlo. Pero siendo honrado no me queda otro remedio que aceptarlo así."211

El artículo de Kazin había provocado reacciones bastante airadas entre los norteamericanos residentes en la Isla. Con ironía René Marqués responde críticamente no solo a Kazin sino a esos mismos sectores que: "...asumiendo el papel de nuevos Quijotes, prefieren defender al 'pobre puertorriqueño' de los ataques del Sr. Kazin"212. Mediante una reintrepretación de las proposiciones enunciadas por Kazin, Marqués homologa los adjetivos "dócil" y "pacífico", aludiendo explícitamente a la política conciliadora del estadolibrismo impulsada por el gobernador Luis Muñoz Marín, cuya acción de propaganda hacia el exterior había acuñado y promovido la frase "revolución pacífica"213. En este texto deja abierta la necesidad de profundizar el problema de la docilidad, lo que efectivamente lleva a cabo unos meses después en El puertorriqueño dócil. Este ensayo comienza con una serie de definiciones y etimologías de la palabra docilidad de las cuales el autor adopta una, tomada del Gran diccionario de Sinónimos castellanos de Roque Barcia:

" 'Docilidad es carecer de fuerza y aun de voluntad para oponer resistencia a lo que los demás exigen, insinúan o mandan; cierta como propensión a obedecer, a seguir el ejemplo, el consejo de otros, lo cual nace ya de la propia debilidad y flaqueza, ya de ignorancia, y de desconfianza de la propia inteligencia, conocimiento o fuerza'. Ateniéndonos a la anterior definición, de ella se desprende que el hombre sumiso, manso o dócil es necesariamente un ser débil ('carece de fuerza y aun de voluntad') o ignorante (lo cual nace..., de 'ignorancia') o víctima de un patético complejo de inferioridad ('desconfianza de la propia inteligencia, conocimiento o fuerza')"214.

\footnotetext{
${ }^{211}$ Marqués, René (1972). "El ruido y la furia de los críticos del Sr. Kazin", en Ensayos: $1953-$ 1971, ed. cit., p. 122.

${ }^{212}$ Ibid., p. 120.

${ }^{213}$ Véase Picó, Fernando (1988). "La década 'tranquila': 1955-1965", capítulo 14 de Historia general de Puerto Rico, Río Piedras, Huracán, especialmente pp. 270-273.

${ }^{214}$ Marqués, René (1972). El puertorriqueño dócil (Literatura y realidad psicológica), ed. cit., pp. 153-154.
} 
El lugar de enunciación que asume Marqués no es muy diferente del ocupado por Pedreira en Insularismo: prevalece la función diagnosticadora del intelectual, ya no de un cuerpo enfermo sino de una "personalidad" colectiva. Se identifica la imagen del escritor construida en el texto con la del "psicólogo social". Marqués no se distancia de ciertas construcciones imaginarias del pueblo puertorriqueño, presentes en tradiciones literarias anteriores aunque próximas al autor, como las de los ensayistas Antonio S. Pedreira, Emilio S. Belaval y Tomás Blanco, como así también en obras de ficción, como la producción novelística de Enrique Laguerre. Estos autores conformaron una determinada práctica discursiva caracterizada por ejes tan significativos como la vinculación cultural con las tradiciones hispánicas, la defensa del castellano, la representación de los valores del mundo rural boricua y sus hombres, la idealización del mundo pasado y perdido por la invasión norteamericana. Se los conoció con el nombre de "jibaristas", por haber hecho del jíbaro, campesino blanco, un emblema de la nacionalidad. Muchas de las ideas que impregnan estos textos se refieren, de manera pesimista, a la imposibilidad de enfrentar la avasallante cultura metropolitana estadounidense. En general, en sus obras persiste una tendencia a analizar y explicar tendenciosamente el "conformismo colectivo", en las características étnicas o psicológicas del "ser puertorriqueño". Los personajes de ficción y las caracterizaciones del puertorriqueño en los ensayos y obras de ficción coinciden en estigmatizarlo como "ñangotado", "aplatanado", "invertebrado" y, como observamos en Marqués, "dócil". Para los jibaristas habría una suerte de persistencia casi determinista de rasgos que caracterizan al sujeto colectivo puertorriqueño y que impediría por tanto a la comunidad concretar con éxito su lucha por la independencia. Marqués traza la continuidad histórica entre aquellas imágenes del puertorriqueño del pasado y el puertorriqueño actual, aunque desprendiéndose de las tesis deterministas. Para el escritor la docilidad ha de considerarse "característica adquirida" más que "mal hereditario o congénito"215, apuntando críticamente al sistema político de Puerto Rico que, complacientemente, sostiene el colonialismo:

\footnotetext{
${ }^{215}$ Este deslinde que le permite a Marqués, a pesar de la comunión ideológica, separarse de los jibaristas, no se realiza en el cuerpo central del ensayo sino en nota al pie bajo la numeración 46 .
} 
"Lo que en la década del veinte era aplatanado (moralmente aplastado, sumiso) y ñangotado (espiritualmente en cuclillas) -ambos términos, invenciones lingüísticas del propio puertorriqueño cuando aun se permitía el lujo de ser franco consigo mismo, son ya reveladores de su psicología- se convirtió en 1930 en resignado y fatalista, para evolucionar con la hipocresía ladina hasta el pacífico y tolerante, que hoy hemos puesto en boga. Pero es el político actual en colaboración con algún que otro sociólogo complaciente, quienes han llevado el concepto al colmo de la expresión eufemista: el puertorriqueño dócil ha venido a ser, para ellos, nada más y nada menos que democrático"216

Una vez más la referencia a las políticas internas y externas alentadas por Partido Popular Democrático y su líder Muñoz Marín se torna explícita. Puerto Rico fue incluido desde 1950 en el programa de asistencia técnica a los países en vías de desarrollo que formó parte de la política exterior norteamericana bajo la presidencia de Harry S. Truman, en pleno contexto de la guerra fría. Truman anunció el ofrecimiento del programa en el cuarto punto de su discurso inaugural de 1949, cuando hizo un llamado a los países democráticos para que pusieran sus recursos y conocimientos técnicos a disposición de las entonces llamadas áreas "atrasadas" del mundo. La participación de Puerto Rico en el punto IV fue fundamental para la internacionalización del modelo de desarrollo dependiente "Operación manos a la obra" y la defensa de la fórmula del estadolibrismo. El Partido Popular Democrático desplegó una enorme publicidad favorable a desarrollar este punto, para sustituir la llamada imagen del país como "tierra azotada" por la más amable de "vitrina de la democracia"217. Pero, según la cientista social Mayra Rosario Urrutia, a través del punto IV no se habría logrado una real democratrización del país sino una vía, Puerto Rico mediante, para canalizar las políticas estadounidenses colonialistas, especialmente respecto a América Latina y el Caribe ${ }^{218}$. Para Marqués la democracia en su país no es compatible con la persistencia del colonialismo, de allí que homologue dócil y democrático:

\footnotetext{
${ }^{216}$ Marqués, René (1972). El puertorriqueño dócil (Literatura y realidad psicológica), ed. cit., p. 156. (Las cursivas son del autor).

217 Sobre esta cuestión véase Urrutia, Mayra Rosario (1993). "Detrás de 'La Vitrina': expectativas del Partido Popular Democrático y política exterior norteamericana, 1942-1954", en Alvarez-Curbelo, Silvia y Castro, María Elena (editoras). Del nacionalismo al populismo: cultura y política en Puerto Rico, Río Piedras, Ediciones Huracán y Universidad de Puerto Rico, pp. 147-177.
} 
"Si aplatanado era aguijón hiriente clavado con fines éticos en el marasmo del alma colonial, su más flamante sinónimo -democrático- es droga estupefaciente piadosamente vertida sobre la conciencia del hombre dócil puertorriqueño para que éste acepte, sin escrúpulos, su condición de tal." 219

Si bien Marqués no apela en este ensayo al tópico de la familia puertorriqueña, alude sin embargo a la composición familiar y su correlato con lo social, para indagar las variadas causas de la docilidad puertorriqueña. Como en el caso de Pedreira la prédica del ensayista se impregna de una marcada misoginia ${ }^{220}$, donde se revela la nostalgia de lo que en el presente se vive como pérdida: el cambio de la organización familiar sustentada en la figura del pater familiae por lo que Marqués señala como "...instauración del patrón matriarcal estilo anglosajón en 1940 y su consecuente y arrollador desarrollo en el transcurso de los últimos veinte años." ${ }^{221}$ Resulta interesante observar cómo estalla y se revela en el discurso, sin ninguna sutileza, una apología del machismo como "baluarte cultural" del puertorriqueño, que para el autor aparece defendido sólo en el espacio de las prácticas literarias de los escritores masculinos:

"Aparentemente, son ellos -los escritores- los únicos que en la sociedad puertorriqueña han reaccionado con agresividad y rebeldía ante la desaparición del último baluarte cultural desde donde podía aún combatirse, en parte, la docilidad colectiva: el machismo, versión criolla de la fusión y adaptación de dos conceptos seculares, la honra española y el pater familiae romano."222

\footnotetext{
${ }^{218}$ Urrutia, Mayra Rosario (1993). "Detrás de 'La Vitrina': expectativas del Partido Popular Democrático y política exterior norteamericana, 1942-1954", ed.cit., p. 149.

${ }^{219}$ Marqués, René (1972). El puertorriqueño dócil (Literatura y realidad psicológica), ed. cit., p. 158.

${ }^{220}$ Para un análisis de la presencia del par misoginia y machismo en René Marqués véanse los siguientes artículos: Solá, María (1979). "René Marqués ¿Escritor misógino?", Sin Nombre, San Juan, Puerto Rico, vol. X No. 3, octubre-diciembre, pp. 83-97, y Barradas, Efraín (1977). "El machismo existencialista de René Marqués", Sin Nombre, San Juan, Puerto Rico, vol. VIII, No. 3, octubre-diciembre, pp. 69-81.

${ }^{221}$ Marqués, René (1972). El puertorriqueño dócil (Literatura y realidad psicológica), ed. cit., p. 170.

${ }^{222}$ Marqués, René (1972). Ibid., p. 171.
} 
Como Pedreira, que veía con desasosiego la creciente presencia femenina en el espacio público, Marqués, con palabras y conceptos casi idénticos a pesar del lapso temporal que distancia a uno y otro ensayista, se refiere con temor al "avance agresivo" ${ }^{\text {"23 }}$ de la mujer en las diferentes esferas sociales de la vida puertorriqueña. El pasaje recién citado es muy revelador también respecto de la función social que el ensayista le asigna a la literatura, ya que el subtítulo de El puertorriqueño dócil es (Literatura y realidad psicológica), escrito entre paréntesis, con pretensión aclaratoria. ¿Dónde radica para el autor el vínculo entre ambos campos? En su concepción y construcción de un programa ideológico y literario de tesis, como prácticamente lo ejemplifica la mayoría de sus textos de ficción. Según Arcadio Díaz Quiñones la obra del escritor "...vista en conjunto y a pesar de su aparente diversidad, es

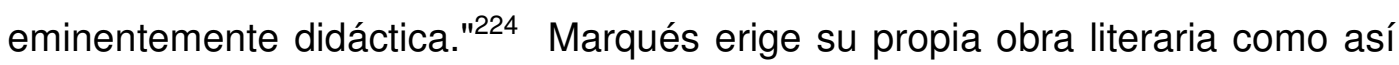
también la de algunos escritores puertorriqueños contemporáneos a la suya (Enrique Laguerre, César Andreu Iglesias, entre otros) como ejemplos de "escritura subversiva"225. Es el escritor "inconforme" el que pone al descubierto en sus obras la realidad psicológica del puertorriqueño, es decir su docilidad, sugiere el ensayista, simplificando los variados y complejos vínculos entre literatura y sociedad. Marqués percibe en la literatura puertorriqueña, especialmente en la producida por los sectores más jóvenes -entre ellos José Luis González, Pedro Juan Soto y Emilio Díaz Valcárcel-, la expresión de una agresividad que, por oposición, torna más visible la docilidad social. Y, reanudando su tarea de escritor-psicólogo-social explica esta nueva expresión literaria como "válvula de escape psicológica, sublimación del complejo de culpa colectivo."226

\footnotetext{
${ }^{223}$ Marqués, René (1972). El puertorriqueño dócil (Literatura y realidad psicológica), ed. cit., p. 171.

${ }^{224}$ Díaz Quiñones, Arcadio (1982). "Los desastres de la guerra: para leer a René Marqués", en El almuerzo en la hierba (Llórens Torres, Palés Matos, René Marqués), ed. cit., p. 166. Agrego este pasaje, de la misma página: "Marqués esgrimió la literatura como arma de combate contra el imperialismo y contra los valores de la sociedad capitalista moderna, y también en defensa de los valores morales, estéticos, políticos y religiosos una clase social vencida por el nuevo colonialismo."

${ }^{225}$ En el apartado del ensayo titulado "Función psicológica del escritor 'subversivo': los alivios de conciencia", la subversión de los escritores puertorriqueños entre los cuales se autoincluye el ensayista consiste fundamentalmente en, con palabras de Marqués, "aporrear la docilidad colectiva", en El puertorriqueño dócil (Literatura y realidad psicológica), ed. cit., p. 188.

${ }^{226}$ Marqués, René (1972). Ibid., p. 193.
} 
A pesar de esta paradoja, que entrañaría el riesgo de volver inocuo el rol crítico de los discursos literarios, Marqués propone a la literatura como práctica discursiva social específica, cuya función, a través de la ficción, la polémica, el ensayo, consistiría en mostrar los puntos de conflicto presentes y proponer representaciones de la identidad puertorriqueña. De allí que el autor no solo postule una construcción de la imagen y función social del escritor que conjuga una ideología literaria y una ética de la escritura, sino que además, presenta el propio lugar de sus obras en la sociedad, como modelos o ejemplos de una "escritura comprometida", al modo sartreano. Para Marqués, el conflicto histórico concreto es el colonialismo que, en la medida que no pueda ser combatido, redunda negativamente en el complejo de identidad del puertorriqueño, según intenta demostrar en su tesis del docilismo. Las soluciones simbólicas toman cuerpo en las prácticas discursivas de los escritores, lo que implica, según consigna María Teresa Gramuglio que "el ser escritor y escribir literatura se invisten de un sentido y de un valor específicos que diferencian a la práctica literaria de otras prácticas de escritura como la que pueden realizar, por ejemplo, filósofos, publicistas, historiadores, tratadistas y sociólogos." ${ }^{227}$ En El puertorriqueño dócil René Marqués se vale de la literatura contemporánea de su país para analizar el conflicto "moral" del colonialismo, y a la vez, inscribe sus propios textos (cuentos, obras de teatro, prólogos, ensayos), como modelos de una moral de la forma. A esta cuestión apunta Arcadio Díaz Quiñones, cuando observa que la característica sobresaliente de casi todas las piezas dramáticas de Marqués, consiste en mostrarse como catástrofes ejemplarizantes, con finales apoteósicos, rotundos, purificadores. ${ }^{228}$ Para este crítico René Marqués defendió desde su obra una utopía conservadora: el viejo mundo hacendado en la nueva ciudad dominada por los valores de la etapa industrial:

"En la ciudad -y aprovechando las instituciones y posibilidades que ella ofrecía- predicó su nacionalismo agresivo y nostálgico, denunció el envilecimiento del 'materialismo' moderno, propuso purificaciones y

\footnotetext{
${ }^{227}$ Gramuglio, María Teresa (1992). "La construcción de la imagen", en: La escritura argentina, vol. Colectivo, Universidad Nacional del Litoral, Ediciones de La Cortada, p. 41.(Las negritas son de la autora).

${ }^{228}$ Díaz Quiñones, Arcadio (1982). "Los desastres de la guerra: para leer a René Marqués", ed. cit., p. 134.
} 
heroísmos, combatió con ánimo apostólico a los ideólogos de la sociedad industrial dependiente. El 98 había sido para él, una tragedia, un cataclismo; la máquina, la industrialización, los tecnócratas eran los peores enemigos. La patriarcal grandeza de la sociedad precapitalista era el paraíso perdido."229

Cuando en 1967 aparecen reunidos por primera vez los ensayos de René Marqués compuestos entre 1953 y $1966^{230}$, el autor interviene sobre todo a través de la incorporación de numerosas notas a pie de página que dan cuenta de las variaciones contextuales producidas en los escritos entre una y otra fecha. Respecto de El puertorriqueño dócil resulta interesante notar el agregado de un extenso apéndice que, paradójicamente, atenúa los alcances pretendidos con la tesis de la docilidad sostenida en 1960, al incorporar un argumento que antes no había sido considerado. Marqués se refiere al creciente proceso de militarización de Puerto Rico, aunque sin explicitar que los motivos de ese incremento de las fuerzas armadas, cada vez más presentes en la Isla, respondía claramente a la estrategia del gobierno de los Estados Unidos, visiblemente alarmado por la fuerza de irradiación de la Revolución Cubana. El ensayista vincula a través de esta cuestión el colonialismo anterior, el español, y el del presente, el norteamericano, ya que para ambas metrópolis Puerto Rico funcionó como bastión estratégico del poder imperial en el Caribe:

"Un factor importante que suponemos se ha inferido -dada la condición colonial de Puerto Rico por siglos-, pero que no hemos auscultado en detalle en aquellos trabajos de este libro que abordan o mencionan la docilidad puertorriqueña, ha sido y es, bajo ambos regímenes -el español y el norteamericano-, las desproporcionadas fuerzas de represión oficial contra la población civil, en relación a la pequeñez geográfica de la Isla". ${ }^{231}$

Esa "desproporción" entre las fuerzas militares y la civilidad en Puerto Rico explicaría entonces para Marqués a la docilidad puertorriqueña como la única respuesta posible ante una desigualdad histórica de fuerzas. En el

\footnotetext{
${ }^{229}$ Díaz Quiñones, Arcadio (1982). "Los desastres de la guerra: para leer a René Marqués", ed. cit., pp. 166-167.

${ }^{230}$ Se trata de la edición anterior a la fechada en 1972 que corresponde a todas las citas textuales de Marqués realizadas hasta aquí. Se denomina Ensayos (1953-1966), a cargo de la misma editorial, Antillana, publicada en 1967. El apéndice se reproduce también en la edición de 1972. ${ }^{231}$ Marqués, René (1972). "Apéndice", en El puertorriqueño dócil, ed. cit., p. 204. (cursivas del autor)
} 
apéndice la docilidad como carencia y debilidad se tornan, para sorpresa del lector, virtudes del pueblo puertorriqueño, instrumentos para ejercer una batalla civil contrahegemónica: "Los puertorriqueños deberíamos, después de todo, sentirnos orgullosos por el terror pánico que nuestra docilidad ha desatado, tanto en Washington como en San Juan, especialmente durante los últimos treinta años." ${ }^{232}$ Marqués lleva a cabo una operación discursiva propia de la argumentación polémica que consiste en la inversión del punto de vista. Se trata de "dar vuelta" la argumentación adversa y, sin alterar los elementos que la componen, extraer una conclusión diametralmente opuesta. Lo que resulta aquí paradójico es que el ensayista invierte su propia argumentación, no la de algún adversario, transformando la docilidad en una característica moral no sólo positiva sino además combativa, que le permite una valoración del pueblo puertorriqueño como sujeto colectivo, ausente en el cuerpo principal del ensayo:

"De todos modos -dada la desproporcionada cantidad de fuerzas represivas oficiales- es obvio que se nos tiene miedo como pueblo. Es decir, a pesar de nuestra docilidad, nos tiene miedo no solo el gobierno local que presuntamente nos representa, sino el imperio más rico y desvastadoramente poderoso del mundo occidental, del cual somos colonia." 233

Puede leerse el ingenuo optimismo de Marqués a partir de una explicación contextual a la fecha de la incorporación del apéndice de 1966. En 1964 Luis Muñoz Marín había dejado la gobernación de Puerto Rico, aunque seguían liderando al país las fuerzas populistas, considerablemente mermadas luego del fracaso desarrollista que habían impulsado. Se preveía para 1967 la celebración de un plebiscito para intentar resolver el estatus de la Isla ${ }^{234}$, el que efectivamente se llevó a cabo. Se puede conjeturar que Marqués en 1966 cifraba sus esperanzas en la voluntad popular de un cambio respecto del estatuto colonial de la Isla. Como señalé en el capítulo anterior el resultado del plebiscito reafirmó la fórmula estadolibrista, sin embargo el ensayista no

\footnotetext{
${ }^{232}$ Marqués, René (1972). "Apéndice", en El puertorriqueño dócil, ed. cit., p. 208.

${ }^{233}$ Marqués, René (1972). Ibid., p. 209.

${ }^{234}$ Véase capítulo I "Introducción", p. 48.
} 
incorpora un nuevo apéndice a la reedición de sus Ensayos de 1972 para dar indicios o proponer posibles explicaciones ante tal hecho. Por el contrario, unos años después, en una entrevista fechada en 1977 Marqués sostenía: "Yo me reafirmo en mi tesis sobre El puertorriqueño dócil, y los demás que opinen lo que quieran." ${ }^{235}$ Como explica Arcadio Díaz Quiñones, para leer a René Marqués hay que tener en cuenta la preocupación didáctica de su literatura y su aspiración a dar lecciones morales y rotundas, lo que lo torna un escritor estático desde el punto de vista ideológico: "Sus 'verdades' no evolucionan; Marqués avanza sin rectificaciones, reiterando y amplificando,"236 y yo agregaría, mostrando sus propias contradicciones.

\section{3 Nuevas miradas: ampliación de la "familia puertorriqueña" en El país de cuatro pisos ${ }^{237}$ de José Luis González}

En 1980 se publica en Puerto Rico El país de cuatro pisos y otros ensayos del reconocido escritor José Luis González (1926-1996), libro con el cual agita el campo intelectual del país, generando agudas polémicas y polarizaciones encendidas entre quienes lo encumbraron o lo denostaron. ${ }^{238}$ Tal vez haya que buscar el origen de esa recepción polémica en las palabras iniciales de González, cuando transcribe la pregunta disparadora de su texto que le formuló "un grupo de jóvenes estudiosos puertorriqueños de las ciencias sociales" en un seminario en la Universidad de Puerto Rico: "¿Cómo crees que ha sido afectada la cultura puertorriqueña por la intervención colonialista

\footnotetext{
${ }^{235}$ Entrevista citada por Rosado, Josué (1979). "La docilidad puertorriqueña. René Marqués: su concepto del hombre puertorriqueño actual", Sin Nombre, San Juan, Puerto Rico, vol. X No. 3, octubre-diciembre, pp. 98-114. La cita corresponde a la p. 113.

${ }^{236}$ Díaz Quiñones, Arcadio (1982). "Los desastres de la guerra: para leer a René Marqués", en

El almuerzo en la hierba (Llórens Torres, Palés Matos, René Marqués), ed. cit., p. 153. (cursivas del autor)

${ }^{237}$ González, José Luis (1982). El país de cuatro pisos y otros ensayos, ed.cit.

${ }^{238}$ Para citar dos ejemplos de estas polarizaciones véase la reseña elogiosa de Juan M. García Passalacqua "An interpretation for the 80's", San Juan Star, 27-12-80, p. 19, y por el contrario el comentario negativo de Manuel Méndez Ballester, "Un ataque brutal", El Nuevo Día (San Juan), 5-12-80, p. 31. Hubo entre 1980 y 1982 varias reseñas y artículos en diferentes medios locales (Claridad, El Mundo, El Reportero) y caribeños (Revista Casa de las Américas) que dieron cuenta de la recepción crítica del ensayo de José Luis González. Para mayor información véase el artículo de Quintero Rivera, Ángel (1983). "Historia de unas clases sin historia para el análisis cultural", donde realiza comentarios críticos y complementarios al ensayo El país de cuatro pisos, en: Cuadernos, edición del Centro de Estudios de la Realidad Puertorriqueña, Río Piedras, pp. 1-47.
} 
norteamericana y cómo ves su desarrollo actual?"239, interrogación punzante por su vigencia.

Si bien la tentación de recurrir a la voz magisterial puede hallarse en el marco de esta relación docente-alumno, en el espacio institucional en el cual transcurre -el claustro universitario-, como así también en el género escogido "un ensayo de interpretación de la realidad histórico-cultural puertorriqueña"-, desafía en buena medida los riesgos de la autoridad monofónica de la "voz del maestro" 240 , aunque sin eludirlos del todo. Su análisis rehuye la cristalización conceptual a través del carácter de "notas" dado a su ensayo y el matiz provisorio asignado a la interpretación, abierto más que conclusivo en algunos momentos. Sin dudas González adopta posiciones totalizadoras, evidentes en el tratamiento de la dicotomía cultura de las clases dominantes y cultura de las clases dominadas, desde un binarismo un tanto esquemático.

En El país de cuatro pisos se reconoce un diálogo explícito con el llamado movimiento de nueva historiografía ${ }^{241}$ de Puerto Rico, un equipo intelectual $^{242}$ que desde principios de los años setenta creó nuevos espacios de discusión y de difusión de la historia y culturas puertorriqueñas, especialmente a través del Centro de Estudios de la Realidad Puertorriqueña (CEREP). Con marcada perspectiva interdisciplinaria el CEREP encaró investigaciones en torno a temas prácticamente dejados de lado por la historiografía oficial, como la esclavitud, el legado cultural africano, la incorporación de la mujer al mundo del trabajo, la formación de la clase obrera puertorriqueña, el desarrollo de las barriadas populares, la producción cultural de los sectores populares, la emigración puertorriqueña a Nueva York. EI CEREP se sumó a los aportes del semanario Claridad, órgano de la Federación de Estudiantes ProIndependencia, y a la revista La escalera (1966-1973), realizada por profesores

\footnotetext{
${ }^{239}$ González, José Luis (1982). El país de cuatro pisos y otros ensayos, ed. cit., p. 11.

${ }^{240}$ González Echevarría, Roberto (2001). La voz de los maestros. Escritura y autoridad en la literatura latinoamericana moderna, ed.cit., especialmente "Preámbulo" pp. 19-27 y capítulo 1 "El extraño caso de la estatua parlante: Ariel y la retórica magisterial del ensayo latinoamericano", ed.cit., pp. 28-61.

${ }^{241}$ Rivera, Marcia (1994). "La nueva historiografía puertorriqueña", mimeo, gentileza de la autora y Díaz Quiñones, Arcadio (1984). "Recordando el futuro imaginario", revista Sin Nombre, Vol. XIV, \#3, abril-junio, pp. 16-35.

${ }^{242}$ A través del análisis de las ficciones dieciochescas de Rodríguez Juliá que propongo en el capítulo IV, se señalará asimismo el peso de esta nueva corriente historiográfica en autores de ficción, como el mismo Rodríguez Juliá, Luis Rafael Sánchez, Ana Lidia Vega, Luis López Nieves, entre otros.
} 
universitarios, donde se publicaron los primeros ensayos renovadores de la historiografía puertorriqueña. ${ }^{243}$ La impugnación de los modelos paternalistas anteriores acerca de la historia y de la sociedad puertorriqueña (especialmente los diseñados por la Generación del Treinta), fue el eje de la producción intelectual de estos renovados sectores, a la vez que propusieron la formulación de nuevos emblemas y maneras de narrar el pasado. A estas publicaciones se sumaron las revistas literarias como Zona de carga $y$ descarga, editada por Rosario Ferré y Olga Nolla, la revista de poesía Ventana y la renovada revista Sin Nombre (1970-1985), dirigida por Nilita Vientós, que estimuló la realización de certámenes literarios, de ensayo histórico y de plástica, propiciando un espacio diferente respecto de las instituciones académicas para las nuevas producciones artísticas, literarias y culturales del país. En este contexto, que auspiciaba revisiones críticas, nuevos modos de expresión, perspectivas integradoras del análisis político, económico, social y cultural de Puerto Rico, el ensayo de José Luis González abonó un campo que impulsaba la necesidad de cambios. Por otra parte en el mismo año de publicación de El país de cuatro pisos (1980), González dio a conocer otro texto innovador, llamado La llegada. Esta ficción histórica situada en Puerto Rico a finales del siglo XIX narra la "llegada" de los norteamericanos a la Isla, a la vez que escenifica también la historia de un género, la crónica, y sus posibilidades de representar una multiplicidad de voces y puntos de vista, proponiendo una revisión crítica del emblemático año 98.

Si Insularismo articuló desde sus páginas la homología nación y familia puertorriqueña como una metáfora integradora y armónica, en El país de cuatro pisos la familia se amplía con hijos y entenados, a través de la inclusión de los muy diversos movimientos inmigratorios que poblaron el país, con especial énfasis en el aporte africano. Mientras que en las obras dramáticas de René Marqués el espacio privilegiado era la casa solariega de los hacendados criollos, reducto cerrado de defensa contra la industrialización y "continente de

\footnotetext{
${ }^{243}$ Para nombrar a algunos de los destacados intelectuales responsables de la renovación historiográfica menciono los trabajos de Ángel Quintero Rivera, Fernando Picó, Marcia Rivera, Arcadio Díaz Quiñones, profusamente citados en la bibliografía de la presente tesis, quienes en los setenta fundaron el Centro de Estudios de la Realidad Puertorriqueña (CEREP), cuyo proyecto aspiraba a una drástica revisión y problematización de los paradigmas históricos, literarios y culturales dominantes en Puerto Rico.
} 
la nación"244 como destaca Juan Gelpí, El país de cuatro pisos en cambio, como lo indica su título, desplaza la metáfora espacial a los "buildings", propiedades horizontales destinadas las barriadas durante el auge populista de los años cincuenta y que albergaron las capas medias y trabajadoras. El "país de cuatro pisos" pluraliza no solo el espacio sino también los sectores sociales que lo habitan. El ensayo de José Luis González propone incluir en su análisis la perspectiva clasista, desde enfoques ideológicos de corte marxista, como queda explícitamente manifestado en la incorporación de una cita de Antonio Gramsci extraída de los Cuadernos de la cárce ${ }^{245}$ en el epígrafe que inicia el texto, sobre las relaciones entre los intelectuales y el pueblo en torno al concepto de nación. También toma de Gramsci el concepto de hegemonía, para analizar las relaciones entre culturas dominantes y culturas dominadas en el marco del colonialismo pasado y presente del país.

Para José Luis González el fracaso de la independencia respecto de España se debió fundamentalmente a la debilidad política de la clase dirigente nativa, la incipiente burguesía nacional conformada por la clase hacendada y profesional criolla:

"(...) la ideología de la clase hacendada y profesional criolla (lo que más se asemejaba entonces a una incipiente burguesía nacional) entre 1868 y 1887 fue lo que determinó el tránsito del asimilismo al autonomismo en la actitud política de esa clase. A lo que nunca pudo llegar ésta, ni siquiera en 1898, fue a la convicción de que Puerto Rico era ya una nación capaz de regir sus propios destinos a través de un Estado independiente". ${ }^{246}$

González observa las contradicciones de esta clase, entre su discurso sobre la cultura nacional puertorriqueña que devino dominante en la sociedad del país y el acatamiento de la dominación, primero española y luego norteamericana:

\footnotetext{
${ }^{244}$ Gelpí, Juan (1993). Literatura y paternalismo en Puerto Rico, ed. cit., p. 121.

245 José Luis González, cuando se radica en México a raíz de las presiones y censuras vividas en Puerto Rico en los años duros del macartismo, trabajó como traductor para la editorial Era y tuvo a su cargo la revisión de la traducción al castellano de los Cuadernos de la cárcel de Antonio Gramsci.

${ }^{246}$ González, José Luis (1982). El país de cuatro pisos y otros ensayos, ed. cit., p. 16.
} 
"(...) esa clase oprimida por la metrópoli era a su vez opresora de la otra clase social puertorriqueña, la clase formada por los esclavos (hasta 1873), los peones y los artesanos (...). La 'cultura de los oprimidos', en Puerto Rico, ha sido y es la cultura producida por esa clase. (...) Y de ahora en adelante, para que podamos entendernos sin equívocos, hablemos de 'cultura de élite' y de 'cultura popular' ". ${ }^{247}$

El ensayo de González promueve visibilizar los aportes de esa cultura popular, silenciada y oculta en la historiografía dominante. A través de la imagen del "país de cuatro pisos" se propone revisar la conformación cultural plural y heterogénea de Puerto Rico, como capas o pisos diferentes que se van superponiendo sin anularse unos a otros, sino más bien diversificándose a través de los contactos, aunque se produzcan en muchas ocasiones de manera tensa y violenta. La primera capa o el "primer piso" del país se conforma con el aporte de dos grupos étnicos de preponderante incidencia, el indígena y el africano. Para González esta primera capa vincula cultural e históricamente a Puerto Rico con el resto del Caribe: "La cultura popular puertorriqueña, de carácter esencialmente afroantillano, nos hizo, durante los tres primeros siglos de nuestra historia poscolombina, un pueblo caribeño más."248 El "segundo piso" proviene de la oleada inmigratoria de la primera mitad del siglo XIX, constituida en gran número por refugiados de las colonias hispanoamericanas que luchaban por su independencia, a los que se sumó un nutrido grupo de extranjeros -ingleses, franceses, holandeses, irlandeses. En una segunda etapa, a mediados de siglo, una nueva oleada compuesta mayormente por corsos, mallorquines y catalanes, consecuencia de la política colonial metropolitana que por entonces propiciaba el "blanqueamiento" de su colonia. Estos sectores, sobre todo los de la última ola de inmigrantes, se instalaron en la zona montañosa de la Cordillera Central y construyeron su riqueza a través de las haciendas cafetaleras y de la explotación del campesinado:

"El mundo de las haciendas cafetaleras, que en el siglo XX vendría a ser mitificado como epítome de la 'puertorriqueñidad', fue en realidad un mundo dominado por extranjeros cuya riqueza se fundó en la

\footnotetext{
${ }^{247}$ González, José Luis (1982). (1982). El país de cuatro pisos y otros ensayos, ed. cit., pp. 1819.

${ }^{248}$ Ibid., p. 22.
} 
expropiación de los antiguos estancieros criollos y la explotación despiadada de un campesinado nativo que hasta entonces había vivido en una economía de subsistencia." 249

Muestra así González cómo la sociedad puertorriqueña del siglo XIX poco y nada respondía al "mito de una homogeneidad social, racial y cultural" ${ }^{250}$, erigido tanto por los miembros de la Generación del Treinta como por los sectores más tradicionales del independentismo; más bien se trataba de una sociedad fuertemente dividida por intereses de clase, raciales, económicos y culturales, donde además la élite estaba a su vez escindida entre los hacendados de la montaña por un lado, y los profesionales y comerciantes de los sectores urbanos por el otro, mientras que la clase dominada se dividía entre los sectores campesinos más blancos, de la zona montañosa, conocidos como jíbaros y el sector mestizo, mulato y negro de la costa. Sobre estas divisiones y tensiones internas se constituyó el "tercer piso" del país, marcado por el año 1898 y la invasión norteamericana. González percibe que mientras los sectores letrados se atrincheraron en una concepción única de la cultura puertorriqueña, que veía su deterioro bajo el régimen norteamericano, la que se entiende como la "otra" cultura puertorriqueña, la popular, sufrió más bien un desarrollo, aunque accidentado y lleno de vicisitudes: "El vacío creado por el desmantelamiento de la cultura de lo puertorriqueños 'de arriba' no ha sido llenado, ni mucho menos, por la intrusión de la cultura norteamericana, sino por el ascenso cada vez más palpable de la cultura de los puertorriqueños 'de abajo'."251

González explica que tanto la clase dominante como la clase dominada acogieron la llegada del invasor, aunque por motivos muy diferentes: la primera porque vio en los norteamericanos "el preludio de la anexión de Puerto Rico a la nación más rica y poderosa -y más 'democrática', no hay que olvidarlo- del planeta." ${ }^{252}$; la segunda, porque con la llegada de éstos vislumbró "la oportunidad de un ajuste de cuentas con la clase propietaria en todos los

\footnotetext{
${ }^{249}$ González, José Luis (1982). El país de cuatro pisos y otros ensayos, ed. cit., p. 23.

${ }^{250}$ Ibid., p. 25.

${ }^{251}$ Ibid., p. 30.

${ }^{252}$ Ibid., p. 31.
} 
terrenos." ${ }^{253}$ La clase dominante se sintió defraudada cuando constató que la invasión no traía consigo la anexión ni la participación en la creciente economía capitalista sino la subordinación a la misma; la clase dominada se sintió liberada del yugo y del racismo de esa élite del segundo piso y en esa liberación vio su propio desarrollo. En 1898, la invasión norteamericana, al desplazar a los hacendados puertorriqueños e imponer el sistema de plantaciones y monocultivo del azúcar "empezó a echar un tercer piso, sobre el segundo todavía mal amueblado"254. González analiza que la respuesta esgrimida por estos sectores desde el espacio cultural fue la conservación de los valores del sector hacendado, perspectiva que reinterpreta y polemiza con las posiciones de la enseñanza oficial respecto de esta misma cuestión:

"El telurismo característico de la literatura producida por la élite puertorriqueña en el siglo XX no responde, como todavía se enseña generalmente en los cursos de literatura puertorriqueña en la Universidad, a una desinteresada y lírica sensibilidad conmovida por las bellezas de nuestro paisaje tropical, sino a una añoranza muy concreta y muy histórica de la tierra perdida, y no de la tierra entendida como símbolo ni como metáfora, sino como medio de producción material cuya propiedad pasó a manos extrañas." 255

Este fragmento indica una de las estrategias de análisis más visibles en el ensayo de José Luis González, como "provocador quebrantador de mitos" según observa Ángel Quintero Rivera, a lo que agrega que el aporte del ensayista no consiste sólo en la crítica a la cultura dominante del país sino en el planteamiento de una nueva manera de ver, desde una perspectiva, con palabras que citan a González "socialista, popular, mestiza y caribeña." ${ }^{256}$ Otro mito que aparece fuertemente cuestionado es el del "jibarismo" literario ${ }^{257}$, producido por la cultura de élite, al cual el ensayista percibe como un mito "tercamente anacrónico", producto del prejuicio racial y social de ese sector que eleva al campesino blanco como símbolo de la puertorriqueñidad. Para el

\footnotetext{
${ }^{253}$ González, José Luis (1982). El país de cuatro pisos y otros ensayos, ed. cit, p. 33. (cursivas del autor)

${ }^{254}$ Ibid., p. 27. (cursivas del autor)

${ }^{255}$ Ibid., pp. 34-35.

${ }^{256}$ Véase Quintero Rivera, Ángel (1983). "Historia de unas clases sin historia para el análisis cultural", ed. cit., p. 2.

${ }^{257}$ Véase esta cuestión en el apartado sobre René Marqués, especialmente p. 21 del presente capítulo.
} 
autor se trata además de una falacia histórica porque entre las décadas del treinta y cuarenta, cuando aparece con mayor fuerza este mito, el jíbaro había dejado de existir como factor demográfico de importancia, frente al crecimiento de los sectores mestizos, mulatos y proletarios. Justamente en la década del cuarenta señala los comienzos de la construcción del "cuarto piso" del país, con la confluencia del populismo puertorriqueño y el carácter cada vez más dependiente de la Isla respecto de Estados Unidos, lo que González ve como una alianza interesada entre "el capitalismo tardío norteamericano" y "el populismo oportunista puertorriqueño"258. Desde su presente de enunciación, 1980, el ensayista analiza el progresivo resquebrajamiento del cuarto piso cuyos primeros signos de derrumbe se ven claramente en la década del sesenta con la intensificación del "desempleo y marginación masivos, dependencia desmoralizante de una falsa beneficencia extranjera, incremento incontrolable de una delincuencia y una criminalidad en gran medida importadas, despolitización e irresponsabilidad cívica." ${ }^{259}$

José Luis González esgrime en su ensayo una apelación, desde mi punto de vista, riesgosamente esencialista, ya que propone como vía para la construcción de la "verdadera identidad puertorriqueña" promover el desarrollo de la cultura popular, como la única que podría representar la "voluntad nacional de este país." ${ }^{260}$ Creo que aquí se notan los límites de su propuesta, ya que al ubicar la problemática cultural en el análisis de clase, si bien abona fecundas posibilidades, entraña por otra parte la rigidización binaria entre cultura dominante o hegemónica y cultura popular o contrahegemónica. Como sostiene Ángel Quintero Rivera "luchar contra la cultura dominante, asumiendo como clase dirigente aún la clase de hacendados, es, a mi juicio, luchar contra un fantasma"261. Quintero Rivera lee en el ensayo de González una positiva lucha contra los remanentes, sobre todo culturales de esa vieja clase, pero critica acertadamente que el ensayista no repare en la carga residual de los mismos. González tampoco señala cómo efectivamente interfirió la intervención

\footnotetext{
${ }^{258}$ González, José Luis (1982). El país de cuatro pisos y otros ensayos, ed. cit., pp. 40-41.

${ }^{259}$ González, José Luis (1982). Ibid., p. 41.

${ }^{260}$ González, José Luis (1982). Ibid., p. 40. Ambas referencias entrecomilladas son de la misma página.

${ }^{261}$ Quintero Rivera, Ángel (1983). "Historia de unas clases sin historia para el análisis cultural", ed. cit., p. 16.
} 
norteamericana en el desarrollo de la cultura popular. Sorprende que un escritor $^{262}$ que fue uno de los primeros en dar cuenta en sus ficciones de las emigraciones a Nueva York, no aluda en El país de cuatro pisos a esta cuestión, sobre todo teniendo en cuenta la valiosa contribución de los emigrados a la conformación de una cultura popular puertorriqueña, aunque sí esté presente en otros de los textos que forman parte del volumen, por ejemplo en "Literatura e identidad nacional en Puerto Rico" y "En el escritor en el exilio." 263

Pese a estas limitaciones, sin dudas, el ensayo de José Luis González aportó sobre todo una renovada visión sobre el desarrollo cultural puertorriqueño que el autor presenta como necesariamente histórico, en el marco de una recepción crítica caracterizada por un énfasis revisionista y contestatario. La insistencia en procurar la integración de Puerto Rico a la comunidad caribeña subraya también la necesidad de mostrar cómo en al área antillana se comparten procesos similares, históricos, sociales, culturales, étnicos, de los cuales no está exento el país. González destaca, a contrapelo de las posiciones más conservadoras, el valioso aporte del plurilingüismo caribeño, desde una perspectiva que coincide con la de Édouard Glissant ${ }^{264}$ : "La gran comunidad caribeña es una comunidad plurilingüe. Eso es real e irreversible. Pero eso, en lugar de fragmentarnos y derrotarnos, debe enriquecernos y estimularnos." 265 En sus conclusiones subraya una vez más el carácter multirracial y heterogéneo de la sociedad puertorriqueña, y que las identidades no son sólo lingüísticas sino construcciones más complejas, que trascienden incluso la sugerente metáfora plural de los "cuatro pisos".

\footnotetext{
${ }^{262}$ Entre las ficciones de José Luis González que dan cuenta de las migraciones a Nueva York se destacan la novela corta Paisa (un relato de la emigración) de 1950 y los cuentos compilados en 1973 bajo el título En Nueva York y otras desgracias.

${ }^{263}$ González, José Luis (1982). "Literatura e identidad nacional en Puerto Rico" y "El escritor en el exilio", ambos en El país de cuatro pisos y otros ensayos, ed. cit., pp. 45-90 y 105-113 respectivamente.

${ }^{264}$ Véase al respecto el capítulo I.

${ }^{265}$ González, José Luis (1982). El país de cuatro pisos y otros ensayos, ed. cit., p. 44.
} 


\section{4 Pliegues y repliegues del verbo bregar en la historia cultural puertorriqueña moderna: El arte de bregar. Ensayos ${ }^{266}$, de Arcadio Díaz Quiñones}

En el año 2000, con el siglo XX tocando su fin, Arcadio Díaz Quiñones publica una colección de ensayos, El arte de bregar, libro concebido como un mosaico plural que recorre la historia cultural de Puerto Rico desde el emblemático 1898 hasta el otro fin de siglo. El epígrafe que abre la colección resulta muy significativo. Tomado del poema "Exile" del escritor antillano Derek Walcott ${ }^{267}$ subraya una situación de enunciación que comparten tanto el poeta como el ensayista: la del intelectual exílico, para decirlo con palabras de Ana Pizarro, sujetos caracterizados como aquellos que "...hablan desde un espacio que les pertenece y les es ajeno al mismo tiempo, desde un 'entre lugar' (...)"268 Arcadio Díaz Quiñones, uno de los más lúcidos ensayistas y críticos culturales puertorriqueños, en cuya obra podemos leer una continuidad respecto de uno de sus precursores fundamentales, Ángel Rama, ha desarrollado su labor crítica como intelectual emigrado en los Estados Unidos. En la nota preliminar que antecede al conjunto de ensayos el autor señala que sus textos fueron compuestos a lo largo de la década de los noventa y en estrecho vínculo con su labor docente como académico de la Universidad de Princeton.

Esta situación que impone la distancia del intelectual emigrado atraviesa al propio sujeto que escribe, quien se reconoce a sí mismo en varias figuras errantes, entre las que se destacan José Martí, Pedro Albizu Campos, José Luis González y Lorenzo Homar, protagonistas del análisis y comentario de los diversos ensayos que conforman El arte de bregar. Todos ellos, figuras fundamentales de la modernidad caribeña, compartieron situaciones de exilio, emigración, desplazamiento, temas que constituyen el centro de interés de Díaz Quiñones, como se lee en la nota preliminar: "En particular me ha interesado el 'afuera' y el 'adentro' en el mundo colonial, y las posibilidades de nuevos comienzos abiertas por los desplazamientos y las emigraciones." 269

\footnotetext{
${ }^{266}$ Díaz Quiñones, Arcadio (2000). El arte de bregar. Ensayos, San Juan de Puerto Rico. Ediciones Callejón.

${ }^{267}$ Walcott, Derek (1980). The Fortunate Traveller, Nueva York, Farrar \& Strauss.

${ }^{268}$ Pizarro, Ana (2002). "El archipiélago de fronteras externas" en: El archipiélago de fronteras externas, ed.cit., pp. 15-31.

${ }^{269}$ Díaz Quiñones, Arcadio (2000). El arte de bregar. Ensayos, ed. cit., p. 13.
} 
Preocupaciones que nos permiten leer los vínculos entre este conjunto de ensayos y aquel otro publicado en 1993, La memoria rota ${ }^{270}$ donde el autor proponía volver visible una de las lagunas más obvias de la memoria histórica puertorriqueña, la "ruptura" producida por la migración masiva de puertorriqueños a los Estados Unidos. En uno y otro conjunto de ensayos se analizan las transformaciones de las nociones de identidad, ligadas a procesos de rememoración, memoria y olvido. En ambos el autor establece lazos fecundos con reflexiones de importantes pensadores e historiadores de la cultura, como Edward Said, Pierre Nora, Hannah Arendt, Theodor Adorno, Frantz Fanon, Ángel Rama, entre otros. A su vez explicita un diálogo con la tradición ensayística puertorriqueña, con la cual parece establecer vínculos de afiliación ${ }^{271}$ pero también, como propongo analizar, de marcada diferenciación: "Igualmente sostengo un diálogo -a menudo imaginario y nostálgico- con los ensayistas puertorriqueños que han bregado tan creativamente con el género, estableciendo nuevos saberes y trazando nuevos caminos para la crítica."272 Uno de los ensayos de Díaz Quiñones está dedicado a Antonio S. Pedreira, figura que resulta paradigmática en la tradición ensayística puertorriqueña, como he analizado antes, y a quien parece por lo menos difícil, para los intelectuales del país, excluir, obviar u olvidar. Como destaca Juan Gelpí respecto de la propuesta de Díaz Quiñones: "En vez de generalizar a partir de un 'qué somos' o un 'cómo somos' (Pedreira), El arte de bregar elabora un cuidadoso mosaico ensayístico de posibilidades a partir del 'qué hacemos o de qué hemos hecho' en nuestra historia cultural de los últimos cien años." ${ }^{273}$

Voy a detenerme particularmente en el ensayo inicial, titulado "De cómo y cuándo bregar", donde el autor traza una compleja red de significaciones a partir de los múltiples sentidos que entraña para los puertorriqueños el verbo bregar. Se trata de una palabra que se cuela en todos los intersticios de la

\footnotetext{
${ }^{270}$ Díaz Quiñones, Arcadio (1993). La memoria rota, ed. cit.

${ }^{271}$ Edward Said establece una diferenciación entre los conceptos de filiación y afiliación en el campo de la cultura, correspondiendo el primero a la idea de una linealidad de tipo biológica, parental, por tanto obligada, mientras que el segundo concepto remite más bien a una comunión de tipo ideológica, basada en creencias, filosofías, visiones de mundo en común, por tanto electiva. Véase Said, Edward (1985). Beginnings. Intention \& Method, Nueva York, Columbia University Press, "Preface", p. xiii.

${ }^{272}$ Díaz Quiñones, Arcadio (2000). El arte de bregar. Ensayos, ed. cit., p. 15.

${ }^{273}$ Gelpí, Juan (2000). Reseña crítica a El arte de bregar, en: Revista de Estudios Hispánicos, Universidad de Puerto Rico, vol. XXVII, núm. 2, pp. 437-440. (El paréntesis aclaratorio es mío)
} 
cotidianeidad, abraza lo alto y lo bajo, revierte sus significados, los vuelve ofensivos o procaces, desestabilizando, tanto la lengua como las nociones fijas de la identidad. El infinitivo se torna performativo, es acto de habla y acción, es también "...otro orden del saber, un difuso método sin alarde para navegar la vida cotidiana, donde todo es extremadamente precario, cambiante o violento, como lo ha sido durante el siglo XX para las emigraciones puertorriqueñas y los es hoy en todo el territorio de la isla." ${ }^{274}$ Destaco el adverbio temporal, el "hoy" que contextualiza la reflexión del ensayista, donde, transcurridos cien años de la dominación imperialista de los Estados Unidos, el puertorriqueño sigue "bregando" con una situación colonial que no muestra señales de cambio. Entre las múltiples significaciones del verbo que propone desplegar Díaz Quiñones, una de ellas, la más explorada en el texto, implica el concepto de "negociación", y vinculado a éste, el de la identidad, eje de uno de los debates más recurrentes de la cultura puertorriqueña. La pregunta que recorre el ensayo podría formularse en los siguientes términos: cómo brega el sujeto puertorriqueño por la conformación de su identidad -cultural, política, históricaen el encuentro y negociación entre la mirada imperial y la mirada local. Para poder responder a la pregunta el autor elige una propuesta que conlleva la idea de recorrido, desplazamiento, tornando visibles a los ojos del lector los diversos itinerarios del sentido por los que transita el verbo bregar.

Díaz Quiñones apela también a la noción de archivo, concepto fuertemente vinculado a la memoria. El archivo del bregar se constituye en la intersección productiva de la cultura letrada, de la biblioteca (por ejemplo, las citas de autoridades tomadas de diferentes diccionarios que dan cuenta de las acepciones y etimologías del verbo bregar), con la rica oralidad cotidiana puertorriqueña, con los diversos usos populares otorgados al infinitivo. En este sentido se puede decir que el autor opera con una idea del archivo muy similar a la sostenida por Michel Foucault en La arqueología del saber, donde el archivo se piensa como una práctica que media entre la tradición y el olvido, ya que "...hace aparecer las reglas de una práctica que permite a la vez a los enunciados subsistir y modificarse regularmente. Es el sistema general de la

${ }^{274}$ Díaz Quiñones, Arcadio (2000). "De cómo y cuándo bregar", en: El arte de bregar. Ensayos,ed. cit., p. 20. 
formación y de la transformación de los enunciados." ${ }^{275}$ También, con Bajtín ${ }^{276}$, adscribe a la conveniencia de reunir los aportes de lo oral junto con las fuentes documentales como elementos discursivos, integrados en una totalidad narrativa.

Díaz Quiñones traza tres campos de significación amplia en los cuales se manifiesta el verbo bregar: las esferas del trabajo, del placer erótico y de la negociación. Si por un lado el verbo mantiene el sentido etimológico de "luchar", "lidiar", también conserva otra significación por fuera de la "ley escrita", buscar un acuerdo, dirimir sin violencia conflictos muy polarizados. La conjunción de verbo y adjetivo en el enunciado "bregar bien" entraña el concepto de trabajar con esmero y eficacia, y Díaz Quiñones relaciona este matiz con el sentido que le asigna Hannah Arendt al verbo actuar en La condición humana: "tomar una iniciativa, comenzar, poner algo en movimiento."277 Pero en otro contexto el verbo puede adquirir una connotación negativa, marcar una distancia, indicar rechazo: "Cuando ya no se puede más, se dice, significativamente: Yo con eso no brego."278 Diaz Quiñones adapta el concepto de archivo al lenguaje informático cuando alude a la imagen de "software cultural", como una memoria abierta que se va actualizando y perfeccionando, muy atenta al habla, a los modos de construir frases, a las prácticas sociales y sus contextos. El matiz erótico del verbo se da solo en el contexto cultural puertorriqueño, como una particular apropiación de una de sus tantas acepciones, "amasar o sobar el pan", donde el infinitivo se carga de connotaciones corporales y sensuales. Pero los sentidos del verbo son tan escurridizos como la lengua hablada, $y$, entonces el infinitivo adquiere otras significaciones que remiten a la experiencia colonial, no solo puertorriqueña sino también caribeña.

Bregar remite también a las prácticas cimarronas de la sociedad esclavista, la brega es el arte de la fuga, la capacidad de construir lo que

\footnotetext{
${ }^{275}$ Foucault, Michel (1970). La arqueología del saber, Madrid, siglo XXI, p. 221 (cursivas del autor).

${ }^{276}$ Bajtín, Mijaíl M. (1974). La cultura popular en la Edad Media y el Renacimiento, Barcelona, Barral Editores.

${ }^{277}$ Cita de Arendt incorporada por el autor. Véase Díaz Quiñones, Arcadio (2000). "De cómo y cuándo bregar", en: El arte de bregar. Ensayos, ed. cit., p. 22.

${ }^{278}$ Ibid., p.42.
} 
Quintero Rivera llama el "mundo de la contraplantación"279. Díaz Quiñones compara las prácticas cimarronas como fugas o diásporas interiores con los movimientos de la emigración puertorriqueña a los Estados Unidos; la brega es también la estrategia de sobrevivencia puesta en práctica por los emigrados en situaciones complejas de adaptación al nuevo espacio, lengua, costumbres. El autor deslinda y vincula entre sí las muy diversas formas de significación del verbo bregar en una perspectiva que permite aproximarlo a la "poética de la relación" de Édouard Glissant, donde el acento está puesto especialmente en el modo de encontrar relaciones, enlaces, nudos, tramas. El verbo se desplaza metonímicamente, y cada una de sus acepciones se trama indefectiblemente con la historia del país y su contexto caribeño.

Por otra parte cada uno de los sentidos del infinitivo se encarna en figuras particulares, historias de vida que van desde el relato de un pelotero emigrado hasta los recuerdos de una escritora de la emigración, pasando también por las ambigüedades de la política de Muñoz Marín, hasta los particulares sentidos de la lengua poética de Palés Matos. Tanto las figuras individuales como los sentidos diferentes del bregar se van anudando en una red o malla en la cual no está ausente la tensión, el contrapunto entre los distintos campos de significación. Así, por ejemplo, Díaz Quiñones contrapone la expresión "bregar bien" con aquella otra conocida como "¡Ay bendito!". Esta última frase que connota el lamento, el pesimismo, fue muy utilizada por los miembros de la Generación del Treinta, y remitía especialmente a la imagen de la pérdida y la nostalgia de los modos de vida anteriores a la invasión norteamericana. Para el autor bregar bien "(...) ha ido compitiendo sigilosamente con la piedad y la autocompasión del ¡Ay bendito!"280. De este modo Díaz Quiñones toma distancia y se diferencia de las construcciones identitarias que caracterizaron los enfoques negativos de Pedreira o de René Marqués respecto del pueblo puertorriqueño. Más bien insiste en el carácter performativo del infinitivo, en cuanto a una acción que implica también, "la capacidad para encontrar soluciones a medias, para actuar de acuerdo con la

\footnotetext{
${ }^{279}$ Quintero Rivera, Ángel G. (1998). Salsa, sabor y control. Sociología de la música tropical, México, Siglo XXI Editores. Véase también capítulo I, p. 33.

${ }^{280}$ Díaz Quiñones, Arcadio (2000). "De cómo y cuándo bregar", ed. cit., p. 21.
} 
'lógica de lo menos malo' y del compromiso que es a menudo el bregar."281 Aunque se explicita el diálogo con los ensayistas del pasado, mediante un interés compartido en la pregunta sobre la identidad puertorriqueña, la propuesta de Díaz Quiñones se aparta del empeño en fijar identidades que caracterizó la tradición ensayística anterior, como se observa en el siguiente pasaje del texto que resume claramente el gesto rearticulador de su ensayo: "(...) la afirmación de una identidad cultural monolítica y excluyente no permite reconocer los muchos espacios, tiempos, creencias y contextos locales que conforman la constitución misma de lo puertorriqueño."282

Voy a centrame en dos ejemplos que articulan un contrapunto particular en el ensayo, en tanto representan una puesta en acto de la brega como negociación y también del doblez o duplicidad que connota el verbo. En un caso se trata de un héroe popular del béisbol; en el otro, de un líder populista. Ambos alcanzan sus picos más altos de popularidad en la década del cincuenta; sus trayectorias desde ámbitos muy distintos- el deporte, la políticale permiten a Díaz Quiñones reconstruir una época de cambios y desplazamientos vertiginosos en la vida puertorriqueña. Víctor Pellot ${ }^{283}$, puertorriqueño negro que se convierte en un mítico héroe popular al triunfar en las Grandes Ligas del béisbol en los Estados Unidos, encierra en su relato de vida una de las formas del bregar: un saber pragmático y estratégico que le provee al individuo recursos para mediar y suavizar antagonismos, posibles exclusiones, rechazos: "Es una línea de conducta muy práctica que hace posible sobrevivir con cierta dignidad, aun cuando sea simulando teatralmente que se ha resuelto algo." ${ }^{284}$ Víctor Pellot brega contra la discriminación racial pero también contra el menoscabo que sufre por ser puertorriqueño. Su brega se emblematiza en el uso y desplazamiento entre los dos nombres con los cuales se lo conoce: Víctor Pellot en la Liga de Béisbol Profesional de Puerto

\footnotetext{
${ }^{281}$ Díaz Quiñones, Arcadio (2000). "De cómo y cuándo bregar", ed. cit., p. 25. ${ }^{282}$ Ibid. p. 76.

${ }^{283}$ Rodríguez Juliá alude a Víctor Pellot en su crónica Las tribulaciones de Jonás, texto que Díaz Quiñones tiene en cuenta y cita, aunque el tratamiento de la figura es muy diferente en cada caso. La figura del beisbolista en la crónica remite a una escena de la infancia del autor, donde el cronista niño recuerda a Pellot en un gesto de exhibición de su éxito, transitando las calles de su barrio con su cadillac convertible y rodeado de mujeres rubias. En Díaz Quiñones, en cambio, el héroe popular del béisbol encarna el complejo "entre lugar" cultural e identitario.

${ }^{284}$ Díaz Quiñones, Arcadio (2000). "De cómo y cuándo bregar", ed. cit., p. 32.
} 
Rico; Vic Power en los equipos de las ligas de Canadá y Estados Unidos. Vic, apócope de Víctor, Power, su apellido materno, deformación impuesta por la institución escolar al verdadero apellido de la madre, Pové, en la etapa más aguda del proceso de americanización de la Isla. Para Díaz Quiñones el traslado entre uno y otro nombre con los cuales se identifica al pelotero constituye una estrategia de supervivencia en un medio hostil y reproduce así mecanismos centrales de adaptación de las tradiciones cimarronas.

Sin embargo, la estrategia cimarrona de Pellot, también puede ser interpretada desde otra perspectiva: como una metáfora del carácter "indeciso" o "doble"285 de la moderna cultura política puertorriqueña. Para Díaz Quiñones el reverso negativo de la brega está representado particularmente por el líder del Partido Populista Democrático, Luis Muñoz Marín. El doblez o desdoblamiento que implica la brega como negociación muestra su otra faz: los riesgos de la impostura, la máscara engañosa. La brega puede ser entonces "una artimaña para simular que se está confrontando algo", cuando, por el reverso, demuestra que "se está claudicando intelectual o políticamente. (...) Muñoz Marín parecía encarnar la brega: ser uno en dos, perfectamente bilingüe, de sólida tradición criolla y moderna, leal a los puertorriqueños y a los norteamericanos." ${ }^{186}$ El verbo muestra entonces su rostro de Jano bifronte mediante la política que lleva adelante el líder populista, quien encarna la "brega colonial". Dos hechos claves marcaron su gobierno: la llamada Operación Manos a la Obra y la creación del Estado Libre Asociado 287 . "Los nombres mismos expresan un ejercicio complejo y la naturaleza lábil del Estado puertorriqueño: en ellos conviven una imposibilidad y una necesidad."288, señala el autor al reflexionar sobre ambos. Si por un lado la "doble ciudadanía" implicó ventajas tangibles (ensanchamiento de la educación pública, programas de vivienda y salud, beneficios sociales para los veteranos de guerra, etc), por el otro se acentuó cada vez más un anexionismo agresivo por el cual se eclipsó la idea misma de poder convertir al país en un estadonación. Durante el gobierno de Muñoz Marín se pusieron en marcha las migraciones masivas a los Estados Unidos. En la década del cincuenta

\footnotetext{
${ }^{285}$ Ibid., p. 41.

${ }^{286}$ Ibid., p. 52 (cursivas del autor).

${ }^{287}$ Véase capítulo I .

${ }^{288}$ Díaz Quiñones, Arcadio (2000). "De cómo y cuándo bregar", ed. cit., p. 59.
} 
alrededor de medio millón de puertorriqueños que quedaron fuera del proyecto modernizador tuvieron que abandonar el país:

"Una de las paradojas profundas de la historia puertorriqueña del siglo 20 es que el Partido que forjó el mito del campesino 'jíbaro' con los signos de su cultura como base de su política populista, creó vertiginosamente las condiciones para que los jíbaros reales emigraran en masa a los Estados Unidos, y acabó dándoles la espalda." 289

Si en el caso de Víctor Pellot la simulación constituye una estrategia para poder bregar con los prejuicios raciales y con los nuevos saberes bilingües y dilemas inéditos de su experiencia como emigrado, en el caso de Muñoz Marín, por el contrario, la brega se torna "artimaña", manipulación conciente que puede reconocerse en una de sus frases célebres, cuando caracteriza a Puerto Rico como: "un pueblo hispanoamericano compuesto por buenos ciudadanos de Estados Unidos."290

Ahora bien, la política de Luis Muñoz Marín, como antes mencioné, instituyó por un lado el Estado Libre Asociado, y por otro, el fomento de la migración masiva. Díaz Quiñones analiza ambas cuestiones también a partir de un sistema de oposiciones y contradicciones internas. El ELA, desde la paradoja que enuncia su nombre, representa cabalmente la idea de doblez o desdoblamiento, institución ambivalente "debido a ese carácter elusivo, la 'libertad' y la 'asociación' "291, que resultan incomprensibles para gran parte de los propios norteamericanos y también para muchos intelectuales latinoamericanos. El ensayista destaca lo que encierra esta contradicción, situando históricamente la constitución de esta institución híbrida:

"El Estado Libre Asociado era una solución a medias en la que estaban implícitos el poder desproporcionado del imperio, su imponente maquinaria, y los centros de gravedad de la Guerra Fría. Es preciso recordar que el Estado Libre Asociado se proclamó en 1952, en medio de la guerra de Corea, y un año antes de la política del New Deal y del cambio de gobierno en los Estados Unidos. La utopía consistió en separar la acción del presente de los resultados conflictivos del futuro;

\footnotetext{
${ }^{289}$ Díaz Quiñones, Arcadio (2000). "De cómo y cuándo bregar", ed. cit., p. 52 (cursivas del autor).

${ }^{290}$ Frase de Muñoz Marín citada por Díaz Quiñones, Arcadio en La memoria rota, ed. cit., p. 19.

${ }^{291}$ Díaz Quiñones, Arcadio (2000). "De cómo y cuándo bregar", ed. cit., p. 69.
} 
en atenuar, ya que no borrar, el enorme poder colonial. La isla era, y es, un puesto militar fronterizo de los Estados Unidos." 292

La propuesta de Arcadio Díaz Quiñones postula, como lo muestra la cita anterior, tender puentes entre el pasado y el presente. El hoy implica también la situación de los emigrados puertorriqueños en los Estados Unidos. Si en la década del cincuenta el PPD conminó a la emigración masiva como una forma de enmascarar el problema de la desocupación que la modernización e industrialización de la Isla no habían resuelto satisfactoriamente, ¿cómo se puede leer e interpretar desde el presente la situación actual de los emigrados y sus vínculos con Puerto Rico? El autor postula una paradoja, aquellos que fueron expulsados de su país a su vez se reorganizaron en la diáspora reivindicando valores culturales de su país de origen y participando solidariamente en los procesos políticos que afectaban a la Isla: "Esa brega es, por supuesto, muy compleja. Lejos de anular la cultura puertorriqueña, las comunidades puertorriqueñas de la emigración la han reactivado con gran energía y creatividad."293 Díaz Quiñones revisa y modifica el concepto que había sostenido en La memoria rota, en tanto la emigración constituyó históricamente una ruptura pero también propició otras formas, inéditas, de vinculación y religación con el espacio natal. Cuando se detiene en la producción del artista plástico Antonio Martorell, la mirada de Díaz Quiñones se centra particularmente en una instalación del artista que consiste en "múltiples y mudables casas", muestra itinerante con la cual recorre los desplazamientos de los migrantes puertorriqueños, desde ciudades de la Isla como Cayey, Ponce, San Juan, hasta ciudades de la metrópolis como Chicago y Nueva York. La obra de Martorell, portátil, muchas veces construida a partir de materiales efímeros, corresponde para el ensayista a una cultura en tránsito:

"Las 'casas' de Martorell convocan las secretas continuidades de la cultura, sin escamotear las discontinuidades ni las fragmentaciones del mapa. Es una búsqueda de otro lugar. En las últimas décadas, pocos han propuesto con semejante creatividad una forma de ver que asuma los deseos, los desplazamientos y los aleatorios mapas de lo

\footnotetext{
${ }^{292}$ Díaz Quiñones, Arcadio (2000). "De cómo y cuándo bregar", ed. cit., pp.69-70.

${ }^{293}$ Ibid., p. 77 (cursivas del autor).
} 
puertorriqueño. Quizás sea el artista plástico que mejor ha comprendido las dimensiones liberadoras e inventivas de la brega." ${ }^{294}$

Entre los múltiples sentidos de la brega que el ensayista recorre, sin dudas, este último que entraña lo "inventivo" y "liberador" es el que elige el autor para sí, también como una expresión de deseo, como posibilidad de lograr la adhesión del lector. Sin embargo no deja de volver visibles una y otra vez el carácter complejo y contradictorio del infinitivo que le permite reflexionar sobre la identidad puertorriqueña en su carácter dilemático, en tanto mantiene al sujeto dividido por su doble condición de ciudadano y súbdito colonial.

Rechaza la posible conversión de la brega en mito identitario; por el contrario, si la acción del bregar permitió la creación de espacios de participación y de relativa autonomía, pese a lo asimétrico del poder colonial: "Uno de los resultados alentadores es que nadie goza del monopolio del 'nosotros' puertorriqueño." ${ }^{295}$, sintetiza Díaz Quiñones. La réplica a una línea de pensamiento inaugurada por Antonio S. Pedreira es clara, si recordamos la pregunta que inicia Insularismo, "¿cómo somos? o a un ¿qué somos? los puertorriqueños globalmente considerados. ${ }^{296} \mathrm{Si}$ las respuestas articuladas por Pedreira, Tomás Blanco, Emilio S. Beleval, Vicente Géigel Polanco, René Marqués, sobre la identidad y el nosotros puertorriqueño gozaron por largas décadas del "monopolio" en el campo intelectual del país, la propuesta de Díaz Quiñones rehuye tanto monopolizar como cristalizar construciones identitarias excluyentes y homogeneizadoras. De allí que también procure explicitar su propia "brega" respecto de la tradición ensayística que lo ha precedido, manifestada en la tensión continuidad y ruptura. Hay una afiliación respecto de una tradición de pensamiento crítico que se plasmó en un género, pero también una marcada diferencia ideológica con aquella, como se puede observar en la cita siguiente, donde se apela y se adscribe a las concepciones adornianas acerca del género ${ }^{297}$ : "La brega, de hecho, guarda semejanzas con el ensayo

\footnotetext{
${ }^{294}$ Díaz Quiñones, Arcadio (2000). "De cómo y cuándo bregar", ed. cit., p. 80.

${ }^{295}$ Ibid., p. 86.

${ }^{296}$ Pedreira, Antonio S. (1970). Insularismo en: Obras de Antonio S. Pedreira, ed. cit., p. 25.

${ }^{297}$ Véase Adorno, Theodor (1962). "El ensayo como forma", en Notas de literatura, Barcelona, Ariel (reproducido en Pensamiento de los Confines, nro. 1, segundo semestre de 1998, Buenos Aires, pp. 247-259). Leemos en el texto de Adorno la siguiente caracterización del género: "Es inherente a la forma del ensayo su propia relativización: el ensayo tiene que estructurarse como
} 
literario, género que se aleja deliberadamente de la ilusión de totalidad, y permite proceder metódicamente sin método, como dijo Adorno." ${ }^{298}$ En términos de Adorno, Díaz Quiñones adopta positivamente aquello que se le cuestiona el ensayo, su carácter fragmentario y accidental, su liberación de la idea tradicional de verdad. ${ }^{299}$

Los cuatro ensayos revisados definen en buena medida las formas en que se ha imaginado y narrado lo nacional en Puerto Rico a lo largo del siglo $\mathrm{XX}$, a pesar de, e incluso a contrapelo de, la ausencia política de una correspondencia entre estado y nación. En ellos encontramos, más allá de los matices y diversos enfoques adoptados, una reflexión acerca de la condición colonial del ciudadano puertorriqueño. En Insularismo Pedreira se propone, según observa María Elena Rodríguez Castro, "...lograr la nación, aún sin el estado. Este es, por lo tanto, un discurso nacional que, desde la subordinación colonial, es contestatario pero con aspiraciones hegemónicas." ${ }^{300}$ Las aspiraciones hegemónicas a las cuales alude Rodríguez Castro tienen que ver, no sólo con la construcción identitaria de un "nosotros los puertorriqueños", sino también con la aspiración ideológica de Pedreira en cuanto a lograr el objetivo político de la formación de élites cultas, conformadas por liberales de origen criollo, "capaces de denunciar a los enemigos de la nación y de guiar paternalmente a las masas", añade Rodríguez Castro ${ }^{301}$. El ensayo de René Marqués, en tanto revela el carácter híbrido y dependiente del Estado Libre Asociado, pone en crisis el viejo orden impuesto por el populismo de los cuarenta y luego por el desarrollismo de los cincuenta. Aunque su discurso constituye una dura crítica de las contradicciones de la política populista, sin

si pudiera suspenderse en cualquier momento. El ensayo piensa discontinuamente, como la realidad es discontinua, y se encuentra su unidad a través de las rupturas, no intentando taparlas." (cito por Pensamiento de los Confines, ed. cit., p. 255)

${ }^{298}$ Díaz Quiñones, Arcadio (2000). "De cómo y cuándo bregar", en: El arte de bregar. Ensayos, ed. cit., p. 81 .

${ }^{299}$ Adorno, Theodor (1998). "El ensayo como forma", en Pensamiento de los Confines, nro. 1, segundo semestre, Buenos Aires, p. 251.

${ }^{300}$ Rodríguez Castro, María Elena (1993). "Las casas del porvenir: nación y narración en el ensayo puertorriqueño", ed. cit.,p. 40.

${ }^{301}$ Rodríguez Castro, María Elena (1993). "Las casas del porvenir: nación y narración en el ensayo puertorriqueño", ed. cit., p. 40. 
embargo no deja de articular una representación del pueblo puertorriqueño visiblemente reductora y fija. La propuesta de José Luis González, construida sobre los cimientos de una nación mulata y caribeña y la preeminencia de la cultura popular sobre la de élite, impugna los principales ejes de la memoria cultural dominante, a la vez que da cuenta de una contramemoria que coloca en su centro a los sectores previamente confinados a los márgenes (negros, mulatos, obreros, sectores populares). Sin embargo, el programa de restitución para la nación con el cual González cierra El país de cuatro pisos, a contrapelo de la tendencia desmitificadora del ensayo, funda su propio mito: "la actualización de la Federación Antillana que propusiera Betances en el siglo XIX y que en su versión enfatiza, ahora, el componente afroantillano.", como precisa Rodríguez Castro ${ }^{302}$.

Este matiz programático que se advierte en los ensayos hasta aquí aludidos parece eclipsarse en el recorrido a través de los distintos procesos por los que atravesó y atraviesa la cultura moderna puertorriqueña en "De cómo y cuándo bregar" de Arcadio Díaz Quiñones. Pero esta ausencia no debe entenderse como una falta de abordaje político a la cuestión de la puertorriqueñidad, como se puede ver en la sistemática negación a contribuir al olvido de un hecho fundamental en la historia del país: la emigración a los Estados Unidos. Díaz Quiñones adopta una perspectiva crítica diaspórica, lo cual supone pensar la cultura, el arte y la literatura más allá y a veces también por el reverso de las construcciones imaginadas dominantes de la nación, sobre todo en sus prerrogativas en relación con la lengua, el territorio, la representación de un "nosotros" homogéneo y estable.

La figura del desplazamiento en el contexto global del imperio se vincula con lo que Homi Bhabha ${ }^{303}$ llama "unhomely fictions", ficciones dislocadas, en las que el habitar y estar en casa se enuncian como problema. Las "casitas" de Martorell que analiza Díaz Quiñones se piensan como ficciones dislocadas, interesantes en cuanto evitan el vaciamiento de significado y la aplicación mecánica del concepto de diáspora, nomadismo, exilio, desplazamiento, como prácticas contestatarias de los miembros de las comunidades desplazadas y

\footnotetext{
${ }^{302}$ Ibid., p. 53.

303 Bhabha, Homi (2002). "Introducción", especialmente apartado "Vidas extrañas (unhommely): la literatura del reconocimiento", en: El lugar de la cultura, ed. cit., pp. 26-35.
} 
también como conceptos que forman parte del vocabulario teórico de la crítica poscolonial. El movimiento emigratorio de los puertorriqueños a Estados Unidos procura al autor atender a las diferentes inscripciones de lo local y lo identitario en la dinámica misma de la emigración.

Si bien los cuatro ensayos permiten visibilizar el carácter discursivo y construido en torno al problema de la identidad puertorriqueña, no agotan la cuestión, por supuesto. Como señalé antes, refiriéndome a Benedict Anderson, es necesario desprender la relación entre narratividad e identidad nacional de las restricciones genéricas. También en Puerto Rico, a pesar de la preeminencia y por momentos hegemonía del ensayo de corte culturalista, las ficciones de la puertorriqueñidad se exploran en formas discursivas muy diferentes como la novela, el cuento, la crónica y la poesía.

En el año 1968, luego de 28 años en el poder, el Partido Popular Democrático perdió las elecciones. La crisis del populismo fue paralela a una importante renovación en el campo de las artes plásticas, música, literatura e historiografía ${ }^{304}$, que sirvió de eje a debates sobre nuevas formas de relación política con la sociedad junto al surgimiento de un nuevo modo de sentir la pertenencia a la nación. Distintos grupo en las décadas del sesenta y del setenta se propusieron abrir nuevos canales de expresión, rompiendo con las nociones oficiales de la cultura, ampliando las posibilidades de la creación colectiva y recuperando importantes elementos de la cultura popular. Los discursos literarios e ideológicos de las décadas anteriores representaban una construcción verbal interpretativa que aseguraba la coherencia y la integración. Pero aquel modelo fue esclerosado por las propias transformaciones sociales, por la crisis del proyecto modernizador, por las consecuencias de la emigración, y por una compleja red de procesos que tenían como telón de fondo la Revolución Cubana y la guerra de Vietnam.

La nueva producción literaria de estos años rompe los límites insulares con el enorme éxito de la novela La guaracha del Macho Camacho de Luis Rafael Sánchez, publicada en 1976. La renovación expresiva de esta obra pone de manifiesto el distanciamiento respecto de los modelos literarios anteriores. Se apela al humor, a las parodias de la cultura letrada, a la

\footnotetext{
${ }^{304} \mathrm{Al}$ respecto véase nota 93 del presente capítulo.
} 
inscripción de elementos de la cultura popular que van desde la adopción de un léxico de la calle hasta la incorporación de la música popular caribeña, no solo a través de la cita intertextual sino en el desarrollo de una prosa rítmica muy particular, basada en repeticiones y anáforas.

De 1976 es también otro libro muy importante en el proceso de renovación del campo literario puertorriqueño, Papeles de Pandora, de Rosario Ferré, donde, como su obra posterior, se destacan las relaciones entre la categoría de género sexual yescritura. Junto con escritoras como Magalí García Ramis, Olga Nolla, Carmen Lugo Filippi y Ana Lydia Vega, entre otras, exploran la diversidad lingüística, social, étnica, cultural y religiosa de Puerto Rico, distanciándose del patriarcalismo cultural de las pasadas generaciones literarias.

A esta variada producción femenina hay que sumar el universo narrativo de los textos de José Luis González, Edgardo Sanabria Santaliz, Juan Antonio Ramos, Luis López Nieves, entre otros, quienes exploran las crisis sociales, la emigración y la violencia. Juan Gelpí habla de una "escritura contracanónica"305 como un rasgo que permitiría englobar la nueva producción literaria del país, especialmente a partir de la década del ochenta. El canon desafiado, desautorizado, impugnado, parodiado, según las diversas estrategias de escritura de cada autor, sería el canon paternalista y nacionalista dominante entre los años treinta y sesenta. La hipótesis resulta muy productiva, pero, corre el riesgo de homogeneizar una producción literaria más compleja, en donde las operaciones de ruptura respecto de la retórica nacionalista anterior conviven con posiciones ambiguas y contradictorias de incorporación/rechazo del pasado nacionalismo cultural.

Tanto los recientes trabajos críticos sobre cultura y literatura en Puerto Rico que he citado hasta aquí, como así también las nuevas orientaciones que rigen las obras de ficción, sugieren la problematización de sostener discursos integradores y totalizantes que den cuenta de una identidad nacional. Estos textos (narrativos, poéticos, ensayísticos, cronísticos), al subrayar y representar cuestiones tales como los conflictos del bilingüismo y la lengua heredada, la cultura popular, la oralidad, la representación de actores sociales como los

\footnotetext{
${ }^{305}$ Juan Gelpí (1993). Literatura y paternalismo en Puerto Rico, ed.cit, p. 136.
} 
emigrados y los "nuyoricans"; la revaloración de los legados culturales y sociales de los sectores negros y mulatos; la vinculación de Puerto Rico con el resto del Caribe y América Latina; la revisión crítica de la historia de la dependencia colonial del país, a través de articulaciones entre historia y ficción, configuran lo puertorriqueño desde otras miradas que acentúan la multiplicidad, la heterogeneidad y la dispersión de la comunidad imaginada como nación puertorriqueña. Bajo estas perspectivas, los próximos capítulos se proponen explorar en textos de Edgardo Rodríguez Juliá y Manuel Ramos Otero, como representantes de la renovada literatura del país en los últimos años, las ficciones de la puertorriqueñidad que ambos construyen. 


\title{
III. Dilemas de la puertorriqueñidad: sobre las crónicas de actualidad de Edgardo Rodríguez Juliá
}

\author{
“¿Cómo definir este pueblo? Definirlo es fácil, pero iqué difícil es \\ describirlo! Es pueblo pueblo, mi pueblo puertorriqueño en su diversidad \\ más contradictoria (...)"
}

Edgardo Rodríguez Juliá, El entierro de Cortijo

\begin{abstract}
Entrevistado por Julio Ortega, Edgardo Rodríguez Juliá caracteriza una importante parte de su producción textual como "crónicas de actualidad" y brinda una definición al respecto:
\end{abstract}

"Ahora, la crónica que propongo en este momento es un modo nuevo de dar testimonio de los cambios sociales tan precipitados que están ocurriendo en nuestra sociedad. Es una manera de ir a la calle, de dar testimonio directo, evitando la formalidad del ensayo, incluyendo algo de lo narrativo y, sobre todo, dando una visión muy personal, muy testimonial de los hechos, de los acontecimientos; de aquello que, por decirlo así, captura la imaginación del pueblo, la imaginación popular."306

Tanto las crónicas de actualidad como aquellos textos que ficcionalizan el siglo XVIII puertorriqueño ${ }^{307}$ se vinculan entre sí, ya que en ambas modalidades la imaginación se postula como una forma de conocimiento, conjetural en las novelas, de observación de una realidad en las crónicas,

\footnotetext{
${ }^{306}$ Ortega, Julio (1991). “1. Crónica de entierros, ficción de nacimientos”, entrevista a Edgardo Rodríguez Juliá, en: Reapropiaciones (cultura y nueva escritura en Puerto Rico), Río Piedras, Editorial de la Universidad de Puerto Rico, p. 125.

${ }^{307}$ Me refiero a las novelas del llamado ciclo de la Nueva Venecia, que se analizan en el capítulo IV, La renuncia del héroe Baltasar (1974), La noche oscura del Niño Avilés (1984) y El camino de Yyaloide (1994). Véase el siguiente pasaje proveniente de El entierro de Cortijo, donde se explicita la continuidad entre el oficio del cronista en el pasado y en el presente: "Morenos, morenos por todos lados y solo una Mont Blanc para escribir... No, el oficio de cronista dieciochesco me lo prohíbe: ni siquiera una libreta, ni una grabadora, tampoco una cámara Minox. Prefiero escribir la crónica pasándola solo por el ojo y el oído, soy tercamente subdesarrollado, basta con escribir al otro día, cuando la memoria aún conserva frescos los detalles. Sálvese lo que pueda salvarse entre el momento vivido y la crónica escrita. Se perderá casi todo, claro, pero permanecerán las imágenes, los detalles más empecinados, esos que no pueden renunciar al recuerdo a pesar de la traición de la memoria...". Rodríguez Juliá, Edgardo (1991).El entierro de Cortijo, Río Piedras, Ediciones Huracán, 5ta. edición, p. 17 (todas las citas textuales corresponden a esta edición).
} 
especulativas en los dos casos, en el sentido etimológico del adjetivo que remite al espejo y la contemplación, operaciones intelectuales que se estrechan hasta confundirse en sola propuesta en Puertorriqueños (Álbum de la Sagrada Familia puertorriqueña a partir de 1898). Entre varios de los conceptos que se entrelazan en la cita precedente quiero destacar el de visión, que constituye un elemento central en las ficciones del autor, donde la imagen y las actividades asociadas a los verbos ver/mirar/contemplar se constituyen en centro de producción de la escritura.

La remisión al espejo o la observación de la realidad como referente extratextual en las crónicas de actualidad no implica que se postulen como instrumentos de la mimesis realista. Aunque el sentido de la vista y la mirada como indagación testimonial cobran un lugar primordial, en tanto el cronista ocupa el espacio del observador, sin embargo, el conocimiento de lo real al cual accede resulta provisorio, complejo, paradójico, revela siempre fallas, fisuras, sesgos. En la configuración autorial que se construye en las crónicas de actualidad $^{308}$ de Rodríguez Juliá el narrador se autorrepresenta como un "espejuelado", de mirada miope, cuyos lentes filtran, alteran, distancian, median entre la actividad de mirar y lo contemplado, como así también media y selecciona la instancia de la escritura, el pasaje de la mirada al lenguaje, la narración de lo observado.

Otro concepto importante presente en la cita del escritor sobre la crónica es el de "testimonio". Caracterizado por Ana María Amar Sánchez como una forma específica, el relato testimonial o de no-ficción es aquel que mantiene el compromiso con los hechos, sin embargo éstos sufren un proceso de "subjetivación" al pasar a través de los sujetos que son la clave de su transformación narrativa ${ }^{309}$. Este proceso de subjetivación se puede vincular con lo que Rodríguez Juliá describe como una "visión muy personal de los hechos", aunque esta fuerte intromisión de la subjetividad no es privativa del

\footnotetext{
${ }^{308}$ También los cronistas de las ficciones del dieciocho, como se verá en el próximo capítulo, perciben la realidad desde variados instrumentos ópticos como mirillas, catalejos, periscopios, lupas, "vasto repertorio de instrumentos visuales, que afinan, forman y deforman la visión", con palabras de Áurea María Sotomayor, "Escribir la mirada", en: Duchesne Winter, Juan (editorcompilador) (1992). Las tribulaciones de Juliá, San Juan, Editorial del Instituto de Cultura Puertorriqueña, pp. 117-167.

${ }^{309}$ Amar Sánchez, Ana María (1995). El relato de los hechos, Rosario, Beatriz Viterbo, pp. 4754.
} 
testimonio. Carlos Monsiváis, en la introducción a su compilación $A$ ustedes les consta. Antología de la crónica en México ${ }^{310}$, propone múltiples acercamientos para intentar definir las modalidades propias del subgénero narrativo crónica, y entre ellas destaca que en el trabajo de la crónica persiste la reconstrucción literaria de sucesos o figuras y el empeño formal domina sobre las urgencias informativas. Agrega Monsiváis: "Esto implica la no muy clara ni segura diferencia entre objetividad y subjetividad" ${ }^{111}$ que se refuerza, además, por el marcado uso de la primera persona narrativa. En el relato testimonial, aunque se pone en evidencia el trabajo constructivo de un sujeto textual que vuelve visibles las operaciones del montaje, recorte, selección de lo que se narra, la presencia del narrador tiende a desvanecerse u ocultarse para dar paso a la voz de los testimoniantes. En las crónicas literarias contemporáneas (Carlos Monsiváis, Elena Poniatowska, Pedro Lemebel, Luis Rafael Sánchez, para nombrar algunos ejemplos de sus más reconocidos cultores), por el contrario, el narrador no se ausenta, aun en los casos en que se explora la oralidad del otro, rasgo que se reitera en las crónicas de actualidad de Rodríguez Juliá. Esta cualidad es destacada por Myrna García-Calderón cuando observa en las crónicas contemporáneas del autor puertorriqueño "la feroz intromisión del $Y_{0}{ }^{\prime 312}$, a lo cual cabe agregar que el yo que se representa en estos textos se exhibe marcadamente autobiográfico, como si intentara mostrar al lector "que está ante relatos directos, no mediados, de la vida real narrados por individuos reales", para decirlo con palabras de Sylvia Molloy respecto de la escritura autobiográfica hispanoamericana ${ }^{313}$. El narrador de las crónicas de Rodríguez Juliá tiende a desdibujar los límites entre narrador-cronista y autor, aunque, pese a los datos biográficos concretos y señas de identidad inequívocas ${ }^{314}$, no

\footnotetext{
${ }^{310}$ Monsiváis, Carlos (1980). "Introducción”, A ustedes les consta. Antología de la crónica en México, México, Ediciones Era, pp. 13-76.

${ }^{311}$ Ibid., p. 13.

312 García-Calderón, Myrna (1997). "El espacio intersticial y transitorio de la nueva crónica puertorriqueña", en: Revista de Crítica Literaria Latinoamericana, Año XXIII, No. 45, LimaBerkeley, pp. 293-306.

${ }^{313}$ Molloy, Sylvia (1996). Acto de presencia. La escritura autobiográfica en Hispanoamérica, México, Fondo de Cultura Económica, p. 27.

${ }^{314}$ Entre las múltiples señas de identidad que vinculan narrador/autor se destacan las referencias al nombre propio, a la fecha de nacimiento, a la historia familiar del autor, a la profesión de escritor, a los títulos de sus obras, etc. En este sentido cabe citar un juicio de Rodríguez Juliá sobre la autofiguración en las crónicas de actualidad: "Yo nunca desaparezco de mis crónicas. Todo lo contrario. Soy un personaje central. Un poco es el escritor mirando por encima del
} 
se presenta como un sujeto unitario sino que adopta diversas máscaras. La figuración de la persona narrativa no es la misma en las diferentes crónicas, como se verá a través del análisis textual propuesto en los próximos apartados.

Julio Ortega considera a Edgardo Rodríguez Juliá como "el heredero de esa larga tradición fugaz" hispanoamericana que es la de la crónica, subgénero que atraviesa distintas épocas y modulaciones "desde Colón, que creyó ver palmas como el primer escenario del paraíso hasta Martí que vio en la palma la promesa del huerto republicano"315, vinculando entre sí en esta tradición a variados autores del pasado y contemporáneos, tales como José Martí, Alejo Carpentier, García Márquez, Luis Rafael Sánchez. Por su parte Rodríguez Juliá en diferentes entrevistas ${ }^{316}$, en ensayos como "Tradición y utopía en el barroco caribeño"317, en numerosos pasajes autorreflexivos de sus crónicas como en una de las últimas publicadas, titulada "Cronistas"318, se incluye entre los escritores de crónicas, modalidad narrativa cuyo papel en la historia de la conformación de la literatura latinoamericana ha sido central. De su lugar imprescindible como gran relatora de hechos en los siglos de la conquista y colonización de América, hasta su importantísimo rol en el proceso de profesionalización del escritor finisecular durante el Modernismo ${ }^{319}$, la crónica asume en la actualidad diversas funciones y reconfiguraciones genéricas particulares. Para algunos especialistas, como los ya mencionados Ana María

hombro del espectador... Alguna gente me ha criticado eso, que yo no desaparezco de mis crónicas. Pero es que yo no voy a desaparecer porque yo soy la crónica." Citado por María Elena Rodríguez Castro, de una entrevista inédita, cuyos fragmentos reproduce en su artículo "Memorias conjeturales: las crónicas mortuorias", en: Duchesne Winter, Juan (editorcompilador) (1992). Las tribulaciones de Juliá, ed. cit., pp. 63-92. (p. 79)

315 Ortega, Julio (2002). "Prólogo. Nueva crónica de las Islas" a Rodríguez Juliá, Edgardo. Caribeños, San Juan, Instituto de Cultura Puertorriqueña, pp. vii-xiii.

${ }^{316}$ Dos entrevistas importantes en la cuales Rodríguez Juliá reflexiona sobre la crónica son "El cronista hecho crónica", por Gloria Borrás, Puerto Rico Ilustrado, El Mundo, 14 de junio de 1987, pp. 10-13, y "Crónica de entierros, ficción de nacimientos" por Julio Ortega, en: Reapropiaciones. Cultura y nueva escritura en Puerto Rico, ed. cit. pp. 123-162.

${ }^{317}$ Rodríguez Juliá, Edgardo (2002). "Tradición y utopía en el barroco caribeño", en: Caribeños, ed. cit., pp. 65-73.

${ }^{318}$ Rodríguez Juliá, Edgardo (2002). “Cronistas”, en: Caribeños, ed. cit., pp. 185-191.

319 Sobre la inserción y desarrollo de la crónica en la literatura finisecular, véase González, Aníbal (1983).La crónica modernista hispanoamericana, Madrid, Ediciones José Porrúa Turanzas; Ramos, Julio (1989). Desencuentros de la modernidad en América Latina, México, FCE.; y Rotker, Susana (1992). La invención de la crónica, Buenos Aires, Ediciones Letra Buena. 
Amar Sánchez y Myrna García-Calderón, la crónica ha evolucionado incorporando las influencias de la corriente llamada "New Journalism" que, desde mediados de los años sesenta, autores como Truman Capote, Tom Wolfe, Norman Mailer, entre los más reconocidos, han desarrollado en los Estados Unidos, combinando el reportaje veraz, característico del periodismo, con materiales ficticios. Varias crónicas de Rodríguez Juliá, por ejemplo Puertorriqueños, fueron publicadas como colaboraciones del autor en el suplemento cultural dominical del diario de mayor tirada de su país, El Nuevo Día, para ser editadas posteriormente como libros. Pero otras, como Las tribulaciones de Jonás y El entierro de Cortijo, se publicaron directamente como libros, sin haber pasado por el formato periodístico, aunque incluyendo algunas características de éste, por ejemplo, la utilización del reportaje y la fotografía. No obstante, en todos los casos se trata de crónicas, sin importar el medio en el cual hayan sido editadas.

Ana María Amar Sánchez incluye Las tribulaciones de Jonás y El entierro de Cortijo bajo la categoría de relatos de no-ficción ${ }^{320}$. Para esta crítica los narradores de ambos textos son "periodistas". Sin embargo una lectura atenta de las crónicas nos revela un sujeto narrador que se autoconfigura como escritor y cronista, destacando su función diferente y diferenciada de la del periodista, como se advierte en la siguiente cita de El entierro de Cortijo : "Por acá los muchachos de la prensa ya abordaron cámara en mano el pick up que les ofrecerá una perspectiva privilegiada, aunque impotente para captar en toda su plenitud la diversidad humana del entierro."321 Por el contrario el cronista, con las herramientas que le proporciona la imaginación literaria y la ficción, puede compensar la "impotencia" del periodista mediante la invención creativa y la construcción de significados, aún cuando éstos se revelen contradictorios. $\mathrm{Si}$ las tomas panorámicas niegan las individualidades, el escritor-cronista es quien se ocupa de rescatarlas, detiene el paso de la multitud, elige rostros e inventa biografías: "Ahora quiero un golpe de vista que sea capaz de resumir

\footnotetext{
320 "Sin dudas, es muy fuerte la presencia del narrador-periodista en los textos de Rodríguez Juliá", afirma Ana María Amar Sánchez refiriéndose a las crónicas Las tribulaciones de Jonás y El entierro de Cortijo, en: El relato de los hechos, ed. cit., pp. 51-52.

${ }^{321}$ Rodríguez Juliá, Edgardo (1991). El entierro de Cortijo, ed. cit., pp. 52-53. (cursivas del autor)
} 
toda esta complejidad.(...) No, es imposible, tendré que volver a los rostros, a los individuos, para que esto signifique algo."322

Las crónicas de Rodríguez Juliá participan de la hibridez característica de esta modalidad textual ${ }^{323}$, en la cual se advierte una contaminación genérica donde se conjugan el relato testimonial, la reflexión ensayística, la narratividad de un cuento o novela corta, las diversas figuraciones de la voz narrativa, la fragmentación del relato, el culto de la pequeña historia, la inclusión del registro oral, entre otros rasgos que le permiten al cronista, retomando la reflexión inicial del autor sobre las crónicas, "evitar la formalidad del ensayo". Sobre esta cuestión María Elena Rodríguez Castro propone pensar a Rodríguez Juliá como "cronista moderno que evade el formalismo del ensayo para dar testimonio del mismo objeto de su reflexión: la sociedad puertorriqueña."324 Cuando la crítica se refiere al ensayo está aludiendo a la tradición ensayística puertorriqueña en torno al debate sobre la identidad nacional ${ }^{325}$. En múltiples ocasiones Rodríguez Juliá se ha reconocido partícipe de esta tradición indagatoria sobre la condición puertorriqueña, como declara en la entrevista que le hizo Julio Ortega: "Lo más importante es insistir en el hecho de la tradición y esa tradición es la de explicar lo que es Puerto Rico. El problema de la identidad aflora a través de las generaciones. Creo que soy solidario con esta tradición.”326 0 también, en otra entrevista realizada por María Julia Daroqui para el suplemento literario del periódico El Nacional, cuando el escritor afirma que: "El problema de la 'identidad puertorriqueña', tan estudiado en el ensayo de la generación de los años treinta, se ha convertido para nosotros en una especie de obsesión historicista, de esclarecimiento de

\footnotetext{
${ }^{322}$ Rodríguez Juliá, Edgardo (1991). El entierro de Cortijo, ed. cit., p. 77. (cursivas del autor).

${ }^{323}$ Contaminación genérica que se percibe en la vacilación del crítico Juan Duchesne Winter a la hora de definir el género al cual pertenece la crónica El entierro de Cortijo: "El ensayo narrativo de Edgardo Rodríguez Juliá que ofrece su testimonio del entierro multitudinario de Rafael Cortijo (...)", para, más adelante, nombrar el texto como "crónica de entierros" junto con Las tribulaciones de Jonás, véase "Multitud y tradición en El entierro de Cortijo", Narraciones de testimonio en América Latina, Río Piedras, Editorial de la Universidad de Puerto Rico, 1992, pp. 181-208. (el subrayado es mío)

${ }^{324}$ Rodríguez Castro, María Elena (1992). “Memorias conjeturales: las crónicas mortuorias”, en: Duchesne Winter, Juan (editor-compilador) Las tribulaciones de Juliá, ed. cit., p. 70.

${ }^{325}$ Véase al respecto el capítulo II.

${ }^{326}$ Ortega, Julio (1991). “1. Crónica de entierros, ficción de nacimientos”, entrevista a Edgardo Rodríguez Juliá, en: Reapropiaciones (cultura y nueva escritura en Puerto Rico), ed.cit., p. 123.
} 
nuestro problema social y colonial a través de la memoria histórica". ${ }^{327}$ Este enunciado revela, por una parte, la vinculación o traspaso de un "legado" -el problema de la identidad- que confiere una articulación entre los treintistas y un "nosotros" inclusivo al cual, en otros textos, Rodríguez Juliá también alude como "nuestra generación, la de 1946"328 (año de nacimiento del autor). En este sentido Juan Gelpíi ${ }^{329}$ señala que la "filiación" al planteo de la identidad nacional no debe confundirse con la "afiliación" a la retórica y conceptos del nacionalismo cultural treintista. La fluidez, la fragmentariedad y la multiplicidad de la experiencia social y cultural de Puerto Rico proponen otras imágenes y versiones de lo nacional, que emerge como el espacio de lo heterogéneo, contradictorio y complejo en las crónicas de actualidad de Rodríguez Juliá.

El problema de la puertorriqueñidad funciona como un hilo conductor en estos textos, y cobra cuerpo y forma especialmente en la exploración de la cultura popular: los efectos histórico-sociales de la muerte de Luis Muñoz Marín, fundador del populismo puertorriqueño y arquitecto del Puerto Rico moderno (Las tribulaciones de Jonás); el entierro del músico popular, renovador del ritmo de la plena, Rafael Cortijo (El entierro de Cortijo); los avatares del show televisivo de mayor audiencia en la Isla (Una noche con Iris Chacón); el proceso de modernización de Puerto Rico, perturbadoramente contradictorio (Puertorriqueños. Álbum de la sagrada familia puertorriqueña a partir de 1898); los dilemas de la vigencia del colonialismo (El cruce de la bahía de Guánica); la pasión por el béisbol entre los puertorriqueños (Peloteros); la comida local (Elogio de la fonda). En todas estas crónicas se destaca la exploración de la oralidad popular, donde se registra la heterogeneidad de la composición social del país:

"Resucito la crónica, género fundante de nuestra realidad americana, para dar testimonio de un mundo sumido en el trajín del

\footnotetext{
${ }^{327}$ Daroqui, María Julia. "Formular la 'verdadera historia' " (Entrevista al escritor puertorriqueño Edgardo Rodríguez Juliá), en "Papel literario", suplemento del periódico El Nacional, Caracas, 22 de julio de 1990.

${ }^{328}$ Rodríguez Juliá, Edgardo (1994). "Mapa de una pasión literaria", en: Estudios, Revista de Investigaciones Literarias, Año 2, Nro. 4, Caracas, jul.dic., p. 5.

${ }^{329}$ Gelpí, Juan (1993). "Las tribulaciones de Jonás ante el paternalismo literario", en: Literatura y paternalismo en Puerto Rico, ed. cit., pp. 45-60. Los conceptos de filiación/afiliación están usados en el sentido que les asigna Edward Said. Véase al respecto la nota al pie número 123 del capítulo II.
} 
cambio. (...) La palabra lumpen del arrabal, el anglicismo del neorican, la expresión del jíbaro ancestral lo mismo que la del señor de clase media o la del estudiante combativo, cobran en la proximidad del espacio narrativo un valor iconográfico, emblemático..." ${ }^{330}$

A la heteroglosia discursiva de estos textos se le suma un particular trabajo con la representación espacial, donde "el trajín del cambio" parece haberse instalado con especial énfasis en la trasformación urbana de la ciudad de San Juan, llevada a cabo por el desarrollismo populista en los años cincuenta del siglo $X^{331}$ y que el cronista registra en su rol de observador, a través de sus continuos desplazamientos por la ciudad, sus "barriadas" y "caseríos", playas, avenidas principales y callejuelas, incluyendo también en este recorrido a la ciudad de Nueva York, como centro principal de los movimientos emigratorios puertorriqueños a los Estados Unidos. En los avatares de las transformaciones desarrollistas emerge con fuerza la memoria personal del narrador, un sujeto testimonial que se reconoce inmerso en ese proceso histórico y social: "Yo había sido testigo de la transformación de Puerto Rico; mi infancia y adolescencia sufrieron el propio tránsito familiar de la pequeña burguesía rural a la nueva clase media suburbana." ${ }^{332}$ Sin embargo la memoria funciona como un filtro, trabaja a partir de fragmentos, retazos; el lugar de enunciación del cronista se relativiza en la dispersión y la subjetivización, en las diferentes máscaras adoptadas a lo largo de los textos, incluida la autobiográfica, y en la continua problematización de la voz y el foco narrativos. Brevemente, para resumir esta caracterización general de las crónicas contemporáneas de Rodríguez Juliá planteada hasta acá, quiero citar las observaciones de Myrna García-Calderón, quien concluye al respecto:

\footnotetext{
${ }^{330}$ Rodríguez Juliá, Edgardo (2002). “Tradición y utopía en el barroco caribeño”, en: Caribeños, ed. cit., p. 71.

${ }^{331}$ Sobre la trasformación del espacio y la vida cotidiana a partir del desarrollismo fomentado por el Partido Democrático Popular liderado por Luis Muñoz Marín observa Arcadio Díaz Quiñones: "Las flamantes neveras se colocaban en el comedor, y hasta en la sala. Pocos años después serían desplazadas por los televisores. Fuimos a ver, temerosos y embobados, el rutilante Professional Building de la parada 22 en Santurce: ya teníamos nuestro propio rascacielos." Véase el ensayo "La vida inclemente", en: La memoria rota, ed. cit., p. 21.

${ }^{332}$ Rodríguez Juliá, Edgardo (1984). Las tribulaciones de Jonás, Río Piedras, Ediciones Huracán, (todas las citas textuales corresponden a esta edición).
} 
"Todas estas crónicas tienen varios rasgos en común: en todas está presente un interés por entender y explicar la condición puertorriqueña, todas se centran en personajes claves de diversos desarrollos sociales, políticos y económicos que de algún modo contribuyen a un cambio en la sociedad puertorriqueña, en todas hay una exploración de la imaginación a través del tejido de la lengua, en todas el aspecto lingüístico (parodia, detallismo, silencios, etc.) se construye en el eje que define la narración y todas ellas asumen una posición crítica e iconoclasta con relación a la realidad y los personajes discutidos." 333

En las próximas páginas propongo distintas aproximaciones a un conjunto de crónicas de actualidad de Edgardo Rodríguez Juliá, para reflexionar a partir de su análisis, sobre los complejos dilemas en torno a la puertorriqueñidad y su representación textual.

III. 1 Crónicas escatológicas de Puerto Rico. Sobre Las tribulaciones de Jonás, El entierro de Cortijo y Una noche con Iris Chacón

III.1.1 Crónicas de entierros

"El duelo es, por regla general, la reacción frente a la pérdida de una persona amada o de una abstracción que haga sus veces, como la patria, la libertad, un ideal, etc."

$$
\text { melancolía" }
$$

Sigmund Freud, "Duelo y

\footnotetext{
${ }^{333}$ García Calderón, Myrna (1997). "El espacio intersticial y transitorio en la nueva crónica puertorriqueña”, ed. cit., pp. 302-303.
} 
A comienzos de la década del ochenta, Edgardo Rodríguez Juliá publica dos crónicas, Las tribulaciones de Jonás (1981) y El entierro de Cortijo (1983). Ambas se escriben a partir de pérdidas -reales y simbólicas-, y toman como eje ceremonias colectivas fúnebres: el entierro del líder y fundador del Partido Popular Democrático, Luis Muñoz Marín, patriarca descendiente de terratenientes criollos, responsable del establecimiento del Estado Libre Asociado, y el velatorio y entierro del músico popular, descendiente de esclavos, Rafael Cortijo $^{334}$, conguero y timbalero, precursor de la salsa y renovador de la plena ${ }^{335}$. Las dos "ocasiones luctuosas" ${ }^{\text {"336 }}$ concitaron una enorme afluencia de personas de diversa condición social que hicieron públicas sus múltiples expresiones de duelo y luto, agudamente registradas por el cronista en los textos. Los entierros de ambas figuras, caracterizados por su dimensión colectiva, se pueden analizar a partir de las categorías de manifestación, desfile, cortejo, procesión, estudiadas por Louis Marin ${ }^{337}$, como eventos que poseen una estructura compleja y diversa, a la vez real y simbólica, cuyo carácter colectivo tiene la capacidad de transformar relaciones reales y específicas en communitas. En las dos crónicas el narrador testimonia la conformación de la communitas, aunque en confrontación con su imposibilidad de asumirse como nación.

Luis Muñoz Marín murió el 30 de abril de 1980 y su entierro se llevó a cabo el 2 de mayo. El duelo nacional en el que se sumió el país no tiene

${ }^{334}$ Sobre Cortijo y su Combo, véase Quintero Rivera, Ángel (1999). Salsa, sabor y control. Sociología de la música tropical, especialmente el capítulo II, "De 'El Pablo pueblo' a 'La maestra vida'. Mito, historia y cotidianidad en la expresión salsera”, México, siglo XXI, pp.87200.

${ }^{335}$ La plena es una composición musical de forma binaria, y consta de una estrofa de dos períodos, con un interludio instrumental intercalado. Muestra la alternancia de solista y coro común a toda la expresión musical afroamericana. Mientras el guía vocal hace sus inspiraciones, el coro repite el motivo temático central, que responde al estilo del refranero. Habitualmente, las voces cantan al unísono, aunque a veces se mueven por terceras o sextas. El texto se estructura a la manera de la copla, con versos de seis y ocho sílabas; a veces se combinan de ocho y de diez. Las piezas de este género se componen tanto en modo mayor como en modo menor. Su melodía ondulante se expresa mediante frases breves, que hacen un contrapunto con el doble tiempo marcado por la sección rítmica, lo que origina un producto muy sincopado. La gama temática abarca asuntos referidos a la vida cotidiana, especialmente del ámbito popular, en tono humorístico, satírico y burlón.

336 “Afuera, en la calle Providencia, la espera se transformó paulatinamente en un ir y venir de actitudes encontradas, casi extrañas a eso que se llama la ocasión luctuosa." Rodríguez Juliá, Edgardo (1991). El entierro de Cortijo, ed. cit., p. 50.

${ }^{337}$ Marin, Louis (1994). "Une mise en signification de l'espace social: manifestation, cortège, défilé, procession", en: De la représentation, París, Seuil-Gallimard, pp. 46-61. 
precedentes en Puerto Rico. El cortejo fúnebre recorrió en el lapso de 12 horas el itinerario entre San Juan y Barranquitas, trayecto significativo, como señala Juan Gelpí, ya que termina en el lugar del nacimiento del líder: “...el entierro sale de la capital, pasa por los pueblos y campos y llega al pueblo en que nació Luis Muñoz Marín. Dicho de otro modo el entierro es una especie de reunión de los puertorriqueños que recorre gran parte del país." ${ }^{338}$ Se reunieron líderes políticos de diferentes tendencias ideológicas, representantes de varios países de América Latina, pero fundamentalmente distintos grupos sociales (urbanos, campesinos, niños, estudiantes, mujeres, ancianos) que dan cuenta de la multiplicidad del pueblo puertorriqueño. Heterogeneidad que también se hace presente en el entierro de Rafael Cortijo, fallecido el 3 de octubre de 1982 y sepultado el día 6, como constata el narrador en más de una ocasión cuando se esfuerza por aprehender aquello que se le escurre, la "diversidad contradictoria" ${ }^{\text {"39 }}$ del pueblo puertorriqueño. Como en la ceremonia fúnebre del líder político, la multitud que despidió al músico también se desplaza desde la barriada proletaria conocida como el caserío Luis Llórens Torres hasta el cementerio de Villa Palmeras. En las dos crónicas la toponimia construye, a partir de los lugares por donde se desplaza la multitud en procesión, circuitos significativos y articuladores de un "discurso espacial"340 que subraya la complejidad narrativa de ambos textos.

Ahora bien, si antes se afirmó que las dos crónicas mortuorias se fundan en pérdidas reales y simbólicas, cabría preguntarse qué significados cobran las figuras de Luis Muñoz Marín y de Rafael Cortijo en estos textos. En la breve reseña histórica sobre Puerto Rico en el capítulo inicial destaqué la importancia del líder político del Partido Popular Democrático, Luis Muñoz Marín, en el proceso de modernización de Puerto Rico. Fue el primer gobernador electo del país, bajo cuya larga gestión (1949-1964) se establecieron y desarrollaron tres

\footnotetext{
${ }^{338}$ Gelpí, Juan (1993). “Las tribulaciones de Jonás ante el paternalismo literario”, ed. cit., p. 52. ${ }^{339}$ Rodríguez Juliá, Edgardo (1991). El entierro de Cortijo, ed. cit., p. 18 (véase epígrafe inicial del presente capítulo).

${ }^{340}$ Louis Marin destaca que en eventos tales como la manifestación, el desfile, el cortejo, la procesión hay una manipulación del espacio y los lugares preexistentes a estos desplazamientos, lo que le permite pensar en una organización discursiva del espacio y analizar la articulación de frases entre los distintos puntos de los recorridos como "narrativa de las trayectoria." Marin, Louis (1994). "Une mise en signification de l'espace social: manifestation, cortège, défilé, procession", ed. cit., pp. 50-51.
} 
grandes proyectos que marcaron un giro histórico en la Isla: el establecimiento del Estado Libre Asociado, la Operación Manos a la Obra y la Operación Serenidad, con el fin de impulsar el desarrollo industrial, económico, social y cultural del país. Durante su gobierno la agricultura dejó de ser la principal fuente de trabajo del país, que cedió su puesto al crecimiento industrial, lo que generó un éxodo incesante desde las zonas rurales hacia las zonas urbanas, especialmente, hacia la capital, San Juan. El desarrollismo populista de Muñoz Marín fomentó la transformación urbana de las principales ciudades puertorriqueñas, a través de la reactivación de la industria de la construcción y la edificación de barrios proletarios y edificios de propiedad horizontal. Aunque también, como señalé antes ${ }^{341}$, este proceso reveló pronto sus fisuras internas que lo llevaron a colapsar hacia finales de la década del sesenta: el ELA no resolvía sino que profundizaba la vigencia del colonialismo, sumado al desgarro provocado por la política de las emigraciones forzosas a los Estados Unidos por el alto índice de desempleo y la dependencia metropolitana, cada vez mayor, a través del sistema de cupones y planes asistenciales para los residentes en la Isla, excluidos del "milagro económico".

Sobre este período retomo las agudas observaciones que propone Arcadio Díaz Quiñones, testigo lúcido y desencantado de aquella época, en dos ensayos ya citados que forman parte de su libro La memoria rota. Me refiero a "La vida inclemente" y "Los años sin nombre", de los cuales incluyo los siguientes fragmentos, críticamente descriptivos de la cuestión:

"Éramos los hijos del vasto movimiento político y social iniciado en los años cuarenta por el Partido Popular Democrático, los beneficiarios de las gestiones renovadoras en el terreno educativo y social, de la transformación dirigida por la Compañía de Fomento Industrial y del Banco Gubernamental de Fomento." (...) "Pero lo cierto es también que en el Puerto Rico de los años cincuenta y sesenta se identificaba democracia con producción y capitalismo. (...) Nos acostumbraron a las estadísticas triunfantes, a la expansión vertiginosa de los centros urbanos, de las urbanizaciones, de las carreteras". (...) "La ciudad se iba transformando, cambiando su rostro ante los atónitos ojos de nuestras abuelas, sin que esa transformación fuera acompañada de un replanteo cultural significativo del pensamiento urbano." ${ }^{342}$

\footnotetext{
${ }^{341}$ Véase capítulo I, especialmente pp. 41-51.

${ }^{342}$ Estos párrafos corresponden a Díaz Quiñones, Arcadio (1993). "La vida inclemente”, en : La memoria rota, ed. cit., pp. 19, 21 y 31 respectivamente.
} 
'El 'milagro', sin embargo, no podía ocultar las contradicciones. El gobierno tuvo que garantizar la 'paz industrial' y la mano de obra barata. Al mismo tiempo fomentó la emigración de miles y miles de puertorriqueños a los Estados Unidos. (...) El Partido Popular toleró, impotente, la expansión militar y naval en la isla, y los puertorriqueños tuvieron que pelear y morir en Corea y Vietnam. Una de cada tres mujeres puertorriqueñas ha sido esterilizada. Los proyectos de reforma agraria fueron totalmente abandonados. ${ }^{343}$

En Las tribulaciones de Jonás, el cronista -quien se configura desde la enunciación autobiográfica- aparece también, coincidiendo con Díaz Quiñones, como "hijo" del vasto movimiento iniciado por el populismo. A pesar de sus repetidas manifestaciones de independentismo ideológico y de su distanciamiento crítico respecto de la política del líder del PPD, no puede evitar la ambivalencia que le provoca Luis Muñoz Marín, atrapado bajo los efectos de su poder carismático, como Jonás dentro del vientre de la ballena, mito bíblico al que se alude en el título de la crónica ${ }^{344}$. El narrador-cronista adopta, entre distintas formas de autofiguración, la del intelectual, espejuelado y miope, pero lúcido, cuya mirada y percepción del otro (Muñoz Marín, el pueblo seguidor del líder) revierte sobre sí mismo. La indagación se torna por momentos irreverente, irónica, bastante incisiva y pesimista:

"A pesar de la distancia ideológica su vida había afectado profundamente la mía. ¿Consistía precisamente en ello la grandeza? ¿Reside ésta ahí, justo en ese ámbito donde nuestra oposición ideológica se desvanece ante la obra ineludible? El sitio donde vivo, la institución donde trabajo, las libras de sobrepeso, la formación ósea de mi hijo y el bienestar diario han resultado de un proyecto social que este hombre formuló, que llevó a cabo junto a otros hombres que como él creyeron que la compasión es el principal fundamento del quehacer político. A pesar de la minúscula idea entre ceja y ceja, la grandeza de Muñoz Marín me alcanza, tocándome inevitablemente. Sin él millares de vidas puertorriqueñas habrían sido completamente distintas. ¿Por qué la veneración de todo un pueblo?..."345

\footnotetext{
${ }^{343}$ Díaz Quiñones, Arcadio (1993). "Los años sin nombre”, Ibid., pp. 121-122.

${ }^{344}$ María Elena Rodríguez Castro sugiere certeramente que la alusión al mito bíblico entraña también la imagen del desarrollismo como una ballena que termina tragándose incluso al propio Muñoz Marín. Véase el artículo de la autora "Memorias conjeturales: las crónicas mortuorias", ed. cit., pp. 63-92.

${ }^{345}$ Rodríguez Juliá, Edgardo (1984). Las tribulaciones de Jonás, ed. cit., pp. 52-53.
} 
Las tribulaciones de Jonás se organiza como una crónica que pone en escena la tensión entre pasado y presente, fundamentalmente al indagar los efectos y dispersión de la utopía populista de los años cincuenta en la crisis de los años ochenta. Muñoz Marín se destaca en el texto como el responsable de un país carente de estado y que compensa dicha ausencia adoptando el rol de patriarca protector de la "familia puertorriqueña", metáfora que está en la base ideológica del populismo, como se analizó en el capítulo anterior. Por su parte, en El entierro de Cortijo, Rafael Cortijo representa al sujeto colectivo, la "gente de caserío", hacia la cual el desarrollismo populista se desplazó e intentó abarcar con gestos de paternalismo político (salud pública, ampliación educativa, viviendas económicas, urbanizaciones, etcétera). Cortijo y su Combo alcanzaron enorme popularidad en Puerto Rico entre los años cincuenta y sesenta, época que coincide con la aún triunfante política del PPD. Rafael Cortijo Verdeja nació en Santurce ${ }^{346}$, área conformada históricamente desde el siglo XVIII en los márgenes de San Juan y habitada principalmente por negros libres que brindaban servicios a los habitantes de la capital colonial. En los años cincuenta del siglo XX fue escenario de la dramática migración interna ante la crisis de la economía agrícola. Según indica el sociólogo Ángel Quintero Rivera, la franja territorial costera de Puerto Rico -que incluye los márgenes de Santurce, a Piñones y a Loíza-, era famosa en el país por el desarrollo de los ritmos populares de bomba y plena:

"De la tradición de los grupos que se reunían espontáneamente a tocar bomba y plena en las esquinas de la calle Calma surgió, bajo el liderato del conguero y timbalero Rafael Cortijo, un conjunto musical que habría de constituirse en el más importante antecedente puertorriqueño inmediato de la salsa. Cortijo combinó la tradición percusiva del rumbón de esquina, con la tradición latino-caribeña de los conjuntos para el baile 'social' (de salón) donde predominaban los vientos-metal.".347

\footnotetext{
${ }^{346}$ Sepúlveda, Aníbal y Carbonell, Jorge (1987). Cangrejos-Santurce. Historia ilustrada de su desarrollo urbano (1519-1950), San Juan, CARIMAR.

${ }^{347}$ Quintero Rivera, Ángel (1999). “De 'El Pablo pueblo' a 'La maestra vida'. Mito, historia y cotidianidad en la expresión salsera", en: Salsa, sabor y control. Sociología de la música tropical, ed. cit., p. 162. Quintero Rivera explica que la bomba es la música más claramente asociada históricamente a la plantación esclavista y a la población negra, se caracteriza por un ritmo que se logra con un repiqueteo característico de dos tambores. Dicho ritmo se melodiza, se camuflea melódicamente en la música tropical. La bomba puertorriqueña es música de canto antifonal (de "llamado" y "respuesta" entre solista y coro) cuyas melodías y letras son generalmente muy sencillas y repetitivas, es fundamentalmente música para bailar.
} 
La popularidad del músico se incrementó además por su incursión en los medios de comunicación masiva. Cortijo y su Combo tuvieron su espacio televisivo en los programas La Taberna India y Jueves de Bobby Capó, además de su show diario por Radio El Mundo. Formó parte de su Combo Ismael "Maelo" Rivera, "el sonero mayor", cuyas modulaciones vocales hicieron furor entre los seguidores del grupo.

Las dos crónicas coinciden en cuanto se construyen a partir de ceremonias fúnebres; evocan los mismos ejes temporales (décadas del cincuenta y sesenta en confrontación con la década del ochenta); convocan personajes célebres y populares, líderes, uno de un vasto movimiento político, otro de un vasto movimiento de música popular, y en ambos casos la muerte deviene "acontecimiento cultural". Así Juan Duchesne Winter afirma que en estas obras de Rodríguez Juliá se traspasa el empleo retórico de las metáforas mortuorias, para volver visible "...no el hecho cultural como manifestación de la muerte, sino la muerte como acontecimiento cultural. ${ }^{348}$ Desde esta perspectiva propongo entonces una interpretación de ambas crónicas mortuorias para analizar las dimensiones simbólicas que cobran las ceremonias fúnebres como interrogaciones sobre la identidad nacional del pueblo puertorriqueño.

Las tribulaciones de Jonás se divide en cuatro partes: la primera vez que el cronista ve, en su infancia, a Muñoz Marín; una entrevista al líder, junto a otros intelectuales, fechada en 1978; la crónica del entierro en 1980, y finalmente una iconografía comentada de Muñoz Marín. En la primera parte el narrador evoca y se percibe a sí mismo desde la perspectiva de un niño de diez años, quien relata a modo de rito de iniciación centrado en la mirada, cómo fue la primera vez que vio Luis Muñoz Marín. El narrador intenta recrear la perplejidad infantil, los ojos de un niño que aún no comprenden pero testimonian el concepto de liderazgo, y sus tensiones. Los padres, aunque opositores a Muñoz, sin embargo, espían al líder, semiocultos detrás de las persianas:

\footnotetext{
348 Duchesne Winter, Juan (1992). "Multitud y tradición en El entierro de Cortijo",en Narraciones de testimonio en América Latina, ed. cit., p. 182.
} 
"Me aupé más en la baranda, quise ver a Muñoz Marín, todo el mundo hablaba de aquel hombre, terrible enemigo de mi madre, señor de la política con corteja y hasta querida, el hombre más famoso de Puerto Rico, el jefe, el caudillo, el viejo, el casi dictador decía a veces mi padre... Y yo aquí, en el balcón, y está pasando por Aguas Buenas!"349

La representación del espacio, el balcón, instaura una imagen de lo alto, impone una distancia, un límite difícil de franquear. El niño, que luego devendrá escritor, se retira del entorno familiar y observa los hechos desde la altura, aunque desearía estar en la calle, como parece sugerir el desencanto de la expresión "Y yo aquí." La escena infantil opera como un emblema de la contradictoria posición del sujeto que se reitera en la crónica, atrapado entre el distanciamiento crítico y la intimidad de los afectos.

Antes de iniciar la entrevista con Muñoz Marín en la segunda parte, el cronista se caracteriza en su rol de intelectual e independentista, profesor de literatura y escritor, capaz de rechazar la compasión que pueda provocarle el entrevistado, envejecido y afásico. Pero la recreación del encuentro se relata desde la posición vulnerable de un sujeto que se configura en relación contraria a la del intelectual, paradójicamente aniñado: "Muñoz me mira sorprendido: por un momento pensé que yo le caía mal, o peor, que me consideraba el de las preguntas y los comentarios pendejos" ; "Me reconocí como un niño malcriado, comemierda, altanero, justo al nivel del peor mandarinato y blanquitismo del país" ; "Yo, bebé post-Muñoz, criado con leche Pet y Carnation, me echo a un lado, prefiero mirar desde la valla, no convertirme en víctima de esa demagogia que están incubando." 350

El narrador aniñado se coloca a sí mismo en el lugar figurado del "hijo", frente a la decaída pero todavía autoritaria imagen del patriarca, que le genera contradictorios sentimientos: amor y rencor, admiración y decepción, compasión y burla. La tensión equívoca entre los polos de la atracción y el rechazo, se percibe también a través de los diferentes apelativos con los cuales el cronista nombra y califica a Muñoz Marín: desde el uso objetivo del nombre y apellido, pasando por los más fríos y distantes "Patriarca", "el Viejo", "el vate",

\footnotetext{
${ }^{349}$ Rodríguez Juliá, Edgardo (1984). Las tribulaciones de Jonás, ed. cit., p. 20.

350 Rodríguez Juliá, Edgardo (1984). Las tribulaciones de Jonás, ed. cit., párrafos correspondientes a las páginas 31,49 y 34 respectivamente.
} 
el "jodido animal político", el "Renegado", hasta el más afectuoso y cercano "Don Luis".

En la narración del entierro, en la tercera parte ${ }^{351}$, el cronista se esfuerza por invocar la distancia, para registrar una muerte hiperbólica, que deviene espectáculo barroco. Como en su infancia, se ubica en lo alto: "Equidistante entre el afán de testimonio y todo aquel dolor a mi alrededor, alcé la vista hacia la colina frente al Capitolio." ${ }^{\text {"352 }}$ Sin embargo sucumbe a la cercanía y se zambulle en la multitud: es apretujado por la gente, arrastrado por la muchedumbre, contagiado por el dolor que se inscribe en su cuerpo, le sube por la garganta y le nubla la mirada, centro de organización de la crónica. Para alejar el fantasma de la (auto)compasión, el cronista necesita adoptar otra autofiguración, esta vez como intérprete o exégeta que pretende desentrañar un enigma, descifrar "el misterio de aquella relación entre Muñoz Marín y su pueblo". ${ }^{353}$ Rubén Ríos Ávila lee en la construcción de esta última imagen del narrador la búsqueda de una figura de autor como fuente de autoridad narrativa: "El autor no es una sicología, ni tan siquiera una autobiografía: es un constructo, una rúbrica controladora que se figura como sujeto para controlar la proliferación del sentido y detener la textualidad desbocada." ${ }^{354}$ Voz autorial que se manifiesta también en la última parte de Las tribulaciones de Jonás, donde la escritura se combina con las fotografías de Luis Muñoz Marín. Estructurada como un álbum fotográfico comentado, como "último valor cúltico

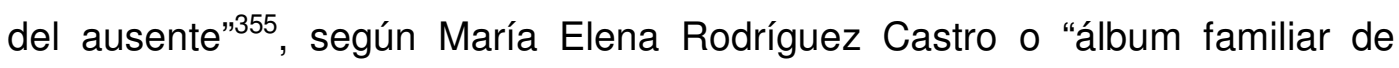
despedida"356 para Juan Gelpí, en esta iconografía el cronista interpreta una serie de fotos de Muñoz que sustentan una visión muy personalizada del líder.

\footnotetext{
${ }^{351}$ La tercera parte de Las tribulaciones de Jonás es la que se reconoce como crónica, y el narrador está situado como testigo en un espacio exterior, la calle, siguiendo el recorrido del cortejo fúnebre del líder. Véanse los estudios críticos ya citados de Juan Gelpí "Las tribulaciones de Jonás ante el paternalismo literario"; María Elena Rodríguez Castro, "Memorias conjeturales: las crónicas mortuorias" y Rubén González (1991). "Las tribulaciones de Jonás: la historia detrás de la historia", en: La Torre, revista de la Universidad de Puerto Rico, año V, Núm. 18, abril-junio, pp. 133-155.

${ }^{352}$ Rodríguez Juliá, Edgardo (1984). Las tribulaciones de Jonás, ed. cit., p. 64.

${ }^{353}$ Ibid., p. 65.

${ }^{354}$ Ríos Ávila, Rubén (1992). "La invención de un autor: escritura y poder", en: Duchesne Winter, Juan (editor-compilador) Las tribulaciones de Juliá, ed. cit., pp. 33-62. (p. 55)

${ }^{355}$ Rodríguez Castro, María Elena (1992).“Memorias conjeturales: las crónicas mortuorias”, ed. cit., p. 91.

${ }^{356}$ Gelpí, Juan (1993). “Las tribulaciones de Jonás ante el paternalismo literario”, ed. cit., p. 52.
} 
El entierro de Cortijo carece de una organización en partes ya que la narración en primera persona remeda los modos del fluir de la conciencia. Los distintos momentos de la crónica se corresponden con los diferentes lugares por donde se desplaza el cortejo fúnebre, descriptos con detallismo fotográfico por el narrador. Desde el rol de testigo y cronista, el sujeto textual asume una posición de distanciamiento y extrañeza, respecto de los "otros" que acompañan y lloran al muerto ("Morenos, morenos por todos lados y sólo una Mont Blanc para escribir..." ${ }^{\text {357 }}$ ), y también respecto de sí mismo. La lapicera Mont Blanc, burlona sinécdoque del escritor, se desplaza hacia la posición social y étnica del cronista (intelectual universitario de clase media, blanco), en cuya autoconfiguración no está ausente la ironía:

"Pero no crean: también yo seré sometido a la mismísima reducción: Un blanquito de cara mofletuda, bigotes de punta al ojo y espejuelos es una presencia turbadora en Lloréns; también ellos son capaces de leerme, ya me tienen leído: ese tiene cara de mamao...Mera, dame diez chavos... Puse voz de negrero mallorquín y le grité, eso sí, entre dientes...No tengo..." ${ }^{358}$

Adoptar un disfraz (negrero mallorquín) o impostar la voz son tretas que no le quitan al intelectual "espejuelado" su carácter de intruso en el caserío. Si antes, refiriéndome a las distintas configuraciones del yo en Las tribulaciones de Jonás, mencioné la imagen del intelectual miope pero lúcido, en El entierro de Cortijo se repite esta construcción. En las dos crónicas se advierte una fuerte impronta autorreflexiva, presente en las diversas referencias y postulados sobre la crónica como modalidad narrativa y también en las especulaciones sobre el lenguaje, en las posibilidades y límites para inscribir en el texto la lengua del otro, la oralidad popular, desde la distancia que le impone al narrador el manejo de una lengua escrita y culta. El desplazamiento espacial del cronista, del centro de la ciudad a sus márgenes (Caserío Llórens Torres), indica a su vez otra clase de desplazamiento, lingüístico en este caso, y no es casual que el narrador prefiera el uso del verbo "traspasar", en referencia a los límites que debe franquear. Espaciales, por un lado, ya que el recorrido hasta el Caserío se emblematiza con la clásica figura del descenso a los infiernos,

${ }^{357}$ Rodríguez Juliá, Edgardo (1991). El entierro de Cortijo, ed. cit., p. 17.
${ }^{358}$ Ibid., p. 13 (las cursivas son del autor). 
cuando el narrador se refiere al "averno de Llórens Torres"359, y también lingüísticos, como se lee en el siguiente fragmento:

"El prejuicio de clases reduce hasta el límite paranoico: Por algo vine en taxi; ¿dónde demonios dejo el carro ahí en Llórens? Traspasar este corredor mítico de violencia es casi asegurarse una cañona a manos de algún teco de bejuco desesperado. Mi pana, ese lenguaje es como la cifra de una distancia insalvable entre mi condición y la de ellos. Mano, esto de la lucha de clases sí que va en serio."360

Si el lenguaje se representa como "cifra de una distancia insalvable", ésta se marca en el texto tipográficamente, mediante el uso reiterado de la letra cursiva o bastardilla para dar cuenta del habla suburbana y callejera. La escritura de la crónica aparece asediada por las cursivas, que transcriben la lengua del otro, pero no la "traducen". Si bien hay una mediación porque la palabra del otro se traslada de los registros popular al culto, oral al escrito, el narrador no reordena esa oralidad, por ejemplo, subordinándola a explicaciones mediante notas al pie o a través de un glosario. Pareciera más bien que hay una cierta complicidad, a pesar de la distancia subrayada, entre los sectores sociales que habitan el Caserío y el narrador, en tanto, ambos aparecen como sujetos socialmente desplazados, atravesados por el fracaso de la utopía desarrollista muñocista:

"Me eduqué en el Colegio San José, pero muchos de mis panas eran de la República de Colombia, incluyendo aquel notorio Paniagua que me adoptó como el espejuelado residente de su rumbón de esquina de los viernes por la noche... Santo Cielo! ¿Qué diría mi madre? Víctima inocente del desclasamiento resultante de la movilidad implantada por el desarrollismo muñocista (qué horror, tanta palabrería sociológica para decir que nos mudamos de un caserón de Aguas Buenas a la 65 de Infantería!) algo bueno saqué de todo ello: un individualismo feroz y una vocación solitaria que trata a todas las tribus con igual ironía; ese desclasamiento me obligó a imaginar y observar; he ahí la semilla de mi vocación literaria."361

\footnotetext{
${ }^{359}$ Véase el siguiente fragmento: “(...) está en la entrada, ya me lo advirtió el taxista, un poco sorprendido de que un espejuelado inteligente descendiera al averno de Llórens para tocar el cadáver del conguero-timbalero mayor, el gran Cortijo, hijo predilecto de la grey cangrejera." Ibid. p. 15 (cursivas del autor).

${ }^{360}$ Rodríguez Juliá, Edgardo (1991). El entierro de Cortijo, ed. cit., p. 12 (cursivas del autor).

${ }^{361}$ Ibid.,p. 16 cursivas del autor).
} 
Esta cita muestra asimismo la construcción autobiográfica del sujeto, que, como En las tribulaciones de Jonás, vuelve hacia el pasado, hacia la

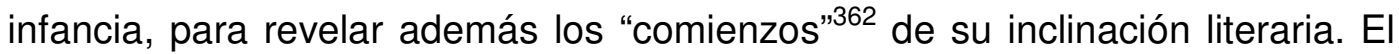
narrador comparte con los habitantes del Caserío situado en Santurce los efectos sociales de la política de Muñoz Marín, que simbólicamente se manifiestan en las coordenadas espaciales, en cuyos trazos se dibuja el nuevo mapa de clases promovido por el PPD:

“... pienso que la Baldorioty cruza estas dos coordenadas del todavía más venerable Cangrejos para destacar que el desarrollismo muñocista pasó por este país. La Providencia abajo es calle de caserío, vía de falansterio muñocista; la Providencia arriba, hacia Villa Palmeras, es calle de barrio proletario; ya se perfila que esta crónica será el encuentro de muchos cruces históricos."363

Los cruces -históricos, sociales, lingüísticos además de los espacialesse tornan encrucijadas para el cronista. Para Juan Duchensne Winter el narrador de la crónica cumple la función de "guía anagógica", y agrega: "Está adentro y está afuera, respondiendo al particular cronotopo de su ensayo narrativo: la inmersión del intelectual en la multitud como testigo inmediato de sus rumbos y errares." 364 Las tensiones atraviesan la percepción del sujeto, quien oscila entre el distanciamiento y la cercanía, entre el adentro y el afuera, entre la inmersión y la expulsión, entre la memoria de los hechos y su escritura. Tanto en El entierro de Cortijo como en la tercera parte de Las tribulaciones de Jonás, correspondiente a la ceremonia fúnebre del Muñoz Marín, se produce el mismo efecto ilusorio de yuxtaposición entre lo visto y lo narrado, como si el cronista discurriera sobre lo que describe en el momento mismo en que se suceden los hechos. En este sentido la incorporación de lo oral contribuye a connotar esta ilusión de presencia y simultaneidad.

Es interesante señalar que la inclusión de la oralidad popular difiere entre una y otra crónica; su uso es bastante menos notable en Las

\footnotetext{
${ }^{362}$ Véase Said, Edward. (1985). Beginnings. Intention \& Method, Nueva York, Columbia University Press, donde analiza las importantes significaciones del topos del comienzo de la escritura.

${ }^{363}$ Rodríguez Juliá, Edgardo (1991). El entierro de Cortijo, ed. cit., pp. 11-12.

364 Duchesne Winter, Juan (1992). "Multitud y tradición en El entierro de Cortijo",en Narraciones de testimonio en América Latina, ed. cit., p. 188.
} 
tribulaciones de Jonás, aunque en ambos textos se apela al uso de la bastardilla. Mientras que en El entierro de Cortijo el narrador conoce los límites lingüísticos entre los habitantes del Caserío y su habla, notamos también que se atreve a traspasarlos incorporando una enorme cantidad de términos y expresiones orales en su crónica. En Las tribulaciones de Jonás, en cambio, el narrador queda expulsado de los registros de habla del campesinado conocido como jíbaro, sector rural que -como se observó en el capítulo ll- fue mitificado como esencia de la nacionalidad puertorriqueña por los populistas al mismo tiempo que desaparecía como actor social real, arrasado por el desarrollismo. Ante las palabras de dolor de la campesina a la cual el narrador describe como "la plañidera", éste solo puede transcribirlas pero no comprenderlas:

“'Tú nos dites de comer, tú nos sacates las niguas! Si yo lo que tenía era una casita de paja'... (...) La palabra sonó ajena, y entonces me dije: Maldito sea, ¿qué tú haces aquí?... A mano no tenía ningún diccionario, lejos estaba de la seguridad de los libros y las teorías...¿Qué es una nigua?...'Tú que nos sacaste de las niguas!'...¿Qué diantres es una nigua ${ }^{365}$ ? (...) Justo en el desconocimiento de aquella palabra se cifraba la distancia entre mi insuficiencia y la humanidad plena de aquella mujer."366

Juan Gelpí lee en Las tribulaciones de Jonás las huellas y residuos del discurso paternalista de las pasadas generaciones literarias. Interpreta que la forma en que Rodríguez Juliá recoge y transcribe la oralidad urbana en esta crónica manifiesta su paternalismo literario: "El cronista, entonces, pasa a ser un padre figurado que manipula y, hasta cierto punto, subordina la oralidad 'bastarda' del otro."367 Asimismo María Elena Rodríguez Castro ${ }^{368}$ sostiene, respecto de estas dos crónicas, que es en la lengua donde se inscribe insistentemente tanto la heterología de la composición social como la incapacidad del cronista para registrarla. Mi interpretación difiere un tanto de ambas posiciones, ya que, especialmente a partir de El entierro de Cortijo, siguiendo con otras crónicas como Puertorriqueños, Una noche con Iris

\footnotetext{
${ }^{365}$ Nigua (voz caribe) es un insecto muy parecido a la pulga, pero más pequeño.

${ }^{366}$ Rodríguez Juliá, Edgardo (1984). Las tribulaciones de Jonás, ed. cit., pp. 64-65.

${ }^{367}$ Gelpí, Juan (1993). "Las tribulaciones de Jonás ante el paternalismo literario", ed. cit., p. 56.

${ }^{368}$ Rodríguez Castro, María Elena (1992).“Memorias conjeturales: las crónicas mortuorias”, ed. cit., p. 86.
} 
Chacón, El cruce de la Bahía de Guánica, uno de los procedimientos que adopta el cronista para dar cuenta de la heterogeneidad social es la inscripción de la oralidad popular urbana en el cuerpo textual de sus relatos ${ }^{369}$. Tampoco me parece que solamente se pueda desplazar el sentido de la bastardilla al significado de bastardo, como sugiere Gelpi ${ }^{370}$, aunque sea evidente que la marcación tipográfica destaca en la superficie textual la diferencia no sólo lingüística, sino también social y cultural que detenta el narrador. Por otra parte en la construcción del sujeto que se percibe en ambas crónicas se insiste en sus ambivalencias, en sus limitaciones e incapacidades (la miopía), en su insuficiencia (en Las tribulaciones de Jonás no conoce lo que es una nigua, en El entierro de Cortijo no accede a la oración inteligible que Ismael "Maelo" Rivera susurra en el oído del amigo muerto), instancias que lo alejan definitivamente de la figura de un narrador cómodo en su omnisciencia, que fija la lengua del otro como mero registro costumbrista.

\section{1. 2 Barroco caribeño y fúnebre}

"La iconografía de las ars moriendi reúne pues en la misma escena la seguridad del rito colectivo y la inquietud de una interrogación personal."

Philippe Ariès

“...toda imaginación es, abierta o secretamente, melancólica.”

Julia Kristeva

Las tribulaciones de Jonás y El entierro de Cortijo, crónicas del ars moriendi, muestran los ritos fúnebres colectivos como una suerte de fiesta barroca, que no disimula sino más bien acentúa los contrastes, la convivencia del luto y del espectáculo, como se nota claramente en estas dos citas:

\footnotetext{
${ }^{369}$ Véase al respecto la cita de Rodríguez Juliá sobre la crónica en la página 111 de este capítulo, donde describe el proceso de apropiación de la lengua del otro.

370 "Manipular la voz ajena, sobre todo la voz de los sectores populares de la sociedad puertorriqueña, situándola en el espacio 'bastardo' de la bastardilla, será un procedimiento muy marcado en el Rodríguez Juliá cronista a partir de El entierro de Cortijo." Gelpí, Juan (1993). "Las tribulaciones de Jonás ante el paternalismo literario", ed. cit., p. 57.
} 
"Pero nací en este Caribe hispánico y barroco, novelero e impresionable; la muerte exhibe en estas latitudes todos sus carismas. Ese escorial permanente que es la cultura hispánica y barroca se concreta aquí en el cuerpo yacente de mi plenero mayor. Cortijo, Cortijo, un Cortijo silencioso que prefiero no mirar.(...) Barroco, barroco por todos lados y sólo una Mont Blanc para escribir."( El entierro de Cortijo ${ }^{371}$ )

"En aquella desorganizada y barroca demostración de duelo el afecto prevalecía sobre los rigores del estado. Era el entierro de nuestro caudillo agropecuario por excelencia; ausente tenía que estar la solemnidad de un estado propio que este país caribeño ha sido incapaz de fundar en más de cuatrocientos años de colonialismo." (Las tribulaciones de Jonás ${ }^{372}$ )

El tema de la muerte se exacerba durante el Barroco ${ }^{373}$ y el cadáver aparece como un emblema que recuerda al hombre su caducidad, asociado a su vez al tópico del tiempo, a la obsesiva preocupación por la fugacidad del devenir temporal, por la brevedad de la vida. En El entierro de Cortijo el cronista se detiene en varias ocasiones a reflexionar sobre la exhibición del cadáver como "el memento mori por excelencia" ${ }^{174}$. Pero, mientras acepta la escena escatológica como parte del rito colectivo del duelo, la rechaza para sí mismo: "Yo prefiero ni mirar, jamás he disfrutado de ese husmeo; ladeo la cara, como si esa presencia ahí fuera la del perfectísimo otro. Sí, porque morir es convertirse en el otro perfecto, el inalcanzable." ${ }^{\text {"375 }}$ Alteridad del sujeto, descripta en términos que nos recuerdan las reflexiones de Maurice Blanchot a propósito de la imagen y el despojo. La muerte es ausencia, el difunto ha dejado el mundo detrás suyo, pero el cadáver no pertenece al mundo aunque tampoco está fuera de él: "...quien acaba de morir está, ante todo, más cerca de la condición de cosa. ${ }^{, 376}$ Las reflexiones iniciales del cronista en El entierro de Cortijo sugieren la misma línea de pensamiento: “...un cadáver de cuerpo presente es una presencia inquietante, precisamente por el hecho de que la

\footnotetext{
${ }^{371}$ Rodríguez Juliá, Edgardo (1991). El entierro de Cortijo, ed. cit., pp. 24-25.

${ }^{372}$ Rodríguez Juliá, Edgardo (1984). Las tribulaciones de Jonás, ed. cit., p. 68.

${ }^{373}$ Véase Maravall, José Antonio (1975). La cultura del Barroco, Barcelona, Ariel.

374 "Exhibir el cadáver es, claro está, el memento mori por excelencia. La comunidad husmea el cadáver sólo para permanecer con un conocimiento de la muerte excesivamente imperfecto. Pero es decisivo para el barroco hispánico el testimonio de la materia al fin derrotada... No somos nada! Carroña. Vanidad de Vanidades!... Polvo eres y en polvo te convertirás...". Rodríguez Juliá, Edgardo (1991). El entierro de Cortijo, ed. cit., pp. 23-24. En la cita se reproducen tópicos barrocos junto con remanidas frases populares. (cursivas del autor)

375 Ibid., p. 25.

${ }^{376}$ Blanchot, Maurice (1992). El espacio literario, Apéndice 2, Buenos Aires, Paidós, p. 246.
} 
ausencia no acaba de cumplirse del todo."377 Para el pensador francés el "despojo mortal", el cadáver, representa para el individuo la presencia de lo desconocido, que lo amenaza con los efectos de la despersonalización y con la "neutralidad absoluta de la muerte". El narrador de las dos crónicas se siente amenazado por la potencia de la muerte, cuya manifestación en el cadáver revierte especularmente sobre el sí propio: "Detrás de tal rechazo al memento mori la fracasada ilusión de que eso no me sucederá a mí." ${ }^{\text {378 }}$ Sin embargo el narrador, que hace de la mirada su principal instrumento perceptivo, contempla el cuerpo de Cortijo como una concesión al ejercicio de su oficio de cronista: 'Pero este oficio requiere algo más que preferencias. A pesar de la inclinación a la mirada lateral, aquí me obligo a permanecer mirando el rostro de la muerte" ${ }^{\text {"379 }}$. En cambio, en Las tribulaciones de Jonás, el cronista acepta el mandato matriarcal de la esposa del líder: "Cortijo es, con excepción de Albizu Campos, el muerto que más he mirado. Doña Inés me prohibió mirar a Muñoz Marín. ${ }^{380}$, recuerda en El entierro..., al evocar y cotejar ambas ceremonias fúnebres. La diferencia que se plantea en estas dos actitudes del cronista contemplar al muerto o no- emana del distinto registro afectivo: la muerte del caudillo suscita compasión, la del músico, perplejidad y reflexión: "Mi acercamiento a Muñoz Marín es profundamente generacional; quizás me encuentre en ese azaroso puente entre el sentimiento y el conocimiento."381; mientras que sobre Cortijo expresa: "Como no hay fuerte evocación personal o terrible desgarramiento emocional, mirar el rostro de un muerto famoso es ejercicio ideal para mi espíritu atribulado con la catástrofe de la muerte.."382

Tanto en Las tribulaciones de Jonás como en El entierro de Cortijo el narrador introduce un juego óptico, en el cual su mirada remeda una cámara fotográfica cuya lente maneja distintos planos, de distanciamiento y lejanía o bien de aproximación y focalización. Cuando asume la posición distanciada se ubica en lugares altos o alejados y su mirada se vuelve abarcativa, intentando aprehender a la multitud como si fuera un todo. En Las tribulaciones de Jonás

\footnotetext{
${ }^{377}$ Rodríguez Juliá, Edgardo (1991). El entierro de Cortijo, ed. cit., p. 11 (cursivas del autor).

${ }^{378}$ Ibid.., pp. 25-26 (cursivas del autor).

379 Ibid., p. 26.

${ }^{380}$ Ibid., p. 26.

${ }^{381}$ Rodríguez Juliá, Edgardo (1984). Las tribulaciones de Jonás, ed. cit., p. 58.

${ }^{382}$ Rodríguez Juliá, Edgardo (1991). El entierro de Cortijo, ed. cit., p. 26.
} 
el pueblo está representado fundamentalmente por los sectores rurales, los jíbaros ${ }^{383}$, al borde de su extinción como grupo social. Pese a la "demencial variedad de este pueblo agradecido" la mirada-lente del narrador logra capturarlo. En El entierro de Cortijo también se adopta la posición panorámica, el golpe de vista, pero se fracasa en el intento de representar al conjunto, la mirada-lente se desenfoca ${ }^{384}$ : “....me interesaba la toma frontal, la panorámica que me entregaría una perspectiva emblemática del entierro (...) pero ocurre que la multitud resulta incapaz de posar."385

El cronista contempla y registra en ambos entierros el proceso de elaboración de la pérdida, conocido como el "trabajo del duelo", que Sigmund Freud describe en su célebre ensayo "Duelo y melancolía" ${ }^{386}$. Frente a la comprobación de la pérdida del objeto amado el sujeto expresa una profunda desazón anímica y el trabajo de duelo consiste en retirar paulatinamente la líbido de los vínculos que lo unen a ese objeto, experiencia que siempre se revela como traumatizante ${ }^{387}$. El narrador de las dos crónicas mortuorias subraya el carácter colectivo de este proceso de duelo, que se plasma en la repetición con variantes de determinadas acciones y gestos que afectan al pueblo como communitas: el llanto, el canto, el desborde y la confusión.

En Las tribulaciones de Jonás un conjunto de mujeres, nombrado bajo la expresión colectiva de "las plañideras", Ileva a cabo el ritual comunitario del llanto, las lágrimas como manifestación corporal del dolor:

"Entre la muchedumbre se suceden los gritos de las mujeres; se acalla uno y surge otro, como si estas plañideras se hubiesen puesto de acuerdo para mantener vivo el testimonio del dolor. A mi alrededor se congregan esos rostros de un pueblo casi olvidado, de una generación al borde del silencio histórico. Son rostros de gente verdadera, hijos del

\footnotetext{
${ }^{383}$ Véase la siguiente cita: "Sí, porque de estos jíbaros y humildes ya van quedando muy pocos. Una generación más y de ellos solo quedará el recuerdo de su azarosa y compleja humanidad." Rodríguez Juliá, Edgardo (1984). Las tribulaciones de Jonás, ed. cit., p. 62.

${ }^{384}$ Véase este pasaje: "Ya es notable: este entierro ya está desenfocado, hace tiempo la curiosidad ha vencido a la pena, la rumba se ha impuesto, quizás sea ésta la última voluntad del difunto.” Rodríguez Juliá, Edgardo (1991). El entierro de Cortijo, ed. cit., p. 84.

${ }^{385}$ Ibid., p. 77.

${ }^{386}$ Freud, Sigmund (1990). "Duelo y melancolía", en Obras completas, volumen 14 (1914-16), Buenos Aires, Amorrortu editores.

387 “¿En qué consiste el trabajo en que el duelo opera? (...) El examen de la realidad ha mostrado que el objeto amado ya no existe más, y de él emana ahora la exhortación de quitar toda libido de sus enlaces con ese objeto.” Ibid., p. 242.
} 
dolor y de la esperanza, jamás aficionados a la neurosis y los tranquilizantes. Lloran con un pudor solemne, y ese gemido sube desde los pies, ya que se asordina entre los cuerpos, ya que el planto se hace con la cabeza baja, lamento que encuentra su mejor fuente en la intimidad del recuerdo." 388

Un procedimiento que se destaca en las dos crónicas es el desplazamiento perceptivo que realiza el narrador: entre la muchedumbre o el grupo, en este caso las plañideras, selecciona (focaliza) un individuo, que, como en las imágenes fotográficas y pictóricas, se percibe visualmente como la figura que sobresale del fondo:

"Permanecí en la escalinata; así podría estar cerca de aquel sitio donde la multitud formaba un grumo de quejidos. De pronto la doña se 'desmelenó', un grito casi animal sacudió la solemnidad del momento, la plañidera comenzó una letanía sólo interrumpida por el llanto. (...) El planto, los piropos de las plañideras, todo el repertorio medieval y barroco del dolor hispánico poseyó momentáneamente a la mujer."

Si en Las tribulaciones de Jonás el llanto se vincula especialmente con los sujetos femeninos, en El entierro de Cortijo, aunque también se describen algunas lloronas, las lágrimas son derramadas por hombres, en particular los músicos que acompañaron al plenero. El cronista registra meticulosamente dos rituales de despedida que son también la cifra de los gestos luctuosos que prevalecen en el entierro del músico: la resignación y la rebeldía. Cheo Feliciano e Ismael Rivera encarnan en el texto ambos sentimientos, en tanto el primero puede elaborar la pérdida mientras que el segundo se inclina hacia la melancolía, atendiendo nuevamente a la distinción establecida por Freud. Si en el trabajo de duelo se acata la comprobación de que el objeto amado ya no existe, en la melancolía la situación de pérdida y el sentido de empobrecimiento del mundo del duelo revierte sobre el yo, ya que el melancólico manifiesta una relación de identificación narcisista con el objeto. El yo melancólico querría incorporar ese objeto según la fase oral o caníbal del desarrollo de la líbido, devorándolo. Esta instancia regresiva de la melancolía implica según Freud

\footnotetext{
${ }^{388}$ Rodríguez Juliá, Edgardo (1984). Las tribulaciones de Jonás, ed. cit., pp. 62-63.

${ }^{389}$ Ibid., p. 64.
} 
que "la pérdida del objeto hubo de mudarse en una pérdida del yo."390 La secuencia en la cual el narrador describe cómo Cheo Feliciano brinda su último adiós al amigo muerto revela la aceptación resignada de la pérdida, manifestada incluso en su actitud corporal, tranquila y firme:

"Cheo se planta frente al cadáver como si se propusiera la tarea de lograr algún conocimiento. Pero no es así, ya lo sé, el gesto resulta engañoso: Esa mirada tan cercana a la ternura pretende conciliarse, meramente alcanzar la resignación perfecta. (En otros hombres que desfilaron frente al cadáver observé, una y otra vez, el mismo gesto: un intento de precaria reconciliación con la adversidad consumadísima de la muerte. Luego de la rebeldía ante la gran bestia, el esfuerzo por acatar...)"391

Veamos ahora cómo se describe la reacción de dolor de Ismael Rivera, en este largo y significativo fragmento de El entierro de Cortijo:

"Primero tocó el tul y le dedicó una mirada tierna; pero ya no pudo más y volvió a llorar sin compostura ni consuelo. Maelo, como todo auténtico artista, tiene la sensibilidad a flor de piel; sus emociones pueden más que el pudor; bien que se inclina a dejarse llevar por el dolor, quiere abandonarse a la pena lo mismo que a su testimonio. Por eso levanta el tul y toca la cara de Cortijo, y cuando ya no puede más retira el vaporoso velo del espíritu y quiere probar la carne. Se echa a llorar, frente con frente, sobre el compadre muerto; le besa la frente, le toca los cachetes tiesos, quiere comérselo a dentelladas secas $y$ calientes, quiere llevarse en el tacto, en la piel misma del desconsuelo, algo de su perfectísimo amigo, algo que el tiempo jamás le podrá arrebatar. Maelo no se consuela con la memoria. Quiere tocar la materia de su dolor; no pretende conseguir la tranquilidad que logró Cheo Feliciano cuando devolvió el diminuto crucifijo a su sitio." 392

La cita revela, mediante la cursivas, un famoso intertexto, la elegía que el poeta español Miguel Hernández le dedica a su amigo muerto Ramón Sijé 393 ; pero las "dentelladas secas y calientes" sugieren también la incorporación simbólica del objeto perdido por la vía de la "devoración”, como referencia a los

\footnotetext{
${ }^{390}$ Freud, Sigmund (1990). "Duelo y melancolía", ed. cit., pp. 246-247.

${ }^{391}$ Rodríguez Juliá, Edgardo (1991). El entierro de Cortijo, ed. cit.,p. 27 (paréntesis del autor).

${ }^{392}$ Rodríguez Juliá, Edgardo (1991). El entierro de Cortijo, ed. cit.,pp. 39-40.

${ }^{393}$ Hernández, Miguel (1977). "Elegía”, en: Antología, selección y prólogo de María de Gracia Ifach, Buenos Aires, Losada, novena edición, pp. 56-58. El verso que transcribe Rodríguez Juliá pertenece al décimo terceto de la elegía: "Quiero escarbar la tierra con los dientes,/ quiero apartar la tierra parte a parte/ a dentelladas secas y calientes."
} 
textos freudianos que el narrador demuestra conocer y manipular con eficacia. Maelo manifiesta mediante la hiperbólica expresión de su dolor el complejo melancólico de la herida abierta. No elaborar el trabajo de duelo puede conducir al sujeto a la atonía, a la carencia de deseo, al desinterés pesimista ante el mundo. Maelo es rescatado de los excesos de su dolor por un grupo de mujeres. Reunidas como en un coro de la tragedia griega, retiran al cantante de la escena: "A estos hombres tan sensibles hay que rescatarlos de su propia debilidad, de sus propios excesos, no vayan a desaforarse hasta la locura..."394, acota el cronista.

A las expresivas lágrimas que se derraman en una y otra crónica cabe agregar otro rito colectivo de sublimación del dolor: el canto comunitario. No se trata de solemnes marchas fúnebres sino de canciones populares que cobran una dimensión especial en los textos. En Las tribulaciones de Jonás la muchedumbre entona el "Lamento Borincano" y en El entierro de Cortijo la multitud canta "La Borinqueña". ¿Qué significaciones entrañan una y otra canción en el imaginario popular puertorriqueño? Para responder a esta pregunta es necesario detenerse brevemente en los orígenes de ambas canciones y en el contexto histórico que subyace a éstas. El "Lamento borincano", canción conocida en América Latina como "El jibarito", fue compuesta en 1929 por el músico puertorriqueño Rafael Hernández, uno de los más importantes compositores latinoamericanos de boleros, rumbas $y$ guarachas. En 1918 fue reclutado por el ejército norteamericano y al finalizar la guerra se estableció en Nueva York, donde trabajó como obrero de fábrica. El sociólogo Ángel Quintero Rivera ${ }^{395}$ señala que en las composiciones de Hernández aparecen tópicos tales como el nomadismo, el desplazamiento, la separación, la ausencia, que luego se tornarían emblemáticos de la temática migratoria. En el "Lamento borincano" no aparece esta cuestión sino que se presentan las vicisitudes del campesinado en su incorporación a la economía de mercado. Sin embargo, para este investigador, es posible leer en el desplazamiento del campo a la ciudad una alusión a la emigración a la

\footnotetext{
${ }^{394}$ Rodríguez Juliá, Edgardo (1991). El entierro de Cortijo, ed. cit.,p. 43.

395 Quintero Rivera, Ángel (1999). "Lo íntimo y lo social: el bolero. Rafael Hernández: el nomadismo y los tríos", en: Salsa, sabor y control. Sociología de la música tropical, ed. cit., pp. 300-310.
} 
metrópolis, de allí que el "Lamento Borincano"396 se convirtiera en una canción muy representativa para los emigrados puertorriqueños en los Estados Unidos, particularmente en Nueva York.

Los orígenes de "La Borinqueña" son más difusos. Se trata de una danza que se popularizó en Puerto Rico hacia mediados del siglo XIX y fue paulatinamente adquiriendo un lugar preeminente en la simbología nacional. En 1952, con el establecimiento del Estado Libre Asociado, se promovió la adopción de la canción como himno nacional del país, cuando desde casi un siglo antes los sectores populares ya identificaban a "La Borinqueña" con la lucha nacional. Con el ELA se estableció también como símbolo patrio la bandera monoestrellada, izada por primera vez por Luis Muñoz Marín en el acto oficial del 25 de julio de 1952, donde se proclamó la Constitución del Estado Libre Asociado. La bandera y los himnos, señalan los historiadores del nacionalismo, se establecieron en la mayoría de los países en el siglo XIX, como un esfuerzo de los entonces emergentes estados nacionales burgueses modernos para consolidar o "inventar" tradiciones sobre las cuales debían cimentarse las nuevas bases de legitimidad que requerían dichas organizaciones políticas abarcadoras. De este modo Eric Hobsbawn ${ }^{397}$ habla de "tradiciones inventadas", como aquellas construidas y formalmente instituidas, que emergen durante un período breve y mensurable y se establecen con gran rapidez. Este conjunto de prácticas construidas como tradiciones inventadas tienen un especial desarrollo especialmente en los momentos de consolidación de los estados nacionales. Hobsbawn señala además cómo se adaptaron canciones tradicionales, provistas de nuevas melodías y contenidos patrióticos, como un proceso similar al que se llevó a cabo con "La Borinqueña", aunque con una diferencia muy bien observada por Ángel Quintero Rivera: "Es significativo que el Estado encomienda entonces un

\footnotetext{
${ }^{396}$ Edgardo Rodríguez Juliá dedica en su libro Caribeños un breve ensayo a Rafael Hernández, titulado "El regreso del cumbanchero. La música de Rafael Hernández", en donde señala respecto de "Lamento borincano" su vinculación con la emigración: "Como Preciosa más adelante, el Lamento borincano es un canto a la patria desde las perspectiva nostálgica del emigrante. Son canciones a una patria distante y ensoñada, que hemos tenido que abandonar para mejorar nuestra fortuna." El "Lamento borincano", del año 1929, está atravesado por la desesperanza en que se sumió Puerto Rico por la llamada Gran Depresión norteamericana. Véase este ensayo en Caribeños, ed. cit, pp. 243-250.

${ }^{397}$ Hobsbawn, Eric (1983). "Introducción: la invención de la tradición", en: Hobsbawn, E. y Ranger, Terence (eds.) (2002). La invención de la tradición, Barcelona, Crítica, pp. 7-21.
} 
nuevo arreglo -marcial- de la canción, pero popularmente todos siguen tocándola y cantándola en su género original de danza." ${ }^{398}$ Puerto Rico, como país que no asumió la organización jurídico-política del estado-nación, adopta, sin embargo algunas de sus prácticas simbólicas, "inventa" sus tradiciones: la bandera, el himno. Aunque se intenta transformar la canción en marcha como símbolo de la identidad nacional, sin embargo el pueblo continúa entonando "La Borinqueña" con ritmo de danza, vinculando así la identidad nacional con su base sociocultural. En una y otra canción se conserva la alusión a la voz taína con la cual se denominaba a Puerto Rico antes de su colonización, Borinquen, rescatándose así también los orígenes étnicos de los primeros pobladores de la isla.

Leemos en Las tribulaciones de Jonás: “...la multitud comenzó a cantar Lamento Borincano, canción que por su criollismo desplazaría a La Borinqueña como himno del entierro. Era la canción sobre el jíbaro cantada con el recuerdo agradecido de su redención." 399 En el entierro de Muñoz Marín, cómo señalé antes, es el sector rural jíbaro el que aparece mayoritariamente representado en el texto, identificado con el "jibarito" al cual alude la canción. El "Lamento Borincano" vuelve a ser entonado una vez más durante el entierro del líder político, en la voz de la cantante popular Ruth Fernández, quien, desafiando la autoridad religiosa del Cardenal de San Juan, torna su gesto en acto de resistencia cimarrona ${ }^{400}$ : "Ruth Fernández quiso cantar en la Catedral el Lamento Borincano. La sacralidad de Roma también tendría que hacer sus concesiones a los valores de todo un pueblo."401 El acto de rebeldía es significativo, sobre todo si se tiene en cuenta que la autoridad religiosa había permitido unos momentos antes que se tocara en la Catedral una canción muy querida por Muñoz, "Old Man River", de carácter popular pero norteamericana. El episodio, narrado con mucho humor, es aprovechado por el narrador para señalar las distancias insalvables entre la iglesia y los sectores populares,

\footnotetext{
${ }^{398}$ Quintero Rivera, Ángel (1999). "Ponce, la danza y lo nacional”, en: Salsa, sabor y control. Sociología de la música tropical, ed. cit., especialmente pp. 253-267.

${ }^{399}$ Rodríguez Juliá, Edgardo (1984). Las tribulaciones de Jonás, ed. cit., p. 66.

${ }^{400}$ Ruth Fernández es una cantante negra de Ponce, con lo cual su acto de rebelión ante la autoridad religiosa y blanca se puede leer como cimarrón, en alusión a los gestos rebeldes y ansias libertarias de los esclavos negros que huían de las plantaciones. Véase capítulo I de la presente tesis.

${ }^{401}$ Rodríguez Juliá, Edgardo (1984). Las tribulaciones de Jonás, ed. cit., p. 83.
} 
como así también para desplazar esta brecha, con sentido autocrítico e irónico, a los sectores políticos identificados ideológicamente con el independentismo al cual adscribe el cronista: “¿No le pasa a la Iglesia lo mismo que a los independentistas? No está en 'sintonía' con el pueblo... La única diferencia es que mientras la Iglesia amenaza con el fuego eterno, nosotros amenazamos con quitar los cupones de alimentos." 402

En El entierro de Cortijo, por instancia del músico Orvil Miller, se entona "La Borinqueña": "Entonces fue que Orvil Miller tomó la batuta y dijo lo siguiente: No podemos enterrar a Rafael Cortijo sin cantar 'La Borinqueña'. Dirigió a la muchedumbre a través de los acordes de esa ilusión necesaria que es el himno nacional." ${ }^{403}$ Orvil Miller actúa como un maestro de ceremonias que intenta solemnizar un ritual fúnebre que había cobrado ribetes de carnaval. Durante todo el trayecto que siguió la procesión -desde el Centro Comunal de Llórens Torres donde se llevó a cabo el velorio hasta el cementerio- la multitud marchó cantando, homenajeando a Cortijo a través de la entonación de algunas de las composiciones más populares de su Combo, como "Negro Bembón”, "El bombón de Elena”, "Maquinolandera”, como así también tocando y bailando salsa y rumba. El gesto de Orvil, cantar el himno ante el ataúd, cubierto además por la bandera puertorriqueña, otorga al ritual fúnebre otras connotaciones, en tanto parece generar la ilusión de una comunidad imaginada como nación ${ }^{404}$. El cronista, contemplador lúcido y escéptico de la escena, desnuda sin ambages el carácter conjetural y utópico de esa precaria communitas cuando subraya "el desgarramiento múltiple del país, las fisuras que ya pronto dolerán." ${ }^{305}$

La entonación en común del "Lamento Borincano" desolemniza el ritual fúnebre de Muñoz Marín y lo impregna de una fuerte dimensión afectiva. "La

\footnotetext{
${ }^{402}$ Ibid., p. 84.

${ }^{403}$ Rodríguez Juliá, Edgardo (1991). El entierro de Cortijo, ed. cit.,p. 92.

${ }^{404}$ Benedict Anderson señala el sentido de los himnos nacionales, cuya entonación en festividades patrias provoca una experiencia de simultaneidad y unisonancia que describe en estos términos: "Precisamente en tales momentos, personas del todo desconocidas entre sí pronuncian los mismos versos con la misma melodía. La imagen: unisonancia. Cantando la Marsellesa, la Waltzing Matilda y la Raya indonesia se puede experimentar la unisonalidad, la realización física de la comunidad imaginada en forma de eco." En: Anderson, Benedict (1993).Comunidades imaginadas. Reflexiones sobre el origen y la difusión del nacionalismo, México, FCE, p. 204.

${ }^{405}$ Rodríguez Juliá, Edgardo (1991). El entierro de Cortijo, ed. cit.,p. 93.
} 
Borinqueña" pretende provocar el efecto contrario durante el entierro de Cortijo, aunque se trata de una ceremonia de despedida imposible de solemnizar. En las dos crónicas la multitud se desborda, numérica y afectivamente. Hay corridas, empujones, apretujones, gritos, anarquía. En Las tribulaciones de Jonás el cronista establece una homología entre la ausencia de solemnidad en el entierro del líder político más importante del país y la vigencia del colonialismo en la Isla: no puede llevarse a cabo un ritual de funeral de estado en un país que carece de estado:

"En aquel atropellado comienzo se iba revelando la naturaleza del entierro. Muy lejos estábamos de un funeral de estado, donde la pompa y el estricto ceremonial enfrían el dolor del pueblo. En aquella desorganizada y barroca demostración de duelo el afecto prevalecía sobre los rigores del estado."/ "Pero es así su pueblo, ajeno a los rigores del estado, irreverente ante la autoridad armada, un hatajo de anarquistas irredimibles."/ "iEste país se quedó sin estado! Lo único permitido en este entierro es la espontaneidad!"/ "Aquel entierro de estado iba resultando el más demencial visto sobre la faz de la tierra..."406

La galería de fotos y sus comentarios, que constituyen la última parte de esta crónica, no se inicia con una foto de Muñoz sino con la fotografía del entierro del mariscal Tito de Yugoslavia, fallecido apenas unos días después que el líder político puertorriqueño. La foto revela una ceremonia con todo el rigor ritualista de un funeral de estado. En la página siguiente y dialogando con esta foto aparece una toma del entierro de Muñoz. El contraste entre una y otra es por demás significativo, ya que las imágenes fotográficas ${ }^{407}$ en sí mismas se constituyen como textos que comunican al lector/espectador un sentido que el narrador ha ido tramando una y otra vez a lo largo de la crónica. La foto del entierro de Tito connota la presencia del Estado, la foto del entierro de Muñoz Marín, su ausencia. Muñoz es el padre y no el jefe de Estado: "En nuestra relación con el caudillo no media el estado; más bien asumimos al jefe como una variante necesaria de la familia, del amor paterno filial. De ahí que su ataúd fuera manoseado hasta el delirio por las manos dolientes de su

\footnotetext{
${ }^{406}$ Rodríguez Juliá, Edgardo (1984). Las tribulaciones de Jonás, ed. cit., citas correspondientes a las páginas $67-68,73,74$ y 79 .

${ }^{407}$ Me detendré en la particular relación que se establece entre imágenes fotográficas y texto en crónicas de Rodríguez Juliá a través del análisis de Puertorriqueños unas páginas más adelante.
} 
pueblo." ${ }^{408} \mathrm{Si}$ Ismael Rivera parecía al borde de "devorar" el cuerpo de su amigo muerto en El entierro de Cortijo, aquí es el pueblo como sujeto colectivo el que aparece al borde de la canibalización ritual que Freud describe en Tótem y Tabú $^{409}$. Un amigo del narrador, cuyos comentarios se reproducen en el texto, manifiesta un temor compartido por ambos: "...que se cayera el ataúd y ese cadáver quedara despedazado por la multitud.." ${ }^{410}$ La muerte del padre figurado instaura también el problema de su sucesión. ¿Qué político del Partido Popular Democrático ${ }^{411}$ puede sustituir a Muñoz? ¿Quién puede soportar el peso del legado de semejante liderazgo? El cronista escéptico reconoce con su irónica lucidez que quien asuma su lugar "...siempre tropezaría con el peso de aquel hombre cuya muerte era aún más peligrosa que su vejez"\$12.

En La muerte de Cortijo la multitud no acierta a expresar el sentimiento doloroso de la pérdida a través de una ceremonia solemne o ritual; la multitud, más bien, se inclina hacia el "desmadre" y la confusión. Como observa Áurea María Sotomayor hay algo perdido en los gestos del pueblo que no llegan a cuajar como desea el cronista y que atañe a la tradición luctuosa ${ }^{413}$. El narrador registra entonces cómo "la tradición estalla en mil pedazos conflictivos" ${ }^{\text {"14. }}$

“¿Dónde se perdió la coherencia de los gestos? ¿Dónde zozobró esa memoria de las cosas y los gestos que es la tradición? ¿Por dónde anda un pueblo que apenas puede conciliar sus actos con sus sentimientos, o aquellos con el rito?... El rito anda moribundo, hay tantas intenciones fantasmales y tantos gestos insepultos. Posiblemente en ello resida eso que tan solemnemente llamamos crisis histórica."415

En las dos crónicas se alude a la crisis histórica de los años ochenta, aunque el cronista evade la visión posterior del narrador histórico para privilegiar en cambio la visión personal de los hechos: "Sálvese lo que pueda

\footnotetext{
${ }^{408}$ Rodríguez Juliá, Edgardo (1984). Las tribulaciones de Jonás, ed. cit., p. 100.

${ }^{409}$ Freud, Sigmund (1972). Tótem y tabú y otras obras, en: Obras completas XIII, Madrid, Buenos Aires, Amorrortu, pp. 3-163.

${ }^{410}$ Rodríguez Juliá, Edgardo (1984). Las tribulaciones de Jonás, ed. cit.,p. 93.

${ }^{411}$ En la crónica se alude explícitamente a Rafael Hernández Colón, quien fue durante dos períodos gobernador de Puerto Rico por el PPD, en los años 1973-1977 y 1985-1989.

${ }_{412}$ Rodríguez Juliá, Edgardo (1984). Las tribulaciones de Jonás, ed. cit.,p. 67.

${ }^{413}$ Sotomayor, Áurea María (1992). "Escribir la mirada", en: Duchesne Winter, Juan (editorcompilador). Las tribulaciones de Juliá,ed.cit., p. 149.

${ }^{414}$ Rodríguez Juliá, Edgardo (1991). El entierro de Cortijo, ed. cit.,p. 96.

${ }^{415}$ Ibid., p. 95.
} 
salvarse entre el momento vivido y la crónica escrita. Se perderá casi todo, claro, pero permanecerán las imágenes, los detalles más empecinados, esos que no pueden renunciar al recuerdo a pesar de la traición de la memoria." ${ }^{416}$ En reiteradas ocasiones el cronista afirma su incapacidad, sus limitaciones para describir a su pueblo puertorriqueño diverso, contradictorio, "país de muchas tribus", al cual no le caben las categorías tan transitadas de la "familia puertorriqueña" o las más recientes como las que José Luis González ${ }^{417}$ propone en El país de cuatro pisos. El narrador constata una necesidad: "Hay que inventar nuevas categorías para describir esto." ${ }^{\text {418 }}$ A pesar del reconocimiento de su insuficiencia, sin embargo el cronista logra plasmar la diversidad, traslada al texto esos "detalles más empecinados" que cobran cuerpo cada vez que capta las individualidades del conjunto, según los modelos pictóricos de los cuadros de El Bosco y Brueghel ${ }^{419}$ aludidos en El entierro de Cortijo. Cheo Feliciano acomodando el rosario entre las manos de Rafael Cortijo; Ismael Rivera llorando sobre el rostro del amigo muerto; la plañidera dolida ante el ataúd de Muñoz Marín, "el mulato rostro N.I.C", el "viejo dependiente de la calle Cruz", "la mulatita pizpireta", la "loca de barriada" entre muchos otros, una galería de personajes que son parte del "pueblo pueblo, mi pueblo puertorriqueño en su diversidad más contradictoria"420.

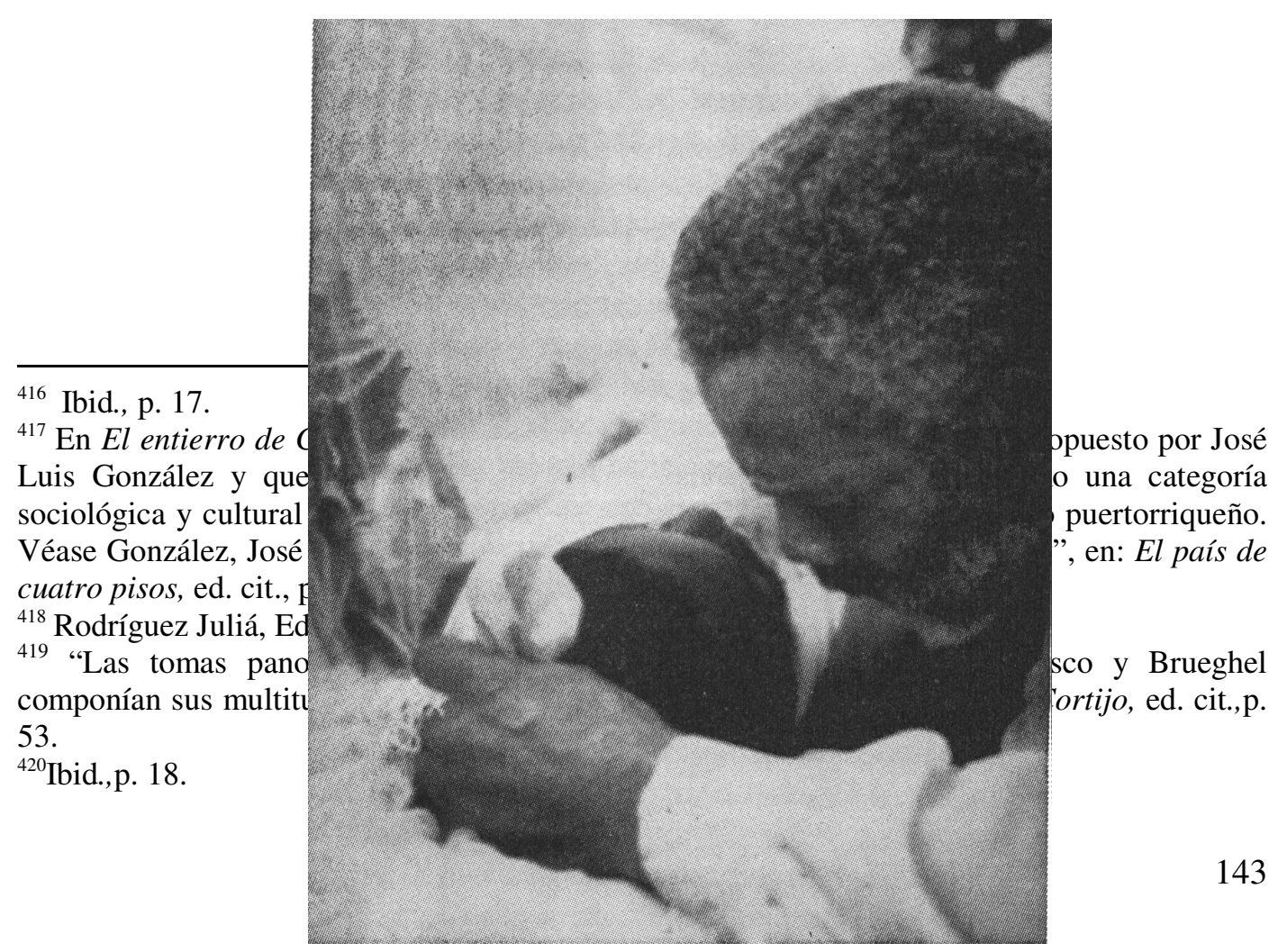


Ismael Rivera se despide de Rafael Cortijo

En el epígrafe de Philippe Ariès, citado al comienzo de este apartado, el historiador francés observa en las ceremonias fúnebres una relación inversa entre la seguridad del rito colectivo y la inquietud existencial que afecta al individuo. Destaca como temas de reflexión la aparición del cadáver ("transido", "carroña") en el arte y la literatura y afirma que: "La muerte se convirtió en el sitio donde el hombre adquirió mayor conciencia de sí mismo." ${ }^{421}$ El concepto del speculum mortis, la muerte como espejo que explora Ariès, se aproxima a las múltiples expresiones y reflexiones del narrador de ambas crónicas mortuorias, quien se enfrenta a través de la muerte del otro (Muñoz Marín, Rafael Cortijo) con los fantasmas de su propia "imaginación melancólica". Me refiero aquí a los análisis propuestos por Julia Kristeva sobre la melancolía literaria en su libro Sol negro. Depresión y melancolía ${ }^{422}$, donde describe la experiencia de la melancolía decible ${ }^{423}$ como aquella que abre el espacio de una subjetividad heterogénea, dolorosa aunque gozosa, que se complace en la contemplación y asegura al artista un dominio sublimatorio sobre la cosa perdida. Kristeva desarrolla el tópico de la escritura como trabajo de duelo, pero se trata de un trabajo de duelo triunfante, ya que el gesto de la escritura

\footnotetext{
${ }^{421}$ Ariès, Philippe (2000). Morir en Occidente, Buenos Aires, Adriana Hidalgo editora, p. 47. El trabajo del historiador francés da cuenta de las distintas concepciones y actitudes ante la muerte, desde la edad media hasta la contemporaneidad, en la cultura cristiana occidental.

${ }^{422}$ Kristeva, Julia (1997). Sol negro. Depresión y melancolía, Caracas, Monte Ávila Editores.

${ }^{423}$ Ibid., especialmente capítulos I, II y IV.
} 
fue realizado y a la distanciación del objeto perdido la acompaña la exaltación de la creatividad. La escritura de las crónicas mortuorias incluye un testimonio de la tristeza e inquietud, individual y colectiva, pero también la superación de ese estado, que se manifiesta en el texto como marca simbólica. Así como "la comunidad le busca la vuelta a este asunto tan espinoso"424, -la muerte-, recurriendo a la invención de señales vitales (llorar, cantar, incluso el baile y la irreverencia durante el entierro de Cortijo, el desorden en el entierro de Muñoz), el cronista le busca la vuelta a su propia melancolía. Hace de la escritura un rito de entierro, en el sentido que le asigna Michel de Certeau a esta práctica, cuando señala que: “...la escritura desempeña el papel de un rito de entierro; ella exorciza a la muerte al introducirla en el discurso." ${ }^{425}$ Aunque De Certeau trabaja el concepto de escritura desde su dimensión historiográfica, señala sin embargo un rasgo común con la literatura, la función simbolizadora de la escritura:

"Por otra parte, la escritura tiene una función simbolizadora; permite a una sociedad situarse en un lugar al darse en el lenguaje un pasado, abriendo así al presente un espacio: 'marcar' un pasado es darle su lugar al muerto, pero también redistribuir el espacio de los posibles, determinar negativamente lo que queda por hacer, y por consiguiente utilizar la narratividad que entierra a los muertos como medio de fijar un lugar a los vivos." 426

Las crónicas mortuorias de Rodríguez Juliá revelan la función simbolizadora de la escritura descripta por De Certeau. En una crónica se relata cómo el pueblo tributa su homenaje y brinda su último adiós al caudillo popular, para narrar también cómo con la desaparición de Muñoz se muere un período histórico que marcó, para bien y para mal, profundamente al país. En la otra, si bien se "marca" también el pasado, se testimonia asimismo la época "post-muñoz", como la califica en reiteradas ocasiones el cronista, cuyas huellas se inscriben en el cuerpo social heterogéneo y desgarrado del Puerto

\footnotetext{
${ }^{424}$ Rodríguez Juliá, Edgardo (1991). El entierro de Cortijo, ed. cit.,pp. 24-45 (cursivas del autor).

${ }^{425}$ De Certeau, Michel (1993). "El lugar del muerto y el lugar del lector", en "La operación historiográfica", cap. II, La escritura de la historia, México, Universidad Iberoamericana, 2da. edición, p. 116.

${ }^{426}$ Rodríguez Juliá, Edgardo (1991). El entierro de Cortijo, ed. cit.., 116-117 (cursivas y entrecomillado del autor).
} 
Rico contemporáneo. La metáfora privilegiada del pasado -la familia puertorriqueña como imagen aglutinante- se dispersa, estalla en múltiples fragmentos y se vuelve imposible de sostener: "La mitología a que nos obliga la muchedumbre se desmorona; esa cursilona ideología que casi nos convence

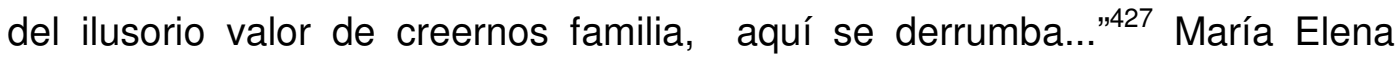
Rodríguez Castro ${ }^{428}$ propone leer El entierro de Cortijo como la contrapartida de Las tribulaciones de Jonás, en el sentido en que se establece entre ambos textos una relación conjunta de entierros y fundaciones: se entierra el mito de la familia puertorriqueña para dejar paso al "lugar de los vivos" mencionado por De Certeau, como el heterogéneo y contradictorio "país de muchas tribus". ${ }^{429}$

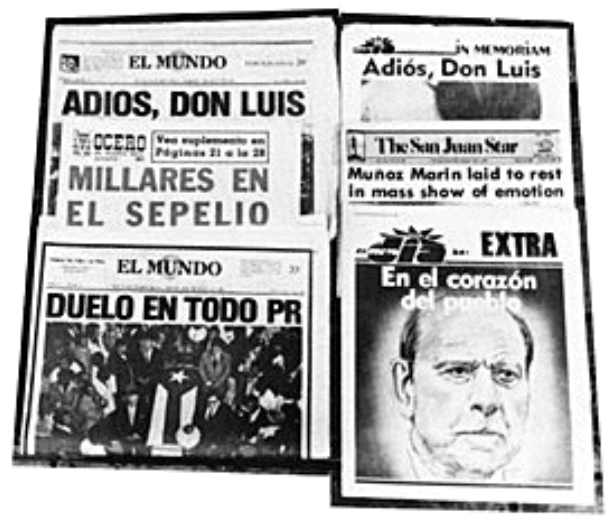

La muerte de Luis Muñoz Marín en la prensa de Puerto Rico

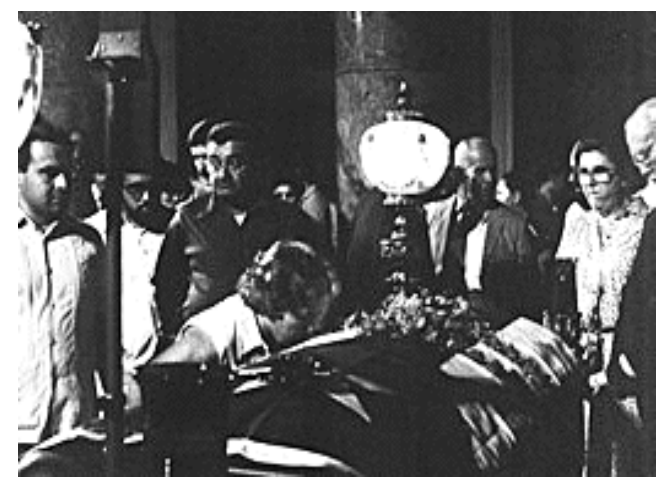

El velorio de Don Luis y, abajo,

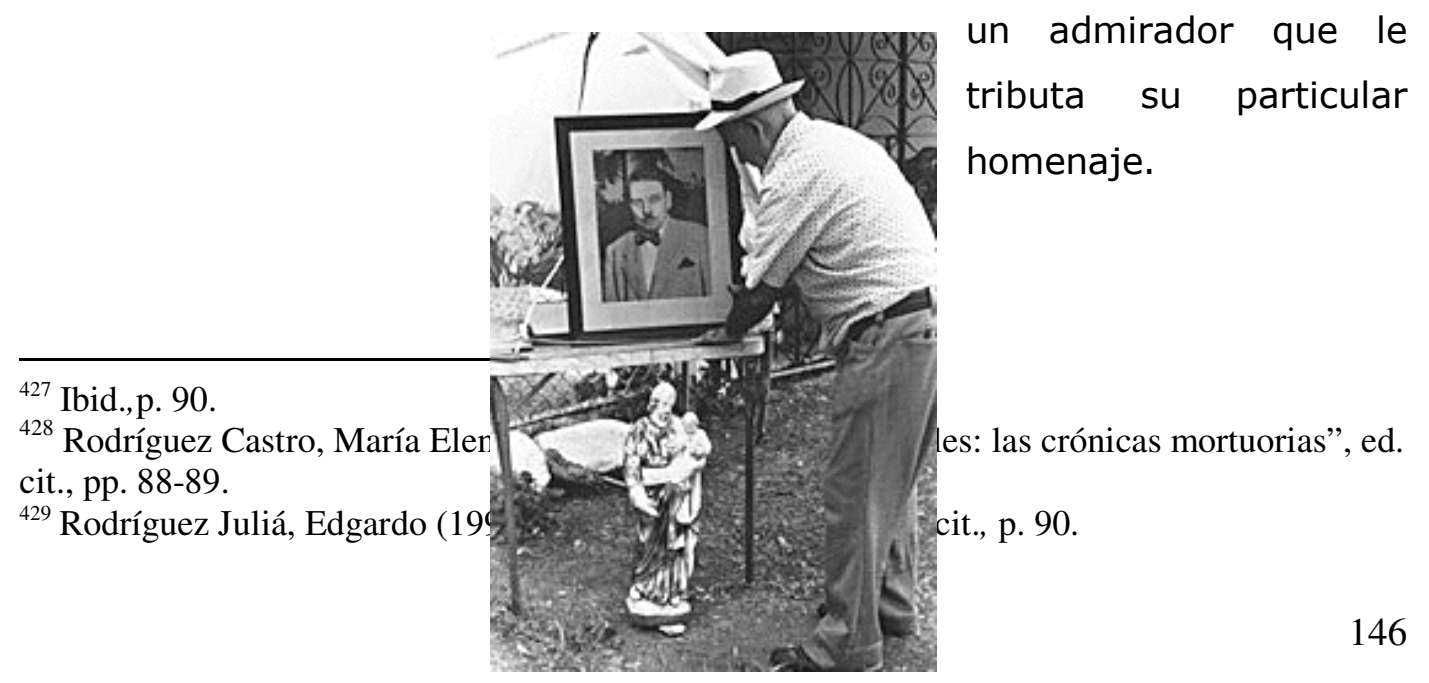


III.1.3 Rituales escatológicos: el cuerpo de la nación en Una noche con Iris Chacón ${ }^{430}$

"Toda la historia actual del cuerpo es la de su demarcación, de la red de marcas y signos que lo cuadriculan, lo parcelan, lo niegan en su indiferencia y su ambivalencia radical para organizarlo en un material estructural de intercambio/signo..."

Jean Baudrillard

Rodríguez Juliá concibe al cuerpo como signo en Una noche con Iris Chacón, desde una perspectiva próxima a la que propone Jean Baudrillard al leer el cuerpo como un sistema de sentidos ${ }^{431}$. La vinculación entre cuerpo y texto se repite a lo largo de la crónica, y es objeto de reflexión y autorreflexión, por ejemplo, cuando el narrador califica ambiguamente su escritura, indecisa "entre el género de la crónica y la crónica de lo venéreo" ${ }^{432}$, o también, en la especial connotación que adquiere la palabra cerebro y su acción, cerebración, en el léxico puertorriqueño: "Significativamente, llamamos cerebros en Puerto Rico a las gustosas fantasías eróticas”, nos explica Ángel Quintero Rivera ${ }^{433}$. En la crónica el cuerpo de Iris se construye como objeto de reflexión y cerebración a la vez, en tanto es visto, descripto y comentado no sólo por la voz narradora del cronista sino también por un colectivo que lo enuncia: de la cerebración individual se pasa a la cerebración colectiva, representada por la incorporación de otras miradas y voces (hombres, mujeres, "gringos", incluso un niño), como público diverso reunido en torno a un ícono de la cultura popular puertorriqueña, el show de la vedette Iris Chacón:

"Aquí sentado, perfectamente seducido por mi soledad de voyeur, me encuentro a mitad de camino entre la ensoñación y la observación, indeciso entre el género de la crónica y la crónica de lo venéreo. Es difícil la ecuación: debo testimoniar y a la vez rescatarme de esa turba enemiga allá afuera, celebrar con ellos el cerebro de todos y fundar el

\footnotetext{
${ }^{430}$ Rodríguez Juliá, Edgardo (1986). Una noche con Iris Chacón, Río Piedras, Editorial Antillana, primera edición (todas las citas textuales corresponden a esta edición).

${ }^{431}$ Baudrillard, Jean (1993). El intercambio simbólico y la muerte, Caracas, Monte Ávila, $2^{\mathrm{a}}$. Edición, p. 117.

${ }^{432}$ Rodríguez Juliá, Edgardo (1986). Una noche con Iris Chacón,ed. cit., p. 126.

${ }^{433}$ Quintero Rivera, Ángel (1999). Salsa, sabor y control. Sociología de la música tropical, ed. cit., p. 25.
} 
mío propio, ahí sin distracciones, en la perfecta serenidad del silencio oscuro...". 434

Como en las crónicas anteriormente analizadas, en ésta se destaca la especial connotación que adquiere el sentido de la vista, puesto que el narrador adopta el rol del voyeur ${ }^{435}$, del mirón, acentuando así otras posibilidades de la percepción visual, vinculadas en este caso al erotismo. La mirada atrevida, penetrante, se propone como conocimiento e implica a la vez la fascinación y el distanciamiento característicos del voyeurismo, pero también la mirada en espejo, donde la contemplación del otro revierte sobre el sujeto que contempla. Si en la caracterización general de las crónicas de actualidad de Rodríguez Juliá insistía en las mediaciones y filtros que afectan subjetivamente la observación del cronista -por ejemplo el marcado y reiterado uso de los espejuelos- aquí la mirada se empaña progresivamente a través del ensimismamiento melancólico del narrador, cuyo filtro ya no son los lentes sino la bebida, la lenta escansión de los martinis: "Aquí estoy sentado en la mesa solitaria, a los treinta y siete años un poco cansadas las ilusiones; añoro el monóculo del distanciamiento y, sobre todo, esa altanería justo en el corazón de mi timidez. Aquí estoy atado frente a mi martini Beefeater..."436

La tensión narrativa se sostiene entre la referencia extratextual que dispara el texto y su construcción discursiva. Lo que suscita la atención del cronista esta vez no está ligado a acontecimientos colectivos de la magnitud de los entierros de Muñoz Marín y Rafael Cortijo, sino más bien a una historia mínima: la crónica reconstruye uno de los shows ofrecidos por la cantante y vedette Iris Chacón en el Hotel Caribe Hilton. A diferencia de las crónicas mortuorias, caracterizadas por los desplazamientos a través de espacios abiertos por donde circulaba no solo la multitud doliente sino también el

${ }^{434}$ Rodríguez Juliá, Edgardo (1986). Una noche con Iris Chacón, ed. cit., p. 126 (cursivas del autor).

${ }^{435}$ En la crónica se alude a Freud, quien aborda la cuestión del voyeurismo o la escopofilia como perversión sexual en sus célebres Tres ensayos de teoría sexual : “... el placer de ver se convierte en perversión cuando: a) se circunscribe con exclusividad a los genitales; b) se une a la superación del asco (voyeur: el que mira a otro en sus funciones excretorias), o c) suplanta a la meta sexual normal, en lugar de servirle de preliminar." Véase Freud, Sigmund (1995). Tres ensayos de teoría sexual (1901-1905), en : Obras completas, volumen VII, , Buenos Aires, Amorrortu, octava reimpresión, p. 142.

${ }^{436}$ Rodríguez Juliá, Edgardo (1986). Una noche con Iris Chacón, ed. cit., pp. 125- 126 (cursivas del autor). 
cronista, en Una noche con Iris Chacón prevalecen la inmovilidad, el encierro y el aislamiento individual: "Cada quien ha borrado un poco su soledad; como en el cine, nos hemos convertido, ahí en lo oscuro, en solitarios espectadores de la cámara lúcida." ${ }^{437}$ La homologación del cerrado recinto del club del hotel con el cine y la cámara lúcida ${ }^{438}$ acentúan las connotaciones de la cerebración, la fantasía y el voyeurismo; el cronista no se traslada físicamente, sino que sus devaneos corresponden esta vez a las fantasías eróticas, aunque, como se verá, no son las únicas que ocupan el discurrir del narrador.

Comenzaré por la referencia extratextual a Iris Chacón, para luego detenerme en lo que representa esta figura femenina, sobre todo a partir de la construcción de su cuerpo. Conocida como "la vedette de América" y convertida en un ícono de la sensualidad boricua (en Venezuela se la apodó "La bomba puertorriqueña"), inició su carrera como bailarina hacia fines de los años sesenta, en un show de la televisión puertorriqueña de mucho éxito. En los años setenta debutó como cantante y su álbum "Yo soy Iris Chacón" (1972) alcanzó enorme difusión en el mercado discográfico de la isla. La popularización de su figura se debió especialmente al espacio televisivo que ocupó los días sábados, "El show de Iris Chacón", programa que se mantuvo en el aire hasta entrados los años ochenta. También fueron muy famosas sus presentaciones a partir de 1972 en el Club Caribe del Hotel Caribe Hilton, espectáculo que Rodríguez Juliá aprovecha como motivo de su crónica, aunque cuando ya la figura de Iris ha comenzado a perder su glamorosa condición de artista para acercarse a su condición real de mujer, "en carne, sudor y hueso",339.

El cuerpo de Iris se percibe e inscribe en la crónica como potencia semiótica, a través de la acumulación de sentidos que porta a lo largo del texto.

\footnotetext{
${ }^{437}$ Rodríguez Juliá, Edgardo (1986). Una noche con Iris Chacón, ed. cit., p. 127 (cursiva del autor).

${ }^{438}$ El escritor mexicano Salvador Elizondo explica que la cámara lúcida o también llamada cámara clara fue usada en la publicidad comercial a principios del siglo XIX. La describe así: "Un sistema de prismas graduables proyecta sobre el papel la imagen virtual del modelo que el dibujante traza siguiendo los contornos que aparecen en el visor." Véase "Aparato", incluido en: Camera lúcida, México, FCE, tercera edición, 2001, p. 73. Véase también el notable ensayo de Roland Barthes (1998). La cámara lúcida. Nota sobre la fotografía, Buenos Aires, Paidós, 5ta. edición, especialmente pp. 180-181. La cámara lúcida no solo se usó para el ámbito de la publicidad sino también para la producción de imágenes eróticas.

${ }^{439}$ Rodríguez Juliá, Edgardo (1986). Una noche con Iris Chacón, ed. cit., p. 129.
} 
Se exhibe como objeto de la escopofilia del narrador y también de un sujeto colectivo mayor, el pueblo puertorriqueño. Su descripción se carga de connotaciones fetichistas: aparece fragmentado, como un cuerpo de mujer cortado en pedazos, desgranado por el lenguaje que lo parcializa, especialmente a través del tropo de la sinécdoque ${ }^{440}$. El apellido de Iris, vocablo que se usa en el lenguaje coloquial de Puerto Rico para designar al trasero, hace las veces de su mayor atributo erótico pero también alude, figuradamente, a la sexualidad del puertorriqueño y a una época política del país, el gobierno de Carlos Romero Barceló ${ }^{441}$ del Nuevo Partido Progresista, fuerza que entonces promovía (y aún hoy promueve) la estatidad de Puerto Rico, es decir, su anexión a los Estados Unidos:

"Purgado de su vergüenza excrementicia, el trasero de Iris Chacón se convierte en ícono de la inclinación erótica del varón puertorriqueño. (...) El trasero de La Chacón, es objeto a la vez que emblema, hecho a la vez que símbolo, actualidad lo mismo que promesa. Después de casi veinte años de tiernos cuidos, lo hemos visto envejecer en la televisión, a veces nos parece desmadrarse por la gordura siempre acechante de los muslos. Ha pasado por divorcios y rumores, un parto, toda suerte de sensacionalismos Teve Guía, y aún es capaz de resumir toda una época política: la era Carlos-Cuchín." ${ }^{442}$

El trasero de Iris Chacón se puede leer también, como apunta Milagros Socorro en tanto "...emblema de una obsesión, una estética, una sexualidad nacional -o nacioanal- que integra lo que aparentemente está diseminado (una población dividida entre la isla y el espacio continental norteamericano); aglutina lo que aparentemente está amenazado de dispersión (los elementos

\footnotetext{
${ }^{440}$ Así, por ejemplo, Tzvetan Todorov señala que "la sinécdoque consiste en emplear la palabra en un sentido que es una parte de otro sentido de la misma palabra, según uno u otro tipo de descomposición, una u otra dirección." Un poco antes distingue el proceso que denomina "descomposición" según dos direcciones: material o conceptual. De allí que en la sinécdoque "la 'parte' material es menor que su todo, mientras que la parte 'sémica' es más general que el todo." Véase Todorov, Tzvetan, "Sinécdoques", en: VV.AA. (1982). Investigaciones retóricas II, Barcelona, Ediciones Buenos Aires, pp. 45-58.

${ }^{441}$ Carlos Romero Barceló ganó las elecciones como gobernador de Puerto Rico en 1976 y fue reelecto para un segundo mandato en 1980, extendiéndose su gestión hasta las elecciones de 1984.

${ }^{442}$ Rodríguez Juliá, Edgardo (1986). Una noche con Iris Chacón, ed. cit., p. 117.
} 
de una cultura asediada por la penetración de otra imperial)." ${ }^{443}$ Esta crítica observa el uso de la sinécdoque como tropo integrativo según lo describe Hayden White ${ }^{444}$, en el sentido en que la partes funcionan como réplicas microcósmicas del todo. De allí que el cronista elija una gradación que va de lo concreto a lo abstracto -ícono, emblema, símbolo- para dar cuenta del desplazamiento sinecdóquico y figurativo del trasero de Iris, desde su carnadura material hasta su proyección política y cultural.

Una noche con Iris Chacón se divide en dos partes: la primera, titulada "A manera de prólogo", imita la estructura retórica del ensayo -una escritura expositiva, el uso de la cita de autoridades, la enunciación aseverativa- aunque en clave paródica y apelando al humor. La segunda parte constituye la crónica propiamente dicha, con un título que fija las coordenadas espaciales y temporales del suceso que dispara la escritura: "2 de noviembre de 1983, Club Caribe del Caribe Hilton: Show de Iris Chacón". Cada parte está precedida de epígrafes muy significativos, que remiten, en el primer caso a los ámbitos de la cultura alta y la oralidad popular local; en el segundo caso, a la cultura letrada puertorriqueña de fines de siglo XIX y de los años treinta del siglo XX. El primero pertenece a Juan Ramón Jiménez e incorpora mediante la traducción al segundo, del poeta irlandés William B. Yeats ${ }^{445}$ : "Amor, amor, amor/ -Lo dijo Yeats-/ Amor en el lugar/ del excremento/ Asco de nuestro ser/ nuestro principio y nuestro fin." ${ }^{46}$ El tercero es de carácter anónimo y alude al vocablo que se usa en el lenguaje coloquial de Puerto Rico para designar al trasero: "En el país de los grandes/ el chacón es rey." Los tres epígrafes se vinculan entre sí por sus referencias escatológicas, incrementadas a lo largo de la primera parte del texto a través de la reconstrucción de una tradición cultural escatológica trazada por el narrador. Los dos epígrafes de la segunda parte corresponden, uno al poeta de los años treinta Francisco Matos Paoli, y el otro

\footnotetext{
${ }^{443}$ Socorro, Milagros (1994).”El género de la crónica y la crónica de lo venéreo. Notas en torno a Una noche con Iris Chacón de Edgardo Rodríguez Juliá", en: Estudios. Revista de investigaciones literarias, número especial dedicado a literatura del Caribe, Año 2, nro. 4, pp. $31-42$.

${ }^{444}$ White, Hayden (1998). Véase el apartado "La teoría de los tropos" de la "Introducción: la poética de la historia", en: Metahistoria. La imaginación histórica en la Europa del siglo XIX, Buenos Aires, Fondo de Cultura Económica, pp. 41-47.

${ }^{445}$ El epígrafe de W.B. Yeats citado es el siguiente: "Love has pitched his mansion in/ The place of excrement.” Rodríguez Juliá, Edgardo (1986). Una noche con Iris Chacón, ed. cit., p. 105.

${ }^{446}$ Ibid., p. 105.
} 
al pensador y ensayista Eugenio María de Hostos, cuyas principales obras circularon a fines del siglo XIX. Ambos epígrafes se vinculan por sustentar la misma concepción, ya tópica, de la exuberancia del cuerpo de la mujer antillana, de amplias caderas y nalgas abundantes, imagen que se repite también a lo largo de la crónica por las referencias y citas de la poesía negrista de Luis Palés Matos ${ }^{447}$, donde se cristaliza la figura de la mulata antillana como signo cultural del Caribe.

En la primera parte el cronista apela a registros de lo grotesco ${ }^{448}$, lo obsceno $^{449}$ y lo escatológico ${ }^{450}$, además de adoptar una perspectiva altamente irónica e incisiva para dar cuenta del objeto de su indagación, la "culofilia"

${ }^{447}$ La poesía de Palés Matos puso el acento en el mundo negro antillano. Según el poeta Hugo Gutiérrez Vega "Palés canta y celebra la estética corporal y artística de los pueblos marcados por el signo del Caribe", la tierra antillana cobra forma en el cuerpo de la mujer mulata: "es un Caribe principalmente femenino" -agrega Gutiérrez Vega-, "tiene el profundo sentido de la tierra, el movimiento acompasado de un caderamen rotundo como la comba del cielo." Arcadio Díaz Quiñones observa acerca del libro más reconocido de Palés, su Tuntún de pasa y grifería (1937) , la conjunción de la guerra erótica y la poética de la guerra "racial" provocada por las vanguardias negristas: "Recordemos que la mezcla racial era, para Pedreira, origen de 'confusión', la alteridad máxima. Es evidente que en el Tuntún de pasa y grifería Palés invirtió los presupuestos de Pedreira, y refutó, implícitamente, la ideología racial de Insularismo." Véanse la excelente edición de Tuntún de pasa y grifería preparada por Mercedes López Baralt, Río Piedras, edición conjunta del Instituto de Cultura Puertorriqueña y la Universidad de Puerto Rico, 1993; Gutiérrez Vega, Hugo (1998). "Luis Palés Matos y el Caribe", La Jornada semanal, correspondiente al día 19 de abril. Díaz Quiñones, Arcadio (1997). "Isla de Quimeras: Pedreira, Palés y Albizu", Revista de Crítica Literaria Latinoamericana, Año XXIII, No. 45, LimaBerkeley, primer semestre, pp. 229-246 (la cita del autor corresponde a este artículo, pp. 241242. Díaz Quiñones, Arcadio (1982). "Luis Palés Matos", en: El almuerzo en la hierba, ed. cit., pp. 73-119.

${ }_{448}$ Uso el adjetivo grotesco en su sentido de "oculto", “enterrado", según la acepción señalada por Noé Jitri, para quien "grotesco tiene otra filiación relacionada con lo oculto, lo que está enterrado." Véase Jitrik, Noé (1993)."Rehabilitación de la parodia", en: La parodia en la literatura latinoamericana, volumen colectivo coordinado por Roberto Ferro, Instituto de Literatura Hispanoamericana, Facultad de Filosofía y Letras de la Universidad de Buenos Aires, Serie Monográfica, p. 19.

449 "Obsceno", según el Diccionario de la Real Academia Española significa "impúdico, torpe, ofensivo al pudor", posiblemente proviene de una corrupción o modificación del vocablo latino scena y significaría literalmente fuera de escena. Según el psicoanalista Ariel Arango, “...obsceno sería así lo que no debe verse en la escena, o sea en el teatro de la vida." Véase Arango, Ariel (1987). Las malas palabras, Buenos Aires, Legasa, 7ª edición, p. 16.

${ }^{450}$ El término "escatología" proviene del griego skór, skatós, que significa excremento, y logos, tratado, conocimiento, usándose además para expresar todo el conjunto de creencias y doctrinas de ultratumba. Tomo esta etimología del capítulo IV del libro de Ariel Arango, Ibid., p. 57. El psicoanálisis freudiano aborda la relación entre lo escatológico vinculado a lo excrementicio y a la sexualidad. Véase una síntesis de esta cuestión que Freud aborda en muchos de sus textos en el prólogo que escribe a la traducción al alemán del libro de J.G. Bourke, Scatologic Rites of All Nations, en Freud, Sigmund (1990).Obras Completas, volumen 12 (1911-1913), Buenos Aires, Amorrortu editores, pp. 357-361. 
puertorriqueña: "Los puertorriqueños somos grandes culófilos; si no me creen, ¡miren la popularidad de la Chacón por casi quince años! Se trata del queridísimo objeto de nuestras fantasías eróticas." ${ }^{451}$ Hay incorporación de malas palabras ${ }^{452}$, provocativas, de carácter sexual, entre las que sobresale, como del cuerpo de la monumental Iris Chacón, el vocablo "culo", cargado de una particular plurisemia:

“¿No tiene el trasero otra función que incitar la lujuria? Sí, además de cumplir con el modesto oficio de asentaderas, las nalgas son el lugar de la sodomía y la escatología. Entonces la valoración se vuelve confusa, el espacio gnóstico del trasero resulta trisémico: por un lado apunta al hartazgo de la concupiscencia, por el otro recala en el pecado contra natura, más allá es el memento mori de nuestra existencia, asco de nuestro ser, nuestro principio y nuestro fin. Típica trinidad, obligado abigarramiento católico: el culo es un fracatán de voliciones y signos coincidentes." ${ }^{.453}$

La cita ilustra claramente la articulación de lo alto y lo bajo, lo culto y lo popular, las citas en latín pero también la procacidad, a través de un discurso que apela a una tradición literaria: la sátira, especialmente la que proviene del barroco español y particularmente de Quevedo. La intención satírica se advierte en el fragmento citado en la invectiva contra el catolicismo, donde se adopta un léxico y estilo propios del discurso religioso, aunque mediante un mecanismo de inversión del lenguaje, se lo cambia de sentido. La "típica trinidad", la "trisemia" satirizan preceptos del catolicismo como la "santísima trinidad"; la inclinación erótica del varón puertorriqueño por el trasero se homologa a la idea de culto, creencia, religión ${ }^{454}$.

$\mathrm{Si}$, como señalé antes, la primera parte de la crónica imita la forma del ensayo, lo hace acentuando el efecto de "pastiche satírico" según lo entiende

${ }^{451}$ Rodríguez Juliá, Edgardo (1986). Una noche con Iris Chacón, ed. cit., p. 109.

452 “'Sabemos ahora que las 'malas palabras' son 'malas' porque son obscenas. Y son obscenas porque nombran sin hipocresía, eufemismo o pudor lo que no debe mencionarse nunca en público: la sexualidad lujuriosa y veraz." Véase Arango, Ariel (1987). Las malas palabras, ed. cit. , pp. 16-17.

${ }^{453}$ Rodríguez Juliá, Edgardo (1986). Una noche con Iris Chacón, ed. cit., p. 115.

${ }^{454}$ Véase en esta cita el efecto satírico que provoca la imitación burlesca del lenguaje litúrgico del catolicismo: "El chacón desaparece ante nuestros ojos y de él tenemos una idea más perfecta. La visita del Señor se convierte así en una especie de iconostasio, aquel biombo que tapaba la misa en los comienzos del cristianismo. El acceso a lo sagrado ya tiene que pasar por la idea. De la idolatría hemos pasado a la fe." Rodríguez Juliá, Edgardo (1986). Una noche con Iris Chacón, ed. cit., p. 117. 
Gerard Genette, es decir, "una imitación estilística con función crítica o

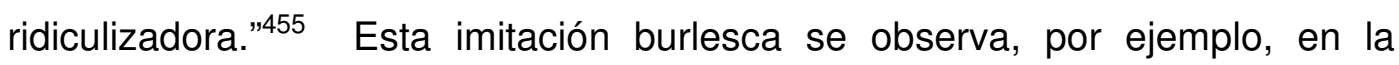
disparatada etimología de la palabra "culo" que construye el narrador, en la cual confluyen las alusiones cultas al famoso diccionario etimológico de la lengua castellana del filólogo español Joan Corominas, junto con el uso oral y popular del término "chacón", no sólo en Puerto Rico sino en la tradición popular antillana; también se ve en la parodia sexista de los sistemas clasificatorios, cuando el narrador describe una tipología de los diferentes traseros. Se apela asimismo al uso burlesco de la cita de autoridades: se despliega una red de referencias escatológicas provenientes de la cultura alta literaria, filosófica, pictórica, que le ofrece al narrador-ensayista de la primera parte la posibilidad de autorizar el tema central de su crónica: las connotaciones simbólicas y culturales del trasero de Iris Chacón que se desarrollan en la segunda parte del texto. En la reconstrucción de una tradición culta de lo escatológico se alude particularmente al libro Gracias y desgracias del ojo del culo (1626), de Francisco de Quevedo y Villegas, extensamente citado en varios pasajes del texto. Se incorporan frases en latín en reiteradas ocasiones, especialmente el proverbio de San Agustín inter feces et urinam nascimur, entre heces y orina nacemos, ya que los excrementos eran para el santo la prueba irrefutable de la ruindad de nuestra carne. Se citan pasajes y anécdotas de autores muy variados, que incluyen los ya nombrados Juan Ramón Jiménez y William B. Yeats, como así también James Joyce, D.H. Lawrence, Martín Lutero, Juan Goytisolo, Simone de Beauvoir, Sigmund Freud, hasta pinturas de Hieronymus Bosch y esculturas del paleolítico.

Pero además de esta red de referencias a la cultura occidental se invocan las tradiciones locales: se citan versos de Luis Palés Matos y se incorpora al texto, antes de comenzar la segunda parte, una reproducción del óleo "El Club" de Rafael Ferrer, pintor puertorriqueño al cual Rodríguez Juliá le dedica Una noche con Iris Chacón como así también un ensayo ${ }^{456}$. Ambos coinciden en la representación, en un caso poética, en el otro pictórica, del

\footnotetext{
${ }^{455}$ Genette, Gerard (1989). Palimpsestos. La literatura en segundo grado, Madrid, Taurus, p. 31. Para Genette el pastiche es una de las especies de la parodia.

${ }^{456}$ Véase Rodríguez Juliá, Edgardo (1989). "El jardín violado y recuperado: la pintura de Rafael Ferrer en las Terrenas", en: El cruce de la Bahía de Guánica, Río Piedras, Editorial Cultural, pp. 159.
} 
cuerpo de la mulata antillana, como objeto erótico y sensual, pero también como representación simbólica de la tierra antillana. Rodríguez Juliá señala que "Palés concibe la posibilidad de una poesía en que la celebración de estas tierras siempre estará cercana a cierta inquietud: será una poesía en cuyo trasfondo se testimonia el pecado original cometido en estas latitudes, la esclavitud...". ${ }^{457}$ Lee en la poesía palesiana la confluencia del lirismo unida a la toma de conciencia histórica y política. Respecto de los óleos de Rafael Ferrer Rodríguez Juliá interpreta en ellos los sentidos de la ensoñación erótica donde la mirada voyeurista implica también la cuestión de la alteridad, ya que los cuerpos desnudos de negras y mulatas entrañan también "la explotación del cuerpo moreno por el cuerpo blanco en la esclavitud." ${ }^{258}$

Esta cuestión -la esclavitud, el sometimiento- aparece como objeto del discurrir del narrador en Una noche con Iris Chacón, cuando el cronista dirige su mirada hacia dos grupos que representan el lugar del otro en la historia occidental: los esclavos negros y las mujeres. La incorporación de una cita de la novela Juan sin Tierra de Juan Goytisolo, donde se describen los hacendados esclavistas y católicos espiando las costumbres sexuales de los esclavos, dispara una reflexión sobre la religión como instrumento de colonización y sometimiento. La escena de la novela de Goytisolo se construye en torno a la figura de un sujeto que mira; invisible para los negros, enfatiza su distancia del campo observado e interpreta en la sexualidad de un cuerpo enigmático, rasgos diferenciales específicos -étnicos, morales. El personaje de Goytisolo representa el lugar del amo, negativamente valorado en la crónica: "el trópico oculta un modo del deseo nunca ajeno a la memoria de la explotación esclavista; la caña a cortarse y la mirada del amo sobre la negra eran dos maneras de la misma reducción." ${ }^{459}$ La explotación esclavista instrumentaliza el sometimiento sexual como herramienta de poder, el esclavo se reifica en el lugar del cuerpo -en el lugar del trabajo, del fundamento productivo de la sociedad, de la sexualidad y de la reproducción misma. En la

\footnotetext{
${ }^{457}$ Rodríguez Juliá, Edgardo (1998). "Utopía y nostalgia en Palés Matos”, La Jornada Semanal, 19 de abril, p. 3.

${ }^{458}$ Rodríguez Juliá, Edgardo (1989). "El jardín violado y recuperado: la pintura de Rafael Ferrer en las Terrenas", en: El cruce de la Bahía de Guánica, ed. cit., p. 153.

${ }^{459}$ Rodríguez Juliá, Edgardo (1986). Una noche con Iris Chacón, ed. cit., p. 133.
} 
figura del amo aparece la ambivalencia dada por los desencuentros entre la dependencia y el deseo del objeto mismo de su abyección:

“...la ancestral memoria colectiva recala en dos pilares de nuestra formación como pueblo: el catolicismo y la esclavitud, el cristianismo anti- bujarrón por excelencia y una institución donde en medio de la conversión del otro en mera herramienta productiva, también existía la insaciable curiosidad por su extrañeza, por su otredad en todos los órdenes, aquí cifrada en el fisgoneo de sus preferencias coitales, precisamente lo más cercano -desde el punto de vista esclavista- a su condición como bruto sólo bueno para el inclemente trabajo del cañaveral."

Como los amos esclavistas, los espectadores del Show de Iris Chacón se esconden en la penumbra del club, para dar rienda suelta a la cerebración; a través de la mirada individual del cronista voyeur se busca el punto de encuentro y coincidencia entre la propia percepción y la colectiva, efecto que se representa en el texto mediante el desplazamiento de la primera persona narrativa en singular al plural y colectivo nosotros:

"Como en el óleo El Club de Rafael Ferrer, la fantasía reclama luz mientras que la mirada se oculta en la oscuridad. (...) El escenario iluminado es tan voraz como ella. (...) El escenario la desnuda y a la vez nos confiesa: su soledad radical a lo más que se parece es a nuestra conciencia; pero ésta se ha ido de juerga, está por ahí grajeándose con la fantasía. Su poder sobre nosotros es tal que permanecemos absortos en el objeto único de su atención."461

La mujer, como sujeto colectivo, aparece en la crónica sometida sexual y socialmente por el estigma del machismo puertorriqueño. Desde los primeros párrafos del texto el narrador anatemiza la concepción del rol de la mujer en la sociedad de su país, atenaceada entre "los dos grandes paradigmas de una sociedad barroca y sutilmente machista: Que en casa se quede el theotokos chancletero, casi casto en la crianza de los nenes, mientras especializamos nuestros apetitos carnales hacia esa corteja o chilla que nos ofrece el sudor

\footnotetext{
${ }^{460}$ Ibid., p. 116.

${ }^{461}$ Rodríguez Juliá, Edgardo (1986). Una noche con Iris Chacón, ed. cit., p. 127 (cursivas del autor).
} 
erótico sin los riesgos del menstruo saltado." ${ }^{462}$ La cita reproduce lo que Adrianne Rich señala respecto de la ideología patriarcal, en tanto ésta no puede prescindir de la dicotomía que escinde a las mujeres en puras e impuras $^{463}$. El uso de las cursivas acentúa desde la textura visual del enunciado otra clásica dicotomía patriarcal: la madre y esposa ${ }^{464}$ en el espacio doméstico sacralizado (la mujer es theotokos) en oposición al espacio exterior y masculino de la querida, "la chilla de barra que nos sacia los jueves y

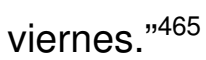

El cuerpo femenino aparece fetichizado por la mirada masculina, como se advierte en la descripción del cuerpo de Iris Chacón como una diseminación de objetos parciales, donde se destacan las diversas prendas del vestuario de la artista a lo largo del show, y especialmente la parte del cuerpo que se constituye como una suma de sentidos: "iel glorioso culo de la Chacón en toda su redondez y simétrica lozanía! (Difícil de describir, ya lo sé, es como escribir sobre una bañera...)"466 Las mujeres no están exentas de caer también en las trampas del machismo que les impone una educación patriarcal. El cronista reconstruye un momento del show donde Iris establece una homología entre las diversas partes de su cuerpo y los principales lugares turísticos del país, una topografía erótica donde es posible reconocer el intertexto palesiano, aunque con un sentido muy diferente al propuesto por el poeta. En el poema "Mulata- Antilla" de Tuntún de pasa y grifería de Palés Matos se asiste a un viaje metafórico por el cuerpo de la mulata y por el mar de las islas, viaje de conocimiento erótico e intelectual a esa tierra donde, como en "L'invitation au voyage" de Charles Baudelaire, “Là, tout n'est qu'ordre et beauté/ Luxe, calme

\footnotetext{
${ }^{462}$ Ibid., p. 107 (cursivas del autor).

${ }^{463}$ En su libro Of Woman Born. Motherhood as Experience and Institution (1976), Adrianne Rich señala que para poder mantener la dicotomía pura e impura respecto del sujeto femenino: "...each in its contradictory purity, the masculine imagination has had to divide women, to see us, and force us to see ourselves, as polarized into good or evil, fertile or barren, pure or impure." (Nueva York, W.W. Norton \& Company, p. 34)

${ }^{464}$ Rosario Ferré, en su libro Papeles de Pandora, (México, Joaquín Mortiz, 1976), tiene un cuento excelente, "Cuando las mujeres quieren a los hombres" que desarrolla la cuestión de la esposa y la querida en la sociedad puertorriqueña. Pero, lo interesante de la perspectiva que propone Ferré, es la búsqueda de la desarticulación de esta dicotomía patriarcal. Las mujeres, en vez de recurrir al enfrentamiento, construyen una silenciosa y poderosa alianza entre ambas, que implica también una suerte de simbiosis corporal de las dos mujeres.

${ }^{465}$ Rodríguez Juliá, Edgardo (1986). Una noche con Iris Chacón, ed. cit., p. 108.

${ }^{466}$ Rodríguez Juliá, Edgardo (1986). Una noche con Iris Chacón, ed. cit., p. 131.
} 
et volupté." ${ }^{467}$ En el viaje por la anatomía de Iris, el narrador también alude a la poesía de Baudelaire, para destacar la diferencia tanto con el poeta francés como con Palés: "Ese proyecto de convertir su cuerpo en mapa turístico ya pronto se encontrará con la procacidad puertorriqueñísima de ella y de su público." ${ }^{468}$ No hay tal viaje de conocimiento, sino de reconocimiento: "L'Invitation au voyage de Iris yacía rota en el piso", declara el cronista, reconociendo la chabacanería, la vulgaridad, la bellaquería, la procacidad convertida en relajo como marcas de una controvertida identidad nacional. En esta crónica se asiste a una serie de desplazamientos, que van del cuerpo parcelado de Iris a la condición de la mujer en una sociedad fuertemente patriarcal como la puertorriqueña; de la situación de la mujer a la condición del puertorriqueño, como sujeto colonial:

“¿Por qué las mujeres la incitan a una mayor vulgaridad? A través de Iris reconocen su propia sexualidad rebajada por el machismo; pero el resentimiento a veces se manifiesta como insólita complicidad con quien humilla: son dos sentimientos contradictorios -uno de protesta, el otro de celebración- que se regodean en la misma manifestación externa del machismo, es decir, la procacidad."469

Una líneas más abajo el cronista amplía la respuesta:

“...(las mujeres) Acatan y se rebelan, volcándose en esa rabia - a veces velada, a veces manifiesta- del oprimido. $Y$ ese resentimiento se manifiesta con la bayoya, el vacilón montado en el salón con La Iris; el puertorriqueño va consiguiendo palmo a palmo -desde una timidez inicial- el alebrestamiento de gallinero, el relajo, jel barullo!, que caracteriza su particular modo de agresión colectiva." 470

Si se observa la secuencia establecida a lo largo de la crónica es posible notar una progresiva representación de sectores subalternos respecto de la cultura hegemónica patriarcal, -los esclavos, las mujeres-, y en la misma isotopía se incorpora "el puertorriqueño" como sujeto colectivo. La obsesión

\footnotetext{
${ }^{467}$ Baudelaire, Charles (1947). Les fleurs du mal, París, Fasquelle Éditeurs, pp. 94-95.

${ }^{468}$ Rodríguez Juliá, Edgardo (1986). Una noche con Iris Chacón, ed. cit., p. 139.

${ }^{469}$ Rodríguez Juliá, Edgardo (1986). Una noche con Iris Chacón, ed. cit., p. 142 (cursivas del autor).

${ }^{470}$ Ibid., p. 142 (paréntesis aclaratorio mío, cursivas del autor).
} 
sexual por el trasero de Iris Chacón se propone como una marca de identidad cultural propia, puertorriqueña. Por una parte parecería que el cronista propusiera, como sugiere la lectura de Milagros Socorro que, mientras la culofilia puertorriqueña mantenga su vigencia con tanta fuerza y vitalidad, la cultura del país podrá hacer frente a los embates de la cultura imperialista: "Más aún, las nalgas son el lugar. El lugar que reterritorializa una cultura y el lugar de la transgresión." ${ }^{471}$ Pero la crónica también permite leer una significación diferente, donde "las nalgas son el lugar de la sodomía y la escatología"472, y el riesgo de la "penetración" se traslada del espacio sexual al político, tal como lo expresa Manuel Ramos Otero, en su ensayo "De la colonización a la culonización". Para este autor Rodríguez Juliá se vale del "mito de carne y hueso" de Iris Chacón para mostrar que: "En el banquete imperialista de la colonia, hemos vuelto los ojos hacia la Gran culonia para olvidarnos del otro culo imperial que por tanto tiempo venimos hueliendo.", para agregar, conciente del carácter provocador de su interpretación: "Si su autor no pretende esta interpretación de su texto, no hay remedio, el papel aguanta todo lo que le pongan."

Sylvia Molloy ${ }^{474}$ sostiene que en el siglo XIX las culturas se leen como cuerpos, y que a su vez los cuerpos se leen y se presentan para ser leídos como declaraciones culturales. La crítica observa también que en esta pasión escópica, descripta en términos de lujuria de ver, quien observa suele ocupar el rol de diagnosticador de la sociedad, interceptándose así los discursos científico-médicos con los sociales. Ejemplos de esta retórica de la enfermedad fueron analizados en el capítulo II cuando señalé el uso de las metáforas orgánicas en Insularismo de Antonio S. Pedreira, como también en los retratos psicológicos de la mentalidad colonizada trazados por René Marqués en El puertorriqueño dócil, cuyos antecedentes se encontraban en la narrativa naturalista de Manuel Zeno Gandía, al autor de La charca y las Crónicas de un

\footnotetext{
${ }^{471}$ Socorro, Milagros(1994). "El género de la crónica y la crónica de lo venéreo: notas en torno a Una noche con Iris Chacón de Edgardo Rodríguez Juliá”, ed. cit., p. 41.

${ }^{472}$ Rodríguez Juliá, Edgardo (1986). Una noche con Iris Chacón, ed. cit., p. 115.

${ }^{473}$ Ramos Otero, Manuel (1991). "De la colonización a la culonización”, en: Cupey, Revista de la Universidad Metropolitana, Río Piedras, vol. VIII, pp. 63-78. La cita corresponde a la página 76.

${ }^{474}$ Molloy, Sylvia (1994). "La política de la pose”, en: Ludmer, Josefina (comp.). Las culturas de fin de siglo en América Latina, Rosario, Beatriz Viterbo, pp. 128-138.
} 
mundo enfermo. ¿Persiste el rol del "diagnosticador" en la figura del cronista de Una noche con Iris Chacón? Y si así fuera, ¿se mantendría entonces una vigencia del paternalismo cuyos residuos observa Juan Gelpí en las crónicas de Rodríguez Juliá, a propósito de su lectura de Las tribulaciones de Jonás? ${ }^{475}$ María Elena Rodríguez Castro señala una diferente configuración del cronista que se percibe en las crónicas posteriores a Las tribulaciones de Jonás y El entierro de Cortijo. Para esta crítica "se trata, también, del abandono del cronista perplejo de las crónicas mortuorias por el cronista distanciado y cómodamente instalado en la mirada paternalista de las crónicas anteriores." ${ }^{\text {476 }}$ Sin embargo no desarrolla ni argumenta esta diferencia. En este sentido prefiero la posición de Rubén Ríos Ávila, para quien esta distancia es traicionera y relativa:

"El narrador se aleja de su héroe derrotado o de su pueblo insuficiente, es decir, se aleja de los objetos de su deseo, para seguir reconociéndose en ellos a la distancia, y ese escritor que aspiraba a encarnar al autor que consignara la inconciencia de su pueblo, termina convirtiéndose en el fiscal entre seducido y escandalizado de su propio inconsciente, un espacio permanentemente insubordinado e indomesticable, donde reinan invictos los monstruos que la escritura no llega a exorcizar. Todo texto le devuelve a un escritor su rostro extrañado, como si fuera otro, y en Rodríguez Juliá ese otro es su país natal que se resiste a armarse como un modelo manejable y que se le impone, por el contrario, como su autorretrato más fiel. ${ }^{477}$

Si en las crónicas Las tribulaciones de Jonás y El entierro de Cortijo la escritura revela un intenso proceso de búsqueda respecto de la compleja realidad puertorriqueña, en Una noche con Iris Chacón la indagación parece cesar y el cronista esboza entonces una respuesta que, de todos modos, no deja de plantearse en términos de un dilema: al puertorriqueño, como sujeto colectivo, le queda como utopía posible expresar, no su rebelión, sino su insatisfacción -los rasgos menudos del relajo, la irreverencia, el barullo-, para depositar allí la huella controvertida de su amenazada identidad nacional.

\footnotetext{
${ }^{475}$ Gelpí, Juan (1993). "Las tribulaciones de Jonás ante el paternalismo literario”, ed. cit., p. 52. ${ }^{476}$ Rodríguez Castro, María Elena (1992)."Memorias conjeturales: las crónicas mortuorias”, ed. cit., p. 92.

${ }^{477}$ Ríos Ávila, Rubén (1992). "La invención de un autor: escritura y poder”, en: Duchesne Winter, Juan (editor-compilador) Las tribulaciones de Juliá, ed. cit., pp. 33-62.
} 


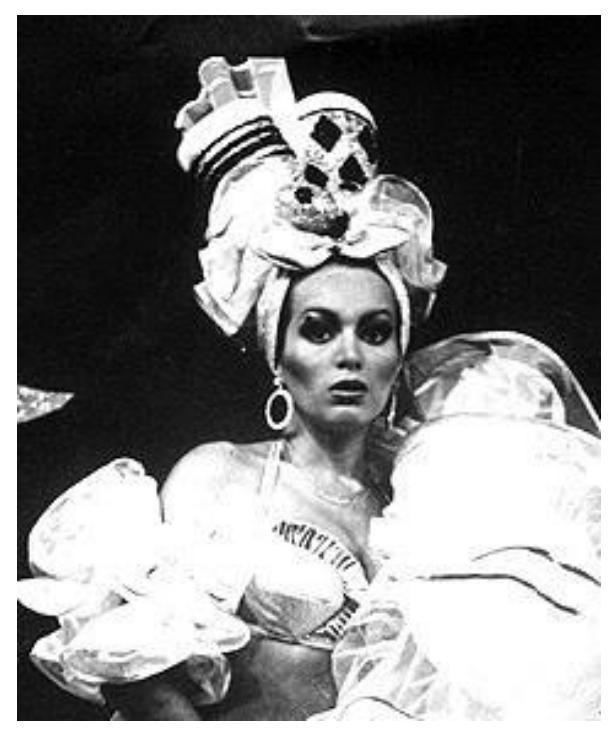

Iris Chacón, "la Bomba Puertorriqueña"

\title{
III. 2 Topografía y memoria: sobre las crónicas "El Cerro Maravilla (octubre-noviembre de 1983)" y El cruce de la Bahía de Guánica
}

\begin{abstract}
"En tanto categorías de la percepción de raíz histórica y fundamental contingencia, tiempo y espacio siempre están estrechamente ligados de manera compleja; prueba de ello es la intensidad de los discursos de la memoria presentes por doquier más allá de las fronteras, tan característicos de la cultura contemporánea en los más diversos lugares del mundo."
\end{abstract}

Andreas

Huyssen

Desde el título de la crónica de Rodríguez Juliá, "El Cerro Maravilla (octubre-noviembre de 1983)" ${ }^{\prime 47}$, se combinan las categorías espaciales y temporales, no solo por la relación de contigüidad que se advierte a simple vista, sino también por la indagación que propone el texto sobre los intrincados caminos de la memoria individual y social, cuando éstas resultan, además, afectadas por la dinámica de los medios de comunicación masiva. Las fechas aludidas en el título corresponden a los meses durante los cuales se televisó la investigación senatorial que reabrió la causa conocida como "caso Maravilla". La mirada del cronista se detiene particular y críticamente en la espectacularización y trivialización, a raíz de su tratamiento televisivo, de un terrible hecho político que atentó contra los derechos humanos en Puerto Rico:

\footnotetext{
${ }^{478}$ Rodríguez Juliá, Edgardo (1986). "El Cerro Maravilla (octubre-noviembre de 1983)”, en: Una noche con Iris Chacón, ed. cit., pp. 53-101.
} 
"Mientras tanto, se comenta que a mediodía todo Puerto Rico ve las vistas públicas con más atención que a la más reciente telenovela, superando en los ratings televisivos al mismísimo show de Iris Chacón." ${ }^{479}$ Desde las coordenadas espacio-temporales del título se vuelve hacia atrás, al año en el que ocurrieron los hechos, 1978, cuando el día 25 de julio tres jóvenes puertorriqueños identificados como independentistas obligaron a un chofer de taxi a subir a las torres de comunicaciones del Cerro Maravilla para efectuar desde allí un acto simbólico de sabotaje, ya que pretendían proclamar la independencia de Puerto Rico. La fecha elegida por los jóvenes era altamente significativa, en tanto corresponde al día en que se llevó a cabo la invasión norteamericana a través de la Bahía de Guánica. Pero además, esa misma fecha fue erigida por Luis Muñoz Marín como inicio del sistema de gobierno del Estado Libre Asociado en 1952 y desde entonces se celebra oficialmente como el "Día de la Constitución"480.

Dos de los jóvenes desconocían que uno de ellos era un agente encubierto de la División de Inteligencia de la Policía de Puerto Rico, y que una vez en el Cerro serían emboscados por las fuerzas policiales. Carlos Soto Arriví, hijo del reconocido escritor Pedro Juan Soto ${ }^{481}$, y Arnaldo Darío Rosado, fueron ejecutados a sangre fría, cuando estaban detenidos y arrodillados en el piso. En aquel momento la policía como fuerza corporativa encubrió el hecho, tratado como represión de un acto subversivo. Sin embargo, tanto la familia de los dos jóvenes brutalmente asesinados como la oposición política independentista, acusaron públicamente al entonces gobernador de la Isla, Carlos Romero Barceló, por la planificación y eventual encubrimiento de los hechos. El historiador Fernando Picó ${ }^{482}$ señala que durante la campaña política

\footnotetext{
${ }^{479}$ Ibid., p. 61.

${ }^{480}$ Según el historiador César Moliné la elección del día 25 de julio para celebrar oficialmente el día de la constitución del Estado Libre Asociado fue "estratégicamente seleccionada para solapar un evento que ocurrió exactamente 54 años antes", refiriéndose a la invasión norteamericana. Véase el artículo "El 25 de julio y la catarsis boricua", publicado en Internet, página sobre Puerto Rico, http://home.coqui.net

${ }^{481}$ Pedro Juan Soto, junto con José Luis González, fue uno de los escritores que durante la década del cincuenta representó en sus ficciones a los sectores desplazados por la emigración. Entre sus obras se destacan su libro de cuentos Spiks (1956) y su novela Ardiente suelo, fría estación (1961), donde se examinan la discriminación que sufre el emigrado en Nueva York como así también las dificultades de readaptación al regresar al lugar natal cuando no se ha tenido la chance de triunfar.

${ }^{482}$ Picó, Fernando (1988). Historia general de Puerto Rico, ed. cit., p. 280.
} 
de 1980 para las elecciones de gobernador, se alegaba que los dos jóvenes se habían rendido al verse rodeados por policías y que éstos los ejecutaron posteriormente. Si bien el Partido Popular Democrático no ganó las elecciones y fue reelecto Romero Barceló, los Populares obtuvieron en cambio el control del Senado, logrando que éste, a través de una comisión senatorial jurídica, iniciara una investigación sobre lo sucedido, dirigida por Héctor Rivera Cruz.

El Senado de Puerto Rico, liderado por la oposición autonomista, efectuó una extensa vista senatorial transmitida en vivo por radio y televisión. Decenas de agentes policíacos, oficiales del gobierno y peritos de todo tipo desfilaron por el estrado compuesto por una representación senatorial de cada partido. Rodríguez Juliá escribe su crónica a partir de estas vistas mediatizadas especialmente por la televisión, como un relato testimonial que, más que atenerse a la factualidad estricta del acontecimiento, apunta a su representación, como espectáculo mediático, para reflexionar acerca de las relaciones entre la memoria y los medios de comunicación de masas. El cronista se ubica en diversas posiciones: por un lado se lo percibe en su papel de testigo, como un espectador más de las vistas, pero también adopta el rol del periodista de investigación, incorporando partes del reportaje que le hiciera a Marcos Ramírez, asesor legal del Senado de Puerto Rico; asume también su rol de cronista, en un sentido cercano al analizado en las crónicas mortuorias, como observador de las actitudes de su propio pueblo, en este caso, convocado en el Cerro Maravilla como nuevo espacio de peregrinación laica.

María Elena Rodríguez Castro, refiriéndose a las crónicas mortuorias de Edgardo Rodríguez Juliá, observa una suerte de competencia entre los medios de comunicación especialmente audiovisuales (radio, T.V) que trasmitían en vivo, tanto el entierro del líder político Luis Muñoz Marín como del gran plenero Rafael Cortijo, y las crónicas literarias propuestas por el autor, a pesar de que en ellas pudiera plasmarse un efecto de simultaneidad respecto de los hechos descriptos. Para esta crítica las crónicas de Rodríguez Juliá:

“...son el otro filtro que absorbería y traduciría el evento, compitiendo con el lenguaje de la informática pero incorporándolo y jerarquizándolo a un orden que considera superior, la literatura. Los medios informan, pero la literatura interpreta dotando de sentido a la serie inestructurada de los hechos: 'ningún camarógrafo, ningún 

fotógrafo da la dimensión moral de lo visto y vivido como la literatura.'

Si se acepta la hipótesis de Rodríguez Castro acerca de la competencia entre medios y literatura, en esta crónica en particular dicha competencia sufre un efecto de desfasamiento temporal, ya que en "El Cerro Maravilla (octubrenoviembre de 1983)" hay una mayor distancia cronológica entre los hechos y la fecha que figura al final de la crónica, agosto de 1985, como datación de la escritura de la misma, en comparación con las crónicas mortuorias, donde la brecha entre los sucesos y su narración es menor. Las vistas, como lo indica su nombre, fueron "vistas" y seguidas a través de su trasmisión televisiva y radial, produciéndose lo que Jesús Martín-Barbero describe como la "hegemonía de la experiencia audiovisual sobre la tipográfica." ${ }^{484}$ Pareciera que el efecto buscado por Rodríguez Juliá en su texto fuera el inverso: hay un predominio de la letra y la tipografía (cursivas, entrecomillados, blancos tipográficos), con la única excepción de la incorporación de una fotografía, lo que produce a su vez un desplazamiento del registro audiovisual, no literario, a un registro literario, a través de la forma crónica.

¿Por qué escribir entonces lo que la cámara y el audio ya registró antes, de manera directa y simultánea? La cita de María Elena Rodríguez Castro despunta la respuesta, al reproducir una reflexión del autor sobre ese plus que la literatura otorga, -una "dimensión moral" sobre los hechos-, que los medios no serían capaces de aportar. En El cruce de la Bahía de Guánica Rodríguez Juliá vuelve sobre esta cuestión, cuando, en un momento autorreflexivo, se confirma el valor conferido a la escritura como práctica simbólica, a contrapelo de la valoración social que se le da en su país:

\footnotetext{
${ }^{483}$ Rodríguez Castro, María Elena (1992).“Memorias conjeturales: las crónicas mortuorias”, ed. cit., p. 69. La cita de Rodríguez Juliá incorporada con comillas simples corresponde a una entrevista inédita al autor realizada por Rodríguez Castro, bajo el título de Yo soy la crónica. (el subrayado es mío)
}

${ }^{484}$ Martín-Barbero, Jesús (2002). "Medios y cultura en el espacio latinoamericano", en: Iberoamericana, Francfort, Año II, Nueva época, junio, nro. 6, pp. 89-106. En torno al debate sobre medios de comunicación masiva y cultura en América Latina véase del mismo autor su libro: De los medios a las comunicaciones: comunicación, cultura y hegemonía, Barcelona, Ediciones Gustavo Gil, 1987. 
"Conozco a Pedro Juan Soto. Nos une, sobre todo, la contradictoria vocación de escribir para un pueblo que apenas lee; se trata del consabido afán de erradicar, mediante la escritura, los más secretos demonios, personales y colectivos; pero en Puerto Rico ese oficio tiene pocos testigos, siempre se arriesga uno a la vanidad $o$ al solipsismo..."

Escribir sobre las vistas posibilita contrarrestar el efecto efímero de "memoria mediática"486 que provocó la reinstalación pública del "caso Maravilla" a través de la prensa, la T.V. y la radio; porque la memoria es poco confiable y siempre está acosada por el fantasma del olvido, la escritura -a pesar del solipsismo o de la vanidad-, poseería entonces la capacidad de preservar o al menos compensar los embates de la desmemoria. En este sentido resultan muy significativos los párrafos de apertura de la crónica: se trata de un microrrelato donde el cronista narra una anécdota de su infancia. En el año 1950 sus padres lo llevaron en un flamante y recién adquirido Pontiac a una manifestación pública y popular de la fe: "Entonces los tres -mi padre, mi madre y yo- nos unimos a la solemne procesión de beatos y noveleros que llegaba de todas partes de Puerto Rico, buscando el sitio exacto en Sabana Grande donde la Virgen se apareció." ${ }^{487}$ El narrador describe cómo el sitio de la aparición religiosa se transformó en un lapso relativamente breve, de súbito y colectivo espacio devoto, en solitario y abandonado punto de la frágil memoria social: "El fervor se encogió ante el olvido. El sitio bendito se convirtió en relicario, luego en pequeño museo casi abandonado."488

La historia de la aparición milagrosa de la Virgen de la Sabana Grande entraña una fábula sobre los alcances y límites de la memoria que el cronista aprovecha para trazar un paralelo con las dimensiones casi religiosas que

\footnotetext{
${ }^{485}$ Rodríguez Juliá, Edgardo (1989). El cruce de la Bahía de Guánica, Río Piedras, Editorial Cultural, p. 45.

${ }^{486}$ Andreas Huyssen utiliza el concepto de "memoria mediática", refiriéndose al espacio e incidencia cada vez mayor que ocupan los medios en la percepción social y política del mundo, como así también el impacto potencial de los nuevos medios sobre la temporalidad, operando e influyendo decididamente sobre la memoria personal, generacional y pública. Veáse el capítulo "Pretéritos presentes: medios, política, amnesia", en: Huyssen, Andreas (2002). En busca del futuro perdido. Cultura y memoria en tiempos de globalización, México, Fondo de Cultura Económica, pp. 13-40.

${ }^{487}$ Rodríguez Juliá, Edgardo (1986). "El Cerro Maravilla (octubre-noviembre de 1983)", en: Una noche con Iris Chacón, ed. cit., p. 57 (cursivas del autor).

${ }^{488}$ Ibid., p. 60.
} 
cobra el Cerro Maravilla como topos de peregrinación laica, en tanto se erige en monumento el mismo lugar en donde ocurrieron los asesinatos de los dos jóvenes independentistas. Pero a esta topolatría se le añade otro efecto que la mirada del cronista destaca y deplora: la transformación del lugar en una suerte de recreo turístico y comercial, donde se exhiben y venden triviales objetos kitsch tales como souvenirs (camisetas y gorras con la inscripción: "Yo estuve en Maravilla", tapetes, carpetitas), hasta comida alusiva como las "chuletas Maravilla":

"Un muchacho flaco, sonriente y de bigotón, recibe las sonrisas del público consumidor de Maravilla... En treinta años hemos pasado de la creencia ancestral en los milagritos a la recordación efímera de los souvenirs. Sin dudas somos más sociedad que antes; pero en el camino a Damasco, que va de Sabana Grande al cerro Maravilla, una parte de nosotros se extravió para siempre. En cuarenta años más los exvotos a la Virgen del pozo serán testimonios casi arqueológicos de una antigua inocencia. Pero estos souvenirs de Maravilla quedarán como prueba de nuestro culto a la necedad y el cinismo del fast-buck..."489

El Cerro Maravilla, como sitio de la memoria, ha sido objeto de un proceso de espectacularización y mercantilización provocado por la incidencia de los medios de comunicación. La popularidad de la figura del investigador Héctor Rivera Cruz se parangona con la celebridad de los famosos de la farándula: "Aparece en la revista Vea como si fuera el más caliente artista farandulero." ${ }^{490}$ Pero la mirada crítica no se detiene solamente en los medios, ya que como observa Andreas Huyssen ${ }^{491}$ la mercantilización no oblitera el hecho histórico. La crónica pone también el acento de manera incisiva en el tratamiento político de los asesinatos, cuya investigación resurge en momentos de campañas electorales. Es notable en la crónica el uso de frases construidas con carácter de sentencias, donde se advierte en el discurso la posición ética

\footnotetext{
${ }^{489}$ Rodríguez Juliá, Edgardo (1986). "El Cerro Maravilla (octubre-noviembre de 1983)”, ed. cit. p. 65 (cursivas del autor).

${ }^{490}$ Ibid., p. 61.

${ }^{491}$ Andreas Huyssen se detiene en el tratamiento más reciente que los medios le han dado a tragedia del Holocausto, desde películas, proliferación de museos, docudramas, sitios de internet, libros de fotografía, historietas, etc., y señala al respecto: "Aun cuando el Holocausto ha sido mercantilizado interminablemente, no significa que toda mercantilización lo trivialice indefectiblemente como hecho histórico." Véase En busca del futuro perdido. Cultura y memoria en tiempos de globalización, ed. cit., p. 25.
} 
que asume el autor. Por un lado en "El Cerro Maravilla (octubre-noviembre de 1983)" hay una postulación de la memoria contra los embates del olvido: "Los hechos aún no se olvidan; pero la memoria de ellos resulta cada vez más borrosa"492. donde además el cronista incita a la indagación y develación de la verdad: "Pero el monstruo, mientras se niegue a nacer, mientras no se sepa toda la verdad, se comerá lentamente nuestras entrañas, nuestro sentido de la justicia, nuestra más elemental decencia, y entonces habrá más Casos Maravilla."493 En este sentido la alusión al aguafuerte de Goya, -cuya famosa inscripción desnuda las relaciones entre racionalidad y monstruosidad: "Los sueños de la razón engendran monstruos"- , cobra una especial connotación en el texto, agrega esa dimensión moral que afecta a la literatura según las consideraciones de Rodríguez Juliá antes señaladas. El nosotros inclusivo señala el desplazamiento de la perspectiva del cronista, con el fin de hacer coincidir su percepción individual con la de un sujeto colectivo, ya que, como se afirma en El entierro de Cortijo: "El filtro del cronista es la memoria, la personal y la colectiva, también los prejuicios, ¿por qué no?"494 La escritura de la crónica, a dos años del proceso de las vistas, invita al lector a no olvidar, a no transformar el Cerro Maravilla en emblema de la desmemoria, en "relicario", en "museo casi abandonado"495 como aquel otro de la Virgen de Sabana Grande.

En "El cruce de la Bahía de Guánica y otras ternuras de la Medianía (25 de julio de 1983)"496 -título completo de la crónica- espacio y tiempo forman también una particular conjunción, ligada a la memoria histórica de los puertorriqueños y a la memoria personal del cronista. Estados Unidos, en el marco de la Guerra Hispanoamericana, invadió a Puerto Rico el día 25 de julio de 1898 a través de la Bahía de Guánica. La flota invasora, al mando del general Nelson Miles, había planificado la ocupación a través de Fajardo, pero a último momento se optó por Guánica, ya que estratégicamente este punto les

\footnotetext{
${ }^{492}$ Rodríguez Juliá, Edgardo (1986). “El Cerro Maravilla (octubre-noviembre de 1983)”, ed. cit. p. 60 .

${ }^{493}$ Ibid., p. 71 (cursivas del autor).

${ }^{494}$ Rodríguez Juliá, Edgardo (1991). El entierro de Cortijo,ed. cit., p. 17.

${ }^{495}$ Rodríguez Juliá, Edgardo (1986). "El Cerro Maravilla (octubre-noviembre de 1983)", ed. cit., p. 60 .

${ }^{496}$ Rodríguez Juliá, Edgardo (1989). "El cruce de la Bahía de Guánica y otras ternuras de la Medianía”, ed. cit., pp. 9-49.
} 
permitía a las fuerzas norteamericanas capturar rápidamente la ciudad de Ponce y bloquear de manera más efectiva los focos de resistencia española. Pero el 25 de julio es también una festividad hispánica que celebra al apóstol Santiago, patrono de Guánica. La fecha se torna entonces una suerte de guarismo complejo que concita sobre sí la convergencia múltiple y contradictoria de distintos eventos. Como se señaló en la lectura de la crónica "El Cerro Maravilla (octubre-noviembre de 1983)", el 25 de julio se celebra oficialmente la declaración de la Constitución del Estado Libre Asociado y, a partir de 1978, se le añade la conmemoración luctuosa del asesinato de los jóvenes independentistas en el Cerro Maravilla. La superposición de diferentes capas de sentido que aluden a situaciones tan diversas y tensas entre sí alrededor de una misma fecha, es descripta y nombrada por el narrador con una certera imagen, la metáfora del palimpsesto: "El 25 de julio la criolla elegancia del malecón se alborota con el frenesí de las fiestas patronales, y éstas coinciden -cual palimpsesto histórico- con la llegada de los americanos, con la inauguración del Estado Libre Asociado, con el crimen del Cerro Maravilla."497

La tensión que entraña la superposición histórica de los sucesos se revela en la contradicción que supone que el mismo día sea motivo de festejo para algunos sectores del país, ya sean los guaniqueños que celebran sus fiestas patronales y los autonomistas que conmemoran el establecimiento del ELA, o bien motivo de protesta y dolor para otros sectores de la sociedad, los nacionalistas, socialistas e independentistas que el mismo día se reúnen para protestar por la invasión de 1898, también los familiares directos de los jóvenes masacrados. El día 25 de julio en Guánica se le revela al narrador como una cifra espacio-temporal en la que "se agolpan todas las tiernas y pocas veces aterradoras contradicciones de este pueblo." ${ }^{498}$ Las tensiones también atraviesan al yo narrador, atrapado en una encrucijada de lealtades complejas que debe cruzar, como la Bahía que recorre a nado y cuyas aguas se tornan un espejo de la memoria y la conciencia individuales.

\footnotetext{
${ }^{497}$ Rodríguez Juliá, Edgardo (1989). "El cruce de la Bahía de Guánica y otras ternuras de la Medianía", ed. cit., p. 25.

${ }^{498}$ Ibid., p. 28.
} 
Como es habitual en las crónicas de actualidad de Rodríguez Juliá, la figuración autorial se construye desde la posición autobiográfica. Se alude al nombre propio del autor, a los títulos de algunas de sus obras, a su esposa e hijo, y se insiste en la "medianía" cronológica nombrada en el título. En más de una ocasión el narrador repite su edad, sus treinta y seis años, que evocan el verso de Dante, la mitad del camino de la vida del hombre: "Yo, por mi parte, ya cumplí los 36 . Hace seis años que nado con él, y lo he visto, en estos últimos meses, aflojar la brazada, resentir un poco, solo un poquito, la fuerza de mis hombros alcanzados por la medianía del camino.,499 El narrador, junto a Bill, su amigo americano, cruzan juntos por tercera vez la Bahía de Guánica, en el marco de una competencia de natación organizada con motivo de las fiestas patronales. El cruce de la bahía connota la celebración de un ritual privado de amistad que va cobrando diversas significaciones a lo largo de la crónica: Bill es el amigo que le ha enseñado al narrador los secretos del nado a mar abierto, es veinte años mayor que el cronista. Por una parte ocupa el rol del maestro para el narrador, pero también evoca la figura paterna; además connota por su nacionalidad la presencia de lo norteamericano en la Isla. La competencia de natación se torna paulatinamente en una soterrada rivalidad entre ambos amigos que emerge poco a poco, como la resaca que el mar empuja hacia la orilla, y que alcanza dimensiones que rebasan lo personal:

"No hay motivo para obviar nuestra sorda competencia. (Para mí también se vuelve importante ganar un trofeo de latón.) ¡Qué gane el mejor! Le llevo veinte años y he rebajado veinte libras desde que crucé por última vez esta bahía. Eres amigo de lealtad perfecta; pero de los buenos padres a veces sólo merecemos una buena lección: tú me hiciste nadador, ahora quisiera derrotarte, repetir, casi sin pudor, ese ciclo eterno de amor y rivalidad. ${ }^{, 500}$

Pero Bill no es la única figura en el texto que remite a las imágenes de autoridad del padre o del maestro. El narrador narra su encuentro en Guánica con un mítico representante de las letras puertorriqueñas: el poeta épico y

\footnotetext{
${ }^{499}$ Rodríguez Juliá, Edgardo (1989). "El cruce de la Bahía de Guánica y otras ternuras de la Medianía”, ed. cit., pp. 14-15 (cursivas del autor).

${ }^{500}$ Ibid., p. 33.
} 
nacionalista Juan Antonio Correjter ${ }^{501}$. El viejo poeta aparece en el texto como una presencia relevante en el pasado personal del cronista: "Correjter fue figura importante en mis años de formación literaria" ${ }^{\text {"502, }}$, pero también con indudable peso en el pasado histórico y político de los nacionalistas de Puerto Rico. El poeta encabeza todos los años una ceremonia que deviene ritual: una marcha de protesta contra la invasión norteamericana de 1898. Su figura es leída por el cronista como un emblema anacrónico y tierno a la vez. Vestido con su boina de guerrillero y su guayabera de viejo comunista, su persona concita un sentimiento de ambivalencia semejante al que le produjera al autor la visión de Luis Muñoz Marín envejecido y afásico en Las tribulaciones de Jonás, una mezcla compleja de burla y compasión. Sin embargo la presencia del viejo poeta implica también un llamado de atención sobre el debilitado compromiso ideológico del independentismo del narrador, como una padre que descubre a su hijo en el momento exacto de cometer una falta, como se observa en el siguiente pasaje, cuando Correjter le pregunta al cronista:

"¿Vas para Guánica? Aquella pregunta tocaba una de esas secretas claves del independentismo, una de esas frases dichas a mitad de camino entre la paranoia y el esnobismo. Decir ¿Vas para Guánica? Implica necesariamente: ¿Vas para Guánica a protestar por la invasión yanqui de nuestro suelo patrio? ¡Terrible!; en todo caso iba para Guánica a una absurda competencia de natación donde sólo está envuelta la vanidad.... ${ }^{503}$

El viejo poeta evoca también el palimpsesto histórico que representa el 25 de julio, y agrega otra capa más de historia a la fecha, al sugerir la superposición de los asesinatos del Cerro Maravilla con la masacre de Ponce ocurrida en 1937, donde, en una emboscada, fueron asesinados militantes civiles del nacionalismo puertorriqueño.

\footnotetext{
${ }^{501}$ Juan Antonio Correjter (1908-1985) fue un muy importante poeta puertorriqueño cuya obra pareció seguir el imperativo martiano de reunir ética y estética. Se unió a la causa del Partido Nacionalista con el fin de luchar por la independencia de su país. Militó junto a Pedro Albizu Campos, y como él, debió padecer persecuciones políticas, estadías en prisión, tanto en Puerto Rico como en los Estados Unidos, ya que fue acusado en más de una ocasión de conspirar para derrocar el gobierno norteamericano en Puerto Rico.

${ }^{502}$ Rodríguez Juliá, Edgardo (1989). "El cruce de la Bahía de Guánica y otras ternuras de la Medianía", ed. cit., p. 18.

${ }^{503}$ Ibid., p. 19.
} 
Una tercera figura aparece en la crónica sujeta a su rol de padre, en este caso de manera trágica, ya que se trata del escritor Pedro Juan Soto quien conmemora en la misma fecha el asesinato de su hijo en el Cerro Maravilla. El acto político de nacionalistas, independentistas y socialistas en Guánica cobra entonces la dimensión fúnebre del memorial; el cronista registra cómo se le imprime a la fecha el ribete negro del luto, cómo el crimen impune se transforma en herida abierta:

"Entonces le tocó hablar a Pedro Juan Soto. El discurso me resulta extraño. Apenas alcanzo en su voz algo del hombre que conozco. En esa voz el autor de Spiks asume toda la extrañeza del Caso Maravilla, toda la dura e impenetrable objetividad de su tragedia. El hijo muerto vuelve a susurrar desde el fondo de esa mudez infranqueable. Los acentos del discurso están colocados según la prosodia de una invocación. Esa voz extraña es como una máscara ceñida para penetrar al infierno, al desorden representado por un crimen que permanece impune. ${ }^{504}$

El narrador recuerda un encuentro anterior con Pedro Juan Soto, donde aparecen armónicamente reunidas las imágenes del escritor y del padre, literal y simbólicamente. Pedro, como figura de autoridad literaria, le comenta a Rodríguez Juliá, en ese entonces incipiente escritor, sus opiniones sobre algunos de sus escritos. Mientras lo hace regaña, no solo al joven escritor, sino también a su hijito Carlos que lo acompañaba: "En ese momento el misterio de la paternidad y el aprendizaje literario se cruzaban." ${ }^{505} \mathrm{Si}$ en el pasado el narrador ocupó de alguna manera el rol figurado del hijo, del aprendiz, del discípulo, lo que se advierte en el presente de la enunciación es un afianzamiento de la propia autoridad narrativa, $y$, por lo tanto, un distanciamiento respecto de aquellas figuras paternales que detentaban de algún modo la autoridad: Bill, Correjter, Soto ${ }^{506}$. Sin embargo se trata de un distanciamiento atravesado por ambivalentes afectos donde se mezclan la ironía y la compasión, la burla y el respeto, el extrañamiento y la cercanía, ese

\footnotetext{
${ }^{504}$ Rodríguez Juliá, Edgardo (1989). "El cruce de la Bahía de Guánica y otras ternuras de la Medianía", ed. cit., pp. 47-48.

${ }^{505}$ Ibid., p. 48.

${ }^{506}$ Sobre la construcción de la figura de autor en la narrativa de Edgardo Rodríguez Juliá véase Ruiz Cumbia, Israel (1999). "Edgardo Rodríguez Juliá y las paradojas de la (autor)idad narrativa", en: La Torre, año IV, número 12, abril-junio, pp. 449-468.
} 
"ciclo eterno de amor y rivalidad" que el narrador destaca especialmente respecto de Bill.

Como en las crónicas analizadas en los apartados anteriores, en "El cruce de la Bahía de Guánica" la mirada vuelve a cobrar un lugar central. El comienzo del texto remite a una imagen cuya percepción resulta desdoblada: el lector asiste a la descripción de la bahía desde la perspectiva distante que le impone el narrador, quien observa el paisaje desde la orilla, pero también desde su conocimiento cercano y vivencial de la bahía, a partir de su experiencia como nadador que ha surcado sus aguas. El mar posee una doble significación en la imagen trazada por el cronista, como una suerte de Jano bifronte, ya que, por un lado muestra "el rostro apacible de las aguas, allá desde la orilla", y por el otro, desde aguas adentro, "cobra aquí su gesto más amenazante." ${ }^{507}$ Inmediatamente después de la descripción y reflexión sobre el mar el narrador introduce el hecho histórico, la invasión norteamericana a través de la bahía de Guánica, vinculando de este modo el gesto acechante del mar con la amenaza real del colonialismo. Se puede leer aquí una referencia al clásico ensayo de Antonio S. Pedreira, Insularismo, donde el enemigo externo era el mar, porque acentuaba la insularidad, el aislamiento del país ${ }^{508}$. En la crónica de Rodríguez Juliá el mar no aísla sino que es el espacio peligroso por donde ingresa la Historia como acontecimiento, escrita con mayúsculas, que cambia para siempre al país, al someterlo a la irrupción de un nuevo orden colonial cuya vigencia se mantiene en el presente: "Aquel puerto apacible, refugio de taciturnos pescadores, manso panorama marino para los amodorrados balcones frente a sus aguas, de pronto, casi sin aviso, recibiría la visita de la Historia." ${ }^{509}$ Pero el cronista no ansía detenerse en la historia ${ }^{510}$, no

\footnotetext{
${ }^{507}$ Rodríguez Juliá, Edgardo (1989). "El cruce de la Bahía de Guánica y otras ternuras de la Medianía”, ed. cit., p. 11.

${ }^{508}$ Véase, por ejemplo, el pasaje siguiente de Insularismo: "Entre el mar Caribe y el océano Atlántico, Puerto Rico levanta su paralelogramo casi uniforme, rodeado por un roto collar de islotes pequeñitos, inhóspitos para la tertulia. Es la menor de las tres Antillas Mayores y el constante tutelaje de sus albaceas la ha mantenido muchos siglos en inviolable minoridad. Esta vieja niñez prolongada hasta el presente, regida por institutrices mandatarias, nos obliga a una reglamentación limitadora de la amistad antillana y por ende de la confraternidad hispanoamericana y universal. Nuestra minoría de edad nos separa del mundo." Pedreira, Antonio S. (1970). Insularismo, en: Obras de Antonio S. Pedreira, tomo I, San Juan, Instituto de Cultura Puertorriqueña, p. 123.

${ }^{509}$ Rodríguez Juliá, Edgardo (1989). "El cruce de la Bahía de Guánica y otras ternuras de la Medianía", ed. cit., p. 12.
} 
busca asumir la visión posterior propia del narrador histórico, sino leer y entender los signos de un presente sabiendo que éstos no pueden soslayar el pasado; son "estos ochenta y seis años de Carnaval colonial boricua" que se condensan en la fecha-palimpsesto del 25 de julio de 1983 indicada en el título de la crónica.

El "carnaval colonial boricua" encarna en las fiestas patronales de Guánica, que le permiten al cronista-observador contemplar una vez más, envuelto en una mezcla de curiosidad distante y seducción, las actitudes de la multitud convocada en los populares festejos. La crónica se escribe entonces a partir de dos movimientos que crean una estructura de contrapunto: un cronista que metafóricamente se zambulle entre la muchedumbre y un narradornadador que se sumerge en las aguas del mar. Pero, a diferencia del mar, la muchedumbre no posee gestos amenazantes sino contradicciones que concitan la atención, el asombro y finalmente la aceptación resignada del cronista, como la emblemática parejita de niños cuyos disfraces postulan una imagen supuestamente "tierna" del Estado Libre Asociado que la irónica descripción del narrador hace estallar:

"Detrás de la reina iqué viva Mildred I!, viene una parejita de niños. iAy pero qué cosa más mona, son una chulería en pote!, exclaman las doñas vendedoras de alcapurrias y tacos. El viene vestidito de Uncle Sam, emblematizado de pies a sombrero de copa con la bandera de esa diarrea yanqui que invadió la patria, según la retórica de Correjter. ¡Virgen pura! ¡Santo Cielo! En la misma calle, allá al final, los discursos terribles de Correjter contra la invasión yanqui aún resuenan, y

\footnotetext{
${ }^{510}$ Dos escritores puertorriqueños en la década de 1980 exploran las relaciones historia y ficción en propuestas muy diferentes al tratamiento que hace sobre la cuestión Rodríguez Juliá, en ambos casos teniendo en cuenta como eje la invasión norteamericana a Puerto Rico en 1898. La ficción histórica de José Luis González, La llegada (crónica con "ficción”) (1980, Río Piedras, Ediciones Huracán), ficcionaliza la llegada de las tropas invasoras a Llano Verde, un pueblo inventado que encarna al país entero. Se trata de una novela, donde el escritor combina el relato histórico documental con las técnicas y estructuras de la ficción. El otro ejemplo, más complejo desde el punto de vista de su estructura, es el texto de Luis López Nieves, Seva: historia de la primera invasión norteamericana de la isla de Puerto Rico ocurrida en mayo de 1898 (1991, San Juan, Editorial Cordillera, sexta edición). Este libro recoge el texto que fuera originalmente publicado el 23 de diciembre de 1983 en el periódico Claridad. Leído en su momento por el público en general como un documento histórico que daba otra versión de la invasión, en realidad se trata de un texto ficcional, construido con discursos que emulan relatos testimoniales, cartas, documentos. En El cruce de la Bahía de Guánica se apela a la memoria histórica pero no se trabaja con la relación historia y ficción que proponen, en cambio, estos dos ejemplos. La mirada del cronista se centra en su presente, característica de las crónicas de actualidad del autor.
} 
aquí, con esa miradita que escapa temerosa a la de todos los curiosos, una boricuita de ocho años, vestida con la bandera de Puerto Rico, le sirve de consorte a un Uncle Sam con chiva de algodón, excesivamente distante de la pubertad, ya que no totalmente ajeno al expansionismo del bisoño imperio." 511

Las cursivas marcan tipográficamente dos registros verbales que se interceptan con el del cronista, las voces de "las doñas" del pueblo y la retórica combativa y anacrónica del poeta nacionalista, que, como la fecha palimpsesto del 25 de julio, se superponen entre sí, "en la misma calle" y en la misma página del texto. La reunión de actores sociales diversos y contradictorios hace exclamar al narrador, al final de la crónica, una constatación: “¡Santo Cielo! ¡Es la misma gente!: Los del rincón patriótico y éstos, los de malecón de las tres $B$ (baile, botella y baraja), json la misma gente!...." ${ }^{\text {. }}$ Al final del texto, el uso de los verbos en primera persona del plural, sugiere la autoinclusión del escritor en el sintagma colectivo "somos la misma gente". De este modo, como propone la lectura de Rubén Ríos Ávila refiriéndose a la figura de autor que se desprende de las crónicas de actualidad de Rodríguez Juliá, "el aspirante a autor de su pueblo escribe para dejarse escribir por él, y para resignarse a decir, como Flaubert de Madame Bovary: Puerto Rico soy yo."

Si la inmersión del sujeto en la multitud que abarrota las calles de Guánica durante los festejos de las fiestas patronales entraña un efecto similar al señalado en las otras crónicas vistas hasta aquí, -la ilusión de un individuo cuya mirada se intercepta con la de un colectivo mayor-, adentrarse en las aguas del mar denota en cambio la acentuación del solipsismo y el fluir de la conciencia del narrador. A medida que el narrador-nadador se aleja de la costa sus sentidos se alteran, sobre todo la percepción visual y la auditiva, como así también se disloca su noción del tiempo y el espacio ${ }^{514}$. Cuando predomina en el relato la narración de las sensaciones, el sujeto entra en relación muy

${ }^{511}$ Rodríguez Juliá, Edgardo (1989). "El cruce de la Bahía de Guánica y otras ternuras de la Medianía", ed. cit., p. 28.

${ }^{512}$ Ibid., p. 49.

${ }^{513}$ Ríos Ávila, Rubén (1992). "La invención de un autor: escritura y poder", en: Duchesne Winter, Juan (editor-compilador) Las tribulaciones de Juliá, ed. cit., pp. 61-62.

514 Véase como ejemplo de esta percepción distorsionada el siguiente pasaje: "Llega un momento en que la euforia altera el sentido del tiempo y del espacio. Tal parece que no avanzo en el vaivén de los marullos. La fuerza d e la brazada se anula con el halón de la ola. Por un momento la distancia hasta el atracadero me parece insalvable.” Rodríguez Juliá, Edgardo (1989). "El cruce de la Bahía de Guánica y otras ternuras de la Medianía”, ed. cit., p. 40. 
próxima con su propio cuerpo como sustancia material; a su vez el mundo exterior se torna paulatinamente opaco y confuso. El acto de ver, como vía privilegiada para establecer un nexo con lo real, a pesar de los recaudos del narrador, se empaña:

"Pero hoy, a pesar de los lentes de contacto y la casi nitidez con que veo las cosas del malecón de Guánica, -como seguramente las vieron los americanos al invadir un día como hoy- apenas distingo con el ojo izquierdo la boya roja que debemos rebasar por la parte de adentro, para así no ser descualificados de la competencia. Al soplar en el agua el aire caliente de los pulmones sube y empaña los goggles."

Los goggles, anteojos que usan los nadadores, están empañados; los lentes de contacto no mejoran la mirada, tan solo permiten una percepción difusa advertida en el adverbio que relativiza la percepción a una "casi nitidez". Sin embargo, en esta instancia de aprehensión imperfecta de lo real hay una certidumbre, modelizada por el adverbio "seguramente", que abre una grieta en el relato y permite el ingreso del pasado histórico evocado: desde el cuerpo del narrador, en el mismo sitio y desde la misma perspectiva que antes ocupó el invasor, presente y pretérito se yuxtaponen en la bahía de Guánica.

El narrador-nadador fracasa en su intento de lograr un premio en la competencia, frustración que comparte con su amigo americano. El embotamiento de sus sentidos lo aleja de la meta, se desorienta; lo percibido se le aparece como un dato erróneo de la realidad. Al intentar regresar a la costa se encuentra sumido en el agua sucia y pantanosa donde llegan los deshechos que el mar deposita bajo el atracadero. Si antes, cuando nadaba mar adentro, el cronista experimentó fugaz pero intensamente "la sensación de libertad" ${ }^{216}$ de su cuerpo consustanciado con el fluir del agua, al arribar a la costa, en cambio, se siente sujetado a las limitaciones corporales que parecen anclarlo penosamente en la densidad de lo real:

\footnotetext{
${ }^{515}$ Ibid., p. 38 (cursivas del autor).

516 "Cuando logré esa cadencia precisa, la sensación de libertad que experimenté fue total; ya no había separación entre yo y el agua, la resistencia era mínima, como hacer el amor con la mujer de toda la vida." Rodríguez Juliá, Edgardo (1989). "El cruce de la Bahía de Guánica y otras ternuras de la Medianía", ed. cit., pp. 41-42.
} 
"Entonces intenté salir del agua... Imposible, con lo cansado que estoy, subir al atracadero... De pronto me transformo en el pájaro extraño y torpe que Baudelaire convirtió en el símbolo del poeta. La euforia de la flotación y el rocío de la espuma de pronto se vuelven babote, esa negruzca arena de mangle que no me permite bracear, que captura mis piernas como si fuera arena movediza. Me levanto, doy traspiés en el babote, por momentos éste me llega hasta las rodillas."

Cuando el narrador-nadador logra finalmente salir a la superficie un niño burlón le grita una frase que se repetirá dos veces en la crónica, acentuándose cada vez más su connotación pesimista: "¡Fracaso total!"518 Resuena en sus oídos cuando se reencuentra con Bill, una vez que la competencia ha concluido. Se torna en trágico latiguillo cuando el cronista reseña lo sucedido en el Cerro Maravilla, al comentar la proclama que intentaron lanzar los jóvenes como "un acto simbólico; como los nacionalistas en 1950, reafirmarían ante los Estados Unidos y el mundo, justo el día de la invasión norteamericana, la existencia de una nación puertorriqueña. Pero no fue así, jFracaso total! ${ }^{519}$

La referencia al año de 1950 imprime a la crónica la idea de una continuidad entre la violencia del pasado y la del presente, el palimpsesto histórico se recubre de otra capa. Rodríguez Juliá alude con ese año a un acto de rebelión nacionalista sucedido en 1950 que fue duramente reprimido por la policía insular, con una cifra de 28 muertos en San Juan. Además hubo otras víctimas en distintos municipios, como el de Utuado, donde se masacraron a cinco nacionalistas después que estos se hubieran entregado, en un episodio que jamás fue esclarecido.

En "El Cerro Maravilla (octubre-noviembre de 1983)" y en "El cruce de la Bahía de Guánica y otras ternuras de la Medianía (25 de julio de 1983)" el recuerdo se encarna en fechas y espacios que se vuelven emblemas, también en la escritura misma de las crónicas, instancias que se condensan como "lugares de memoria", según lo formula Pierre Nora ${ }^{520}$. Ambos textos bien

\footnotetext{
${ }^{517}$ Ibid., p. 43 (cursivas del autor).

${ }^{518}$ Ibid., p. 43 (cursivas del autor).

${ }^{519}$ Ibid., p. 44 (cursivas del autor).

${ }^{520}$ Nora, Pierre (director y comp., 1998). Les lieux de mémoire, París, Gallimard. Nora explica que la construcción de una tradición se condensa en "lugares de memoria", fechas, emblemas, monumentos, modas, museos, relatos, edificios, libros, etc. Estos "lugares de memoria", ya sean metafóricos o de cemento, de hierro o de papel, pesados o inmateriales, no siempre pueden
} 
pueden suscribir las reflexiones de Arcadio Díaz Quiñones respecto de la memoria como práctica, como ejercicio del pensamiento estrechamente vinculado a la escritura:

"Memor, la palabra latina según comenta David F. Krell en su erudito libro sobre reminiscencia y escritura Of memory, Reminiscence and Writing, pertenece a un núcleo semántico asociado siempre con el pensamiento como actividad, como práctica. Imprimir, para los antiguos filósofos y poetas, era una manera de no olvidar, una actividad. La memoria está a menudo asociada a la escritura o a la iconografía, a todo lo que hace posible la conservación, para ser recuperado en otro momento." 521

\title{
III. 3 De la iconoteca familiar a la iconoteca social. Notas sobre la relación escritura y fotografía en Puertorriqueños (Álbum de la Sagrada Familia puertorriqueña a partir de 1898) ${ }^{522}$
}

"Las fotografías, que por sí solas son incapaces de explicar nada, son inagotables invitaciones a la deducción, la especulación y la fantasía".

fotografía.

Susan Sontag, Sobre la

\begin{abstract}
Este retrato de família
Está um tanto empoeirado.

Já nào se vê no rosto do pai

Quanto dinheiro ele ganhou.

$O$ retrato nào me responde

Ele me fita e se contempla
\end{abstract}

ser localizados geográficamente, pero constituyen para Nora un instrumento de inteligibilidad de la historia.

${ }^{521}$ Díaz Quiñones, Arcadio (1993). La memoria rota, ed. cit., p. 72.

522 Rodríguez Juliá, Edgardo (1992). Puertorriqueños (Álbum de la Sagrada Familia puertorriqueña a partir de 1898), Madrid y Río Piedras, Editorial Plaza Mayor, (Biblioteca de Autores de Puerto Rico), 3ra. edición, (todas las citas textuales están tomadas de esta edición, el libro fue editado por primera vez en 1988). 
Nos meus olhos empoeirados.

E no cristal se multiplicam

os parentes mortos e vivos.

Já nào distingo os que se foram

dos que restaram. Percebo apenas

a estranha idéia de família

viajando através da carne.

Carlos Drummond de Andrade, "Retrato de familia"

Como explica Nelson Schapochnik, Carlos Drummond de Andrade emprende en su poema "Retrato de familia" una operación de traducción del lenguaje no verbal de la fotografía a la lengua poética ${ }^{523}$. En Puertorriqueños (Álbum de la Sagrada Familia puertorriqueña a partir de 1898), Rodríguez Juliá realiza una operación similar, ya que se trata de un libro de crónicas ${ }^{524}$ construido a través de la reunión fecunda entre la fotografía y la escritura, entre la imagen y el entramado verbal, donde las fotos también operan como textos que se dejan leer y escribir, o, como señala el epígrafe de Susan Sontag ${ }^{525}$, las fotos son estímulos para la imaginación, "disparadores"526 de la escritura. Asimismo Puertorriqueños reproduce en su soporte, es decir como objeto libro, el formato del álbum fotográfico, e impone además al receptor del texto una doble tarea: leer y mirar, invitando al destinatario a asumir el lugar privilegiado por el cronista, el del espectador, que aquí comparte con los lectores.

Inspirado en la producción del artista plástico Antonio Martorell, cuya obra Álbum de familia (1978) -serie gráfica donde trabaja los arquetipos fotográficos de la familia y su relectura estética- motiva su propio texto, Rodríguez Juliá reconoce otra deuda, en este caso de filiación, al dedicar su libro a su padres, cuyas fotos, provenientes del álbum privado y familiar del

\footnotetext{
${ }^{523}$ Schapochnik, Nelson (1998). "Cartòes-postais, álbuns de familia e ícones da intimidade”, en: Novais, Fernando (coordinador general de la colección) y Sevcenko, Nicolau (organizador del volumen), República; da Belle Époque à Era do Rádio, História da vida privada no Brasil, vol. 3, pp. 424-512.

${ }^{524}$ Las crónicas que componen Puertorriqueños (Álbum de la Sagrada Familia puertorriqueña a partir de 1898), fueron publicadas como una serie en la sección Viva del periódico El reportero, (San Juan), entre el 5 de marzo y el 31 de marzo de 1984; posteriormente fueron reunidas como libro en 1988.

${ }^{525}$ Sontag, Susan (1977). Sobre la fotografía, Buenos Aires, Sudamericana.

526 "Disparador" como motivación de la escritura del texto, pero también en el sentido de la mecánica de la fotografía, como el dispositivo que acciona la cámara fotográfica.
} 
autor, conviven con fotografías históricas y testimoniales de diferentes momentos de la vida social y pública de los puertorriqueños a partir de 1898. Aludiendo a esta combinación de lo público y lo privado en Puertorriqueños señala Áurea Sotomayor: "Rodríguez Juliá construye un segmento de nuestra historia íntima a partir de las fotos del álbum familiar y el isleño aunando lo autobiográfico y lo nacional, la intrahistoria y la historia."

Si el título del libro -Puertorriqueños- connota la ilusión de totalidad, el subtítulo, en cambio, acota esta significación amplia. Álbum de la Sagrada Familia puertorriqueña a partir de 1898 indica, por un lado el álbum fotográfico, especialmente el familiar, como una práctica social muy vinculada a la clase media que, como sugiere Susan Sontag, permite a cada familia construir una crónica de sí misma, "un conjunto de imágenes portátiles que atestigua la solidez de sus lazos." 528 La "sagrada familia" apunta al modelo religioso cristiano de la organización familiar y social occidental, pero el gentilicio "puertorriqueña" la circunscribe al ámbito de lo nacional, aludiendo irónicamente a la operación retórica de unidad y consenso en torno a la sacralización de la imagen familiar promovida por los miembros de la Generación del Treinta y resignificada por los discursos del populismo, particularmente a través de la voz de su líder Luis Muñoz Marín. ${ }^{529}$ Juan Gelpí $^{530}$ observa que el cronista en parte se siente atraído por la concepción tradicional de la gran familia puertorriqueña, pero ya no para proponerla como estrategia de cohesión nacional sino más bien para registrar, por el contrario, los vestigios de su fragmentación, de su erosión, de su pérdida. Como se lee

\footnotetext{
${ }^{527}$ Sotomayor, Áurea María (1992). "Escribir la mirada", ed. cit., p. 132.

${ }^{528}$ Sontag, Susan (1977). Sobre la fotografía, ed. cit., pp. 18-19. Para Sontag el desarrollo del álbum familiar funciona como una suerte de paliativo para contrarrestar la disolución familiar que se produce a partir de la revolución industrial. Respecto del álbum fotográfico y su vinculación con el espacio doméstico y familiar, escribe Walter Benjamin: "Entonces fue la época en que comenzaron a aparecer los álbumes de fotografía. En los lugares más fríos de la casa, sobre las consolas o armarios, allí era donde más probable se encontraran: cuero cubierto con picaportes de metal y páginas de corte dorado tan gruesas como un dedo, sobre las cuales las tontamente vestidas o embellecidas figuras estaban distribuidas -el tío Alex y la tía Riekehe, Trudy cuando pequeña, papá en su primer semestre. Y finalmente, para completar la versión, nosotros mismos: como Tiroleses de salón, canturreando, los sombreros balanceados contra abetos pintados, o como marineros, una pierna rígida y la otra doblada, como es apropiado, descansando contra un poste entapizado." Véase Benjamín, Walter (1977)."Breve historia de la fotografía", $E c o$, t.xxxi/2 nro. 188, junio, p.155. Reproducido también en Benjamín, Walter (1989). Discursos interrumpidos I, Madrid, Taurus, pp. 61-83.

${ }^{529}$ Sobre Luis Muñoz Marín véase el capítulo II.

${ }^{530}$ Gelpí, Juan (1993). "Las tribulaciones de Jonás ante el paternalismo literario”, ed. cit., p. 52.
} 
en los siguientes pasajes del texto el narrador parece constatar la dispersión de la metáfora familiar: "La familia lleva en su seno el germen de todas las separaciones imaginables."; "La familia es la promesa de una memoria que se irá borrando hasta sólo quedar la presencia del destino, la terca y constante humanidad del otro sometida al mismo desgaste."; "La memoria tradicional y el tótem familiar serán derrumbados a fuerza de movilidad y desarraigo." 531

La referencia a 1898 en el subtítulo de Puertorriqueños, el año emblemático pero cargado de zonas oscuras según la aguda mirada de Díaz Quiñones ${ }^{532}$, se carga de diversas significaciones a lo largo del texto, en parte al mostrar las estrategias de la penetración imperial a través de la acción transculturadora de la educación y la salud. Puertorriqueños se constituye entonces como la narración de una historia alterna, relatada por un puertorriqueño y enfrentada a otro álbum fotográfico, el de la mirada colonizadora del fotógrafo norteamericano Walter Townsend, a quien las fuerzas invasoras encomendaron la tarea de fotografiar y documentar en 1899 la ocupación de la isla. Sus fotos fueron incluidas en los dos tomos compilados por William S. Bryan, Our Islands and their People ${ }^{533}$ :

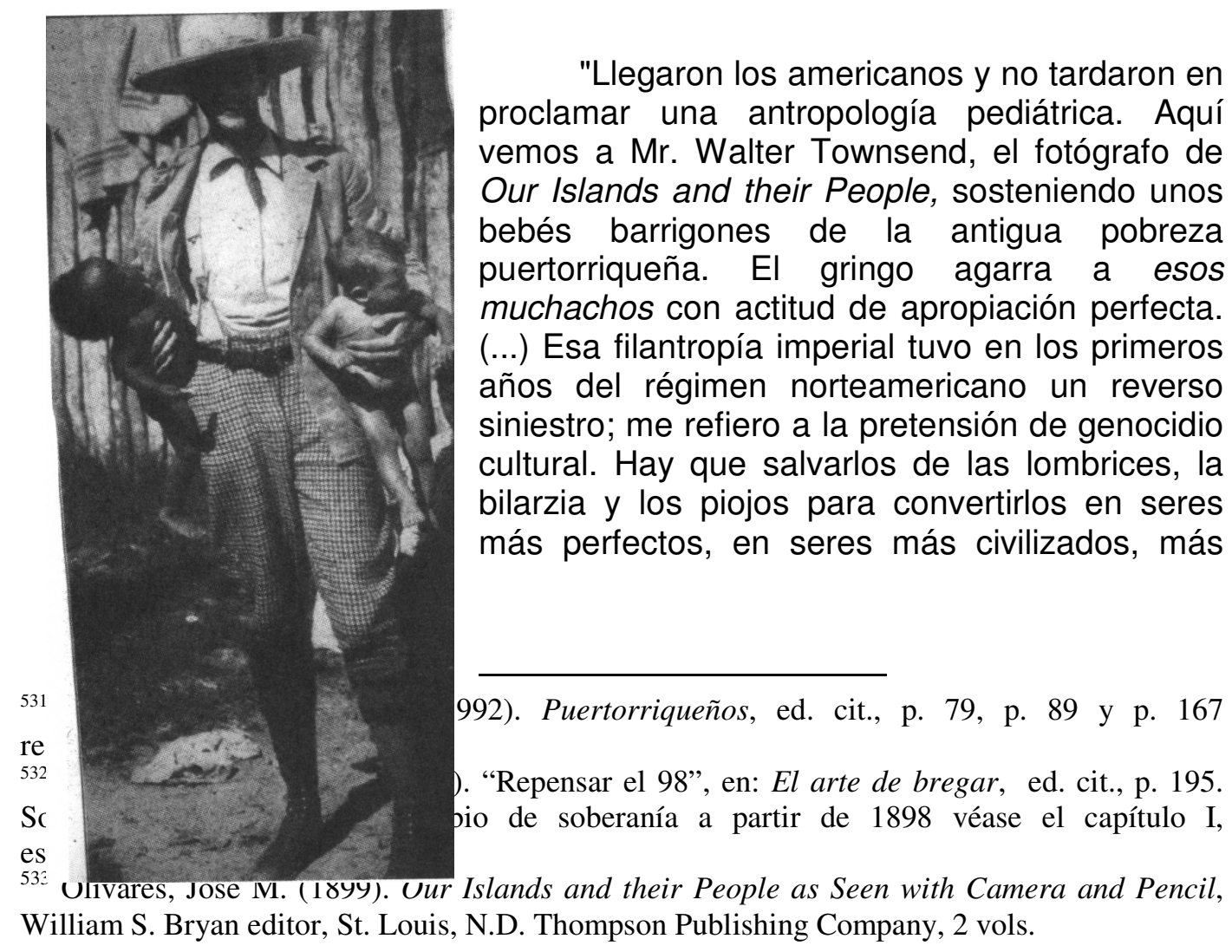


parecidos a los yanquis, en fin, transformarlos en americanos." 534

El álbum que construye Rodríguez Juliá, fundado en el juego entre diversas miradas, incorpora también, como se observa en el fragmento antes citado, la presencia de los "ojos imperiales" al que explora Arcadio Díaz Quiñones cuando sostiene que las guerras del 98 entrañaron para Filipinas, Puerto Rico y Cuba una enorme e insólita visibilidad $^{536}$, gracias al espectacular desarrollo de la tecnología y la simplificación de la Kodak portátil. El planteo del álbum alterno también es posible pensarlo a partir de las reflexiones de Edward Said expresadas en su libro Cultura e imperialismo ${ }^{537}$ en torno al complejo intercambio entre las colonias y las metrópolis, donde se ponen en juego dos tipos de miradas: por un lado las lecturas que las colonias hacen de las metrópolis en las diferentes etapas de su relación; por otro, la lectura que hace la metrópoli de la colonia como objeto de deseo y de imagen especular para construir su propia subjetividad $^{538}$, cuestión que se vuelve a trazar especialmente en el primero de los epígrafes de Puertorriqueños donde se plantea el problema de la identidad. Extraído de una crónica de viaje del siglo XVIII de André Pierre Ledrú, Viaje a

${ }^{534}$ Rodríguez Juliá, Edgardo (1992). Puertorriqueños, ed. cit., pp. $76-77$ (cursivas del autor).

${ }^{535}$ Aludo aquí al título del libro de Mary Louise Pratt (1997). Ojos imperiales. Literatura de viajes y transculturación (Quilmes, Universidad Nacional de Quilmes), donde la autora analiza la tradición de crónicas y relatos de viaje y conquista escritos por los europeos y sus descendientes americanos, destacando la relación de dominio implicada entre observante y observado.

${ }^{536}$ Díaz Quiñones, Arcadio (2000). "El 98: la guerra simbólica”, en: El arte de bregar, ed. cit., pp. 210-248.

${ }^{537}$ Said, Edward (1996). Cultura e imperialismo, Barcelona, Editorial Anagrama.

${ }^{538}$ Véase el siguiente pasaje de Puertorriqueños, donde el cronista plantea la exégesis de una foto proveniente del archivo imperialista: "Detrás de unas banderas americanas colocadas como crespones emblemáticos de la nueva sociedad, un grupo de mujeres posa para la cámara. (Nuestra nueva imagen nos resulta tan insólita que parecemos objetos de una manía turísticaantropológica, actitud imitada de la pasión yanqui por fijarnos en la química de Eastman Kodak. Somos algo así como seudoturistas en nuestra propia tierra. Ya en 1899 se publica una recopilación de fotos hecha por las fuerzas invasoras. Su título -Our Islands and their Peopleevidencia la concepción territorial del bisoño imperio, también ese afán antropológico de la cultura anglosajona)”. Rodríguez Juliá, Edgardo (1992). Puertorriqueños, ed. cit., p. 20. 
la Isla de Puerto Rico en el año $1797^{539}$, pone en escena la mirada sobre el otro que construye el viajero, a partir de su definición eurocéntrica de la "identidad moral" del puertorriqueño como producto directo del clima tropical. El segundo epígrafe, tomado del "Diario Secreto" del obispo Don José de Tres Palacios y Verdeja, importante personaje que hace las veces de cronista en la novela La noche oscura del Niño Avilés ${ }^{540}$, reflexiona sobre la "imperfección" del recuerdo y la implacabilidad de la muerte, apelando a la complicidad de un lector que reconozca el carácter apócrifo de tal "diario secreto". Puertorriqueños se constituye en la intersección y contrapunto que proponen los dos epígrafes: el archivo (histórico, fotográfico, documental, social y también privado) y la imaginación novelesca, a través de la combinación de diversas modalidades genéricas: crónica, relato, historia, ensayo, álbum fotográfico, autobiografía, novela.

El tópico que atraviesa el entramado de Puertorriqueños -la paulatina transformación y crisis de la familia a partir del 98- se emblematiza en el "álbum de fotos", objeto de numerosas reflexiones por parte del narrador. El cronista postula a la fotografía, al modo barthesiano, como imagen connotativa que, a pesar de su carácter de "reproducción analógica de la realidad"541, adquiere múltiples significaciones a través de procedimientos (el enmarcado, la pose, los vestidos, los objetos, la selección, el encuadre, la compaginación, el trucaje, la sintaxis), que permiten leer la foto como texto. Según Barthes en la fotografía hay un mensaje analógico, denotado, sin código, sobre el cual se sobreimprime otro mensaje, codificado, connotado. La connotación codifica lo analógico fotográfico imponiéndole un sentido secundario, histórico y cultural. A partir de este sentido secundario que trasciende la concepción de la fotografía como análogon de lo real, posibilitando entonces pensar las fotos como textos sobre los cuales rigen reglas de producción y de lectura, Rodríguez Juliá

\footnotetext{
${ }^{539}$ Ledrú, André Pierre (1971). Viaje a la Isla de Puerto Rico en el año 1797, San Juan, Editorial Coquí, 5ta. edición. El epígrafe es el siguiente: "A estas causas físicas y propias del clima de la isla, hay que agregar las accidentales y morales. La falta de ejercicio, el inmoderado uso de licores y bebidas cálidas, los desvelos, las pasiones del amor llevadas a último grado, todo revela la efervescencia que produce en la sangre el calor."

${ }^{540} \mathrm{El}$ análisis de esta novela se aborda en el próximo capítulo.

${ }^{541}$ Barthes, Roland (1977). "El mensaje fotográfico", en El análisis estructural, introducción y selección de Silvia Niccolini, Buenos Aires, CEAL, pp. 103-116.
} 
propone en su crónica-álbum una correlación entre la imagen fotográfica y el relato, entre la labor del fotógrafo y la del cronista:

"De este modo el arte de la fotografía también es narración, ya que es el enlace feliz de la ocasión única y privilegiada convertida en recuerdo y la época transformada en nostalgia. En el Álbum de Familia el fotógrafo es un cronista que usa el espacio pictórico para narrar. El modo de la familia en el tiempo se mueve entre esos dos polos, el recuerdo y la nostalgia."

El cronista construye historias en torno a las fotografías, verbalizando las imágenes, hiperconnotando las fotografías e incluso, por momentos, produciendo sentidos enteramente nuevos, que se proyectan retrospectivamente sobre las imágenes. Los lectores tenemos entonces que volver la página para ubicar y mirar nuevamente la fotografía que dispara la historia. Otras veces, el texto reemplaza directamente la fotografía, "ilustrada" con la minuciosa descripción de alguna foto que no ha ingresado al álbum, o bien vuelve visible a través de la palabra el campo ciego de la imagen, arrastrando al lector/espectador fuera del marco estricto de la fotografía.

La reunión de lo pictórico y lo fotográfico se subraya a lo largo del libro, sobre todo a través de la incorporación preferida de retratos por sobre otro tipo de representaciones:

"La fotografía exige la pose antes asumida por el retrato. En el reverso del nuevo medio aparece la nostalgia del retrato al óleo. Se pretende usar la cámara fotográfica sólo como un instrumento mecánico para conseguir una semblanza superior a la que procuraba el ojo del retratista. Así nace la fotografía como negación y a la vez como imitación del retrato. $" 543$

Pero además el retrato se concibe estrechamente vinculado al discurso autobiográfico en tanto que construcción narrativa, incluso con su peculiar imperativo documental según lo caracteriza Sylvia Molloy. ${ }^{544}$ La pose del fotografiado dice sobre sí mismo y también sobre su clase social, sus ritos y costumbres, su tiempo, su espacio: "La pose es un decir autobiográfico desde

\footnotetext{
${ }^{542}$ Rodríguez Juliá, Edgardo (1992). Puertorriqueños, ed. cit., p. 78 (el subrayado es mío).

${ }^{543}$ Rodríguez Juliá, Edgardo (1992). Puertorriqueños, ed. cit., p. 15.

${ }^{544}$ Molloy, Sylvia (1996). Acto de presencia, ed. cit., p. 18.
} 
las condiciones de clase. ${ }^{" 545}$ Nelson Schapochnik ${ }^{546}$, en su riguroso estudio sobre el álbum familiar, las postales y los íconos de intimidad, constata en el álbum de familia el predominio de esta particular modalidad de registro fotográfico: el retrato como vera efigie. Los retratos de un determinado período permiten pensar acerca de lo cotidiano, la sociabilidad, los ritos de pasaje e imbricaciones entre la esfera privada y la esfera pública. Asimismo en la historia de la fotografía se suele señalar que en sus comienzos la principal actividad de la práctica fotográfica fue el retrato y los primeros retratistas siguieron el modelo pictórico. Walter Benjamín concibe a la fotografía como una producción no aurática, sin embargo le concede al retrato fotográfico lo que denomina "valor de culto", es decir, una imagen producida en relación a cierto ritual, religioso o secular:

"En la fotografía, el valor exhibitivo comienza a reprimir en toda la línea al valor cultual. Pero éste no cede sin resistencia. Ocupa una última trinchera que es el rostro humano. En modo alguno es casual que en los albores de la fotografía el retrato ocupe un puesto central. El valor cultual de la imagen tiene su último refugio en el culto al recuerdo de los seres queridos, lejanos o desaparecidos. En las primeras fotografías vibra por vez postrera el aura en la expresión fugaz de una cara humana." 547

Puertorriqueños comienza con una reflexión del cronista acerca de la memoria a través de dos acciones que se aproximan entre sí pero que entrañan significaciones diferentes, el recuerdo y la nostalgia:

"La nostalgia es un modo de recuperación que no se consuela con el recuerdo. El recuerdo convierte el pasado en objeto; la nostalgia pretende rescatar apasionadamente para el presente el aroma de lo ya vivido. La fotografía es, de este modo, un medio necesario para abandonarse a la nostalgia, para intentar esa recuperación imposible. ${ }^{548}$

Si el recuerdo implica el riesgo de reificar o museificar el pasado, la nostalgia apela a estrechar los vínculos entre ese pasado y el presente. Se

\footnotetext{
${ }^{545}$ Rodríguez Juliá, Edgardo (1992). Puertorriqueños, ed. cit., p. 15.

${ }^{546}$ Schapochnik, Nelson (1998). "Cartòes-postais, álbuns de familia e ícones da intimidade”, ed. cit., p. 463.

${ }^{547}$ Benjamín, Walter (1989). "La obra de arte en la época de la reproductibilidad técnica", en: Discursos interrumpidos I, ed. cit., p. 31.

${ }^{548}$ Rodríguez Juliá, Edgardo (1992). Puertorriqueños, ed. cit., p. 11. (cursivas del autor)
} 
postula entonces a la fotografía como invitación y medio para sumergir al sujeto en una suerte de memoria compartida, donde la nostalgia no impida el examen crítico del presente: "El pasado que se intenta recuperar a través de fotos y tarjetas postales -iconografía de una convivencia- será sometido simultáneamente a la burla y la compasión."549 A su vez, la insistencia del cronista en la paradójica "recuperación imposible" de la nostalgia como "aroma de lo ya vivido", se aproxima a las reflexiones de Roland Barthes en su ensayo La cámara lúcida. Notas sobre la fotografía, cuando observa que: "Lo que la Fotografía reproduce al infinito únicamente ha tenido lugar una sola vez: la Fotografía repite mecánicamente lo que nunca más podrá repetirse existencialmente." 550 Por eso los retratos fotográficos son el espacio privilegiado que muestra la relación entre sujeto, imagen y tiempo, como fragmento de la vida de un individuo sustraído al tiempo, lo cual implica a su vez una relación velada con la muerte, como apunta Benjamín cuando destaca el valor cultual de la imagen como último refugio de los que ya no están. También Barthes reflexiona sobre el carácter ominoso de la fotografía cuando percibe en ella "el retorno de lo muerto". 551

Numerosos pasajes del Álbum se detienen en la indagación acerca de la relación entre fotografía, temporalidad y muerte, por ejemplo en el texto XI, titulado "Los nenes". Las fotografías de la infancia, propias y ajenas, no concitan la ternura sino la compasión, especialmente la autocompasión de un sujeto que al observarse a sí mismo en la imagen fotográfica, como un fragmento detenido del tiempo, reconoce que sólo es posible separar una porción de algo medible, la propia vida: "Es terrible que las fotos de los niños sean las que más hablan sobre la rabia del tiempo"; también: "La fotografía nos invita a ser testigos de un testimonio donde el tiempo desgarra el espacio más cercano, la proximidad más entrañable." ${ }^{252}$ En este sentido la siguiente cita de la crónica subraya la relación compleja entre fotografía, tiempo, memoria, discontinuidad y pérdida, cuando el cronista narra la perplejidad que le produce observarse a sí mismo en una fotografía sobre la cual no alcanza a recordar

\footnotetext{
${ }^{549}$ Ibid., p. 11.

${ }^{550}$ Barthes, Roland (1998). La cámara lúcida. Notas sobre la fotografía, ed. cit., p. 31.

${ }^{551}$ Ibid., p. 39.

${ }^{552}$ Rodríguez Juliá, Edgardo (1992). Puertorriqueños (Álbum de la Sagrada Familia puertorriqueña a partir de 1898), ed. cit., pp. 84 y 85 respectivamente.
} 
cuándo ni dónde fue tomada, circunstancia que produce un efecto de extrañamiento del sujeto respecto de sí mismo, como afirma Barthes cuando apunta que la fotografía es el "advenimiento de yo mismo como otro: una disociación ladina de la conciencia de identidad”553.

"Me enfrento a esa foto con una perplejidad irredenta. No recuerdo nada de ese día, pero ahí estoy. Pertenezco al retrato como si fuera personaje de una obra de ficción. Mi memoria no alcanza nada, ni siquiera tropiezo con esa ruina benévola. Se trata de algo que fue, que existió, y ahora sólo recupero como una substancia no sólo vencida por el tiempo, sino también ya por siempre muerta en mi memoria. He sido retratado, luego soy... Pero precisamente ahí está la falacia: Nada de lo que está ahí permanece hoy; la luz reflejada en mi cuerpo y el de mi hermano Chiqui, capturada en la sensible filmilla Kodak, alumbra implacablemente los recuerdos. Se trata de una guiñada cruel, de una trompetilla del tiempo, de una burla que no se compadece de la carne." 554

Si bien en Puertorriqueños se advierte una profusión de zonas textuales donde se insiste en la nostalgia y el paso irremediable del tiempo, subrayándose el sentido de la pérdida en tanto la foto preserva el vestigio de lo desaparecido: los niños que dejaron de serlo, las parejas perdidas, los soldados muertos, los emigrados que no pudieron retornar a la tierra natal, los barrios transformados en "buildings" y urbanizaciones como marcas indelebles del desarrollismo populista, se hallan presentes también otras posibilidades en torno a la imagen fotográfica. El álbum fotográfico que construye el cronista participa asimismo del carácter social que Pierre Bourdieu ${ }^{55}$ le asigna a la fotografía, en la medida en que forma parte de las redes simbólicas de una época, de una clase o de un grupo artístico: “¿Qué es un álbum familiar? El álbum de familia es una manía pequeño burguesa." ${ }^{256}$, se pregunta y responde el cronista en las páginas iniciales de su crónica-álbum. De allí que algunos retratos que se constituyen como registros de la vida privada sean vistos a su

\footnotetext{
${ }^{553}$ Barthes, Roland (1998). La cámara lúcida. Notas sobre la fotografía, ed. cit., p. 44.

${ }^{554}$ Rodríguez Juliá, Edgardo (1992). Puertorriqueños (Álbum de la Sagrada Familia puertorriqueña a partir de 1898), ed. cit., pp. 129-130.

${ }_{555}$ Bourdieu, Pierre (1978). Un art moyen -essai sur les usages sociaux de la photographie, París, Minuit. Véanse también, aunque con mayor hincapié en las relaciones entre fotografía e historia: Freund, Gisèle (1976). La fotografía como documento social, Barcelona, Gustavo Gili y Kossoy, Boris (2001). Fotografía e historia, Buenos Aires, La Marca, Biblioteca de la mirada. ${ }_{556}$ Rodríguez Juliá, Edgardo (1992). Puertorriqueños, ed. cit., p. 12.
} 
vez como parámetros de sociabilidad, por ejemplo aquellos vinculados a ritos sociales: la fiesta de los quince años, la foto de casamiento, el retrato de promoción escolar o universitaria. Pero a diferencia de la concepción de Susan Sontag sobre el álbum familiar como objeto que atestigua la solidez de los lazos familiares, la lectura de las fotos que lleva a cabo el cronista subraya más bien la idea de una separación inevitable: "El retrato de bodas siempre insinúa la embarazosa aceptación de esa fragilidad oculta en un compromiso casi imposible. Ese para toda la vida es algo así como la utopía de la vida sentimental."

Si se piensa con Schapochnik al álbum de familia como una crónica urdida en base a infinitas lagunas, la propuesta de Puertorriqueños sugiere volver visibles aquellas zonas oscuras que han quedado al margen del álbum: "Mientras tanto, esa luz que se cuela por las celosías no da tregua, se añeja más y más con los años infelices que nunca testimonió el álbum." ${ }^{" 558}$ La iconoteca familiar y doméstica amplía sus marcos para dar cabida a significativas ausencias del discurso histórico puertorriqueño: los primeros años de la dominación norteamericana, el creciente protagonismo social de las mujeres, los sectores negros descendientes de esclavos, los emigrados puertorriqueños en los Estados Unidos, los campesinos desplazados a la ciudad. El álbum fotográfico de Rodríguez Juliá dialoga e incorpora fotos de un libro pionero en la investigación testimonial sobre la Guerra Hispanoamericana y sus efectos en Puerto Rico, la Crónica de la Guerra Hispanoamericana en Puerto Rico (1922) de Ángel Rivero. ${ }^{559}$ De allí está tomada, por ejemplo, la foto de Martín Cepeda, descendiente de esclavos, quien perdió su brazo en la Guerra del 98:

"¿Qué hace ese negro manco en el Álbum de Familia? ¿Por qué aparece ahí? ¿De quién es ese abuelo mandinga? Se trata de esa foto que nos perturba por desconocer la identidad del retratado, por no querer reconocer la contundencia de la raja. Aparte de que es el abuelo negro de todos nosotros, Martín aparece como un intruso en la complacencia sentimental pequeño burguesa. Nos mira perplejo ante la curiosidad que su brazo perdido veintidós años antes provoca en

\footnotetext{
${ }_{557}^{550}$ Rodríguez Juliá, Edgardo (1992). Puertorriqueños, ed. cit., p. 73.

${ }^{558}$ Ibid., p. 73.

${ }^{559}$ Rivero, Ángel (1972). Crónica de la Guerra Hispanoamericana en Puerto Rico, San Juan, Instituto de Cultura Puertorriqueña.
} 
nosotros. Martín Cepeda es entonces restituido a la familia puertorriqueña (...)." 560

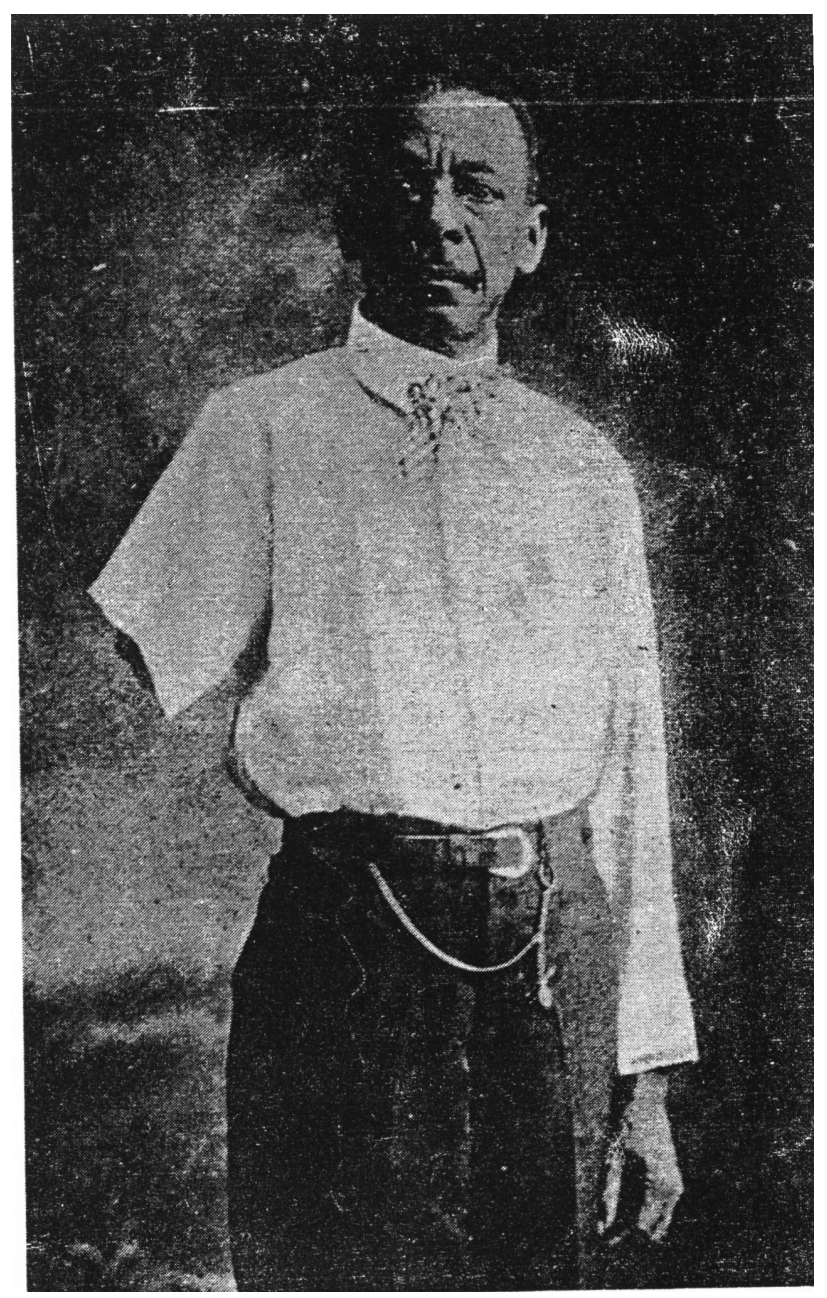

Martín Cepeda

La inclusión de Martín en el álbum manifiesta explícitamente el deseo de romper la homogeneidad étnica de la metáfora familiar. La incorporación de la foto de un descendiente de esclavos se realiza inmediatamente después de un pasaje donde el narrador ha caracterizado a su abuelo paterno como "artesano,

${ }^{560}$ Rodríguez Juliá, Edgardo (1992). Puertorriqueños, ed. cit., p. 28 (cursivas del autor). 
mulato, maestro de obras, republicano y masón"561. Martín entonces, como el suyo propio, "es el abuelo negro de todos nosotros", es decir, es la herencia africana, con su ignominiosa historia esclavista, que el cronista asume como un desafío ante el prejuicio racial en Puerto Rico, como así también ante los discursos historiográficos que se niegan a aceptar el peso real del esclavismo en el país. A su vez Cepeda, quien peleó contra los yanquis en la Guerra Hispanoamericana, convirtiéndose en figura de la resistencia contra el imperialismo, se enlaza con el presente. Su apellido convoca para el narrador la filiación con la música popular del barrio proletario y negro de Cangrejos, cultura atravesada por una cimarronería"562 característica: "su apellido lo concibo ineludiblemente unido a Cataño o a los Cepedas cangrejeros de la bomba." $" 563$

La fotografía posibilita también la rearticulación de la identidad asediada por la fragilidad y precariedad que entraña la situación del emigrado: "El retrato se transforma en cédula de identidad ante la extrañeza, en detente que reafirma la identidad ante lo ajeno. La foto dirigida a la familia traza la ruta de esa identidad: La familia nos cobija ante lo extraño." ${ }^{564}$ En este sentido resultan muy significativos tanto los pasajes textuales como los fotos que dan cuenta de la emigración, especialmente a la ciudad de Nueva York, en los cuales el cronista se detiene en los rituales de religación con el espacio natal, mediante las fotografías que los emigrados envían a las familias que permanecen en el país. En esas imágenes el narrador, en su rol de observador, focaliza en pequeños detalles que muestran de alguna manera el deseo de triunfo en la tierra ajena que los retratados intentan proyectar en las fotos, deseo no exento de una melancólica fragilidad. Allí aparecen emblemas de la gran urbe que marcan notables diferencias con el paisaje isleño, ya que la mayoría de las fotos se sacan en las azoteas de los altos edificios, en las bocas de los subterráneos 0 en las bombas de incendios, lugares preferidos por los emigrantes puertorriqueños para constatar su presencia en el Norte:

\footnotetext{
${ }^{561}$ Rodríguez Juliá, Edgardo (1992). Puertorriqueños, ed. cit., p. 25.

${ }^{562}$ Véanse en el primer apartado de este capítulo las consideraciones sobre la plena y la bomba y los importantes aportes de Ángel Quintero Rivera sobre esta cuestión.

${ }^{563}$ Rodríguez Juliá, Edgardo (1992). Puertorriqueños, ed. cit., p. 25.

${ }^{564}$ Ibid., p. 104 (cursivas del autor).
} 
"Las bocas del subway, lo mismo que las azoteas, son esos sitios inequívocos que confirman el arribo a la extrañeza. Así se doma el espacio ajeno, estableciendo la estadía en lo que no hay allá; la boca del subway está tan lejos de Caparra Terrace que sólo hay consuelo en posar para la parentela de Puertorro. El acá y el allá se conjugan en un detente que es a la vez cédula de identidad y visa de estadía. La foto se convierte en el documento del estar y el ser. ${ }^{, 565}$

Las fotografías elegidas para figurar en el texto XXI "Nueva York y otras sonrisas", reiteran el espacio abierto de las azoteas, donde "el emigrante puertorriqueño escapa a la claustrofobia del building." sonrisas de los retratados, el cronista lee las huellas de la experiencia dolorosa del migrante, su soledad, sus temores, su crisis de identidad: "Hay algo que tiene la azotea... Ahí evitamos esas miradas indiscretas que reconocen nuestra extranjería. En la calle seríamos reducidos al papel de extraños, o, peor aún, de turistas permanentes. ${ }^{567}$ Pero el narrador no solo interpreta aquello que la foto manifiesta sino que su mirada traza un recorrido imaginario desde el exterior de la azotea al interior de un departamento habitado por un emigrado puertorriqueño, para registrar allí una estrategia de reterritorialización capaz de conjurar el desarraigo:

"En el building de al lado ese otro fantaseoso se ha construido allá cerca del último rincón del apartment, al lado de la cocina- un jardín tropical en miniatura: su colección de plantas caribeñas quizás sea la obsesión arcádica del regreso; la nostalgia se confunde con los clisés turísticos. ${ }^{2568}$

Señala Gastón Bachelard que los rincones son refugios que le permiten al sujeto replegarse sobre sí, "espacios de la inmovilidad" que se convierten en "espacios del ser" $"$ "Si lo que caracteriza al sujeto migrante es su desplazamiento, un angustiante sentimiento de desarraigo, una disociación entre el aquí-ahora y el entonces-allá, una experiencia de la transitoriedad y de la transitividad en la cual, con palabras de Abril Trigo, "la promesa del regreso a

\footnotetext{
${ }^{565}$ Rodríguez Juliá, Edgardo (1992). Puertorriqueños, ed. cit., p. 153.

${ }^{566}$ Ibid.,p. 151.

${ }^{567}$ Ibid., p. 153

${ }^{568}$ Ibid., p. 154

${ }^{569}$ Bachelard, Gastón (1992). La poética del espacio, Buenos Aires, FCE, $3^{\text {a }}$. edición, p. 172.
} 
casa se vuelve imposible, ante la progresiva certidumbre de que la migración es tan solo un viaje de ida" ${ }^{570}$, el rincón-jardín tropical de la cita precedente constituye un "espacio del ser" que vuelve del algún modo habitable la distopía del presente del emigrado.

Puertorriqueños registra con especial énfasis ciertos momentos de la historia del país, siempre en relación con un sector social, la clase media ${ }^{571}$ : los inicios de la ocupación norteamericana; las décadas del veinte y del treinta; los años de la Segunda Guerra Mundial, subrayando sobre todo la década del cincuenta, como los años atravesados por la "utopía propuesta por el desarrollismo muñocista". 572 Esa década remite a la infancia del cronista y es la que permite articular la historia personal con la historia colectiva, donde la biografía se manifiesta como un discurso mediador entre el yo y el nosotros puertorriqueños, como puede advertirse en el uso de las desinencias verbales y pronombres que remiten a la primera persona del plural:

"Por aquella época también nos arropó ese paisaje urbano que amenaza con transformarnos en suburbio de Orlando Florida: Llegaron los Tastee Freez y los centros comerciales, de los ollejos y el tabaco hilao pasamos a la fiebre de las boleras y las visitas al Drive Inn los sábados por la noche. Las urbanizaciones establecían soberanamente su presencia definitoria." 573

La década del cincuenta aparece en el álbum de Puertorriqueños irónicamente descripta bajo el lema de la "La Pax Muñocista", título del texto XIX. El cronista se detiene en detalles pequeños, casi nimios pero muy reveladores, como la imagen del sello conmemorativo del Estado Libre Asociado donde aparece la figura del jíbaro junto a la rueda que alegoriza el

\footnotetext{
${ }^{570}$ Trigo, Abril (2003). "Migraciones", en: Memorias migrantes. Testimonios y ensayos sobre la diáspora uruguaya, Rosario, Beatriz Viterbo, pp. 37-62.

${ }^{571}$ En Puertorriqueños no aparece un muy importante sector del país: la clase obrera, sino que, como antes aclaré, la perspectiva que adopta el cronista proviene de su inserción en la clase media. Sin embargo, como se verá más adelante, se destacan los aportes fundamentales de la cultura popular. Sobre la cuestión de las luchas obreras en Puerto Rico véase Quintero Rivera, Ángel G. (1972). Lucha obrera: Antología de grandes documentos en la historia obrera puertorriqueña, Río Piedras, CEREP y también del mismo autor (1988). Patricios y plebeyos: burgueses, hacendados, artesanos y obreros. Las relaciones de clase en el Puerto Rico de cambio de siglo, Río Piedras, Ediciones Huracán.

${ }^{572}$ Rodríguez Juliá, Edgardo (1992). Puertorriqueños, ed. cit., p. 134.

${ }^{573}$ Ibid., p. 160 (cursivas del autor).
} 
progreso. Varios pasajes del álbum-crónica dan cuenta del desplazamiento y exclusión sufridos por el sector campesino jíbaro como consecuencia de las políticas desarrollistas, como la historia de Don Julio narrada en el texto XX, obligado a mal vender su parcela de tierra ante el avance de las urbanizaciones. De hecho Puertorriqueños, que se abre con un pasaje muy breve a modo de presentación denominado "Acercamientos", se inicia más bien con el segundo texto, "Collages y salas campesinas". Allí el cronista propone una reflexión sobre el álbum de familia a partir de una fotografía que da cuenta del interior de una vivienda rural, donde coexisten emblemas y elementos de un pasado jíbaro junto con objetos inútiles característicos de la modernización desarrollista. Si el álbum es "una manía pequeño burguesa", ¿dónde plasma entonces el jíbaro su mundo familiar? No en las hojas acartonadas de un libro, sino en la pared de madera de su casilla, más precisamente en la sala, espacio principal de su hogar. El cronista lector de imágenes interpreta aquellas que atiborran la desvencijada pared, convertida en una suerte de retablo de íconos diversos:

"De este modo, en esa pequeña sala campesina el retrato de un soldado que un día salió para Corea a defender la democracia se coloca al lado de un cromo de almanaque del Papa Juan XXIII. La democracia americana convive con el pietismo católico. ¿Por dónde anda ese recorte de periódico con la imagen de un Kennedy de mirada soñadora? El chaparro Papa campesino y el católico irlandés demócrata amigo de Muñoz Marín, jese cruce de todos los populismos imaginables!"574

El almanaque de una ferretería, un Sagrado Corazón, la estampa de Cristo, una santita de yeso en una hornacina de madera, un quinqué, una radio rota, un televisor sin tubo para guardar el maíz de las gallinas, la fotografía del nieto emigrado a Nueva York, un retrato del gobernador de Puerto Rico Hernández Colón ${ }^{575}$, enumeración, catálogo que permite leer una información denotada, que da cuenta a partir de la relación entre objetos y personas de un sector social finalmente desplazado por la misma política populista que lo ensalzara. Para el narrador la foto de la salita campesina se desplaza

\footnotetext{
${ }_{574}^{575}$ Rodríguez Juliá, Edgardo (1992). Puertorriqueños, ed. cit., pp. 12-13.

${ }^{575}$ Rafael Hernández Colón fue gobernador de Puerto Rico entre 1972 y 1976, y luego por dos períodos consecutivos entre 1984 y 1992, representando al PPD (Partido Popular Democrático).
} 
metonímicamente hasta alcanzar un sector más vasto, al cual caracteriza como "la nueva pobreza": "La nueva pobreza se traga ese desarrollismo inerme ante la vigencia del pasado en que todo funcionaba a fuerza de ser elemental." ${ }^{576}$

En otro pasaje interesante del álbum-crónica el narrador rescata una figura de su pasado familiar, a partir de la cual rastrea sus propios orígenes como escritor, ligados a la actividad literaria de su tío abuelo, Don Ramón Juliá Marín. Discípulo de Zeno Gandía, se lo recupera del olvido a través de las palabras autorizadas de otro novelista consagrado, Enrique Laguerre ${ }^{577}$ :

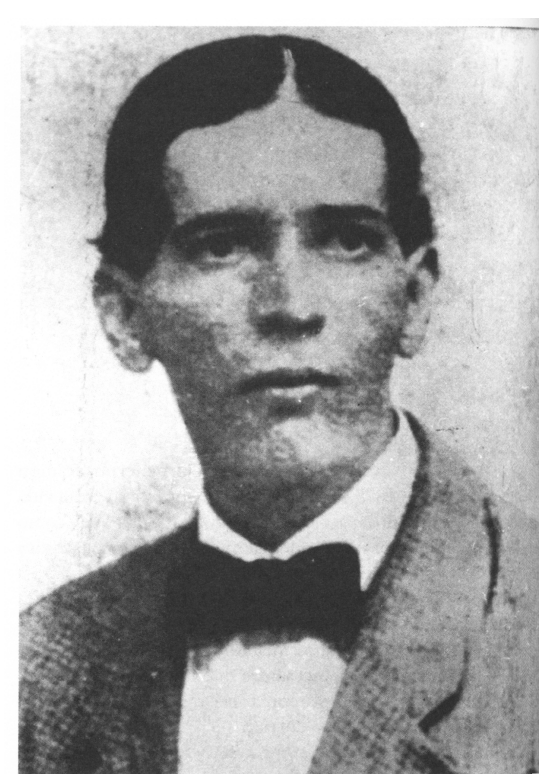

"Ramón Juliá Marín, autor de Tierra adentro y La Gleba, es un joven cautivado por el periodismo y la literatura, fiel cronista de una época volcada en la confusión y sacudida por el cambio. De él nos dice Enrique Laguerre en un artículo escrito en el año 1940 para la revista Isla: 'Tiempo es ya de que se le rescate del olvido y que se le estudie con cariño, porque nadie como él supo recoger el latir de esa época tan significativamente en nuestra historia de pueblo: 1898-1907: transición, inestabilidad, inseguridad'", ${ }^{578}$

La cita es reveladora en diversos aspectos. Muestra la constitución de la subjetividad del escritor, quien, en el retrato del otro, proyecta una idea de sí mismo, de lo que es la literatura, a la vez que involucra una estética y una ética de la escritura. El tío abuelo fue escritor y periodista- actividades compartidas

\footnotetext{
${ }^{576}$ Rodríguez Juliá, Edgardo (1992). Puertorriqueños, ed. cit., p. 14.

${ }^{577}$ Enrique Laguerre fue uno de los narradores más representativos del "jibarismo literario" de la década del cuarenta. Entre sus obras se destacan las novelas La llamarada, Solar Montoya y La resaca. El sentido que destaco en la frase "palabras autorizadas" implica el importante posicionamiento de Enrique Laguerre en el campo intelectual de las letras puertorriqueñas en la década del cuarenta. La estrategia de Rodríguez Juliá al incorporar un juicio de valor emitido por el propio Laguerre sobre su antepasado Ramón Juliá Marín remite a la cita de autoridad y funciona por lo tanto como una operación de legitimación.

${ }^{578}$ Rodríguez Juliá, Edgardo (1992). Puertorriqueños, ed. cit., pp. 31-32.
} 
con el autor-, y también "cronista" de una época conflictiva ${ }^{579}$. El narrador se escribe a sí mismo en ese otro yo condensado en la figura del tío escritor; se inscribe en una genealogía literaria que legitima otro autor, Enrique Laguerre, y opera en el presente, como lo hiciera en su tiempo su antepasado, con ojo "implacable y certero cuando destaca las contradicciones de una sociedad en proceso de transformación." 580

En la lectura de Puertorriqueños que propone Áurea María Sotomayor se subraya especialmente cómo el cronista registra las contradicciones de su sociedad, que se manifiestan en la erosión de una de sus principales entidades sociales, la familia: "Puertorriqueños es la tercera crónica mortuoria de nuestro autor; el cadáver que se expone aquí es el de la familia." ${ }^{251}$ Numerosos pasajes del texto abonan esta lectura, y en este sentido me interesó destacar las relaciones entre fotografía y muerte, temporalidad, nostalgia y recuerdo. Sin embargo el álbum-crónica de Edgardo Rodríguez Juliá muestra también el reverso de sus visos fúnebres. Si los lazos de sociabilidad ya no son posibles de encarnar en la metáfora familiar, parecen anudarse en las ricas y variadas manifestaciones de la cultura popular, sobre todo en el plano de la música, como se advierte en las consideraciones del cronista sobre la plena: "La plena va al acontecimiento concreto, al detalle feliz, ni melindres amorosos ni quejas ancestrales, se trata aquí de contar el suceso de ayer o de hoy, de convertir la música popular en crónica."

Entonces la música popular también puede postularse como crónica que posibilita el ingreso al álbum de otros sectores sociales, aunque sus rostros no hayan sido retratados por la cámara fotográfica. Así, en el capítulo $\mathrm{V}$, se relatan

\footnotetext{
${ }^{579}$ Rodríguez Juliá retoma los paralelismos con la figura de su tío abuelo escritor en "Cronistas", donde leemos, por ejemplo: "Mi tío abuelo materno, Ramón Juliá Marín, nació en 1878 y murió en 1917. Durante su corta vida intentó, como yo, ser novelista en una colonia caribeña. A él, como a mí, le tocaron tiempos de grandes cambios. A él le tocó la época de la invasión norteamericana y el cambio a la soberanía U.S.A., a mí me tocó el vendaval del panfletero de Dios y la época de un pretendido pacto de soberanía con U.S.A. Aparte de las confusiones nominales y las altisonantes metáforas, quedan las transformaciones, las metamorfosis incesantes que mortifican la memoria. Ambos hemos querido testimoniar el cambio, cómo nos cambió la crisis de los tiempos que corrían." Véase Rodríguez Juliá, Edgardo (2002). "Cronistas", en Caribeños, ed. cit., p. 185.

580 Rodríguez Juliá, Edgardo (1992). Puertorriqueños (Álbum de la Sagrada Familia puertorriqueña a partir de 1898), ed. cit., p. 33.

${ }_{582}^{581}$ Sotomayor, Áurea María (1992). "Escribir la mirada”, ed. cit., p. 152.

582 Rodríguez Juliá, Edgardo (1992). Puertorriqueños (Álbum de la Sagrada Familia puertorriqueña a partir de 1898), ed. cit., p. 36 (el subrayado es mío).
} 
los comienzos de la plena a principios del siglo $X X$ como un tipo de composición musical estrechamente ligada a los sectores negros, mulatos y proletarios del país: "Es nuestra primera música proletaria, ocupada de la concreción de un mundo nuevo que es necesario describir y narrar." ${ }^{583}$ La plena es también testigo de los primeros movimientos emigratorios a los Estados Unidos, como se advierte en las referencias a las memorias del tabaquero Bernardo Vega. Asimismo el relato de la emancipación femenina, su inserción en el mundo del trabajo, el quebrantamiento de los mandatos patriarcales y el desafío al machismo puertorriqueño proviene de las mujeres de la clase media baja. Sus historias se plasman en las canciones de Sylvia Rexach ${ }^{584}$, fundadora del primer conjunto musical femenino en Puerto Rico, quien en la década de 1940 es, según la descripción que nos brinda el cronista, la que "mejor expresa en la cultura popular los amores, las frustraciones, la soledad de unas mujeres que van transformando el estereotipo femenino, que se atreven a romper con normas hasta entonces inviolables." ${ }^{~ 585}$ La figura del cantante Daniel Santos ${ }^{586}$, cuya voz popularizó las composiciones del gran bolerista puertorriqueño Pedro Flores, atravesadas por temas tales como el desplazamiento, la separación, la ausencia, le otorga un lugar privilegiado a las problemáticas en torno a la emigración. Ellas desgranan la historia menuda de la educación sentimental ${ }^{587}$ de toda una generación que el cronista retrata en el

\footnotetext{
${ }^{583}$ Rodríguez Juliá, Edgardo (1992). Puertorriqueños, ed. cit., p. 36.

${ }^{584}$ Sylvia Rexach (1922-1961) fue una muy importante cantante y compositora puertorriqueña, creadora y líder del conjunto musical "Las Damiselas", integrado exclusivamente por mujeres, con el cual recorrió la Isla. Entre sus canciones más conocidas figuran "Olas y arena", "Idilio", "Alma adentro", "Nave sin rumbo", "Había una vez".

${ }^{585}$ Rodríguez Juliá, Edgardo (1992). Puertorriqueños, ed. cit., p. 61. El cronista sugiere un paralelismo entre el circuito culto y el popular, al comparar el erotismo de algunas composiciones de Sylvia Rexach con poemas de Julia de Burgos, la escritora puertorriqueña más importante de los años cuarenta.

${ }^{586}$ Daniel Santos (1916-1992) emigró con su familia a Nueva York. Descubierto por el maestro Pedro Flores se convirtió en uno de los cantantes de bolero más importantes de América Latina. En 1941 se alistó en la armada de los Estados Unidos. Destinado en Hawai, donde pasó la guerra, compuso allí algunos de sus temas famosos, como Adiós a los Muchachos y El regreso. En 1946, en Cuba, invitado a un programa radial que siempre comenzaba con el tema musical "Anacobero", Daniel Santos fue presentado como "El Anacobero", al cual luego se le añadió el adjetivo "inquieto" para dar cuenta de la agitada vida del músico. Con este sobrenombre se lo conoció en toda América Latina. Su vida y su música fueron transformados en textos por Salvador Garmendia, Josean Ramos y Luis Rafael Sánchez, en su imperdible novela La importancia de llamarse Daniel Santos, Hanover, Ediciones del Norte, 1988.

${ }^{587}$ Se puede pensar la propuesta de Rodríguez Juliá en torno a las relaciones entre la cultura y los grupos sociales a partir del concepto de "estructura de sentimiento" de Raymond Williams.
} 
texto XVIII, bajo el título "Jiras y Canciones, Tropicalismo y Placer". Asimismo Puertorriqueños alude, aunque no se detiene, en la oposición binaria que dividió a los jóvenes puertorriqueños en las décadas de 1970 y 1980 en cocolos y rockeros $^{588}$, es decir entre los partidarios de la salsa y los seguidores del rock: "Surge el teenager, la adolescencia se convierte en un mundo aparte, se va gestando entre los partidarios de Cortijo y Chubby Checker esa feroz dialéctica que culminará en las disputas de cocolos y rockeros."

El álbum-crónica abre así complejas redes que traman las relaciones dinámicas entre la sociedad y sus expresiones culturales, interrogando y respondiendo al dilema que atraviesa todas las crónicas analizadas hasta ahora: las posibilidades, también los límites de la construcción de una identidad colectiva puertorriqueña, que, como toda identidad resulta ser un artificio discursivo de efecto retroactivo. $\mathrm{Si}$, como sugiere metafóricamente Abril Trigo ${ }^{590}$, la identidad es una esfinge bifronte que no deja de interpelarnos, para Rodríguez Juliá una de sus formas posibles de articulación se plasmaría desde los sectores productores de la cultura popular del país, tanto de los que habitan la Isla como de aquellos que viven en la emigración, como se lee en los siguientes pasajes del texto:

"Es en la pequeña burguesía y las clases proletarias -abocadas como están a permanecer en el país si el desempleo no obliga a la emigración- donde se evidencian los perfiles de una cultura verdaderamente nacional. " / (La arqueología de la cultura popular puertorriqueña habría que hacerla en los niuyores y los coneticots. Valoraciones, modas, maneras y actitudes permanecen fosilizadas en un ambiente que se inclina a la conservación justo por la hostilidad que lo

Para Williams toda formación cultural se define en una distintiva comunidad de experiencias. Estructura de sentimiento es la cultura de un período determinado, pero en la forma en que esa cultura fue vivida por sus productores y su público, en experiencias que interrelacionan formas de pensamiento y de vida, donde no se trata de oponer el sentimiento al pensamiento sino considerar el pensamiento en tanto sentido y al sentimiento en tanto pensado. En Puertorriqueños, particularmente en el texto XVIII se percibe la música popular de las décadas del cuarenta y del cincuenta como estructuras de sentimiento. Véase Williams, Raymond (1977). The Long Revolution, Londres, Penguin.

588 Ángel Quintero Rivera señala que esta división identitaria dicotómica entre cocolos y rockeros se ideologizó entre la aceptación mimética de los procesos de homogeneización cultural global representados por el rock y la valoración de una identidad propia, caribeña, representada por la salsa. Véase del autor Salsa, sabor y control, ed. cit., p. 176.

${ }^{589}$ Rodríguez Juliá, Edgardo (1992). Puertorriqueños, ed. cit., p. 165.

${ }^{590}$ Trigo, Abril (2003). "Memorias", en: Memorias migrantes. Testimonios y ensayos sobre la diáspora uruguaya, ed.cit., pp. 77-102. 
rodea. Si quieren ver los dash repletos de talismanes familiares, vayan al Barrio y busquen algún taxista puertorro.) ${ }^{591}$

Retomando las sugerentes reflexiones de Trigo en torno al concepto de identidad, como "el inasible meollo de la cultura, el evasivo, viscoso y suntuoso entretejido de la libido y la política, lo práctico y lo simbólico, la necesidad y la contingencia" ${ }^{\text {"292 }}$, es evidente que como tal no ha dejado de interpelar y asediar una y otra vez a nuestro autor. Puertorriqueños dialoga con la cultura popular de Rafael Cortijo e Ismael "Maelo Rivera", también con el show de Iris Chacón. Las fotos del álbum, aquellas que inscriben en sus imágenes lo que el cronista registra como reafirmación del "sentimentalismo boricua" 593 estrechan sus vínculos con las fiestas patronales descriptas en Guánica; la violencia del caso Maravilla ilumina otros agresiones del pasado, todas ellas relacionadas con la intervención imperialista de los Estados Unidos a partir de 1898; las plañideras jíbaras del entierro de Muñoz Marín habitan la sala campesina de la fotografía que se describe con esmerado detalle casi al comienzo del álbum.

Las crónicas vistas hasta aquí fueron producidas y publicadas en la década del ochenta, años retratados como de grave crisis política en Puerto Rico, en los cuales parecen emerger con fuerza todas las contradicciones y paradojas de la política del estadolibrismo. "Años sombríos" como los describe Arcadio Díaz Quiñones, que atestiguan el colapso del "milagro económico" que había propiciado el desarrollismo, para subrayar más bien la realidad cotidiana del desempleo, el aumento de las desigualdades sociales y la pobreza:

"La incomunicación y el aislamiento de muchos puertorriqueños, la diáspora a que han sido forzados miles de trabajadores, la fragmentación de su conciencia histórica, las formas de alineación que comporta el vacío de un pasado devorado por la propaganda y la desinformación, todo ello hace necesario recuperar, aunque sea en líneas generales, los orígenes del colapso de los años sin nombre."594

\footnotetext{
${ }^{591}$ Rodríguez Juliá, Edgardo (1992). Puertorriqueños, ed. cit., pp. 43 y 139 respectivamente (cursivas y paréntesis del autor).

${ }^{592}$ Trigo, Abril (2003). "Memorias", en: Memorias migrantes. Testimonios y ensayos sobre la diáspora uruguaya, ed.cit., p. 77.

${ }^{593}$ Véase el texto XIII, "Cursilería nuestra de cada día”, Ibid., pp. 91-100.

${ }^{594}$ Díaz Quiñones, Arcadio (1993). “Los años sin nombre”, en: La memoria rota, ed. cit., p. 120.
} 
Años que las crónicas de Rodríguez Juliá nombran, recrean, reinventan, recuerdan, interpelan, con ironía pero también con profundo afecto y dolor, para hacernos visibles a los lectores su entrañable "pueblo puertorriqueño en su diversidad más contradictoria." ${ }^{395}$

${ }^{595}$ Rodríguez Juliá, Edgardo (1991). El entierro de Cortijo,ed. cit., p. 18. 


\section{Fábulas de la puertorriqueñidad: invenciones, versiones y visiones del siglo XVIII en La renuncia del héroe Baltasar, La noche oscura del Niño Avilés, El Camino de Yyaloide y Campeche o los diablejos de la melancolía de Edgardo Rodríguez Juliá}

"Digamos, sin eufemismos, que el siglo XVIII sigue siendo una gran laguna de nuestra historiografía. Las pocas noticias anchas que de él tenemos indican, por ahora, que no se alteró fundamentalmente en nada la gestación pausada y descolorida de la conciencia puertorriqueña."

Antonio S. Pedreira

"Decidí inventarme un Siglo XVIII que fuera como una pesadilla de la historia puertorriqueña. Las pesadillas también hablan de la realidad."

Juliá Edgardo Rodríguez

Publicada en 1974, La renuncia del héroe Baltasar ${ }^{596}$ es la primera novela de Edgardo Rodríguez Juliá. Marca, por lo tanto, su inicio como escritor, entendido desde la perspectiva crítica de Edward Said ${ }^{597}$ que postula el comienzo como el primer paso en la producción intencional de sentido que puede recorrer toda o parte de la obra de un autor y que entraña, en consecuencia, un proyecto subyacente. Desde este punto de vista la novela inicial de Rodríguez Juliá condensa una constelación de sentidos que el autor retoma, explora y profundiza en dos novelas posteriores - La noche oscura del Niño Avilés (1984) y El camino de Yyaloide (1994)- como así también en su notable ensayo Campeche o los diablejos de la melancolía (1986), sobre el pintor puertorriqueño de origen mulato José Campeche.

\footnotetext{
${ }^{596}$ Rodríguez Juliá, Edgardo (1986). La renuncia del héroe Baltasar, Río Piedras, Cultural. (Primera edición 1974, por Editorial Antillana)

${ }^{597}$ Said despliega la noción de comienzo y sus variaciones, como un momento en el tiempo, un lugar, un principio o una acción; también en el sentido de origen. El topos del comienzo se asocia a una idea de precedencia y/o de prioridad. Suele comportar la designación de una intención subsiguiente. Con respecto a una obra dada, o a un corpus de obras, una intención de comienzo implica la noción de una inclusividad creada, dentro de la cual se desarrolla la obra. Véase Said, Edward (1985). Beginnings. Intention \& Method, ed.cit., especialmente cap. I "Beginnings Ideas" y cap. II, “A Meditation on Beginnings", pp. 1-78.
} 
Brevemente se podrían resumir algunas de las cuestiones principales que atraviesan este importante conjunto textual: una datación temporal que recrea como marco histórico el siglo XVIII en Puerto Rico, época propuesta como origen y fundación de la nacionalidad puertorriqueña; la reconstrucción del pasado se constituye mediante la incorporación e intersección de archivos, crónicas y documentos, tanto reales como apócrifos e inventados, y el relato de los hechos se articula a través de la multiplicación de narradores que ocupan diversos roles: historiadores, cronistas y poetas, obispos, secretarios y amanuenses entre otros; el autor utiliza la imitación y la parodia al remedar el lenguaje arcaizante y el estilo de las crónicas coloniales dieciochescas; el siglo XVIII se representa a través del concepto barroco de la tensión, un siglo de luces y sombras que aparece evocado a partir de las aguafuertes y pinturas de Goya y los dibujos de Piranesi, como época de la razón pero también de monstruos, pesadillas y destrucción ${ }^{598}$.

Si la imaginación pictórica ocupa el centro de la reflexión del autor en su ensayo dedicado a Campeche, la apelación a la imaginería visual, a los instrumentos ópticos, y a la mirada y los modos de ver prolifera en las novelas, repitiéndose como procedimiento fundamental en las crónicas de actualidad antes recorridas. El siglo XVIII puertorriqueño no sólo aparece pintado en la obra de Campeche sino que Rodríguez Juliá acude también a la tradición pictórica europea al producir imágenes que evocan a los artistas ya citados Goya y Piranesi-, junto con Hyeronimus Bosch -más conocido como El Boscoy Peter Bruegel. Áurea María Sotomayor ${ }^{59}$ resume en este sentido que la imaginación narrativa de Rodríguez Juliá se articula sobre la memoria visual y que el autor se presenta como un "ficcionalizador de imágenes."

La proliferación de las metáforas visuales se suma a los conceptos de visión, vidente, visionario, que hacen del siglo XVIII el espacio y tiempo propicios para el desarrollo de las utopías, como la ciudad libertaria proyectada por el Niño Avilés en La noche oscura del Niño Avilés. Tanto en las novelas

\footnotetext{
${ }^{598}$ Las ficciones del siglo XVIII de Rodríguez Juliá, como destaco luego, dialogan con la novelística de Alejo Carpentier donde se evoca este mismo siglo, inserto en el espacio caribeño, tales como El reino de este mundo y El siglo de las luces.

${ }^{599}$ Sotomayor, Áurea María (1992). "Escribir la mirada", en: Duchesne Winter, Juan (editorcompilador). Las tribulaciones de Juliá, San Juan, Editorial del Instituto de Cultura Puertorriqueña, pp. 117-167. La cita corresponde a la p. 122.
} 
como en el ensayo en el origen de la nacionalidad puertorriqueña aparecen tensiones y conflictos étnicos, que se traducen mediante metáforas eróticas donde se exploran las relaciones entre blancos, mulatos y negros en la sociedad colonial puertorriqueña del siglo XVIII. Sin embargo la evocación histórica -más allá de sus falsificaciones y ambigüedades explícitas-, manifiesta también otra particularidad: se vuelve al XVIII para leer y buscar en el pasado una explicación, casi siempre insatisfactoria, del presente colonial puertorriqueño. En uno y otro momento resultan imprescindibles los aportes de los sectores negros y mulatos en la conformación histórica y cultural del país, donde el modelo del cimarronaje adquiere particular peso.

Teniendo en cuenta la fecha, la aparición de La renuncia del héroe Baltasar (1974) coincide con el movimiento de la nueva historiografía puertorriqueña antes señalado ${ }^{600}$, cuando entran en crisis concepciones y tradiciones históricas y culturales muy arraigadas en la sociedad puertorriqueña, para dar paso a una revisión de la historia colonial del país que subraya aspectos escamoteados, poco tratados o directamente eludidos por la historia oficial, como el esclavismo y la herencia cultural africana. Las ficciones del siglo XVIII de Edgardo Rodríguez Juliá ponen el acento en los conflictos derivados del esclavismo, sobre todo a través de metáforas corporales y eróticas que procuran recuperar un cuerpo casi borrado por la explotación esclavista. De este modo en estos textos convergen espacios tales como el palenque, conflictos como las grandes revueltas de esclavos, acciones características del cimarronaje como las fugas, es decir, diferentes imágenes que vinculan estrechamente las ficciones del autor con una dimensión mayor que excede los límites nacionales para abarcar la historia antillana.

Si antes, refiriéndome al concepto de los comienzos propuesto por Said, destaqué cómo el inicio puede entrañar para un autor el desarrollo de un proyecto subyacente, se podría afirmar que en el caso de Rodríguez Juliá éste empieza a cobrar cuerpo en su novela La renuncia del héroe Baltasar, particularmente mediante las características en común expuestas hasta aquí. Aunque bajo el pretexto de una perspectiva analítica más ordenada propongo leer el corpus textual por separado, se podrían pensar a la primera novela del

${ }^{600}$ Véase al respecto el capítulo II. 
autor, junto con La noche oscura del Niño Avilés, El camino de Yyaloide y el ensayo Campeche o los diablejos de la melancolía como modulaciones diferentes y diferenciadas de un texto único y memorable acerca de la identidad cultural puertorriqueña. Al respecto César Salgado lee La renuncia del héroe Baltasar como "novela precursora" de un ciclo narrativo sobre el siglo XVIII que Rodríguez Juliá ha descrito de diversas formas a distintos interlocutores y en diferentes intervenciones bajo la denominación común de Crónicas de la Nueva Venecia ${ }^{601}$. Salgado señala que dicho ciclo:

“(...) constituye una enorme y compleja alegoría moral sobre numerosos temas: los peligros inherentes a la ostentación absoluta del poder, las terribles consecuencias del abuso de la 'mentira piadosa' en el orbe político, la destrucción que suelen ocasionar las irrealizables ambiciones utópicas, 0 la fragmentación cultural de la sociedad puertorriqueña contemporánea." 602

Me detendré entonces en el análisis de La renuncia del héroe Baltasar, como novela de los "comienzos", precursora y prefiguradora de un proyecto narrativo, tanto imaginativo como conceptual, más amplio del autor.

\footnotetext{
${ }^{601}$ Rodríguez Juliá, en una entrevista que le hiciera Julio Ortega, le describe al crítico un proyecto de trilogía sobre el siglo XVIII, que luego reformula como tetralogía, sin incluir en ella La renuncia del héroe Baltasar. Estaría compuesta por La noche oscura del Niño Avilés, El camino de Yyaloide (las únicas novelas efectivamente publicadas de dicho ciclo) y otras dos tituladas 1797 y Pandemónium (proyectadas pero hasta hoy no realizadas). Por otra parte en una intervención del autor recogida en la compilación Imágenes e identidades: el puertorriqueño en la literatura (1985) Rodríguez Juliá cita un fragmento de una carta que le escribió al escritor José Luis González en 1979, describiendo su ciclo bajo el tentativo título de Crónicas de Nueva Venecia, reordenando las ficciones de otra manera, ya que la primera parte sería Pandemónium, la segunda El camino de Yyaloide y finalmente el ciclo cerraría con La noche oscura del Niño Avilés. Mi propuesta procura reunir las ficciones del siglo XVIII efectivamente publicadas, incluyendo el ensayo sobre Campeche porque, a pesar de tratarse de otro género, en este último texto se advierten importantes redes temáticas y formales que los vinculan. Por otra parte Campeche o los diablejos de la melancolía es un ensayo literario, donde se ponen en juego mecanismos propios de la ficción, como se analizará más adelante. Véase Ortega, Julio (1991). "1. Crónica de entierros, ficción de nacimientos", entrevista a Edgardo Rodríguez Juliá, en: Reapropiaciones (cultura y nueva escritura en Puerto Rico), Río Piedras, Editorial de la Universidad de Puerto Rico, pp. 123-162.

${ }^{602}$ Salgado, César (1999). “Archivos encontrados: Edgardo Rodríguez Juliá o los diablejos de la historiografía criolla", Cuadernos Americanos, núm. 73, pp. 153-203 (la cita corresponde a la p. $155)$.
} 


\section{IV.1 Biografías infames, héroes apócrifos, archivos alterados y falsos historiadores en La renuncia del héroe Baltasar}

"El principio es siempre ese instante de distanciamiento de la multiplicidad de los posibles; para el narrador, supone desprenderse de la multiplicidad de las historias posibles para aislar y hacer narrable aquella historia que ha decidido contar en esta velada." acabar"

Italo Calvino, "El arte de empezar y el arte de

"Son el irresponsable juego de un tímido que no se animó a escribir cuentos y que se distrajo en falsear y tergiversar (sin justificación estética alguna vez) ajenas historias."

Jorge Luis Borges, Historia universal de la infamia

Un supuesto historiador, Alejandro Cadalso, dicta tres conferencias en la prestigiosa institución letrada del Ateneo puertorriqueño. Desde su presente, señalado entre las fechas que van del 4 al 10 de enero de 1938, se remonta a la segunda mitad del siglo XVIII para narrar acontecimientos "ocurridos" en una colonial San Juan, entre los años 1753 y 1768. Cuenta la historia de un héroe local, el esclavo rebelde Baltasar Montañez, como producto de la invención del poder colonial detentado por la maquiavélica figura de un obispo, Don José Larra de Villaespesa. El historiador deviene narrador principal y en sus conferencias trae al presente los hechos dieciochescos, reorganizando el relato a través de una multiplicidad de materiales de distinta índole como cartas, crónicas, testimonios, escritos anónimos, poemas, fragmentos de dramas, dibujos, edictos inquisitoriales, despachos. A su vez la información contenida en estos materiales se presenta de manera contradictoria y el historiador recurre entonces al artificio de otorgarle voz a diversos comentaristas, cronistas, poetas, también a los protagonistas, pluralizando las perspectivas de un relato cuya trama revela una estructura narrativa bastante compleja, pese a la dimensión relativamente breve de la novela.

Tanto la alusión al Ateneo puertorriqueño como las fechas que datan las tres conferencias que componen la novela producen un efecto de realidad 
según la definición de Roland Barthes ${ }^{603}$, en tanto dichas coordenadas espaciotemporales funcionan como detalles concretos que imprimen al texto una ilusión referencial: el historiador ficticio pertenece al mismo recinto letrado preferido por los intelectuales de la Generación del Treinta y sus conferencias se producen en aquella década, como se indica en la mención del año 1938. Además, como lo ha señalado la crítica en diversos artículos sobre la novela, la estrategias retóricas del historiador-narrador Alejandro Cadalso se asemejan claramente a las esgrimidas en el proyecto cultural de los treintistas, sobre todo en su intento de articular la identidad puertorriqueña a través de discursos paternalistas y magisteriales, similares a los analizados en el capítulo II a través del ejemplo característico de Insularismo de Antonio S. Pedreira. Así Rubén Ríos Ávila concibe al personaje del historiador como un "alter ego autorial" que, en este caso, "representa la generación del treinta, la primera generación de intelectuales puertorriqueños formada bajo la dominación americana, y la generación fundadora de la ensayística de la ontología del ser nacional." ${ }^{1604}$ En esta misma dirección se orienta el trabajo de Carmen Hilda Santini, al establecer el paralelismo entre la crisis histórica que afecta a los miembros de la Generación del Treinta, amenazados ante la avanzada cultural del imperio dominante y la crisis historiográfica que emerge en la década del setenta, cuando Rodríguez Juliá publica la novela. Esta autora subraya además que en el año 1938 surge un nuevo partido político: el Partido Popular Democrático, cuyas políticas marcadamente desarrollistas son el objeto de numerosas crónicas de actualidad del autor, como propongo analizar en el próximo capítulo. Carmen Santini observa que en aquel año:

"Estaba discutiéndose intensamente el destino político de Puerto Rico y se fundó un nuevo partido en el que se cifraron muchas esperanzas, ya que en su origen había un rechazo de la situación

\footnotetext{
${ }^{603}$ Barthes, Roland (1987). "El efecto de realidad", en: El susurro del lenguaje. Más allá de la palabra y la escritura, Buenos Aires, Paidós, pp. 179-187.

${ }^{604}$ Ríos Ávila, Rubén (1992). "La invención de un autor: escritura y poder", en: Duchesne Winter, Juan (editor-compilador), Las tribulaciones de Juliá, San Juan, Editorial del Instituto de Cultura Puertorriqueña, pp. 33-62 (la cita corresponde a la p. 51). Por su parte César Salgado adhiere a la identificación propuesta por Ríos Ávila en el artículo citado en la nota 7, como así también Eduardo González Rodríguez, en su artículo "Dos posesas (escritura e historia) en las obras de Edgardo Rodríguez Juliá", Revista de Estudios Hispánicos, Universidad de Puerto Rico, vol. XXVII, Núm. 2, 2000, pp. 299-318.
} 
colonial. En este contexto fue que Rodríguez Juliá colocó a su imaginario historiador cuestionándose la historia del 'borroso' siglo XVIII."605

Alejandro Cadalso funciona además como un hilo conductor que permite amalgamar las tres novelas publicadas sobre el siglo XVIII, ya que el historiador-narrador ocupa en ellas un mismo rol que César Salgado define con acierto: el del "compilador-archivero", pues "recoge, consulta y edita las crónicas, que recupera textos extraviados para ubicarlos en un espacio de legitimidad institucional (una conferencia en el Ateneo puertorriqueño o su edición en forma de libro) y así brindarles el imprimatur de lo verídico."606 Para Salgado la figura de Cadalso no sólo se identifica con la de los intelectuales del Treinta, sino que, a lo largo de las tres novelas, es posible advertir una superposición de otros discursos historiográficos que permiten entrever en el personaje desde una figura de enorme peso en la historiografía criolla de fines del siglo XIX como la de Alejandro Tapia y Rivera, hasta intelectuales de los años cuarenta, tales como Arturo Morales Carrión. El Ateneo puertorriqueño, fundado en 1876, fue renovado por los miembros de la Generación del Treinta con el objeto de resaltar la tradición hispánica, en el sentido que propone Arcadio Díaz Quiñones ${ }^{607}$, cuando observa que para los treintistas España ocupó un lugar prestigioso como el origen inmemorial de la cultura ante el avance norteamericano, no exclusivamente en el terreno de lo político, sino sobre todo en el campo de la lengua, la educación y la cultura ${ }^{608}$. César

\footnotetext{
${ }^{605}$ Santini, Carmen Hilda (2000). "La renuncia del héroe Baltasar y la ficcionalización de la historia", en: Revista de Estudios Hispánicos, Universidad de Puerto Rico, vol. XXVII, Núm. 2, pp. 319-331 (la cita corresponde a la p. 325).

${ }^{606}$ Salgado, César (1999). "Archivos encontrados: Edgardo Rodríguez Juliá o los diablejos de la historiografía criolla”, ed. cit., p. 161.

${ }^{607}$ Díaz Quiñones, Arcadio (2000). "Pedreira en la frontera", en: El arte de bregar. Ensayos, San Juan, Ediciones Callejón, pp. 96-102.

${ }^{608}$ Véase la siguiente observación del historiador Luis Ángel Ferrao sobre la revalorización del hispanismo entre los sectores letrados en la década del treinta: "Inmersos en la urgente tarea de definir los parámetros de la identidad puertorriqueña, deseosos por dotar a su pueblo de una conciencia clara de su origen histórico, los miembros más autorizados de la élite intelectual creyeron encontrar en el elemento español, europeo y occidental la piedra angular sobre la que se sostenía la nacionalidad. Frente al incontenible oleaje de influencias 'exóticas' provenientes del norte anglosajón, protestante y utilitarista, este sector adoptó una postura hispanista que concebía la tradición ibérica, el castellano y, en muchos casos, el catolicismo, como valores inherentes a la puertorriqueñidad." Ferrao, Luis A. (1993). "Nacionalismo, hispanismo y élite intelectual en el Puerto Rico de la década de 1930", en: Rodríguez Castro, María Elena y Álvarez-Curbelo (ed. y comp.), Del nacionalismo al populismo: cultura y política en Puerto Rico, Río Piedras, Ediciones Huracán, pp. 37-60 (la cita corresponde a las pp. 46-47).
} 
Salgado señala que entre las actividades principales llevadas a cabo por los ateneístas figuraban las operaciones proceratistas de consagración de héroes locales erigidos como patriotas, modelos de ciudadanía y de nacionalidad:

"La mejor síntesis del programa proselitista de este Ateneo revitalizado fue el de la sección de Historia, que llevó a cabo la resurrección de un tipo de formato historiográfico iniciado por Alejandro Tapia y Manuel Elzaburu en los orígenes de la institución: la celebración de la persona y obra del prócer criollo en su natalicio a través de la conferencia erudita orientada al gusto popular."

Tal descripción bien le cuadra al historiador de la novela de Rodríguez Juliá, Alejandro Cadalso, con la salvedad de destacar que el héroe Baltasar Montañez exaltado en sus tres conferencias se revela como un antiprócer, un personaje que bien podría formar parte de la galería de biografías infames de Historia universal de la infamia de Jorge Luis Borges, en la dirección que traza el segundo epígrafe de este apartado: biografías producidas mediante las acciones conjuntas de "falsear y tergiversar ajenas historias"610. Sylvia Molloy, cuando caracteriza los relatos que forman parte del libro borgeano, destaca la parodia y al exceso como los principales procedimientos constructivos de la obra. Observa que el texto de Borges recurre a la historia previa para organizarla de manera diferente, para desviarse de la misma; también la importante presencia de un diálogo entre un texto y otro que le sirve de pretexto y por último un fecundo contacto entre lector y autor a través de la duplicidad de la parodia: "contacto basado ya en un referente compartido, ya en la lejanía, convencionalmente hiperbólica, que proponen estos desorbitados

\footnotetext{
${ }^{609}$ Salgado, César (1999). "Archivos encontrados: Edgardo Rodríguez Juliá o los diablejos de la historiografía criolla”, ed. cit., p. 167.

${ }^{610}$ Borges, Jorge Luis (1986). "Prólogo a la edición de 1954", Historia universal de la infamia, Buenos Aires, Emecé, p. 10. En esta introducción Borges destaca procedimientos muy afines a los que recorren La renuncia del héroe Baltasar: observa que sus biografías infames son de naturaleza barroca, entendida ésta desde el barroquismo intelectual y humorístico de Baltasar Gracián y John Donne. Alude también a la utilización de la parodia y la hipérbole, en el sentido en que el barroco deliberadamente "agota (o quiere agotar) sus posibilidades y que linda con su propia caricatura." (paréntesis del autor, cita en p. 9). En la novela de Rodríguez Juliá se apela a la parodia sostenidamente (los discursos de Cadalso que remedan y caricaturizan el formato historiográfico de los treintistas, las deliberadas imitaciones de la retórica de las crónicas de los siglos XVII y XVIII, para nombrar solo dos ejemplos), a la hipérbole y a un sentido del humor corrosivo.
} 
relatos." ${ }^{11}$ Estas mismas operaciones reaparecen en la novela de Rodríguez Juliá, donde la biografía inventada de Baltasar Montañez se constituye como un "desorbitado relato", que re-escribe y se desvía enormemente de un texto previo, incluido en el libro Leyendas puertorriqueñas ${ }^{612}$. Como indica César Salgado el novelista retoma el nombre de un personaje real, Baltasar Montañez, pero lo desubica respecto de su contexto original:

'El referente 'Baltasar Montañez' aparece primero en la Historia de Puerto Rico de Salvador Brau, donde se hace constar la erección de la Capilla del Santo Cristo de la Salud en San Juan como consecuencia del desbocamiento y muerte de un jinete con este nombre en unas carreras en la cuesta del convento en 1753; en Leyendas puertorriqueñas, Cayetano Coll y Toste usa este dato para fabricar un mito, haciendo que Montañez sobreviva misteriosamente al desbocamiento y que por este milagro se erija la capilla." ${ }^{\text {"613 }}$

Asimismo Carmen Santini da cuenta de la construcción del falso milagro en torno a Baltasar Montañez, tomando como fuente la Historia cronológica de Puerto Rico de Federico Ribes Tovar. A pesar de su extensión vale la pena reproducir el relato de aquel hecho histórico que deviene legendario:

"Un accidente durante una carrera de caballos realizada en celebración del día de San Juan Bautista en el año 1753, inspiró a un residente de San Juan para construir una capilla contra la muralla sur de la ciudad. Uno de los jinetes, un joven llamado Baltasar Montañez, perdió el dominio de su caballo al final de la calle y éste saltó por encima del bajo parapeto, cayéndose de lo alto de la muralla y matándose él y su jinete. Uno de los espectadores que presenció el trágico accidente, Tomás Mateo Prats, apeló al Cristo de la Salud mientras el caballo saltaba por encima de la muralla, y poco después tenía él construida la Capilla del Cristo de la Salud contra la muralla en el lugar del accidente, pagando todos los costos, a fin de prevenir tragedias semejantes en el futuro. Un rumor se extendió entre los creyentes de que el jinete Baltasar Montañez, había sobrevivido milagrosamente, pero hay prueba documentada de que resultó muerto lo mismo que su montura.,"614

\footnotetext{
${ }^{611}$ Molloy, Sylvia (1999). Las letras de Borges y otros ensayos, Rosario, Beatriz Viterbo, p. 34. ${ }^{612}$ Coll y Toste, Cayetano (1983). Leyendas puertorriqueñas, selección, adaptación y versión moderna de José Ramírez Rivera, extraídas de la versión original de 1925, Mayagüez, Libero.

${ }^{613}$ Salgado, César (1999). “Archivos encontrados: Edgardo Rodríguez Juliá o los diablejos de la historiografía criolla”, ed. cit., p. 156.

${ }^{614}$ Reproduzco el pasaje según la cita que proviene del artículo de Carmen Hilda Santini (2000). "La renuncia del héroe Baltasar y la ficcionalización de la historia", ed. cit., p. 326.
} 
Por un lado este fragmento insinúa el desvío fabulador de los hechos, la conversión mítica de un episodio en milagro al señalar el rumor popular sobre la salvación del jinete, muy bien aprovechado por Rodríguez Juliá. También provee información sobre otro de los nombres usados por el novelista para un importante personaje de La renuncia del héroe Baltasar, Don Tomás Mateo Prats, desubicándolo de su contexto real para incluirlo en la ficción novelesca como el General Prats, Secretario General del Gobierno de Puerto Rico y padre desolado de la joven esposa blanca del héroe mulato. Por último indica el año de 1753 al cual se remonta el historiador ficticio Alejandro Cadalso para reconstruir los acontecimientos suscitados en torno a y por Baltasar. En la novela Rodríguez Juliá transforma al jinete blanco en esclavo, hijo de Ramón Montañez, líder de una importante revuelta negra ocurrida en 1734. La participación de Baltasar en las carreras de 1753 resulta producto de un siniestro plan político, fundado en un artificio barroco propio de las artes escénicas y visuales ${ }^{615}$-la tramoya y el trompe l' oeil-, cuya eficacia en ambos casos reside en el engaño del sentido de la vista:

"El jinete -que en ocasión ya ha recibido órdenes de cabildo a lo relativo- frenará su equino -magnífico animal por lo que han referido en testimonio los palafreneros del obispado- al borde mismo de la muralla. Todo lo dicho causará gran confusión, y los ánimos de esta buena feligresía que me honro en llevar por el camino de la salvación eterna, atribuirán a causa divina lo que tiene causa humana. Es menester lograr en los corazones pía reverencia a este milagro manifestado por hombres; pero justificado por Dios Padre Celestial para sosiego y paz de su amada grey." ${ }^{.616}$

El fragmento citado corresponde al personaje que ocupa el rol del tramoyista por excelencia en la novela: el obispo Larra, quien, como el historiador Alejandro Cadalso es un personaje creado por el autor, cuyas cartas y despachos apócrifos son utilizados por el narrador como fuentes y

\footnotetext{
${ }^{615}$ Véase al respecto Maravall, José Antonio (1984). Teatro y literatura en la sociedad barroca, edición a cargo de Francisco Abad, Barcelona, Crítica.

${ }^{616}$ Rodríguez Juliá, Edgardo (1986). La renuncia del héroe Baltasar, ed. cit., p. 11.
} 
documentos "auténticos" para develar "el enigma"617 de Baltasar. El supuesto milagro forma parte de un elaborado proyecto para sugestionar y controlar a los esclavos en un momento de gran inestabilidad social. El sujeto engañado es pasible a su vez de ser manipulado a partir de los efectos y sentimientos provocados por la tramoya: compasión, culpa, asombro, piedad, temor. La figura del héroe inventado se vuelve a lo largo de la trama una suerte de simulacro, un personaje carnavalesco que adopta múltiples máscaras. Una de ellas incumbe al milagro falaz que Alejandro Cadalso se empeña en develar: "Hoy no nos cabe la menor duda de que el incidente del caballo despeñado en las fiestas hípicas de 1753 fue un milagro montado para cautivar la imaginación popular."618 La palabra clave de este pasaje se cifra en el participio "montado", en tanto revela una operación característica sobre la cual está construida la novela: el montaje. A su vez éste puede ser entendido en el sentido propuesto por Salgado, quien observa que en la novela de Rodríguez Juliá hay una desarticulación sistemática de continuidades semántico-documentales, donde varios referentes históricos se desubican o se recolocan y se reordenan anacrónicamente, o bien se puede entender el montaje desde la perspectiva de puesta en escena, de teatralidad, de simulacro. Ambas operaciones están presentes en La renuncia del héroe Baltasar, enfatizadas además por una estructura narrativa de cajas chinas donde los marcos de la ficcionalidad se potencian al máximo. Así el historiador Cadalso convoca a la vez al archivo y a la "equívoca región del mito y la leyenda", a la "magia del ensueño"619. El obispo Larra acude a la "mentira piadosa" para tramar la invención de un héroe con el fin de manipular a los sectores populares y acrecentar su poder político. La imaginación alucinada de Baltasar inventa a su vez "el jardín de los

\footnotetext{
${ }^{617}$ En el comienzo de la novela, es decir, en la primera conferencia de Alejandro Cadalso, se observa cómo se parodia la retórica de los discursos historiográficos treintistas. Cadalso insiste en el estudio del héroe como esencia del siglo XVIII, caracterizándolo repetidas veces como "oscuro", "enigmático", "enigma". El historiador se presenta a sí mismo como aquel que, mediante la documentación y el archivo, está autorizado para develar dicho enigma. Por su parte Rubén Ríos Ávila lee un paralelismo entre los comienzos de la novela de Rodríguez Juliá y el Facundo de Domingo F. Sarmiento, subrayando en ambos el viaje arqueológico al pasado para desentrañar un enigma, aunque con un resultado irónicamente opuesto en el caso de $L a$ renuncia..., por la ausencia de una "sombra imitable" como la del caudillo sarmientino, de una tradición, como dice el crítico, "aunque sea para desbancarla, o sobre todo para desbancarla." Véase Ríos Ávila, Rubén (1992). "La invención de un autor: escritura y poder”, ed. cit., p. 45.

${ }^{618}$ Rodríguez Juliá, Edgardo (1986). La renuncia del héroe Baltasar, ed. cit., p. 10.

${ }^{619}$ Ibid., pp. 8 y 9.
} 
infortunios", cuya descripción evoca las imágenes perturbadoras y escatológicas de El jardín de las delicias de El Bosco ${ }^{620}$. Debería entonces rectificar una afirmación anterior: el gran tramoyista de La renuncia del héroe Baltasar resulta ser, más que el obispo Larra, el propio Rodríguez Juliá.

\section{IV.1.2 El (anti)héroe Baltasar o la conciliación imposible}

La puesta en escena del falso milagro le permite al cínico obispo transfigurar al mulato Baltasar en instrumento y actor prominente de la política colonial de apaciguamiento que pretende llevar a cabo. La construcción del prócer exige determinadas prácticas, -una emblemática y la edificación de un monumento-, para legitimarlo ante la opinión pública:

"Las autoridades coloniales hicieron lo indecible por edificar en torno a Baltasar el atractivo del mito y la magia. No sólo mandaron a edificar un monumento a la memoria del milagro que asistió a su persona, sino que pretendieron hacer de él una figura carismática destinada a lograr la confianza de su pueblo. El retrato al óleo que le hizo Juan Espinosa, en el año 1754, muestra a un joven y apuesto negro vestido con el uniforme virreinal de Calatrava y el sable dorado de la orden inquisitorial de Indias., ${ }^{621}$

Las prácticas de legitimación de Baltasar perpetradas por el obispo acentúan aun más la falsificación, puesto que dejan al descubierto los artilugios y mecanismos de los sectores poderosos -la alianza entre los representantes eclesiásticos y los funcionarios coloniales- para mantener sus prerrogativas de dominación. El retrato de Baltasar subraya la pose como proyección teatral de una paradoja, en la cual el traje vuelve visible la impostura: los emblemas del poder (sable, uniforme) se tornan disfraz en el cuerpo del mulato, quien se presta a colaborar en la manipulación de la cual es objeto.

\footnotetext{
${ }^{620}$ Los paralelismos y parodizaciones entre las imágenes del Jardín de los infortunios de la novela y las imágenes plásticas de la pintura de Jerónimo Bosch son analizadas por Lizabeth Paravisini (1984). "La renuncia del héroe Baltasar: parodia, mito e historia", Plural, núm. 4, pp. 101-108.

${ }^{621}$ Rodríguez Juliá, Edgardo (1986). La renuncia del héroe Baltasar, ed. cit., p. 10.
} 
La invención del héroe por parte del obispo en el siglo XVIII se presenta en la novela de manera paralela a la construcción discursiva de la figura del prócer que lleva a cabo el historiador Cadalso en sus conferencias. En ambos casos se producen efectos inversos a los buscados, ya que si el obispo pretende hacer del mulato un emblema de pacificación e integración étnica, su objetivo vira bruscamente hacia la rebelión sangrienta y la violencia destructiva. En tanto que la pretensión proceratista de Cadalso, en consonancia con los ideales del patriotismo sustentados por los ateneístas, se transforma en farsa; el Baltasar visionario deviene un perverso y enajenado mental que busca vengarse de su propio pueblo. De allí que el historiador-narrador, a medida que avanza la trama de la novela al igual que sus investigaciones, desista del archivo, de los documentos y despachos que connotan la historiografía, para aferrarse cada vez más a una versión poética de los hechos, según su representación en la pieza teatral que lleva un título muy similar al de la novela, El héroe Baltasar de Alejandro Juliá Marín, otro alter ego autorial que se reitera en las ficciones dieciochescas de Rodríguez Juliá, y que hace las veces de cronista y poeta. Rubén Ríos Ávila interpreta que en la confluencia del nombre Alejandro, que comparten tanto el historiador Cadalso como el poeta Juliá Marín, se alude al escritor de fines del XIX Alejandro Tapia y Rivera, coincidiendo en este punto con César Salgado. Pero además subraya que el doble apellido remite al tío abuelo del autor, Ramón Juliá Marín ${ }^{622}$, también escritor y cronista, como su sobrino nieto: "En estas fórmulas compuestas, donde el linaje literario y el linaje familiar se confunden, el autor produce una imagen de la estirpe letrada a la que pertenece" ${ }^{623}$, observa Ríos Ávila, interesado en la construcción de la figura de autor en las ficciones de Rodríguez Juliá.

La segunda operación que trama el maquiavélico obispo Larra en torno a Baltasar, una vez convencido el pueblo del aura milagrosa que encarna el mulato, es organizar una boda mixta que sea recibida por los sectores populares como signo de reconciliación étnica de los sectores en pugna negros y blancos-, al proponer el casamiento entre el nuevo héroe y la niña

\footnotetext{
${ }^{622}$ Sobre el peso del tío abuelo escritor en la configuración autorial de Rodríguez Juliá como cronista remito al capítulo III, en el apartado donde analizo la crónica Puertorriqueños.

${ }^{623}$ Ríos Ávila, Rubén (1992). "La invención de un autor: escritura y poder”, ed. cit., p. 51.
} 
blanca Josefina Prats, hija del Secretario de Gobierno. Entre las crónicas apócrifas que componen el plural mosaico de voces narradoras sobresale la de uno de los numerosos secretarios del obispo Larra ${ }^{624}$, quien describe el efecto que produjo entre los sectores negros de la población de la isla la entronización de Baltasar como héroe conciliador:

"Este humilde testigo que escribe estas brevísimas estampas, ha visto cómo el llamado Baltasar Montañez ha recorrido con muy magníficas muestras de culto los sectores más convulsos por las antiguas rebeliones de Lucifer. El populacho le rinde culto a este muñeco, a este héroe de muy real simulacro, e imagina en él la esperanza de cumplimiento del anómalo y diabólico deseo de romper cadenas, y de ese modo violar lo dispuesto por el Señor de los cielos. El llamado Baltasar desempeña a perfección suma su papel conciliatorio entre las dos razas que habitan esta muy grácil y bella isla, y restaura al más firme plinto la hegemonía del cristiano sobre el hereje."625

El cronista asume el papel de testigo y mediador, quien desde el lugar del observador -"humilde testigo"-, se constituye sin embargo como sujeto dominante y portavoz de los prejuicios étnicos de las élites criollas blancas, quienes demonizan a los sectores negros y mulatos, estigmatizándolos como descendientes de Lucifer y habitantes naturales del infierno por el color oscuro (quemado) de la piel ${ }^{626}$. Inmediatamente después de la reproducción del texto

\footnotetext{
${ }^{624}$ En la novela aparece en primer término un secretario del obispo, autor de la Crónica de lo sucedido bajo el obispado del muy insigne y santísimo su Excelencia Don José Larra de Villaespesa. Luego los secretarios se multiplican en diversas figuras que adoptan seudónimos burlescos, como Ramón García Oviedo o Juan del Gólgota; Alonso Bustamante y Morales o El confeso de la calavera; Rodrigo Pérez de Tudela. Todos ellos dan cuenta con detalles diferentes de la boda entre Baltasar y Josefina; sus versiones son contrariadas, por otra crónica, esta vez de Rafael Contreras (véase el uso humorístico del nombre, en tanto Contreras contradice a los otros cronistas). También se citan los testimonios del "cronista oficial de la gobernación", del llamado Redactor Privado Adjunto de Gobernación y Asuntos Civiles, éste último como cronista testigo de la rebelión negra; en suma, se multiplican los relatos y Cadalso, lejos de develar el enigma del Baltasar, termina por aceptar la "verdad de la ficción" de los poemas y del drama de Alejandro Juliá Marín.

${ }^{625}$ Rodríguez Juliá, Edgardo (1986). La renuncia del héroe Baltasar, ed. cit., pp. 12-13.

626 "Los negros, según entonces se decía, eran de raza despreciable, descendientes de Cam y de Canaán, sobre los cuales pesaba la bíblica maldición del patriarca Noé, en la cual se basaban algunos teólogos, falsos exégetas del génesis, para justificar la esclavitud de los negros y hasta de los indios, unos y otros 'gente de color' predestinados al yugo de los blancos cristianos. (...) La oscura piel de indios y negros evocaba la chamusquina del fuego infernal, según decían." Véase Ortiz, Fernando (1975). Historia de una pelea cubana contra los demonios, La Habana, Editorial de Ciencias Sociales, p. 39.
} 
del cronista interviene la voz del historiador, en cuyos comentarios se percibe claramente una continuidad ideológica con el cronista, puesto que en su discurso Cadalso repite los mismos prejuicios del siglo XVIII. Así, por ejemplo, describe el casamiento entre Baltasar y Josefina en términos de "sacrificio al Moloc negro" de la joven blanca, o bien nombra a los sectores negros de manera despectiva, como "la negrada" en consonancia con la voz usada por el cronista del XVIII, "populacho": "La negrada ha sido confundida por medio de la ilusión de la libertad."

Recordemos una vez más la fecha en que el historiador pronuncia sus conferencias, 1938. Ese mismo año se publica en Puerto Rico un ensayo de amplia difusión dentro de la producción textual de los treintistas: El prejuicio racial en Puerto Rico de Tomás Blanco. Allí su autor sostiene un discurso conciliador respecto de las alteridades étnicas insoslayables en la sociedad puertorriqueña, para oponerse a esta marcada heterogeneidad. Blanco insiste en la inexistencia del prejuicio racial en Puerto Rico, puesto que, según afirma en su ensayo "nuestra cultura general es blanca, occidental, con muy pocas y ligerísimas influencias no españolas", agregando que la "población de color está completamente hispanizada culturalmente."628 Arcadio Díaz Quiñones advierte en el ensayo de Blanco la presencia de otra operación, vinculada a la crisis de los años treinta de la sociedad puertorriqueña. Consiste en la confirmación de la inexistencia del prejuicio racial en su país debido a la bondad esencial del mundo hispanocriollo frente a la crueldad racista del norteamericano: "El enfrentamiento de dos mundos irreconciliables le sirve a Blanco para montar su defensa de la esencial bondad de la colonia española, y simultáneamente, para lanzar un larga ofensiva contra el nuevo imperialismo racista." ${ }^{29}$ Díaz Quiñones lee el discurso patriarcal de Blanco como un acto defensivo donde se busca compensar la discordante situación interna del país y el ímpetu imperialista norteamericano, fortaleciendo la convivencia, la unidad nacional. El ensayista acude también a la consabida metáfora de la "gran

\footnotetext{
${ }^{627}$ Rodríguez Juliá, Edgardo (1986). La renuncia del héroe Baltasar, ed. cit., p. 14.

${ }^{628}$ Blanco, Tomás (1985). El prejuicio racial en Puerto Rico, con estudio preliminar de Arcadio Díaz Quiñones, Río Piedras, Huracán (originalmente publicado en 1938).

${ }^{629}$ Díaz Quiñones, Arcadio (1985). "Tomás Blanco: racismo, historia, esclavitud", en $E l$ prejuicio racial en Puerto Rico, ed. cit., p. 40.
} 
familia" puertorriqueña, con el fin de atenuar los conflictos étnicos y sociales, aunque deba para ello suprimir la complejidad y opresión del mundo esclavista.

El historiador Cadalso de La renuncia del héroe Baltasar parece sostener al comienzo de la novela una postura similar a la esgrimida por Blanco, en cuanto a la búsqueda de una figura heroica y conciliadora; sin embargo la alteridad étnica del mulato desafía el mito homogeneizador de la "gran familia puertorriqueña", y por último, como se verá, no constituye un factor de reconciliación sino más bien de destrucción nihilista respecto del orden colonial, claramente conflictivo por su marcada jerarquización social y étnica. Además porque la preconizada ausencia de "prejuicio racial" en Puerto Rico se desdibuja a medida que el historiador da cuenta de la progresiva "degeneración de Baltasar": "Son múltiples los testimonios que han quedado de la degeneración de Baltasar."630 El concepto de "degeneración", de raigambre positivista ${ }^{631}$, reproduce prejuicios y estereotipos en torno a los sujetos negros como portadores de vicios morales y psicológicos.

Pero también es posible advertir en las explicaciones e hipótesis del historiador otras perspectivas que complejizan la cuestión de la alteridad étnica, por ejemplo conceptos próximos a las tesis de Frantz Fanon ${ }^{632}$ expuestas en su libro Piel negra, máscaras blancas, que Cadalso infiere a partir de los extractos del diario de Baltasar citados. En ellos resuenan ecos del problema de la alienación de la identidad del sujeto negro antillano en el espacio social colonial donde, como explica Homi Bhabha, el deseo colonial siempre se articula en relación con el lugar del Otro y en consecuencia permite el sueño de la inversión de papeles. Con palabras de Fanon: "Es cierto, pues no hay nativo que no sueñe al menos una vez al día con ponerse en el lugar

\footnotetext{
${ }^{630}$ Rodríguez Juliá, Edgardo (1986). La renuncia del héroe Baltasar, ed. cit., p. 52.

${ }^{631}$ Julio Ramos destaca que aún en el marco de los discursos abolicionistas del siglo XIX proliferan fantasías fóbicas de contagio y contaminación respecto de los esclavos, que responden al peso de los discursos higienistas y positivistas de la época, visibles incluso en la temprana etapa criminológica del antropólogo cubano Fernando Ortiz, por ejemplo en su libro El hampa afro-cubana. Véase del autor (1996) "Cuerpo, lengua, subjetividad" en: Paradojas de la letra, Caracas, Ediciones eXcultura, pp. 23-35.

${ }^{632}$ En la reseña de Efraín Barradas el crítico advierte la posibilidad del intertexto de Fanon pero solo lo sugiere, sin analizar la cuestión: "Quizás sea mera sugestión y no haya en la novela prueba que apoye mi aseveración, pero encuentro que su visión de la historia está también estructurada a partir de una detenida lectura de Fanon." Véase Barradas, Efraín (1976). Reseña crítica a La renuncia del héroe Baltasar, en: Sin Nombre, vol. VII, Nro. 1, julio-septiembre, pp. 69-71. Decidí explorar esta sugerencia como se advierte en los párrafos a continuación.
} 
del colono." ${ }^{633}$ Para Bhabha la fantasía del nativo es precisamente ocupar el lugar del amo manteniendo su lugar en la ira vengativa del esclavo, lo cual genera sentimientos encontrados y una fuerte ambivalencia. Tal proceso de inversión conlleva consecuencias altamente neurotizantes según Fanon, al engendrar una personalidad dividida que mitifica al otro (blanco) a la vez que desprecia al sí propio (negro). En la novela de Rodríguez Juliá Baltasar fantasea con ocupar el lugar del blanco, gesto que ya se había manifestado en la pose asumida en el retrato, donde se revela la mimesis del sujeto colonizado respecto del colonizador, como así también al aceptar el cargo de Secretario de Gobierno, desplazando a su suegro blanco. El joven mulato admite ser instrumento de la manipulación del obispo con el fin de llevar a cabo un acto de "ira vengativa" en contra de la población negra a la cual pertenece, porque la considera responsable de la muerte de su padre, líder de una revuelta cimarrona fracasada. En este sentido, siguiendo a Fanon, Baltasar se revela como "negrófobo" y resentido: "Yo muy servidor, odio a mi pueblo. (...) Y llevo en mi gran entraña el deseo de odiar lo más amado por mi querido padre."634 Asimismo interpreta su gesto de renuncia a la esposa blanca como un acto de poder y de humillación que invertiría los papeles de dominador y dominado, de amo y de esclavo ya que, según explica Cadalso: "Renunció carnalmente a su bella esposa; la relación carnal con ella lo convertía en poderoso humillado por el desprecio del débil." ${ }^{\text {635 }}$

Sin embargo, Baltasar escribe en su diario, cuando examina su negativa al contacto sexual con Josefina: "En mí aúlla el deseo de toda una raza; pero he aquí que no es un deseo de placer, sino de humillación. $Y$ es por ello que temo al treparla una muy glácida mirada de odio que me haga notar la debilidad de mi intento..." ${ }^{.636} \mathrm{El}$ acento está colocado en la acción de mirar, puesto que la mirada del blanco congela y confina al otro al lugar de la inferioridad, la debilidad, el desprecio; entonces la fantasía del trastrocamiento de papeles

\footnotetext{
${ }^{633}$ Frantz Fanon citado por Homi Bhabha (2002). "Interrogar la identidad. Frantz Fanon y la prerrogativa poscolonial", en: El lugar de la cultura, Buenos Aires, Manantial, pp. 61-89 (la cita corresponde a la p. 65)

${ }^{634}$ Rodríguez Juliá, Edgardo (1986). La renuncia del héroe Baltasar, ed. cit., p. 25.

${ }^{635}$ Ibid., p. 54.

${ }^{636}$ Ibid., p. 55.
} 
termina paradojalmente reproduciendo los esquemas de dominación del sujeto colonial sobre el colonizado:

“¿Quería decir aquélla serpiente con mitra que yo, después de los muchos sucesos, servía a los deseos de un hombre que me despreciaba a razón de mi raza, o en otras letras, que conservaba intacta la virginidad de su hija, honrando como fiel esclavo el deseo del amo?"637

Baltasar concibe otra estrategia: la compleja construcción de una serie de mirillas y dispositivos para amplificar los sonidos que unen entre sí sus aposentos y los de Josefina, con el fin de hacerse mirar y escuchar mientras participa de desenfrenadas orgías, para incitar el deseo de su mujer y humillarla con su renuncia a consumar el acto sexual:

"Y colocaré en su habitación una mirilla que dé a mi retiro de placer, y será esta mirilla la permanente tentación en aquellas fantaseosas noches cuando mediando los oidores su mente inventará los más deliciosos y rizados placeres de la carne. Oirá los rumores, el vivísimo jadeo que emiten los cuerpos convulsos por el inmenso placer que es el de la carne, y entonces deseará unirse a la orgía; pero será posible sólo por la mirada, la que doblega su cuerpo a mi gran voluntad sin yo sufrir persecución de sus ojos." 638

Pero una vez más, quien queda colocado en la posición privilegiada del voyeur, quien permanece invisible a los ojos del otro mientras mira y espía los movimientos de un cuerpo enigmático, es la mujer blanca, la que representa simbólicamente los intereses del $a^{6 m 0^{639}}$. Si Baltasar pretendía someter a Josefina a la humillación como uno de los medios para asumir su dominación, su intento fracasa. El héroe termina por renunciar al poder que ejercía vicariamente como instrumento del obispo Larra, transformándose en un sujeto melancólico y contemplativo, impasible e impotente.

\footnotetext{
${ }^{637}$ Ibid., p. 55. En el fragmento citado se alude también a la dialéctica hegeliana del esclavo y el amo, que fue utilizada por Fanon como herramienta teórica para comprender las relaciones blanco-negro.

${ }^{638}$ Rodríguez Juliá, Edgardo (1986). La renuncia del héroe Baltasar, ed. cit., pp. 55-56.

${ }^{639}$ En la crónica Una noche con Iris Chacón (1986) de Rodríguez Juliá, hay un pasaje significativo donde el cronista reflexiona sobre el voyeurismo del amo esclavista y subraya el "fisgoneo del amo de las preferencias coitales" del esclavo (véase capítulo anterior).
} 
La referencia intertextual a Fanon queda doblemente desviada en la novela. En primer lugar por su descontextualización y desubicación temporal, en tanto aparece en el discurso de un personaje del siglo XVIII como Baltasar, como así también en las elucubraciones del historiador, anteriores a la publicación del famoso libro Peau noire, masques blancs de 1952; sin embargo este anacronismo forma parte de los mecanismos constructivos y formales de la novela, basados en operaciones de montaje, como antes expliqué. Me interesa destacar la segunda desviación en la alusión a Fanon, de carácter ideológico esta vez. El intelectual martiniqueño, médico psiquiatra, procura comprender lo que llamó "psicopatología del negro" en un contexto de profunda dominación colonial, donde la situación del sujeto antillano colonizado aparece atravesada por la destrucción de su cultura original y la imposición de valores occidentales, lo que lo transforma en un individuo dilacerado y desestructurado psicológicamente puesto que se le ha inculcado una imagen negativa de sí mismo. En el discurso de Cadalso los argumentos de Fanon cambian de signo, puesto que el intelectual martiniqueño abogó y luchó a favor de los procesos de descolonización. El historiador de la novela subraya en cambio la imposibilidad del sujeto negro de transformar su situación de dominado, para concluir que: "Reconocía Baltasar la incapacidad del negro -depositario de las pasiones del esclavo y su sicología- para lograr la humillación del blanco."640 La aclaración entre guiones que introduce el historiador-narrador reproduce el prejuicio étnico arraigado, puesto que confina al esclavo al lugar atávico de la pasión en detrimento de la racionalidad. El discurso diagnosticador de Cadalso, a pesar de las referencias a Fanon, más bien sugiere entonces su consonancia ideológica con los argumentos sostenidos por los treintistas, especialmente por Antonio S. Pedreira, quien postulaba la debilidad de la "raza inferior", refiriéndose con este giro despectivo a la herencia africana.

\section{IV.1.3 "Historiadores de papel"641: potens imaginatio de la otra historia}

\footnotetext{
${ }^{640}$ Rodríguez Juliá, Edgardo (1986). La renuncia del héroe Baltasar, ed. cit., p. 55.

${ }^{641}$ Tomo el título a partir del artículo de Pacheco, Carlos (2000). "Historiadores de papel: la metahistoria en la reciente ficción hispanoamericana", en: Canovas, Rodrigo y Mozven, Roberto (editores). Crisis, apocalipsis y utopías. Fines de siglo en la literatura latinoamericana, Santiago, Pontificia Universidad Católica.
} 
Resulta muy significativa la lectura que propone Cadalso de los dibujos que representan distintas escenas eróticas en torno a Baltasar, puesto que colocan al sujeto negro bajo el estereotipo de la lascivia y la sexualidad desenfrenada, el deseo y la amoralidad casi animal del cuerpo, sin dejar por ello de subyugar al narrador. Por un lado el hallazgo de la colección revela la pasión archivista del historiador, por el otro se la parodia, desde la perspectiva del fetichismo documental que destaca con acierto Salgado ${ }^{642}$ :

"Hoy me detendré, al comenzar el paseo que nos llevará a la morada del segundo Baltasar, en una curiosidad bibliográfica poco conocida y comentada. Me refiero a la colección de dibujos de Juan de Espinosa que hoy se guardan en el Archivo Municipal de San Juan. Estos dibujos no han sido estudiados y comentados debido a su escabrosa temática: los dibujos recogen diversas escenas de las orgías que Baltasar celebraba en las recónditas habitaciones del Palacio de Gobernación." ${ }^{643}$

Cadalso combina entonces dos perversiones, el fetichismo mencionado por Salgado y el voyeurismo que destaca Áurea Sotomayor, puesto que el lector viaja por la pupila fascinada del historiador, a través de su mediación descriptiva, donde las imágenes devienen relato: "A simple vista, todo el erotismo de la novela parece concentrase en una práctica aparentemente voyeurista. Sin embargo, el lector no mira; sólo lee. Y lee lo que informa el ojo del narrador." ${ }^{644}$ Las orgías ilustradas por Juan de Espinosa ${ }^{645}$, el arquitecto leproso, son a su vez objeto de una doble mirada, la que produce el discurso historiográfico presuntamente objetivo de Cadalso y la versión poética

${ }^{642}$ Véase el siguiente comentario crítico de Salgado sobre la "pasión de archivo": "Es por eso que el gesto característico de toda historiografía criolla puertorriqueña es el eureka (lo encontré): al querer contribuir a la generación de un archivo del país, cada historiador anuncia enfáticamente el rescate de un documento extraviado en el laberinto de la burocracia imperial para recolocarlo en el espacio insular y así imprimirle un carácter ontológico -hacerlo emblema de la identidad patriarcal criolla- que reemplace su función pragmática/colonizadora original.", en: "Archivos encontrados: Edgardo Rodríguez Juliá o los diablejos de la historiografía criolla", ed. cit., p. 165 (cursivas del autor).

${ }^{643}$ Rodríguez Juliá, Edgardo (1986). La renuncia del héroe Baltasar, ed. cit., p. 53.

${ }^{644}$ Sotomayor, Áurea María (1992). "Escribir la mirada”, ed. cit., p. 126 (negritas de la autora).

${ }^{645} \mathrm{El}$ nombre del arquitecto remite, una vez más, al uso particular que hace Rodríguez Juliá en sus novelas de nombres históricos descontextualizados para designar a personajes inventados. En este caso el nombre coincide en parte con el de Juan de Espinosa Medrano, conocido como "El Lunarejo", sacerdote peruano quien en 1662 da a conocer su texto Apologético a favor de don Luis de Góngora, reconocido como el primer ejemplo de crítica literaria hispanoamericana. El personaje histórico y el ficticio coincidirían en su apego a las formas estéticas del barroco. 
que a partir de dichos dibujos compone Alejandro Juliá Marín. Los dos registros -el del historiador y el del poeta- quedan contrastados aunque imbricados entre sí, ya que la narración detallista de las escenas eróticas por parte del historiador evoca la meticulosidad descriptiva de los relatos del Marqués de Sade, mientras que los comentarios lírico-filosóficos, por momentos bastante crípticos de Juliá Marín, remedan el estilo poético barroco conceptista, estableciéndose un particular contrapunto entre historia y poesía.

Esta concepción que estrecha los vínculos entre imaginación poética e histórica se diferencia de otras que circulan en el texto, como las alusiones a las corrientes historiográficas de Unamuno de amplia difusión entre los ateneístas de la década del treinta, presentes en las primeras páginas de la novela ${ }^{646}$. Efraín Barradas propone leer el final de la obra como "falla narrativa", ya que para el crítico "se abandona el recurso de la conferencia del cual tan bien el autor se había valido en toda la novela." "'47 Sin embargo no sucede tal cosa; más bien se insinúa que Alejandro Cadalso renuncia a las posibilidades develadoras e interpretativas de los discursos históricos tradicionales; elige finalizar su tercera exposición (y por lo tanto la novela) apelando a la ficción, citando a la literatura. Concluye con la lectura de un fragmento del drama de Alejandro Juliá Marín que supone una concepción de la historia estrechamente vinculada a la imaginación poética, como se advierte en la invocación romántica del historiador al poeta: “¡Oh poder el del poeta! ¡Adivinador de la posible historia!”648

\footnotetext{
${ }^{646}$ Cadalso esgrime, como fuente de autoridad historiográfica al comenzar su ciclo de conferencias, la categoría de la intrahistoria sostenida por Miguel de Unamuno en su ensayo En torno al casticismo. El concepto unamoniano se deriva de la "historia interna" común a la historiografía del siglo XIX y se fundamenta en la idea de que existen ciertos valores que son eternos y que configuran la esencia del ser nacional. En la novela hay una recurrencia irónica a la noción de la intrahistoria, ya que apunta directamente a una de las concepciones básicas de los discursos de la tradición culturalista puertorriqueña, arraigados en interpretaciones esencialistas de la identidad nacional. La figura del héroe Baltasar, como antes se mencionó, constituye el reverso paródico de los ideales identitarios sostenidos por los ateneístas, ya que, como destaca Salgado, era imposible que los miembros de la Generación del Treinta sostuvieran como héroe salvador de la patria a un sujeto negro o mulato.

${ }^{647}$ Barradas, Efraín (1976). Reseña crítica a La renuncia del héroe Baltasar, en: Sin Nombre, vol. VII, Nro. 1, julio-septiembre, pp. 69-71.

${ }^{648}$ Rodríguez Juliá, Edgardo (1986). La renuncia del héroe Baltasar, ed. cit., p. 114. En este pasaje resuenan ecos de las concepciones de Giambatista Vico, quien localiza el origen de la historia en la poesía y declara a la imaginación como un método de conocimiento superior a la razón. (Véase al respecto La nueva ciencia de Vico).
} 
No es casual que en la referencia al autor de los dibujos como un arquitecto leproso se cifre otra figura de artista que padeció lepra, el escultor brasileño del siglo XVIII Aleijadinho, retratado luminosamente por José Lezama Lima en "La curiosidad barroca" ${ }^{\text {" }} 49$. El historiador, cuya mirada queda atrapada en la fascinación que le provocan las imágenes, le asigna a los dibujos de Espinosa propiedades que forman parte del aparato conceptual y poético del cubano, tales como potens e imago ${ }^{650}$, cuando afirma que en los trazos del arquitecto leproso se percibe "esta seducción de la potens imaginatio."651 José Lezama Lima postula en Las eras imaginarias (1971) un particular enlace entre historia y poesía a partir de determinadas imágenes que se convirtieron en el paradigma de una cultura, por lo que propone estructurar la historia como "crónica poetizable de imágenes", descartando la lógica de la sucesión, de la causalidad, del devenir temporal. Ya en La expresión americana (1957) el escritor cubano había propuesto una historia cultural de América Latina al mostrar cómo las imágenes, a lo largo de cuatro siglos, fueron constituyendo la imago de los americanos. En el ensayo inicial del volumen, "Mitos y cansancio clásico", Lezama afirma que: "Una técnica de la ficción tendrá que ser imprescindible cuando la técnica histórica no pueda establecer el dominio de sus precisiones. Una obligación casi de vivir lo que ya no se puede precisar." ${ }^{652} \mathrm{Si}$ me detuve en estos postulados lezamiamos es porque creo que, aunque en la figura de Cadalso confluyen diferentes modelos y representantes de variadas corrientes historiográficas y culturales, el historiador-narrador se inclina más bien por el dominio de la imaginación y la invención poética. En este sentido se podría retomar la afirmación de Rubén Ríos Ávila cuando señala a Cadalso como una suerte de alter ego del autor y pensar entonces que también Rodríguez Juliá, al igual que el personaje

\footnotetext{
${ }^{649}$ Lezama Lima, José (1988). "La curiosidad barroca", en: La expresión americana, Confluencias, La Habana, Letras Cubanas, pp. 229-246.

${ }^{650}$ Para la comprensión de estos conceptos véase de José Lezama Lima el ensayo "Las imágenes posibles" (en: Confluencias, ed. cit., pp. 300-321) donde afirma que en la poesía se concibe al mundo como imagen, y su libro fundamental Las eras imaginarias (Madrid, Fundamentos, 1971). Allí también Lezama Lima reconoce la influencia de Vico en su obra.

${ }^{651}$ Rodríguez Juliá, Edgardo (1986). La renuncia del héroe Baltasar, ed. cit., p. 60.

${ }^{652}$ Lezama Lima, José (1988). "Mitos y cansancio clásico", en: La expresión americana, ed. cit., p. 217.
} 
narrador de su novela, elige la seducción del potens imaginatio que brinda la ficcionalización.

Pero el arquitecto leproso no solo ha cronicado en imágenes las fantasías eróticas de Baltasar sino también sus pesadillas utópicas mediante el diseño del "Jardín de los infortunios", concebido en parte como una inversión cruel del tópico del paraíso terrenal de la naturaleza americana y también como el reverso paródico del perfil urbano racionalista, alcanzado por la ciudad de San Juan en el siglo XVIII ${ }^{653}$. En una carta del joven mulato al obispo Larra describe así su concepción del Jardín de los infortunios:

"Y fue este sueño el que me ha llevado a disponer de un Jardín de los infortunios que proteja nuestra muy preciada soberanía. Será plantado como defensa militar en el mesetón del Morro, y consistirá de los más apacibles rincones que ocultarán horribles trampas, fosas de inundación, depósitos de bichos venenosos y toda clase de inmundicias y muertes terribles. (...) Y de repente me atrevo a adelantarle la idea de que algún día todas nuestras costas gozarán de la defensa referida. $Y$ ello será así porque lo que más nos ofrece esta isla es la oportunidad de que la naturaleza engañe y mate." "654

Con la construcción del Jardín de los infortunios como una anti-arcadia Baltasar se propone utilizar la fuerza destructiva de la naturaleza, pero semejante poder amenaza el sistema defensivo de murallas de la ciudad, y, como señala Sara Ann Smith, pone en riesgo entonces "la construcción vertical de los colonos que asegura la estabilidad y la supervivencia de la cultura hegemónica." 655 De allí que la Inquisición decida encarcelar al mulato

\footnotetext{
${ }^{653}$ En el análisis que traza Rodríguez Juliá de un cuadro de Campeche (retrato del Gobernador Ustáriz) destaca un detalle del mismo, una ventana a través de la cual se vislumbra el diseño urbanístico racionalista de San Juan hacia fines del siglo XVIII: "El buen gobierno -ese estado ilustrado que concibe el poder sólo como instrumento para alcanzar el bienestar general- aquí aparece convertido en promotor de obras públicas", y agrega que "Campeche nos sugiere que el espacio perfecto de la ciudad trazada en el mapa utópico es el recuerdo ciudadano de la arcadia, ámbito de la Edad Dorada, lugar donde aún no había aparecido el mazo de Caín. Pero a este lado de la historia, en el reino de este mundo, los hombres se afanan en la construcción de la ciudad histórica, en ese quehacer cuya realización se fundamenta en el poder del estado." (Rodríguez Juliá, Edgardo (1986). Campeche o los diablejos de la melancolía, ed. cit., pp. 20 y 21 respectivamente). El Jardín de los infortunios de la novela se revela en cambio en las antípodas de esta San Juan utópica dieciochesca, como un espacio alucinado, como una goyesca pesadilla de la razón.

${ }^{654}$ Rodríguez Juliá, Edgardo (1986). La renuncia del héroe Baltasar, ed. cit., p. 49.

${ }^{655}$ Smith, Sara Ann (1995). "Violencia y heterotopía en La renuncia del héroe Baltasar", La Torre, Revista de la Universidad de Puerto Rico, año IX, Núm. 33, enero-marzo, pp. 71-88.
} 
bajo el argumento de su "falso culto a Jardines"656, aunque tal excusa esconda el temor de la institución religiosa a perder el control de la situación creada por Larra y sin prever que dicha medida finalmente acarrearía la rebelión violenta de los sectores negros de la población. A pesar de que la Inquisición decide restaurar a Baltasar a su posición de Secretario de Gobierno, éste se rehúsa a volver al cargo, renuncia al poder y se mantiene ajeno e impasible ante la creciente espiral de violencia que ha generado su actitud. Los hechos se narran desde la perspectiva de un cronista de la época, donde la sublevación se detalla con extremosidad ${ }^{657}$ y exceso, en un relato que parece evocar, mediante la deformación hiperbólica, la representación de la revolución haitiana negra de 1804 y sus prolegómenos de fines del siglo XVIII, plasmados en la novela El reino de este mundo de Alejo Carpentier:

"Leguas y leguas de rica caña de azúcar hecha ceniza por la infinita bestialidad de esta raza. (...) El cielo se había ennegrecido con muchos vahos sulfúreos. Aquel aire que apenas se podía respirar, cargado de un denso humo, invadido por una lluvia persistente de cenizas, tampoco daba paso a la mirada. Eran pocos los contornos distinguidos en aquel infierno digno de la visión de un Dante Alígero o un Jeremías Bosco."658

Rodríguez Juliá se aleja de la rigurosa investigación documental que caracteriza las ficciones históricas de Carpentier ${ }^{659}$, puesto que en La renuncia del héroe Baltasar se describen rebeliones sangrientas y multitudinarias de

\footnotetext{
${ }^{656}$ Rodríguez Juliá, Edgardo (1986). La renuncia del héroe Baltasar, ed. cit., p. 70.

${ }^{657}$ Entiendo el concepto de extremosidad en el sentido propuesto por José Antonio Maravall, estrechamente vinculado a la estética barroca: "El autor barroco puede dejarse llevar de la exuberancia o puede atenerse a una severa sencillez. Lo mismo puede servirla a sus fines una cosa que otra. En general, el empleo de una o de otra, para aparecer como barroco no requiere más que una condición: que en ambos casos se produzcan la abundancia o la simplicidad, extremadamente. La extremosidad, ése sería un recurso de acción psicológica sobre las gentes, ligado estrechamente a los supuestos y fines del Barroco." Maravall (1975). La cultura del barroco, Barcelona, Ariel, p. 426. En la obra de Rodríguez Juliá la extremosidad opera por la abundancia.

${ }^{658}$ Rodríguez Juliá, Edgardo (1986). La renuncia del héroe Baltasar, ed. cit., p. 79.

${ }^{659}$ Según observa Roberto González Echevarría, Carpentier imprime a sus ficciones un nuevo cauce a través de "la búsqueda en textos olvidados de personajes oscuros, de biografías incompletas que él completará en sus relatos con sólida documentación y rigurosa (y casi) comprobable cronología." Véase del autor (1977)."Fugitive Island", en: Alejo Carpentier: The Pilgrim at Home, Ithaca and London, Cornell University Press.
} 
esclavos, de una magnitud inverosímil en la historia de Puerto Rico ${ }^{660}$, donde no hubo revueltas como la de Haití, país que representa la primera república negra que instaura un estado propio. Si, como analiza González Echevarría, aún en las escenas de violencia de El reino de este mundo prevalece "el Carnaval, el teatro, la entrega a las llamadas de la carne, pero además, la inversión de las jerarquías, la indeterminación"661; si también es posible advertir una concepción de la historia como un ciclo de repeticiones inexorables, donde la escena central de la narración carpenteriana es la celebración del paso de un ciclo a otro, en la novela de Rodríguez Juliá, por el contrario, no hay tono celebratorio sino sarcástico; el relato de la revuelta se describe más bien como un carnaval sangriento, que cede paso a un teatro de imágenes apocalípticas y escatológicas. El detallismo descriptivo exacerbado termina provocando un efecto burlesco respecto del modelo propuesto por la novela de Carpentier ${ }^{662}$, ya que subraya el excedente grotesco y obsceno en la representación de la violencia de los sublevados:

"¡Qué horror! Sobre el piano de la niña Carmencita encontramos la cabeza decapitada del que fuera el muy noble Sr. Cambó, y en su boca, embutidos salvajemente, sus órganos pudendos. Tirado sobre el gran sofá de la bella mansión, encontramos el torso desnudo del Sr. Cambó, y había sido colocado en muy obscena postura. Amarrado al trasero del que fuera ¡Oh Dios mío! aquel muy noble y distinguido señor, se encontró la cabeza de su leal capataz negro."663

\footnotetext{
${ }^{660}$ Como se consignó en el capítulo I, en Puerto Rico hubo importantes movimientos de resistencia esclava, principalmente durante el siglo XIX, muy bien estudiados por Guillermo Baralt (1982), Esclavos rebeldes: conspiraciones y sublevaciones de esclavos en Puerto Rico (1795-1873) y por Benjamín Nistal Moret (1984), Esclavos prófugos y cimarrones: Puerto Rico, 1770-1870 (véase la nota 89 del capítulo I). También AA.VV (1992). La tercera raíz. Presencia africana en Puerto Rico, San Juan, Centro de Estudios de la Realidad Puertorriqueña (CEREP).

${ }^{661}$ González Echevarría, Roberto (1977). "Fugitive Island", ed. cit. , p. 57.

${ }^{662}$ En su artículo "Imágenes de la conquista y la colonia en la novelística hispanoamericana contemporánea: notas para una interpretación" Aníbal González recorta un corpus de novelas que dialogan con la obra de Carpentier, como modelo para emular pero también para distanciarse de él. Para González sus autores, entre ellos Edgardo Rodríguez Juliá, cuestionan los mecanismos causales y la visión providencialista de la historia que subyace en las ficciones históricas del escritor cubano Carpentier. (En: Revista de Estudios Hispánicos, año XIX, 1992, pp. 431-448)

${ }^{663}$ Rodríguez Juliá, Edgardo (1986). La renuncia del héroe Baltasar, ed. cit., p. 81.
} 
La renuncia del mulato a ejercer su rol de líder, su indocilidad paralela a su cinismo, la traición a la memoria de su padre y a su comunidad negra, tornan a Baltasar un resentido, cuyo odio a la humanidad y sed de destrucción lo conducen a la enajenación y al suicidio. "La destrucción de todo lo creado era su máxima ambición: es decir, acabar con la cultura dominante" concluye Eduardo González Rodríguez al referirse al personaje, agregando al respecto que: "En el fondo es un suicida, porque comprende que no puede desprenderse de su condición de colonizado, de sus resentimientos." "664

Baltasar Montañez, reverso absurdo de las figuras heroicas, podría compartir su sitio entre las biografias infames de Borges junto al irredimible y espantoso Lazarus Morell y los otros personajes extremos que la componen. Si en la novela de Rodríguez Juliá prevalecen la fabulación, los desvíos históricos, aquello que en general los artículos críticos hasta aquí citados suelen condensar como "imagen apócrifa del siglo XVIII puertorriqueño", es interesante subrayar la potencialidad de la literatura sugerida por el autor: "Intento establecer en la textualidad las posibilidades de lo que nunca fue; pero ello no significa que lo apócrifo esté ajeno a la verdad histórica."665 Para poder reinventar "ese siglo XVIII borroso"666 sobre el cual el discurso histórico se revela insuficiente se requiere entonces, con palabras de Lezama ${ }^{667}$, la imprescindible técnica de la ficción, por su capacidad de revivir lo que ya no se puede precisar; también la paciencia arqueológica de recoger fragmentos textuales o documentales, "para unirlos con la argamasa textual esfuminando los límites entre realidad y ficción, para dar la ilusión de que 'otra' historia es

\footnotetext{
${ }^{664}$ González Rodríguez, Eduardo (2000). "Dos posesas (escritura e historia) en las obras de Edgardo Rodríguez Juliá", Revista de Estudios Hispánicos, U.P.R., vol. XXVII, Núm. 2, pp. 299-318.

${ }^{665}$ Rodríguez Juliá, Edgardo (2000). "Tradición y utopía en el barroco caribeño”, en: Caribeños, ed. cit., p. 69.

${ }^{666}$ Rodríguez Juliá, Edgardo (1985). “A mitad de camino”, en: Asela Rodríguez de Laguna (ed.), Imágenes e identidades: el puertorriqueño en la literatura, Río Piedras, Huracán, p. 131. ${ }^{667}$ Jorge Luis Borges y José Lezama Lima son dos modelos literarios de importante peso para Rodríguez Juliá. Al respecto véase el sugerente artículo del autor "Borges, Lezama Lima y la expresión americana", donde afirma: "Borges y Lezama Lima son, desde sus antípodas, mis escritores criollos por excelencia." (En: La Torre, Revista de la Universidad de Puerto Rico, año II, Núm. 8, octubre-diciembre 1988, pp. 681-688).
} 
posible", según las reflexiones de Fernando Ainsa acerca de los vínculos entre ficción e historia en América Latina. ${ }^{668}$

\section{IV.2 La noche oscura del Niño Avilés ${ }^{669}$ o la poética de la desmesura}

"Desmesura. f.f. Exceso, desordenado, falta de medida y proporción. Es compuesto de la preposición Des, y el nombre mesura. Lat. Inmoderatio, Irregularitas."

Diccionario de Autoridades de la Real Academia Española

\section{IV.2.1 De la proliferación}

"Yo diría que el barroco es aquel estilo que deliberadamente agota (o quiere agotar) sus posibilidades y que linda con su propia caricatura."

Jorge Luis Borges, "Prólogo" a Historia universal de la infamia

Descripta como "novela alegórica", bajo los trazos de "una especie de gigantismo deliberado" (Aníbal González); leída como "una suma totalizadora del neobarroco" (Antonio Benítez Rojo); interpretada como "novela extensiva y compleja" que "explora el teatro de la historia caribeña como el espectáculo barroco de una pesadilla" (Julio Ortega); propuesta como una inversión de la isla utópica racionalista "para deslizarse a la convivencia de los opuestos, hacia la antítesis barroca" (Susana Zanetti), o bien como "un reexamen de la realidad

${ }^{668}$ Ainsa, Fernando (2004). "Construcción y demolición de los sistemas celebratorios de la historia en América Latina", en: Chibán, Alicia (Coordinadora). El archivo de la independencia y la ficción contemporánea, Salta, Universidad Nacional de Salta, pp. 9-16.

${ }^{669}$ Rodríguez Juliá, Edgardo (2002). La noche oscura del Niño Avilés, Caracas, Biblioteca Ayacucho. La novela fue editada por primera vez en el año 1984 por la editorial Huracán, de Río Piedras, Puerto Rico, con una tirada muy corta. En el año 1991 la Editorial de la Universidad de Puerto Rico realiza una segunda edición de la obra, con algunas modificaciones respecto de la primera versión. La Biblioteca Ayacucho basa su edición en la del año 1984, aunque propone también algunas correcciones. Más adelante precisaré detalles acerca de las ediciones de la novela. Todas las citas textuales que incorporo corresponden a la edición de Biblioteca Ayacucho. 
histórica", como "una historia disidente" (Rubén González); como "parodia del archivo historiográfico criollo" pero asimismo como representación de un "barroco escatológico" (César Salgado); reseñada como novela de "autodevoraciones", de "un hinchado complejo barroco a punto de estallar" (César Aira), advertimos que todas estas lecturas críticas ${ }^{670}$ de La noche oscura del Niño Avilés (1984), más allá de sus diferentes enfoques y abordajes textuales, coinciden en subrayar el alto y complejo nivel de invención narrativa de la novela, su imaginación alucinada, y, me gustaría agregar, su desmesura, indudablemente vinculada al barroquismo ${ }^{671}$ de la obra, rasgo muy destacado en las citas precedentes. En este sentido se podría afirmar que en la novela opera como principio constructivo principal la proliferación barroca, en cuanto procedimiento retórico de aumento de la materia verbal, y asimismo, como variante de la amplificatio o amplificación artística de la dicción, conceptos que Irlemar Chiampi distingue de la siguiente manera:

"Amplificación y proliferación coinciden en tanto que dilatación ornamental del discurso, siempre que se entienda el aumento, no como una adjunción inerte, sino dotada de función estructural. Ambas presuponen, igualmente, un centro de irradiación de los signos, pero mientras la amplificación sostiene la centralidad de un punto de referencia, en la proliferación se tiende a multiplicarlo y a borrarlo por el movimiento exacerbado del alejamiento del foco generador." ${ }^{772}$

${ }^{670}$ González, Aníbal (1986). "Una alegoría de la cultura puertorriqueña: La noche oscura del Niño Avilés, de Edgardo Rodríguez Juliá", en: Revista Iberoamericana, núms. 135-136, abrilseptiembre, pp. 583-590; Benítez Rojo, Antonio (1996). "Niño Avilés, o la libido de la historia" (capítulo 8), en: La isla que se repite. El Caribe y la perspectiva posmoderna, ed. cit., pp. 277304, publicado anteriormente como artículo en La Torre (Nueva época), nro. 12, 1898, pp. 587-608; Ortega, Julio (1991). "Dos variaciones barrocas: Sarduy y Rodríguez Juliá", en: Reapropiaciones (Cultura y nueva escritura en Puerto Rico), ed. cit., pp. 63-65; Zanetti, Susana (1994). "Las historias fingidas de La noche oscura del Niño Avilés de Edgardo Rodríguez Juliá", en: Estudios. Revista de Investigaciones Literarias, año 2, No. 4, Caracas, jul.-dic., pp. 11-29. González, Rubén (1988). "La noche oscura del Niño Avilés”, en: Plural, nro. 204, pp. 96-102; Salgado, César (1999). "Archivos encontrados: Edgardo Rodríguez Juliá o los diablejos de la historiografía criolla", ed. cit., pp. 153-203; Aira, César (1997). "La noche oscura del Niño Avilés (Autodevoraciones)", en: Nómada, núm. 3, pp. 30-32.

${ }^{671}$ La relación entre el concepto de la desmesura y la estética barroca ha sido frecuentemente señalado por la crítica. A modo de ejemplo quisiera citar el siguiente pasaje de la especialista Aurora Egido, donde caracteriza el estilo barroco como "La estética de lo monstruoso y de lo diverso" (...) "apoyada por los logros del deleite que justificaban la amplificación y la desmesura". Véase Egido, Aurora (1990). "La hidra bocal. Sobre la palabra poética en el barroco.", en: Fronteras de la poesía en el barroco, Barcelona, Crítica, p. 94.

${ }^{672}$ Irlemar Chiampi agrega: "La compulsión por esparcir erráticamente los signos señala, asimismo, el horror vacui que ya encontramos en la amplificación, pero llevado a un grado paroxístico por el ofuscamiento del centro de convergencia. Como en muchos cuadros barrocos, 
Si antes, al referirme a La renuncia del héroe Baltasar, destaqué procedimientos tales como el exceso y la parodia, la hipérbole y el trompe l'oeil, en La noche oscura del Niño Avilés no solo se reiteran sino que se exacerban, como se advierte en su notable profusión verbal, plasmada en la importante dimensión y expansión del texto, a diferencia de la condensación y brevedad de la primera novela. Por ello insisto en su matriz proliferante, que no solo atañe a la voluminosa cantidad de páginas de la obra, sino especialmente a lo que Chiampi define como función estructural de la proliferación, su descentración o multiplicación del centro de referencia que, en este caso en particular, interesa en cuanto al funcionamiento interno del texto. La novela está construida a partir de la numerosa citación de documentos tales como diarios secretos, anónimos y apócrifos, variadas crónicas, relaciones, tratados teológicos y testimonios notariales, comentados en parte por el narradorarchivista Alejandro Cadalso, el mismo personaje conferencista de La renuncia del héroe Baltasar, pero cuyas intervenciones paulatinamente son desplazadas por otras voces narradoras, que se multiplican y proliferan en la novela a través de diferentes focalizaciones y miradas.

Antes de continuar y, para que luego pueda comprenderse con mayor claridad el funcionamiento estructural de la proliferación, intentaré describir sumariamente la compleja trama argumental de la novela. La noche oscura del Niño Avilés comienza con un prólogo firmado por el historiador Alejandro Cadalso, fechado en 1946. Refiere el hallazgo de una colección de documentos, descubierta en 1913, por otro archivista de nombre José Pedreira Murillo. La colección consta de variadas crónicas que conciernen a los eventos bélicos "ocurridos" entre 1772 y 1773 a partir del sonado caso del Niño Avilés, rescatado de entre los restos de un naufragio, y a quien se lo denomina con el nombre de su salvador, Juan Avilés. Popularmente adquiere la reputación de ser un poseído del diablo, por haberse salvado tan milagrosamente de la terrible catástrofe de la fragata Felipe II. Colocado el niño bajo la custodia del obispo Larra (también personaje principal de La renuncia...), éste aprovecha la fama diabólica del infante para manipular e intimidar a la población, para lo cual

la proliferación lingüística describe una curva elíptica o parabólica en torno al centro de representación que acaba por descentrar, creando un sistema de radiaciones centrífugas." Véase de la autora "La proliferación barroca en Paradiso", en: Chiampi, Irlemar (2000). Barroco y modernidad, México, Fondo de Cultura Económica, pp. 184-185. 
manda a construir un horroroso habitáculo que amplifica demencialmente el llanto de la criatura, sugestionando a los isleños que no pueden conciliar el sueño. La creencia en la presencia del demonio transfigurado en el Niño Avilés provoca en la población una serie de trastornos, entre ellos, el éxodo masivo de los criollos que abandonan San Juan Bautista de Puerto Rico, y una enorme rebelión de esclavos cimarrones, quienes, bajo el mando del caudillo Obatal, toman la ciudad y ocasionan la caída del gobierno de Larra, quien muere defenestrado por el ejército rebelde negro. Pero Obatal, además, se apodera del Niño para usarlo como un amuleto protector mientras intenta fundar en San Juan la utópica y libertina ciudad de las Quimbambas. Con el fin de evitar semejante anarquía se hace cargo del poder el obispo Don Felipe José Trespalacios y Verdeja, quien organiza una campaña de asedio para rescatar la plaza tomada por los negros. Paralelamente se produce una guerra civil entre los dos bandos cimarrones que se disputan el poder: uno, acaudillado por el ya mencionado Obatal, el otro, por su enemigo Mitume, antes su segundo en el mando, pero que ha decidido rebelarse por sentirse desplazado y ofendido por quien fuera su líder. Gran parte de la trama de la guerra civil entre los dos bandos es relatada a través de un juego de voces en el cual se destacan dos "cronistas": Julián Flores, conocido como el "Renegado", y Gracián, amanuense del obispo Trespalacios. El primero, aventurero y espía, actúa como doble agente infiltrándose en el reino negro donde traba amistad con Obatal y Mitume, optando finalmente por apoyar la insurrección de este último. El segundo, testigo privilegiado de las acciones de Trespalacios, oficia además como su ayudante en un acto de espectacular exorcismo donde el obispo logra expulsar una profusa cantidad de demonios de la ciudad de San Juan.

Por otra parte el historiador Cadalso refiere también el hallazgo de un retablo de pinturas, miniaturas muy detallistas que describen la fundación de una ciudad lacustre hacia finales del siglo XVIII, Ilamada Nueva Venecia, espacio utópico y visionario proyectado por el Niño Avilés hacia el año 1797 como una colonia para negros libertos y cimarrones, episodio que en la novela no se narra, aunque se lo anticipa, a través de la cita de un fragmento del diario apócrifo del pintor José Campeche. La noche oscura del Niño Avilés funcionaría entonces como el primer volumen del conjunto llamado Crónicas de 
la Nueva Venecia antes mencionado ${ }^{673}$, en cuyo prólogo Cadalso describe su proyecto editorial que consiste en develar la historia secreta y oculta de Nueva Venecia, oficialmente considerada como una leyenda por gran parte de los historiadores de sesgo positivista, quienes califican a la ciudad como "embeleco". Para refutar esta versión don Alejandro se constituye en el compilador y editor autorizado de la "Colección Pedreira", y, como señala César Salgado "(...) selecciona, compila, transcribe, analiza, combina y ordena documentos", aunque "no cuestiona, modifica, resume, ni abrevia" ${ }^{674}$ los textos recogidos. De allí que notemos en esta novela que, a diferencia de La renuncia del héroe Baltasar, la voz del historiador se adelgaza paulatinamente, reemplazada por el vasto discurrir documental y por la intervención de otras voces de enunciación.

En efecto, en el prólogo y los cuatro primeros capítulos del texto, si bien los hechos se dan a conocer a través de la citación directa de diversas fuentes y documentos, sin embargo éstos son mediados y comentados a través de una misma instancia enunciativa: la del historiador Alejandro Cadalso. Pero a partir del capítulo $\mathrm{V}$ y hasta el final de la obra, se minimizan las intervenciones de Cadalso, produciéndose una proliferación de tipo narracional ${ }^{675}$, que consiste en la multiplicación de los signos de la enunciación. Encontramos entonces diversos narradores "cronistas", entre los cuales se destacan, por un lado, los ya mencionados Gracián y Julián Flores, el "Renegado", ambos a cargo de la trama principal del relato, y por otro, una suma de diferentes voces: Severino Pedrosa y Don Gaspar de Sotomayor, cronistas de Cabildo; Don Vicente Huerta de León y el Niño Pimentel, secretarios del malhadado Obispo Larra; Don Ramón Cruz Cepero, médico del Cabildo; Don Juan de Urrutia, cronista de la Capitanía. Además se interpolan en la novela diversos "diarios" ${ }^{\text {"676 }}$, como el

\footnotetext{
${ }^{673}$ Este episodio formaría parte de una tercera novela de Rodríguez Juliá de la proyectada trilogía Crónicas de la Nueva Venecia, como antes expliqué. Véase para más detalles la nota 6 del presente capítulo.

${ }^{674}$ Salgado, César (1999). “Archivos encontrados: Edgardo Rodríguez Juliá o los diablejos de la historiografía criolla", ed. cit., pp. 179 y 182 respectivamente.

${ }^{675}$ En mi descripción de una tipología de distintos modos de manifestarse la proliferación en $L a$ noche oscura del Niño Avilés me ha resultado sumamente fecundo el citado artículo de Irlemar Chiampi "La proliferación barroca en Paradiso" (véase nota 77). Sigo algunas de sus categorías y propongo también otras.

${ }^{676}$ En efecto, el capítulo I de La noche oscura... se inicia con la cita del texto apócrifo de un personaje histórico como lo fue el pintor José Campeche, titulado pomposamente Diario de la
} 
del Obispo Trespalacios, cuyo discurso mesiánico se manifiesta en su Diario Secreto. Las voces enunciadoras de los documentos citados producen un efecto narrativo particular, en tanto parte de los hechos parecieran "narrarse solos", como señala Salgado677. Se observan también las intervenciones de una tercera persona, por momentos omnisciente ${ }^{678}$, a cuyo cargo se trama el relato, muy descriptivo y moroso, de la construcción de la torre, testimonio de la ciudad utópica proyectada por el Niño Avilés y construida por el arquitecto leproso, figura que evoca al personaje de Juan de Espinosa de la novela anterior. Este episodio, narrado elíptica y fragmentariamente, aparece interferido por una primera persona que encarna la voz del arquitecto. A esta compleja red de múltiples instancias de enunciación se le suma, desde el capítulo primero de la novela, otra perspectiva más: los comentarios crípticos y paratextuales, breves poemas en prosa, firmados con las iniciales A.J.M., que corresponden al poeta Alejandro Juliá Marín, también presente en La renuncia del héroe Baltasar.

El efecto que produce esta proliferación narrativa dispersa el centro de convergencia del discurso, difuminándose no solo la presencia autorial de Cadalso sino también la configuración de la (autor)idad narrativa de la obra. Sin embargo, como ya lo había sugerido Rubén Ríos Ávila ${ }^{679}$ al señalar la función del personaje-narrador del historiador como un alter ego del escritor en la primera novela de Rodríguez Juliá, en La noche oscura del Niño Avilés la presencia del autor no desaparece del todo. Emerge en parte en un gesto autobiográfico en clave de humor: en el prólogo firmado por Alejandro Cadalso

muy apoteósica fundación de Nueva Venecia. Hallamos también fragmentos de un Diario anónimo como asimismo otro texto inventado, el ficticio Diario Secreto de otro personaje histórico como lo fue el obispo Trespalacios y Verdeja. Más adelante detallaré cómo el autor recurre al mismo procedimiento utilizado en su primera novela: la técnica del montaje, donde varios referentes históricos se desubican o se recolocan y se reordenan anacrónicamente.

${ }^{677}$ Salgado, César (1999). “Archivos encontrados: Edgardo Rodríguez Juliá o los diablejos de la historiografía criolla”, ed. cit., p. 177.

${ }^{678}$ Edgardo Rodríguez Juliá caracteriza la figura del narrador de su novela de la siguiente manera: "En La noche oscura logro una auténtica voz omnisciente, sin el rebuscamiento de la distancia absoluta que en La renuncia se logra a través del conferenciante; también insisto en una omnisciencia mediatizada por las distintas voces que llevo adentro, esa multitud de escritores que son como las distintas voces de un parodista, que ansían, como me señalaba Vivas Maldonado, una voz única. Me siento cómodo con la primera persona y la ilusión de una tercera." Véase del autor el texto autorreflexivo "A mitad de camino", incluido en: Rodríguez de Laguna, Asela (ed.) (1985), Imágenes e identidades: el puertorriqueño en la literatura, Río Piedras, Huracán, p. 135.

${ }^{679}$ Véase al respecto la nota número 9 de este capítulo. 
se indica el día 9 de octubre del año 1946, fecha de nacimiento de Edgardo Rodríguez Juliá. Por otro lado interviene a través de alusiones y anacronismos deliberados que alteran tanto la textualidad cronística dieciochesca como la discursividad historiográfica de Cadalso, acercándose más bien al estilo peculiar de las crónicas contemporáneas analizadas antes ${ }^{680}$. Notamos entonces que, dentro del múltiple abanico de voces enunciadoras, se infiltra una en particular, que se manifiesta en modulaciones léxicas muy características de la jerga urbana callejera y marginal de las drogas. Esta apertura de la novela hacia el ámbito de la oralidad se observa también en las referencias a las expresiones musicales contemporáneas al presente de la escritura de la novela: plenas, salsas, ritmos caribeños provenientes de los sectores populares. De esta manera La noche oscura... constituye un complejo tramado de diferentes voces y fuentes, escritas y orales, que se superponen, interceptan, alternan, interpolan, promoviendo la ubicuidad de la voz narrativa responsable de la enunciación del texto.

A esta proliferación de tipo narracional se le añade otra: la llamada sintáctica, caracterizada por Irlemar Chiampi como la que desvía el curso de la narrativa por la inserción de un relato que, al extenderse desmesuradamente provoca la dispersión de la trama central. Uno de los ejemplos más claros en la novela de Rodríguez Juliá lo encontramos en el episodio narrado y protagonizado por el cronista Julián Flores, el "Renegado", quien relata un extraño viaje a las tierras del Jardín de Yyaloide, guiado por su amante negra, la "reina del África". El caudillo Obatal había encomendado al cronista una misión de embajada ante el rebelde Mitume, para lo cual emprende un intrincado recorrido acompañado por la mujer de origen africano. Así como el

\footnotetext{
${ }^{680} \mathrm{Si}$ atendemos a la respuesta que Rodríguez Juliá le brinda a su entrevistador Julio Ortega, se advierte que para el autor la relación entre pasado y presente entrelaza el universo novelesco de sus obras con sus crónicas de actualidad. Léase el siguiente pasaje: "La historiografía tradicional, el historicismo, el positivismo histórico, aún modelan esa gran vaca sagrada que conocemos como Historia. La novela La noche oscura es irreverente con esa historia porque se niega a mirar el pasado desde el pasado. Mi novela intenta un diálogo con ese pasado como significación para nosotros, para el presente. Ese diálogo, esa interlocución tiene que ser, por lo tanto, sincrónico y ucrónico, un espacio de congregación para todas las voces y poses, actitudes y modos, que me explique la actual agresividad y resentimiento de un joven lumpen y mulato de Villa Palmeras desde las coordenadas de una revuelta de esclavos en el dieciocho. (...) En vez de nombrar a mis héroes Obatal y Mitume, los debí llamar Rafael Cortijo e Ismael Rivera." Véase Ortega, Julio (1991). "1. Crónica de entierros, ficción de nacimientos", entrevista a Edgardo Rodríguez Juliá, ed.cit., pp. 154-155.
} 
itinerario espacial se bifurca y enreda hasta llegar al utópico vergel de Yyaloide, paralelamente el relato del viaje se fragmenta en una serie de capítulos impares (XIII, XV, XVII, XIX, XXI), hasta culminar en el capítulo XXIII, donde el Renegado pierde definitivamente a su amada y se desvanece toda posibilidad de permanecer en las tierras arcádicas. Estos capítulos constituyen en sí una historia alterna que se desvía de la fábula principal, donde se narran los preparativos de lo que será la gran batalla cimarrona entre Obatal y Mitume, como así también el asedio que impone Trespalacios a la ciudad tomada. Por otra parte la utopía arcádica y su imposibilidad de concreción reaparecen en la tercera novela dieciochesca, El camino de Yyaloide, que recrea el mismo espacio paradisíaco como uno de los puntos de estadía del viaje iniciático emprendido por el Niño Avilés, ya adolescente.

Pero la inserción de este relato condensa también otras significaciones, que se despliegan a lo largo de toda la novela. Por una parte la relación entre el cronista blanco criollo y la mujer negra articula, a través de las metáforas sexuales y eróticas, conflictos y tensiones étnicas complejas respecto de los orígenes y conformación de una comunidad imaginada ${ }^{681}$ puertorriqueña hacia fines del siglo XVIII, en una sociedad todavía colonial y esclavista, que contiene a su vez sutiles alusiones a la situación del presente isleño, en especial respecto de la vigencia de prejuicios de clase y de etnia. Por otra parte la historia de la joven negra permite el ingreso del sueño utópico cimarrón del retour, para apelar a la categoría analizada por Édouard Glissant a la que hicimos referencia en el primer capítulo de nuestra tesis: la pulsión o impulso de retorno a la tierra ancestral, al África ${ }^{682}$. La mujer, cuyo nombre propio Johari- solo se revela hacia el final del episodio, cobra dimensiones mágicas y religiosas a lo largo del relato. Aparece asociada a divinidades africanas tales como Yemayá, diosa de los mares y también Ochún, diosa de los ríos, conocida como la Venus del panteón yoruba ${ }^{683}$, ambas estrechamente vinculadas al erotismo, la fertilidad, el amor. A su vez, como explica Antonio Benítez Rojo, Ochún se muestra como una divinidad múltiple y contradictoria:

\footnotetext{
${ }^{681}$ Me refiero al concepto trabajado por Benedict Anderson, explicado en el capítulo II, véanse especialmente pp. 54-55.

${ }^{682}$ Véase el capítulo I , el apartado dedicado a Édouard Glissant, pp. 9 y siguientes.

${ }^{683}$ Véase Cabrera, Lydia (1974). Yemayá y Ochún: Kariocha, Iyalorichas y Olorichas, Madrid, Colección del Chicheruku en el Exilio.
} 
"Porque aquella imagen milagrosa del altar era para ellos uno de los orichas más populares del panteón yoruba: Ochún Yeyé Moró, la prostituta perfumada; Ochún Cayode, la alegre bailadora; Ochún Aña, la que ama los tambores; Ochún Akuara, la que prepara filtros de amor; Ochún Edé, la dama elegante; Ochún Fumiké, la que concede hijos a las mujeres secas; Ochún Funké, la que lo sabe todo; Ochún Kolé-Kolé, la temible hechicera". ${ }^{84}$

Para el Renegado la mujer africana ocupa alternadamente varios de estos roles, quedando peligrosamente sujetado al deseo que le provoca: "Más que deseoso estaba de tenerla ante mis ojos, a la reina de África que sin aviso y sin piedad me había robado el corazón, ya que no el albedrío." "Su pasión no deja de ocultar la incertidumbre que le provoca ese cuerpo otro, cuya alteridad enigmática es controlada a través de la demonización de la mujer, representada como bruja y hechicera:

"Corrió a la playa, a buscar caracoles, regresando a mí con risillas y travesuras. Todo esto me asustaba, y pensé que la diabla, aquella bruja de la harto lejana África, a poco me mataría, dejándome estirado como un bunbún sobre la arena, con los pies mirando al cielo."

A medida que el Renegado pierde el rumbo camino a cumplir con su embajada, quien se constituye en su guía es la mujer. Su agudo sentido de la orientación la vincula a otra divinidad yoruba, esta vez masculina, Eleggua, deidad viajera, señor de los caminos y las encrucijadas: "En cosas de brújula y orientaciones la etíope es el más agudo ingenio que jamás he visto, verdadera bruja de los caminos." ${ }^{687}$ Paulatinamente, mientras transcurre el viaje, se produce una inversión de los roles de género tradicionalmente asignados a la mujer y al varón ${ }^{688}$. El cronista se vuelve pasivo y dominado, y la joven, por el

\footnotetext{
${ }^{684}$ Benítez Rojo, Antonio (1996). "Introducción", en: La isla que se repite. El Caribe y la perspectiva posmoderna, ed.cit., p. xx. Benítez Rojo asocia esta divinidad yoruba a la griega Afrodita, ya que ambas "son a la vez luminosas y oscuras; reinan en un espacio donde coincide el placer y la muerte, el amor y el odio, la voluptuosidad y la traición." (p. xx).

${ }^{685}$ Rodríguez Juliá, Edgardo (2002). La noche oscura del Niño Avilés, ed.cit., p. 99.

${ }^{686}$ Ibid., p. 196.

${ }^{687}$ Rodríguez Juliá, Edgardo (2002). La noche oscura del Niño Avilés, ed.cit ., p. 221.

${ }^{688}$ Como agudamente sintetiza Josefina Ludmer respecto de las oposiciones binarias de género: "Se sabe que en la distribución histórica de afectos, funciones y facultades (transformada en mitología, fijada en la lengua) tocó a la mujer dolor y pasión contra razón, concreto contra
} 
contrario, asume el mando: sabe manejar las riendas del coche a caballos, provee comida y agua dulce, conoce las encrucijadas para llegar al vergel de Yyaloide, tierra que significativamente quiere decir "en lengua africana, mujer jefe"689.

El relato ocupa un lugar central en la estructura de la novela: se inserta hacia la mitad de la obra (el episodio de Yyaloide, como antes señalé, se cierra en el capítulo XXIII de los cuarenta y ocho que componen La noche oscura...), pero su relevancia consiste especialmente en erigir una imagen altamente utópica y por ello mismo imposible del sueño cimarrón de retorno a las raíces, a la tierra originaria, experiencia incapaz de ser plenamente compartida o siquiera comprendida por el sujeto blanco. Como explica Glissant, la primera pulsión de una población transplantada que no está segura de poder mantener en el lugar de su traslado el antiguo orden de su valores, es la del Retorno (Retour) a África: "El Retorno es la obsesión de lo Uno: no hay que cambiar el ser." ${ }^{690}$ En los capítulos que preceden al relato del viaje a Yyaloide el Renegado, en su carácter de cronista testigo, describe con detalle pero también con mirada escéptica, no exenta de ironía, otra importante escena de retour: la fundación del reino negro llevada a cabo por el caudillo Obatal en la plaza de San Juan Bautista. Como un acto de restauración del orden ancestral, los esclavos más ancianos, originarios de África, aclaman entre sus descendientes, a sus nuevos reyes y reinas, en un intento infructuoso de recrear en el nuevo espacio y tiempo, lo que la esclavitud había devastado:

"Fíjense ustedes que aquella era la más grande celebración desde que Obatal se hizo dueño del poder, pues en ésta la gente de las distintas tribus de África aclamarían a sus reyes y reinas. Digo que era la restauración de la dignidad de todo un pueblo, ni más ni menos, expulsado cruel y salvajemente de su muy lejana África por la pólvora europea. En aquella plazoleta se anudarían lazos con la antiquísima tradición que la crueldad del blanco había destruido."

\footnotetext{
abstracto, adentro contra mundo, reproducción contra producción." Véase de la autora "Tretas del débil”, en: González, P. y Ortega E. (eds.). La sartén por el mango, San Juan. Huracán, 1984, p. 17.

${ }^{689}$ Rodríguez Juliá, Edgardo (2002). La noche oscura del Niño Avilés, ed.cit ., p. 194.

${ }^{690}$ Glissant, Édouard (1997). Le discours antillais, París, Éditions Gallimard, p., p. 44.

${ }^{691}$ Rodríguez Juliá, Edgardo (2002). La noche oscura del Niño Avilés, ed.cit ., p. 73.
} 
Si el fragmento precedente sugiere una mirada compasiva por parte del cronista, en otros pasajes se revela en cambio la burla, una ironía desengañada que describe la ceremonia como una representación teatral y fantasmagórica, que procura mantener precariamente una tradición de mando pero que carece de poder real: los nuevos reyes y reinas del África no gobiernan en el territorio americano sino que están sujetos a una nueva tiranía, no ya la del hombre blanco esclavista sino paradójicamente la del caudillo plebeyo y negro Obatal: "Todos sabíamos que eran reinos de fantasía, pero poco engañosa era la felicidad de hallarse libres. $Y$ era lo más preciado de reinos tan tiernos que la tiranía no podía brotar en sus ámbitos. Y aquellos eran los reyes más queridos, pues solo gobernaban sobre la ilusión de libertad." "692 Fantasía, ternura e ilusión de libertad que terminan bruscamente en una matanza perpetrada por Obatal, quien construye su poder mediante la crueldad y el terror. En este sentido el personaje del caudillo comparte con el antihéroe Baltasar de la primera novela de Rodríguez Juliá, rasgos de alienación y resentimiento, que lo llevan a actuar violentamente contra su propio pueblo. El sueño del retorno al África termina cínicamente convertido en una pesadilla oscura y siniestra que subvierte la luminosa ceremonia de restauración, transformada en cruel genocidio:

"...y fue que allá abajo, en la más baja plazoleta de San Felipe de Morro, vi los cuerpos destrozados de los que quisieron ver la bella restauración de los reinos africanos. Había miles de cuerpos rotos por la dura piedra, y las bajas troneras que desembocan en el roquedal habíanse convertido en canales de sangre. Todos aquellos desgraciados lucían posturas imposibles para el humano continente, y era que tantos huesos rotos obligaban a grande burla de la semejanza de Dios, ya que así también de su imagen. Y luego, por largo rato, contemplé aquel fracaso de la libertad." $" 993$

La utopía del regreso condensada en el ritual africano de reyes y reinas deviene entonces anti-utopía, y anticipa también el fracaso de las distintas visiones utópicas que se trazan a lo largo de la novela, entre ellas, la de Yyaloide. Johari había sido una de las reinas de aquella ceremonia de

\footnotetext{
${ }^{692}$ Ibid., p. 76.

${ }^{693}$ Rodríguez Juliá, Edgardo (2002). La noche oscura del Niño Avilés, ed.cit ., p. 78.
} 
restauración, proviniendo su consorte de la tribu africana de los lbos, caracterizada por su rebeldía ante la esclavitud y por sus acciones constantes de cimarronaje. Ante la violencia desatada y temiendo volver a ser sometido a la esclavitud, el muchacho se suicida, poniendo en escena una de las aporías del anhelado retorno: la muerte como retour, como camino trágico pero liberador de la esclavitud, “...el rey quiso matarse para lograr la libertad ansiada; es creencia de los lbos que en la muerte hacen travesía de regreso a las tierras de África."694

Para llegar a Yyaloide el Renegado y su acompañante se desvían del itinerario original, pero se sugiere más bien que el desplazamiento ${ }^{695}$ que realizan se mueve en círculos, como si atravesaran no espacios contiguos sino superpuestos, uno real, el otro mítico, de allí que el cronista pierda asimismo la noción de la temporalidad ${ }^{696}$. En tanto Julián Flores solo percibe la naturaleza caribeña como obstáculo, plagada de mangles, marismas, pantanos, palmares, sol abrasador, la joven, en cambio, lee en ese mismo paisaje los signos de un espacio otro ${ }^{697}$ que simbolizan su tierra originaria, al cual el escepticismo del Renegado califica como quimera, reproduciendo irónicamente en su discurso

\footnotetext{
${ }^{694}$ Ibid., p. 238.

${ }^{695}$ Estos pasajes de La noche... oscura dialogan intertextualmente con la novela Los pasos perdidos (1953) de Alejo Carpentier, donde asistimos a un mítico viaje a la otredad caribeña, protagonizado por un musicólogo europeo que también se deja guiar por una mujer, en este caso, nativa, de nombre Rosario, quien le revela el lugar de la ciudad oculta en la selva, Santa Mónica, espacio edénico y adánico, finalmente reino prohibido al cual el sujeto blanco y europeo no puede regresar jamás. Véase Carpentier. Alejo (1985). Los pasos perdidos, Madrid, Cátedra.

${ }^{696}$ Véase el siguiente pasaje de la novela: "Más hacia la costa, a distancia de un disparo de arcabuz, vi la encrucijada donde nuestro viaje se extravió... Parece que hemos vagado en círculos... No pude entender cómo habíamos estado tantísimo tiempo en la tierra de Yyaloide, pues el cruce quedaba a corta distancia del mogote." (La noche oscura del Niño Avilés, ed.cit ., p. 244).

${ }^{697}$ Fernando Aínsa señala que: "La utopía es siempre dualista en tanto concibe y proyecta una contra-imagen cualitativamente diferente de las dimensiones espacio-temporales del presente. Toda utopía presupone el rechazo del tiempo presente o del lugar (espacio) donde se vive, cuando no de ambos a la vez, y la representación de un territorio que está en 'otro lugar' (otro espacio) u 'otro tiempo', pasado o futuro." En este sentido Yyaloide representa un espacio utópico, en tanto remite a la idea de un territorio que está en otro lugar (África). Sin embargo se proyecta en suelo americano, lo cual lo vuelve también un espacio cimarrón, donde la naturaleza montaraz esconde, protege y aísla. Véase Aínsa, Fernando (1999). La reconstrucción de la utopía, Buenos Aires, Ediciones del Sol, p. 37.
} 
los arquetipos míticos y legendarios a través de los cuales se proyectaba el suelo americano en el vasto corpus de Crónicas de Indias ${ }^{698}$ :

"Pero nada de aquello entendí; ella hablaba como si hubiéramos descubierto el sitio de El Dorado, o la muy codiciosa fuente de la juventud, tierras de todos los lares, anhelos del mundo. (...) También me dijo que aquel vergel era la tierra de las aguas dulces. Cuando me lo repitió no pude sino reírme; a nuestro alrededor solo había mangles y pantanos, playas donde la sal espesaba el aire."699

Johari se constituye también en una suerte de Beatriz negra ${ }^{700}$, con la capacidad de guiar, develar e incluso vedar al cronista viajero la posibilidad del paraíso. En su tierra de Yyaloide despliega la desnudez edénica de su cuerpo en armonía con la naturaleza, recupera su lengua materna a través del canto de melodías en lengua africana, se reencuentra con Mato, un manatí domesticado que la transporta a la inocencia de la infancia y puede lograr, aunque fugazmente, la ansiada libertad. La descripción de Yyaloide donde se conjuga la belleza del paisaje, tanto natural como humano, se construye mediante otra imagen arquetípica de América que inaugura el Diario colombino del primer viaje: la del tópico clásico del locus amoenus. Fertilidad, abundancia y la promesa de riquezas despiertan la codicia de los primeros conquistadores y en este sentido el Renegado se identifica con la crueldad del europeo conquistador, cuyo objetivo principal era el hallazgo de oro. Poseído por la sed del enriquecimiento fácil se hunde en supersticiones que afirman que bajo la frente de un manatí se esconde una piedra preciosa, de valor incalculable y

\footnotetext{
${ }^{698}$ Como señala Margarita Zamora, América se había presentido en la imaginación occidental incluso antes del primer viaje colombino: "Bajo nombres como Tule, Antilia, las Hespérides y la Atlántida se había inscripto en los lenguajes del mito, la leyenda y las profecía." Véase de la autora "Todas son palabras formales del Almirante': Las Casas y el Diario de Colón”, Hispanic Review nro. 57, año 1989, p. 25. Al respecto remito al clásico ensayo de Alfonso Reyes, "Última Tule", Obras completas, Tomo XI, México, FCE, 1960 y también a los estudios de Fernando Aínsa, Los buscadores de la utopía, Caracas, Monte Ávila, 1977; De la edad de oro a El Dorado. Génesis del discurso utópico americano, México, FCE, 1992 y el volumen antes citado La reconstrucción de la utopía (1999). Aínsa señala el peso de mitos y espacios imaginarios que reaparecen en la descripción del territorio americano tales como la Edad de Oro, el Paraíso Terrenal, El Dorado, las Amazonas, la Fuente de Juvencia, la Ciudad de los Césares, entre otros.

${ }^{699}$ Rodríguez Juliá, Edgardo (2002). La noche oscura del Niño Avilés, ed.cit ., p. 194.

${ }^{700}$ Julián Flores, en un episodio que se narra antes del viaje a Yyaloide, ha sido guiado por Mitume al llamado reino de las Quimbambas, campamento libertario de Obatal, cuya descripción remeda el descenso a los infiernos dantesco, cuestión que retomo más adelante.
} 
propiedades curativas, provocando con su actitud ambiciosa y violenta el resquebrajamiento del mundo armónico recién alcanzado: "Y durante la noche asomó la codicia; donde hubo armonía, surgió la discordia, que ya no hubo tregua en el mundo, pues el pez volvió al mar y el hombre pobló de tristeza y desolación el páramo de su alma."

El vergel se transforma en espacio de la violencia y del abuso del sujeto blanco, cuando Julián Flores asesina con vileza a Mato, sin poder retornar sobre sus "pasos perdidos" a la ruta del paraíso que le franqueara Johari. El final del episodio de Yyaloide remite intertextualmente a otro paraíso. Me refiero a la monumental novela de José Lezama Lima, Paradiso, particularmente al capítulo III que relata las relaciones entre el joven Andrés Olaya y el millonario Elpidio Michelena, en Cuba. En una secuencia retrospectiva que actúa como matriz proliferante de un largo relato se detallan en la novela lezamiana las orgías de Michelena en su finca, que culminan en el asesinato de un manatí hembra, al igual que Mato, de nombre Isolda, cuya muerte conduce finalmente a la ruina al millonario ${ }^{702}$. Tanto el relato inserto en Paradiso como el narrado en la novela de Rodríguez Juliá constituyen ejemplos de proliferación sintáctica, donde, con palabras de Irlemar Chiampi, el movimiento dispersivo de la proliferación narrativa cesa cuando el texto recobra su centro de convergencia, es decir, cuando establece la relación de causalidad entre lo proliferante y lo proliferado $^{703}$. Así en La noche oscura del Niño Avilés el capítulo XXIII cierra el episodio de Yyaloide, para reencausar la trama hacia las acciones bélicas de la novela: por una parte la gran batalla entre Obatal y Mitume; por la otra, el sitio y la acometida militar del obispo Trespalacios para rescatar la ciudad de San Juan de la dominación cimarrona.

Antonio Benítez Rojo señala que en la larga tradición literaria que narra las expediciones a El Dorado se puede observar una tipología de tres clases de escritores/viajeros ${ }^{704}$. Aquellos que regresan de la aventura afirmando su imposibilidad, caracterizados por una extremada lucidez que los previene de

\footnotetext{
${ }^{701}$ Rodríguez Juliá, Edgardo (2002). La noche oscura del Niño Avilés, ed.cit ., p. 248.

${ }^{702}$ Véase de Lezama Lima, José (1988). Paradiso, especialmente capítulo III, edición crítica coordinada por Cintio Vitier, México, Archivos.

${ }^{703}$ Chiampi, Irlemar (2000). "La proliferación barroca en Paradiso", ed. cit., p. 186.

${ }^{704}$ Benítez Rojo, Antonio (1996). (1996). La isla que se repite. El Caribe y la perspectiva posmoderna, ed.cit., p. 201.
} 
adentrase por la senda engañosa de los espejismos. Una segunda categoría en la que se encuentran los que alcanzaron la estremecida visión del espacio maravilloso, pero sólo por un instante y jamás lograron repetir la experiencia. Finalmente, aquellos que retornan con la razón perdida, afirmando que la visión de la ciudad áurea se ha quedado impresa con ellos para siempre. Si trazamos una analogía entre éstos y aquellos viajeros-escritores que han entrevisto el paraíso, al Renegado el edén se le revela, en un primer momento, como espacio mítico, territorio perdido inexorablemente, visión irrepetible y velada para siempre, utopía en el sentido que le asigna Fernando Aínsa, inevitablemente enraizada con la imagen del Paraíso perdido ${ }^{705}$. En un segundo momento Yyaloide se constituye en imagen obsesiva que lo conduce paulatinamente a la pérdida de la razón y la lucidez, tornándose sus escritos retazos ininteligibles, fantasmales y difusos.

\section{VI.2.2 La proliferación espacial: ciudades invisibles, territorios de la utopía, lugares de sueños y pesadillas, sitios de la memoria y el olvido en \\ La noche oscura del Niño Avilés}

"Ocurre con las ciudades lo que en los sueños: todo lo imaginable puede ser soñado, pero hasta el sueño más inesperado es un acertijo que esconde un deseo, o bien su inversa, un temor. Las ciudades, como los sueños, están construidas de deseos y temores, aunque el hilo de su discurrir sea secreto, sus normas absurdas, sus perspectivas engañosas, y cada cosa esconda otra."

invisibles

Italo Calvino, Las ciudades

\footnotetext{
${ }^{705}$ Aínsa, Fernando (1992). De la edad de oro a El Dorado. Génesis del discurso utópico americano, ed. cit., p. 15.
} 
En el bellísimo libro Las ciudades invisibles de Italo Calvino ${ }^{706}$ el viajero veneciano Marco Polo le relata al emperador melancólico Kublai Kan el itinerario de sus viajes y le describe una serie de ciudades imaginarias, fuera del espacio y tiempo reales, urbes inventadas, metafóricas, ciudades ocultas e invisibles que cobran dimensión y solo se nos muestran en el lugar de la palabra literaria, de la ficción, en el cuerpo del texto. Polo narra visiones y éstas, como señala el epígrafe, se asemejan a los sueños, bajo cuya superficie se revela otro sentido. De allí que Calvino advierta en el prólogo de su libro sobre una dimensión dual de la urbe: por un lado, la ciudad utópica, construida de deseos, de sueños, que aunque no se la descubra no puede dejar de buscarse, y por el otro, la ciudad infernal, oculta, edificada de temores, de pesadillas. En La noche oscura del Niño Avilés, el personaje historiador, don Alejandro Cadalso, se declara "partidario de esta ciudad invisible" ${ }^{\text {"707, }}$ refiriéndose con tal epíteto a la mítica y libertaria Nueva Venecia que fundara el Avilés en 1797. Citando el vasto acopio de fuentes documentales y cronicones que conforman su archivo, Cadalso reproduce los diversos nombres y fórmulas que dan cuenta de la mítica ciudad como "ciudad lacustre", "monstruous city", "ciudad maldita", "desaforada visión utópica", "embeleco", "quimera", "pandemónium", en definitiva, espacio dual que conjuga el deseo y el temor, la utopía y el infierno, el espacio real y el invisible subrayados por Calvino en su libro y que el historiador de la novela condensa de la siguiente manera:

"Lo cierto es que Nueva Venecia también desapareció de la memoria colectiva del pueblo, ya para siempre desterrada al olvido, convertido su recuerdo en pesadilla de la historia, borrada de libros y canciones su breve posadura en el tiempo. Nueva Venecia se convertía así en oscuro reverso de nuestra pacífica y respetable historia colonial. Era el miedo agazapado tanto en el colono como en el colonizado, el riesgo inherente a todo esfuerzo libertario, el peligro implícito en cualquier dominación.,708

\footnotetext{
${ }^{706}$ Calvino, Italo (2002). Las ciudades invisibles, Madrid, Siruela, segunda edición (publicado originalmente en 1972).

${ }^{707}$ Rodríguez Juliá, Edgardo (2002). La noche oscura del Niño Avilés, ed.cit ., p. 18.

${ }^{708}$ Rodríguez Juliá, Edgardo (2002). La noche oscura del Niño Avilés, ed.cit ., p. 19.
} 
El libro de Calvino se revela en la novela de Rodríguez Juliá como intertexto privilegiado. Provee imágenes que contribuyen al diseño de los múltiples espacios que se superponen en La noche oscura..., donde se describen sucesivamente la ciudad oculta, la ciudad aérea, la ciudad arcádica, la civitas diaboli, la ciudad utópica, es decir, una concepción de la ciudad como aquella que contiene todas las urbes imaginables, muy similar a la propuesta del escritor italiano. Las referencias más claras a Las ciudades invisibles aparecen particularmente en los paratextos firmados por Alejandro Juliá Marín, comentarios cuya prosa poética se construye a partir de breves estampas que conjugan imágenes visuales y reflexiones variadas, de estilo semejante a los relatos de Calvino ${ }^{709}$. Procuro detenerme entonces en la particular proliferación del espacio que se produce en la novela de Rodríguez Juliá, para analizar las diversas significaciones de las ciudades invisibles que coexisten, se vislumbran, se ocultan y emergen entre las páginas de La noche oscura del Niño Avilés.

\section{- El reino de las Quimbambas o la ciudad cimarrona}

"Es una expresión corriente en España la de decir los quintos infiernos para significar un lugar de lejanía inmensa, inalcanzable como en Cuba decimos con vulgar afronegrismo: en las Kimbambas o en las Kimbámbulas."

Fernando Ortiz, Historia de una pelea cubana contra los demonios

Julián Flores se constituye en el cronista privilegiado del mundo negro, ya que es uno de los pocos blancos a quien se le permite el acceso al campamento del caudillo Obatal, erigido en la abandonada ciudad de San

\footnotetext{
${ }^{709}$ Véanse, para ejemplificar esta conjunción estilística entre los textos de Calvino y los paratextos de la novela de Rodríguez Juliá, los dos siguientes ejemplos: "Muchos hombres han visitado la ciudad que presentimos con cada paso, la estancia luminosa que esperamos encontrar a la vuelta de la esquina, consuelo del incesante peregrino. Conocerás a los hombres según la nostalgia que sientas por aquel espacio perfecto, una vez entrevisto allá al fondo de la oscura calle." (La noche oscura del Niño Avilés, ed.cit ., p. 164) "La ciudad se te aparece como un todo en el que ningún deseo se pierde y del que tú formas parte, y como ella goza de todo lo que tú no gozas, no te queda sino habitar ese deseo y contentarte. Tal poder, que a veces dicen maligno, a veces benigno, tiene Anastasia, ciudad engañosa (...)" (Las ciudades invisibles, ed.cit., p. 27.)
} 
Juan, y, posteriormente, se le franquea también el paso al campamento de Mitume, en los caños de Miraflores, espacios que representan el palenque cimarrón como sitio de la contralegitimidad. Anteriormente señalé que la trama principal de la novela está sujeta a la doble mirada de este narrador y de un segundo cronista, Gracián, cuyas perspectivas establecen un particular contrapunto sobre los mismos episodios, que ambos interpretan de modo diferente. Julián Flores, el Renegado, en consonancia con el seudónimo con el cual se lo reconoce, es un marginado, emparentado con los personajes de la novela picaresca ${ }^{710}$ : "En la guarnición he sido aguador, alcahuete, secretario de capitanía, miliciano, mendigo, cronista, embustero, sastre, cocinero (...)."711 Como subraya Susana Zanetti su estatuto como cronista es ambiguo:

"Al igual que los otros cronistas, sabe que el buen cumplimiento de su función descansa en la distancia que sea capaz de colocar entre su tarea de relatar los hechos y el inmiscuirse en ellos (...); sin embargo, se entrega a la aventura del bando cimarrón en todas sus dimensiones." 712

Si el Renegado es quien se hace cargo de la dimensión épica del relato, Gracián, en cambio, no traspone los límites de su función, mantiene prudentemente la distancia, ayudado por catalejos, periscopios, lupas y otros instrumentos ópticos que median entre su mirada y los hechos narrados:

\footnotetext{
${ }^{710}$ En el género picaresco el protagonista es un individuo marginal, que se desplaza por la sociedad aprendiendo y experimentando varios papeles y oficios, donde además, en su rol de narrador, relata su propia vida al estilo de una confesión. La novela picaresca tiene también la estructura de un relato de viaje, no solo en sentido literal sino también simbólico: la búsqueda de un paraíso, inexistente o perdido. Por medio de la sátira el narrador picaresco critica la sociedad de su presente, desenmascarando aspectos negativos de la misma. En la novela de Rodríguez Juliá el cronista Julián Flores se desplaza constantemente, ocupando diversos roles como los que se advierten en el pasaje citado (además es doble agente, espía para Trespalacios pero a la vez brinda sus servicios a Obatal y luego a Mitume), transita la experiencia de la utopía y el paraíso perdido, incluye pasajes confesionales, como por ejemplo sus sentimientos amorosos hacia Johari, critica los excesos de poder que encarnan los caudillos. Sobre las características del género picaresco véanse el detallado artículo de Sharon Magnarelli, " "El camino de Santiago' de Alejo Carpentier y la picaresca", Revista Iberoamericana, vol. XL, enero-marzo, 1974, n. 86, pp. 67-86 y el clásico estudio introductorio de Francisco Rico en: La novela picaresca española, Barcelona, Planeta, 1967, pp. IX-CLXXXIX.

${ }^{711}$ Rodríguez Juliá, Edgardo (2002). La noche oscura del Niño Avilés, ed.cit ., p. 135.

712 Zanetti, Susana (1994). "Las historias fingidas de La noche oscura del Niño Avilés de Edgardo Rodríguez Juliá", ed. cit., pp. 25-26.
} 
"Entonces montamos sobre la tarima grande asombro, por mi madre, y aseguro que era un catalejo con forma de chimenea. Aquel monstruo mecánico se alzó cual jirafa por encima de la fronda del cayo, y cuando encontraba el blanco sobre el follaje torcía el pescuezo en agudo ángulo, truco prodigioso que nos permitía ver el jaleo en los otros canales sin necesidad de delatar nuestra presencia." ${ }^{713}$

El secretario del obispo Trespalacios, cuyo nombre no por casualidad remite al barroco literario, nos brinda la crónica de todas las acciones bélicas de la novela, a través del tópico del mundo como teatro, como representación, como espectáculo. Pero su distanciamiento le impide inmiscuirse y buscar el sentido de la Historia, a diferencia del Renegado quien se sumerge en ella, aún con el costo de arriesgar su cuerpo (pierde una pierna), su lucidez y su vida: " ¡Maldito sea! A fe mía que me encuentro en el remolino de la historia, mi voluntad ajena y el corazón sobresaltado." ${ }^{714}$ Abandona entonces el papel del cronista como "testigo de la historia", "hombre de gabinete" para tornarse cronista "impertinente", "sometido por la historia al nuevo papel de héroe"715. Como tal ingresa, se desplaza y describe el espacio cimarrón.

El campamento de Obatal se constituye mediante dos dimensiones. Una se corresponde con el espacio real de la ciudad de San Juan Bautista de Puerto Rico hacia fines del siglo XVIII. Especialmente remite a un lugar histórico concreto: la Fortaleza de San Felipe de Morro, símbolo de la ciudad amurallada, racional, concebida por el ingeniero militar de Felipe II, lo mismo como defensa de la urbe que como emblema del poderío imperial. La ciudad tomada por los esclavos y transformada en espacio rebelde se revela como el reverso de la San Juan racionalista. Se torna escenario de danzas tribales, rituales africanos, ceremonias religiosas, comidas típicas, desaforado carnaval que borra los vestigios y huellas del lugar que antes fuera bastión militar, español y católico, para superponerle su otredad más radical:

"Pero aseguro que la más grande celebración ocurre en las almenas de San Felipe de Morro. Pues allí se celebra, bajo la sombra de los altos muros, unas danzas que son como despojos, así de violentos y

\footnotetext{
${ }^{713}$ Rodríguez Juliá, Edgardo (2002). La noche oscura del Niño Avilés, ed.cit ., p. 274.

${ }^{714}$ Ibid., p. 165.

${ }^{715}$ Ibid.,p. 165.
} 
convulsos se muestran los bailarines negros. $Y$ todo esto es cosa de grande maravilla que enseguida relataré." 716

"El mar de negros se movía ondulante, ansioso y en mil direcciones, sin orden ni sosiego, siempre al compás de los tambores que no cesaban en su muy frenético ritmo. Cerca de la muralla centenaria de piedra y argamasa, fueron construidos aquellos precarios bohíos de yaguas y pencas de palmas, que allí en el interior de aquellas zahúrdas, había grande cantidad de fogones de leña y piedras. Y las negras se acuclillaban al lado de estos rústicos fogones y calderos donde deliciosa crepitó la fritanga, fama verdadera de las más viejas, mujeres de jumazo al diente y pañolones en la cabeza."717

El Renegado, como "cronista impertinente" y curioso, relata con detalle el proceso de transformación de la ciudad de San Juan en espacio cimarrón. Por momentos asume una posición de observador distanciado, como la que sostiene en la escena que describe una danza ritual africana, cuya significación interpreta y traduce para el posible destinatario urbano de su crónica, ocupando un rol que se podría caracterizar como "narrador etnólogo":

"Pues son tres danzas las que he visto hasta ahora, y que pueden ser descritas de este modo: Una forma ruedo de hombres y mujeres, y tiene acompañamiento de tambor. La otra no tiene música, que quizás es bailada en silencio por llamarse 'de los pájaros'. Pues en esta danza las mujeres cimbrean mucho las caderas, los pechos y la cintura, todo ello de muy sensual modo. Y las negras alzan muchísimo el vuelo de sus faldas cuando dan el paso de pájaro, muy nostálgica evocación que este baile hace. Entonces golpean el suelo mientras paran los pechos. $Y$ antes de que este gesto se convierta en brusco arrebato, hunden las erectas tetas y alzan codos y brazos como si fueran a volar, y pienso que esta evocación es fiel emblema del deseo negro de remontar vuelo hacia la libertad de su pasado en el grande continente de África"718.

Pero a pesar de su posición privilegiada hay una zona de la expresividad de los negros a la cual el cronista blanco, como sujeto letrado, no puede acceder, en parte porque no comprende la lengua de los esclavos -"lengua muy extraña, mezcla de castellano y africano"- ${ }^{719}$, como así tampoco otras formas alternas de comunicación que alcanza a percibir pero que le resultan

\footnotetext{
${ }^{716}$ Rodríguez Juliá, Edgardo (2002). La noche oscura del Niño Avilés, ed.cit ., p. 67.

${ }^{717}$ Ibid., p. 99.

${ }^{718}$ Rodríguez Juliá, Edgardo (2002). La noche oscura del Niño Avilés, ed.cit .,p. 67.

${ }^{719}$ Ibid., p. 75.
} 
inaccesibles a la escritura como el repique de los tambores, "pues cada golpe sobre el cuero, con su tono particular, equivalía a palabra, a memoria.",720 Julián Flores se acerca a las figuras de cronista construidas en las "crónicas de actualidad" de Rodríguez Juliá antes trabajadas, por la impronta fuertemente autorreflexiva de sus textos y también por el reconocimiento de las limitaciones y posibilidades para inscribir en su relato la lengua y cultura del otro. Si en las crónicas de actualidad el narrador reconoce su pertenencia al sector intelectual, en La noche oscura... tanto Gracián como el Renegado se constituyen, con palabras de Susana Zanetti, como "dos letrados que luchan por representaciones, por construcciones del mundo, concientes de que ellas suponen la disputa por el poder simbólico." ${ }^{721}$

Sin embargo el carácter pícaro y aventurero de Julián Flores le otorga una mayor permeabilidad a la hora de dar cuenta de algunas zonas de la expresión popular, como la que se observa en los largos pasajes destinados a describir la africanía culinaria, todo un catálogo de platos típicos que evocan la cornucopia caribeña, tan presente en las páginas de Paradiso de Lezama Lima. Discurso de la abundancia, como lo caracteriza Julio Ortega ${ }^{722}$, de poderosa impronta utópica pero que también entraña su imagen antitética: la carencia. Si por un lado el Renegado interpreta la profusión y sabrosura de los manjares antillanos en el campamento rebelde mediante la clásica imagen de la "restauración de la Edad de Oro", advierte también los peligros y extremosidad a los cuales conduce el exceso, apelando a la tópica barroca : "La rueda inexorable de la diosa fortuna me decía que tanta abundancia de hoy se convertiría en hambre de mañana." ${ }^{173}$ En efecto, una de las estrategias del obispo Trespalacios para derrocar la ciudad cimarrona consiste en cortar el acceso a la ruta que provee de víveres a la capital tomada por Obatal, de allí que Julián Flores intente infructuosamente persuadir al indolente caudillo para "limitar y abolir la Edad de Oro"724.

\footnotetext{
${ }^{720}$ Ibid., pp. 74-75.

${ }^{721}$ Zanetti, Susana (1994). "Las historias fingidas de La noche oscura del Niño Avilés de Edgardo Rodríguez Juliá", ed. cit., p. 25.

${ }_{722}$ Julio Ortega propone una teoría de la representación de América Latina a través de la elaboración de tres modelos discursivos: el de la abundancia, el de la carencia y el discurso de lo virtual. Véase del autor El discurso de la abundancia, Caracas, Monte Ávila, 1992.

${ }^{723}$ Rodríguez Juliá, Edgardo (2002). La noche oscura del Niño Avilés, ed.cit ., p. 101.

${ }^{724}$ Ibid., p. 102.
} 
A la ciudad histórica de San Juan se le borronean sus ámbitos criollos e hispánicos, sin que éstos se difuminen del todo, para que prevalezca en ella la dimensión cimarrona, los incesantes toques de tambor, los puestos y bohíos de la cocina afrocaribeña, las danzas y ceremonias negras. Pero este espacio que se constituye, como antes señalamos, sobre las coordenadas reconocibles de la urbe real esconde también una ciudad alterna, subterránea, hecha de signos y símbolos ominosos, laberíntica e intrincada, construida de temores y deseos como las ciudades invisibles que describe Calvino. En el largo capítulo XI de la novela el Renegado narra su peregrinación al Reino de las Quimbambas, relato de viaje o descenso a los infiernos, en el cual el cronista es guiado por el guerrero Mitume, Virgilio negro que conduce al cronista blanco a través de laberintos de altas bóvedas, torres y pasadizos, extrañas rampas y puentes colgantes, "ruta colmada de rarezas" del mítico reino de la muerte, pues parece ser ella el único y dramático camino de regreso al África del sueño cimarrón. El cronista se detiene en la paradójica percepción de un espacio cuya fundación descansa en la inversión, en la duplicación engañosa de los espejos, más bien de los espejismos, que tornan siniestro un lugar antes reconocido como familiar:

"Mi lucidez quedó un poco suspendida, y todo mi cuerpo se aligeró, y aunque no flotaba me presentía en el interior de secreto recinto colgado al vacío. Y esto del recinto secreto se me ocurrió porque jamás vi, en mis frecuentes visitas al bastión del Morro, estas torres que recordaban las de Babel antigua. Aquel recinto quizás pertenecía a pesadilla de la historia; pero lo más extraño era que desde el sitio donde yo estaba podía verse la luna llena, por lo cual era evidente que las torres estaban en este mundo, localizadas allá en la más alta de las muchas plazas que hay en esta fortaleza de San Felipe de Morro. Pero todos estos pensamientos me parecían desatinos, pues bien recordaba haber bajado y no subido, que las rampas y túneles subterráneos gravitaban más hacia el centro mismo del infierno que hacia las regiones etéreas." ${ }^{726}$

Así como Dante imagina al infierno como un desmesurado abismo a modo de embudo o cono que se ahonda bajo el hemisferio boreal hasta el centro de la tierra, el reino de las Quimbambas remite a la subterránea

\footnotetext{
${ }^{725}$ Ibid ., p. 117.

${ }^{726}$ Rodríguez Juliá, Edgardo (2002). La noche oscura del Niño Avilés, ed.cit ., p. 118.
} 
geografía infernal, si atendemos también a la explicación que nos brinda Fernando Ortiz $^{727}$ en el epígrafe de este apartado, al señalar la correlación entre esta voz afrocaribeña con la acepción de los "quintos infiernos". Por otra parte en el canto $\mathrm{V}$ del Infierno dantesco se relatan los tormentos a los cuales son condenados los lujuriosos, y gran parte del recorrido que realiza el Renegado a través del Reino de las Quimbambas consiste en un viaje erótico, más bien una orgía, a la cual el cronista se entrega con lascivia y docilidad, sin resistirse a las tentaciones de los sentidos: "Según Mitume, Obatal deseaba que yo gozara de todos los placeres de la carne, y por ello señaló hacia dos negras bellísimas que se burlaban de mi asombro allá en el fondo de la zahúrda con risillas y susurros, galanía de su donaire, diablejas más que mujeres."728 Si la idea del viaje de ultratumba entraña en la Divina Comedia un sentido purgativo del alma, la visión del otro mundo como guía para la salvación, el descenso como etapa previa al ascenso, la figuración del pecado como paso necesario para la manifestación de la verdad revelada, muy diferentes son las significaciones del acceso a las Quimbambas que experimenta el Renegado. Se sugiere que no solo se transporta su espíritu sino particularmente su cuerpo. El concepto de ascesis que se advierte en la obra de Dante se despliega aquí mediante una inversión barroca que acentúa la sensualidad, el goce desaforado e intenso, que incluye también la crueldad y el dolor. La última etapa del viaje del cronista consiste en una visita al recinto del caudillo, al "gabinete colgante de Obatal Supremo."729 El héroe cimarrón se le revela como un sujeto saturnino, acechado por los "diablejos de la melancolía", caudillo fracasado y patético, síntesis de la desmesura del poder y la irracionalidad del delirio, que se ha propuesto conducir a su pueblo hacia la muerte:

"Y él mismo lo dijo: No había fundado ciudad dorada, sino construido puente a los antiguos reinos de África. Sólo en aquel lejano país ellos conocieron la libertad, que en estas tierras ni el rabo le habían visto. ¡Sólo les queda el recuerdo de los antiguos reinos, de los antepasados!, y para cruzar el grande océano es necesario morir." 730

\footnotetext{
${ }^{727}$ Ortiz, Fernando (1975). Historia de una pelea cubana contra los demonios, ed. cit., p. 203.

${ }^{728}$ Rodríguez Juliá, Edgardo (2002). La noche oscura del Niño Avilés, ed.cit ., p. 120.

${ }^{729}$ Rodríguez Juliá, Edgardo (2002). La noche oscura del Niño Avilés, ed.cit ., p. 139.

${ }^{730}$ Ibid., pp. 146-147 (cursivas del texto).
} 
La dimensión onírica del reino de las Quimbambas la aproxima más bien a una oscura pesadilla, como Adelma, la ciudad que Marco Polo describe al emperador como aquella que sólo se percibe en sueños y la habitan muertos, o Eusapia, donde sus habitantes han reproducido una ciudad idéntica bajo tierra para evitar un salto brusco de la vida a la muerte, ciudades invisibles, ocultas, que se fugan no solo de las coordenadas espaciales sino también de las temporales. El espacio cimarrón proyectado por Obatal no se funda en ningún sitio concreto sino en el deseo; tampoco se posa en el tiempo, el reino de las Quimbambas se constituye entonces como utopía y ucronía. Mitume, enigmático y esquivo guía del Renegado, le advierte al cronista sobre la prohibición de hablar con las mujeres que habitan en las Quimbambas "sobre el mundo de afuera, el tiempo de la historia"731, sugiriendo más bien la dimensión mítica y atemporal del reino, fugitiva como un sueño. Toda la experiencia del viaje le sucede al Renegado durante la noche, como una parodia de los llamados "sueños de anábasis", expediciones del alma al mundo del espíritu, de larga tradición en la Edad Media y que, como observa Octavio $\mathrm{Paz}^{732}$, alcanza su forma más plena, compleja y perfecta en la Divina Comedia. Pero, como antes señalé, no se desplaza el alma del cronista sino fundamental e intensamente su cuerpo, desviándose así del género literario del spirito peregrino. Por otra parte su estado de ensoñación no responde a una condición fisiológica natural del dormir, sino que es consecuencia de las diversas sustancias narcóticas que experimenta Julián Flores, cuyos efectos se describen con minuciosidad y con un léxico que remite a la jerga lumpen contemporánea de las drogas ${ }^{733}$ : "Nos acostamos a fumar. Las mangas del

\footnotetext{
${ }^{731}$ Rodríguez Juliá, Edgardo (2002). La noche oscura del Niño Avilés, ed.cit ., p. 123.

${ }^{732}$ El comentario de Paz se incluye en el apartado que dedica al análisis de Primero Sueño de Sor Juana Inés de la Cruz. Véase del autor: Sor Juana Inés de la Cruz o las trampas de la fe, México, FCE, 1991, p. 473.

${ }^{733}$ Son bastante numerosos, por momentos reiterativos, los pasajes de la novela que describen el particular mundo de las drogas, donde el autor apela a reproducir términos de la jerga puertorriqueña que dan cuenta de diferentes sustancias, como la mota, maloja, humito (marihuana); el perico (pase de cocaína). El personaje del obispo Trespalacios, afecto a las diversas variedades del rapé, aparece también aspirando el povo (la cocaína), en un episodio de ribetes humorísticos, donde invita a su amanuense Gracián a probar la sustancia mágica, diciéndole "huele un cachito", frase que remite a una muy popular bomba, llamada "Cachito pa'huelé" (véase el capítulo X de la novela). El efecto polifónico que se produce resulta muy
} 
narguile traían a nuestros labios aquel espeso humo que subía lento, ceremonioso, sagrado. (...) ¿Dónde estoy? ¿Quién soy?”734 Por eso, una vez que despierta, que la lucidez regresa junto con la luz del día, la visión de las Quimbambas se esfuma como un sueño, la "noche oscura" deja paso al desengaño de la mirada barroca:

"Desperté a la mañana siguiente, la garganta seca, el buche florido y los sesos como un timbal. (...) Estábamos en la plazoleta superior del Morro. Ya recordaba; pero cuando busqué en el aire luminoso la estancia del reino celeste, aquella torre que fue perturbación de mi ingenio y esfuerzo de mi aliento, sólo encontré más luz, vacío que desengañó el espíritu, desencantó los ojos. La ciudad invisible de las altas torres no estaba allí en el candente cielo..."735

En la tradición del viaje de anábasis el sueño liberaba al alma del cuerpo; en el viaje del Renegado al reino de las Quimbambas, por el contrario, se desatan las pulsiones del cuerpo, remitiendo más bien a la concepción freudiana del sueño como liberación del deseo. Se apela también al retorno de lo reprimido, de allí la dimensión escatológica del itinerario recorrido, donde se entrelazan, acechantes, el goce y la muerte.

Para Rubén González la restauración del reino africano que propone Obatal se postula en la novela como posibilidad y valoración de otro pasado, disidente, que, como forma de lo inexistente, es un llamamiento a la imaginación. Pero las guerras entre los dos bandos cimarrones, pródigas de rencor y odio, conducen al reino negro a su destrucción inevitable. Por eso, concluye González, "el pasado propuesto es un modelo utópico que fracasa"736. La lectura de Julio Ortega se aviene a esta interpretación cuando subraya que en la novela de Rodríguez Juliá la rebelión de esclavos presenta la "propuesta de una fundación histórica alterna, hecha no sobre el mito del origen sino sobre

particular, en tanto se sobreimprime a las voces añejadas de los cronistas un tono marginal, urbano, callejero, de un Puerto Rico muy actual.

${ }^{734}$ Rodríguez Juliá, Edgardo (2002). La noche oscura del Niño Avilés, ed.cit ., p. 126.

${ }^{735}$ Rodríguez Juliá, Edgardo (2002). La noche oscura del Niño Avilés, ed.cit ., p. 161.

${ }^{736}$ González, Rubén (1988). “La noche oscura del Niño Avilés”, ed. cit., p. 100. 
el del Apocalipsis."737 De allí que el Renegado reproche al caudillo Obatal la fundación de las Quimbambas como reino de la muerte, camino trágico del anhelado retour: "Se me avivó más la indignación, y entonces probé mis tres bemoles cuando le aseguré:- Pues mire Obatal que no ha fundado usted la ciudad dorada, sino Necrópolis, el caserío de los muertos..."738

\section{- Las ciudades aéreas o la nostalgia del espacio perfecto}

"Vi la Ciudad santa, la nueva Jerusalén, que descendía del cielo y venía de Dios, embellecida como una novia preparada para recibir a su esposo"

Un impulso ascendente, donde predominan y se entrecruzan discursos milenaristas, místicos y utópicos, persigue a los principales personajes de la novela, aunque, paralela y paradójicamente, los arroja al abismo, a la destrucción, a la melancolía y a la muerte. En el caso de Obatal, su obsesivo deseo de tender un puente al África, lo conduce a la edificación de una vertiginosa ciudad oculta suspendida en el aire, como una altísima torre o aguja que, sin embargo, culmina en la inversión del espacio aéreo deseado: "La torre tendrá como base la plataforma del aire... Quiero decir... que su aguja será la misma que ya conocemos, pero vista desde arriba; de este modo su ascensión será para abajo."739 En su diseño confluyen referencias a la bíblica torre de Babel: los capataces, albañiles y carpinteros que la construyen no pueden ponerse de acuerdo entre sí , ya que "la confusión del lenguaje hablado no les permitió establecer las condiciones del pacto."740 En su trazado laberíntico de

\footnotetext{
${ }^{737}$ Ortega, Julio (1991). “Teoría y práctica del discurso popular (Luis Rafael Sánchez y la nueva escritura puertorriqueña), en: Reapropiaciones (Cultura y nueva escritura en Puerto Rico), ed. cit., p. 34.

${ }^{738}$ Rodríguez Juliá, Edgardo (2002). La noche oscura del Niño Avilés, ed.cit ., p. 147.

${ }^{739}$ Rodríguez Juliá, Edgardo (2002). La noche oscura del Niño Avilés, ed.cit ., p. 199.

${ }^{740}$ Ibid., p. 199.
} 
rampas y plataformas se encuentran alusiones plásticas al cuadro de Brueghel que representa la torre babélica, como así también imágenes que evocan las arquitecturas imaginarias dibujadas por Piranesi. Pero sin dudas la ciudad aérea planeada por el caudillo Obatal dialoga con la Ciudadela la Ferrière de Henri Cristophe, tal como aparece en las páginas de El reino de este mundo (1949) de Alejo Carpentier: "Cristophe, de súbito, se acordó de la Ciudadela la Ferrière, de su fortaleza construida allá arriba, sobre las nubes." ${ }^{741}$ La ciudadela, como la ciudad de las altas torres de Obatal, también se erige sobre la crueldad y el sometimiento de un caudillo negro que no duda en sacrificar a su propio pueblo, ya que parte de su arquitectura se funda en los cuerpos de los trabajadores que se vuelven la siniestra argamasa de las paredes y rampas que la conforman ${ }^{742}$. En ambas novelas los espacios aéreos se alzan sobre la impronta del utopismo. Así para Cristophe "la Ciudadela La Ferrière sería el país mismo, con su independencia, su monarca, su hacienda y su pompa mayor"743, mientras que para Obatal la ciudad de las altas torres representa "la radiante visión de una libertad casi perfecta." ${ }^{\text {"44 }}$ Pero el verbo en condicional en un caso, el participio relativo en el otro, anticipan el fracaso de tales proyectos. La desmesura de los dos líderes los conduce indefectiblemente a la ruina y la destrucción. Como en La renuncia del héroe Baltasar hallamos en La noche oscura... oblicuas referencias a la revolución haitiana, mediadas por el intertexto de Carpentier, aunque alejadas de la documentación histórica que caracteriza las ficciones del cubano, y que se expresan en las alusiones continuas a las fobias y temores de la burguesía criolla blanca ante el creciente y amenazador poder negro.

\footnotetext{
${ }^{741}$ Carpentier, Alejo (1981). El reino de este mundo, en: Dos novelas, La Habana, Letras Cubanas, p. 98.

${ }^{742}$ Véanse como ejemplo los paralelismos entre estas dos escenas, la primera correspondiente a la novela de Carpentier y la segunda a La noche oscura...: "Sobre ejes de carretas empotrados en las murallas se afianzaban los puentes volantes por los cuales el ladrillo y la piedra eran llevados a las terrazas cimeras, tendidas entre abismos de dentro y de fuera que ponían el vértigo en el vientre de los edificadores. A menudo un negro desparecía en el vacío, llevándose una batea de argamasa. Al punto llegaba otro, sin que nadie pensara más en el caído." (El reino de este mundo, ed. cit., pp.80-81) "Pero una vez que la aguja se fue abriendo en dos inmensos arcos, comenzaron las dificultades: Los andamios de apoyo, proyectados desde la aguja, no soportaban el peso de los gigantescos aleros que se extendían al vacío. Muchos albañiles perdieron sus vidas al caer desde aquellas alturas abismales; tenían que trabajar acostados sobre el aire, colgando de vértigos y sogas." (La noche oscura del Niño Avilés, ed.cit ., p. 212).

${ }^{743}$ Rodríguez Juliá, Edgardo (2002). La noche oscura del Niño Avilés, ed.cit ., p. 83.

${ }^{744}$ Ibid., p. 199.
} 
Sin embargo hay en la novela de Rodríguez Juliá personajes históricos, y tal como sucede en su primera obra, éstos aparecen descolocados y reubicados respecto de sus fuentes documentales y referentes reales. Así, otra importante elucubración en torno a la ciudad aérea se constituye a través de los discursos mesiánicos del obispo don José de Trespalacios, figura histórica que Rodríguez Juliá recrea a partir de un retrato del pintor José Campeche, también ficcionalizado en la novela, y además, autor del cuadro que da nombre y rostro al Niño Avilés, como se verá más adelante. Don Felipe José de Trespalacios fue obispo de Puerto Rico por un lapso de cuatro años, entre 1785 y 1789. Según consigna el riguroso trabajo de César Salgado hay pocas noticias históricas acerca del obispo, sugiriendo más bien que Rodríguez Juliá prefirió guiar su imaginación novelística en la obra plástica de Campeche ${ }^{745}$ antes que en el escaso registro histórico para configurar a este personaje ${ }^{746}$. En La noche oscura... se lo representa como un sacerdote obeso y sibarita, poderoso pero melancólico, cuyo principal placer proviene particularmente de la boca, en dos sentidos posibles. Por un lado, acechado por el pecado de la gula, alimenta su glotonería a través de la preparación y degustación de exquisitos y suculentos platos que combinan condimentos de la cocina española y caribeña. Por el otro se alude a su elocuencia y admirable retórica, que su secretario Gracián por momentos parodia, atribuyéndole el apodo de "pico de oro" por su destreza verbal. Pero además se constituye como escritor mediante la redacción de un Diario Secreto, varios de cuyos fragmentos se intercalan como documentos que conforman la trama de la historia oculta que intenta develar Cadalso. Como destaca acertadamente Salgado el obispo ficticio aparece dotado con facultades muy superiores a las del histórico personaje, en tanto ocupa de facto el poder colonial que los desvaríos de su malhadado antecesor, el obispo Larra, y la consecuente rebelión negra, habían trastocado, extendiéndose su dominio, según la cronología de la novela, desde su llegada a Puerto Rico en 1773 hasta fines del siglo XVIII. Su habilidad

\footnotetext{
${ }^{745}$ El retrato del obispo Trespalacios y otras importantes pinturas de José Campeche se reproducen en un número monográfico doble dedicado al artista puertorriqueño en la revista $L a$ Torre (Revista General de la Universidad de Puerto Rico), Año XX, Núm. 77-78, juliosept./oct.-dic., 1972, pp. 87-212 (vol. 77).

${ }^{746}$ Salgado, César (1999). “Archivos encontrados: Edgardo Rodríguez Juliá o los diablejos de la historiografía criolla", ed. cit., p. 157.
} 
política se funda en el arte de la negociación, logrando constituir un ejército blanco para sitiar la invadida ciudad de San Juan, mediante la reunión de múltiples actores, que incluye desde los criollos desplazados hasta los renegados integrantes de la secta de los avileños, además de contar con el auxilio mercenario de tres galeones de piratas ingleses. Aunque su catolicismo reaccionario lo lleve a demonizar ${ }^{747}$ el luteranismo inglés, accede sin embargo a una tregua con los piratas, siguiendo la consigna jesuita para la cual "el fin justifica los medios".

Trespalacios construye su poder desde un espacio particular, su "gabinete volante", duplicación y réplica del "gabinete colgante" de Obatal. Se trata de un recinto aéreo que se eleva en el mástil mayor de su nave capitana y que hace las veces de panóptico, estratégica atalaya a partir de la cual los ojos del obispo se posan y abarcan lugares, abiertos y recónditos, de la isla de Puerto Rico. Rodeado de un vasto repertorio de instrumentos ópticos, el aposento remeda un gabinete de física, donde se destaca una suerte de periscopio, que el cronista Gracián describe con asombro y detallismo, subrayando su monstruosidad barroca, puesto que brinda una imagen invertida de aquello que se contempla:

"A la verdad que semejante máquina concebida por el ingenio del Obispo Trespalacios era más útil para el espionaje, emblema de ese oficio, pues con ella podíamos ver si ser vistos. Y esta maravilla se llama perescopio, aunque para nosotros no tuviera este nombre de sabios, sino galano apodo de jodones, y la conocíamos por la jirafa, justo por su costumbre de sacar el pescuezo sobre la enramada. (...) Como podemos advertir, la máquina es un engendro óptico, cámara bruja para multiplicar siempre invertidos los ecos de luz." ${ }^{778}$

Pero el obispo prefiere escudriñar las batallas desde una posición vicaria, cediendo sus instrumentos ópticos a la mirada sesgada del cronista Gracián, quien le narra lo que observa mientras el sacerdote glotón prepara suculentas viandas caribeñas. Trespalacios opta por otro tipo de visión,

\footnotetext{
${ }^{747}$ Trespalacios, aludiendo a la toma de la ciudad de San Juan por los negros como una invasión de demonios, afirma lo siguiente: "Pues sí, y allá han caído sobre la siempre fidelísima ciudad de San Juan Bautista, y esta lluvia de diabólicos follones ha sido la más grande catástrofe ocurrida en estas tierras desde que los demonios luteranos de Drakeo y Cumberlando pusieron ojos sobre sus riquezas." ( La noche oscura del Niño Avilés, ed.cit ., p. 152, cursivas del texto).

${ }^{748}$ Rodríguez Juliá, Edgardo (2002). La noche oscura del Niño Avilés, ed.cit ., pp. 274-275.
} 
introspectiva a la vez que utópica, que traslada a las páginas de su Diario Secreto: la añorada Civitas Dei. Con obvias referencias al tratado La ciudad de Dios de San Agustín, el obispo le explica a su amanuense Gracián que "la ciudad de Dios es un espacio perfecto que anhelamos acá abajo en la ciudad humana"749.

Para el santo de Hipona la Ciudad de Dios no existía como un proyecto para desarrollarse en la historia y en el tiempo, no era la iglesia militante ni un reino terreno; su desenvolvimiento tendría lugar en la eternidad, en un espacio donde la iglesia triunfante de los elegidos viviría en la presencia de Dios Padre y del Cordero Cristo ${ }^{750}$. Al hombre le correspondería habitar la Civitas Terrena, donde se establecen relaciones de jerarquía y por lo tanto de sujeción, que son garantes del ordenamiento en la vida social. A su vez, en contraposición a la imagen de la Civitas Dei se erige otra, corruptora, hija de Caín, plagada de maldiciones, dolores y muerte. Los paradigmas de esa ciudad pecadora eran Babilonia y Roma, ámbitos terrenales que tendrían su continuidad en el infierno, en la Civitas Diaboli, ciudad regida por Satanás. Ecos de las concepciones agustinianas se perciben en la utopía que persigue Trespalacios, hasta convertirse, como la ciudad aérea de Obatal, en obsesión y delirio místico:

"Habilitar este páramo para la convivencia es la muy santa encomienda de la fe. De este modo, mi vida se ha vuelto hazaña y obra, pues la vocación contemplativa jamás traería a los hombres el consuelo que tanto añoran. (...) A fe nuestra que la hazaña estará siempre en la memoria de los hombres, y es que se trata de fundar la Civitas Dei, ciudad ligera que trepada allá en las nubes es construida con la espesa maldad de los hombres. Esta ciudad de Dios está extendida a lo largo de la humana, aunque también aseguro que se oculta mucho a nuestra vista." 751

Si para San Agustín la Ciudad de Dios está fuera de las coordenadas espaciales y temporales que sujetan al hombre, la desmesura del proyecto del obispo se funda en proyectar un espacio perfecto en una dimensión humana. Para Trespalacios la restauración del orden en la ciudad de San Juan entraña

\footnotetext{
${ }^{749}$ Ibid., p. 152.

${ }^{750}$ Véase Agustín de Hipona, San (1966). La ciudad de Dios, México, Porrúa.

${ }^{751}$ Rodríguez Juliá, Edgardo (2002). La noche oscura del Niño Avilés, ed.cit., p. 372.
} 
una concepción urbana donde la ciudad, paradigma del orden y la armonía, cosmos creado por el hombre frente al caos de la naturaleza, representa el buen gobierno y la vida política regida por la razón. Según esta perspectiva su rol, más que eclesiástico, se proyecta hacia la función política del estadista: "...entiendo que para poder convivir los hombres tienen que fundar el artificio del Estado, verdadera máquina que hace posible el sano tránsito del comercio, la provechosa distribución del trabajo y la muy férrea vigilancia del general orden." ${ }^{752}$ Pero el prelado no se complace con regir la Civitas Terrena que la cita precedente describe. El pecado de la soberbia, que finalmente lo conduce a la sinrazón y la melancolía, lo impulsan a proyectar sobre el espacio de San Juan la apocalíptica Nueva Jerusalén bíblica, otorgándole una dimensión humana a la que sólo poseía un estatuto celestial: "y es que la plaza fuerte de San Juan Bautista se ha convertido en Nueva Jerusalén. (...) Debemos habilitar esta Nueva Jerusalén; la inmóvil ciudad de Dios tiene que ser despertada al trajín de los hombres." ${ }^{\prime 753}$ Quien antes se había mostrado en la novela como una suerte de teólogo ortodoxo y reaccionario culmina acercándose a posiciones heterodoxas, más próximo a los acechos del delirio místico, que a la racionalidad dieciochesca que la ficción de Rodríguez Juliá hace estallar una y otra vez.

Una tercera figuración de la ciudad aérea se asoma, intercalada entre textos fragmentarios, por momentos bastante crípticos, que describen la fantasmagórica construcción del arquitecto leproso: "Ahora hablaré del arquitecto, de ese leal compañero del caudillo allá en las entrañas del laberinto. Su oficio no ha sido la torre, sino esa oculta ciudad fundada en la ilusión." ${ }^{, 754}$ Aparece en un primer momento como aquel que proyecta sobre el papel el utópico reino negro que quiere fundar Obatal, pero luego el personaje adquiere una dimensión propia en la novela, sobre todo en aquellos pasajes donde su voz asume el relato. Paulatinamente aislado, acechado por la lepra y la incomprensión, su figura se compone de diversas referencias literarias. Como el pintor leproso de La renuncia del héroe Baltasar, evoca al escultor Aleijandinho retratado por José Lezama Lima en "La curiosidad barroca";

\footnotetext{
${ }^{752}$ Ibid., p. 378.

${ }^{753}$ Rodríguez Juliá, Edgardo (2002). La noche oscura del Niño Avilés, ed.cit., p. 421.

${ }^{754}$ Ibid., p. 254.
} 
también se lo describe bajo los trazos del mítico Minotauro, más próximo a la versión del texto borgeano ${ }^{755}$ que a la del mito griego, donde el monstruo ocupa el papel de víctima de su laberinto, edificio que en la novela está representado por la torre infinita e inconclusa que lo aprisiona. En torno a este enigmático personaje y su proyectada urbe aérea se conforman además diversas sectas y religiones marginales, que creen percibir en los dibujos del arquitecto el plano de una ciudad celestial: "La arquitectura del maestro gafo jamás fue tan sutil y peligrosa. Cada gesto de su arte era interpretado de mil maneras, engendraba cientos de herejías." ${ }^{\text {"756 }}$ Proliferación y multiplicación de diversas heterodoxias que aproximan estos pasajes de la novela a otro relato borgeano, "Los teólogos" ${ }^{\prime 757}$, donde la contraposición de las creencias termina por neutralizarlas y anularlas entre sí. Finalmente la ciudad aérea del arquitecto leproso no se concreta en dimensiones espaciales o temporales sino que se erige tan solo en el plano de lo imaginario y de lo visionario, de allí que Aníbal González interprete que dicho espacio representa en la novela "la utopía más 'pura', una especie de archi-utopía o, lo que parece más probable, una alegoría misma del concepto de 'utopía' (vocablo que significa en griego 'no hay tal lugar')." ${ }^{\prime 758}$

Las ciudades aéreas se duplican en las notas al calce firmadas por Alejandro Juliá Marín que comentan, reinterpretan, puntualizan los diferentes espacios trazados, provocando un efecto especular entre texto y paratexto, "espejeando la novela en una prosa poética entre paródica y sublime", según destaca Rubén Ríos Ávila ${ }^{759}$.

\section{- La Civitas diaboli o la ruta hacia Pandemónium}

"En aquellos tiempos era abrumadora en la población de Remedios, la gran cantidad de demonios que allí pululaban."

\footnotetext{
${ }^{755}$ Me refiero al cuento "La casa de Asterión”, en: Borges, Jorge Luis (1961). El aleph, Buenos Aires, Emecé, segunda edición, pp. 67-70.

${ }^{756}$ Rodríguez Juliá, Edgardo (2002). La noche oscura del Niño Avilés, ed.cit., p. 283.

${ }^{757}$ Borges, Jorge Luis (1961). "Los teólogos", en : El aleph, ed. cit., pp. 45. En el cuento de Borges, como en la novela de Rodríguez Juliá, hay referencias explícitas a las concepciones agustinianas plasmadas en La ciudad de Dios.

${ }^{758}$ González, Aníbal (1986). "Una alegoría de la cultura puertorriqueña: La noche oscura del Niño Avilés, de Edgardo Rodríguez Juliá", ed. cit., p. 587.

${ }^{759}$ Ríos Ávila, Rubén (1992). "La invención de un autor: escritura y poder”, ed. cit., p. 49.
} 
demonios

Fernando Ortiz, Historia de una pelea cubana contra los

Si el reino de las Quimbambas proyectado por Obatal remitía a la geografía del infierno dantesco, la ciudad de los demonios de La noche oscura... en cambio no se emplaza en ningún sitio mítico, sino que se trata de San Juan como ciudad posesa y sometida a un espectacular rito de exorcismo por parte del obispo Trespalacios. El prelado ha podido recuperar la plaza tomada por los negros, no tanto por sus habilidades como estratega militar, sino porque la fantasmal guerra civil entre los bandos enemistados, que culmina en la tremenda confrontación ecuestre entre Obatal y Mitume, echa por tierra el reino cimarrón. Pero antes de permitir el regreso de los criollos dispersos Trespalacios debe expulsar de la capital una profusa cantidad de diablejos, que para el obispo fueron los que encendieron y promovieron la rebelión esclavista, de allí que vea en la figura de Obatal la encarnación de Leviatán, demonio que representa el pecado de la soberbia. Refiriéndose al caudillo expresa:

"-Ese prieto por lo visto está dentro del pellejo de Leviatán soberbio, que la batalla es a la vez contra hombres y demonios, por eso mismo te digo que terminado el bombardeo debemos apechar con el más grande exorcismo que jamás se haya visto en estas tierras de América, y con la oración debemos edificar como una grande torre para que los demonios suban a las agujas de la ciudad invertida." ${ }^{\prime 60}$

El ritual exorcista se torna impactante escena política que el obispo aprovecha para someter a sus feligreses y permanecer en el poder. Cuando Gracián le pregunta: “¿también asumirá el Estado después del exorcismo general?", el astuto y ambicioso prelado le responde: “-Ante la ausencia de gobierno, Gracián, vístase Cristo de rey, asuma su ministro el garrote de Caín."761 Así el primer acto que oficia consiste en la ceremonia pública de bautismo del Niño Avilés en una fecha de alto valor simbólico: el 24 de diciembre. La criatura, antes manipulada por el obispo Larra, protagonista

\footnotetext{
${ }^{760}$ Rodríguez Juliá, Edgardo (2002). La noche oscura del Niño Avilés, ed.cit., pp. 153-154 (cursivas del texto).

${ }^{761}$ Ibid., p. 361 (cursivas del texto).
} 
involuntaria del culto heterodoxo de la secta de los avileños, primero talismán mágico de Obatal y luego de Mitume, tampoco escapa a los maquiavélicos manejos de Trespalacios, quien pretende hacer del Niño un nuevo mesías: “Dentro de tres días será Navidad. Hay que inculcarle al pueblo que la liberación del Avilés es el nacimiento de Cristo." 762

César Salgado advierte en la novela un "furor demonológico, más propio del siglo XVII"763 que del XVIII, época en la cual se desarrolla la acción. Destaca en este sentido la importancia de un texto citado por la crítica ${ }^{764}$ en relación con La noche oscura... pero ajeno a la historiografía criolla de Puerto Rico: la Historia de una pelea cubana contra los demonios (1960). El libro de Fernando Ortiz, que remeda de manera paródica los tratados de demonología, discurre de manera erudita, enciclopédica pero también muy divertida, sobre las creencias en la presencia del demonio en América, a partir del caso de la villa cubana de San Juan de los Remedios del Cayo, ejemplo de las llamadas villas traslativas de las Indias, asentamientos que, por diversas razones, la mayor parte de las veces por el asedio y saqueo pirata, eran trasladadas de la costa hacia tierra adentro. Según relata Ortiz, entre 1672 y 1691 se intentó en varias ocasiones mudar la villa cubana de los Remedios del Cayo para protegerla de la piratería, pero sus pobladores se mostraban bastante reacios a trasladarse. El cura de la parroquia y comisario de la Santa Inquisición, el padre José González de la Cruz, quien pretendía que el traslado de la villa se hiciera a tierras de su propiedad, ingenió una hábil estrategia: hacer creer a los moradores que el lugar estaba poseído por los demonios. Así lo narra Ortiz en esta amena cita de su libro:

"El cura de la parroquia y comisario de la Santa Inquisición pretendió que el permanente traslado de la villa se hiciera a tierras de una hacienda de su propiedad privada, pero los alcaldes se opusieron. Aquél, viéndose desobedecido, acudió para apoyo del negocio nada menos que a las amenazas de Lucifer e hizo que un notario diera fe

\footnotetext{
${ }^{762}$ Ibid., p. 355 (cursivas del texto).

${ }^{763}$ Salgado, César (1999). “Archivos encontrados: Edgardo Rodríguez Juliá o los diablejos de la historiografía criolla”, ed. cit., p. 187.

${ }^{764}$ Los trabajos críticos antes citados de Aníbal González y Antonio Benítez Rojo señalan el libro de Fernando Ortiz como intertexto de La noche oscura.. pero sin desarrollar un análisis sobre esta cuestión. En cambio el artículo de Salgado, aunque de manera general, apunta algunos paralelismos entre la novela y La pelea cubana contra los demonios.
} 
oficial de lo que decía el mismísimo demonio, hablando desde las entrañas de Leonarda, una negra posesa; pero los ediles remedianos no se asustaron ni accedieron." ${ }^{\prime 765}$

Ortiz adjunta una serie de documentos que figuran como apéndices de su volumen, y brinda además cantidad de información sobre demonología y ritos exorcistas, en gran parte usada por Rodríguez Juliá. En la novela se explicita la lectura del texto del cubano, en un hilarante pasaje donde Gracián describe las trampas para cazar demonios que ha mandado a construir el "furor demonológico" del obispo: "Dice Don José que estas trampas tienen algo más que renombre, pues a buen uso limpiaron los aires entumecidos de Villa Remedios, en Cuba, durante un exorcismo allí practicado hace un siglo..766 En La pelea cubana contra los demonios se describen con esmerado detalle desde objetos usados como talismanes contra el diablo hasta las oraciones que deben recitarse para aliviar a los posesos, elementos que la novela reproduce. Así sucede por ejemplo con la Cruz de Caravaca que esgrime Trespalacios, descripta por Ortiz como amuleto exorcista para realizar portentos y espantar demonios, o con los llamados detentes, muy característicos de la religiosidad popular y que varios personajes de La noche oscura..., entre ellos el mismo Niño Avilés, ostentan. El antropólogo cubano señala que son a la manera de escapularios, "pañitos de lana con la figura del Corazón de Jesús y la inscripción '¡Detente! Que el Sagrado Corazón está conmigo' para que lea y obedezca el diablo." ${ }^{767}$ El sacerdote de la poseída villa Remedios alegó que había llegado a exorcizar la hiperbólica suma de más de ochocientos mil demonios, pues como explica Ortiz, "que los demonios se organizaban y distribuían en tropas, falanges o tercios, era cosa entonces muy bien sabida." ${ }^{" 768}$ Paralelamente Trespalacios le ordena a su amanuense: "-iHay que hacer inventario de demonios!", antes de expulsar una numerosa legión de diablejos que muy impíamente se habían asentado una iglesia de la capital posesa. Así como Ortiz describe los nombres y jerarquías de la escala demonológica, aclarando la paridad entre Satanás, Lucifer y Belcebú, en la

\footnotetext{
${ }^{765}$ Ortiz, Fernando (1975).’Prólogo del autor", Historia de una pelea cubana contra los demonios, ed. cit., p. 20.

${ }^{766}$ Rodríguez Juliá, Edgardo (2002). La noche oscura del Niño Avilés, ed.cit., p. 382.

${ }^{767}$ Ortiz, Fernando (1975). Historia de una pelea cubana contra los demonios, ed. cit., p. 91.

${ }^{768}$ Ibid.,p. 124.
} 
novela el obispo le brinda a Gracián la misma explicación sobre los nombres del demonio: "Satanás, Belcebubo y Lucifer son en realidad un mismo diablazo."769

Los momentos más desopilantes de los rituales exorcistas que se desarrollan en La noche oscura... son a la vez grotescos y escatológicos. Incluyen la incorporación de malas palabras y obscenidades, sobre todo en torno a las ventosidades, que según precisa Ortiz, ofenden a los demonios, puesto que, a pesar de ser ellos mismos característicamente pestilentes, "sin embargo, son muy sensibles en el infierno a cierta fetidez, cuando parece implicar vejamen a su siempre empecinada soberbia." 770 En la Civitas Diaboli que intenta desterrar el obispo exorcista abundan los episodios de pronunciada procacidad, como éste que relata a continuación Gracián, asombrado testigo del ritual que Trespalacios le impone a un descarado diablejo:

"Allí vi cómo se retorcía de dolor al caer, Don José siempre acercándole el hierro de Caravaca; también blasfemó con muy soeces palabras, se cagó en Dios, en la Virgen del Carmen y todos los muertos, que esta destemplanza no la puse en dudas, pues el muy cochino dejaba tras de sí bien espeso fumón de pedos. Al fin Don José lo persiguió, a fuerza de rocearle agua bendita, hasta una de las puertas laterales; pero aseguro que tan magistral despojo pudo lograrlo no sin antes echar mano de todas sus mañas, y a fe mía hubo larga retahíla de Vade Retro Satanás y otros detentes, chulerías oficiosas en la lengua del Romano."771

Las distintas acciones de exorcismo que el obispo encara como implacable misión de su oficio religioso, narradas desde la perspectiva de Gracián, lindan con el humor y el relajo, en una complicidad jocosa que torna cómico lo dramático, disparatado lo serio, burlesco lo solemne. Barullo, vacilón, relajo, se constituyen en rasgo identitario característico de los sectores populares puertorriqueños, cuestión que Rodríguez Juliá explora sobre todo en sus crónicas de actualidad ${ }^{772}$. Así sucede durante el episodio en el cual

\footnotetext{
${ }^{769}$ Rodríguez Juliá, Edgardo (2002). La noche oscura del Niño Avilés, ed.cit., p. 371.

${ }^{770}$ Ortiz, Fernando (1975). Historia de una pelea cubana contra los demonios, ed. cit., p. 164.

${ }^{771}$ Rodríguez Juliá, Edgardo (2002). La noche oscura del Niño Avilés, ed.cit., p. 371.

${ }^{772}$ Los pasajes procaces de la novela se reiteran como imágenes de lo grotesco y escatológico en crónicas como "Una noche con Iris Chacón"; también las formas del humor popular, conocidas como relajo, barullo, vacilón, presentes en las crónicas mortuorias de Rodríguez Juliá, donde
} 
Trespalacios bendice por primera vez al Niño Avilés. Rodeado de feligreses que desean retornar a la ciudad y que acompañan la ceremonia, como dice Gracián, "más por temor que por convencimiento", una estruendosa ventosidad desploma la seriedad del acto, provocando la hilaridad general entre los presentes, ante lo cual "quiso don Pepe acabar con la cháchara del viento sigiloso, de modo que tan santa ceremonia no terminara en chiste y relajo."773 Actitudes y gestos socarrones, parcialmente liberadores, desafían la autoridad sin alcanzar a constituirse en actos de rebelión. Se trata más bien de apelar a la corrosión del humor como una forma colectiva y catártica de conjurar el temor. María Julia Daroqui subraya que los tópicos del grotesco que aparecen en la novela abren la posibilidad de representar el mundo de lo bajo, afiliando la ficción de Rodríguez Juliá a tradiciones literarias tales como las de Rabelais, Quevedo y Saavedra Fajardo, un autor bastante peculiar y marginal del barroco hispanoamericano. En este aspecto apunta que el lenguaje escatológico usado por Rodríguez Juliá conduce a un descenso de lo alto a lo bajo, para añadir que "la burla, la grosería y la crueldad ponen en escena sentidos del mundo de lo profano."774

El eficaz exorcismo del obispo expulsa varios de los demonios listados con detalle por Ortiz, como Asmodeo, "príncipe de la lujuria"; Esmón, "general de los que faltan a la palabra que dan"; Belial, "capitán y regidor de gitanas, adivinos, brujos y hechiceros"; Auristel, "gobernador de jugadores y blasfemos"; Boraz, "príncipe de la envidia y señor de los que la profesan"; Astarot, "gobernador de infames logreros, cuatreros y usureros"; Renfás, "diablo cojuelo, gobernador de la pereza y dueño de los perezosos." ${ }^{\prime 75}$ Tipología diabólica que Trespalacios aprovecha para construir con ella un discurso colonial de la alteridad caribeña, donde el otro se constituye a partir de imágenes negativas, cristalizadas y estereotipadas según la versión dominante del sujeto colonizador. El negro, el mulato, el indio pero también el criollo, sobre todo al campesino jíbaro puertorriqueño, aparecen estigmatizados por los

los velorios y entierros se transforman en comparsas de carnaval, aspectos señalados en el capítulo anterior.

${ }^{773}$ Rodríguez Juliá, Edgardo (2002). La noche oscura del Niño Avilés, ed.cit., p. 348.

${ }^{774}$ Daroqui, María Julia (1993). "Las pesadillas de la historia en La noche oscura del Niño Avilés", en: Las pesadillas de la historia en la narrativa puertorriqueña, Caracas, Monte Ávila y Centro de Estudios Latinoamericanos Rómulo Gallegos, p. 100.

${ }^{775}$ Ortiz, Fernando (1975). Historia de una pelea cubana contra los demonios, ed. cit., p. 106. 
prejuicios étnicos que prevalecen en la mirada "imperial" del obispo. Así, según el peculiar relato que el prelado traza acerca de la conquista y colonización de Puerto Rico, indios y criollos comparten la debilidad de someterse al diablejo Renfás que rige a los perezosos: “¿Quién está en esa hamaca? ¡No es el indio! Bien vale llamarse ya el criollo, o jíbaro a secas, cruce de la mala hacienda española y aquellos engendros de la vagancia que fueron los indios."

Aunque el obispo no menciona su nombre alude a la crónica del francés André Pierre Ledrú, Viaje a la Isla de Puerto Rico en el año 1797, donde el autor viajero alegaba que el clima tropical y benigno de la isla incitaba a sus pobladores a la pereza y a la lujuria, discurso que Trespalacios reproduce en las páginas de su Diario secreto:

"Lo dicho por este viajero es muy cierto; en todo el santo orbe no hay gente más fiestera y perezosa que los criollos de esta isla de San Juan Bautista. (...) Y estos aborrecidos se inclinan mucho a la lujuria, así cría Asmodeo los hijos que Renfás engendra. También es inclinación de los tediosos el mucho juego y la ira súbita. Estos dos males que también engendra Renfás son como los gemelos de la constelación de vicios que fecunda la pereza, terrible caja de Pandora, ya que no cornucopia del desvarío." 777

En los argumentos esgrimidos por Trespalacios se perciben claras resonancias de las discusiones y planteos en torno a la visión negativa sobre la impronta del negro, del mulato y del indio en la cultura e historia puertorriqueñas presentes en ensayos de enorme peso tales como Insularismo de Antonio S. Pedreira y El prejuicio racial en Puerto Rico de Tomás Blanco, como así también referencias explícitas a la imagen del "añangotado" de El puertorriqueño dócil de René Marqués ${ }^{778}$. A ellas se le suma la continua demonización del otro que Fernando Ortiz denuncia como estrategia de

\footnotetext{
${ }^{776}$ Rodríguez Juliá, Edgardo (2002). La noche oscura del Niño Avilés, ed.cit., p. 393.

${ }^{777}$ Ibid., p. 430. Recordemos que una cita de la crónica de viaje de Ledrú funciona como epígrafe de Puertorriqueños, junto con otra extraída del Diario secreto de Trespalacios, como se señaló en el capítulo anterior.

${ }^{778}$ En la novela hay referencias a las "taras ancestrales" producto de la "mezcla racial" según la retórica de la enfermedad tan típica de Pedreira, como así también alusiones al "añangotado" como imagen de la docilidad del puertorriqueño, tan repelida por René Marqués. Remito al análisis del peso de estos ensayos en cuanto a la construcción de la identidad puertorriqueña, aspectos señalados en el capítulo II.
} 
dominación "para justificar la esclavitud de los negros y hasta la de los indios, unos y otros 'gente de color' predestinados al yugo de los blancos cristianos. ${ }^{~} 779$, mecanismo apropiado por el maquiavélico obispo en su empeño de dominación y preservación del poder.

Pero la eficacia exorcista del eclesiástico no logra expulsar al inhallable Leviatán, demonio de la soberbia, cuya persecución y visiones arrojan a Don José al desvarío, a la sinrazón, a la melancolía paralizante. La novela se cierra a través de la crónica de Gracián que relata el exorcismo frustrado de diablo tan principal. El obispo le confiesa a su fiel amanuense una pesadillesca revelación, donde la Civitas Diaboli coincide con el espacio lacustre de la futura Nueva Venecia. La visión se torna entonces predicción, presagio de un hecho venidero que condensa la imagen de una ciudad doble, cuyo reflejo invertido espejea en las aguas de los caños y canales:

"-Bien recuerdo que en la visión de anoche los caserones se levantaban con gran señorío sobre el muy frondoso mangle, y aquellos edificios estaban montados sobre grandes zocos de caoba y ausubo, su altura en los bajos aires era tal que toda la ciudad quedó reflejada en los canales. ${ }^{\text {"“780 }}$

César Salgado, cuando señala los paralelismos entre la novela y la Historia de una pelea cubana contra los demonios de Fernando Ortiz, concluye que el antropólogo cubano escribe su texto para condenar y burlarse del atavismo del siglo XVII, considerado como "el apogeo de los demonios" frente a la modernidad de los adelantos racionalistas del siglo XVIII. En cambio Rodríguez Juliá niega tal adelanto, "des/reubicando los hechos un siglo después en Puerto Rico"781. Si, como destaca Salgado, Juliá injerta el período barroco de demonios, persecuciones y exorcismos en pleno siglo de las luces, una vez más el escritor puertorriqueño hace suyas las famosas palabras del aguafuerte de Goya: en sus ficciones del XVIII "Ios sueños de la razón engendran monstruos."

\footnotetext{
${ }^{779}$ Ortiz, Fernando (1975). Historia de una pelea cubana contra los demonios, ed. cit., p. 39.

${ }^{780}$ Rodríguez Juliá, Edgardo (2002). La noche oscura del Niño Avilés, ed.cit., pp. 456-457.

${ }^{781}$ Salgado, César (1999). "Archivos encontrados: Edgardo Rodríguez Juliá o los diablejos de la historiografía criolla", ed. cit., p. 188.
} 


\section{- La ciudad arcádica o la utopía criolla}

"La Arcadia es justamente la sublimación de la naturaleza, su conversión en gesto."

Edgardo Rodríguez Juliá, Campeche o los diablejos de la melancolía

Si bien la configuración del espacio arcádico se reveló fundamentalmente en el mítico jardín de Yyaloide, la novela retoma el tópico del locus amoenus para erigirlo como deseo utópico de los sectores criollos desplazados. El abandono de la ciudad de San Juan había trastocado los modos de vida de este importante grupo social, trasformándolo en caravana trashumante, condenada a la incesante errancia impuesta por el exilio, cuyo último anhelo consistía en desterrar el desplazamiento y fundar un espacio propio. La pluma de Gracián testimonia el bullicioso regreso a la capital de parte de las familias desplazadas por el temor al demonio encarnado en la figura del Niño Avilés:

"A Dios gracias ya había cesado el exilio que desató el Avilés. Familias enteras de avileños llegaban con algunos víveres y pocas pertenencias, al sitio que era el altar del milagro, que allí mismo -ja vista de todos!- se desterraría al Enemigo y sus hordas infernales... Por todos lados hay grande bullicio, tránsito de hombres y bestias. Mientras los niños juegan revolcándose por las bajas arenas del litoral, los hombres entierran la carroña que aún queda por ahí desde el día de la batalla."782

El cronista narra el retorno a la ciudad como metáfora de regreso a un orden, que no deja de ser el que representa la autoridad colonial en la isla y que se encarna en la figura del obispo Trespalacios. Hay, sin embargo, otro grupo de criollos que bajo el liderazgo de uno de ellos, Pepe Díaz, promueve otra dimensión política posible, que desafía la propuesta del eclesiástico de refundar San Juan como "plaza de Cristo", "recinto donde el peregrino no vague más" ${ }^{\prime 783}$. Se trata de criollos jíbaros ${ }^{784}$, quienes pretenden fundar una

\footnotetext{
${ }^{782}$ Rodríguez Juliá, Edgardo (2002). La noche oscura del Niño Avilés, ed.cit., p. 362.

${ }^{783}$ Rodríguez Juliá, Edgardo (2002). La noche oscura del Niño Avilés, ed.cit., p. 372.
} 
colonia libre y cimarrona en los manglares aledaños a la capital. La ciudad arcádica discurre entre las páginas de un testimonio anónimo y del Diario secreto de Trespalacios. En ambos casos se la refuta como una impía y sacrílega restauración de la Edad de Oro y, peor aún, como espacio subversivo y anárquico:

"Pues ahora resulta que un tal Pepe Díaz -vecino de los avileños cuando éstos fundaron colonias en los mogotes cercanos al sitio llamado la Vega- maléficamente reta al gobierno de Dios encarnado en mi ministerio, todo ello con grande felonía e impiedad, que así pretende acabar con lo que ha sido consuelo en el exilio, y me refiero al santísimo amparo en Cristo de la amada grey.",785

Tal como lo aclaran diversos trabajos críticos- Aníbal González, Daroqui, Salgado, Rubén González- se descontextualiza al personaje histórico de Pepe Díaz respecto de su referente real, para construir con él una figura que es el reverso del verdadero héroe que se había destacado en la defensa de San Juan ante un ataque inglés. El historiador Fernando Picó relata que José Díaz fue Sargento Mayor de las milicias urbanas de Toa Alta y que murió bizarramente en la acción del 30 de mayo de 1797, en el ataque perpetrado por las tropas británicas en el puente Martín Peña. Añade que su figura heroica caló hondamente en la tradición oral, como lo demuestra una conocida copla popular que lo menciona ${ }^{786}$. También subraya que parte de la defensa tuvo éxito por llevarse a cabo en terrenos que los ingleses desconocían, especialmente los mangles y arenales que rodeaban Cangrejos y San Antonio. Rodríguez Juliá aprovecha esta información y reubica al sargento Pepe Díaz en las coordenadas ficcionales de su novela como un criollo jíbaro del monte que pretende fundar un espacio propio pero oculto, protegido por la naturaleza enmarañada de caños y manglares. A diferencia de los otros personajes que

\footnotetext{
${ }^{784}$ Ángel Quintero Rivera explica que la palabra jíbaro se comienza a usar hacia finales del siglo XVIII para nombrar al campesino nativo, de costumbres o modales montaraces, rústicas. Asimismo señala los paralelismos históricos entre el jibarismo y el cimarronaje, respondiendo probablemente a la amalgama étnica del mundo americano del escape. Véase del autor (1999). "El tambor camuflado: la melodización del ritmo y la etnicidad cimarroneada", en: Salsa, sabor y control, sociología de la música tropical, México, Siglo XXI, pp. 201-251.

${ }_{785}$ Rodríguez Juliá, Edgardo (2002). La noche oscura del Niño Avilés, ed.cit., p. 390.

${ }^{786}$ Fernando Picó transcribe la copla popular que dice: "En el puente de Martín Peña/mataron a Pepe Díaz/qu'era el soldado más bravo/qu'el rey de España tenía." Véase del autor (1990). Historia general de Puerto Rico, Río Piedras, Huracán, p. 123.
} 
relatan sus visionarias ciudades -Obatal, Trespalacios, el Renegado, el arquitecto- no accedemos a la voz del personaje, sino que su utopía nos es relatada con el sesgo negativo que le imprimen tanto los discursos del obispo como del testigo anónimo. De hecho el espacio que pretende fundar Pepe Díaz se acerca más a las características del palenque cimarrón que a un paisaje arcádico, según la insistente calificación que le impone Trespalacios: "Fue la pretensión de ellos fundar muy arcádica ciudad, sueño éste de perfecta armonía del hombre con la naturaleza; pero aseguro que no he visto gente más desconfiada, facinerosa y cruel que estos malditos peregrinos." La particular naturaleza del manglar no se aviene con la armonía del locus amoenus, ya que por la descomposición orgánica de sus elementos -algas y variados microorganismos la conforman- manifiesta en sus aguas una hediondez perenne. Sin embargo, aparece como el sitio perfecto para el escape cimarrón. Así lo aclara Fernando Picó, cuando señala:

"La mentalidad urbana concibe el manglar como sitio insalubre. Pero para el que vive extramuros, es amparo de libertad y fuente de vida. Es zona de peligro e insubordinación, pero es también fuente de abastos. Al manglar huye el esclavo fugitivo, el soldado desertor y el forajido, pero a él acuden también el carbonero, el pescador y el cazador en busca de sus fuentes de ingreso."

La impugnación que lleva a cabo Trespalacios de la utopía arcádica y de Pepe Díaz, a quien demoniza progresivamente como encarnación de Esmón, Astarot, Boraz y Auristel, no es otra cosa que una estratagema política para desprestigiar a quien puede convertirse en subversivo enemigo político del orden colonial que el obispo detenta. Por ello el prelado insiste en la siguiente reflexión: "Querer la Edad de Oro, exaltar de nuevo la arcadia en esta naturaleza magnífica y exuberante, es desatenderse de la maldad, no encarar la extrañeza del mundo, sobre todo, es resentir el Estado."788 Estado que cobra cuerpo en la figura obesa y obsesiva del eclesiástico, quien, como analiza Rubén González, promueve infructuosamente la instauración de la ciudad letrada. Para este crítico Trespalacios representaría en la novela el papel de la

\footnotetext{
${ }^{787}$ Picó, Fernando (1990). Historia general de Puerto Rico, ed. cit., p. 17.

${ }^{788}$ Rodríguez Juliá, Edgardo (2002). La noche oscura del Niño Avilés, ed.cit., p. 395.
} 
razón ordenadora, aunque fracasada, teniendo en cuenta las reflexiones de Ángel Rama ${ }^{789}$ sobre la planificación del espacio urbano americano como exigencia colonizadora, administrativa, militar, comercial, religiosa, del europeo.

Como todas las utopías que se planifican en la novela la de Pepe Díaz también fracasa. Tal como aparece retratado en la ficción, como un pendenciero cruel, muere en una acción para nada heroica, en una pelea con machete y cuchillo, en una taberna. Testigo de la escena es el cronista Gracián, quien relata la muerte del criollo a través de la hipérbole barroca, del grotesco y del patetismo inverosímil y mordaz de un cómic:

"Su cabeza saltó por el aire todavía con la pava puesta, a fe mía que cuando rebotó sobre tonel con golpe sordo aún reía a mandíbula batiente. El humillado retrocedió más por asombro que por miedo. El tronco del galano tuvo fuerzas para levantarse, fue como a recoger la cabeza, y luego de que gesto tan imposible le sorprendiera, un momento quedó de pie cual fontana de sangre, ya que no surtidor de malísimos humores." 790

\section{- Anudando lecturas: Nueva Venecia o la síntesis imposible}

"¿Existió Nueva Venecia? Ahora le toca al lector otorgar su fallo, resolver tan largo litigio, contemplar este tríptico infinito y desolado."

Avilés

Edgardo Rodríguez Juliá, La noche oscura del Niño

Nueva Venecia se erige en la novela como espacio permanentemente desplazado y postergado en su concreción, cuya fundación implica siempre otro lugar, incluso respecto de las propias páginas del texto, si atendemos a la promesa del autor, incumplida hasta ahora, de publicar Pandemónium, último libro del ciclo que haría las veces de crónica fundacional de la utópica ciudad $^{791}$. Sin embargo Nueva Venecia emerge, entrevista en los sueños y

\footnotetext{
${ }^{789}$ Véase Rama, Ángel (1984). La ciudad letrada, Montevideo, Arca, Fundación Ángel Rama.

${ }^{790}$ Rodríguez Juliá, Edgardo (2002). La noche oscura del Niño Avilés, ed.cit., p. 438.

${ }^{791}$ Edgardo Rodríguez Juliá, en una entrevista llevada a cabo en agosto de 2004, comenta que ha dejado en suspenso la publicación de Pandemónium porque de alguna manera ya no forma parte de su actual proyecto creador, señalando que: "El sentido que cobraría ahora enfrascarme en la publicación de esa tercera parte: ya yo no sé si esa novela que ya está escrita la puedo revisar con la misma convicción con que edité esas novelas, La noche en los años ochenta y la otra ya
} 
pesadillas que persiguen a los principales personajes de la obra, en los vestigios de torres derrumbadas y ruinosas que acechan inexplicablemente el paisaje urbano de San Juan, en los trazos fantasmales del tríptico pintado por el artista leproso, en los contradictorios cronicones y variados documentos del obsesivo historiador Alejandro Cadalso. Como tal, en tanto ciudad imaginaria, ficticia, textual, invita a la sugerencia del epígrafe de este apartado -ser contemplada-, es decir, ser leída e interpretada por los lectores, dada la particular interrelación entre la mirada y la escritura que se repite en la obra de Rodríguez Juliá.

Para Antonio Benítez Rojo Nueva Venecia, como ciudad lacustre e ilegítima, fundada en la abigarrada naturaleza de caños y manglares, representa una síntesis ficcional de todos los palenques y poblados cimarrones caribeños, espacios libertarios rebeldes y contralegítimos, opuestos a la hegemonía opresora de la plantación. La anhelada urbe de La noche oscura... constituye para este crítico una puesta en escena del "allá de lo caribeño", un lugar supersincrético y ahistórico que amalgama a las culturas no occidentales de la región, añadiendo que:

"Se trata, por supuesto, de la representación de una ciudad mítica, la ciudad del deseo; no del deseo censurado por el preconciente, sino de la libido misma cuyo impacto vital y excesivo inviste todo el texto. Tal ciudad ha sido destruida y borrada de los archivos y del recuerdo colectivo; la novela, precisamente, se propone como parte de un manuscrito de dudosa autenticidad que narra su historia olvidada. Así, Nueva Venecia puede leerse como el 'otro' Caribe, como el subversivo y 'oscuro' reverso de la manipulada historia de las islas.",792

Destaca además que Nueva Venecia representa una suma de ciudades transgresoras, asociándola a las villas heréticas y contrabandistas de Yaguana, Bahayá y Puerto Plata; a Port Royal, la llamada "Gomorra de las Antillas"; también al fabuloso quilombo de Palmares, "la ciudad cimarrona más poderosa y duradera de la historia”, y, por supuesto, a Canudos, la ciudad

en los años noventa. Es un problema; pero es un problema mío como escritor, nadie me está esperando. Nadie está esperando esas obras.”. La entrevista permanece inédita y fue realizada por el especialista español Eduardo San José Vázquez, de la Universidad de Oviedo. Agradezco la gentileza del crítico quien me ha facilitado el material y autorizado a citarla. Esta entrevista formará parte del dossier dedicado a la actual literatura puertorriqueña, cuya preparación está a mi cargo, para ser publicado en la revista Orbis Tertius número XII, Centro de Estudios de Teoría y Crítica Literaria, Facultad de Humanidades de la Universidad Nacional de La Plata.

${ }^{792}$ Benítez Rojo, Antonio (1996). "Niño Avilés o la libido de la historia", ed.cit., p. $283 .$. 
nordestina de Brasil "arrasada a cañonazos tras un sitio memorable" ${ }^{\text {"793. Pero }}$ estas comunidades transgresoras que subraya Benítez Rojo tuvieron su sitio real en la historia, y su existencia se preservó en el ejercicio de la memoria, oral y escrita. Nueva Venecia, en cambio, "desapareció de la memoria colectiva del pueblo, ya para siempre desterrada al olvido, convertido su recuerdo en pesadilla de la historia." ${ }^{794}$ Se conforma más bien a partir de la clásica definición de la utopía: "Región que no existe en ninguna parte; un país imaginario"795 En este sentido Susana Zanetti apunta que la Nueva Venecia del Niño Avilés se hace cargo de las significaciones de la "ciudad oscura", concebida como una irónica vuelta de tuerca respecto de la utópica Amouroto de Tomás Moro, ya que en la novela de Rodríguez Juliá la utopía se vuelve quimera destruida:

"Nueva Venecia se vuelve a las ciudades perdidas, a Tenochtitlan o a la Atlántida, al mismo tiempo que recrea en el paisaje del trópico, la intranquilidad que las sinuosidades de las islas traman con los reflejos de luces y sombras instalados, más que en la tierra, en el agua y en el aire, como sucede en esa otra ciudad a la que alude, la Venecia del carnaval y la precaria permanencia." ${ }^{196}$

Por su parte Aníbal González interpreta la novela como una "gran alegoría acerca de la historia de la cultura puertorriqueña", que se manifiesta en los proyectos visionarios y utópicos encarnados en los espacios que hemos venido describiendo hasta aquí. Para este crítico el reino cimarrón proyectado por Obatal representaría una utopía de corte neoafricano; la Ciudad de Dios de Trespalacios sería una utopía hispanizante y neomedieval, mientras que la Arcadia criolla de Pepe Díaz simbolizaría una utopía hecha a la medida de los criollos blancos de la isla. Todas ellas, incluida Nueva Venecia como suma de estas ciudades utópicas, constituyen para González versiones alegóricas de las ideas expresadas en varias obras clásicas de interpretación social y cultural

\footnotetext{
${ }^{793}$ Rodríguez Juliá, Edgardo (2002). La noche oscura del Niño Avilés, ed.cit., pp. 286-287.

${ }^{794}$ Ibid.,p. 18.

${ }^{795}$ Cito según la definición que brinda Bronislaw Baczko en su esclarecedor ensayo "Utopía", de su libro Los imaginarios sociales. Memorias y esperanzas colectivas, Buenos Aires, Nueva Visión, 1999, pp.55-123.

${ }^{796}$ Zanetti, Susana (1994). "Las historias fingidas de La noche oscura del Niño Avilés de Edgardo Rodríguez Juliá”, ed. cit., p. 28.
} 
producidas durante la década del treinta, tales como el citado ensayo Insularismo (1934) de Antonio S. Pedreira; el Prontuario histórico de Puerto Rico (1935) de Tomás Blanco, y Tuntún de pasa y grifería (1937) del poeta Luis Palés Matos:

"El Niño Avilés nos ofrece una especie de catálogo alegórico de estas distintas concepciones de la cultura insular, y más aún, las hace chocar entre sí, enfrascándolas en una polémica que el texto representa como una especie de épica burlesca. La lucha entre el caudillo negro Obatal y el peninsular obispo Trespalacios podría servir de alegoría para el debate implícito (pero no por eso menos real) entre las ideas de un Palés Matos (quien reivindicó el papel del negro en la cultura puertorriqueña) y las de un Pedreira (cuya concepción de la cultura puertorriqueña es esencialmente hispanófila." ${ }^{797}$

Pero la novela va bastante más allá de la interesante lectura de Aníbal González, tal vez demasiado ceñida a los márgenes de significación que plantean las alegorías. Una perspectiva diferente adopta César Salgado, proponiendo centrar su atención en la dimensión histórica del texto, aspecto bastante soslayado por las lecturas críticas que han preferido destacar la dimensión simbólica de Nueva Venecia en particular y de la novela en general. Toma en cuenta el valioso trabajo de Roberto González Echevarría ${ }^{798}$ donde plantea la representación de la figura del archivo en un importante corpus de la narrativa latinoamericana contemporánea como emblema y símbolo de las relaciones entre poder y escritura a partir del descubrimiento y colonización de América. En parte Salgado propone leer la novela de Rodríguez Juliá como "ficción de archivo", pero desde un ángulo diferente al de González Echevarría, subrayando más bien el efecto paródico de las prácticas archivológicas de la historiografía tradicional puertorriqueña. Si en La renuncia del héroe Baltasar, como oportunamente señalamos, se puede leer una parodia del archivo proceratista criollo, en La noche oscura... las prácticas de recuperación documental que esgrime Cadalso remedan la figura del "libro-archivo" de la historiografía del liberalismo autonomista del siglo XIX. Para Salgado el paradigma del libro-archivo lo constituye la Biblioteca histórica de Puerto Rico

797 González, Aníbal (1986). "Una alegoría de la cultura puertorriqueña: La noche oscura del Niño Avilés, de Edgardo Rodríguez Juliá", ed. cit., p. 587.

798 González Echevarría, Roberto (2000). Mito y archivo. Una teoría de la narrativa latinoamericana, México, Fondo de Cultura Económica. 
publicada por Alejandro Tapia y Rivera en 1854, una minuciosa recopilación de documentos, fragmentos de crónicas, relaciones, memorias, diarios, que abarcan desde el descubrimiento de la isla de Puerto Rico hasta el sitio de San Juan en 1797 por parte de los ingleses. El crítico analiza rigurosamente la presencia intertextual de este libro, como así también de otros dos, la edición realizada en 1866 por José Julián Acosta de la Historia geográfica civil y natural de la isla de San Juan Bautista de Puerto Rico de Fray Agustín Iñigo Abbad y Lasierra $^{799}$ y el Boletín Histórico de Puerto Rico (1814-1927) de Cayetano Coll y Toste. La Crónica de la Nueva Venecia constituye entonces una parodia de estos textos y aclara que:

"La absurda localización de estas crónicas -en el leprosario de la Isla de Cabras, en los caños de Santurce- ilustra el carácter diaspórico, escurridizo y desperdigado -siempre desubicado- del Archivo insular, y satiriza el modo en que su búsqueda compulsiva -el deseo de reubicarlo- remite a lugares imprevistos, vulnerables, marginales y abstractos, dentro y fuera de la égida imperial.. 800

Nueva Venecia, a través de su oscuro imaginario iconoclasta, como espacio licencioso cimarrón, revela para Salgado el resquebrajamiento del discurso legitimador de la identidad puertorriqueña del criollismo, ya que es incapaz de generar nociones heroicas o legendarias de la historia del país, sin que desemboquen dramáticamente en las "pesadillas de la Historia",801 como las Ilama el propio Rodríguez Juliá. El crítico no niega la fabulación de la historia presente en la novela pero señala que la falsificación va de la mano con su redocumentación, dando cuenta así de "esa misteriosa simbiosis que existe entre la verdad y la mentira." 802

\footnotetext{
${ }^{799}$ Antonio Benítez Rojo analiza con profundidad la presencia intertextual de la crónica de Iñigo Abbad en su estudio sobre La noche oscura, destacando particularmente las marcas retóricas que deja el texto del cronista en la novela, particularmente en las descripciones de castas y costumbres. Pero también subraya que el particular barroquismo del texto de Rodríguez Juliá se opone a la "tersa, precisa y ordenada prosa neoclásica" del fraile. Véase del autor (1996). "Niño Avilés o la libido de la historia", ed. cit., p. 279.

${ }^{800}$ Salgado, César (1999). “Archivos encontrados: Edgardo Rodríguez Juliá o los diablejos de la historiografía criolla", ed. cit., p. 183.

${ }^{801}$ Rodríguez Juliá, Edgardo (1989). "Puerto Rico y el Caribe: historia de una marginalidad", La Torre, 3.11, pp. 513-529.

${ }^{802}$ Salgado, César (1999). “Archivos encontrados: Edgardo Rodríguez Juliá o los diablejos de la historiografía criolla”, ed. cit., p. 198.
} 
Carl E. Schorske define tres modos de evaluar la configuración de la ciudad europea en los últimos doscientos años: la ciudad como virtud, la ciudad como vicio y la ciudad más allá del bien y del mal. La primera, desarrollada en el siglo XVIII a partir de la filosofía de la llustración, concibe el espacio urbano como encarnación del progreso social y cultural de la sociedad. El desarrollo industrial de las primeras décadas del siglo XIX fortalece en cambio una imagen antitética: la ciudad como vicio, donde acecha el peligro de la mezcla social. Hacia 1850, en el marco de una nueva cultura de la subjetividad, emerge un actitud intelectual que sitúa a la ciudad más allá del bien y del mal. Es la ciudad moderna que se vuelve visible en la poesía de Baudelaire, en "un eterno hic et nunc, cuyo contenido es la transitoriedad, pero una transitoriedad permanente." ${ }^{\circ 03}$ Nueva Venecia, como síntesis imposible de las distintas utopías trazadas en la novela, participa de las tres categorías que señala Schorske, teniendo en cuenta, por supuesto, los diferentes punto de partida entre el teórico y nuestro autor. En parte posee trazos de una San Juan dieciochesca e iluminista, concebida racionalmente como emblema del poderío imperial español. Pero asimismo revela su perfil opuesto, tramado en las representaciones del vicio del reino de las Quimbambas y de la Civitas diaboli. Por último, su fundación no se alcanza a consumar en las páginas del libro. No se afinca en ningún espacio concreto, revelándose como transitoriedad permanente, reflejo, fuga, deseo, utopía. A ella le caben las palabras finales del ensayo de Schorske, muy próximas a la concepción de Rodríguez Juliá, que hablan de "un sueño de la llustración que se había convertido en pesadilla."

\section{IV.2.3. El Niño Avilés, historia de una mirada}

\footnotetext{
${ }^{803}$ Schorske, Carl E. (1987). "La idea de la ciudad en el pensamiento europeo: de Voltaire a Spengler", separata de Punto de Vista nro. 30, año X, julio-oct., pp. iii-xix.

${ }^{804}$ Schorske, Carl E. (1987). "La idea de la ciudad en el pensamiento europeo: de Voltaire a Spengler", ed. cit., p. xix. Estas últimas palabras citadas de Schorske apuntan a la pesadilla histórica del nazismo.
} 


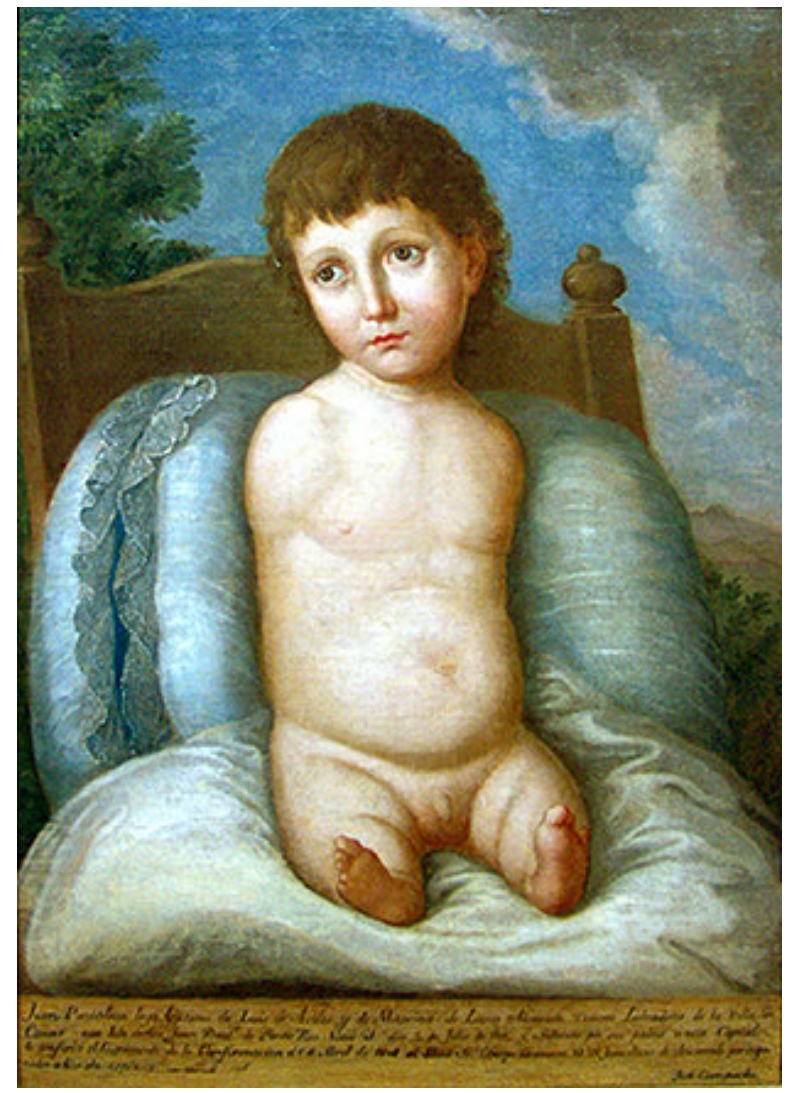

José Campeche y Jordán (San Juan, Puerto Rico 1751-1809)

El niño Juan Pantaleón Avilés de Luna Alvarado 1808

Óleo sobre tela

Sin marco: 27 3/8" x 19 5/8"

Colección del Instituto de Cultura Puertorriqueña

Para finalizar mi acercamiento a la inagotable novela de Rodríguez Juliá quiero proponer una inversión barroca de lo que podría haber sido punto de partida: aludir a las significaciones que encierra el título La noche oscura del Niño Avilés. Sin duda se advierten resonancias de los versos místicos del fraile carmelita San Juan de la Cruz, reunidos en su famoso tríptico poético Noche obscura del alma, donde se canta la huida del alma de la prisión de los sentidos, en medio de la noche, para lograr la unión divina ${ }^{805}$. En este sentido, según apunta Susana Zanetti ${ }^{806}$, la novela apela a mostrar diversos caminos de la ascesis, "noches oscuras", que remiten a tópicos barrocos tales como la soledad y el peregrinaje incesante del hombre. El personaje del obispo Trespalacios es quien mejor encarna esta concepción, repetida en las

\footnotetext{
${ }^{805}$ Véase la edición preparada por Alonso, Dámaso (1946). La poesía de San Juan de la Cruz, Madrid, Gredos. La poesía de este escritor místico se caracteriza por lo que la crítica ha denominado un "erotismo a lo divino", donde la unión amorosa con Dios se metaforiza en términos de goce sensorial.

${ }^{806}$ Zanetti, Susana (1994). "Las historias fingidas de La noche oscura del Niño Avilés de Edgardo Rodríguez Juliá”, ed. cit., p. 13.
} 
reflexiones que atiborran las páginas de su Diario secreto, donde se anudan los conceptos del peregrinaje barroco, del destierro, del exilio y de la noche oscura mística:

"Así me aventuro, con íntimo miedo y temblor, a crear un nuevo espacio luminoso, recinto donde el peregrino ya no vague más, dulce plaza de un Cristo que nos devolverá el paseo, ámbito del comercio y la ordenada buena vida, fuente donde se alivia la sed del desterrado, esperanza para la noche oscura que es el exilio." 807

Como se vio antes, el sueño de convertir a la ciudad de San Juan en recinto donde se erija el Estado paternal que reúna y albergue a sus hijos dispersos, fracasa para el obispo. Sumido en la melancolía, solo le queda transitar la "noche oscura" de sus visiones y pesadillas plagadas de demonios, "obligado como está a peregrinar en extravío"808, según la imagen desolada del prelado que traza Gracián en el cierre de la obra.

Hay también en la novela un predominio del ámbito nocturno. La noche es el momento privilegiado en el cual transcurren los principales hechos de su trama, muchos de los cuales se narran como si se trataran de sueños, visiones, alucinaciones, pesadillas, diferentes conceptos cuya afinidad reside en su dimensión nocturnal. Si por un lado la noche remite al mundo subterráneo de las sombras, al imperio del mal y de la muerte, como sucede, por ejemplo, en el episodio donde se relata el descenso del Renegado al reino de las Quimbambas, encontramos también otras posibilidades de significación, donde el espacio nocturno se vincula con las connotaciones románticas de la videncia y la revelación de lo oculto y lo misterioso ${ }^{809}$. Pero en La noche oscura... tales posibilidades se frustran; no se arriba a la "clarividencia", sino, por el contrario, a la opacidad del sentido y a la confusión de los sentidos. El sueño de la Nueva Venecia, que enhebra las diversas vicisitudes de la novela, se revela como "oscura visión del Niño Avilés", según consigna en las páginas de su Diario apócrifo el pintor Campeche: "Algo me dijo que todo aquello era sueño

\footnotetext{
${ }^{807}$ Rodríguez Juliá, Edgardo (2002). La noche oscura del Niño Avilés, ed.cit., p. 362.

${ }^{808}$ Ibid., p. 460.

${ }^{809}$ Marcel Raymond establece una continuidad entre la tradición poética romántica que apela a los conceptos del sueño, la ensoñación y la videncia, y la dimensión onírica que privilegia el surrealismo. Véase del autor su libro De Baudelaire al surrealismo, México, FCE, segunda edición, 1996.
} 
engañoso, o quizás uno de los temibles saltos en que nuestra lucidez vaga fuera del mundo sensible." 810 Nocturna utopía abortada, cuyos fantasmas alcanzan al presente del relato y obsesionan al historiador Cadalso; aquejado del "mal de archivo"811 solo desea desentrañar "la imagen de un recinto al parecer reprimido por la memoria colectiva" ${ }^{\prime 12}$, encerrado, como la alusión que entraña su apellido, en la laberíntica maraña de papeles que conforman su "libro-archivo".

Surge ahora el interrogante en torno al nombre propio que preside el título de la obra. ¿Quién es el visionario Niño Avilés? El retrato que hace las veces de epígrafe de este apartado nos brinda una respuesta. Al calce del cuadro de José Campeche, pintor dilecto de la élite puertorriqueña criolla del siglo XVIII, se encuentra la siguiente inscripción:

«Juan Pantaleón hijo legítimo de Luis de Avilés y de Martina de Luna Alvarado. Vecinos labradores de la Villa de/ Coamo en la Isla de San Juan Bautista de Puerto Rico. Nació el día 2 de julio de 1806, y conducido por sus padres a esta Capital/ le confirió el Sacramento de la Confirmación el 6 de abril de 1808 el Ilmo. Sr. Obispo Diocesano D. D. Juan Alejo de Arizmendi por cuya orden/ se hizo esta copia cogida del natural. José Campeche.»

Rodríguez Juliá, fascinado por la extraña criatura del cuadro, se apropia de su nombre pero también de su semblanza, para lograr lo que Salgado ${ }^{813}$ describe como "la desubicación y reinvención más radical de un referente histórico", en comparación con las ya mencionadas del obispo Trespalacios, Pepe Díaz y el propio Campeche. Conforme explica la nota al calce, el niño coameño, nacido sin brazos, fue retratado por José Campeche a solicitud del primer obispo puertorriqueño Juan Alejo de Arizmendi, luego que éste le administrara al menor la Confirmación. La obra documenta un caso médico que

\footnotetext{
${ }^{810}$ Rodríguez Juliá, Edgardo (2002). La noche oscura del Niño Avilés, ed.cit., p. 27.

${ }^{811}$ Jacques Derrida en su ensayo Mal de archivo, teniendo presentes las discusiones en torno al archivo de Michel Foucault, replantea la cuestión desde el paradigma psicoanalítico freudiano. Además de la función político-institucional del Archivo, observa una dimensión inconsciente del mismo, donde reside una "perturbación" o "enfermedad" que atenta contra su normatividad. La pasión archivística sugiere para Derrida "una diabólica pulsión de muerte, de agresión o de destrucción." Véase Derrida, Jacques (1997). Mal de archivo. Una impresión freudiana, Paco Vidarte trad., Trotta, Madrid, p. 17.

${ }^{812}$ Rodríguez Juliá, Edgardo (2002). La noche oscura del Niño Avilés, ed.cit., p. 15.

${ }^{813}$ Salgado, César (1999). “Archivos encontrados: Edgardo Rodríguez Juliá o los diablejos de la historiografía criolla", ed. cit., p. 157.
} 
en su época atrajo la atención de curiosos e "ilustrados" como el propio obispo, cuyas tesis promovían el estudio científico de fenómenos de la naturaleza ${ }^{814}$. Pero la magia que emana de la imagen del cuadro imanta también al escritor, como le revela Rodríguez Juliá a Julio Ortega en una entrevista, cuando, ante la pregunta del crítico sobre la documentación utilizada para configurar al personaje del Niño, le responde que su única fuente ha sido el retrato de Campeche: "Lo único histórico es la mirada melancólica. $Y$ un poco la novela es la explicación de esa mirada melancólica." ${ }^{815}$ En 1986, apenas dos años después de la primera edición de La noche oscura..., vuelve sobre el cuadro del Avilés en su ensayo Campeche o los diablejos de la melancolía, donde interpreta una serie de retratos del pintor aúlico como imágenes que narran la emergencia del sujeto criollo puertorriqueño en el siglo XVIII. Propongo detenerme brevemente en este texto, para dar cuenta de los vínculos estrechos que mantiene con las novelas hasta aquí analizadas, en especial con La noche oscura del Niño Avilés.

\title{
IV.3.1 Campeche o los diablejos de la melancolía: bocetos y estampas de la identidad puertorriqueña
}

\begin{abstract}
"Pues ya se sabe que es el ojo el que se apresura a cerrar un Sentido allí donde la mirada se esfuerza por abrirlo."

Eduardo Grüner, El sitio de la mirada
\end{abstract}

La cita del epígrafe manifiesta una tensión entre aquello que pareciera poder homologarse -el par ojo/mirada-, pero que sin embargo revela una oposición -sentido cerrado/sentido abierto-, como una tensión que trasciende la vista para postular a la mirada como una forma posible del conocimiento. La visión, el ver, el deseo de ver, la pulsión escópica, la mirada escrutadora, irónica, la mirada lasciva, la mirada melancólica por una parte, y por otra, la inscripción de esa/s mirada/s en la página, el pasaje que impone el

814 Dávila, Arturo (1971). José Campeche 1751-1809, San Juan, Instituto de Cultura Puertorriqueña.

${ }^{815}$ Ortega, Julio (1991). “1. Crónica de entierros, ficción de nacimientos”, entrevista a Edgardo Rodríguez Juliá, en: Reapropiaciones (cultura y nueva escritura en Puerto Rico), ed. cit., p. 149. 
desplazamiento entre la vista y la escritura, entre el sujeto que percibe y aquello que es percibido como imagen para ser descripta, inscripta, escrita, atraviesan buena parte de las ficciones de Edgardo Rodríguez Juliá recorridas hasta aquí.

En la composición de Campeche o los diablejos de la melancolía se destaca la combinación de imágenes y texto, similar a la crónica Puertorriqueños, donde el signo visual y el signo lingüístico se unen en una sola propuesta que es el texto contado. Los lectores accedemos a una subjetiva galería de retratos del pintor mulato ${ }^{816}$ : son algunas pinturas elegidas como representativas del mundo colonial del XVIII, descriptas e interpretadas por Rodríguez Juliá en su papel de "exégeta de la imagen plástica", como acierta Áurea Sotomayor ${ }^{817}$. Advertimos también la pasión por el archivo, ya que la memoria se conserva a través de las imágenes y de las palabras, combinadas por el narrador mediante diálogos y contrapuntos, glosas y descripciones, que median no solo entre la imagen y la letra, sino también entre la textualidad contemporánea y el archivo de crónicas del siglo XVIII. Así en Campeche la cita textual es el mecanismo de apropiación del archivo del pasado, cuando el narrador-ensayista nos conduce a aquel tiempo considerado fundacional de la identidad puertorriqueña y nos invita a leer fragmentos de la "Memoria de D. Alexandro O’Reylly sobre la Isla de Puerto Rico, Año 1765"818.

El sujeto que mira puede leer los cuadros de Campeche porque ellos condensan una "escritura pictórica"819, y es el pintor del siglo XVIII, según la

\footnotetext{
${ }^{816}$ José Campeche nació en San Juan, en 1751 y falleció en la misma casa donde había nacido en 1809. Era de origen mulato, aunque en su pintura tanto este sector como los esclavos rara vez aparezcan. Rodríguez Juliá traza su biografía teniendo en cuenta el libro de Alejandro Tapia y Rivera, Vida del pintor puertorriqueño José Campeche (Barcelona, Editorial Rumbos, 1967) como así también el libro de Arturo Dávila, José Campeche 1751-1809, ed. cit. En su carrera de pintor Campeche se destacó como retratista de la élite puertorriqueña de la segunda mitad del siglo XVIII.

${ }^{817}$ Sotomayor, Áurea María (1992). "Escribir la mirada", ed. cit., p. 127.

${ }^{818}$ A diferencia de La noche oscura... en el ensayo sobre Campeche Rodríguez Juliá despliega en las citas y notas al pie las fuentes documentales usadas, destacando la colección compilada por Eugenio Fernández Méndez, Crónicas de Puerto Rico (San Juan, Ediciones Estado Libre Asociado de Puerto Rico, 1957), en la cual figura un texto muy citado por el escritor, la “Memoria de D. Alexandro O'Reilly sobre la isla de Puerto Rico, Año 1765". A partir de las recomendaciones que hizo O’Reilly, la Corona bajo Carlos III impulsó una serie de reformas tales como refortificar San Juan, reorganizar la milicia, estimular la inmigración, controlar el contrabando, medidas que ejemplifican el pensamiento ilustrado y reformista de aquella época. ${ }^{819}$ Rodríguez Juliá, Edgardo (1986). Campeche o los diablejos de la melancolía, ed. cit., p. 24.
} 
tesis que alienta el ensayo, quien provee las primeras imágenes de la nacionalidad puertorriqueña:

"Antes de la literatura fue la pintura. La obra de Campeche le provee a nuestra nacionalidad una imagen que se adelanta al testimonio literario; tendremos que esperar hasta el siglo XIX para que nuestra cultura se convierta en verbo."/ "Ocupa esta pintura dos grandes temas: La conformación de la individualidad criolla y la fundación emblemática del estado." 820

Áurea Sotomayor precisa que Rodríguez Juliá se detiene en los tres estamentos protagónicos de la visión de Campeche: la administración colonial, la burguesía criolla y el clero. Esa incipiente nacionalidad que advierte representada en los retratos del pintor, lejos de promover la unión de los diversos sectores parece más bien acentuar las marcadas diferenciaciones y jerarquías. Así, por ejemplo, el ensayista se centra en los avatares del sector criollo como conjunto social, a partir de una lectura de los emblemas, gestos y detalles que imprime "el giro venenoso del pincel "821 de Campeche en sus retratados y que Juliá identifica e interpreta con características tales como la inquietud, el desasosiego, la tristeza, la melancolía, la rivalidad de clases, la utopía.

El narrador se autofigura al interior del texto como un espectador, cuya mirada especula a su vez sobre la mirada de los retratados estableciendo un juego entre el sujeto que mira/ es mirado/ se ve a sí mismo mientras mira. De este modo observa e interpreta la mirada crítica del pintor sobre su retratados, especialmente los sectores criollos, como una tensión étnica entre la élite mulata y la élite criolla: "Se trata de la mirada implacable con que un desclasado mira a otro, con que un criollo mira a otro que compite con él por las mismas prebendas, por los mismos beneficios y privilegios. "822 Asimismo el escritor, como lector de imágenes, es "punzado" por ciertos detalles de los cuadros de Campeche, en el sentido del punctum barthesiano: "eso" que parte de la escena como una flecha y hiere al sujeto, lo perturba "pinchazo, agujerito, pequeña mancha, pequeño corte y también casualidad", en términos de

\footnotetext{
${ }^{820}$ Ibid., p. 7 y 9 respectivamente.

${ }^{821}$ Rodríguez Juliá, Edgardo (1986).Campeche o los diablejos de la melancolía, ed. cit., p. 52.

${ }^{822}$ Ibid., p. 52.
} 
Barthes $^{823}$. Esta perturbación que hiere la retina y subjetividad de quien contempla se produce en parte porque la pintura de Campeche participa de la paleta manierista, cuya técnica pictórica se funda en introducir el descentramiento de la representación. Como consecuencia se rompe el equilibrio típicamente renacentista de la escena organizada alrededor de la/s figura/s central ${ }^{824}$. Si bien los cuadros analizados, comentados, sobrescritos, son retratos en los cuales hay figuras, la mirada del sujeto que organiza el pasaje de la imagen al texto, va a privilegiar particulares aspectos de los cuerpos representados, sobre todo respecto de las poses de los retratados, que revelan una inadecuación, una fisura, un desarreglo perturbador. En el análisis del retrato del criollo Don Valentín Martínez, para detenernos en un ejemplo, el sujeto que observa es punzado por un detalle que parece nimio: la sombra de barba del rostro del retratado, a la cual se le asigna un sentido moral: "delata ausencia de nobleza en el rostro" ${ }^{225}$. Este detalle peculiar dispara una especulación histórico-social sobre al advenimiento del sector criollo en Puerto Rico en el siglo XVIII y sus tensiones con otros sectores, como la élite mulata a la cual pertenece el propio Campeche y las autoridades coloniales de la isla, en su mayoría de origen peninsular:

"En don Valentín vemos, sobre todo, un ciudadano proveniente de una esfera separada del marco institucional de la colonia. Ahí está el germen de lo criollo. Este es justamente ese esfuerzo por concebir una convivencia progresivamente distinta de la peninsular, de origen isleño y con propia definición. En ese esfuerzo por separarse del ámbito administrativo-colonial también existe el anhelo de aceptar cargos, sobre

\footnotetext{
${ }^{823}$ Barthes, Roland (1998). La cámara lúcida. Nota sobre la fotografía, Madrid, Paidós. En este ensayo sobre la fotografía Barthes distingue dos conceptos respecto de la imagen: studium y punctum. El studium tiene que ver con el interés general, con la connotación cultural de la imagen. El punctum en cambio se caracteriza por su subjetividad y fuerza metonímica, no es buscado sino que "sale de la escena como una flecha y viene a punzarme." (p. 64).

${ }^{824}$ Sigo las ideas de Eduardo Grüner para quien esta técnica pictórica de descentramiento manierista es paralela al descubrimiento de la órbita elíptica hecho por Kepler, idea que rompe la imagen cosmológica de un universo con un núcleo central. También en el universo políticoideológico, agrega el crítico, de una concepción centrada en el Estado Absolutista se pasa a una duplicación del espacio político que lo divide en Estado y Sociedad. Véase del autor El sitio de la mirada. Secretos de la imagen y silencio del arte, Buenos Aires, Grupo Editorial Norma, 2001, especialmente la tercera parte, pp. 253-383. Sobre este aspecto remito también a la propuesta de Severo Sarduy, en su importante libro Ensayos generales sobre el Barroco, particularmente el apartado III "La cosmología barroca: Kepler", México, FCE, 1987, pp. 177198.

${ }^{825}$ Rodríguez Juliá, Edgardo (1986).Campeche o los diablejos de la melancolía, ed. cit., p. 52.
} 
todo si éstos son más de dignatarios que de funcionarios. El prestigio institucional atrae a la vez que la convivencia insular se enajena del mismo. Ahí aparece la incertidumbre de lealtades que sufre el criollo. Se es y no se es. Hay un anhelo de pertenecer a la vez que se manifiesta la necesidad de separación." ${ }^{826}$

La lectura y exégesis del retrato de don Valentín Martínez organiza una mirada y su interpretación sobre un determinado sector social: los criollos puertorriqueños, especialmente las clases en ascenso, están marcadas por la incompletud y la inseguridad. El pintor se torna implacable y revela mediante detalles que parecen menores la impostura de tal estamento; paralelamente el ensayista arriba a una valoración negativa: el resentimiento del criollo es su característica más pertinaz. Ahora bien, Rodríguez Juliá propone no solo leer e interpretar las imágenes visibles sino también atender a los espacios en blanco de la representación pictórica, los "silencios" de los cuadros de Campeche, donde brillan por su ausencia importantes sectores populares que constituyeron a su vez la base económica de la etapa colonial: los esclavos, los mulatos, los libertos, los campesinos ${ }^{827}$. Atribuye estas ausencias a una "miopía" por parte del pintor: "Apenas se detiene en el pueblo. Semejante miopía posiblemente tenga origen en su propia condición racial y social." 828 Para el escritor la obra de Campeche manifiesta un afán de autovalidación por parte del pintor mulato, el cual se convierte en la fuente oculta de la melancolía que impregna todos sus cuadros: puede representar al otro (la administración colonial, el clero, la casta militar, etc) pero no puede dar cuenta de su propia identidad étnica y de clase. La única vez que en sus retratos aparece el sector popular es en el considerado como el último y el más singular de sus cuadros, donde pinta al niño Juan Pantaleón Avilés ${ }^{829}$.

\footnotetext{
${ }^{826}$ Ibid., p. 52 (cursivas del autor).

${ }^{827}$ Véase el siguiente pasaje: "Pero he aquí que esta mirada triste no testimonia la propia condición; del lado de acá del lienzo, en el mutismo del oficio artesanal, ha quedado la otra clase contenedora de aquella nacionalidad en ciernes del XVIII, es decir, la élite mulata. Acá, allá, de todos modos fuera del oficio y el espacio pictóricos, se oye el rumor del fundamento económico de aquella sociedad; en la pintura de Campeche solo una vez aparecerán los esclavos. ( Ibid. p. 8)

${ }^{828}$ Ibid., p. 127.

${ }^{829}$ Véase el Î́ndice del catálogo de José Campeche Jordán, reproducido en la revista La Torre (Revista General de la Universidad de Puerto Rico), núms. 77-78, ed. cit., pp. 87-211 (vol. 77, jul.-sept.)
} 


\section{3. 2 El niño monstruo: del cuadro a la novela}

"MONSTRO, es cualquier parto contra la regla y orde natural, como nacer el hombre con dos cabeças, quatro braços y quatro piernas; como acontenció en el Condado de Vrgel, en un lugar dicho Carbera, en el año 1343, que nació un niño con dos cabeças, y cuatro pies: los padres y los demás que estauan presentes a su nacimiento, pensando supersticiosamente pronosticar algú grà mal, y que con su muerte se euitaría lo enterraron vivo. Sus padres fueron castigados como parricidas, y los demás con ellos. He querido traer sólo este ejemplo por ser auténtico y escriuirle nuestros coronistas. Dixose monstro Lat. Monstrum a monstrado quiod aliquid significando demonstret. Veras la ley 8. Tir. 33 part. 7."

Covarrubias, Tesoro de la lengua castelana o española

Volvamos unas páginas atrás y miremos una vez más el retrato del Niño Avilés que tanto "punzó" a Edgardo Rodríguez Juliá. La reproducción nos muestra un niño contrahecho, sin brazos, con las piernitas agarrotadas y empequeñecidas, la cabeza grande y ladeada, los ojos un tanto estrábicos y marcadamente tristes. El ensayista se pregunta los motivos que pudieron llevar al obispo Arizmendi a encargar tal obra, y no conforme con las respuestas esbozadas por los historiadores de arte -la curiosidad científica respecto de un error de la naturaleza- propone otra interpretación. El niño es figura emblemática, un ícono que representa y visibiliza a los sectores sociales ausentes o apenas esbozados en la obra del pintor: "Resulta curioso que el pueblo, casi ausente de la pintura de Campeche, estalle en el retrato de Avilés, convertido éste en vivencia de la necesidad, objeto de la mirada curiosa y compasiva." ${ }^{830}$ El retrato del niño Avilés encierra una doble extrañeza: es un "extraño visitante" de la comunidad social representada en la pintura de Campeche por su extracción social campesina pero además es un "monstrillo"831. Si apelamos al significado etimológico del término, monstruo viene de monstrando, lo que debe mostrarse, exhibirse, sacarse a luz, aquello que manifieste lo que debe darse a conocer, mostrar, designar, señalarse ${ }^{832}$.

\footnotetext{
${ }^{830}$ Rodríguez Juliá, Edgardo (1986). Campeche o los diablejos de la melancolía, ed. cit., pp. 123-124.

${ }^{831}$ Ibid., p. 118.

${ }^{832}$ Sigo la acepción de Covarrubias citada por Roberto González Echevarría, en su excelente artículo "El monstruo de una especie y otra", en: Co-textes, Montpellier, nro. 3, 1982, pp. 27 58.
} 
En la última pintura de Campeche emerge "lo que debe mostrarse", el pueblo, que cristaliza en la imagen de un niño deforme, cuya mirada dolorosa metaforiza el sufrimiento, individual y colectivo:

"Este retrato del dolor trasciende el semblante del niño. (...) Y este sufrimiento está relacionado con el pueblo. La mirada del pintor acostumbrada a captar la personalidad y función de la élite criolla y la casta administrativa colonial- se posa aquí en lo disforme, en un hijo del pueblo, cuya desventura les ha traído sufrimiento a sus devotos padres, esos vecinos labradores de Coamo que hicieron la peregrinación hasta San Juan, para conseguirle a su monstrillo confirmación celebrada por Arizmendi". .33

El análisis del retrato del Niño Avilés se desvía hacia una consideración moral de su deformación física. Para Rodríguez Juliá el pintor impregna de tristeza al pincel e infunde en el niño su visión del pueblo, que estalla en la mirada del retratado. La mirada dolorosa del niño va más allá de la limitación de su cuerpo. Encerrado en la prisión de sus miembros disformes la única libertad posible para el niño consiste en expresar y transmitir el dolor a través de sus ojos interrogadores:

"El Avilés carga con un cuerpo y una voluntad que han muerto, más radical aún, carga con la muerte misma, es el emblema absoluto de la misteriosa condición humana. Ahí está el emblema de nuestro sometimiento al cuerpo, a la enfermedad, al dolor y a la muerte. Sólo queda esa persistencia del tiempo en la mirada, nuestra condición, la obediencia del alma. Toda la humanidad doliente se resume en esos ojos terribles pintados por Campeche. El ojo derecho parece más resignado, más obediente, más santo. Pero el ojo izquierdo se desespera, expresa nuestra perplejidad ante la desgracia, ante el sufrimiento de los inocentes. En esa distancia entre el ojo derecho y el izquierdo residen la obediencia y la rebeldía, la salvación y la maldición, la santidad y nuestra soberbia." ${ }^{834}$

El retrato del Niño Avilés le permite al narrador leer en la mirada del infante la mirada del pintor, pero también cuestionarse sobre el yo que mira, en una operación mediante la cual el sujeto se captura a sí mismo bajo la forma imaginaria de un otro exterior. Lo que comparten entonces el Niño retratado, la

\footnotetext{
${ }^{833}$ Edgardo Rodríguez Juliá (1986). Campeche o los diablejos de la melancolía, ed. cit., p. 118. ${ }^{834}$ Ibid., pp. 122-123.
} 
mirada del pintor y la visión del sujeto que contempla a ambos es la melancolía, también la impotencia: "Campeche ha dado rienda suelta a su melancolía"835 afirma el narrador, quien, por única vez se autoincluye en la escena a través del reiterado pronombre posesivo "nuestro" de la cita precedente. Para Marta Traba en la figura del pequeño Avilés "nunca la belleza del desvalimiento pudo encontrar un intérprete más elusivo y conmovedor, cuya pintura rodea lo que toca, dice sin ruido y al fin levanta el tema por sobre toda desventura." ${ }^{136}$ En la sugerente perspectiva de Sotomayor la mirada del niño se vuelve vehículo de insatisfacción aunque no de rebelión, única utopía posible para el pueblo puertorriqueño, porque si "el pueblo es el Avilés, lo popular es lo cautivo, la voluntad sometida., 837

El retrato del pequeño contrahecho se reproduce en la tapa de las dos primeras ediciones de La noche oscura del Niño Avilés, una llevada a cabo por Ediciones Huracán en 1984 y la otra por la Editorial Cultural de la Universidad de Puerto Rico, en 1991. En su tercera edición, la más reciente, a cargo de la prestigiosa Biblioteca Ayacucho, la imagen del Avilés se reemplaza por otra, detalle de un cuadro llamado Espejos y paternalismo, del artista plástico puertorriqueño contemporáneo, Arnaldo Roche-Rabell, en la cual, de manera bastante menos figurativa que en Campeche, se percibe también la representación de un niño. Por otra parte esta última edición se basa en la primera, ya que en 1991 la novela aparece con recortes bastante significativos, donde se descartan todos los paratextos firmados por Alejandro Juliá Marín. En este sentido la última edición se muestra respetuosa de la versión original más larga, según se lo explicita en una nota inicial que aclara que los únicos cambios establecidos y autorizados por Rodríguez Juliá han consistido en la unificación de signos de puntuación y en la corrección de algunas erratas. Con la edición de Ayacucho se evidencian continuidades formales entre La renuncia del héroe Baltasar, La noche oscura... y El camino de Yyaloide, cuyas traman se anudan no solo por la voz del narrador Cadalso sino también por los comentarios exegéticos del poeta. ¿Por qué se deja de lado entonces el cuadro de Campeche? Arriesgo una hipótesis aunque advierto que carezco de

\footnotetext{
${ }^{835}$ Ibid., p. 118.

${ }^{836}$ Traba, Marta (1972). "El ojo alerta de Campeche", en: La Torre (Revista de la Universidad de Puerto Rico), núm. 77-78, ed. cit., pp. 43-51. (vol. 78, julio.-dic.)

${ }^{837}$ Sotomayor, Áurea María (1992). "Escribir la mirada", ed. cit., p. 161.
} 
información para sostenerla. El retrato del Niño Avilés de Campeche ha funcionado para el escritor como una "imagen pregnante" ${ }^{\text {"838, }}$, como se advierte especialmente en el apartado que le dedica en el ensayo sobre el pintor, sin dejar demasiado lugar a la idea que pueda trazarse del niño un lector que no conozca el cuadro. A su vez el título de la pintura de Roche-Rabell-Espejos y paternalismo- juega con dos obsesiones borgeanas que Rodríguez Juliá reconoce también como propias, como vimos particularmente en los análisis de las crónicas Las tribulaciones de Jonás y El cruce de la bahía de Guánica, textos donde explícitamente se especula sobre las imágenes paternas figuradas.

En La noche oscura del Niño Avilés encontramos también variadas transposiciones plásticas del retrato del pequeño, donde el pincel de Campeche se torna, ut pictura poiesis, alucinada pluma barroca que atribuye al niño monstruosidades no físicas sino espirituales. La fábula urdida por el obispo Larra en torno a la demonización del Niño Avilés y que culmina con el exorcismo practicado por Trespalacios, se amplifica hiperbólicamente a lo largo de las distintas instancias de la diégesis narrativa. Para Obatal y sus rebeldes primero, para Mitume luego, el infante, "demonio blanco", constituye un ambiguo signo que reúne maldad y protección. Como "talismán diabólico" acompaña cada batalla, aunque para acallar su llanto se lo amordaza mediante un extraño bozal y se lo mantiene aprisionado en una suerte de saco o costal, cuyas costuras están siempre al borde de estallar, detalles que aluden a la prisión corporal de la deformidad física del niño del cuadro. Cuando el pequeño termina bajo el dominio del obispo Trespalacios, la mirada de Gracián traza una detallada imagen del Avilés, mediada por el retrato de Campeche:

"Ahí casi le tengo puesta la antorcha en el hocico, que Don José ya lo ha desamordazado. Se me figura que en las mejillas tiene como marcas, heridas hechas por el bozal que le apretaron los negros. (...) Miren que tiene los ojos hundidos en las cuencas huesudas, las mejillas chupadas, todo el semblante demacrado. (...) Nadie me creerá que la

\footnotetext{
${ }^{838}$ Los especialistas en artes plásticas analizan el concepto de "pregnancia" de ciertas imágenes, en relación al lugar específico que cobran en tramas culturales particulares. Hay imágenes más poderosas (o valiosas) que otras para determinadas culturas. Agradezco la explicación brindada por la crítica de arte Laura Malosetti-Costa. Remito a los importantes aportes sobre el poder de la imagen en relación con su traducción al lenguaje verbal de Louis Marin, especialmente su libro De la représentation, París, Seuil-Gallimard, 1994.
} 
chola se le agigantó, quizás por la grande cantidad de agua que los demonios suelen llevar en los sesos... Pero aparte de su infeliz semblante, el Avilés parecía como aliviado de la infame carga que llevó por tanto tiempo. A pesar de su muy notable fondo de tristeza, los ojos de aquel niño eran los de cualquier cristiano." ${ }^{839}$

El fragmento citado se aproxima a las reflexiones del narrador-ensayista de Campeche o los diablejos de la melancolía, en particular respecto de la mirada dolorosa del niño. Gracián reconoce en el infante su humanidad perdida; sin embargo actúa como cómplice del obispo para transformar al Avilés en un monstruoso instrumento de dominación política.

Una última cita plástica se reconoce claramente en el relato de una de las tantas pesadillas visionarias que aguijonean a Trespalacios y que transcribe así en su Diario secreto:

"Pues ahora relataré una de estas extrañas pesadillas. Anoche mismo soñé que el Niño Avilés crecía mucho hasta hacerse hombre; pero a medida que crecía sus miembros se achicaban, encogiéndose hasta desaparecer, quedando el pobre muy tullido, imposibilitado de caminar o de coger cosas, pues era hombre que solo tenía tronco." ${ }^{.840}$

Se subrayan nuevamente las connotaciones monstruosas del niño, pero además se proyectan al futuro, en tanto el pequeño del retrato ha devenido adulto en la pesadilla del prelado.

En el profundo estudio que dedica Roberto González Echevarría ${ }^{841}$ a la figura del monstruo en la estética barroca, particularmente en la obra de Calderón de la Barca, señala una especial característica: la monstruosidad se constituye mediante un ente doble y contradictorio en quien conviven simultáneamente dos naturalezas opuestas. La figura del monstruo revela además las contradicciones que la vinculan a la ideología de su época. El Niño Avilés de la novela se conforma como ente doble: criatura inocente, como reconoce Trespalacios "más víctima de los hombres que de los demonios", pero a su vez estigmatizada como encarnación del diablo, tanto por la

\footnotetext{
${ }^{839}$ Rodríguez Juliá, Edgardo (2002). La noche oscura del Niño Avilés, ed.cit., p. 354.

${ }^{840}$ Ibid., p. 413.

${ }^{841}$ González Echevarría, Roberto (1982). "El 'monstruo de una especie y otra' “, ed. cit., p. 34.
} 
superstición popular como por los maquiavélicos manejos de quienes detentan el poder en la ficción. El infante del retrato de Campeche, devenido emblema en la propuesta de Rodríguez Juliá, también participa de la dualidad del monstruo: a los ojos de la curiosidad ilustrada del siglo XVIII reviste como un "fenómeno", una anomalía de la naturaleza, pero asimismo es un hijo de Dios, y como tal, recibe el sacramento de la confirmación.

Tanto la novela como el ensayo plantean una representación del pasado mediante la cual se indaga también el presente. En Campeche o los diablejos de la melancolía la metáfora monstruosa del Niño Avilés como pueblo cautivo, cuya mirada estrábica oscila entre la obediencia y la rebeldía, parece encarnar en el presente político de Puerto Rico a través del Estado Libre Asociado. Una entidad híbrida, contrahecha, otro "monstruo de la razón", institución doble y paradójica, cuyas contradicciones estallan en su oximorónica fórmula. Si, como sostiene Rodríguez Juliá, en el siglo XVIII el pincel se adelanta a la pluma, puesto que los retratos de Campeche son las que proveen las primeras imágenes de la identidad nacional puertorriqueña, éstos muestran sin embargo conflictos sociales y étnicos, aun sin resolver en el presente. La ausencia de un relato de la nación en aquel siglo se suple mediante la invención narrativa. En este sentido podríamos invertir la propuesta de Hayden White, cuando señala que es posible crear un discurso imaginario sobre acontecimientos reales y que no por ello deja de ser menos "verdadero", ya que "todo depende de cómo uno concibe la función de la imaginación en la naturaleza humana." ${ }^{842}$ En La noche oscura del Niño Avilés el discurso imaginario sobre acontecimientos igualmente imaginarios, o bien, muy desviados respecto de sus referentes históricos, puede sin embargo echar luz sobre aspectos poco conocidos de la historia, si tenemos en cuenta además las palabras con las cuales Rodríguez Juliá ha descrito sus ficciones del XVIII: "Intento establecer en la textualidad las posibilidades de lo que nunca fue; pero ello no significa que lo apócrifo esté ajeno a la verdad histórica." 843

\footnotetext{
${ }^{842}$ White, Hayden (1992). El contenido de la forma: narrativa, discurso y representación histórica, Barcelona, Paidós, p. 74.

${ }^{843}$ Rodríguez Juliá, Edgardo (2002). “Tradición y utopía en el barroco caribeño”, en: Caribeños, ed. cit., p. 69.
} 


\section{- Breve visita a la galería de retratos de Campeche}

"En el asombroso retrato del Gobernador Don Miguel Ustáriz, Campeche pretende algo más que retratar a un hombre poderoso; su intención también es pintar un emblema del poder. El aposento se ha convertido en gabinete, taller del ejercicio de ese mando. Hay un gesto de gran boato en esos cortinajes. Este primer marco del emblema ya nos sitúa en la significación del cuadro; se trata de representar el mando desde una perspectiva idealizada; es como si acudiéramos a la fundación del estado en Puerto Rico." ${ }^{844}$

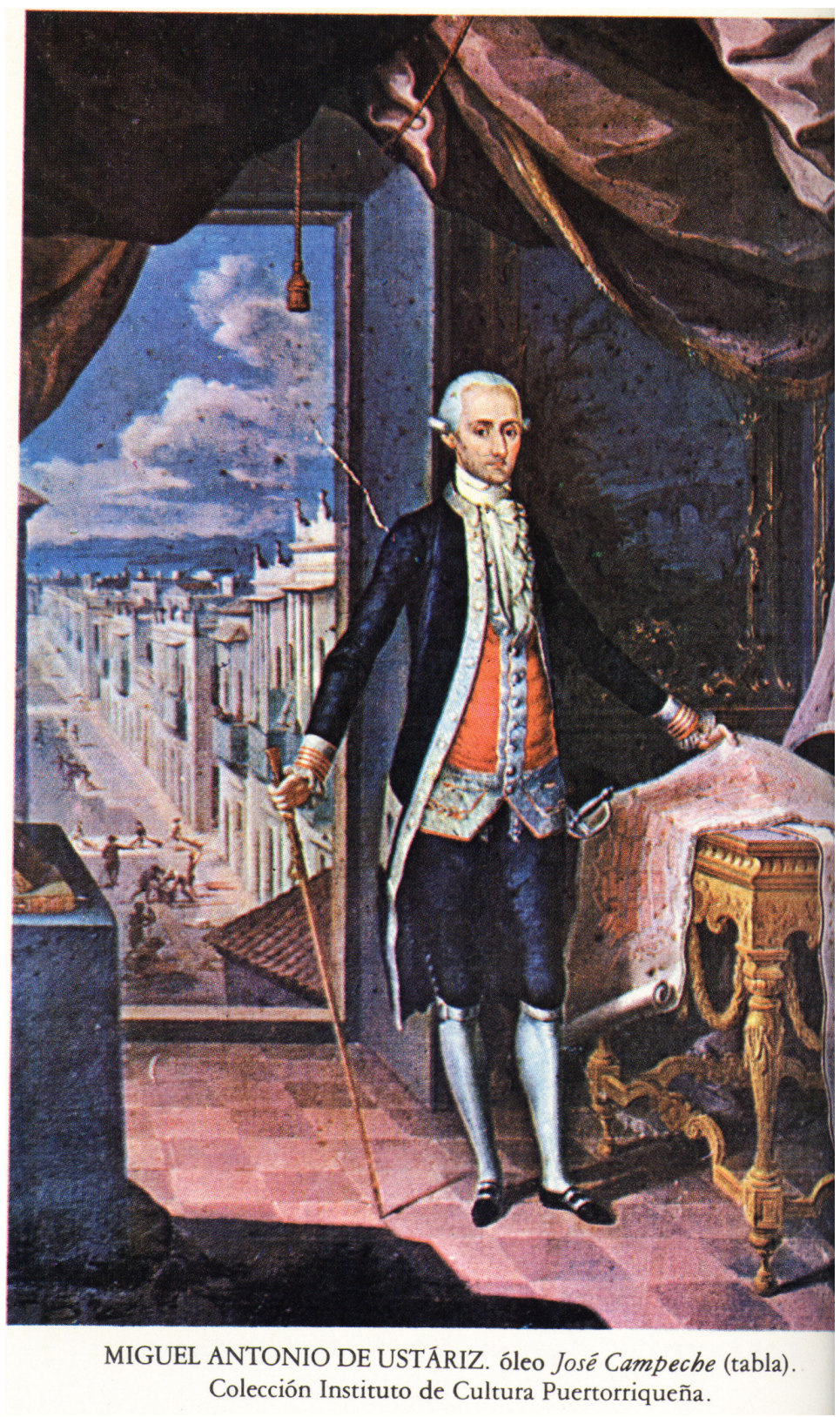

${ }^{844}$ Edgardo Rodríguez Juliá (1986). Campeche o los diablejos de la melancolía, ed. cit., pp. 1314 (cursiva del texto). 
"El retrato de Don José Más Ferrer plantea la consolidación del estado colonial como burocracia; aparece en toda su plenitud la figura del funcionario. Pintado en 1795, este lienzo tiene más parentesco con el retrato de Ustáriz que con el de Castro. Aquí la emblemática se mantiene en la textura misma del realismo. Volvemos a un aposento. Esta vez es el despacho de un funcionario. A la izquierda, sobre un escritorio, el tintero, la carta y los libros. El despacho es al funcionario lo que el gabinete al gobernante, es decir, máquina de voluntad, espacio donde se ejerce el poder ejecutivo." ${ }^{845}$
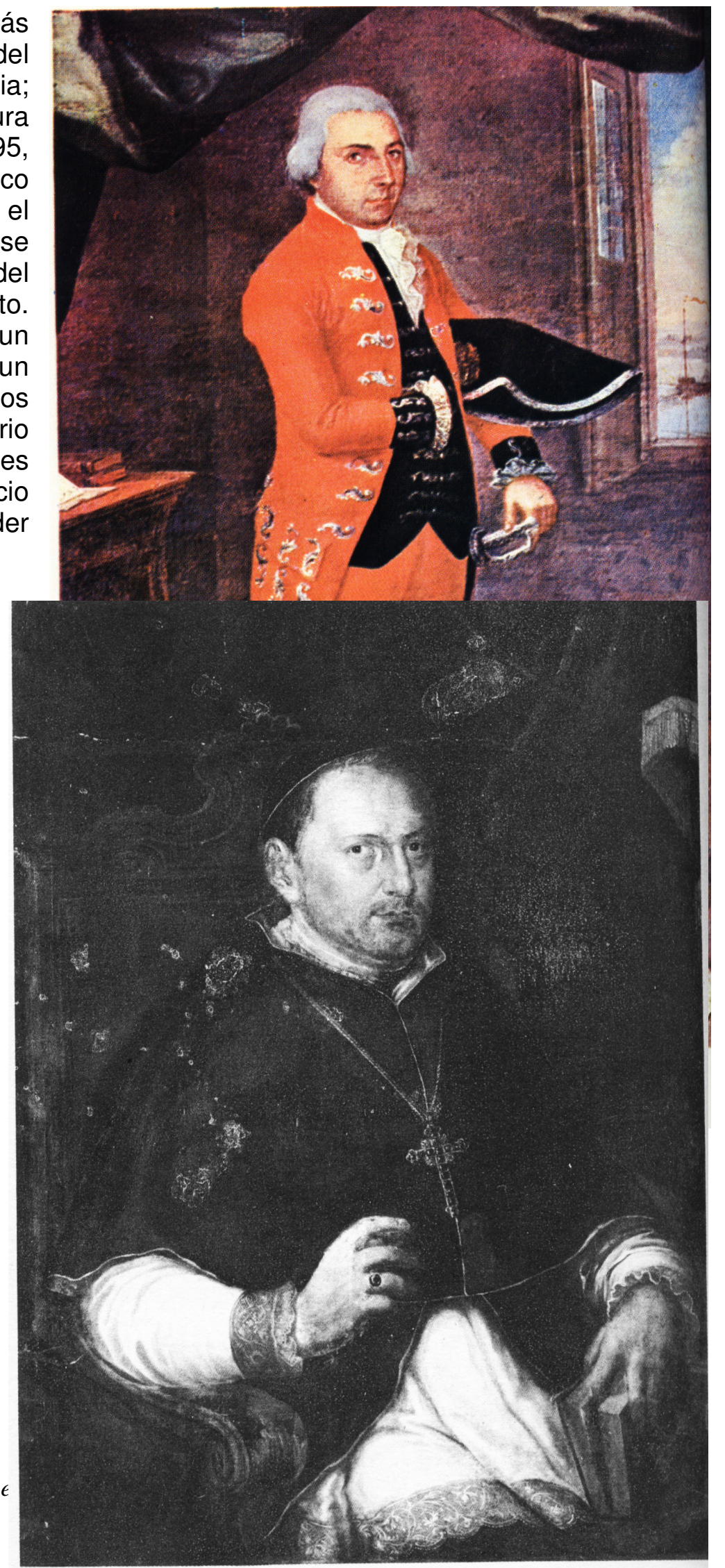

"¿Dónde sitúa Campeche la iglesia? Veamos a sus Obispos: Don Felipe José de Trespalacios y

${ }^{845}$ Edgardo Rodríguez Juliá (1986). Campe 39 (cursiva del texto). 
Verdeja aparece sentado sobre el poder de la iglesia. La contundencia de este retrato arranca precisamente del reconocimiento de lo que es una jerarquía tradicional. Don Felipe José parece sostenido por la tradición, como si más que sentado estuviera bendiciendo desde la silla gestatoria. También es un gobernante, un hombre de poder que hace las veces de funcionario. Gobierna a la vez que administra una tradición, un dogma y unos bienes. Su función está perfectamente plantada en la espesura de este mundo. Por ningún lado se insinúa una emblemática mística, un signo que nos recuerde la santidad de su oficio." 846

\section{4 La ruta del desvarío: El camino de Yyaloide o la antinovela de formación}

"Además lo lejano fabrica miniaturas en todos los puntos del horizonte. El soñador, ante esos espectáculos de la naturaleza lejana, desprende sus miniaturas como otros tantos nidos de soledad donde sueña vivir."

Gastón Bachelard, "La miniatura” (La poética del espacio)

Si antes caractericé a La noche oscura del Niño Avilés como una novela de la desmesura, El camino de Yyaloide apela a su imagen opuesta, la miniatura: se narran la infancia del Niño Avilés y su "viaje menino" de formación; se describe un juguete que reproduce una ciudad a escala mínima; las distintas etapas de la educación del Avilés se representan en una colección de miniaturas manieristas pintadas por Silvestre Andino, hermano ficticio de José Campeche. Por otra parte se atenúan el extremismo y la fantasía desaforada de la novela anterior, aunque se repiten los contrastes barrocos,

${ }^{846}$ Edgardo Rodríguez Juliá (1986). Campeche o los diablejos de la melancolía, ed. cit., p. 101. 
las hipérboles y los pasajes caricaturescos y grotescos. Su estructura narrativa, como en La renuncia del héroe Baltasar, retorna a la tripartición; incluso se puede afirmar que remeda la forma de un tríptico, cuyas alas laterales (el capítulo I "Formación del Niño Avilés" y el capítulo III "El Tarot") funcionan como apoyos de la parte central: el largo capítulo II, titulado "El viaje menino", donde se despliegan los principales episodios del texto. Una vez más la figura del historiador Cadalso participa como instancia mediadora que compila y reordena una secreta colección de crónicas reunidas bajo el irónico título Excelso cronicón de la muy sagrada educación del Avilés; nuevamente este personajenarrador se ocupa de revelar lo oculto, iluminar lo oscuro, restituir al archivo lo obliterado:

"Desde el silencio de los pequeños cuadros y las voces de los cronistas, escuchamos lo seco de un episodio desconocido en la gran Teodicea occidental. Este capítulo oculto de nuestra historia -recientemente desenterrado del olvido por nuestro archivero municipal, Don Eleuterio Fernández Vargas- nos sitúa unos sucesos que el mismo Obispo Trespalacios quiso olvidar: Cuando el fervor popular empezó a tumbarles las cabezas a la imágenes de Cristo, para substituirlas por pequeñas tallas de madera hechas a imagen del Avilés, el Obispo les pidió silencio a todas las autoridades, y 'que Roma jamás se entere'، "847

La novela se centra en la formación del Niño Avilés, paralela al desarrollo de un culto heterodoxo e iconoclasta en torno a su figura. El obispo Trespalacios no se conforma con el testimonio escrito de la formación del Niño Avilés sino que manda a pintar los diferentes momentos de su aprendizaje, archivo de miniaturas que reproduce iconográficamente lo que las crónicas informan y que la mirada de Cadalso (d)escribe, asumiendo una posición cercana a la del narrador-ensayista de Campeche o los diablejos de la melancolía, como lector, intérprete y comentarista de imágenes, aunque ficticias en este caso. Así el primer capítulo se compone de la minuciosa exégesis que Cadalso realiza de siete pequeñas estampas, salvadas de la posterior quema que pretendió borrar cualquier vestigio que aludiera al Avilés y a Nueva Venecia, "miniaturas que Silvestre Andino Campeche -hermano y discípulo del maestro mulato- pintó como homenaje diario de la presencia del Avilés en el templo."848 Para poder descifrarlas Cadalso incorpora numerosas citas, algunas de ellas extraídas del Excelso cronicón;

\footnotetext{
${ }^{847}$ Rodríguez Juliá, Edgardo (1994). El camino de Yyaloide, ed. cit., p. 11.

${ }^{848}$ Rodríguez Juliá, Edgardo (1994). El camino de Yyaloide, ed. cit., p. 11.
} 
otras provienen del Diario secreto de Trespalacios, continuación de aquel otro que figura en La noche oscura... y en tercer lugar, como contrapunto sarcástico tanto de las imágenes como de los escritos mencionados, se transcriben pasajes de la crónica de Gracián, cuyo título -Cronicón satírico, caprichos burlescos a lo criollo- evoca el ácido humor de un escritor del barroco hispanoamericano como Juan del Valle y Caviedes.

En El camino de Yyaloide Gracián ha perdido su función de secretario y fiel amanuense del obispo. Distanciado del centro de poder su pluma se torna vulgar y recalcitrante instrumento crítico de mordacidad aguda y humor procaz, más próxima al relajo y barullo puertorriqueños, tan presentes en los episodios en torno a la ciudad posesa de la novela anterior. Entre los variados ejemplos de la intromisión de la voz contrapuntística y corrosiva del cronista me detengo en uno, entre hilarante y escatológico, que tiene lugar cuando Cadalso describe la segunda miniatura compuesta por Silvestre Andino. Se trata de un tríptico que reproduce en imágenes una "prueba de humores" a la que se somete al pequeño. Por un lado la prolija prosa del historiador pretende describir la escena con cierta objetividad informativa, aludiendo a una práctica medieval anacrónica y a contrapelo del desarrollo científico del siglo XVIII. La teoría de los cuatro humores corporales -sangre, flema, cólera o bilis amarilla y bilis negra-, cada uno de los cuales determinaba a su vez cuatro temperamentos -los sanguíneos, los flemáticos, los coléricos y los melancólicos-, fue desarrollada por la medicina grecorromana y por la medieval. En su origen esta particular concepción era de carácter fisiológico, pero paulatinamente se la vinculó a la influencia de los astros, transformándose, como señala Octavio Paz "en una doctrina cosmológica de las pasiones y de los tipos humanos" ${ }^{849}$, sobre todo según la reelaboración que de ella hicieron filósofos y médicos árabes primero, y el hermetismo neoplatónico después. En la novela de Rodríguez Juliá los humores, que son fluidos, se tornan espesamente escatológicos, ya que la mencionada prueba se realiza sobre la materia fecal del Niño Avilés. Mientras que el relato de Cadalso encubre bajo la figura retórica de la elipsis la alusión directa a las heces y la prosa ampulosa de los cronistas oficiales apela a su vez al eufemismo, la pluma satírica de Gracián desnuda sin rodeos la escena grotesca. Refiriéndose al niño escribe burda y llanamente:

\footnotetext{
${ }^{849}$ Octavio Paz brinda una detallada información sobre la teoría de los humores en el capítulo de su libro sobre Sor Juana Inés de la Cruz, cuando analiza la influencia del amor cortés en la poesía amorosa de la monja. Véase del autor Las trampas de la fe, ed. cit., especialmente el apartado titulado "Concilio de Luceros" en la Cuarta parte del libro, p. 271.
} 
"Y el pobre estuvo de cagaletas por tres semanas, así de fuertes fueron los purgantes que le dieron, que no miento al decir que estuvo a punto de perder todos los fluidos del cuerpo, por lo que fue menester ponerle tapón en el trasero. Así pasó que por lograr la profecía por poco pierden al profeta." 850

El "fetichismo documental" de Cadalso, como lo caracteriza César Salgado ${ }^{851}$, tan presente en las novelas antes analizadas, se reitera aquí, sobre todo en el gesto aglutinante del historiador que pretende reunir en un solo archivo los documentos dispersos. Pero tal amalgama, por sus diferentes perspectivas y su marcada heteroglosia, termina provocando un efecto paródico ${ }^{852}$, dada la yuxtaposición de lenguajes oficiales (los cronistas que responden a Trespalacios) y populares 0 coloquiales (la versión escatológica de Gracián). El archivo que desea consolidar Cadalso resulta entonces cómicamente dislocado a través del contrapunto de voces y miradas en tensión que lo conforman.

Supuestamente el Niño Avilés ha sido liberado de su anterior condición demoníaca gracias al exorcismo del obispo, personaje que asume la tutela del pequeño y encarna el rol del padre figurado, pero cuyo paternalismo exagerado y sobreprotector termina por convertir en obsesión la pretendida educación racional e ilustrada que desea imponerle al Avilés. En este sentido El camino de Yyaloide alude al género narrativo bildungsroman, novela de formación, uno de cuyos principales rasgos consiste en "narrar el desarrollo de un personaje -generalmente un joven- a través de sucesivas experiencias que van afectando su posición ante sí mismo, y ante el mundo y las cosas; por ende, el héroe se transforma en un principio estructurante de la obra." ${ }^{\prime 853}$ Es habitual que el aprendizaje sea acompañado por un guía, cuyas enseñanzas y acciones resultan ejemplares para el héroe en formación. Se reconoce como novela modélica del género Los años de aprendizaje de Wilhelm Meister (1795) de Goethe, texto de enorme

\footnotetext{
${ }^{850}$ Rodríguez Juliá, Edgardo (1994). El camino de Yyaloide, ed. cit., p. 21.

${ }^{851}$ Salgado, César (1999). "Archivos encontrados: Edgardo Rodríguez Juliá o los diablejos de la historiografía criolla”, ed. cit., p. 161.

${ }^{852}$ Apelo a la concepción de Bajtín sobre la parodia, estudiada a partir de los ejemplos de Rabelais y Dostoievski como efecto de la heteroglosia novelística en la cual se desestabiliza una estratificación social de dialectos a partir de la yuxtaposición de lenguajes oficiales o exclusivos en contextos populares y coloquiales, o a la inversa, revelándose así tensiones y dislocaciones entre esos estratos. Véase Bajtín, Mikhail (1981). "Discourse in the Novel", en The dialogic imagination, Austin, University of Texas Press, pp. 259-422.

${ }^{853}$ De Diego, José Luis (1998). "La novela de aprendizaje en la Argentina" (primera parte), Orbis Tertius. Revista de Teoría y Crítica Literaria, Centro de Estudios de Teoría y Crítica Literaria, Facultad de Humanidades de la Universidad Nacional de La Plata, nro. 6, año III, pp. 15-40. (la cita corresponde a la página 24, cursivas del autor)
} 
repercusión en su época, estrechamente vinculado al movimiento ilustrado alemán. Pero dentro de la novelística inglesa y bastante anterior al libro de Goethe encontramos una obra como Tom Jones (1749) de Henry Fielding, también considerada como modelo de bildungsroman pero acreedora de un rasgo diferente: el humor como herramienta de crítica social. Dentro de esta línea, donde se reconocen deudas con la tradición picaresca española y el grotesco de Rabelais, se configura un héroe que, lejos de resultar un modelo moral, termina encarnando el papel para nada virtuoso del antihéroe. La novela de Rodríguez Juliá parece acercarse a esta última tradición, ya que apela de manera muy ostensible y recurrente a la sátira y a la ironía para mostrar el lado oscuro del bildungsroman: el fracaso de la educación del Niño, cuyos diferentes maestros no funcionan como guías sino como contraejemplos de dudosa moralidad.

Así sucede con Valentín González, tutor de cámara del pequeño Avilés, su maestro de latín, griego y hebreo, bebedor empedernido de aguardiente, quien alterna sus lecciones de idiomas con azotes de puntero y bastonazos, logrando finalmente que el Niño odie su educación "pues no tenía el pobre la libertad de otros Niños, que siempre lo tenían encerrado con aquel borrachín más hijo de Barrabás que de Aristóteles" ${ }^{854}$, según apunta Gracián. Cadalso describe la figura del trasnochado maestro según la reproduce otra miniatura de Silvestre Andino, cita plástica del cuadro de Campeche que retrata al funcionario criollo Don Valentín Martínez, de quien Rodríguez Juliá toma prestado no solo el nombre sino también su apariencia física. El pincel del pintor ficticio y el del pintor real coinciden en su "giro venenoso", si tenemos en cuenta la traducción escrita de la imagen que lleva a cabo el historiador, cuando, refiriéndose al patético maestro, detalla que "el rostro mofletudo del sabio parece no haber visto navaja en varios días" ${ }^{\text {"855 }}$, al igual que el retrato de Campeche donde la cara del criollo Don Valentín aparece sombreada de barba, tal como se vio en el apartado dedicado a Campeche o los diablejos de la melancolía. Otra caricatura de la función del guía del bildungsroman se encuentra en el personaje que encarna al maestro de esgrima, el veneciano Modotti, traído de Italia por Trespalacios para cultivar la fortaleza, la valentía y la gentileza en el Niño. Sin embargo el resultado de sus lecciones termina en las antípodas de los objetivos trazados por el obispo, ya que introduce a su pequeño discípulo en los juegos de azar, lo lleva a conocer un prostíbulo en los arrabales de la

\footnotetext{
${ }^{854}$ Rodríguez Juliá, Edgardo (1994). El camino de Yyaloide, ed. cit., p. 13.

${ }^{855}$ Ibid., p. 12.
} 
ciudad donde el jovencito se emborracha por primera vez, pero además lo adiestra en la pelea callejera, haciendo del Avilés un pendenciero y precoz asesino.

El pequeño demuestra también, a lo largo de las sucesivas etapas de su controvertida y paradójica educación, una enorme permeabilidad respecto de la adquisición de conocimientos muy variados a los cuales lo somete la tutela del obispo, pero paralelamente manifiesta una profunda melancolía que lo impulsa a abandonar cada una de las actividades que encara, aguijoneado por el tedio. Como en La noche oscura... el peso del retrato del Niño Avilés pintado por Campeche se traslada a esta novela, repitiéndose la referencia a su mirada melancólica. Desde cada miniatura, destaca Cadalso citando a su vez el testimonio de otro cronista, el Avilés: "Nos mira con esos ojos que a veces 'rezumaban la tristeza de quien no entiende su muy agraciada condición' " ${ }^{856}$ Una sola etapa de su formación se relata como relativamente feliz según la versión del historiador, su afición a la música: "Su melancolía se convirtió en pasión artística" ${ }^{\prime 857}$. El Niño revela un talento musical especial, aprende a tocar la flauta y participa de conciertos barrocos que se llevan a cabo en el gabinete letrado de Trespalacios. Si bien el obispo pretende mantenerlo sujeto dentro de los cánones de la música culta, el jovencito prefiere la música popular, los repiques de los tambores de origen africano, las coplas pueblerinas y los bailes de bombas. Se narran sus escapadas nocturnas, junto a su compañero de juegos, el negrito Melodía, esclavo del obispo, quien, como una suerte de lazarillo, conduce y guía al Niño por las barriadas negras aledañas a San Juan -Cangrejos y Piñones-, espacios que, a través de las referencias musicales y sociales, anudan el siglo XVIII del pasado con el presente, la ficción dieciochesca con crónicas contemporáneas tales como El entierro de Cortijo. Melodía, según se anticipa mediante una prolepsis narrativa, se convertirá en el consejero y lugarteniente del Avilés en la fundación de Nueva Venecia. Su nombre evoca y rinde homenaje al trágico protagonista del famoso y más citado de los cuentos de José Luis González, "En el fondo del caño hay un negrito". 858

En El camino de Yyaloide otra miniatura descripta por Cadalso reproduce un concierto barroco ejecutado por los músicos de Catedral en el gabinete de Trespalacios, donde se interpreta música italiana "pues los compositores preferidos del Obispo eran

\footnotetext{
${ }^{856}$ Ibid., p. 11 (cursivas del texto).

${ }^{857}$ Rodríguez Juliá, Edgardo (1994). El camino de Yyaloide, ed. cit., p. 28.

${ }^{858}$ César Salgado advierte esta referencia intertextual en su artículo varias veces citado "Archivos encontrados: Edgardo Rodríguez Juliá o los diablejos de la historiografía criolla", ed. cit., p. 189.
} 


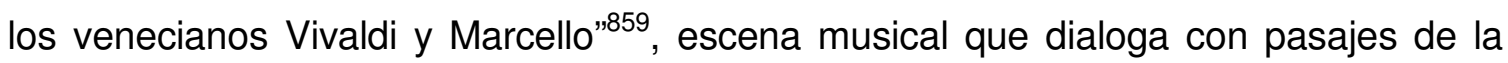
novela de Alejo Carpentier, Concierto barroco (1974). Cuando el historiador se detiene en la enumeración de la instrumentación que conforma la orquesta barroca llama la atención sobre un sorpresivo detalle observado en el pequeño cuadro donde, junto con violines, cellos, flautas y clavicordio, aparecen también "los tamboritos africanos conocidos por pailas." ${ }^{\prime 60}$ La escena se desarrolla durante la noche, al igual que el "concerto grosso" de la novela de Carpentier ${ }^{861}$, como una inesperada culminación del carnaval veneciano, donde la música barroca de Vivaldi se africaniza al ritmo de los tambores del negro Filomeno en la ficción carpenteriana. En Concierto barroco se apuesta y se celebra la posibilidad de un sincretismo transculturador, donde la música occidental se enriquece en contacto con el legado afroamericano. En la novela de Rodríguez Juliá en cambio, se reprime esta opción integradora mediante la interdicción de Trespalacios: "Ha prohibido el toque de tambores en las calles aledañas al Palacio Episcopal, esto es así porque teme que el Niño se incline a gustar de coplas pueblerinas y bailes de bombas." ${ }^{\text {"62 }}$ Prohibición que, como revelan el detalle del cuadro por un lado y las alusiones a la música popular de los barrios negros por el otro, no se cumple. Pareciera más bien que, como lo estudia Ángel Quintero Rivera ${ }^{863}$, el tambor y el ritmo de origen africano se amparan bajo un camuflaje melódico, que disfraza su cimarronería rebelde para que ésta no pierda su vigencia. De allí que el mismo prelado, y a pesar de sus órdenes restrictivas, consienta sin embargo que "la orquesta le interprete algún danzonete a paila de Cortijo, el maestro cafre de Cangrejos, rey del toque aldeano y costeño." ${ }^{864}$ La clara alusión al músico Ismael Cortijo de la cita constituye asimismo una referencia anacrónica, a la manera de las que aparecen en Concierto barroco de Carpentier, donde en un mismo espacio y tiempo conviven Antonio Vivaldi y Louis Armstrong.

Puesto que "la esmerada educación del Avilés se convirtió en obsesión para el Obispo" ${ }^{865}$, empecinado en convertir a su discípulo en un "prócer prospectivo" como lo

\footnotetext{
${ }^{859}$ Rodríguez Juliá, Edgardo (1994). El camino de Yyaloide, ed. cit., p. 26.

${ }^{860}$ Ibid., p. 26.

${ }^{861}$ Carpentier, Alejo (1974). Concierto barroco, México, Siglo XXI.

${ }^{862}$ Rodríguez Juliá, Edgardo (1994). El camino de Yyaloide, ed. cit., p. 29.

${ }^{863}$ Quintero Rivera, Ângel (1998). "El tambor camuflado: la melodización de ritmos y la etnicidad cimarroneada", cap. III, en: Salsa, sabor y control. Sociología de la música tropical, ed. cit., pp. 201-251

${ }^{864}$ Rodríguez Juliá, Edgardo (1994). El camino de Yyaloide, ed. cit., p. 27.

${ }^{865}$ Ibid., p. 37.
} 
caracteriza Salgado ${ }^{866}$, Trespalacios pergeña un "viaje menino" para templar la formación del adolescente de diecisiete años y que el religioso justifica en las páginas de su Diario de la siguiente manera:

"He querido que el Niño dé paso al hombre. Para muchos sabios los viajes son el último primor en la formación de los príncipes, que estos peregrinajes nos vuelven prudentes, siendo como son emblemas de la humana vida. Pero también su alma quedará templada por el espacio; como el viaje es descubrimiento reconocerá en los paisajes buena ocasión para conocer su alma, que ésta se fortalecerá para despejar los miedos que ella misma desata y vencer las tentaciones que acuden a la voluntad cual moscas a la miel. Y, sobre todo, es bueno que el viaje sea largo y a lo desconocido, que sólo así la vanidad y la soberbia se atemperan, dándole muestra al conocimiento de nuestra debilidad ante el tiempo y la inclinación de la voluntad al extravío." ${ }^{867}$

Pero los grandilocuentes objetivos que el obispo le endilga a la travesía del Niño se desmoronan y contrastan con el minúsculo itinerario proyectado: se trata de una expedición lacustre para que el joven explore los caños y manglares aledaños a la ciudad de San Juan, zona pantanosa cuyo difícil acceso impide además el uso de navíos importantes, debiendo desplazarse en humildes y pequeñas chalupas. El "viaje en miniatura", como lo llama Gracián en su sarcástica crónica, se constituye entonces como el reverso paródico de dos modelos de viaje impuesto por el racionalismo iluminista. Por un lado invierte el sentido del viaje utilitario, caracterizado por Adolfo Prieto como aquel que se convierte "tanto en guía de informaciones utilitarias como en índice escrupuloso de herbolarios y zoologías exóticas, de minerales, de remanentes geológicos, de fenómenos climáticos desconocidos (...)"868 Por el otro disloca el modelo ilustrado del voyage philosophique de estirpe voltairiana, donde la naturaleza contribuye a la formación moral y espiritual del individuo. Salgado subraya que el pretendido viaje filosófico termina por inducir en el Niño "un sentimiento profundo de desengaño tipo Calderón." ${ }^{869}$ En efecto, el "viaje menino" se construye a partir del relato de una serie de avatares desafortunados, algunos absurdos, otros tragicómicos, que tienen como protagonista al "capitancito", "pequeño capitán" como lo nombra Gracián, cuya crónica

\footnotetext{
${ }^{866}$ Salgado, César (1999). "Archivos encontrados: Edgardo Rodríguez Juliá o los diablejos de la historiografía criolla”, ed. cit., p. 189.

${ }^{867}$ Rodríguez Juliá, Edgardo (1994). El camino de Yyaloide, ed. cit., p. 54.

${ }^{868}$ Prieto, Adolfo (1996). "Introducción", Los viajeros ingleses y la emergencia de la literatura argentina, Buenos Aires, Editorial Sudamericana, p.14.

${ }^{869}$ Salgado, César (1999). “Archivos encontrados: Edgardo Rodríguez Juliá o los diablejos de la historiografía criolla”, ed. cit., p. 190.
} 
abunda en diminutivos que desnudan irónicamente la irrisoria nimiedad de la pretenciosa expedición proyectada por Trespalacios. Cadalso recompone la trama de la travesía agregando una nueva fuente de información que se suma a la crónica de Gracián y al Diario secreto del obispo: la bitácora de navegación del Avilés. Allí se despliegan tanto las ínfulas heroicas del fatuo jovencito como su ingenuidad extrema y su utopismo delirante, mediante un lenguaje pomposamente retórico que, por su artificiosidad y exageración, se torna ridículo:

"Yo, explorador de caños por encomienda de su Excelencia el Obispo Trespalacios, reconozco en mí el asombro que asaltó a Cortés cuando llegó a la ciudad flotante de Tenoquitlán, el lento pasmo que entristecía a los marinos de Colón, la muy eufórica sorpresa que cautivó a Pizarro cuando descubrió las arcas del Imperio Inca. Triste de mí si mis modestas palabras no conservan para la posteridad este paisaje tan prodigioso que nos ha mantenido inquietos desde media mañana."

La hiperbólica homologación del Avilés con las principales figuras históricas que encarnaron la imagen del "Conquistador" en América, cuyas empresas -en el caso de Cortés y Pizarro- implicaron además el complejo dominio de vastas extensiones territoriales donde se asentaban las principales culturas y civilizaciones amerindias, subraya el efecto burlesco de la comparación. En todo caso el viaje menino del joven se acerca más al mundo enano de Lilliput, escenario de las miserables intrigas de la corte y la ingratitud de los príncipes que se representa en la obra de Johnatan Swift, Viajes de Gulliver a los países de Lilliput (1726) ${ }^{871}$. A medida que el Niño se interna en los manglares pretende acceder al vergel secreto de Yyaloide, espacio arcádico que uno de los acompañantes del viaje -el negro Marcos- ha descrito a través de una leyenda de origen africano. Al mismo tiempo el joven se torna un pequeño y caprichoso déspota, cuya apetencia de conquista no reviste ninguna intención heroica sino erótica: someter a la jibarita que habita dicha región a la vez montaraz y paradisíaca. Una vez más la pluma satírica de Gracián desnuda el equívoco sentido de la exploración de los "caños"

\footnotetext{
${ }^{870}$ Rodríguez Juliá, Edgardo (1994). El camino de Yyaloide, ed. cit., pp. 94-95.

${ }^{871}$ Los viajes de Gulliver de Swift representan para Bronislaw Baczko "un verdadero laboratorio" para los historiadores de la novela utópica, ya que en ellos "las sociedades imaginarias son otras tantas contra-sociedades, visiones cruelmente grotescas de sociedades que se proclaman como ideales, y, al mismo tiempo, amarga sátira del orden social existente." Véase del autor su ensayo "Utopía", en: Los imaginarios sociales. Memorias y esperanzas colectivas, ed. cit., p. 83.
} 
emprendida por el Avilés, donde a su significado literal se le añade su dimensión obscena:

"Pero no, el Avilés se encumbra en el incordio discurso de que a él le debemos arrojo en esta travesía, como si para traspasar espesa niebla tanto ánimo se necesitara; al parecer el desaforado del Niño piensa que este viaje de mierda es la más grande ocasión que han conocido los siglos, desde que Hernán Pizarro conquistó la ciudad colgante de Cuzco. Muchas ganas tengo de decirle que se deje de tantos aspavientos y pejigueras, que más vino él a trepar el Monte de Venus que a explorar el Bosque de Arcadio." 872

El relato del descubrimiento de la región de Arcadia, habitada por un anciano ciego de nombre Gaetano quien vive allí con su hija Raquel, se narra como amplificación y reescritura del espacio arcádico de Yyaloide representado en La noche oscura del Niño Avilés. Por un lado constituye también un lugar mítico y cimarrón según la leyenda oral contada por Marcos, transcripta en la novela mediante la pluma de Gracián. En ella Yyaloide es una sirena protegida por una serpiente acuática llamada Mato (igual que el manatí de La noche oscura...), de la cual se enamora perdidamente el caudillo rebelde Mitumo, cuyo nombre apenas se modifica respecto del personaje Mitume de la ficción anterior. La fábula relata asimismo que el caudillo había fundado una colonia lacustre de negros cimarrones, a la que abandona a su suerte y destrucción, cuando la pasión desmedida por Yyaloide extravía su razón. Lo interesante de este episodio es que Gracián, quien había sido el cronista de las batallas entre Obatal y Mitume y había testimoniado la existencia de los espacios rebeldes y cimarrones, no puede reconocer aquí la cercanía entre esta leyenda y aquellos otros sucesos que su crónica había registrado unos pocos años antes, cuando el Niño Avilés era aún una criatura de pecho. "Y el fundador de aquella colonia de negros cimarrones fue un caudillo de nombre Mitumo, o algo así, que ya se me ha olvidado aquel nombre extraño en lengua de África"873 escribe Gracián en su Cronicón satírico. También pone en duda el relato del esclavo, al cual condena como supersticioso y "muy mañoso, pues todos los acentos estaban puestos más con el propósito de turbar el ánimo que de avivar el conocimiento" 874 , para reconocer su absoluta ignorancia ante la existencia de la ciudad lacustre: "Como en toda mi puta vida jamás había tenido noticias de

\footnotetext{
${ }^{872}$ Rodríguez Juliá, Edgardo (1994). El camino de Yyaloide, ed. cit., p. 97.

${ }^{873}$ Ibid., p. 68.

${ }^{874}$ Ibid., p. 81.
} 
semejante ciudad o suceso, le pregunté en cuál de los caños quedaba la colonia aquella." ${ }^{\prime 75}$ Como si el cronista padeciera de amnesia, ha perdido junto con el recuerdo la capacidad de darle continuidad a sus experiencias. ¿Negación, olvido voluntario o represión inconsciente? La novela se detiene en el enfrentamiento entre la memoria y el olvido, otro elemento que anuda las tramas de La renuncia del héroe Baltasar, La noche oscura del Niño Avilés y El camino de Yyaloide, como una oposición entre aquello que puede ser dicho o representado y lo que debe ser callado y ocultado. Sobre todo cuando en las tres ficciones lo que se esconde y reprime tiene que ver muy especialmente con la herencia africana, con el peso cultural y socioeconómico de los sectores negros, con sus gestas rebeldes, con los enfrentamientos étnicos en la historia de la nación puertorriqueña. Si, como postulaba Ernest Renan ${ }^{876}$, el olvido es el elemento necesario para la formación de una nación, ya que al fin de constituirse homogéneamente "debe olvidar" los antagonismos que la dividieron históricamente, las novelas del siglo XVIII de Rodríguez Juliá muestran sin embargo que, a pesar de la supresión de ciertos recuerdos, la memoria no se pierde. Las imágenes del pasado retornan, aunque sea bajo la forma de fobias, temores, sueños y pesadillas, también como fábulas de origen y leyendas orales que, como señala Salgado ${ }^{877}$-aunque pasen inadvertidas en el registro documental- no por ello dejan de ser menos reales.

Yyaloide en el relato legendario de Marcos se transforma en las fantasías y extravíos del Niño Avilés en la región de Arcadia, ya que identifica este espacio con diversos mitos y tópicos como los de la Edad de Oro, el Paraíso terrenal y el locus amoenus. A la arenga idealista e ingenua del joven para que su reducida tripulación lo acompañe hasta el final del viaje, Gracián contrapone su crónica sarcástica:

"Quiso entusiasmarnos con la idea de cruzar a ciegas aquella neblina espesa, vociferaba una sarta de fantasías que eran como para encabritar al más templado. Nos aseguró que esa tierra de Arcadio era pródiga en frutos, que más era cuerno de la abundancia que pantano, más sitio de holgada dicha que país de estrechas penurias, más paraíso terrenal escondido que estancia donde el dolor se oculta."

\footnotetext{
${ }^{875}$ Ibid., p. 60.

${ }^{876}$ Véase el ensayo seminal de Ernest Renan "Qué es una nación?" (1882), en: Fernández Bravo, Álvaro (comp.) (2000). La invención de la nación. Lecturas de la identidad de Herder a Homi Bhabha, Buenos Aires, Manantial, pp. 53-66.

${ }^{877}$ Salgado, César (1999). “Archivos encontrados: Edgardo Rodríguez Juliá o los diablejos de la historiografía criolla”, ed. cit., p. 196.

${ }^{878}$ Rodríguez Juliá, Edgardo (1994). El camino de Yyaloide, ed. cit., p. 87.
} 
Pero el supuesto vergel que quiere conquistar el Avilés por un lado se contamina de la fetidez propia de la vegetación de los manglares que lo encubre; por el otro sus habitantes -el anciano y su hija- esconden allí la relación incestuosa que los vincula. Las advertencias del negro Marcos acerca de los peligros de adentrase en aquel lugar como así también el componente alegórico de su relato sobre Yyaloide, donde la pasión amorosa se desvía hacia los extremos de la sinrazón, no son escuchados por el Niño, cada vez más soberbio y aislado en su rol de "pequeño capitán". Su viaje iniciático se torna aventura romántica y grotesca. Enamorado perdidamente de la jibarita Raquel, sus ruidosos encuentros sexuales provocan el suicidio patético de su padre Gaetano, que no puede soportar los celos que le provocan la relación entre su hija y el extraviado Niño. La Arcadia deseada se torna más bien trágico Jardín de los Infortunios ${ }^{879}$, donde la violencia desatada enlaza esta ficción con La renuncia del héroe Baltasar. El viaje de formación queda abruptamente interrumpido por la intervención de Trespalacios, que organiza una expedición para rescatar a su descarriado discípulo. Autoritario y patriarcal, pero sin resignarse del todo a la claudicación de sus objetivos pedagógicos, castiga corporalmente al Avilés. A través del ejercicio de la violencia infantiliza aún más al joven, que no puede abandonar su cristalizado papel de "Niño" caprichoso e irresponsable:

"Don Obispo le ordenó que se levantara para coger rumbo hacia la ciudad; pero él solo estaba para menear la cabeza de lado a lado y seguir llorando su desgracia. Entonces Don Obispo levantó el fuete y castigó tanto el lomo del imprudente que hacia él corrí a contenerlo; sabía que luego pagaría con remordimiento cada uno de aquellos azotes. Alcancé el brazo de Don Pepe, con brusco codazo me apartó, caía yo de culo cuando el Avilés ya se levantaba y Don Obispo lo cogía y llevaba por la oreja, arrastrándolo fuera del bosque entre regaños y mojicones." 880

La tercera parte de la novela relata la extraña celebración que organiza Trespalacios para festejar el regreso del Niño Avilés a la ciudad de San Juan, con el fin de reencausar el extravío y apatía de su discípulo en el camino del programa político

\footnotetext{
${ }^{879}$ Cuando el Niño insiste ante Gracián que las tierras recorridas corresponden a la mítica Arcadia, el cronista le responde socarronamente: "A modo de guasa le dije que si esto es jardín debe ser el de los infortunios, aquél concebido por el visionario de Baltasar Montañez con el propósito de convertir la naturaleza en máquina de guerra.” Rodríguez Juliá, Edgardo (1994). El camino de Yyaloide, ed. cit., p. 96.

${ }^{880}$ Ibid., p. 171.
} 
que le ha trazado para hacer de él un líder: "El Niño fue montado en palanquín y paseado por las calles de San Juan, conquistando así la ciudad política del Obispo Trespalacios." ${ }^{881}$ Para que se cumpla la profecía proceratista en torno al Avilés el prelado acude a prácticas reñidas con el cristianismo que su función eclesiástica detenta. Apela al ocultismo, consulta con astrólogos judaizantes y en el último capítulo hace uso del tarot, a través de un retablo extravagante que reproduce los emblemas de este juego en un barroco espectáculo teatral:

"La procesión se había detenido; por fin el Avilés demostró asombro. Se trataba de un retablo que Trespalacios mandó a construir donde aparecían, para perplejidad del pueblo, actores y cómicos que representaban las figuras del Tarot. Trespalacios, quien era muy aficionado a estas cartas, abrió la función, todo el pueblo se arremolinó en torno al retablo de la fortuna., 882

El tableau vivant que se compone resulta una contienda ingeniosa entre los designios del obispo y la rebeldía cada vez más manifiesta del Niño, a través de las significaciones alegóricas que encierra cada carta. El enfrentamiento termina violentamente en el momento en que el Avilés pone en escena la carta más temida, la del demonio, que simboliza el derecho a la insurrección cuando el poder obstruye la justicia y que representa en la diégesis narrativa la oposición del joven a los designios políticos del obispo. La escena finaliza con un alboroto general y una represión sangrienta autorizada por Trespalacios, amedrentado por el creciente culto avileño cada vez más fanatizado e incontrolable.

Sin embargo persiste en el Niño la melancolía, encerrado cada vez más en visiones saturninas y oníricas que lo asaltan con frecuencia y en las cuales imagina la ciudad utópica fundada sobre el agua, la profetizada Nueva Venecia. La novela regresa sobre la imaginería de lo nimio cuando el Avilés se aboca a la única actividad de mover las piezas de aquella ciudad en miniatura que le había obsequiado el obispo con el fin de "fijar la ciudad perfecta" ${ }^{883}$, la urbe utópica que, como las ciudades invisibles de Calvino, "contenía en sus combinaciones todas las ciudades posibles." ${ }^{884}$ En la conclusión de la obra Cadalso informa que Trespalacios ha decidido exiliar a su amado discípulo. Lo envía a estudiar derecho canónico al Colegio de los Jesuitas en La

\footnotetext{
${ }^{881}$ Rodríguez Juliá, Edgardo (1994). El camino de Yyaloide, ed. cit., p. 188.

${ }^{882}$ Ibid., p. 192.

${ }^{883}$ Ibid.,p. 204.

${ }^{884}$ Ibid., p. 204.
} 
Habana, para intentar corregir su inmadurez y profunda apatía. El Niño no se opone a su decisión y sólo pide llevarse consigo la pequeña ciudad de juguete, quizás como único y posible "nido de soledad donde sueña vivir" según la sugerente expresión de Gastón Bachelard ${ }^{885}$ en torno a la dimensión imaginaria de la miniatura.

Bildungsroman fracasado en un caso, biografía infame en otro, utopías destruidas o más bien anti-utopías en los tres casos, las novelas que conforman hasta ahora la Crónica de la Nueva Venecia podrían pensarse también como "ficciones contrafundacionales", si se me permite resignificar la productiva conceptualización de Doris Sommer ${ }^{886}$ con otro matiz. Esta autora considera como "ficciones fundacionales" un grupo de novelas que se escriben y/o publican en forma paralela a la consolidación de los estados modernos. Sostiene que las ficciones y los proyectos estatales se vinculan alegóricamente entre sí, en tanto ambos propenden a una unión. En las novelas dicha unión es de carácter erótico, puesto que se narran historias de amantes que representan regiones particulares, razas, partidos políticos o intereses económicos que deberían amalgamarse a través de la legalidad del matrimonio. Paralelamente los proyectos estatales, erigidos sobre la base de discursos del progreso y la prosperidad, apuntan a la unificación nacional a través de la gobernabilidad de los opuestos, mediante un "matrimonio" simbólico de los sectores en pugna.

Salvando las diferencias y distancias ${ }^{887}$ entre el corpus textual trabajado por Sommer -abarca desde Sab (1841) de Gertrudis Gómez de Avellaneda hasta Doña Bárbara (1929) de Rómulo Gallegos- y las novelas de Rodríguez Juliá, me interesa señalar que el ciclo Crónica de la Nueva Venecia postula un tiempo fundacional localizado en el siglo XVIIII pero a su vez, y a diferencia de las novelas fundacionales revisadas por Sommer, se cancelan las posibilidades de reconciliación social, étnica, política, religiosa, cultural. Las tres ficciones apuntan más bien a poner en escena las divisiones e incompatibilidades entre los diversos grupos sociales y étnicos, donde

\footnotetext{
${ }^{885}$ Remito al epígrafe de este apartado. Véase Bachelard, Gastón (1992). "La miniatura", capítulo VII, La poética del espacio, Buenos Aires, Fondo de Cultura Económica, tercera reimpresión, pp. 184-219.

${ }^{886}$ Sommer, Doris (1993). Foundational Fictions. The Nacional Romances in Latin America, Berkeley, University of California Press.

${ }^{887}$ Apunto someramente algunas diferencias entre uno y otro corpus: en las Crónicas de la Nueva Venecia de Rodríguez Juliá el tiempo fundacional es el siglo XVIII y no el siglo XIX de los textos revisados por Sommer; las gestas significadoras son las rebeliones de esclavos y las respuestas del estado colonial, y no el liberalismo de los criollos autonomistas y emancipadores; y sus protagonistas no son esos criollos sino la convivencia conflictiva de esclavos y cimarrones -negros y blancos- con obispos y gobernantes.
} 
cualquier atisbo de heterogeneidad integradora se malogra mediante la represión sangrienta y la violencia. En este sentido e invirtiendo el sentido de la categoría de Sommer, propongo leer estas obras como "ficciones contrafundacionales". Así en La renuncia del héroe Baltasar, el matrimonio arreglado como "razón de Estado" entre el negro Baltasar Montañez y la mujer blanca fracasa; en La noche oscura... se frustra cualquier atisbo de preservar el vínculo amoroso entre el Renegado y la Reina del África, y en El camino de Yyaloide Trespalacios impide la unión entre el Niño Avilés y la jibarita criolla.

Sommer lee en el corpus de novelas objeto de su estudio una retórica erótica y romántica que las organiza, donde el lenguaje de amor apunta a disciplinar y regir una sexualidad (re)productiva dentro de la esfera doméstica, en la cual la homologación familia/nación provee además un modelo para una consolidación nacional no violenta durante períodos conflictivos. Las ficciones del siglo XVIII de Edgardo Rodríguez Juliá, por el contrario, apuntan más bien a una sexualidad descontrolada, excesiva, erigida sobre el deseo y el derroche hasta el extremo de transfigurar el placer en orgía, trocar el goce en pulsión de muerte. Erotismo sombrío, diabólico, escatológico, donde se advierte la lectura profunda de Georges Bataille, para quien el erotismo es el placer sexual teñido de angustia por la proximidad o coincidencia de la muerte.

Por otra parte, como se afirma en Campeche o los diablejos de la melancolía, el primer mito fundador de la nacionalidad puertorriqueña lo provee la pintura. La pincelada rococó y criolla de Campeche deja en su trazo huellas del "anhelo de fundar un estado", a la vez que muestra los complejos avatares de "testimoniar el mestizaje problemático de su propia época, los callados conflictos dentro de los cuales se escondía, como una semilla inquietante, la pretensión hegemónica de los distintos estamentos y clases que formaban la sociedad colonial." ${ }^{\text {"88 }}$ Tanto las novelas como el ensayo reiteran la referencia al "mazo de Caín", personaje bíblico que mata a su hermano Abel, desencadenando con su crimen el ingreso de la muerte y la violencia en el mundo, la lucha del hombre contra el hombre. La conjunción erotismo/nacionalismo como factor de reconciliación de opuestos se niega en estas ficciones "contrafundacionales", conflictivas y violentas, en el sentido que advierte César Salgado, cuyas conclusiones comparto:

${ }^{888}$ Edgardo Rodríguez Juliá (1986). Campeche o los diablejos de la melancolía, ed. cit., pp. 7-8. 
"El barroco escatológico de Juliá niega los logros del liberalismo preautonomista y pone en escena el divisionismo racial y la represión sangrienta. La devoración de las luces del iluminismo por la espesa noche de un barroco oscurantista constituye la desubicación rectora de todas las novelas 'históricas' de Juliá." ${ }^{889}$

${ }^{889}$ Salgado, César (1999). “Archivos encontrados: Edgardo Rodríguez Juliá o los diablejos de la historiografía criolla", ed. cit., p. 1 


\section{Puerto Rico en Nueva York: escritura, desplazamiento y sujetos migrantes en los cuentos de Manuel Ramos Otero}

"Puertorriqueños del corazón estrujado por las interrogaciones que suscitan los adverbios allá y acá. Puertorriqueños que de tanto ir y venir, informalizan el viaje en la guagua aérea y lo reducen a una trillita sencillona sobre el móvil océano. Que lo que importa es llegar, pronto, a Nueva York. Que lo que importa es regresar, pronto, a Puerto Rico. (...)

Mas, ¿cuál es la tierra prometida? ¿Aquella del ardiente suelo? ¿Esta de la fría estación?"

Luis Rafael Sánchez, "La guagua aérea"

El epígrafe traza las coordenadas del migrante puertorriqueño, sujeto de(I) y sujetado al desplazamiento -deseado y doloroso- entre downtown San Juan-uptown Nueva York, registrado por la aguda mirada de Luis Rafael Sánchez ${ }^{890}$. Se trata de la compleja brega de la cual habla Arcadio Díaz Quiñones, como una "negociación entre la ausencia y la presencia"891, que ha permitido a los puertorriqueños emigrados extender el mapa del territorio natal sobre el suelo norteamericano, sin dejar de subrayar las dificultades y precariedades de la vida en la emigración. Sánchez y Díaz Quiñones aluden en sus respectivos textos al fenómeno del desplazamiento masivo y violento de puertorriqueños a los Estados Unidos que el gobierno de Luis Muñoz Marín alentó, particularmente a partir del establecimiento del Estado Libre Asociado 892 . Si los adverbios "allá"/"acá" a los cuales se refiere "La guagua

\footnotetext{
${ }^{890}$ Véase la crónica de Luis Rafael Sánchez, "La guagua aérea", incluida en el volumen del mismo nombre, San Juan, Editorial Cultural, 1994, texto mencionado en el capítulo I para referirme precisamente al impacto cultural de las políticas de emigración compulsiva alentadas a partir del establecimiento del Estado Libre Asociado en Puerto Rico por el gobernador Luis Muñoz Marín. El epígrafe de Sánchez alude y rinde homenaje al título de la novela de Pedro Juan Soto, Ardiente suelo, fría estación (1961), sobre la emigración puertorriqueña a Nueva York.

${ }^{891}$ Díaz Quiñones, Arcadio (2000). "De cómo y cuándo bregar", en: El arte de bregar, San Juan, Ediciones Callejón, p. 20. Remito al análisis de este ensayo propuesto en el capítulo II.

${ }^{892}$ Véase el capítulo I, particularmente el apartado que reseña la migración compulsiva entre los principales ejes políticos del gobierno de Luis Muñoz Marín, centrados en la consolidación del estadolibrismo. Atendiendo a la perspectiva propuesta por Abril Trigo este particular movimiento migratorio puertorriqueño formaría parte de un fenómeno mayor, estrechamente vinculado a un desarrollo socio-económico desigual entre distintas regiones entrabadas en complejos regímenes de expulsión y atracción, "por lo cual las migraciones obedecen siempre a múltiples cusas de índole social, cultural, política o económica, cuya combinatoria sobredetermina las diversas modalidades de exilios, diásporas, desplazamientos y migraciones históricamente registrable.” En el caso particular de Puerto Rico refuerza además su condición
} 
aérea" de Luis Rafael Sánchez implican un dramático entrejuego entre dos lugares culturales, Juan Flores propone pensar la migración como un "nuevo proceso de formación de la identidad que se libera de este modo de la fijeza categórica de un lugar" ${ }^{\prime \prime 93}$. Flores retoma la sugerente línea de análisis que Julio Ramos despliega en su ensayo "Migratorias"894, donde se detiene en las relaciones entre migración y escritura a partir de la lectura de dos escritores que marcan dos fines de siglo -José Martí y el poeta nuyorican Tato Laviera-; el primero atravesado por el exilio hacia fines del siglo XIX, el segundo por el flujo migratorio transnacional de fines del siglo XX. De este último autor analiza un poema, titulado significativamente "Migración", en el cual hay un deliberado borramiento de los prefijos "in"/ "e". Ramos lee en esta elisión, tanto en el título como a lo largo del poema de Laviera, un modo de problematizar las nociones de "origen" y "destino" como conceptos que fijan el movimiento, y de "límite", en cuanto demarcador de las territorialidades:

"El prefijo registra las coordenadas de un mapa que representa el flujo migratorio en función de un ir a o venir de, del inicio o final del viaje. Para los territorios entre los que se mueve el viajero, la designación de la dirección del movimiento en el prefijo despliega una oposición entre el interior y el exterior de la nación que resulta fundamental para la demarcación del territorio y, por lo mismo, para la producción de su sentido de integridad. Jurídica e ideológicamente esa oposición tiene consecuencias ineluctables: para el territorio que 'recibe', el sujeto que entra en su interior es un elemento extraño, una especie de prolongación física del territorio contiguo, lo que da pie a toda una tropología del 'hospicio' o, en el peor de los casos, de invasión y contagio. Para el territorio que despide, la distancia del emigrante registra, en el mismo devenir del viaje, la integridad del territorio nacional que se cierra con su partida." ${ }^{, 895}$

La diferencia entre inmigrante y emigrante postula otras oposiciones señaladas por Ramos: entrada/salida, adentro/afuera, origen/destino, que

de colonia, puesto que, según Trigo "el flujo migratorio se mueve siempre desde la región periférica, neocolonial o poscolonial a la zona metropolitana." Véase Trigo, Abril (2003). "Migraciones", en: Memorias migrantes. Testimonios y ensayos sobre las diáspora uruguaya, Rosario, Beatriz Viterbo, pp. 37- 62 (la cita corresponde a la p. 37).

${ }^{893}$ Flores, Juan (1997). "Memorias (en lenguas rotas)/Broken English memories", Revista de Crítica Literaria Latinoamericana, Año XXIII, Nro. 45, Lima-Berkeley, pp. 341-350.

${ }^{894}$ Ramos, Julio (1996). “Migratorias”, en: Paradojas de la letra, Caracas, eXcultura, pp. $177-$ 186.

${ }^{895}$ Ibid., p. 182, cursivas y comillas del autor. 
fundamentan una "dramática trama de la identidad" muestra en el devenir de su constitución como tal y pone de manifiesto, por lo tanto, las huellas de una subjetividad en proceso, discontinua, fragmentaria, dispersa, una identidad alternativa que, con palabras de Ramos "escabulle las redes topográficas y las categorías duras de la territorialidad y su metaforización telúrica" ${ }^{\prime \prime 97}$. Por su parte Abril Trigo advierte que dicha identidad no deja de ser conflictiva sino conflictuada, caracterizándola como una "identidad nepantla". Apropiándose del vocablo náhualtl que significa "estar en medio" sostiene que la identidad migrante "está obligada a funcionar siempre en subjuntivo, como si fuera completa e indivisible, a sabiendas de que una identidad plena es sólo una ficción para seguir adelante día a día”, para añadir que:

"En esta experiencia de la transitoriedad y la transitividad, la promesa del regreso a casa se vuelve imposible, ante la progresiva certidumbre de que la migración es tan sólo un viaje de ida, pues ya no queda adonde regresar. Y así el migrante termina alienado de ambos mundos, sumido en un profundo sentimiento de desarraigo, de extranjería, de extrañamiento social, cultural y existencial que le hace sentirse extraño en todas partes, exactamente a la inversa del cosmopolita, quien por definición se siente en todas partes como en su propia casa." ${ }^{\prime 988}$

Hay otro poema de Tato Laviera, titulado "nuyorican", donde el yo poético interpela a una segunda persona -Puerto Rico- a quien le reprocha: "me mandaste a nacer nativo en otras tierras/ por qué, porque éramos pobres, ¿verdad?/ porque tú querías vaciarte de tu gente pobre." En otro verso el sujeto se autodefine, a partir de su complejo lugar de enunciación: "yo soy tu hijo,/ de una migración". ${ }^{899}$ El nombre del poema y también el del libro que lo contiene AmeRícan- se constituye en la intersección de lo que Juan Flores caracteriza como "lengua rota", el spanglish que usan los emigrados puertorriqueños

\footnotetext{
${ }^{896}$ Ramos, Julio (1996). "Migratorias", ed. cit., p. 182.

${ }^{897}$ Ibid., p. 186.

${ }^{898}$ Trigo, Abril (2003). "Migraciones", ed. cit., p. 57 (cursivas del autor).

${ }^{899}$ Laviera, Tato (1985). "nuyorican", en: AmeRícan, Houston, Arte Público Press, University of Houston, Texas, p. 53.
} 
donde inglés y español se interfieren recíprocamente, donde "el español y el inglés se rompen uno en el otro"900:

"La geografía pasa a ser el campo metafórico más rico en esta política de 'ruptura' lingüística y cultural: los contrastes entre el 'aquí' y el 'allá' permean el idioma mismo, desde el habla de todos los días hasta la jerga de las canciones populares y los giros y ocurrencias de la poesía bilingüe."901

No sería pertinente incluir a Manuel Ramos Otero dentro de la llamada literatura nuyorican de la cual forma parte claramente Laviera, estética con la que sin embargo comparte puntos de contacto, como por ejemplo la tematización de la migración puertorriqueña a Nueva York. Aunque Ramos Otero ${ }^{902}$ no resulta "hijo de una migración" forzada sino que elige radicarse en la "otra isla"903, sus ficciones no dejan de aludir de diversas maneras a los desplazamientos, las diásporas, el exilio, la errancia fundamentalmente urbana, de allí que Juan Gelpí proponga leer la narrativa del autor puertorriqueño como una "escritura transeúnte": "El exilio en la gran ciudad será uno de los ejes de su obra. Su literatura es, como pocas, producto de un transeúnte, de un emigrado: el tránsito y el desplazamiento pueblan sus textos. "904 Gelpí incluye a Ramos Otero junto con Rosario Ferré y Ana Lydia Vega como tres escritores que desafían el canon paternalista de la literatura puertorriqueña -eje de su profundo estudio Literatura y paternalismo en Puerto Rico-, puesto que los tres

\footnotetext{
${ }^{900}$ Flores, Juan (1997). "Memorias (en lenguas rotas)/Broken English memories”, ed. cit., p. 348.

${ }^{901}$ Ibid., p. 348.

902 Manuel Ramos Otero emigró a Nueva York en el año 1968, donde escribió casi toda su obra. En varias entrevistas destaca que en su decisión de abandonar San Juan pesó su abierta homosexualidad, más tolerable en la urbe neoyorkina que en su país natal. "Vine a Nueva York en 1968" -relata el escritor a su entrevistadora y agrega: "En Puerto Rico sentía muchísima persecución debido a la apertura de mi sexualidad. Pero no fue sólo eso. Quedé fascinado con la ciudad y con la posibilidad de independencia total que me ofrecía. En Puerto Rico, durante la década del 60, aunque fueras hombre, vivir fuera de tu casa se consideraba raro. Había que vivir con la familia hasta que uno se casara." Véase "Entrevista" de Marithelma Costa, Hispamérica, Año XX, Núm. 59, 1991, pp. 59-67. Gran parte de los trabajos críticos sobre el autor destacan particularmente la problemática homosexual que se representa en varios de los cuentos de Ramos Otero. Más adelante volveré sobre esta cuestión, ya que mi perspectiva de análisis tiene en cuenta la categoría de género sexual, pero no de manera predominante.

903 "La otra isla" es la denominación con la cual se designa a Nueva York, particularmente la isla de Manhatan como destino laboral más frecuente de los emigrados de Puerto Rico.

${ }^{904}$ Gelpí, Juan. (1993). "La escritura transeúnte de Manuel Ramos Otero", en: Literatura y paternalismo en Puerto Rico, San Juan, Editorial de la Universidad de Puerto Rico, pp. 137153. (La cita corresponde a las pp. 137-138)
} 
coinciden de una u otra forma en la dislocación de la retórica nacionalista más arraigada $^{905}$ : Ramos Otero porque escribe sobre la emigración, Ferré ${ }^{906}$ porque dispersa sistemáticamente la metáfora de la casa y la familia puertorriqueñas, Vega porque rompe con la pureza lingüística mediante el uso del spanglish y la oralidad urbana popular.

Por su parte José Luis Vega, en el prólogo de Reunión de espejos, importante antología del cuento contemporáneo puertorriqueño, realiza una pormenorizada reseña del desarrollo de este género en su país, desde finales del siglo XIX hasta los años ochenta del siglo XX. Si hasta entrados los años cincuenta la cuentística puertorriqueña se había caracterizado por el predominio del realismo sociológico y, particularmente a partir de la Segunda Guerra Mundial, por el desarrollo de una vertiente existencialista, muy presente en los relatos de René Marqués, la publicación de En cuerpo de camisa (1966) de Luis Rafael Sánchez marca un quiebre estético, donde el humor y los modos dialectales del habla urbana puertorriqueña irrumpen de manera novedosa ${ }^{907}$. Vega, Gelpí, Efraín Barradas ${ }^{908}$, Arcadio Díaz Quiñones ${ }^{909}$

\footnotetext{
${ }^{905}$ Es decir, la retórica particularmente del ensayismo de la Generación del Treinta, analizada en el capítulo II.

${ }^{906}$ El ensayo de Gelpí se centra en la producción de Ferré entre los setenta y ochenta. Por su fecha de publicación no da cuenta del posterior cambio estético-ideológico de la autora, sobre todo a partir de la publicación de su novela escrita en inglés The House on the Lagoon (New York, Penguin, 1996) que suscitó intensas polémicas en el campo intelectual puertorriqueño, sobre todo cuando fue traducida al español con importantes "lagunas" y supresiones en función de intereses de mercado editorial y por estar destinada al público hispano-lector.

907 "En cuerpo de camisa clausura una etapa de nuestra cuentística y augura una nueva hornada de escritores", señala José Luis Vega en "El rostro en el espejo: hacia el cuento puertorriqueño actual", prólogo de Reunión de espejos, compilación llevada a cabo por Vega (San Juan, Editorial Cultural, 1983, pp. 17-30). Incluye entre otros a Luis Rafael Sánchez, Ramos Otero, Magali García Ramis, Rosario Ferré, Juan Antonio Ramos, Ana Lidia Vega, Mayra Montero y al propio compilador, destacado poeta y narrador.

908 Efraín Barradas compila y edita en los Estados Unidos otra antología de cuentos contemporáneos puertorriqueños, titulada Apalabramiento. Cuentos puertorriqueños de hoy, cuyo subtítulo establece una clara continuidad y homenaje con la antología que editara en Puerto Rico en 1954 René Marqués, llamada Cuentos puertorriqueños de hoy. Barradas propone una ampliación del corpus autoral, teniendo en cuenta la renovación de la cuentística a partir de los años setenta. (Apalabramiento. Cuentos puertorriqueños de hoy, Hannover, Ediciones del Norte, 1983).

${ }^{909}$ Díaz Quiñones, Arcadio (1975). "Prólogo" al número especial de la revista Sin nombre (Año $\mathrm{V}$, vol. V, número 4, abril-junio, pp- 5-8), que recoge cuentos de autores consagrados en este género como José Luis González, René Marqués, Pedro Juan Soto, pero también varios de los que, con palabras de Díaz Quiñones, "se perfilan como otra promoción", entre ellos Ramos Otero, Juan Antonio Ramos, Rosario Ferré. Por otra parte Sin nombre, a instancias de su directora Nilita Vientós Gastón, promueve mediante certámenes literarios, la difusión de nuevos poetas y cuentistas del país.
} 
coinciden en subrayar los años iniciales de la década de 1970 como el momento en que una nueva manera de relatar desafía los moldes heredados de la predominante estética realista anterior. Dos libros ${ }^{910}$ innovan la escena literaria de entonces y ambos se publican en 1971: Cordial magia enemiga de Tomás López Ramírez y Concierto de metal para un recuerdo y otras orgías de soledad de Manuel Ramos Otero ${ }^{911}$. A ellos se les suma la labor difusora que acometieron revistas literarias y culturales como Sin Nombre, de larga trayectoria en el campo intelectual puertorriqueño, como así también otras, fundadas en los años setenta -Penélope o el otro mundo, Ventana y especialmente Zona de carga y descarga ${ }^{912}$-, esta última dirigida por Rosario Ferré y en la cual Ramos Otero se desempeñó como colaborador y también como editor a cargo de la composición de todo el número en dos ocasiones. En $1976^{913}$ se publican otros dos importantes y renovadores libros de cuentos: Los papeles de Pandora de Rosario Ferré y La familia de todos nosotros de Magali García Ramis, textos donde se explora el momento de crisis del proceso

910 "Concierto de metal para un recuerdo y otras orgías de soledad de Manuel Ramos Otero, y Cordial magia enemiga de Tomás López Ramírez, ambos publicados en 1971, inician la sucesión de libros de cuentos innovadores que caracteriza la década. Los nuevos narradores se formaron durante la década del sesenta y enfrentaron los retos y estímulos de fenómenos históricos como el triunfo de la Revolución Cubana y las polémicas que suscitó la Guerra de Vietnam, en la cual participaron muchos puertorriqueños; la lucha antimilitarista; los movimientos en pro de los derechos de sectores subordinados, como los negros, las mujeres y los homosexuales; la agitación estudiantil y la crisis política, social y económica del Estado Libre Asociado, marcada en sus inicios por el triunfo electoral del partido asimilista en 1968.", según la síntesis que propone Ramón Luis Acevedo en "El cuento puertorriqueño contemporáneo", introducción al volumen que compila bajo el nombre de Cuba y Puerto Rico son. Cuentos boricuas (La Habana, ediciones Memoria, del Centro Cultural Pablo de la Torriente Brau, 1998, pp. 9-22)

${ }^{911}$ Ramos Otero, Manuel (1971). Concierto de metal para un recuerdo y otras orgías de soledad, Río Piedras, Editorial Cultural, 1971. (Toda cita posterior remite a esta edición).

912 Juan Gelpí puntualiza algunos de los principales aportes de la revista Zona de carga y descarga, que se publicó entre los años 1972 y 1975, tanto en su difusión de las producciones literarias de los escritores más jóvenes, como así también en la apertura hacia una discusión teórica y de reflexión crítica sobre la literatura en general y la puertorriqueña en particular. Subraya las reflexiones sobre aspectos ligados al feminismo, las propuestas de romper el "insularismo" crítico mediante una profusa sección dedicada a reseñas que delatan el deseo de ampliar modos de lectura. Véase el apartado "El espacio de la crisis y la ruptura: Zona de carga y descarga (1972-1975)", en: Gelpí, Juan. (1993). Literatura y paternalismo en Puerto Rico, ed. cit., pp. 171-182.

913 "Como se sabe, el 1976 fue un año fructífero para la narrativa en Puerto Rico. Se publican La novelabingo de Manuel Ramos Otero, Cinco cuentos negros de Carmelo García Torres y La Guaracha del Macho Camacho. Salen al mercado también Papeles de Pandora de Rosario Ferré y La familia de todos nosotros de Magali García Ramis.” Gelpí, Juan (1993). Ibid., p. 155. Al final del capítulo II subrayo la renovación literaria que emerge con fuerza notable en aquel año de 1976. 
modernizador desarrollista, sobre todo mediante la dislocación de la metáfora populista de la "gran familia puertorriqueña." Sobre este aspecto se detiene José Luis Vega, cuando señala que:

"La familia burguesa (Rosario Ferré) y la familia pequeñoburguesa pueblerina (Manuel Ramos Otero, Magali García Ramis, Edgardo Sanabria Santaliz) son los universos preferidos. En estos autores las crisis familiares operan como un modelo a escala, un reflejo parcial, de la crisis general de la sociedad. ${ }^{\prime 914}$

No es casual que la nueva escena literaria puertorriqueña de los años setenta coincida con las corrientes revisionistas en el campo de la historiografía, dado además el peso que cobran en esta misma época los estudios culturales interdisciplinarios como los que alentó el Centro de Estudios de la Realidad Puertorriqueña (CEREP). En este contexto de apertura y de plurales perspectivas literarias emerge una voz marcadamente singular como la de Manuel Ramos Otero, narrador y poeta, cuyos textos innovadores y desafiantes, en ocasiones corrosivos e irritantes, señalaron un desvío provocativo en la literatura de su país. Así Efraín Barradas destaca que si bien el escritor se "unía a un coro de nuevas voces literarias" lo hacía sin embargo con "un tono tan personal que parecía disonante y que siempre reclamaba atención especial." "915 Jossianna Arroyo arriesga una posición crítica tajante al señalar que las "nuevas voces" a las cuales alude Barradas fueron rápidamente "autorizadas" a ingresar al canon de la nueva narrativa puertorriqueña, mientras que la obra de Manuel Ramos Otero ha sido totalmente excluida: "Su condición de escritor periférico se debe no sólo a su exilio voluntario en Nueva York sino a su particular tratamiento del proceso de escritura." ${ }^{116}$ Para esta crítica la exclusión se cifra particularmente en la perspectiva homosexual que atraviesa la obra del autor, donde el deseo homoerótico transgrede la "narrativa seminal homogeneizadora y masculina" 17 de los discursos tradicionales de la identidad nacional puertorriqueña, proponiendo leer las representaciones del cuerpo como espacio político en los textos de Ramos Otero.

Gran parte de los trabajos críticos que estudian al autor se centran en la articulación de un discurso homosexual que claramente su obra exhibe, tanto en los cuentos como en los poemas, en su única novela y en diversos textos críticos

${ }^{914}$ Vega, José Luis (1983). "El rostro en el espejo: hacia el cuento puertorriqueño actual", prólogo de Reunión de espejos, ed. cit., pp. 27-28.

${ }_{915}$ Barradas, Efraín (1993). “'Epitafios': el canon y la canonización de Manuel Ramos Otero”, revista La Torre (Nueva época), 7.27-28, pp. 319-338. Si bien el artículo de Barradas se centra particularmente en el análisis de la sección titulada "Epitafios" del poemario El libro de la muerte de Manuel Ramos Otero, reseña también la cuentística del autor, subrayando la importancia de incluir a Ramos Otero en un canon de la literatura puertorriqueña, diferente del tradicional y paternalista que analiza Juan Gelpí. Si para este último "la ausencia de un espacio doméstico y la dispersión continua en Ramos Otero sugieren que su obra está escrita fuera (de la casa) del canon", Barradas propone entonces la posibilidad de un canon alternativo. Ambos críticos coinciden en la valoración e inclusión de la obra del autor en las letras puertorriqueñas. La cita de Gelpí está tomada de "La escritura transeúnte de Manuel Ramos Otero", en: Literatura y paternalismo en Puerto Rico, ed. cit., p. 138.

916 Arroyo, Jossiana (1994). "Manuel Ramos Otero: Las narrativas del cuerpo más allá de Insularismo", Revista de Estudios Hispánicos, Facultad de Humanidades de la Universidad de Puerto Rico, XXI, pp. 303-324.

${ }^{917}$ Ibid., p. 305. 
publicados en suplementos culturales de diarios y revistas literarias, en Puerto Rico y en Nueva York. En este sentido, entre los estudios que han privilegiado una lectura crítica desde la perspectiva del género sexual, se destacan especialmente los de Arnaldo Cruz-Malavé. En un artículo más amplio sobre abyección y masculinidad en la literatura puertorriqueña en los Estados Unidos el crítico incluye a Manuel Ramos Otero como aquel que "insistió en no fundar su escritura sino en lo que la podía destruir, la abyección." "918 Cruz-Malavé propone vincular la llamada literatura "nuyorican" con la producción de escritores homosexuales puertorriqueños emigrados a Nueva York, puesto que ambas están escritas "desde este des-tierro, desde este río de la abyección"19. Jossianna Arroyo, Efraín Barradas, Cruz-Malavé insisten en la construcción de un canon alternativo de la literatura puertorriqueña, claramente atravesado por otra marca identitaria, la del género sexual.

Si bien mi lectura atiende a los aportes significativos que trazan estas miradas críticas insoslayables, procuro destacar otras zonas posibles de análisis de los cuentos de Manuel Ramos Otero, donde advierto la presencia repetida, por momentos dramática y paradójica de un sujeto migrante ${ }^{920}$, que encarna diferentes roles, matices y significaciones. Hay variados desplazamientos que entrañan, por supuesto, el viaje paradigmático del emigrado puertorriqueño entre Puerto Rico y Nueva York, pero hay también diversos personajes extranjeros, errantes, que se destacan por su alteridad cultural, étnica, lingüística. Emigrantes desposeídos, solitarios, cuyos desplazamientos connotan la pérdida, a veces la desintegración de la propia subjetividad o bien, la reconstrucción de una identidad que se permite la negociación de los dos espacios (allá/aquí), la posibilidad de disipar la amenaza de discontinuidad y ruptura del flujo migratorio para crear e imaginar nuevas continuidades. Asimismo en varias ocasiones se interceptan y coinciden la figura del migrante y la del escritor; el que se traslada narra, oficia de "cuentero" como veremos a partir de algunos análisis específicos de determinados cuentos, caracterizados por un subrayado gesto autorreflexivo. Se pone en escena el proceso de escritura de los textos, como una práctica que hace del desplazamiento su principio constructivo principal y que muestra también las situaciones y condiciones materiales que acechan al yo escritor. Quiero aludir también a otras modalidades de lo transeúnte que se despliegan en algunos relatos del autor, donde la errancia urbana traza las coordenadas del deseo homoerótico, el llamado "cruceo" que traduce al spanglish el acto del "cruising", el caminar en algún espacio público en busca de una ocasional pareja sexual, según los códigos culturales gay ${ }^{921}$.

918 Cruz-Malavé, Arnaldo (1998). "What a Tangled Web! Masculinidad, abyección y la fundación de la literaura puertorriqueña en los Estados Unidos", en: Daniel Balderston y Donna Guy (comp..), Sexo y sexualidades en América Latina, Buenos Aires, Paidós, pp. 335-355.

919 Ibid., p. 340.

${ }^{920}$ Para la reflexión sobre el sujeto migrante resulta sumamente provechoso el abordaje realizado por Antonio Cornejo Polar, cuyo estudio de la figura del migrante andino no deja de involucrar asimismo un profundo análisis sobre la problemática cultural latinoamericana. Así refiriéndose a la experiencia concreta de Arguedas como migrante andino hacia la capital, Cornejo Polar propone explorar la construcción de una subjetividad migrante, a la que caracteriza diferenciándola de la del mestizo: "Así, mientras que el mestizo trataría de articular su doble ancestro en una coherencia inestable y precaria, el migrante, en cambio, aunque también mestizo en una amplia proporción, se instalaría en dos mundos de cierta manera antagónicos por sus valencias: el ayer y el allá, de un lado, y el hoy y el aquí, de otro, aunque ambas posiciones estén inevitablemente teñidas la una por la otra en permanente pero cambiante fluctuación. De esta suerte, el migrante habla desde dos o más locus y -más comprometedoramente aún -duplica (o multiplica) la índole misma de su condición de sujeto." Véase Cornejo Polar, Antonio (1994). Escribir en el aire. Ensayo sobre la heterogeneidad sociocultural en las literaturas andinas, Lima, Horizonte, p. 209.

${ }^{921}$ Tengo en cuenta los aportes de Evan, David T. (1993). Sexual Citizenship. The Material Construcción of Sexualities, Londres, Routledge. 
Me detendré entonces en estas cuestiones aquí apuntadas, a través del análisis de un corpus de cuentos de Manuel Ramos Otero seleccionado de los tres libros que publicó en vida -Concierto de metal para un recuerdo y otras orgías de soledad (1971), El cuento de la mujer del mar (1979) ${ }^{922}$ y Página en blanco y staccato (1987) ${ }^{923}$, y de su libro póstumo Cuentos de buena tinta $(1992)^{924}$, que reúne muchos títulos de las colecciones antes mencionadas y otros publicados en diferentes medios, especialmente revistas literarias y culturales.

V.1. Subjetividades desplazadas, cuerpos en movimiento: los sujetos migrantes en los cuentos de Manuel Ramos Otero

"La migración implica un movimiento en el que el lugar de la partida y el punto de llegada no son inmutables ni seguros. Exige vivir en lenguas, historias e identidades que están sometidas a una constante mutación. Siempre en tránsito, la promesa de una vuelta a casa -completar la historia, domesticar el circuito- se vuelve imposible." identidad

lain Chambers, Migración, cultura,

En "Hollywood memorabilia"925 el narrador-protagonista se nos muestra como un joven solitario, emigrado a Nueva York, circunstancia que se reitera en otros relatos del mismo volumen del cual forma parte, Concierto de metal para un recuerdo y otras orgías de soledad, primer libro de Manuel Ramos Otero. Se podría trazar un hilo conductor entre varias de las ficciones que lo integran, que gravita sobre la experiencia urbana anónima y, particularmente, sobre la soledad punzante que atraviesa a sus personajes, aludida también en el título ${ }^{926}$ de la obra. En este cuento en particular el personaje se autorrepresenta al borde mismo de una existencia espectral, ligada en parte a una de las actividades que le permiten subsistir en la gran urbe: "De noche

\footnotetext{
${ }^{922}$ Ramos Otero, Manuel (1979). El cuento de la Mujer del Mar, Río Piedras, Huracán. (Toda cita posterior remite a esta edición).

${ }^{923}$ Ramos Otero, Manuel (1987). Página en blanco y staccato, Madrid, Playor, Biblioteca de Autores Puertorriqueños. (Toda cita posterior remite a esta edición).

${ }^{924}$ Ramos Otero, Manuel (1992). Cuentos de buena tinta, San Juan, Instituto de Cultura Puertorriqueña. (Toda cita posterior remite a esta edición).

${ }^{925}$ Ramos Otero, Manuel (1971). "Hollywood memorabilia", en: Concierto de metal para un recuerdo y otras orgías de soledad, ed. cit., pp. 77-85.

${ }^{926}$ El largo título del volumen, dividido en dos mitades, parece oponer la estridencia del concierto metálico al proceso psíquico individual del recuerdo en su primera mitad y una acción que supone una actividad sexual grupal (orgías) a la soledad manifiesta de la segunda mitad.
} 
trabajo de proyeccionista en un cine de segunda (....."927 Proyecta películas clásicas de la época de oro de Hollywood y se identifica con sus heroínas trágicas, presencias fantasmales sobre la pantalla, cuyas muertes prematuras y patéticas desea remedar: "Voy a morir a los treinta arrollado por un vehículo

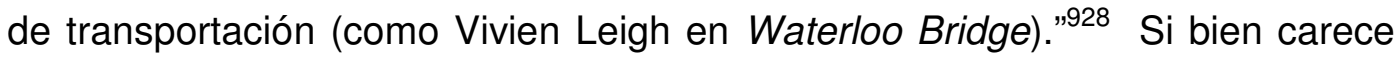
de nombre propio su identidad se construye a través de ciertas marcas: su abierta homosexualidad, su tarea como proyeccionista y fundamentalmente su actividad como escritor, acciones que se desarrollan en el ámbito de la noche y que se contraponen a su trabajo diurno, burocrático, que desdeña con enorme escepticismo $^{929}$. Juan Gelpí lee en la configuración de este personaje una gestualidad solipsista que abunda en el relato y que subraya además la soledad y la individualidad de un narrador urbano cuyo desplazamiento por la ciudad nocturna se plasma también en un discurso errante, ya que el cuento, fuertemente estructurado a partir de la primera persona narrativa, se constituye como una digresión continua de la voz que relata. Arnaldo Cruz-Malavé sostiene que los textos de Ramos Otero cultivaron desde su primer volumen de cuentos "la abierta, franca y descarada indagación del yo, del yo que escribe" ${ }^{\text {"30 }}$. Observa que un número importante de los personajes de sus ficciones duplican con frecuencia circunstancias del propio escritor: son exiliados, escritores o ambos. Pero remarca también que, más allá de las tensiones autobiográficas que puedan atravesar sus textos, el uso de la primera persona encarna en una multiplicidad de voces donde "el yo que cuenta se desdobla en protagonista, pasa sin transición de yo a él o,

\footnotetext{
${ }^{927}$ Ramos Otero, Manuel (1971). "Hollywood memorabilia", ed. cit., p. 77.

${ }^{928}$ Ibid., p. 78.

${ }^{929}$ Véanse los siguientes párrafos del cuento: "En las tardes trabajo en las oficinas del gobierno en un programa de investigación social para crear un sistema perfecto de movilidad. No. Las deficiencias del capitalismo no me interesan."/ "La investigación social y la movilidad y el problemas de los negros (escucho el ruido de varios suspiros de pechos insultados que consideran el racismo el issue universal) no me interesa tanto como el cine y Joan Crawford en Grand Hotel." Ramos Otero, Manuel (1971). "Hollywood memorabilia", ed. cit.., pp. 77 y 79 respectivamente.

${ }^{930}$ Cruz- Malavé, Arnaldo (1993). "Para virar al macho: la autobiografía como subversión en la cuentística de Manuel Ramos Otero", Revista Iberoamericana LXIX, núms. 163-164, enerojunio, pp. 239-263.
} 
destacando su función de máscara, de simulador, de travesti, se desplaza con mayor frecuencia del yo al ella." ${ }^{\prime 931}$

"Hollywood memorabilia" comienza de manera irreverente, cuestionando con su afirmación arrogante la perspectiva de la omnisciencia narrativa: "Yo soy Dios. Y crearé un personaje que se llamará Ángel. Se llamará John. Se llamará Paul."932 A lo largo del relato el yo como personaje asume diversas máscaras, especialmente aquellas que le provee la filmografía hollywoodense de los años treinta y cuarenta, como medio para escapar de su rutina solitaria y de la sordidez de una realidad que el narrador-protagonista califica como "turbia." 933 La soledad aparece como un tópico que se reitera hasta alcanzar una dimensión material, que ocupa el cuerpo del relato: "La otra noche proyecté King Kong para sentirme solo. Con la misma soledad de King Kong. Bruta. Tierna. Sin lugar en la vida."/ "La soledad por ejemplo se presiente porque se vuelve física."/ "Porque en Nueva York es invierno y las calles se quedan tan solas en la madrugada." ${ }^{\text {"934 }}$ Pareciera que la única forma de conjurar esa soledad física que lacera el cuerpo pero sobre todo la subjetividad del yo consiste en la disolución del sujeto mismo. Hacia el fin del relato el proyeccionista comienza a desintegrarse físicamente para reconstituirse en lo proyectado, en las imágenes de sus estrellas favoritas de Hollywood, Greta Garbo, Rita Hayworth, Vivien Leigh, Mae West. Pero estas escenas de diferentes films coinciden en un mismo momento: el de la muerte de la heroína. El cuento deja abierta entonces la posibilidad del mismo final para su narradorprotagonista:

"Pero ya comienzo por desvanecerme. El autor, el proyeccionista, Dios, parecen quedar desintegrados en átomos constantes de luz y siento un impulso flojo que me proyecta con suavidad en el lienzo. El tiempo del proyector al lienzo nunca fue más largo y siento partículas perdidas que aún no terminan su viaje. No quiero pensar en la

\footnotetext{
${ }^{931}$ Cruz- Malavé, Arnaldo (1993). "Para virar al macho: la autobiografía como subversión en la cuentística de Manuel Ramos Otero”, ed. cit., p. 241.

932 Ramos Otero, Manuel (1971)."Hollywood memorabilia”, ed. cit.., p. 77. Los nombres enumerados corresponden a personajes de cuentos que integran este primer volumen y que se reiteran además en los siguientes contarios.

933 "A veces la realidad se vuelve turbia y desde la cabina de proyección recurro a la creación de las imágenes." Ibid., p. 78.

${ }^{934}$ Ibid., pp. 80, 82 y 85 respectivamente.
} 
posibilidad siempre presente de que la proyección se interrumpa sin que los átomos logren integrarse en la ilusión esperada."935

Este viraje del relato hacia las modalidades del fantástico sugiere asimismo un diálogo intertextual con autores que Ramos Otero admira, cita, homenajea: Jorge Luis Borges, Adolfo Bioy Casares, Felisberto Hernández y especialmente Julio Cortázar ${ }^{936}$. Implica también una elección estética que se desplaza del realismo, explícitamente rechazado en un pasaje del cuento, donde el narrador se autodefine como un "fabricante nocturno de ilusiones" en contraposición con lo que llama "instituciones pseudorealistas", como la revista Look que revela la edad de Greta Garbo, procurando quebrar así el mito construido alrededor de la diva: "(el último artículo de Look sobre la Garbo: Garbo is 65, con la portada en plata y negro, me ha dejado incierto porque se intenta destruir su leyenda con el método usual de las instituciones seudorealistas)." 937

"Hollywood memorabilia" condensa y anticipa rasgos y tópicos que atraviesan otros cuentos del escritor: la emigración, la soledad, la errancia urbana, nocturna, vinculada también al cruising homoerótico, el cuestionamiento de los modos realistas de la representación, la inscripción de una primera persona móvil y plural que juega con las posibilidades de la inversión del género sexual ${ }^{938}$, la intercalación de palabras y frases e inglés. En este último aspecto, a diferencia de las expresiones literarias nuyorican que apelan al spanglish, Ramos Otero no hace uso de esta forma dialectal. Sus relatos privilegian el español ${ }^{939}$, pero en el contexto de un sujeto que se mueve

\footnotetext{
${ }^{935}$ Ramos Otero, Manuel (1971). "Hollywood memorabilia", ed. cit., p. 85.

${ }^{936}$ Ramos Otero afirma en una entrevista: "Yo llegué a Borges a través de Cortázar, quien para mí significó la puerta de escape del realismo agobiante de la literatura puertorriqueña." Véase la entrevista de Jan Martínez, "Manuel Ramos Otero o los espejuelos de Mahoma", El Mundo, 10 de noviembre de 1985, pp. 52-53. Más adelante, a través del análisis de otros relatos del autor, volveré sobre el peso de ciertos modelos literarios, particularmente los cuentos cortazarianos.

${ }^{937}$ Ramos Otero, Manuel (1971). "Hollywood memorabilia", ed. cit., p. 83 (cursivas y paréntesis del texto).

${ }^{938}$ La inversión de género sexual se sugiere por la identificación reiterada con las heroínas de los films que el joven proyecta.

${ }^{939}$ En una entrevista antes citada Manuel Ramos Otero contesta acerca de su posición sobre escribir en inglés: "En numerosas ocasiones me planteé escribir en inglés y escribí varios textos. Pero me daba cuenta que sentía un amor muy grande por el español. Y el español no solo significaba español, sino que significaba la lengua del recuerdo, de mi niñez, de todo lo que conocía antes de venir a este país. (se refiere a Estados Unidos)" Aclara que su posición no tiene
} 
entre dos lenguas por su situación de emigrado. La lengua materna se muestra permeable al inglés, cuya presencia se manifiesta como un rumor de fondo en los relatos cuyas tramas se desarrollan en la ciudad de Nueva York y que por momentos salta a la superficie del texto, mediante giros coloquiales, expresiones, palabras sueltas, referencias espaciales, culturales.

"Hollywood memorabilia", "Happy Birthday", "Piel mutada", "Suicidio con hormigas africanas y ciruelas blancas" son relatos cuyas tramas se construyen en un espacio predominantemente urbano, que acecha a sus personajes, pero también los encubre y de alguna manera los protege con su anonimato. El cuento con el cual se cierra Concierto de metal..., significativamente transcurre en otro lugar, un sitio suburbano cuya localización geográfica apenas se sugiere por algunos indicios de la arquitectura de la casa descripta, de la vegetación de su jardín, que remiten a una posible localización puertorriqueña. "La casa clausurada" es el último cuento de la colección, posición privilegiada que para Juan Gelpí insinúa el cierre de un proceso. Pero a su vez el título opera en referencia a un texto previo, "Casa tomada"940 de Julio Cortázar, relato con el cual comparte cierta atmósfera de ambigüedad, de opresión y la incertidumbre del final abierto. Como en "Hollywood memorabilia" el narrador es también el protagonista del cuento, cuya trama se constituye a través de una suerte de monólogo interior. El personaje, llamado Roberto Bracero D'Paso, ha heredado de su madre la casa familiar de su antepasados, clausurada durante años por voluntad de ella. Decide visitarla, acechado por dos impulsos contradictorios: traspasar su umbral o bien, mantenerse fuera de sus límites. "Más que ante una narración en sentido estricto, estamos aquí en el terreno de la conjetura narrativa, aspecto éste que enlaza la obra de Ramos Otero con la de Julio Cortázar" explica Juan Gelpi ${ }^{941}$. En este cuento no hay acción en el sentido narratológico del término sino una disquisición del narrador-

pretensiones puristas ni nacionalistas sino afectivas, subjetivas y estéticas: "No creo que los puertorriqueños de aquí sean menos puertorriqueños por escribir en inglés." También agrega: "Aunque el español constituye una limitación en términos de la difusión de mi obra, seguir escribiendo en español quizás es una artimaña de mi parte para no abandonar lo que mi lengua significa. Por otra parte, mi narrativa siempre ha sido altamente poética y la maravilla de la metáfora me viene en español." Véase "Entrevista" de Marithelma Costa, Hispamérica, ed. cit., pp. 64-65.

940 "Casa tomada" forma parte de Bestiario (1951), primer libro de relatos de Julio Cortázar.

${ }^{941}$ Gelpí, Juan. (1993). "La escritura transeúnte de Manuel Ramos Otero”, ed. cit., p. 143. 
protagonista en torno a la memoria, el recuerdo, el tiempo, el pasado, los orígenes de la genealogía familiar, donde el personaje conjetura acerca de las consecuencias que puede implicar abrir o no la puerta de la casa clausurada.

Por un lado la casa remite metonímicamente a la madre y a la familia: "La familia es mamá, naturalmente. A papá no lo conocí. Mamá era única hija, a ella le quedó la casa y el recuerdo un poco vivo de la madre y el padre." ${ }^{\text {942 En }}$ el relato se subraya una matrilinealidad predominante, que clausura y elide la figura paterna. También, a través del recurso de la prosopopeya, se feminiza la casa, a la cual se le trasponen valores humanos como asimismo un cuerpo de mujer: "La casa. Clausurada. Espera. Porque yo la viole. Piensa que el tiempo perdido podrá reconstruirse a través de mi memoria." ${ }^{943}$ La alusión a Marcel Proust de la cita, reiterada luego en otro momento del texto ${ }^{944}$, se vincula con la acción psicológica principal que lleva a cabo el narrador-protagonista: recordar. Si la descripción externa de la casa clausurada corresponde al presente del relato, mientras el narrador la observa desde afuera, el recorrido por el interior de la misma implica un acto voluntario de la memoria, disparado además por un objeto que entraña la fijación del pasado en el presente eternizado de una fotografía, el álbum familiar:

"Recuerdo las fotos familiares de la casa. Antes de llegar busqué dentro de las páginas del libro de la familia, separando las fotos amarillas, detallando figuras pequeñas, casi espectrales, para saber cómo es la casa, para tomar su imagen y estudiarla con un fervor de análisis, antes de convertirla en hostia y tragarla. Antes de que la casa me asimile o antes de que yo asimile a la casa. Antes de que la hostia recorra mi sistema y se convierta en mierda."

La casa, que es la madre, entraña una amenaza constante para el yo, ser fagocitado, tragado y digerido por ella, obligado a habitar entonces en el pasado, a clausurar cualquier posibilidad de proyección al futuro. Pero a pesar de este riesgo el protagonista establece con ella una relación dual y tanática,

\footnotetext{
${ }^{942}$ Ramos Otero, Manuel (1971). "La casa clausurada", en: Concierto de metal para un recuerdo y otras orgías de soledad, ed. cit., pp. 125-132.

${ }^{943}$ Ramos Otero, Manuel (1971). "La casa clausurada", ed. cit., p. 126.

${ }^{944}$ En un pasaje del cuento el narrador.-protagonista proyecta actividades que desearía realizar antes de morir: "Naturalmente antes debo explorar varias cosas que desconozco, muchas sin importancia, sin ser pertinentes a la vida que llevo, despertar, leer a Proust, salir a la calle y manejar mi auto, comer y regresar al apartamento.” Ibid., p. 129.

${ }^{945}$ Ramos Otero, Manuel (1971). "La casa clausurada", ed. cit., p. 127.
} 
sin salida, que se manifiesta en la oposición antes referida: abrir o no la puerta, dejarse devorar por el claustro materno, por los ancestros, por el pasado, o bien enfrentarse y conjurar el temor para dejar atrás ese mundo muerto, decadente, espectral. Según señala Gastón Bachelard "la casa es un cuerpo de imágenes que dan al hombre razones o ilusiones de estabilidad." "946 Pero lo que el filósofo francés percibe como imágenes positivas en torno a la casa natal (casa como rincón en el mundo, como morada, como protección) se trastocan en "La casa clausurada", cuyo título sugiere otra significación más: la casa como tumba. En este sentido el texto disemina elementos que aluden a lo mortuorio y al tiempo como destrucción: el olor de los ancestros, el polvo, lo ruinoso, la fragilidad de la porcelana Tiffany rota, las alfombras descoloridas y deshechas. El final del cuento mantiene en suspenso el gesto de la mano del narrador-protagonista sobre el picaporte de la puerta, dejando abiertas distintas posibilidades de interpretación, al modo de lo que ocurre en el cuento "Casa tomada" de Julio Cortázar.

Juan Gelpí propone otra lectura de este relato, a través de la presencia de un importante intertexto: la obra dramática Los soles truncos de René Marqués, modelo literario de enorme peso para los escritores puertorriqueños. Advierte en "La casa clausurada" una especie de despedida simbólica de un escritor que ocupó el rol figurado de "padre" de toda una generación literaria en su país. En la obra teatral de Marqués las hermanas Burkhart, luego de la muerte de su padre, se encierran -literalmente se enclaustran- en su casa. Decididas a negarse a encarar la modernidad y atadas a un pasado patriarcal irremediablemente perdido -el mundo de los hacendados-, deciden prenderle fuego a la casa natal. Antes que enfrentar su pérdida por la ruina económica que atraviesan optan por la muerte. Gelpí observa tanto en la descripción de la casa en ruinas de Los soles truncos como en los detalles del interior de "La casa clausurada" la aparición de elementos similares, que remiten a tradiciones pasadas: el quinqué, los candelabros, el piano, la vajilla de plata, la porcelana. Pero si la obra de Marqués lamenta la pérdida del paraíso patriarcal, en el cuento de Ramos Otero, en cambio, su protagonista se regodea en su solipsismo urbano, como se advierte en el siguiente pasaje: "Ahora sólo quedo

${ }^{946}$ Bachelard, Gastón (1992). La poética del espacio, Buenos Aires, FCE, tercera reimpresión, p. 48. 
yo. Un recuerdo lleno de polvo, acostumbrado a la vida rápida, sin detenciones líricas; acostumbrado a la simplicidad maquinal de un Volkswagen rojo ocupando un espacio limitado en las calles de asfalto." ${ }^{\text {"47 }}$ Por otra parte Gelpí sostiene que la familia del narrador que aparece en el cuento se presenta alterada y fragmentada, donde "la casa no es el lugar fundado por el padre, sino el lugar asociado con la figura materna" ${ }^{\text {"48 }}$, gesto que sugiere una erosión de la autoridad que representa la imagen paterna. A diferencia del cierre apoteósico y aleccionador de la obra de Marqués, el crítico destaca que el final de "La casa clausurada", por el contrario, elude una interpretación alegórica del cuento, distanciándose de esta manera y despidiéndose del modelo autoral marquesiano.

Si bien en este cuento no se advierte la figura del migrante, sí se destacan imágenes que aluden al desplazamiento: el viaje de la ciudad a la casa natal, el regreso a los orígenes, el recordar como traslado (retroceso) al pasado, donde la casa natal se niega a otorgarle al sujeto "la ilusión de estabilidad" de la cual habla Bachelard, dejándolo más bien fuera de ella, a la intemperie, como sugiere la interesante lectura de Gelpi ${ }^{949}$.

En "El cuento de la Mujer del Mar"950, relato que da nombre al volumen del cual forma parte, se entrecruzan tres conceptos diferentes -el viaje inmigratorio, el exilio y la migración- que guardan entre sí importantes vinculaciones $^{951}$. El espacio de la narración, la trama de las palabras sobre la

\footnotetext{
${ }^{947}$ Ramos Otero, Manuel (1971). "La casa clausurada", ed. cit., p. 128.

${ }^{948}$ Gelpí, Juan. (1993). "La escritura transeúnte de Manuel Ramos Otero”, ed. cit., p. 144.

${ }^{949}$ En el apartado que Gelpí dedica a estudiar las obras de Ramos Otero, Rosario Ferré y Ana Lydia Vega destaca que los tres se caracterizan de una u otra manera por desafiar el canon de la literatura paternalista puertorriqueña, a la cual metaforiza como una especie de "casa de la nacionalidad"; justamente el desvío que proponen estos tres autores los deja fuera de aquella casa patriarcal, de allí que los presente bajo el acápite de "la escritura a la intemperie." Véase del autor, Literatura y paternalismo en Puerto Rico, ed. cit, p. 136. A este sentido me gustaría agregar la imagen de desamparo existencial y soledad que entraña el concepto de intemperie, sentimiento que recorre todos los cuentos de Concierto de metal...

${ }^{950}$ Ramos Otero, Manuel (1979). "El cuento de la Mujer del Mar", en: El cuento de la Mujer del mar, ed. cit., pp. 87-116.

951 Sigo aquí las distinciones propuestas por Abril Trigo, que brevemente simplifico de la siguiente manera. Trigo contextualiza históricamente el flujo inmigratorio moderno de fines de siglo XIX y comienzos del siglo XX para situar en él al "inmigrante de la modernidad industrial capitalista", quien, aun cuando partiera soñando con el regreso, se embarcaba sin embargo en un posible viaje sin retorno. A pesar del fuerte sentimiento de pérdida por el mundo familiar abandonado, se deja asimilar por la sociedad receptora y se convierte entonces en un "inmigrante." En cambio los procesos de migrancia y diáspora transnacionales particularmente a
} 
página del texto se propone como lugar donde se reúnen e interceptan, por un lado, la historia del narrador, un emigrado puertorriqueño y su amante Angelo, hijo de inmigrantes italianos; por el otro, la historia que cuenta el exilio de la poeta Palmira Parés, la Mujer del Mar, junto con la que narra el viaje a América de la mujer napolitana Vincenza Vitale, "la Donna del Mare". Se trata de relatos de desarraigo y nostalgia, fragmentarios y discontinuos que coinciden no sólo en los desplazamientos y diásporas que afectan a cada personaje, sino también en una misma localización espacial que los vincula -la ciudad de Nueva York-, una misma situación vital que los atraviesa -la ruptura amorosa, el abandono, la soledad y la muerte. Las cuatro tramas se funden además por la presencia constante del mar, "espacio común y lugar de reunión de todos los cuentos"952.

El narrador y su amante se encuentran, quizás por última vez, en la habitación de un hotel ubicado en Christopher Street ${ }^{953}$, coordenada urbana e

partir de la segunda guerra mundial constituyen un nuevo modo de migración que va de las zonas periféricas a las metropolitanas, con la creencia de que el retorno es factible. Mientras los inmigrantes, una vez procesado el duelo por la pérdida, se adaptan y asimilan a su nueva condición, los migrantes "parecen extraviarse en una tierra de nadie de remordimientos y ambivalencias." Para Trigo la migrancia y la diáspora constituyen los modos de migración predominantes en la era global del capitalismo transnacional. Asimismo puntualiza respecto del exilio: "Dos cosas distinguen al exilio: que la partida es involuntaria y forzada, y que el retorno es difícil, sino imposible." Véase Trigo, Abril (2003). "Migraciones", ed. cit., p. 42 y también su artículo "Migrancia: memoria: modernidá", en: Moraña, Mabel (ed.), Nuevas perspectivas desde/sobre América Latina, Santiago, Editorial Cuarto Propoio-IILI, pp. 273-291, 2000. En "El cuento de la Mujer del Mar", como se verá, Vincenza Vitale responde al modelo de la inmigrante, Palmira Parés es una exiliada y el narrador Manuel un migrante.

${ }^{952}$ Gelpí, Juan. (1993). "La escritura transeúnte de Manuel Ramos Otero", ed. cit., p. 153.

${ }^{953}$ Cristopher Street, situada en el barrio del Village de Nueva York, fue el centro de la rebelión ocurrida en el Bar Stonewall en el año 1969, episodio que marca el inicio del movimiento homosexual en los Estados Unidos. Si bien en la obra de Ramos Otero hay una evidente preocupación por dar cuenta de una subjetividad homosexual, tal como lo advierten la mayoría de los trabajos críticos sobre el autor, coincido con la posición de Rubén Ríos Ávila. En su propuesta de comparar la literatura de Ramos Otero con la del escritor cubano Reinaldo Arenas señala afinidades evidentes como la abierta homosexualidad de ambos, el origen caribeño de los dos autores, el exilio en la ciudad de Nueva York. Pero destaca asimismo una diferencia que me interesa subrayar. Según Ríos Ávila "Ramos Otero (...) como muchos puertorriqueños que viven en los Estados Unidos, visitó la isla frecuentemente. Aunque su homosexualidad es frecuentemente tematizada en sus textos, no constituye sin embargo una forma radical del disenso político, como sí ocurre con Arenas. En Arenas, la homosexualidad funciona como contra-ética respecto de la Revolución Cubana." Véase Ríos Ávila, Rubén (1997). "Caribbean Dislocations: Arenas and Ramos Otero in New York", en: Hispanisms and Homosexualities, Sylvia Molloy y Robert Mc Kee Irwin, eds., Durham, Duke University Press, pp. 101-122. (la traducción de la cita es mía). 
ideológica ${ }^{954}$ que se reitera especialmente en la obra poética de Ramos Otero. Pero además el cuarto, sugestivamente marcado con el número 1001 en su puerta, alude a la maravillosa colección de cuentos árabes Las mil y una noches, en particular a lo que se conoce como el "efecto Scherezada" contar para seguir viviendo; también por su estructura narrativa proliferante y de caja china, donde un cuento encierra otros cuentos. En este caso el narrador cuenta para postergar la inevitable separación de su amante: "No es necesario que uno crea en las señales de lo desconocido, era necesario que Angelo siguiera siendo el amado, aún si para retenerlo a mi lado hubiera tenido que contarle el cuento de una mujer que no existió." ${ }^{\text {956 }}$ El narradorprotagonista, del cual no se conoce su nombre propio, se denomina a sí mismo "cuentero", categoría que comparte con otros personajes-narradores que deambulan por las ficciones de Ramos Otero, como veremos próximamente al abordar otros textos del autor ${ }^{957}$. Su relato se inscribe en el espacio cerrado de la habitación del hotel y preside la escena de la escritura un gran espejo, donde se proyectan las imágenes de las diversas historias narradas como así también los cuerpos de los amantes, duplicados y amalgamados en su homosexualidad: "Y fue contra la noche que Angelo dijo quel amor de dos hombres es como el amor de dos espejos." 958

954 Jossianna Arroyo analiza pormenorizadamente las resonancias y significaciones de la Christopher Street en la obra poética de Manuel Ramos Otero. Véase de la autora "Exilio y tránsitos entre la Norzagaray y Christopher Street: acercamientos a una poética del deseo homosexual en Manuel Ramos Otero", Revista Iberoamericana, vol. LXVII, núms.. 194.195, enero-junio 2001, pp. 31-54.

${ }^{955}$ Noé Jitrik explica el "efecto Scherezada" de la siguiente manera: "La narración se propone como representación de una continuidad articulada de acontecimientos semejante a la continuidad de la vida misma; el 'personaje', en esta perspectiva, es, como observaba Freud, la realización absoluta del Eros, pero, como en la vida misma, su continuidad está amenazada, se puede cortar en cualquier momento. Esto sería el 'efecto Schrerezada': ella está obligada a contar un cuento; si no tiene más cuento será condenada."Jitrik, Noé (2000). "El final de la escritura", en: Los grados de la escritura, Buenos Aires, Manantial, nota al pie número 3, p. 114.

${ }^{956}$ Ramos Otero, Manuel (1979). "El cuento de la Mujer del Mar", ed. cit., p. 89.

${ }^{957}$ Más adelante retomo la significación de la figura del "cuentero" en Ramos Otero, noción donde se interceptan la ficción, la historia de vida, el relato oral y el texto escrito.

${ }^{958}$ Ramos Otero, Manuel (1979). "El cuento de la Mujer del Mar", ed. cit., p. 100. En este volumen de cuentos de Ramos Otero se vuelve visible un procedimiento estilístico que se funda en la errata (nótese el "quel" de la cita textual). Encontramos palabras mal escritas, erratas ortográficas, enrevesamientos sintácticos que remedan licencias poéticas. Entiendo estas particulares dislocaciones léxicas y sintácticas como marcas del particular estilo escriturario de Ramos Otero, sobre todo porque su narrativa apunta en varias ocasiones a una contaminación conciente con el discurso poético. 
Por un lado el narrador-cuentero le narra a Angelo el cuento de Palmira Parés, la Mujer del Mar, una poeta de Manatí (Puerto Rico), descripta como una "viajera sonámbula", que debe abandonar su pueblo natal por una historia de amor lésbico escandalosa para su época, los años treinta del siglo XX. La mujer, que ha muerto sola y abandonada en el exilio neoyorkino, representa para el narrador una suerte de imagen especular de $s i^{959}$. Escribir sobre ella implica una manera de narrarse a sí mismo como escritor emigrado, homosexual, desde la (auto)mirada de un yo desnudo y errante cuya única posibilidad de arraigo se constituye en la capacidad de contar: "Yo, desempleado, vagando los días de una ciudad en ruinas, viviendo y escribiendo el cuento de la Mujer del Mar." ${ }^{960}$ Por otra parte Angelo relata al cuentero la historia del viaje de su abuela, Vincenza Vitale, quien, abandonada por su amante, deja atrás su ciudad natal, Nápoles, para transformarse en una inmigrante, cuya diáspora la lleva a la ciudad de San Juan de Puerto Rico primero, después a los Estados Unidos para recalar finalmente en Montreal. Angelo, a través de la historia de su abuela viajera, también llamada la Donna del Mare, deviene entonces, como el narrador, cuentero. Su cuento tiene la particularidad de tramarse a través de diferentes voces, tratándose de un relato marcadamente oral, que se constituye además en la intersección de dos diferentes lenguas, inglés e italiano y que admite una tercera versión o traducción, ya que el narrador traslada la versión oral original al texto escrito, usando para ello el español:

"Yo solo puedo contar el cuento de la Mujer del Mar (la historia nunca antes contada de la poeta maniateña Palmira Parés) y Angelo solo pudo contar 'the story of the wooman of the sea' (tanto escuchó la historia de Vincenza Vitale de la boca de su padre, o se la oyó contar a los ferrocarrileros sicilianos de la New Jersey Central Railoroad en los terrenos baldíos de una estación de Bayonne: la viajera había iniciado el viaje en un puerto de Napoli, detrás de un paisaje del Vesubio, venía de los parrales de Giocaravan llena de polvo, inmóvil en la popa de un velero -'inmobile... on the orange aft of a vaporous vessel', contaba el amado inmóvil, atardeciendo -había atracado en Casablanca y en las Islas Azores había zarpado camino del mar de las Antillas; con otros campesinos del agua salada, en el agosto caluroso del 1913 llegó a San Juan).

\footnotetext{
${ }^{959}$ En un pasaje del cuento el narrador afirma "yo buscándome en los versos viejos de Palmira Parés y la visión fantasma del pueblo costero.” Ibid., p. 100.

${ }^{960}$ Ibid., p. 101.
} 
El orden de sus vidas ha ido diluyéndose en las palabras memoriosas de los cuentos." 961

Ambas historias, la de Palmira Parés y la de Vincenza Vitale, se amalgaman e interceptan entre sí, confundiéndose y fundiéndose además con el relato de amor y muerte que une las vidas de Angelo y del cuentero, en un solo texto fragmentario y discontinuo que los lectores vamos reconstruyendo como si se tratara de reunir las partes de un espejo roto. Juan Gelpí advierte muy bien la función significativa del espejo como modelo organizador del relato $^{962}$ en "El cuento de la Mujer del Mar", notable en las duplicaciones de personajes y situaciones como así también en la relación especular ${ }^{963}$ que antes mencioné entre el cuentero y Palmira Parés, entre La Mujer del Mar de Manatí y la Donna del Mare de Nápoles. Asimismo el crítico destaca la presencia de otro importante registro de lo especular: en el relato de Palmira Parés se cifra, ficcionalizada, la biografía de la poeta puertorriqueña Julia de Burgos (1914-1953), quien concretamente murió en las calles del exilio neoyorkino. Ramos Otero rinde así un homenaje a la vez que establece una alianza con una figura -según subraya Gelpí- doblemente marginada del canon patriarcal, como poeta y como mujer ${ }^{964}$. En la historia de Palmira Parés el narrador menciona el nombre de su amante, Filimelé, personaje de un poema de Luis Palés Matos que simboliza lo inaprensible poético pero también el "numen y esencia de la muerte" $" 965$, significaciones que el cuento reproduce: "A

\footnotetext{
${ }^{961}$ Ramos Otero, Manuel (1979). "El cuento de la Mujer del Mar”, ed. cit., pp. 92-93.

${ }^{962}$ Gelpí, Juan. (1993). "La escritura transeúnte de Manuel Ramos Otero", ed. cit., p. 147.

${ }^{963}$ Véase el siguiente pasaje autorreflexivo del cuento donde se subraya el efecto especular de la literatura: "Hay una correspondencia fatal entre el cuento y la vida, entre el pasado y el destino, entre los poetas y los hombres, entre el amor y la muerte. Pero sólo, tal vez. Nada es más ambiguo que la palabra. Ni siquiera los espejos. Y sin embargo sólo nos sirven las palabras como espejos de nuestros tiempos." Ramos Otero, Manuel (1979). "El cuento de la Mujer del Mar", ed. cit., p. 93.

${ }^{964}$ En el comienzo de su ensayo Literatura y paternalismo en Puerto Rico Juan Gelpí destaca que en la historia literaria de su país ha predominado un paternalismo que excluyó de manera sistemática a las escritoras. Señala que el acceso de Julia de Burgos al canon literario puertorriqueño constituyó una suerte de "intercalación" reparadora en una genealogía literaria fuertemente masculina. Véase del autor especialmente el Capítulo I de Literatura y paternalismo en Puerto Rico, ed. cit., pp. 1-16.

${ }_{965}$ Se trata del poema "Puerta al tiempo en tres voces" en cuyos versos leemos: "Filí-Melé, ¿hacia dónde/ tú, si no hay tiempo para recogerte/ ni espacio donde puedas contenerte?/ Filí, la inaprehensible ya atrapada,/ Melé, numen y esencia de la muerte.” Palés Matos, Luis (1974).
} 
Filimelé la llamaron siempre la mujer de los Poetas. Llegaba a los lugares como llega la muerte, y así como la muerte, se quedaba desnuda, caminando". ${ }^{966} \mathrm{Si}$ la unión de los cuerpos del mismo sexo del narrador y Angelo remitían mediante la duplicación especular a un reflejo narcisista que borraba las diferencias entre uno y otro sujeto, nuevamente se apela a la imagen del espejo para dar cuenta del vínculo homoerótico que propicia la fusión de las identidades entre Palmira y Filimelé:

"Es inevitable que ahora un cuentero lo repita, pero las dos mujeres se amaron por primera vez a través del espejo, entre botellas de ron añejo y telarañas azules, los cabellos de ambas soplados por las aspas de madera del abanico de la Donna del Mare. El pelo enjambrado de abejas de Palmira Parés; las greñas de noches caracoladas de Filimelé. Las dos besándose en la niebla y el salitre del espejo, las dos salpicadas por los marullos del mar y del amor." 967

La cita precedente reescribe versos del poema palesiano para fundir los cuerpos de ambas mujeres en una misma imagen en la que sobresale la "fluida cabellera de abejas enjambrada." 968 Arnaldo Cruz-Malavé refiere también la presencia de otro poema que se conjuga con el de Palés Matos, como se advierte en la consonancia de sus títulos. Junto a "Puerta al tiempo en tres voces" reverbera y responde como un eco "Entre mi voz y el tiempo" de Julia de Burgos ${ }^{969}$, donde el sujeto lírico se desplaza y cruza el espejo /mar/ribera de la muerte, para encontrase consigo misma, con la poeta. Cruz- Malavé destaca, coincidiendo con Gelpí, que "El cuento de la Mujer del Mar" gira obsesivamente en torno a la especularidad, donde los relatos del cuentero y su amante y el cuento narrado por cada de uno de ellos se espejean, volviéndose indistinguibles:

Tomo 1:Poesía (1915-1956), Río Piedras, Editorial Universitaria, Universidad de Puerto Rico, p. 275.

${ }^{966}$ Ramos Otero, Manuel (1979). “El cuento de la Mujer del Mar”, ed. cit., p. 102.

${ }^{967}$ Ibid., p. 101.

${ }^{968}$ Palés Matos, Luis (1974). "Puerta al tiempo en tres voces", ed- cit., p. 275.

${ }^{969}$ Burgos, Julia de (1986). "Entre mi voz y el tiempo", en: Yo misma fui mi ruta, Río Piedras, Huracán, 1986, p. 124. Léanse los siguientes versos: "En la ribera de la muerte,/ hay algo,/alguna voz,/ alguna vela a punto de partir,/ (...) En la ribera de la muerte,/ ¡tan cerca!,/ en la ribera/ (que es como contemplarme en un espejo)". 
"Al igual que el cuentero espera al amante, en el cuento narrado, Palmira Parés, la Mujer del Mar/ Donna del Mare, espera a su doble, a la otra, a la amante asesina en que se convertirá. Palmira Parés/ Vincenza Vitale, las dos nacidas, como Ramos Otero, en ciudades de la costa -Nápoles, Manatí, Puerto Rico- y exiliadas frente al mar -Montreal, Nueva York- se desdoblan en la mujer que las mira desde el otro lado del espejo: la Filí- Melé de Palés (Parés) Matos."

Si bien Cruz- Malavé alude también al tópico del doble presente en la imagen del espejo, el cuento de Ramos Otero rehuye sin embargo la especularidad simplista, la duplicación satisfactoria, tensionando la provisoria tranquilidad de la oposición o del paralelismo binarios. Los espejos del relato cuestionan toda posibilidad de fijar una identidad unificada del yo, refractando por el contrario la amenaza de su disolución:

"El tiempo, la muerte y los espejos, purifican la memoria. Uno sólo envejece en el espejo. El tiempo de nosotros sólo existe en el espejo. La barba de nosotros va creciendo en el espejo y sólo las tijeras plateadas del espejo la vuelven a desparecer. Para que nazca el otro. Amante Amor Amado. De la noche, y vuelva otra vez a ser garzón cenizo volando en el cielo del espejo. La mano mojada de un periódico viejo vuelve a amanecerlo otra vez. Para que vuelva la cara de nosotros. (...) En el espejo todo es tardío como el atardecer. Uno sabe que lo que pasa es el tiempo. Que de nada vale que se rompa el espejo y uno se vuelva nosotros. Que de nada vale dejar la luna del espejo, y ver, que la cara de uno es solamente la cara del espejo, y no saber, que al fin, uno no existe." 971

En el fragmento citado, la sintaxis, el ritmo, las repeticiones léxicas, los paralelismos impregnan de lirismo la prosa del relato; se advierten además resonancias de tres grandes poemas "La noche oscura del alma" de San Juan de la Cruz, "Muerte de Narciso" de José Lezama Lima y "Muerte sin fin" de José Gorostiza, en una apuesta estética que privilegia la mezcla y dispersión de los límites de los géneros literarios, muy característica de la escritura de Ramos Otero. Por otra parte el motivo recurrente del espejo se plasma también en el título de un poemario de Palmira Parés, Los espejos del tiempo, que sumado a sus otros dos libros, Los callejones del exilio y El mar proyectan las

\footnotetext{
${ }^{970}$ Cruz-Malavé, Arnaldo (1993). "Para virar al macho: la autobiografía como subversión en la cuentística de Manuel Ramos Otero”, ed. cit., p. 261.

${ }^{971}$ Ramos Otero, Manuel (1979). "El cuento de la Mujer del Mar”, ed. cit., p. 102.
} 
obsesiones del cuentero y por ende los principales ejes temáticos que atraviesan el relato. Los desplazamientos espaciales que afectan a los personajes del cuento -el cuentero emigrado, Angelo y Vincenza inmigrantes, Palmira Parés exiliada- constituyen asimismo metáforas de la soledad y el desencuentro amoroso. Angelo será caracterizado por el narrador-protagonista como "un emigrante del amor"972 y el amor, más bien su búsqueda, hará las veces de refugio para aquel que está sometido a lo pasajero, al tránsito: "Entonces, uno se exila en el amor como en la ciudades."

En el espacio urbano que se configura en el relato se privilegian determinadas coordenadas que trazan el mapa del deseo homoerótico. Se trata de un circuito donde se reiteran algunos lugares -"los muelles apolillados de New York", los "peldaños orinados e iglesias clausuradas en Christopher Street", el cuarto del Hotel Christopher- zonas que demarcan el "cruceo", la deriva o la "draga"974 que propicia el encuentro fortuito del nuevo amante. Lugares de errancia y contacto sexual, donde se alían el flujo y los fluidos (orina, semen, sangre) ${ }^{975}$ en la circulación nocturna de los cuerpos:

"Tantas noches tomó ese mirar de dos espejos, nuestro viaje nocturno para buscar al otro, por los bares húmedos y los callejones crepusculares, en los muelles apolillados, en la carretera clausurada del Oeste (en el panorama de las ratas azules ahogándose en el Hudson River), en los cuartos negros de bares clandestinos por la madrugada, en todas las ciudades recorridas desde el cuarto del hotel o en las escaleras a la intemperie de Christopher Street." ${ }^{976}$

Pero estos espacios también tienen en común ciertos rasgos de marginalidad y decadencia que parecieran resignificar el impuro amor de las

\footnotetext{
${ }^{972}$ Ibid., p. 100.

${ }^{973}$ Ibid., p. 103.

974 'Deriva del yo, del deseo. La deriva de los sujetos involucrados en el 'mercado homosexual' no se verifica solamente en lo individual -a través de las inscripciones categoriales-, sino que atañe también al plano espacial. La deriva o 'draga' -deambuleo por ciertas calles de la ciudad, a la busca de un amante ocasional, estilo 'programa de una sola noche' - configura el modelo básico de circulación en el medio." Perlongher, Néstor (1997). "Avatares de los muchachos de la noche", en: Prosa plebeya. Ensayos 1980-1992, selección y prólogo de Christian Ferrer y Osvaldo Baigorria, Buenos Aires, Colihue, p. 48.

${ }^{975}$ En "El cuento de la Mujer del Mar" además de la fluidez del agua -el mar- que reúne las cuatro historias, circulan otro flujos que remiten al cuerpo y a la sexualidad como la sangre que religa a las mujeres, el fantasma de una enfermedad de trasmisión sexual como la sífilis, los orines de los rincones urbanos transformados en mingitorios callejeros, espacios marginales que propician el encuentro homosexual.

${ }_{976}$ Ramos Otero, Manuel (1979). "El cuento de la Mujer del Mar”, ed. cit., p. 106.
} 
ciudades del poeta cubano Julián del Casal, condensados en una frase del narrador principal que proyecta la connotación de ruina, resto, desperdicio a todo el ámbito urbano: "Entonces, New York ya estaba en ruinas."977 La ciudad y sus márgenes se vuelven un ámbito atravesado por significaciones mórbidas que entrañan la tumba, la agonía del amor, la muerte como otro exilio. Emigrados, exilados, homosexuales, acechados por una existencia fantasmática, se reúnen e interactúan en uno y otro territorio, la ciudad ${ }^{978}$ y la página del relato: "La ciudad era entonces un cementerio de exilados. Las madrugadas eran de fantasmas de mares"/ "Te cuento el cuento que me contaste, pero en el mío, la muerte es otro exilio y la mujer se ha marchado al mar (a lo mejor se ha ahogado)."979

Si en "El cuento de la Mujer del Mar" el narrador sentencia :"Era imposible vivir y contar la vida a la misma vez"980, todo lo contrario se produce en "Vivir del cuento"981, de Página en blanco y staccato, donde el origen del relato se pierde a través de una serie de personajes que Josefina Ludmer ${ }^{982}$ clasificaría entre aquellos que "saben contar un cuento" y también, como lo indica su título, "vivir del cuento". La narración se estructura a partir de la unión de diversos planos. En el primero, el narrador llamado Manuel ${ }^{983}$, escritor puertorriqueño emigrado, cuenta en primera persona los sucesos que rodean la Primera Conferencia Nacional de Literatura Puertorriqueña en Nueva Jersey ${ }^{984}$,

\footnotetext{
${ }^{977}$ Ibid., p. 100.

${ }^{978}$ Para Juan Gelpí "la fusión o solidaridad entre las figuras marginadas por el canon -una poeta y un cuentero homosexual, ambos exiliados- sólo se puede dar en ese espacio difícil de controlar y disciplinar que es la ciudad." Véase del autor "La escritura transeúnte de Manuel Ramos Otero", ed. cit., p. 149.

${ }^{979}$ Ramos Otero, Manuel (1979). "El cuento de la Mujer del Mar”, ed. cit., pp. 104 y 113-114 respectivamente.

${ }^{980}$ Ramos Otero, Manuel (1979). “El cuento de la Mujer del Mar”, ed. cit., p. 115.

${ }^{981}$ Ramos Otero, Manuel (1987). "Vivir del cuento", en: Página en blanco y staccato, ed. cit., pp. 49-68.

982 Ludmer, Josefina (1977)."Contar el cuento" en Onetti. Los procesos de construcción del relato, Buenos Aires, Sudamericana, pp. 143-185.

${ }^{983}$ En numerosos relatos de Ramos Otero el narrador reproduce el nombre o el apellido del autor, en un juego especular que difumina la distancia entre estas figuras -autor y narrador- y provoca un efecto que Arnaldo Cruz-Malavé ha caracterizado como "narcisismo de la escritura" en tanto la ficción se constituye también como relato autobiográfico. Véase Cruz-Malavé, A. (1993). "Para virar al macho: la autobiografía como subversión en la cuentística de Manuel Ramos Otero", ed. cit., pp. 239-263.

${ }^{984}$ De esta reunión resultó un volumen colectivo que hemos citado antes, Imágenes $e$ identidades: el puertorriqueño en la literatura, editado en 1985 por Asela Rodríguez de Laguna (Río Piedras, Huracán). En este libro se incluye el ensayo de Norma Carr titulado "Imágenes: El
} 
espacio que permite la reunión de Norma Carr, historiadora puertorriqueña cuya investigación gira en torno a la emigración de puertorriqueños a Hawai y de su esposo de origen norteamericano italo-irlandés, de la escritora Magalí García Ramis y del propio narrador, una y otro puertorriqueños; Magali residente en la isla, Manuel, en Nueva York. En otro plano se recrea la carta testimonial de Monserrate Álvarez, anciano puertorriqueño que formó parte del primer contingente de emigrantes de su país a Hawaii, residente en la isla de leprosos de Molokai, quien escribe una carta autobiográfica contestando los requerimientos de Norma Carr, y un tercer plano estaría vinculado con la escritura de un texto, en el cual el narrador principal -Manuel- se ocupa de contar, la historia de Hawaii, reconstruyendo la escasamente documentada emigración de puertorriqueños a esa colonia, y que a su vez opera como complemento de la narración de Monserrate. Todos los "cuenteros" que componen el relato están atravesados de una u otra forma por la situación de la emigración, los desplazamientos geográficos, el plurilingüismo y la heterogeneidad étnica y cultural. Desde Monserrate y su madre, que se amanceba en la emigración con un italiano, siguiendo por el resto de los personajes:

\begin{abstract}
"Norma mencionó que su hija mayor se consideraba puertorriqueña, que se había casado con un japonés y que dominaba perfectamente el japonés, el hawaiiano y el inglés. Yo le dije que una prima hermana mía se había casado con un filipino y que yo no conocía los hijos. Magalí mencionó una cuestión de judío sefardita mallorquín en su pasado. Y el marido de Norma comentó que en Hawaii se daba una yautía que crecía salvaje en el agua pero por más que habían intentado sembrar matas de plátanos el terreno de Hawaii no dejaba que la mata llegara a su madurez y la abuela de Norma les enviaba plátanos por correo desde Puerto Rico."985
\end{abstract}

puertorriqueño en Hawaii" (pp. 105-116), que funciona como pre-texto de "Vivir del cuento" de Ramos Otero. Por otra parte en el relato conviven personajes ficticios como Monserrate junto con otros "reales" tales como el propio narrador, Norma Carr, la cuentista Magali García Ramis, la poeta Vanessa Droz, todos ellos puertorriqueños.

${ }^{985}$ Ramos Otero, Manuel (1987). "Vivir del cuento", pp. 51-52. 
Como señala Áurea María Sotomayor las genealogías que invocan los personajes son producto de diásporas, emigraciones pasadas y recientes, voluntarias o forzadas, multiplicidad étnica, cultural y lingüística, que en todos los casos rompen con la estabilidad de la filiación del emigrado, vinculada con un concepto territorial de la patria y de la identidad nacional ${ }^{986}$. El plátano, como un fruto típicamente tropical y caribeño, sinécdoque de Puerto Rico, también "viaja" a través del correo, y de alguna manera sustituye el acto de escritura de la carta, como sistema de vinculación común entre los emigrados y los familiares que permanecen en la tierra natal.

Los tres planos de la narración se articulan mediante una cadena de cortes y suturas. Por momentos los blancos tipográficos delimitan claramente el espacio destinado a cada plano del relato, pero en otras ocasiones prevalece la continuidad, el pasaje casi ininterrumpido y entrelazado de las voces narrativas que padecen, como los personajes de "El Cuento de la Mujer del Mar", el "complejo de Scherezada":

"Paramos en el bar del hotel y en la penumbra de las velas y el calorcito de los tragos se nos soltó la lengua y nos sentamos: ella me habló del mar y yo le habré preguntado por el mar, ella me dijo que estaba loca por salir de Puerto Rico un tiempo y yo le dije que a mí me pasaba lo mismo con New York y que hacía siglos que no escuchaba un cuento. Magalí me dijo que en Puerto Rico había más poetas por milla cuadrada que en otro país del mundo; yo le dije que por eso mismo en Puerto Rico no nos dejan vivir del cuento. Complejo de Scherezada, nos dijimos. ${ }^{987}$

La actividad de contar se autorrepresenta en el texto como la posibilidad de constituir un espacio alternativo y liberador para el sujeto que narra, como notamos en las reiteradas imágenes cuyo centro es el órgano que permite la construcción y continuidad del relato -la lengua- caracterizada como desatada,

\footnotetext{
${ }^{986}$ Sotomayor, Áurea María (2004). "Genealogías o el suave desplazamiento de los orígenes en la narrativa de Manuel Ramos Otero", en: Femina Faber. Letras, música, ley, San Juan, Ediciones Callejón, pp. 279-306.

${ }^{987}$ Ramos Otero, Manuel (1987). "Vivir del cuento", ed. cit., p. 55.
} 
desenvuelta, desarraigada. El anciano Monserrate puede escribir su carta autobiográfica y trasladar al papel sus memorias cuando "desamarra" su lengua: "Al que no sabe contar el cuento debieran amarrarle la lengua. A lo mejor por eso estoy dirigiéndome a ustedes por carta, porque mi lengua nunca ha merecido estar amarrá." 988 La lengua desamarrada es la que posibilita "vivir del cuento" y se constituye como el principio fundamental de una poética que el narrador formula a través de la voz de otra escritora puertorriqueña, la poeta Vanessa Droz:

"Una noche, en otro bar de otra esquina, me había dicho mi amiga Vanessa: '¿Quiém no conoce el cuemtista? ¿Quiém no conoce esa figura que se detiene em cualquier esquina, escogiemdo como víctima al primer borracho crédulo, al bartemder aburrido cuyos oídos estam prestos al comsuelo momemtaéneo, a la figura que romda calles pero que tambiem forma parte del círculo familiar, al que siempre imvemta sus historias y las que no imvemta las exagera hasta el pumto de la ausencia total de conocimiemto? 'Ese vive del cuemto', 'ese es um cuemtista”, se le motea com desprecio $\mathbf{y}$, al mismo tiempo, com fascinaciom por su capacidad para el imvemto, para el embuste. No hace nada, solo cuemta. Vive y muere del cuemto. Es um paria amado y odiado, romdador de pueblos, imdispensable'."989

Si nos detenemos en las escenas del relato que representan la acción de contar, si releemos el acápite de Pedro Páramo de Rulfo ${ }^{990}$ que marca el comienzo del texto, si revisamos los pasajes en los cuales el narrador

\footnotetext{
${ }^{988}$ Ibid., p. 62.

989 Ramos Otero, Manuel (1987). "Vivir del cuento", ed. cit., p. 65. En este fragmento el narrador remeda la particular pronunciación de la poeta, en un intento de capturar por escrito cierto vestigio de oralidad que rompe a su vez con las normas ortográficas y gramaticales de la lengua escrita "correcta". Lo mismo ocurre cuando se cita la voz de Monserrate, en donde la grafía de las palabras escritas también imitan su pronunciación; ambos casos constituyen ejemplos de una suerte de escritura fonética.

990 El acápite tomado de la novela Pedro Páramo (1955) de Juan Rulfo es el siguiente: "Me di cuenta que su voz estaba hecha de hebras humanas, que su boca tenía dientes, y una lengua que se trababa y destrababa al hablar, y que sus ojos eran como todos los ojos de la gente que vive sobre la tierra." Ramos Otero, Manuel (1987). "Vivir del cuento", ed. cit., p. 49.
} 
reproduce (cita) otras voces (especialmente las de Vanessa, Norma y la de Monserrate), encontramos un itinerario en el engendramiento del texto que va de la voz a la escritura. El texto escrito evoca la oralidad, transcribe hablas, se piensa como un sustituto posible y necesario de lo oral. De allí que el narrador destaque el sentido de la audición, "el soy todo oídos Manuel soy todo oídos"991. Norma Carr es la fuente del texto: su relato -"Ios increíbles cuentos sobre aquellos puertorriqueños que desde 1900 fueron a trabajar a Hawaii como campesinos asalariados" ${ }^{\prime 992}$, dispara la escritura de otro/s texto/s. El narrador escucha la voz de Norma como emblema de los orígenes de su relato:

"Sin saberlo, Norma había detenido el curso de la noche para ser Scherezada, la puertorriqueña hawaiiana del Bronx que opera la rueca de una historia olvidada. ¿Por qué había sido Norma la que había contado el cuento que tenía que ser contado? ¿Por qué Magalí ahora fraguaba las palabras necesarias para seguir contándolo y por qué yo estaba volando sobre el tapiz de un tiempo inconsciente? Los cuentos no surgen de la nada y sin embargo hasta que no se cuentan no hay conciencia de que ese cuento existe. ${ }^{993}$

Si la voz, según Guy Rosolato ${ }^{994}$, contiene la cuestión del origen, los cuentos de Norma materializan el pasaje del silencio a la articulación de la voz, y disparan el texto que escribe el narrador Manuel, lo originan, porque entre la voz de Norma y la del narrador se interpone la escritura. El orden en el engendramiento textual ${ }^{995}$ se materializa en un itinerario que une dos espacios, el de la voz, colectivo, compartido, y el de la escritura, solitario e individual:

\footnotetext{
${ }^{991}$ Ibid., p. 66.

${ }^{992}$ Ibid., p. 50.

${ }^{993}$ Ibid., p. 60.

${ }^{994}$ Rosolato, Guy (1974). Ensayos sobre lo simbólico Anagrama, Madrid.

${ }^{995} \mathrm{Me}$ resultaron sumamente valiosos los aportes sobre la cuestión del origen y engendramiento del cuento trabajados por Jorge Panesi en su aguda lectura de "La casa inundada" de Felisberto Hernández. Véase Panesi, Jorge (2000). "Felisberto Hernández, un artista del hambre", en: Críticas, Buenos Aires, Norma, pp. 183-220.
} 
"Magalí y yo nos fuimos del bar a la maquinilla: lo de ella se llamaría Cuentos de mujeres y lo mío Vivir del cuento." "996

Por otra parte encontramos en "Vivir del cuento" varios comentarios del narrador que tienden al acercamiento entre el discurso histórico y el ficticio: "La mera mención de la palabra 'cuéntame' hacía posible nuestra amistad, fundamentada en la palabra y todos sus recovecos, y preparaba el terreno para una continuidad interrumpida solamente por los libros de historia." ${ }^{\text {"97 }}$ La alusión a una continuidad interrumpida por la historia constituye un gesto autoreferencial respecto de la organización oscilante de este relato, que difumina las fronteras entre el discurso histórico y el ficticio, al cual se le suma también el sesgo autobiográfico de gran parte del texto. La imagen de la continuidad, la infinitud de un mismo relato, la encontramos no sólo en las similaridades temáticas entre el relato de Monserrate y el de Manuel, sino, especialmente, en la crítica de la historia con mayúsculas que sostiene el cuento. En la historia de Monserrate Alvarez en Hawaii en los comienzos del siglo XX, es posible cifrar especularmente la historia del emigrado puertorriqueño en los Estados Unidos, especialmente a partir de la constitución del Estado Libre Asociado (1952). Marginado y excluido a partir de un diagnóstico erróneo por el cual se le achaca una lepra, Monserrate es condenado a otro exilio, por razones higiénicas, en una isla que es un leprosario ${ }^{998}$. Este doble distanciamiento le permite al personaje reconstruir y escribir sus "memorias de emigrado"999 como otro importante itinerario textual que va del relato oral al escrito.

La travesía en barco desde Puerto Rico hasta Hawaii se cuenta como un relato de iniciación y aprendizaje: se sale del mar Caribe a un océano extraño, el Pacífico; en el trayecto, el personaje, aun adolescente, adquiere "saberes".

\footnotetext{
${ }^{996}$ Ramos Otero, Manuel (1987). "Vivir del cuento", ed. cit., p. 60.

${ }^{997}$ Ibid., p. 51.

${ }^{998}$ En "El cuento de la Mujer del Mar" acecha la sífilis, en "Vivir del cuento" se menciona la lepra, enfermedades que se caracterizan por la manifestación de sus síntomas a través de la piel. Esta cadena estalla en cuentos como "Página en blanco y staccato", "Descuento", "La piel de Paul", donde los personajes y narrador padecen SIDA y sufren el sarcoma característico de este virus. Volveré sobre esta cuestión donde las marcas del cuerpo son también metáforas de la escritura en el próximo apartado de este capítulo.

${ }_{999}$ Manuel Ramos Otero, en una entrevista que le hace Jan Martínez ("Manuel Ramos Otero o los espejuelos de Mahoma", ed. cit., pp. 52-53), declara: "Nueva York me ha dado la distancia necesaria para mi escritura", haciendo del desplazamiento espacial un motor y condición de la escritura, mecanismo que sus personajes "cuenteros" repiten.
} 
Aprende a escribir y a leer en español, y a interpretar la lengua del colonizador -el inglés-, lengua de la dominación mediante la cual se traza el retrato del "otro". Monserrate lee en la imagen del emigrado puertorriqueño la construcción colonizadora de una caricatura excluyente: "Aprendí lo suficiente como para leer las palabras 'Porto Rican' debajo de la silueta dibujada de un criminal enmascarado, armado con cuchilla y pistola, que había aparecido en un periódico hawaiiano, y saber que 'Porto Rican' pronosticaba lo malo."1000

Cuando Monserrate queda huérfano, el emigrado sabe que ya no retornará a Puerto Rico, identificando la tierra natal con la madre, a la vez que un pequeño objeto -una taza de coco- se constituye en sinécdoque y cifra de la figura materna/ territorio de origen del sujeto:

"Esa taza de coco es una imagen, una protección digamos, un amuleto si se quiere, es una imagen que hace que mi cabeza viaje por las noches a otro tiempo que no fue mejor pero que fue otro tiempo, tal vez porque para mí Puerto Rico y Flor María son la misma cosa." ${ }^{1001}$

Su tradición, Puerto Rico, es su madre Flor María, y el "nosotros" que trabaja la tierra hawaiiana es ambiguo: "...pero eso llamado nuestro que de repente se sabe ser nosotros. Admito, aquí nosotros es una palabra ambigua. ¿Acaso no lo ha sido siempre a través de nuestra historia?"1002 Para Áurea Sotomayor el descubrimiento tardío del personaje de no ser leproso, como el descubrimiento temprano de no ser el puertorriqueño de las caricaturas y estereotipos que circulan en el cuento ("pillos de barrio" según la Sugar Plantation, "súbditos leales", según el Departamento de Guerra; "peones gringos" en la versión de otros emigrados), torna paradigmática la acción de despojarse de las "etiquetas"1003 identitarias que lo signaban como posesión, peón, puertorriqueño, rostro marcado por la enfermedad. "La historia del emigrado puertorriqueño-hawaiiano produce, en última instancia, un personaje

\footnotetext{
${ }^{1000}$ Ramos Otero, Manuel (1987). "Vivir del cuento", ed. cit., p. 52.

${ }^{1001}$ Ibid., p. 62.

${ }^{1002}$ Ramos Otero, Manuel (1987). "Vivir del cuento", ed. cit., p. 63.

${ }^{1003}$ En un revelador pasaje del relato, los puertorriqueños emigrados inician una rebelión en el barco que los transporta, que comienza con un gesto simbólico, arrancarse las etiquetas: "...mientras Bautista armaba el revuelo doña Pura Pérez había gritado que nos arrancáramos las etiquetas con nuestros nombres y el nombre de la plantación en Hawaii a la que cada cual había sido asignado y las tiráramos por la borda." Ramos Otero, Manuel (1987). Ibid., p. 56.
} 
libre de su atadura genésica a la patria o al "ser" nacional, que solo se define con la única marca del saber contar"1004, subraya Sotomayor. Monserrate se incorpora entonces en el territorio más amplio de los "cuenteros", donde la única carta de ciudadanía o signo de identidad posible del sujeto consiste en una simbólica "letra escarlata" que porta quien vive del cuento, "marcado para siempre con una 'C' colorada"1005.

Juan Gelpí advierte que en los cuentos de Ramos Otero de Página en blanco y staccato se desprende una teoría del cuento como una "defensa de ese género como texto histórico alterno."1006 En "Vivir del cuento" encontramos presente esta idea, no solo en el relato autobiográfico de Monserrate, sino también en la historiadora cuentera (Norma) y en el narrador que evoca la historia hawaiiana con una sutil y a su vez corrosiva ironía anticolonial y antinorteamericana. Pero también están las pequeñas historias, los relatos mínimos, las historias de vida que religan profundamente al narrador Manuel con la escritora Magalí García Ramis y que aluden constantemente a la emigración puertorriqueña a Nueva York. Así Manuel, citando y apropiándose del título de la colección de cuentos de Magalí, La familia de todos nosotros (1976), declara:

"Tanto Magali como yo habíamos contado de ritos y repeticiones familiares, en coincidencias forzadas por los hábitos del domingo: reuniones con siete tías solteras, visitas a la abuela en Vega Baja o al cementerio de Manatí, soledades de habitación con espejo. Ella, tal vez, había anticipado todo con esa línea suya 'la familia de todos nosotros', esa familia que primero es el mundo hasta que el recuerdo la escudriña y la vuelve personaje. Esa familia de todos nosotros se alargaba de repente, en la aventura nuestra de indagar la historia en cada historia, de abrazar la niñez anterior para saber porqué las cosas son como son ahora. Al fin y al cabo, cada aventura es un recuento de las vicisitudes, tragedias y logros de un héroe. Aunque a ese héroe la historia misma lo hubiera vuelto anónimo." ${ }^{1007}$

\footnotetext{
${ }^{1004}$ Sotomayor, Áurea María (2004). "Genealogías o el suave desplazamiento de los orígenes en la narrativa de Manuel Ramos Otero", ed. cit., p. 294.

${ }^{1005}$ Ramos Otero, Manuel (1987). "Vivir del cuento", ed. cit., p. 64.

1006 Gelpí, Juan (1990). Reseña de Página en blanco y staccato en La Torre, Revista de la Universidad de Puerto Rico, año IV, Núm. 14, abril-junio, pp. 245-250.

${ }^{1007}$ Ramos Otero, Manuel (1987). "Vivir del cuento", ed. cit., p. 54.
} 
El cuentero Manuel torna visible a ese héroe anónimo al cual se refiere la cita, a través de la reconstrucción ficcional del testimonio de Monserrate. Individualiza mediante nombre, apellido, historia de vida, uno de aquellos posibles relatos de la diáspora de trabajadores de la caña puertorriqueños a Hawai que ha investigado Norma, a la vez que cifra en la historia colonial de esta isla la de su propio país, "una historia de emigraciones desde los taínos hasta el siglo XX."1008 "Vivir del cuento" evoca insistentemente la conjunción de dos acciones, desplazarse y contar, alianza que, desde otra perspectiva, coincide parcialmente con la sugerente propuesta de lain Chambers:

"Siempre alegórica, siempre hablando de otro, de otra parte y por lo tanto destinada a la discordancia, la escritura abre un espacio que invita al movimiento, a la migración, al viaje. Establece cierta distancia entre nosotros mismos y los contextos que definen nuestra identidad." 1009

Escritor y viajero se presenta el protagonista de "La otra isla de Puerto Rico"1010, relato que sugiere desde su título los sentidos de la alteridad y la duplicidad, presentes también en el doble apellido del personaje Don José Usbaldo Olmo Olmo. El cuento se inicia con su muerte -"el viajero viajaba para otra vida"-1011 ocurrida en Grecia, lejos de su territorio natal, Puerto Rico. Su historia nos llega a través de un narrador que se constituye como receptor y mediador de múltiples voces y fuentes documentales escritas que él se encarga de reunir, apelando a la clásica imagen que homologa el texto al tejido: "Hasta mis manos han llegado los documentos necesarios para ir atando cabos, pero advierto que solamente es una forma de hilar los hechos." ${ }^{1012}$ Por otra parte, como destaca Juan Gelpí, el modelo que sigue el narrador es el de una médium espiritista ${ }^{1013}$, cuestión que impregna al relato de un sesgo fantástico: "Intento ser tan sólo el portavoz del muerto, de la misma manera que

\footnotetext{
${ }^{1008}$ Ibid., p. 55.

${ }^{1009}$ Chambers, Iain (1995). Migración, cultura, identidad, Buenos Aires, Amorrortu, p. 25.

${ }^{1010}$ Ramos Otero, Manuel (1987). "La otra isla de Puerto Rico", en: Página en blanco y staccato, ed. cit., pp. 9-23.

${ }^{1011}$ Ramos Otero, Manuel (1987). "La otra isla de Puerto Rico”, ed. cit., p. 10.

${ }^{1012}$ Ibid., p. 13 (cursivas del texto).

${ }^{1013}$ Gelpí, Juan (1990). Reseña de Página en blanco y staccato, ed. cit., p. 249.
} 
tantas espiritistas puertorriqueñas, discípulas innegables de Allan Kardec y fieles creyentes de potencias yoruba." 1014

Mientras el personaje de José Usbaldo se desplaza constantemente, no ocurre lo mismo con su hermana Liboria Olmo Olmo, quien reside en su país natal, casi sin salir de la decaída hacienda familiar "La Esmeralda", en Arecibo. Los hermanos -mellizos por línea paterna- insinúan en su duplicación otro tópico fantástico: el doble. Han nacido exactamente el mismo día: "Liboria Olmo Olmo y José Usbaldo Olmo Olmo nacieron el 10 de octubre de 1893; ella nació al atardecer y él de noche, y esto se reflejaba hasta en el tinte de piel de los gemelos." ${ }^{1015}$ También mueren en la misma fecha, ochenta y cuatro años más tarde, el primero de agosto de 1977. Si bien en el texto se insiste en los paralelismos que entrañan la gemelaridad de los hermanos, hay un elemento que rompe la ilusoria complementariedad binaria, complicando así la trama y estructura del relato. Para trazar la historia de la familia Olmo Olmo el narrador reconstruye su genealogía, y sugiere en su origen una relación próxima al incesto, ya que los padres de José y Liboria no sólo eran primos hermanos sino que fueron criados juntos:

"El padre, Don José Ariosto Olmo, y la madre, Doña Liboria Lorenxa Olmo, eran primos hermanos nacidos el uno para el otro. En la terrible plaga del cólera morbo que azotó el pueblo de Arecibo en 1855, Liboria Lorenxa perdió a sus padres, víctimas de la epidemia que causó 1.502 muertes. Tenía 6 años cuando se fue a vivir con su tío y el primo de 8 que luego sería su esposo."1016

Se destaca que los esposos Olmo-Olmo son descendientes de la oleada inmigratoria canaria, quienes contribuyeron principalmente al desarrollo del cultivo del café y el tabaco ${ }^{1017}$ en Puerto Rico. Se alude además al peso ideológico que encarnó este sector para los funcionarios coloniales españoles, ya que los inmigrantes fueron destinados principalmente a contribuir al "blanqueamiento" de la sociedad isleña. Sin embargo el narrador subraya un

\footnotetext{
${ }^{1014}$ Ramos Otero, Manuel (1987). "La otra isla de Puerto Rico”, ed. cit., p. 11.

${ }^{1015}$ Ibid., p. 12.

${ }^{1016}$ Ramos Otero, Manuel (1987). "La otra isla de Puerto Rico", ed. cit., p. 12.

${ }^{1017}$ Esta oleada de inmigrantes de origen corso, canario y mallorquín, principalmente dedicados al café y al tabaco, constituyen los actores principales del "segundo piso" que describe José Luis González en su ensayo El país de cuatro pisos (1980), al cual hice referencia en el capítulo II.
} 
desvío significativo, cuando afirma: "vinieron a trabajar la tierra y se quedaron, vinieron para aclarar la raza y colaron café con ella." ${ }^{\text {"1018 }}$ Precisamente la mezcla étnica constituye el elemento que perturba deliberadamente el equilibrio de la relación dual entre los hermanos, puesto que Liboria es hija de José Ariosto pero no de Lorenxa, sino que su madre biológica es Madame Cafolé, negra cimarrona de Martinica. Las genealogías se bifurcan, ampliándose sus ramas hasta abarcar otras diásporas como las que están implícitas en el esclavismo y la trata. La mujer que fuera esclava representa en el cuento la estirpe libertaria e independentista, puesto que interviene en el levantamiento de Ciales, foco de la resistencia criolla, antiespañola y antinorteamericana, transportando armas camoufladas para los rebeldes ${ }^{1019}$. Además su historia se anuda estrechamente con la del narrador, ya que las armas fueron escondidas en bollos de pan, horneados por su abuelo panadero, Llillo Ramos, "supuesto dirigente de las fuerzas rebeldes que tomaron el pueblo de Ciales contra el gobierno español, después de la invasión norteamericana que se inició por el pueblo de Guánica." ${ }^{1020}$ No sólo las genealogías familiares se multiplican, sino también los orígenes del cuento mismo, en cuya construcción se equilibran los aportes de la narración escrita y oral, episodios históricos y otros enteramente ficticios. Confluyen así diversas tramas que le posibilitan al narrador componer un relato fragmentario, tejido a partir de historias leídas -las Memorias de José

${ }^{1018}$ Ramos Otero, Manuel (1987). "La otra isla de Puerto Rico", ed. cit., p. 12.

${ }^{1019}$ En este relato de Ramos Otero, como se vio antes en "Vivir del cuento", parte de la trama se anuda con hechos históricos. Efectivamente hubo un levantamiento en el pueblo de Ciales al poco tiempo de ocurrida la invasión de Guánica en 1898. Fernando Picó relata que mientras se concertaba el armisticio entre España y los Estados Unidos se produjo un vacío de poder ante la proximidad de los norteamericanos y la evacuación de la tropa española, ocasionándose nuevas confrontaciones como la de Ciales, donde un grupo nutrido de personas armadas ocupó el pueblo: "La tropa auxiliar española que había evacuado Ciales regresó con refuerzos y hubo una encarnizada batalla entre ésta y los criollos, con un saldo de trece muertos. Aunque los españoles prevalecieron porque estaban mejor armados y entrenados militarmente, el evento subrayó la incertidumbre que se cernía sobre el destino de Puerto Rico." (Historia general de Puerto Rico, Río Piedras, Huracán, 1990, p. 229). Ramos Otero incluye en el relato histórico un personaje de claro cuño literario, ya que Madame Cafolé se nombra en dos poemas de Luis Palés Matos. En uno de ellos, el más conocido, titulado "Elegía del Duque de la Mermelada" leemos: "Qué gentil va mi Duque con la Madama de Cafolé". (Véase del autor Tuntún de pasa y grifería, edición de Mercedes López- Baralt, Instituto de Cultura Puertorriqueña y Editorial de la Universidad, San Juan, 1993). El narrador de "La otra isla de Puerto Rico" incluye mediante una nota al pie la referencia a los poemas palesianos, provocando un efecto particular, ya que el personaje poético pareciera alcanzar así una dimensión histórica.

${ }^{1020}$ Ramos Otero, Manuel (1987). "La otra isla de Puerto Rico", ed. cit., p. 13. Así como en "Vivir del cuento" coinciden el nombre propio de autor y narrador, en este relato se repiten los apellidos y el mismo lugar de nacimiento: Manatí. 
Usbaldo Olmo Olmo-; escuchadas -la genealogía familiar que traza Liboria Olmo Olmo-, y la "otra" versión, también oral, en boca de una mujer del pueblo, Doña Pancha Tejada, cuya narración desnuda la estirpe bastarda y mulata que da cuenta del particular origen de Liboria; documentos históricos que refieren el levantamiento de Ciales $^{1021}$; los innumerables y desordenados libros que componen la biblioteca de José Usbaldo en su casa natal. Todos estos materiales ingresan al relato, son apropiados por el narrador, quien postula la posibilidad de producción del cuento develando los secretos de la memoria propia y ajena, memoria que jamás se representa como una línea constante en el relato, sino más bien dispersa a través de una cronología imprecisa. En este sentido, como advierte Áurea Sotomayor, es interesante que el narrador-lectorescritor decida romper el orden cronológico de las Memorias de José Usbaldo y comience su lectura por el volumen IV: "No sé por qué comencé por el volumen IV; no era que quisiera buscar claves para su muerte, era más bien para romper con su orden cronológico y garantizarme una perspectiva distanciada."1022

Como en "El cuento de la Mujer del Mar" también hay en este relato una insistencia en la repetición especular que, además de estar presente en los hermanos mellizos, se percibe en las duplicaciones fantasmáticas de estos personajes. Se sugiere la existencia de "otro" José Usbaldo, emigrado puertorriqueño que escribe sus Memorias en la ciudad de Nueva York, y de "otra" Liboria, que ha muerto exactamente el mismo día que su hermano, antes de haber podido relatar su historia al narrador-escritor ${ }^{1023}$. Ambos se complementan: José como memorialista, Liboria, como memoriosa. Se aclara

${ }^{1021}$ En el relato el narrador propone al lector mediante nota al pie la lectura de un libro del historiador Juan Manuel Delgado, publicado en 1980, titulado El levantamiento de Ciales.

${ }^{1022}$ Ramos Otero, Manuel (1987). "La otra isla de Puerto Rico", ed. cit., p. 15.

${ }^{1023}$ El sesgo fantástico del relato se observa también en los deliberados quiebres cronológicos, que alteran la lógica causal y sugieren más bien tiempos paralelos y superpuestos. Por un lado se narra el momento en que Liboria recibe la noticia de la muerte de su hermano junto con los cuatro tomos de sus memorias, despachadas desde Grecia donde ocurrió su fallecimiento. La mujer decide convocar al narrador para una posible edición de estos escritos. La descripción de la casa cubierta por maleza y abandonada sugiere otra posibilidad, vinculada al dato que revela que Liboria había muerto exactamente el mismo día que su mellizo. Entonces el narrador no ha conversado con una Liboria viva sino con su espíritu. Cierta atmósfera de este cuento coincide con el clima fantasmal de hechizos y espíritus presente en la nouvelle Aura (1962) de Carlos Fuentes. 
entonces el sentido al cual antes hice referencia -el narrador como médium-, aquel que escucha y transmite lo que le cuentan los muertos:

"El calor había trepado como una telaraña pero, antes de que me diera cuenta, la voz de Doña Liboria, vestida de negro, había comenzado a tejer sus propios hilos y a proponer cuentos en lo que debió haber sido la tarea investigadora que la lectura nos propone. Hablaba lo mismo de la Revuelta Nacionalista de los cincuenta contra la política muñocista de una isla que se convertiría en un Estado Libre Asociado, que de los tabaqueros puertorriqueños que emigraron a New York desde las postrimerías del siglo pasado hasta sentar las bases de El Barrio, Zigzagueaba por las décadas con la seguridad de un oráculo." ${ }^{1024}$

En esta versión Liboria se afilia a un conjunto de "voces rebeldes", disidentes, entre ellas las de dos referentes históricos de enorme peso entre los sectores antinorteamericanos de Puerto Rico: la obrera e intelectual anarquista Luisa Capetillo y el dirigente nacionalista Albizu Campos, ambos víctimas de persecución ideológica, proscripción y exilio. Paralelamente en la narración del "otro" José Usbaldo, escritor residente en Nueva York, se cifra la historia de las distintas migraciones de puertorriqueños a la gran urbe del norte, desde los primeros obreros tabacaleros a principios del siglo $X X$ hasta la de aquellos sectores que quedaron excluidos de la llamada Operación Manos a la Obra hacia fines de los años cuarenta y principios de los cincuenta ${ }^{1025}$ : "Estamos en medio de los otros de la otra isla de Puerto Rico, más de un millón de fotografías ignoradas en los archivos de emigrantes. Hace tiempo que estamos llegando a esta isla, desde la otra, y ustedes lo saben." ${ }^{1026}$ En este punto del relato nos enfrentamos a otra duplicación especular más compleja, sugerida en la cita precedente y explicitada en el título del cuento: la "otra isla", un espacio sucesivamente deseado, soñado, imaginado, nombrado y entrevisto por los principales personajes del cuento.

\footnotetext{
${ }^{1024}$ Ramos Otero, Manuel (1987). "La otra isla de Puerto Rico”, ed. cit., pp. 14-15.

${ }^{1025}$ Para mayores detalles sobre el contexto histórico de la emigración puertorriqueña a la ciudad de Nueva York remito al capítulo I, especialmente las consideraciones sobre los ejes principales del gobierno de Luis Muñoz Marín.

${ }^{1026}$ Ramos Otero, Manuel (1987). "La otra isla de Puerto Rico”, ed. cit., p. 20.
} 
Por un lado el narrador afirma: "Estamos en otra isla. New York es otra isla." ${ }^{" 1027}$, donde el peso que adquieren en el texto las diásporas puertorriqueñas a la ciudad del norte sugieren la posibilidad de pensar a Puerto Rico como isla de "fronteras externas"1028, cuyo mapa se extiende sigilosamente por fuera y más allá de sus límites geográficos insulares. Por el otro el texto disemina otras significaciones posibles, como las que encierra la voz taína "Oubao-moin", Isla de Sangre, de innegable impronta guerrera y rebelde $^{1029}$ :

"Desde las mágicas islas de Otz y sus volcanes ardientes, surgieron las piedras que en el mar crecieron para ser islas $y$, entre ellas Oubao-moin (Isla de Sangre), fue construida desde la guerra hasta la guerra. Rojo de sangre y negro de luto, como sobre la ceniza negra se reconstruye fuego; carne de achiote para nuestros cuerpos tatuados por carimbos en la carne quemada, rojo crepúsculo que precede la noche de la rebelión secreta; rojo hasta la roja cima de Lares, pero rojo desde antes y hasta ahora rojo, como seguirá siendo rojo el barro que vomitan los cerros. Oubao-moin llamaron los calibanes caníbales caribes a la otra isla de Puerto Rico, antes de que en las márgenes del Mar Rojo, inventaran la bóveda lejana del cielo."1030

En este sentido la "otra isla de Puerto Rico" se constituye como el relato de una "contra-historia" que, al decir de Jossiana Arroyo, muestra "el reverso de la historia oficial de Puerto Rico y describe revoluciones fallidas, migraciones forzadas y voces rebeldes."1031 Esa "otra isla" habría podido abandonar entonces su condición colonial de haber triunfado los levantamientos e insurrecciones (Lares, Ciales, en el siglo XIX) y de haberse escuchado las voces rebeldes (el anarquismo de Luisa Capetillo, el independentismo del nacionalista Albizu Campos en el siglo XX).

\footnotetext{
${ }^{1027}$ Ibid., p. 19.

${ }^{1028}$ Aludo aquí al ensayo de Ana Pizarro trabajado en el capítulo I, a su concepción del Caribe como "archipiélago de fronteras externas."

${ }^{1029}$ Hay también implícita una referencia al poeta neocriollista puertorriqueño Juan Antonio Correjter, de clara filiación independentista como se mencionó en el capítulo anterior, a partir del análisis de la crónica "El cruce de la Bahía de Guánica" de Edgardo Rodríguez Juliá. Correjter escribió un largo poema titulado "Oubao Moin" donde recupera la herencia taína de Puerto Rico y aboga por la independencia de su país. El poema se incluye en su libro Alabanza en la Torre de Ciales (1952).

${ }^{1030}$ Ramos Otero, Manuel (1987). "La otra isla de Puerto Rico", ed. cit., p. 19.

${ }^{1031}$ Arroyo, Jossiana (1994). "Manuel Ramos Otero: Las narrativas del cuerpo más allá de Insularismo", ed. cit., p. 318
} 
Pero, por otra parte, hay algo más en torno a la múltiple connotación de "la otra isla": los personajes que pueden vislumbrarla son los que mueren en el relato, como los hermanos Olmo-Olmo, o el hijo de doña Pancha que muere en la Guerra de Corea. Éste, en la última carta que le envía a su madre, le escribe que "la Isla, desde el avión, parece una tortuga salpicada de sangre..." ${ }^{1032}$, cita que remite a un famoso intertexto cortazariano, fuertemente atravesado por el tópico del doble y la duplicación especular: "La isla a mediodía", de Todos los fuegos el fuego $(1966)^{1033}$. Marini, el protagonista del relato de Cortázar, es sorprendido por la visión recurrente de una isla que se divisa siempre, desde la ventanilla del avión, al mediodía y que posee "una forma inconfundible, como una tortuga que sacara apenas las patas del agua" ${ }^{1034}$. En "La otra isla de Puerto Rico", como en los relatos cortazarianos, se desdibujan los deslindes entre lo real y lo soñado, lo verdadero y lo imaginado, el tiempo lineal y el tiempo cíclico. Cobra peso entonces el epígrafe de Yukio Mishima que enarbola el cuento, donde se subraya la labilidad de las fronteras entre el mundo diurno, el de la historia, y el mundo nocturno, el de los sueños. ${ }^{1035}$

Estos aspectos aquí mencionados en torno a "la otra isla" y su profusa construcción de sentidos confluyen en un pasaje particular del texto, donde el narrador reflexiona sobre "la isla que se repite", en el sentido que le atribuye Benítez Rojo para quien la repetición entraña también una diferencia ${ }^{1036}$. La isla se repite entonces, una vez formando parte de lo real, otra vez como ilusión; en un caso, colonia y bastión militar de un imperio, en el otro, libre y soberana, oposición que emblemáticamente encarnan las figuras de Próspero y Calibán ${ }^{1037}$ aquí mencionadas:

1032 Ramos Otero, Manuel (1987). "La otra isla de Puerto Rico", ed. cit., p. 23 (puntos suspensivos del texto).

${ }^{1033}$ Cortázar, Julio (1997). "La isla a mediodía", en Todos los fuegos el fuego, Buenos Aires, Alfaguara.

${ }^{1034}$ Ramos Otero, Manuel (1987). "La otra isla de Puerto Rico”, ed. cit., p. 108.

${ }^{1035}$ El epígrafe de Mishima, citado de La descomposición del ángel, es el siguiente: "Despierto, tenía voluntad y, aunque lo deseara o no, estaba en la historia; pero en algún lugar de la oscuridad había alguien, quizás histórico, quizás no histórico, situándolo a él contra los sueños”. Ibid., p. 9.

${ }^{1036}$ Benítez Rojo, Antonio (1996). La isla que se repite. El Caribe y la perspectiva posmoderna, ed. cit. Remito a las consideraciones sobre este estudio consignadas en el capítulo I.

${ }^{1037}$ Beatriz Colombi señala con acierto que la figura de Calibán se vuelve, en la cultura latinoamericana "un ideologema que ha servido a innúmeros relatos." Asimismo agrega: "Desde 
"El tiempo se había detenido, como si las láminas cartilaginosas sobre la cabeza ahusada de un enorme pez rémora, se hubieran adherido para cortar su paso y dejarlo suspendido, sin que pudiera jamás tocar el fondo del mar (o de los mares), como pasa en algunas islas de cimientos inalterables, cuya historia ha obligado a la deriva. En Puerto Rico mismo hemos sido testigos de la invisibilidad o visibilidad de Vieques, desde la costa este, y hemos querido atribuirlo a la niebla, a la mortaja de Juracán, a los sentidos humanos, a la intensidad de un espejismo (o revelación) de una explosión atómica, creyendo que cualquier cosa descifrable es Vieques y no Islandia, como si el Mar Caribe y el Mar Árabe no tuviera nada que ver el uno con el otro. Pero si el oráculo de cualquier Próspero pronosticó su 'naufragio' en la isla de San Juan Bautista, el areyto guerrero de Calibán había sembrado las piedras del odio en Borikén. La voluntad es otra cuando es otra la isla y otro el canto de las sirenas cuando el tablero es de mar y los peones somos nosotros. Es más fácil abrirse camino en la maleza con un machete que con un máuser, más certero es el machetazo de un peón a pie que conoce las aldabas de su camino que el mandato de una reina y un rey sin peones que protejan sus torres coloniales en ultramar. Puerto Rico es la puerta del mar, una llave mohosa para la América de las mil lenguas, pero llave al fin." 1038

En la cita precedente Vieques puede leerse como metonimia de Puerto Rico, ya que la pequeña isla situada justo enfrente de la ciudad de San Juan y que alguna vez llegara a ser un paraíso ecológico, fue violentamente militarizada y convertida en estratégica base de operaciones navales a partir del establecimiento del Estado Libre Asociado. Es también una isla que se repite, ya que duplica en la violencia imperial de la cual es objeto, el colonialismo vigente en el país. Pero asimismo insinúa su alteridad, su estirpe belicosa y rebelde, cuando es regida por el "areyto guerrero de Calibán." ${ }^{039}$ Entonces "la otra isla" emerge como "Oubao-moin", "brega", "puerta del mar" que se mantiene abierta al flujo, al tránsito, al desplazamiento del sujeto, donde,

tipo literario en Shakespeare a un progresivo desprendimiento de su fuente literaria para transformarse en símbolo de la barbarie y, finalmente, metáfora de democracia, muchedumbre, apetito e instinto, Calibán es una unidad mínima de una profusa narración donde confluyen tanto ideologías libertarias (antiimperialistas) como conservadoras (elitistas, asentadas en la clase)." (Colombi, Beatriz. "El triunfo de Calibán y el discurso latino", en: Viaje intelectual. Migraciones y desplazamientos en América Latina (1880-1915), Rosario, Beatriz Viterbo, 2004, pp. 95-104). Si bien Colombi se centra en el período histórico-cultural entresiglos (fines del XIX y comienzos del XX), el emblema de Calibán se resignificó para designar al sujeto colonizado en América Latina. Para esta última cuestión remito al ya clásico ensayo Calibán (1971) de Roberto Fernández Retamar. Véase de este último autor Todo Calibán, con prefacio de Frederic Jameson, Buenos Aires, CLACSO, 2004. Esta edición es muy útil ya que reúne, además del ensayo central, Calibán, una serie de otros trabajos del autor relacionados con éste, publicados en los últimos años, donde actualiza la discusión acerca de esta figura.

${ }^{1038}$ Ramos Otero, Manuel (1987). "La otra isla de Puerto Rico", ed. cit., p. 16.

1039 "Areyto" es una voz taína que designa un canto guerrero. Se traduce su sentido como "primero muerto antes que siervo." 
como sugiere Juan Gelpí, el mar se constituye como el espacio que comunica al emigrado con su lugar de origen ${ }^{1040}$.

muerte

V. 2 Contar, recontar, descontar: poéticas del cuento, la enfermedad y la

"Gracias, Señor, por habernos enviado el SIDA./ Todos los tecatos y los maricones de New York, / San Francisco, Puerto Rico y Haití te estaremos/ eternamente agradecidos (...)"

polvo.

Manuel Ramos Otero, "Nobleza de sangre", Invitación al

Una mirada sobre los títulos de algunos cuentos de Manuel Ramos Otero como "Inventario mitológico del cuento", "El cuento de la mujer del mar", "Vivir del cuento", "Página en blanco y staccato", "Descuento"1041, nos sitúa frente a relatos que inscriben en su trayectoria modos de autorrepresentación del proceso de producción y escritura de un texto. La actividad de "contar" y de escribir lo que se cuenta en la página es el resultado de un proceso, en ocasiones complejo y arduo, una lucha con los significantes del silencio y la mudez, equivalentes en el plano fónico del blanco escriturario, donde, con palabras de Áurea Sotomayor, lo que amenaza la escritura del cuento es la presencia de la página en blanco que lo anularía ${ }^{1042}$. Pero esa negatividad cuya imagen más radical es la muerte-, y que acecha al personaje del escritor en los relatos de Ramos Otero, se resuelve, como antes señalamos, a través del emblema de Scherezada de Las mil y una noches: contar para seguir viviendo, contar para conjurar la muerte, contar para desafiar la enfermedad.

El volumen Página en blanco y staccato fue el último libro que el escritor puertorriqueño publicó antes de morir, cuando se sabía irremediablemente enfermo terminal de SIDA, circunstancia que atraviesa, punzante como el

${ }^{1040}$ Gelpí, Juan. (1993). "La escritura transeúnte de Manuel Ramos Otero”, ed. cit., p. 153. Para Gelpí, Ramos Otero invierte la tesis principal sostenida por Antonio S. Pedreira en Insularismo, donde se concibe al mar como factor que aísla a Puerto Rico del resto del mundo. En los cuentos de Ramos Otero, por el contrario, el mar se concibe como lugar que posibilita reunir, comunicar, religar.

1041 "Descuento" se incluye en Página en blanco y staccato, ed. cit., pp. 89-111, y es el relato que cierra dicho volumen

${ }^{1042}$ Sotomayor, Áurea María (2004). "Genealogías o el suave desplazamiento de los orígenes en la narrativa de Manuel Ramos Otero”, ed. cit., p. 279. 
staccato del título, gran parte de sus relatos, donde la inminencia del final -de la vida y de la escritura- constituye un nudo complejo y difícil de desatar. Pocos días antes de morir publicó en el suplemento cultural del periódico El Mundo, de San Juan, su poema-despedida "Nobleza de sangre" que luego formó parte de su segundo libro de poesías -Invitación al polvo- publicado póstumamente ${ }^{1043}$. En "Nobleza de sangre" se emplea un lenguaje de tono religioso que imita las oraciones de constricción y agradecimiento de los feligreses católicos para, con fuerte ironía, detallar los males asociados al SIDA ("sudores o escalofríos", "cansancio", "asco colectivo al Kaposi Sarcoma", "tuberculosis", "flaquencia", "hongos epidérmicos") en un gesto provocativo que descarta nombrar la enfermedad mediante metáforas. Susan Sontag, en su valioso ensayo sobre la retórica de la enfermedad, señala la hipocresía colectiva a la hora de nombrar ciertas enfermedades por su nombre, de allí el uso de ciertas figuras retóricas como la elisión, el eufemismo, el circunloquio para decir, por ejemplo, cáncer. Paralelamente advierte que en las descripciones de esta enfermedad se recurre a un registro metafórico que remite a las imágenes de la invasión y del colonialismo:

"No bien se habla de cáncer, las metáforas maestras no provienen de la economía sino del vocabulario de la guerra: no hay médico, ni paciente atento, que no sea versado en esta terminología militar, o que por lo menos no la conozca. Las células cancerosas no se multiplican y basta: 'invaden'. (...) A partir del tumor original, las células cancerosas 'colonizan' zonas remotas del cuerpo." 1044

Asimismo destaca un léxico altamente punitivo que estigmatiza socialmente al enfermo, quien además de su dolencia padece un consecuente proceso de degradación del yo. Para Sontag el potencial metafórico de la enfermedad creció notablemente con la emergencia del SIDA, ya que gran parte de la sociedad pretende ver metafóricamente en el HIV un juicio moral sobre determinados sectores de la comunidad (homosexuales, drogadictos, negros, extranjeros, pobres):

"Al contrario del cáncer, entendido en la modernidad como una enfermedad propia (y reveladora) del individuo, el sida aparece de una manera premoderna como una enfermedad propia a la vez del individuo y de éste como miembro de un 'grupo de riesgo', esa categoría que suena tan neutral y

1043 Ramos Otero, Manuel (1991). Invitación al polvo, Madrid-Río Piedras, Plaza Mayor, Biblioteca de Autores de Puerto Rico. El título del volumen juega barrocamente con las connotaciones que evoca el término "polvo": el acto sexual, la muerte y conjuntamente el sexo como muerte.

${ }^{1044}$ Sontag, Susan (1996). La enfermedad y sus metáforas y El sida y sus metáforas, Madrid, Taurus, p. 66. 
burocrática y que resucita la arcaica idea de una comunidad maculada sobre la que recae el juicio de la enfermedad." ${ }^{1045}$

"Nobleza de sangre" interpela la condena social que estigmatiza al portador de HIV, a la vez que denuncia la homologación ideológica colonizado= enfermo: "Señor, me voy a tomar la poca libertad que me queda, colonizado al fin/ y definir nuestra identidad: ¡Que nos llamen sidosos de una vez y todas!"1046. El adjetivo humillante y estigmatizador -"sidosos"- se revela entonces contestatario y rebelde. La voz poética revierte además el prejuicio que convierte a la enfermedad en "castigo divino"1047, como se lee en los versos que increpan a la segunda persona, al "Señor" como destinatario que preside el poema-oración: "¿qué te llevó a otorgarles la franquicia/ de la segunda destrucción de Sodoma, a los americanos?"1048

$\mathrm{Si}$ en este poema el lenguaje desnuda mediante su crudeza realista los alcances sociales, políticos e ideológicos de la enfermedad, en el relato "La piel de Paul" 1049 prevalece en cambio un registro metafórico de la dolencia. Para Áurea Sotomayor este texto propicia la fusión entre cuerpo y cuento, proponiendo leerlo como "metáfora del SIDA y metáfora del mecanismo de hacer cuentos". ${ }^{1050}$ Ambos tropos se unen en las connotaciones que entraña la piel de Paul, como se repite en varios fragmentos del relato, entre ellos el siguiente:

"Como si los poros arenosos de la piel de Paul finalmente se hubieran amontonado en su cuerpo. Había en Paul la certidumbre poderosa de no quedarse en la vida, desde el primer instante que una ráfaga de la piel de Paul quedara manchando la ventanilla de un tren, hasta la maquinilla donde luego se contara su historia. A lo mejor fue Paul quien la escribió. Su propia piel, como un velo marchito de un enigma, como la rosa preparada de la muerte."1051

Otro pasaje del texto subraya la reversibilidad implícita entre amar y contar, a la manera de lo que ocurría en "El cuento de la Mujer del Mar": "Amar a Paul y contar su cuento son lo mismo, es decir, que si no hubiera amado a Paul no hubiera tenido nada que contar. Allí lo supe, que mi muerte no me sería tan triste como la suya, que yo me quedaba detrás para morirme (mucho más lentamente) con su muerte." ${ }^{052}$ En la muerte de Paul se agazapa, para proyectarse en un futuro próximo, la propia muerte del narrador, lo cual sugiere la posibilidad del intercambio de identidades entre escritor y personaje o más bien la renuencia a cristalizar la identidad como algo fijo: "Uno es lo que o no es y lo que uno sabe. Uno es lo que no sabe y lo que no es. Uno es lo que

${ }^{1045}$ Sontag, Susan (1996). "El sida y sus metáforas", en: La enfermedad y sus metáforas y El sida y sus metáforas, ed. cit., p. 131.

${ }^{1046}$ Ramos Otero, Manuel (1991). "Nobleza de sangre", en : Invitación al polvo, ed. cit., p. 63.

1047 "El considerar una enfermedad como un castigo es la más vieja idea que se tiene de la causa de una enfermedad, y es una idea que se opone a todo el cuidado que merece un enfermo, ese cuidado digno del noble nombre de medicina". Sontag, Susan (1996). "El sida y sus metáforas", ed. cit., pp. 129-130.

${ }^{1048}$ Ramos Otero, Manuel (1991). "Nobleza de sangre", ed. cit., p. 63. Susan Sontag analiza también las metáforas políticas en torno al SIDA en la era Reagan y cita el terrible juicio del predicador Jerry Falwel para quien "el sida es el juicio de Dios a una sociedad que no vive según Sus reglas". Véase Sontag, S. (1996). "El sida y sus metáforas", ed. cit., p. 143.

${ }^{1049}$ Ramos Otero, Manuel (1992). "La piel de Paul", en: Cuentos de buena tinta, ed. cit., pp. $101-105$.

${ }^{1050}$ Sotomayor, Áurea María (2004). "Genealogías o el suave desplazamiento de los orígenes en la narrativa de Manuel Ramos Otero", ed. cit., p. 305.

${ }^{1051}$ Ramos Otero, Manuel (1992). "La piel de Paul”, ed. cit., p. 104.

${ }^{1052}$ Ibid., p. 104. 
todos saben que uno es. O lo que nadie. La soledad es todos y nadie a la misma vez." 1053

El relato está construido como una larga digresión de una primera persona narrativa que se confirma a sí misma en su rol de "cuentero": "¡Cuentista soy, cuentista fui, cuentista seré!"1054, conciente de las dificultades materiales que acechan al escritor como productor: "A pesar de ser un obrero de la palabra, nunca me han pagado la publicación de un cuento." 1055 Una vez más las ficciones de Ramos Otero apelan a la duplicación especular, donde la muerte de Paul se inscribe en dos planos. Uno que evoca lo real: "al llegar al verano murió Paul"; el otro, de carácter imaginario, corresponde al relato que escribe el cuentista, donde Paul muere violentamente asesinado, "a cuchillazo limpio la piel de Paul se desangra." ${ }^{1056}$ En el final del cuento el cuerpo de Paul y el del narrador se fusionan ("la piel de Paul una frisa de carne para mí"1057) lo cual permite sugerir que la muerte a la que asiste el narrador no sólo es la muerte del otro sino la propia, escrita, como la de Paul, sobre su piel o sobre el papel, superficies que en este relato resultan difícil deslindar.

"Página en blanco y staccato"1058, cuento que da título al volumen, propone una trama compleja donde se entrecruzan diferentes dimensiones narrativas: un plano autobiográfico, un relato de corte fantástico y policial, un texto que cuenta autoreferencialmente su propia gestación. El narrador, de apellido Ramos como el escritor, se presenta en su rol de "cuentero", acechado doblemente por el asalto constante de dos fantasmas, la página blanca y la muerte:

"Lo repito ahora, conciente del poco tiempo con el que cuento para poder despojarme de todas esas páginas en blanco que me han perseguido toda la vida. Los interesados comprenderán que el terror de todo cuentero es que jamás pueda volver a contar otro cuento, que esto mismo lo lleva a deformar realidades y personajes con la esperanza de que no se quedará solo." 1059

El sesgo autobiográfico del relato reaparece además en las alusiones a la enfermedad que padece el narrador -SIDA-, como así también en las referencias a su situación de emigrado, tópico recurrente en el cuento donde se subrayan distintos desplazamientos y diásporas. Como ocurre en "El cuento de la Mujer del Mar", texto con el cual comparte varios puntos de contacto, en "Página en blanco y staccato" la ciudad de Nueva York se representa como el espacio urbano y heteróclito que permite la reunión de las diferentes tramas y personajes dispersos:

"Y entonces, también está New York, un punto esencial del continente, corazón de un imperio que no se le parece, adonde predomina la plaza común del desarraigo, de mujeres y hombres trasplantados por la fuga, desde países lejanos que los periódicos locales no mencionan, de mujeres y hombres que todavía creen que vivir en New York es un tiempo prestado (un pacto con el diablo) para luego volver al puerto inicial de un recuerdo colectivo: Puerto Rico,

\footnotetext{
${ }^{1053}$ Ibid., p. 102.

${ }^{1054}$ Ibid., p. 103.

${ }^{1055}$ Ibid., p. 103.

${ }^{1056}$ Ramos Otero, Manuel (1992). "La piel de Paul”, ed. cit., ambas citas corresponden a la p. 104.

${ }^{1057}$ Ibid., p. 105.

${ }^{1058}$ Ramos Otero, Manuel (1987). "Página en blanco y staccato", en: Página en blanco y staccato, ed. cit., pp. 69-88.

${ }^{1059}$ Ibid., p. 80.
} 
Jamaica, Guyana, Granada, Santo Domingo, Colombia, Panamá, St. Thomas, Haití, el Sur." ${ }^{1060}$

El otro espacio común que amalgama las distintas historias de desarraigo lo constituye el relato mismo, la página blanca del título surcada por "la única tierra valorada aquí, el único bien, la pasión de la escritura." ${ }^{1061}$ La página vacía se va llenando con la historia de un personaje que obsesiona al narrador -Sam Fat-, en cuya genealogía se fusionan diversas diásporas. Hijo de un contrabandista de opio que huyó de China para refugiarse en los Estados Unidos y de una puertorriqueña emigrada en Nueva York, el joven representa en el cuento una cifra de la alteridad ${ }^{1062}$ :

"Desde el momento en que vio al recién nacido, supo que el niño sufriría la agonía del rechazo. Sam Fat había heredado de su madre la negrura de su piel; había salido a su padre en el pelo de aguja, las facciones mongólicas y el ensimismamiento. Los chinos no lo aceptaron como uno de ellos (no solo porque su madre no lo era, sino porque nadie puedo enseñarle ni la lengua ni las tradiciones chinas); los puertorriqueños trataron de ser más tolerantes, pero en el apodo que le pusieron al niño antes de que aprendiera a hablar, Chino, se advertía un tono abusivo de rechazo."1063

Pero como sucede con otros personajes de las ficciones de Ramos Otero, en la genealogía de Sam prevalece la matrilinealidad. Su padre ha muerto antes de que él naciera y el único legado que ha dejado a su hijo es su apellido y algunos rasgos físicos que lo vuelven indefinible: "En el barrio le obligaron a pensarse un monstruo, un accidente, un anacronismo."1064 Por el contrario el narrador despliega con detalles la historia vinculada a los antepasados de la rama materna, que se remontan cuatro siglos atrás, a la época de la trata de esclavos y a la diáspora forzada de los barcos negreros. ${ }^{1065}$ El legado de la madre se constituye en el complejo cruce transculturador de la santería afroamericana que impone a Sam un destino particular: ser un babalao, un sacerdote santero. Como tal recibe un mandato que no puede evitar ni rechazar: vengar en su presente una afrenta del pasado que involucra a sus ancestros e irremediablemente a sí mismo. En el siglo XVI en Puerto Rico una hija de Yemayá, antepasado materno de Sam, había sido quemada en la hoguera por un inquisidor católico, el obispo Nicolás Ramos de los Santos. Ahora, en el presente del relato, en Nueva York, el joven chino-boricua, babalao y descendiente de la deidad africana, se ve obligado a vengar el agravio. Asumiendo la historia de persecución de sus antepasados, Sam Fat decide buscar una víctima para vindicarlos. Es entonces que Sam se transforma en detective, perseguidor y victimario: le tiende una trampa al escritor puertorriqueño Ramos, quien a su vez asume el papel del antiguo inquisidor, del obispo Ramos, pero para convertirse en la víctima, en el perseguido:

\footnotetext{
${ }^{1060}$ Ramos Otero, Manuel (1987). "Página en blanco y staccato", ed. cit., p. 74.

${ }^{1061}$ Sotomayor, Áurea María (2004). "Genealogías o el suave desplazamiento de los orígenes en la narrativa de Manuel Ramos Otero", ed. cit., p. 282.

${ }^{1062}$ Cortés, Jasón (2002). "Buscando al otro. Ética y alteridad en 'Página en blanco y staccato' de Manuel Ramos Otero", Revista Iberoamericana, vol. LXVIII, Núm. 198, enero-marzo, pp. 165-175. El crítico propone una lectura del cuento a la luz de los postulados filosóficos de Emmanuel Levinas en torno al "otro", que desde mi punto de vista resulta un tanto forzado.

${ }^{1063}$ Ramos Otero, Manuel (1987). "Página en blanco y staccato", ed. cit., p. 76.

${ }^{1064}$ Ibid., p. 81.

${ }^{1065}$ Véase el siguiente pasaje del cuento: "Su gente había comenzado la peregrinación en las tierras de Nigeria, habían perdido sus sombras cuando los barcos negreros de Europa saquearon las aldeas de los yoruba y encadenaron sus cuerpos sobre los surcos del mar y los llevaron a las islas.” Ramos Otero, Manuel (1987). "Página en blanco y staccato", ed. cit., p. 78.
} 
"Sólo bastó esa línea para que la historia de Sam Fat y la mía se confundieran en la noche con su vínculo milenario. La clave de todo misterio siempre ha sido la ocultación de los detalles que conducen a la solución final y ser más diabólico que el diablo para inventar el infierno. Cuando el caso bajo escrutinio es un crimen, vale la pena dudar del primero que duda. Un asesino descubre en su cadáver, tanto como su futuro cadáver anticipa las maromas mortales de su asesino. La víctima siempre diseña el método que la vuelve víctima y, ahora, ese segundo compartido con Sam Fat en el intercambio de tragos y en la separación de una cortina gris de nicotina había movilizado nuestro tiempo en la coincidencia fatal de los personajes que se conocen en la misma página en blanco."1066

La cita precedente revela otra constante que advertimos en varios de los textos de Ramos Otero revisados hasta aquí, el tópico del doble, sugerido desde las páginas iniciales del relato a través de las alusiones a cuentos de Jorge Luis Borges como "La forma de la espada", "Tema del traidor y del héroe", "La muerte y la brújula", donde se invierten y distorsionan los papeles de víctima y victimario. En la subtrama policial y fantástica que atraviesa "Página en blanco y satccato" se revela que el escritor Ramos es quien ha tendido todos los hilos para que Sam pueda encontrarlo y asumir así el rol que el narrador le ha asignado: ser el staccato del cuento, el puñal, el instrumento de su propia muerte: "Él era, naturalmente, el staccato del cuento, el puñal perdido." ${ }^{1067}$ Así el cuentero Ramos vive su muerte de manera vicaria, a través de la literatura, asesinado sobre la página en blanco, antes que, en una dimensión realista, enfermo en una cama de hospital, como uno de los finales posibles y deseados por Juan Dalhmann, el protagonista de "El Sur"1068.

"Descuento" es el relato que cierra Página en blanco y staccato y desde su significativo lugar de cierre, el narrador realiza un recuento acerca de cómo surgieron los textos que componen el libro, estableciendo una analogía entre el vacío que sienten los amantes al acabar una relación y el que siente el escritor después de concluir el proceso de creación y escritura de un libro. Arnaldo Cruz- Malavé señala que "Descuento" es el relato que "mejor confirma la intención autobiográfica del escritor" y que Ramos Otero "pretende explicar o mejor justificar todos los cuentos que preceden remitiéndolos a su

\footnotetext{
${ }^{1066}$ Ibid., p. 71.

${ }^{1067}$ Otero, Manuel (1987). "Página en blanco y staccato", ed. cit., p. 85.

${ }^{1068}$ Las referencias a los cuentos de Jorge Luis Borges mencionados: "La forma de la espada", "Tema del traidor y del héroe", "La muerte y la brújula" y "El Sur" corresponden al volumen Ficciones (Buenos Aires, Emecé, 1956).
} 
biografía." ${ }^{1069}$ Sin poner en duda la tensión autobiográfica que recorre el texto, propongo también una lectura donde el esfuerzo de contar y escribir es lo que importa, no tanto el mundo-referente del autor.

"Descuento" es sin duda el relato más autorreflexivo de Manuel Ramos Otero. Parafraseando a Maurice Blanchot ${ }^{1070}$, para quien la literatura empieza en el momento en que es pregunta, un interrogante condensa la poética del cuento de nuestro autor, interrogación que remite a una cita de Truman Capote: "¿Cómo puede un escritor combinar exitosamente dentro de una sola forma digamos, el cuento- lo que conoce de las otras formas de la escritura?"1071 La respuesta que propone "Descuento" se formula desde la significación que entraña la acción de "des-contar": el cuento paradójicamente es no-cuento, o por lo menos, no es lo que la retórica del género nos ha impuesto desde Poe hasta aquí. No hay una sola forma de escritura del relato, sino una escritura múltiple que combina el cuento, el poema, la biografía, el relato oral, los recuerdos, la historia, y cuya delimitación en un género corresponde solamente al lector: "Urge pedirle al lector que nunca piense que yo no le estoy contando un cuento. Si usted decide llamarlo relato, historia, ensayo biográfico o feto de novela, lo acepto."1072

También es posible deslindar otra significación respecto del título del relato que apunta a la homonimia con el verbo contar como actividad narrativa y aritmética: se cuenta, como vimos en "Vivir del cuento", para aplazar el final que es la muerte. En "Descuento" el narrador padece también de SIDA, y la actividad del descuento es resta porque sabe que tiene los días "contados"1073: "Pero esto no es cuento, es un descuento vital para el que lea estas páginas prohibidas, es una biografía auténtica desmenuzada por el presente. Por eso le cuento al lector los más íntimos detalles." ${ }^{\circledR 074}$ ¿Cuál es en definitiva la cuenta

\footnotetext{
${ }^{1069}$ Cruz- Malavé, Arnaldo (1993)."Para virar al macho; la autobiografía como subversión en la cuentística de Manuel Ramos Otero", ed. cit., p. 240.

${ }^{1070}$ Blanchot, Maurice (1993). "La literatura y el derecho a la muerte", en: De Kafka a Kafka, México, Fondo de Cultura Económica, p.107.

${ }^{1071}$ La cita de Truman Capote está tomada del prefacio de Música para camaleones y figura en la página 107 de "Descuento".

${ }_{1072}$ Ramos Otero, Manuel (1987). "Descuento", ed. cit., p. 96.

1073 “(...) enrojecí de la noche a la mañana y quedé sumergido en un insomnio alucinante de fiebres y sudores fríos; consulté espiritistas, horóscopos y médicos que tan solo diagnosticaron lo que siempre había sabido desde niño, que tenía los días contados.” Ibid., p. 108.

${ }^{1074}$ Ibid., p. 99.
} 
que quiere saldar el yo que escribe? ¿Cómo se salda esa cuenta que es un cuento? Llenando el vacío, la página blanca, escribiendo con todos los materiales a mano que colman las páginas de "Descuento": textos propios y ajenos, historias de amor, enfermedad, soledad, emigración, nostalgia, recuerdos, erotismo.

La escritura aparece ilusoriamente como una máquina capaz de detener el tiempo, como en el cuento "El milagro secreto" de Jorge Luis Borges. No es casual que el narrador cite a Borges de la Nueva refutación del tiempo y afirme que "entonces no hay tiempo en la escritura ni escritura en el tiempo. Lo que ahora contaré (o descontaré) realmente no ocurrió, todos esos tiempos siguen siendo absolutos, pero tan absolutos como todos estos tiempos que tomará la escritura de este cuento."1075 La acción de recordar posibilita el deseo de escribir, descubrir los secretos de la memoria ${ }^{1076}$, visitar un pasado cuya cronología es imprecisa, a pesar de las abundantes indicaciones temporales, porque "la escritura es cómplice del recuerdo y modificará lo que ha pasado" ${ }^{\prime 1077}$. El presente aparece como recuerdo del pasado, enuncia ahora lo que pasó y posee la certidumbre de ser presente de y en la escritura de un narrador que se sabe condenado a la muerte: “...pero en los últimos cuatro años que estuve (no sé si todavía lo estoy) escribiendo esos cuentos de vivos, muertos y desparecidos, mi pelo aceleró su blancura en las sienes." ${ }^{1078} \mathrm{El}$ efecto Scherezada en "Descuento" se asocia a la repetición, a la redundancia, se vuelve a contar lo ya contado, pero a su vez se narra algo más pretérito, como si el yo que escribe buscara a través de la repetición algo que estaría en un estado anterior, al cual se trata de acceder a través de un hacerse cuerpo de la palabra: "Las palabras son ojos, son oídos, son lengua, son la piel de nuestra historia (o de mi historia), son el sabor que me permite anticipar el

\footnotetext{
${ }^{1075}$ Ramos Otero, Manuel (1987) "Descuento", ed. cit., p. 89.

1076 En varias ocasiones el narrador señala la inmersión en el recuerdo, la nostalgia y la memoria. Se trata también de la acción de recordar como retroceder, dar cuenta de los orígenes del relato, como leemos por ejemplo en el siguiente fragmento, donde coinciden los verbos recordar y regresar, se retrocede al pasado y se regresa a la Isla, al territorio natal del narrador: "Y volvía a cruzar el mar con ese inevitable zigzag de los que nos fuimos y siempre regresamos cuando podemos, creyendo liberar con esa escritura otra culpa que ya no está en nosotros, viajando al pasado con seguridad para habitarlo y hacerlo regresar a este presente que solo lo recuerda." Ibid., p. 109.

${ }^{1077}$ Ibid., p. 89.

${ }^{1078}$ Ibid., p. 101.
} 
paladar del tiempo."1079 El narrador se esfuerza por dar forma, ordenar mediante la escritura una suerte de historia de lo previo, donde la acción de relatar implica un retroceder a una instancia anterior al advenimiento de los textos.

Notamos que se establece un contrapunto permanente entre dos planos del relato: la historia amorosa entre el narrador y un pintor, quien, como él, es un puertorriqueño emigrado a Nueva York, y la historia o más bien pre-historia del proceso de la escritura de cada cuento. Los vaivenes de la relación erótica (encuentros, desencuentros, deseos, rechazos, interrupciones, reconciliaciones, traiciones, rupturas) estructuran un ritmo -el de la escritura de cada cuento- y sus diversos momentos: vacíos, silencios, ausencias, cortes, comienzos, finales, escritura, re-escritura. El texto expone constantemente mecanismos de especularidad y dualidad, por momentos las obras del yo que escribe y las de su amante pintor se reflejan y duplican: “...sellamos en el acto un tiempo compartido donde sus imágenes habían invadido mi escritura y mis palabras habían modificado sus óleos en una biografía, en una historia, en un cuento abierto." ${ }^{1080}$ Otras veces prevalece la ruptura, el vacío, que sin embargo promueve el avance del relato, del contar. Cuando la relación amorosa amenaza tornarse tanática, sin salida, el narrador y su amante aparecen sumergidos en vastos y frecuentes silencios y distanciamientos cada vez mayores, aumentados por los dos viajes del narrador a Puerto Rico: "Mi amante desapareció del mapa un día y cansado de esperarlo tomé un avión para Puerto Rico, con la perfecta voluntad de buscar mi eterno bálsamo como quien busca la ruta segura de El Dorado."1081 La ruta utópica deviene en el texto un regreso al ámbito materno, una especie de gineceo habitado por la madre y las hermanas del narrador, un viaje originario a partir del cual surgen dos relatos. "La heredera" y "La otra Isla de Puerto Rico".

El relato que da nombre al volumen, "Página en blanco y staccato" es el que plantea las mayores dificultades y angustias en el proceso de su escritura. Silencios, páginas en blanco, soledad, estancamiento, que dan cuenta de un

\footnotetext{
1079 Ibid., p. 94.

${ }^{1080}$ Ramos Otero, Manuel (1987). “Descuento”, ed. cit., p. 103.

${ }^{1081}$ Ibid., p. 96.
} 
texto escrito con el sufrimiento del cuerpo del narrador"1082. "A mí solo me preocupaba que aún no había puesto sobre el papel la historia de Sam Fat, (...) que la escritura se había vuelto una página en blanco, tan necesaria como las páginas escritas pero en blanco, y que la realidad fuera de la página se había vuelto una melodía misteriosa donde yo era torturado por unas agujas afiladas intermitentemente." ${ }^{1083}$ En "Página en blanco y sataccato" la escritura se resuelve con el corte definitivo de la historia amorosa: "Antes que terminara el año, escribí las primeras páginas de Página en blanco y staccato, pinté al apartamento de blanco, violeta y gris, y eché a la basura los objetos que habían sido de mi amante que ya no lo era." ${ }^{1084}$ Pero lo que la ruptura amorosa anticipa es la muerte cercana del narrador, que elige para sí "apresurar unos finales que se dan tan naturales en la escritura"1085. El yo escritor de "Descuento" se despide con la escritura de un texto que es cierre del volumen y a su vez testimonio (testamento) de su relación con la escritura, atravesada por la experiencia de la emigración, el desplazamiento, la soledad en la gran ciudad, la enfermedad, el amor y la muerte.

En "Página en blanco y staccato" hay un momento del texto donde el narrador se detiene y reflexiona sobre el origen de la palabra "Loisaida", término que designa uno de los barrios más populosos de Nueva York, habitado por migrantes de múltiples orígenes pero muy especialmente por aquellos provenientes de Puerto Rico. A contrapelo del discurso dominante que lee en el nombre del lugar una deformación de las palabras Lower East Side, inglés correcto que los migrantes hispanohablantes "pronuncian mal", el cuentero propone en cambio una resignificación de la palabra, en la cual se escucha el eco lejano de otra voz, de otra lengua, de otro espacio: "Mitológicamente, puedo asegurar que hay una correlación entre Loisaida y el Río Grande de Loíza" ${ }^{1086}$ Duplicación del ámbito natal -el río puertorriqueño Loíza- en el espacio de la emigración, como posibilidad de reterritorialización

\footnotetext{
${ }^{1082}$ El sufrimiento corporal se materializa en las marcas que el SIDA inscribe en el cuerpo del sujeto que narra: "La piel se empezó a poner escamosa y presentí que me estaba volviendo una tortuga moribunda." Ibid., p. 108.

${ }^{1083}$ Ibid., p. 106.

${ }^{1084}$ Ramos Otero, Manuel (1987). "Descuento”, ed. cit., p. 107.

${ }^{1085}$ Ibid., p. 94.

${ }^{1086}$ Ramos Otero, Manuel (1987). "Página en blanco y staccato”, ed. cit., p. 80.
} 
ante la experiencia del desarraigo, proceso que también se advierte en el siguiente pasaje del cuento, donde el narrador se pregunta:

“¿Por qué Loisaida, siempre ha sido el barrio de cuanto emigrante llegó a New York buscando el mundo mutuo? No estoy seguro. Quizás debiera de tratar de precisarlo todo y describir sus edificios cayéndose en cantos de ladrillos podridos, el afán de los emigrantes puertorriqueños de construir un jardín en cada lote desolado para que crecieran hierbajos y girasoles, las tiendas de los checoslovacos con sus maravillosas estolas de lana, los restaurantes come-y-vete de los ucranianos aglomerados con desayunadores de salchichas, los policías bosteando a cada rato a los chamacos que en cada esquina venden bolsitas de a cinco de pasto."1087

Como dice James Clifford $^{1088}$ la cultura también viaja, y es desplegada en los nuevos espacios, aunque con temporalidades heterogéneas. Los cuentos de Manuel Ramos Otero donde se amalgaman la escritura y los desplazamientos, donde coinciden el "cuentero" y el emigrado, apuestan a inscribir sobre la página blanca del relato la brega del sujeto migrante, sus memorias de transtierra, su identidad asediada entre el ayer y el hoy, el aquí y el allá:

"Y volví a cruzar el mar con ese inevitable zigzag de los que nos fuimos y siempre regresamos cuando podemos, creyendo liberar con esa escritura otra culpa que ya no está en nosotros, viajando al pasado con seguridad para habitarlo y hacerlo regresar a este presente que sólo lo recuerda."1089

\footnotetext{
${ }^{1087}$ Ramos Otero, Manuel (1987). “Página en blanco y staccato”, ed. cit., pp. 80-81.

1088 Clifford, James (1992). "Travelling Cultures", en: Grossberg, Lawrence, Nelson, Cary y Treichler, Paula (eds.), Cultural Studies, Londres y Nueva York, Routledge, p. 101.

${ }^{1089}$ Ramos Otero, Manuel (1987). "Descuento”, ed. cit., p. 109.
} 
- A manera de epílogo revés."

"Puerto Rico es el barco siempre anclado/ al

Manuel Ramos Otero

"El Estado Libre Asociado es de mirada bifronte, como todo baciyelmismo; preferimos no renunciar a nuestra alma latinoamericana; pero tampoco estaríamos dispuestos a perder la abundancia con la sociedad más rica que ha conocido la historia."

Juliá

Edgardo Rodríguez

En el ensayo "Puerto Rico y el Caribe", Edgardo Rodríguez Juliá se detiene en "esa inquietud sobre el espacio propio"1090 que entraña el territorio caribeño, manifiesta por igual en autores tan distintos entre sí como Palés Matos, Walcott, Césaire y Naipaul, quienes, como él, coinciden en un mismo origen antillano. La pintura de Francisco Oller (1833-1917), artista puertorriqueño cuya paleta se formó en Francia en pleno auge del Impresionismo, le provee al ensayista ciertas imágenes plásticas en cuya oposición vislumbra ese inquieto mapa caribeño ${ }^{1091}$. Advierte en su obra pictórica un cambio que va del sutil cromatismo impresionista a la luz mortificante del trópico que estalla e inunda para siempre sus cuadros; asimismo lee en sus paisajes y bodegones formas de reterritorialización que conjuran el desarraigo del pintor que estuviera tantos años fuera de su Puerto Rico natal: "Los paisajes y bodegones de Oller son una especie de asidero; a través de ellos el artista desarraigado recupera su país de origen."1092 Pero es

1090 Rodríguez Juliá, Edgardo (2002). "Puerto Rico y el Caribe", en: Caribeños, San Juan, Editorial del Instituto de Cultura Puertorriqueña, p. 3 (toda cita posterior remite a esta edición). Previamente fue publicado con el título "Puerto Rico y el Caribe: historia de una marginalidad", en: La Torre, Revista de la Universidad de Puerto Rico, año III, Núm. 11, julio-septiembre 1989, pp. 513-529.

${ }^{1091}$ Así como sucede en su ensayo Campeche o los diablejos de la melancolía, donde, como se vio en el capítulo anterior, la obra del pintor dieciochesco proveía las imágenes fundacionales de Puerto Rico, aquí es la pintura de Oller la que vehiculiza una figuración de lo caribeño. Ambos artistas coincidirían según Rodríguez Juliá en la representación pictórica de la sociedad puertorriqueña como utopía fracasada, por la imposibilidad de la fusión de las distintas clases y etnias.

${ }^{1092}$ Rodríguez Juliá, Edgardo (2002). "Puerto Rico y el Caribe”, ed. cit., p. 4. 
acaso en la pintura más famosa del artista -el enorme lienzo llamado El Velorio- donde observa a través de su pincel satírico y amargo una configuración perturbadora del trópico. Se trata de una escena que representa un baquiné, nombre que daban los esclavos al velorio de un niño, celebrado con una fiesta por la creencia en que los infantes muertos ascendían directamente al cielo. Se encuentran en un mismo espacio peninsulares, negros, mulatos y jíbaros criollos.

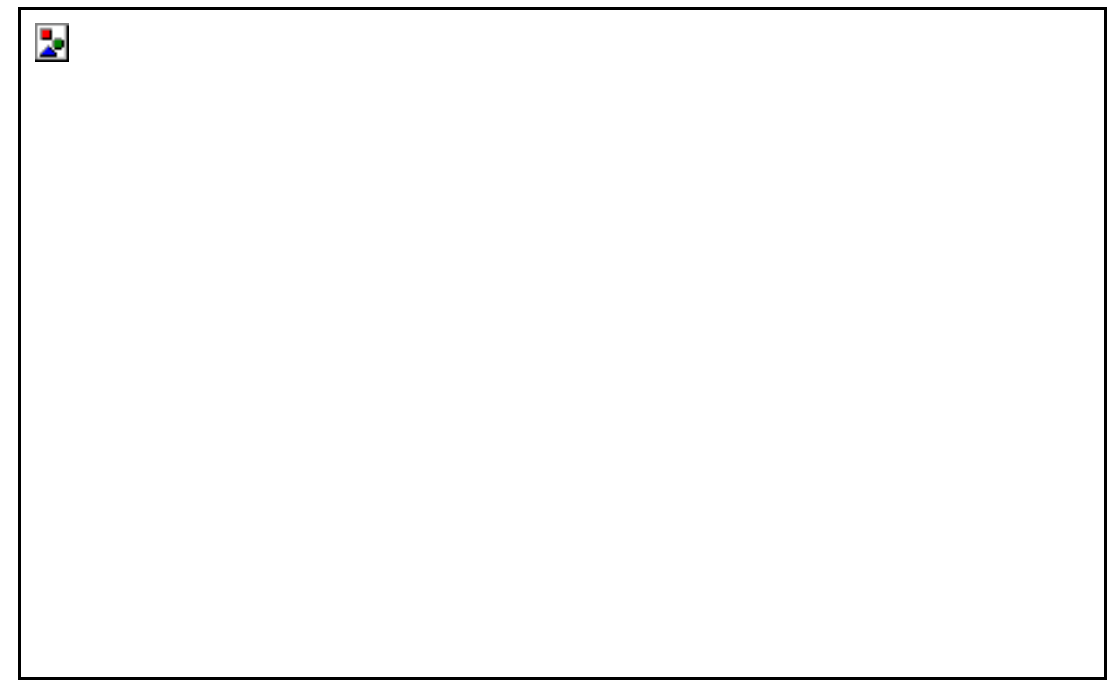

El Velorio (1893) de Francisco Oller

Para Rodríguez Juliá esta reunión no revela ningún tipo de convivencia o fusión integradora de clases y etnias; por el contrario subraya diferencias complejas de reconciliar, alteridades profundas que surcan el espacio caribeño:

"En este lienzo el calor del trópico es una coraza asfixiante que reduce cada personaje a su soledad. Pasamos de la apacible utopía señorial que se resume en los bodegones, coincidencia lírica de todos los frutos del orbe, a una heterotopía perturbadora donde las distintas etnias de nuestro suelo sólo pueden convivir en disonancia." ${ }^{1093}$

Precisamente la tensión entre los términos resaltados en la cita -utopía y heterotopía- abre el camino hacia una reflexión crítica sobre dos nociones asociadas

${ }^{1093}$ Rodríguez Juliá, Edgardo (2002). “Puerto Rico y el Caribe”, ed. cit., pp. 5-6 (cursivas del autor). 
a éstas y que a su vez encierran sutiles pero importantes diferencias conceptuales, antillanía y caribeñidad:

"Decía mi maestro Charles Rosario que para nosotros, los puertorriqueños, el término antillanía tiene significado pleno, pero no los términos caribeño o caribeñidad. Uno nos congrega en la experiencia histórica y cultural compartida con las Antillas Mayores, el otro -the Caribbean- nos somete a una categoría suprahistórica, a un invento de la objetividad sociológica, antropológica o etnológica de origen anglófono, objetividad que siempre funciona en contra del colonizado, como señaló Fanon."1094

Se apela a la voz entrañable del "maestro"1095 para deslindar una diferencia que incumbe no solo el plano semántico, sino también al político e ideológico, en tanto evidencia las complejas relaciones entre las metrópolis y las colonias. Hay una adhesión a este planteo pero también una propuesta para reformularlo desde un presente donde "hoy se habla de caribeñizar a Puerto Rico, de la caribeñización de la sociedad puertorriqueña."1096 Por un lado el concepto de antillanía evoca la tradición histórica independentista del siglo XIX que quiso plasmarse en la Confederación Antillana ${ }^{1097}$ :

"Aquel espacio de congregación, sitio de supuestas coincidencias históricas y culturas evidentemente hermanadas por la lengua, se formuló desde un racionalismo progresista que hoy nos parece algo ingenuo: los pueblos que habían sufrido el mismo colonialismo y también sistemas parecidos de explotación económica, estarían llamados a reunirse bajo una organización política que garantizase su pasado histórico y protegiese su independencia venidera." 1098

Para Rodríguez Juliá la Confederación Antillana se revela como utopía; de alguna manera no deja de ser una categoría suprahistórica con el riesgo de subrayar sólo los vínculos expresos y dejar de lado las importantes diferencias cuyas consecuencias históricas se perciben en el presente, en el colonialismo vigente en Puerto Rico: "Ya hacia fines del Siglo XIX Santo Domingo era independiente, Cuba

${ }^{1094}$ Rodríguez Juliá, Edgardo (2002). "Puerto Rico y el Caribe”, ed. cit., p. 6 (cursivas del autor).

${ }^{1095}$ Charles Rosario aparece mencionado también en la dedicatoria de Las tribulaciones de Jonás donde Rodríguez Juliá lo reconoce como su "padre espiritual" y a quien evoca con gran afecto. También dedica a su memoria Campeche o los diablejos de la melancolía. Las breves pinceladas de su figura entrañable no corresponden a las voz "magisterial" que analiza González Echeverría, aunque sí sus intervenciones dan cuenta de un saber autorizado y reconocido por su discípulo. Sobre los alcances del concepto de "voz magisterial" remito al capítulo II, pp. 59-60.

${ }^{1096}$ Rodríguez Juliá, Edgardo (2002). "Puerto Rico y el Caribe”, ed. cit., p. 6.

${ }^{1097}$ La idea de la unión de las Antillas sobre todo para lograr la ansiada independencia respecto de España y asimismo enfrentar los embates imperialistas norteamericanos aparece presente en el pensamiento martiano. Como concepto político la Confederación Antillana se articula en el ideario del puertorriqueño Ramón Emeterio Betances, quien abogaba por la unión de las Antillas Mayores - Cuba, República Dominicana y Puerto Rico- a fin de liberarse del colonialismo español. La unión antillana se debate en los textos de otro importante intelectual y político puertorriqueño de fines del siglo XIX, Eugenio María de Hostos. Véase Rama, Carlos (1980). La independencia de las Antillas y Ramón Emeterio Betances, San Juan, Instituto de Cultura Puertorriqueña.

${ }^{1098}$ Rodríguez Juliá, Edgardo (2002). "Puerto Rico y el Caribe”, ed. cit., p. 6. 
había sufrido una guerra independentista de diez años y Puerto Rico había protagonizado un Grito de Lares que apenas duró dos días." ${ }^{099}$ La propuesta del autor se aproxima a la noción de antillanidad que formula Édouard Glissant, donde la idea de una unidad y especificidad de las Antillas se plantea particularmente desde su diversidad, su pluralidad de lenguas, culturas e historias, pero también desde la experiencia común e imborrable de la trata y el esclavismo. Así como el escritor francés promueve ampliar el "arco caribeño" subrayando una "poética de la relación" abierta a los diferentes procesos históricos, culturales y lingüísticos de cada isla, Rodríguez Juliá propone estrechar vínculos con el Caribe inglés y francés. De este modo puede resignificar positivamente la noción de lo caribeño: "Entonces the Caribbean deja de ser una acomodaticia categoría de estudios anglófonos para convertirse en algo palpable y vital."1100 Esa materialidad palpable de lo caribeño se traduce en los contactos que anudan comidas -la similitud entre el sancoche trinitario y el puertorriqueño-; detalles arquitectónicos -el infaltable zinc de los techos a dos aguas, los balcones y galerías, los colores con que se pintan las casas- igualmente presentes en Puerto Rico, Martinica, Haití; sonidos, donde un ritmo característicamente boricua -la plena- se habría originado con la visita de isleños del Caribe inglés.

Sin negar la evidencia de estas importantes redes que conforman lo que el autor describe en términos de "una cotidianidad horizontal", ésta, sin embargo, suele estar asociada a una temporalidad que remite más bien al pasado, como una memoria compartida cuyos lazos comunes se vuelven cada vez más precarios en el aquí y ahora caribeños. ${ }^{1101}$ Su mirada incisiva se detiene entonces en escudriñar un presente que se muestra especialmente perturbador para su país: "Pero hoy Puerto Rico se aleja cada vez más de sí mismo".

¿Qué significaciones encierra esta frase? Una respuesta posible se insinúa desde el título de la sección más amplia que incluye al ensayo: "En busca del Caribe perdido"1102. Puerto Rico se aleja irremediablemente de sí mismo cuando se distancia de su caribeñidad para suscribir a la "mimesis colonial"1103 del American way of life. La indagación de Rodríguez Juliá no escabulle las paradojas; por el contrario, ellas subrayan conflictos y tensiones sin resolver como los que proyecta la siguiente interrogación: "¿hay que caribeñizar a Puerto Rico o hay que puertorriqueñizar al

\footnotetext{
${ }^{1099}$ Ibid., p. 7.

${ }^{1100}$ Ibid., p. 8.

${ }^{1101}$ Véase al respecto el siguiente pasaje: "La restauración del viejo San Juan nos queda como un vínculo con un pasado más remoto; pero los espacios del Puerto Rico contemporáneo comienzan a distanciarse, ya irremediablemente, de los del resto del Caribe. Aquella cultura criolla y señorial, de tardes lánguidas que transcurrían según el rechinar de los sillones de caoba, casi ha desaparecido de mi país." Rodríguez Juliá, Edgardo (2002). "Puerto Rico y el Caribe", ed. cit., pp. 9-10.

1102 "En busca del Caribe perdido" incluye además de "Puerto Rico y el Caribe" los siguientes ensayos y crónicas: "Don Edmundo B. Fernández y la máquina del tiempo", "El Desfile (crónica)", "Isleños (Ensayo)" y "Tradición y utopía en el barroco caribeño", todos ellos de algún modo vinculados por obsesiones tales como la relación Caribe y Puerto Rico, el problema de la identidad, la tensión entre pasado y presente, la memoria y la nostalgia.

${ }^{1103}$ Me refiero al concepto trabajado por Frantz Fanon respecto de los procesos de identificación entre sujeto colonizador y sujeto colonizado, que exige al individuo negro "volverse blanco", mimetizarse para no desparecer, lo que conduce a su alienación. (Peau noire, masques blancs, París, Seuil, 1952). También Glissant alude a esta cuestión cuando analiza la política de asimilación practicada por el estado francés en Martinica, a partir del proceso de Departamentalización que promovía una supuesta "igualdad" entre el sujeto martiniqués y el francés metropolitano. Véase al respecto capítulo I, apartado dedicado al análisis de Les discours antillais (1981) de E. Glissant. Remito asimismo al insoslayable libro de Edward Said, Cultura e Imperialismo, Barcelona, Anagrama, 1996.
} 
Caribe?"1104 La segunda premisa revela la continua acción de las prácticas políticas y culturales expansivas de los Estados Unidos sobre el Caribe y más aún sobre Puerto Rico, acción cuyos efectos la globalización contemporánea tiende a acentuar: "Pienso que pocos jóvenes puertorriqueños saben lo que es una estantería de ausubo; todos saben lo que es M.T.V. y dónde queda Orlando. Nuestros espacios se van pareciendo más a los de esta ciudad en la Florida que a los de Santo Domingo." ${ }^{1105}$ Entonces puertorriqueñizar el Caribe impone lo que el autor describe como "una especie muy particular de alienación cultural y política"1106, idea que el texto expande a través de una serie de punzantes preguntas que se disfrazan como retóricas pero que constituyen una significativa toma de posición:

“¿Puede ser el desarrollo de Puerto Rico modelo para alguien? ¿Será posible que nuestra dependencia política y económica, nuestra violencia social se conviertan en proyectos para un Caribe alterno? ¿Qué diálogo se puede establecer entre países en vías de desarrollo y un país cuyo progreso se ha hipertrofiado, transformándose en un furor consumista que posterga la producción?"'1107

Cuando Puerto Rico se aleja del Caribe se encierra en una insularidad que la margina riesgosamente no solo del mapa antillano sino también de América Latina, puesto que cae en un solipsismo que no ofrece posibilidades de salida y en el cual se inscribe la distancia entre el colono y el colonizado, "entre el extranjero que puede venir y yo que no puedo salir." 1108 Como una imagen contrapuesta que quiebra el espejo de la insularidad estalla la coyuntura histórica de la emigración masiva de puertorriqueños a los Estados Unidos, quiebre violento que vuelve a comunicar a Puerto Rico con el resto del archipiélago caribeño, en un sentido muy próximo al que explora Ana Pizarro cuando analiza la diáspora caribeña contemporánea como uno de sus rasgos identitarios más marcados ${ }^{1109}$ :

"Y nos ocurre a nosotros los puertorriqueños, los primeros en lanzarnos a una emigración masiva, que no bien comenzamos a deshacer la maleta en tierras del norte ya estamos añorando la islita. Así permanecemos siempre a mitad de camino. Nunca deshacemos las maletas del todo; he aquí una de las razones de nuestra pobre integración al mundo norteamericano. (...) Hoy el puertorriqueño es uno de los pueblos más desarraigados sobre la faz de la tierra. Apenas empezamos a valorar cómo nos han transformado estas vivencias del exilio, de la emigración y la nostalgia. En este aspecto, la historia del Caribe se parece más a la nuestra." 1110

\footnotetext{
${ }^{1104}$ Rodríguez Juliá, Edgardo (2002). "Puerto Rico y el Caribe”, ed. cit., p. 12.

${ }^{1105}$ Rodríguez Juliá, Edgardo (2002). "Puerto Rico y el Caribe”, ed. cit., p. 10.

${ }^{1106}$ Ibid., p. 12.

${ }^{1107}$ Ibid., p. 13.

${ }^{1108}$ Ibid., p. 18.

${ }^{1109}$ Refiriéndose al Caribe Ana Pizarro señala lo siguiente: "Si la historia de esta región cultural está marcada por identidades diaspóricas desde la trata de esclavos, y si los habitantes de sus islas han tenido una permanente relación de tránsito con las respectivas metrópolis, hoy, en las últimas décadas, el fenómeno de la migración masiva ha tenido, como en algunos países de América Latina, magnitudes tales que han marcado significativamente el mundo del arte, de la literatura, de la vida cotidiana." Véase de la autora "El archipiélago de fronteras externas", en el libro que compila bajo el mismo título, publicado en Santiago de Chile en el año 2002, al cual aludí en el capítulo I.

${ }^{1110}$ Rodríguez Juliá, Edgardo (2002). "Puerto Rico y el Caribe”, ed. cit., p. 19.
} 
Esta experiencia de la discontinuidad que impuso el fenómeno de la migración masiva aludida en la cita promueve repensar la puertorriqueñidad en otros términos. Es a partir de esta fisura donde encontramos un punto de encuentro entre los autores centrales tratados en la tesis, Rodríguez Juliá y Ramos Otero. Desde propuestas estético-literarias muy distintas ${ }^{1111}$ y divergentes entre sí los dos escritores son, para usar la frase de Arcadio Díaz Quiñones, "hijos del vasto movimiento político y social iniciado en los años cuarenta por el Partido Popular Democrático"1112; sus historias vitales y textuales están atravesadas social y culturalmente por la utopía populista promovida por Luis Muñoz Marín, aunque también ambos comparten el rol de testigos desencantados de su rotundo fracaso ${ }^{1113}$. En la imagen de un país fragmentado y disperso se entrecruzan las miradas contrautópicas que atraviesan la literatura de ambos autores. Mientras uno escribe plantado en su isla de Puerto Rico, el otro, en cambio, lo hace desde "la otra isla", Nueva York. Rodríguez Juliá se remonta a la trata esclavista y a la sociedad colonial de la isla en sus ficciones dieciochescas, para propiciar una memoria alterna sobre la fundación del imaginario nacional puertorriqueño. Sus orígenes, como el espacio representado en "El velorio" de Oller, se cimientan sobre una profunda heterotopía social y étnica que continua y estalla en los "dilemas de la puertorriqueñidad" de sus crónicas del presente. En los cuentos de Ramos Otero la presencia del sujeto migrante puertorriqueño encarna el

${ }^{1111}$ Se trata de dos autores cuyas proyectos escriturarios son muy diferentes entre sí, lo cual se advierte, por ejemplo, en los géneros que ambos transitan y en la figuración autorial que se desprende de sus textos. La producción literaria de Ramos Otero se manifiesta particularmente en formas relativamente breves, sus cuentos y poemas, cuyas fronteras, como vimos, muchas veces dispersa y mezcla. Sus relatos promueven una ruptura de la linealidad narrativa, puesto que plantean la complejidad de cómo pensar y escribir una historia, rehuyendo las nociones de totalidad, transparencia, corrección lingüística y apelando a nuevas formas de la subjetividad como las que encarnan las figuras del migrante, del homosexual, del que padece SIDA, del "cuentero". Si bien la producción de Rodríguez Juliá se mueve en géneros que suelen ser pensados como totalizantes -novela, ensayo-, la elección de una forma como la crónica y el modo en que esta interviene significativamente en sus novelas, conduce asimismo a pensar en la preocupación del escritor por conformar nuevos modos de expresión, de lo cuales da cuenta a su vez la particular vinculación que establece en gran parte de sus obras entre imagen y escritura. No obstante y como señalamos a través del análisis específico de sus textos, a pesar de las diferentes máscaras narrativas que esgrime la figura del narrador, hay un peso autoral fuerte aunque éste no revele estrictamente a un sujeto unitario, sino paradójico y dilemático respecto de su función ideológica al interior de la obra. En los cuentos de Ramos Otero el sujeto y asimismo la figura del autor están constantemente sometidos a la amenaza de su disolución, que en su forma más radical se revela en la presencia obsesiva de la muerte. La actividad de contar parece vislumbrarse como la única alternativa que refugia al yo de la intemperie, de la soledad, del solipsismo, del exilio.

${ }^{1112}$ Díaz Quiñones, Arcadio (1993). "La vida inclemente”, en: La memoria rota, Río Piedras, Huracán, p. 19.

${ }^{1113}$ Recordemos que Manuel Ramos Otero nació en 1948 y Edgardo Rodríguez Juliá en 1946. Al respecto vale la pena citar el siguiente texto autobiográfico de Rodríguez Juliá: "Nuestra generación, la de 1946, nació hacia la consolidación de tiempos heroicos, fuimos convencidos de futuros sin falla, nos cautivó la edificación de la utopía latinoamericana y caribeña, la certeza de las esperanzas y la justicia de las promesas. Si la generación comprometida del año 1926 vivió en el año 1989 la edad del desconsuelo ideológico, porque su proyecto ideológico y social -vencedor del fascismo- llegó a una especie de callejón sin salida, mi generación ha vivido el desencanto de las postutopía en tono menor, pero quizás más dramático, es decir, las ilusiones se encandilaron con mayor riesgo, porque llegamos a la juventud justo cuando se empeñaba la palabra en la promesa redentora de un continente." Véase Rodríguez Juliá, Edgardo (1994). "Mapa de una pasión literaria", en: Estudios. Revista de Investigaciones Literarias, año 2, No 4, Caracas, jul.-dic., p. 5. 
asedio constante de su identidad desde su experiencia liminal de transterrado, sumido en un sentimiento de desarraigo y dramático contrapunto entre "el presente vivido distópicamente y la utopía de la patria imaginada."1114

En las ficciones de la puertorriqueñidad que ambos construyen hay ciertas imágenes que se aproximan conceptualmente, a pesar de sus ineludibles diferencias. Pensemos en la figura del Niño Avilés, metáfora monstruosa del pueblo puertorriqueño cautivo, emblema de una institución híbrida como el Estado Libre Asociado. Si su cuerpo entraña una imagen por lo menos contrahecha del país, sus limitaciones físicas connotan el encierro, el aislamiento, la insularidad negativa. Significaciones similares se traman en torno a la isla de Molokai en "Vivir del cuento" de Manuel Ramos Otero. Este espacio aislado y aislante de Hawai destinado a la trágica exclusión de los leprosos en el relato de Ramos Otero, ¿no representa acaso una radical erosión de la "utopía de la patria imaginada" por el sujeto migrante?

La Nueva Venecia, utopía cimarrona, espacio proyectado pero nunca concretado en las novelas de Rodríguez Juliá que recrean el siglo XVIII, es asimismo imaginada como una isla. Connota una historia alterna de Puerto Rico pero que se revela sin embargo destinada al fracaso, al olvido, a devenir "una pesadilla de la Historia." En tanto estas ficciones recuperan parte de la historia silenciada del país -la trata, las rebeliones de los esclavos, el cimarronaje-, en un relato como "La otra isla de Puerto Rico" de Ramos Otero emergen también posibilidades abortadas de rebelión, a cargo de otro importante sector marginado de la Historia concebida con mayúsculas: la población nativa de Puerto Rico. Así el nombre originario de la Isla, la voz taína Oubao-Moin, la Isla de Sangre, proyecta la utopía de la libertad e independencia territorial pero que en el presente del cuento, como la Nueva Venecia de La noche oscura del Niño Avilés, ha fracasado.

Los dos escritores cuestionan de una u otra manera el legado heredado del nacionalismo cultural vigente entre los años treinta y cincuenta en Puerto Rico, particularmente mediante el asedio de la metáfora preferida de entonces, la gran familia puertorriqueña como emblema de la nación, homologación que está en la base ideológica del populismo ${ }^{1115}$. En las crónicas de actualidad de Rodríguez Juliá asistimos a la dispersión de la metáfora familiar, como una imagen insuficiente e incapaz de dar cuenta del cuerpo social heterogéneo y desgarrado del Puerto Rico contemporáneo, tropo cuya erosión más significativa se advierte en Puertorriqueños (Álbum de la Sagrada Familia puertorriqueña a partir de 1898). Si en este autor se observa asimismo un acercamiento paradójico y ambivalente respecto de ciertas figuras simbólicas parentales (Luis Muñoz Marín resulta el ejemplo más interesante), la imagen del pater familiae estalla radicalmente en las ficciones de Ramos Otero. En sus cuentos notamos el predominio de la matrilinealidad o bien la posibilidad de erigir una suerte de familia alterna y sustituta de la tradicional, cimentada sobre la base de otras redes afectivas, como las que se nuclean a través de la amistad, remedo del hogar perdido del sujeto migrante para quien "la promesa del regreso a casa se vuelve imposible." ${ }^{1116}$

Presente distópico del migrante en los relatos de Ramos Otero, heterotopía compleja en las ficciones del pasado y del presente de Rodríguez Juliá, patria imaginada como utopía fracasada en ambos escritores. Si regresamos a las páginas del ensayo antes citado "Puerto Rico y el Caribe" el autor se detiene en una línea del poeta Derek Walcott. Se trata de un verso que quiero transcribir aquí porque

\footnotetext{
1114 Términos utilizados por Abril Trigo para dar cuenta del dramático entrelugar del sujeto migrante. Véase Trigo, Abril (2003). "Migraciones", en: Memorias migrantes. Testimonios y ensayos sobre la diáspora uruguaya, Rosario, Beatriz Viterbo, p.49.

${ }^{1115}$ Véanse las consideraciones al respecto trabajadas en el capítulo II.

${ }^{1116}$ Trigo, Abril (2003). "Migraciones", ed. cit., p. 57.
} 
creo percibir en su forma breve y profundamente significativa una condensación poética de la patria perdida y del desarraigo que alcanzan a uno y otro escritor:

There is nowhere to go. You'd better go ${ }^{1117}$

${ }^{1117}$ Citado por Edgardo Rodríguez Juliá en "Puerto Rico y el Caribe", ed. cit., p. 17. Arriesgo una limitada traducción: "No hay lugar donde ir. Entonces ve." 


\section{BIBLIOGRAFÍA}

\section{- Obras de Edgardo Rodríguez Juliá Novelas}

La renuncia del héroe Baltasar, Río Piedras, Editorial Antillana, 1974 (segunda edición 1986, Editorial Cultural)

La noche oscura del Niño Avilés, Río Piedras, Huracán, 1984 (segunda edición 1991, Editorial de la Universidad de Puerto Rico; tercera edición, 2002, Caracas, Biblioteca Ayacucho)

El camino de Yyaloide, Caracas, Grijalbo, 1994.

Sol de medianoche, Caracas, Grijalbo, 1995.

Cartagena, Madrid-Río Piedras, Editorial Plaza Mayor, 1997.

Mujer con sombrero panamá, Madrid, Mondadori, 2004.

Crónicas

Las tribulaciones de Jonás, Río Piedras, Huracán, 1981.

El entierro de Cortijo, Río Piedras, Huracán, 1983.

Una noche con Iris Chacón, Río Piedras, Antillana, 1986.

Puertorriqueños (Álbum de la Sagrada Familia Puertorriqueña a partir de 1898), Madrid-Río Piedras, Editorial Plaza Mayor, 1988.

El cruce de la Bahía de Guánica, Río Piedras, Editorial Cultural, 1989.

Peloteros, Río Piedras, Editorial de la Universidad de Puerto Rico, 1995.

Elogio de la fonda, Madrid, Playor, 2001.

Caribeños, San Juan, Instituto de Cultura Puertorriqueña, 2002.

Ensayos

Campeche o los diablejos de la melancolía, San Juan, Instituto de Cultura Puertorriqueña, 1986.

Cámara secreta (Ensayos apócrifos y relatos verosímiles de la fotografía erótica), Caracas, Monte Ávila, 1994.

Mapa de una pasión literaria, Río Piedras, Editorial de la Universidad de Puerto Rico, 2003. 
San Juan, ciudad soñada, San Juan, Editorial Tal Cual, 2005.

\section{- Bibliografía crítica sobre Edgardo Rodríguez Juliá (selección)}

Aira, César (1997). "La noche oscura del Niño Avilés (Autodevoraciones)", en: Nómada, núm. 3, pp. 30-32.

Amar Sánchez, Ana María (1995). El relato de los hechos, Rosario, Beatriz Viterbo, pp. 47-54.

Barajas, María Josefina (1998). Imaginarios de una cotidianidad (Puerto Rico en sus crónicas periodístico-literarias de los años 80), Caracas, La Casa de Bello.

Barradas, Efraín (1976). Reseña crítica a La renuncia del héroe Baltasar, en: Sin Nombre, vol. VII, Nro. 1, julio-septiembre, pp. 69-71.

Benítez Rojo, Antonio (1996). "Niño Avilés, o la libido de la historia" (capítulo 8), en: La isla que se repite. El Caribe y la perspectiva posmoderna, ed. cit., pp. 277-304, publicado anteriormente como artículo en La Torre (Nueva época), nro. 12,1898 , pp. 587-608.

Caballero, María (1999). "Rodríguez Juliá: una ojeada sobre Puerto Rico entre la burla y la compasión", en: Ficciones isleñas. Estudios sobre la literatura de Puerto Rico, Río Piedras, Editorial de la Universidad de Puerto Rico, pp. 129164.

Daroqui, María Julia (1993). "Pesadillas, relecturas y miradas oblicuas de la historia", en: Las pesadillas de la historia en la narrativa puertorriqueña, Caracas, Monte Ávila y Centro de Estudios Latinoamericanos Rómulo Gallegos, pp. 87-104.

Daroqui, María Julia. "Formular la 'verdadera historia' " (Entrevista al escritor puertorriqueño Edgardo Rodríguez Juliá), en "Papel literario", suplemento del periódico El Nacional, Caracas, 22 de julio de 1990.

Duchesne Winter, Juan (editor-compilador, 1992). Las tribulaciones de Juliá, San Juan, Editorial del Instituto de Cultura Puertorriqueña. (Contiene los siguientes trabajos: Duchesne Winter, Juan. "Del prólogo al pórtico: criticar un texto llamado Rodríguez Juliá", pp. 13-29; Ríos Ávila, Rubén. "La invención de un autor: escritura y poder", pp. 33-62; Rodríguez Castro, María Elena. "Memorias conjeturales: las crónicas mortuorias", pp. 65-92; Gelpí, Juan. "Las tribulaciones de Jonás ante el paternalismo literario", pp. 95-115; Sotomayor, Áurea María. "Escribir la mirada", pp. 119-167).

Duchesne Winter, Juan (1992)."Multitud y tradición en El entierro de Cortijo", Narraciones de testimonio en América Latina, Río Piedras, Editorial de la Universidad de Puerto Rico, pp. 181-208. 
García-Calderón, Myrna (1997). "El espacio intersticial y transitorio de la nueva crónica puertorriqueña", en: Revista de Crítica Literaria Latinoamericana, Año XXIII, No. 45, Lima-Berkeley, pp. 293-306.

González Rodríguez, Eduardo (2000). "Dos posesas (escritura e historia) en las obras de Edgardo Rodríguez Juliá", Revista de Estudios Hispánicos, Universidad de Puerto Rico, vol. XXVII, Núm. 2, pp. 299-318.

González, Aníbal (1986). "Una alegoría de la cultura puertorriqueña: La noche oscura del Niño Avilés, de Edgardo Rodríguez Juliá", Revista Iberoamericana, núms. 135-136, abril-septiembre, pp. 583-590.

González, Aníbal (1992). "Imágenes de la conquista y la colonia en la novelística hispanoamericana contemporánea: notas para una interpretación", Revista de Estudios Hispánicos, año XIX, 1992, pp. 431-448.

González, Rubén (1988). "La noche oscura del Niño Avilés", en: Plural, nro. 204, pp. 96-102.

González, Rubén (1991). "Las tribulaciones de Jonás: la historia detrás de la historia", en: La Torre, revista de la Universidad de Puerto Rico, año V, Núm. 18, abril-junio, pp. 133-155.

Irizarry, Estelle (1989). "Metahistoria y novela: La renuncia del héroe Baltasar de Edgardo Rodríguez Juliá", La Torre, Revista de la Universidad de Puerto Rico, año III, núm. 9, enero-marzo, pp. 55-67.

Ortega, Julio (1991). "1. Crónica de entierros, ficción de nacimientos", entrevista a Edgardo Rodríguez Juliá, en: Reapropiaciones (cultura y nueva escritura en Puerto Rico), Río Piedras, Editorial de la Universidad de Puerto Rico, pp. 123-162.

Ortega, Julio (1991). "Dos variaciones barrocas: Sarduy y Rodríguez Juliá", en: Reapropiaciones (Cultura y nueva escritura en Puerto Rico), ed. cit., pp. 63-65.

Paravisini, Lizabeth (1984). "La renuncia del héroe Baltasar: parodia, mito e historia”, Plural, núm. 4, pp. 101-108.

Pérez-Ortiz, Melanie (2000). "Del voyeur al mirón: la palabra es la técnica objetivante en los textos de E. Rodríguez Juliá", Revista Iberoamericana, vol. LXVI, núm. 192, pp. 511-532.

Ruiz Cumbia, Israel (1999). "Edgardo Rodríguez Juliá y las paradojas de la (autor)idad narrativa", La Torre, año IV, número 12, abril-junio, pp. 449-468.

Salgado, César (1999). "Archivos encontrados: Edgardo Rodríguez Juliá o los diablejos de la historiografía criolla”, Cuadernos Americanos, núm. 73, pp. 153203. 
Santini, Carmen Hilda (2000). "La renuncia del héroe Baltasar y la ficcionalización de la historia", en: Revista de Estudios Hispánicos, Universidad de Puerto Rico, vol. XXVII, Núm. 2, pp. 319-331.

Smith, Sara Ann (1995). "Violencia y heterotopía en La renuncia del héroe Baltasar", La Torre, Revista de la Universidad de Puerto Rico, año IX, Núm. 33, enero-marzo, pp. 71-88.

Socorro, Milagros (1994)."El género de la crónica y la crónica de lo venéreo. Notas en torno a Una noche con Iris Chacón de Edgardo Rodríguez Juliá", Estudios. Revista de investigaciones literarias, número especial dedicado a literatura del Caribe, Año 2, nro. 4, pp. 31-42.

Zanetti, Susana (1994). "Las historias fingidas de La noche oscura del Niño Avilés de Edgardo Rodríguez Juliá", en: Estudios. Revista de Investigaciones Literarias, año 2, No. 4, Caracas, jul.-dic., pp. 11-29.

\section{- Obras de Manuel Ramos Otero}

\section{Cuentos}

Concierto de metal para un recuerdo y otras orgías de soledad, San Juan, Editorial Cultural, 1971.

El cuento de la mujer del mar, Río Piedras, Huracán, 1979.

Página en blanco y staccato, Playor, Madrid, 1987.

Cuentos de buena tinta, San Juan, Instituto de Cultura Puertorriqueña, 1992.

Novela

La novelabingo, Libro Viaje, Nueva York, 1976.

\section{Libros de poemas}

El libro de la muerte, Río Piedras/New Jersey, Cultural/Waterfront Press, 1985. Invitación al polvo, Madrid-Río Piedras, Plaza Mayor, 1991.

\section{- Bibliografía crítica sobre Manuel Ramos Otero (selección)}

AA.VV. (1991), Homenaje a Manuel Ramos Otero, Río Piedrtas, Universidad de Puerto Rico.

Arroyo, Josseana (2001)."Exilio y tránsitos entre la Norzagaray y Christopher Street: acercamientos a una poética del deseo homosexual en Manuel Ramos Otero", Revista Iberoamericana, vol. LXVII, núms.. 194.195, enero-junio, pp. 31-54. 
Arroyo, Jossiana (1994). "Manuel Ramos Otero: Las narrativas del cuerpo más allá de Insularismo", Revista de Estudios Hispánicos, Facultad de Humanidades de la Universidad de Puerto Rico, XXI, pp. 303-324.

Barradas, Efraín (1982). "Reseña de El cuento de la Mujer del Mar de Manuel Ramos Otero", Revista Iberoamericana, vol. XLVIII, núms.. 117-118, pp. 427428.

Barradas, Efraín (1993). “'Epitafios': el canon y la canonización de Manuel Ramos Otero", revista La Torre (Nueva época), 7.27-28, pp. 319-338.

Cañas, Dionisio (1994). "La mirada marginal de Manuel Ramos Otero", El poeta y la ciudad: Nueva York y los escritores hispánicos, Madrid, Cátedra, pp. 114142.

Cortés, Jasón (2002). "Buscando al otro. Ética y alteridad en 'Página en blanco y staccato' de Manuel Ramos Otero", Revista Iberoamericana, vol. LXVIII, Núm. 198, enero-marzo, pp. 165-175.

Costa, Marithelma. "Entrevista", Hispamérica, Año XX, Núm. 59, 1991, pp. 5967.

Cruz- Malavé, Arnaldo (1993). "Para virar al macho: la autobiografía como subversión en la cuentística de Manuel Ramos Otero", Revista Iberoamericana LXIX, núms. 163-164, enero-junio, pp. 239-263.

Cruz-Malavé, Arnaldo (1998). "What a Tangled Web! Masculinidad, abyección y la fundación de la literaura puertorriqueña en los Estados Unidos", en: Daniel Balderston y Donna Guy (comp..), Sexo y sexualidades en América Latina, Buenos Aires, Paidós, pp. 335-355.

García-Castro,-Ramón (1996). "El cuerpo masculino visto por ojos latinoamericanos: Santa materia (1954) de Benjamin Subercaseaux y 'Vida ejemplar del esclavo y el señor' (1983) de Manuel Ramos Otero", Revista Iberoamericana, vol.VXII, núm.174, pp. 149-61.

Gelpí, Juan (1990). "Reseña de Página en blanco y staccato de Manuel Ramos Otero", La Torre, Revista de la Universidad de Puerto Rico, año IV, núm. 14, abril-junio, pp. 245-250.

Gelpí, Juan (2000). "Conversación con Manuel Ramos Otero ( Nueva York, 3 de mayo de 1980)", Revista de Estudios Hispánicos, Universidad de Puerto Rico, vol. XXVII, núm. 2, pp. 401-410.

Gelpí, Juan. (1993). "La escritura transeúnte de Manuel Ramos Otero", en: Literatura y paternalismo en Puerto Rico, San Juan, Editorial de la Universidad de Puerto Rico, pp. 137-153.

Hernández, Wilfredo (2000). "Homosexualidad, rebelión sexual y tradición literaria en la poesía de Manuel Ramos Otero", en: Balderston, Daniel (editor), Sexualidad y nación, Pittsburgh, Instituto de Literatura Iberoamericana, pp. 225241.

Jan Martínez. "Manuel Ramos Otero o los espejuelos de Mahoma" (Entrevista), El Mundo, 10 de noviembre de 1985, pp. 52-53. 
Montero, Oscar (1980). "Reseña de El cuento de la Mujer del Mar de Manuel Ramos Otero", Sin Nombre, vol. XI, año 3, pp. 65-69.

Ramos Collado, Liliana (2000). "Cervantes en el mamutcandungo: Manuel Ramos Otero lee El Quijote", Revista de Estudios Hispánicos, Universidad de Puerto Rico, vol. XXVII, núm. 2, pp. 241-264.

Ríos Ávila, Rubén (1997). "Caribbean Dislocations: Arenas and Ramos Otero in New York", en: Hispanisms and Homosexualities, Sylvia Molloy y Robert Mc Kee Irwin, eds., Durham, Duke University Press, pp. 101-122.

Sotomayor, Áurea María (2004). "Genealogías o el suave desplazamiento de los orígenes en la narrativa de Manuel Ramos Otero", en: Femina Faber. Letras, música, ley, San Juan, Ediciones Callejón, pp. 279-306.

Torres, Daniel (2000). "El 'Hombre de papel' en Invitación al polvo de Manuel Ramos Otero", Chasqui, Revista de Literatura Latinoamericana, 29, año I, pp. 33-49.

- CONTEXTOS LITERARIOS, HISTORICOS, POLITICOS Y CULTURALES DEL CARIBE EN GENERAL Y DE PUERTO RICO EN PARTICULAR (Selección)

AA.VV. "Homenaje a René Marqués", número especial de la revista Sin Nombre, San Juan, Puerto Rico, vol. X No. 3, octubre-diciembre de 1979. Se cita el texto de la directora de la revista, Nilita Vientós Gastón "René Marqués", pp. 9 y 10. Este volumen recoge trabajos de escritores como Luis Rafael Sánchez y trabajos de críticos como María Teresa Babín, Arcadio Díaz Quiñones, Margot Arce de Vázquez, entre otros.

AA.VV. Revista de Estudios Hispánicos, Universidad de Puerto Rico, vol. XXVII, Núm. 1, 2000, donde se recogen varios trabajos críticos sobre las polémicas lingüísticas en Puerto Rico.

Algarín, Miguel y Piñero, Miguel (1975, editores). Nuyorican Poetry, New York, William Morrow \& Co., Inc.

Alvarez Nazario, Manuel (1982). Origen y desarrollo del español en Puerto Rico (siglos XVI y XVII), San Juan, Editorial de la Universidad de Puerto Rico.

Álvarez-Curbelo, Silvia y Rodríguez Castro, María Elena (editoras, 1993), Del nacionalismo al populismo: cultura y política en Puerto Rico, Río Piedras, Ediciones Huracán.

Andreu Iglesias, César (editor, 2002). Memorias de Bernardo Vega: contribución a

la historia de la comunidad puertorriqueña en Nueva York, 6ta. edición, Río Piedras, Ediciones Huracán. 
Andrews, Kenneth (1978). The Spanish Caribbean: Trade and Plunder, New Haven, Conn, Yale University Press.

Arciniegas, Germán (1959). Biografía del Caribe, Buenos Aires, Sudamericana, séptima edición. (Primera edición 1945)

Baralt, Guillermo (1982). Esclavos rebeldes: conspiraciones y sublevaciones de esclavos en Puerto Rico (1795-1873), Río Piedras, Ediciones Huracán.

Barbosa de Rosario, Pilar (1975). El ensayo de la autonomía en Puerto Rico 1897-1898, San Juan, Imprenta Venezuela.

Bastide, Roger (1971). African Civilizations in the New World, New York, Harper and Row.

Beauchamp, José J. (1976). Imagen del puertorriqueño en las novelas, Río Piedras, Editorial Universitaria.

Beauchamp, José J. (1981). "La novela puetorriqueña: una estructura de resistencia, ruptura y recuperación" en Casa de las Américas, No 124, enerofebrero.

Benítez Rojo, Antonio (1989). La isla que se repite: el Caribe y la perspectiva posmoderna, Hannover, Ediciones del Norte.

Blanco, Tomás (1981). Prontuario histórico de Puerto Rico, prólogo de Margot Arce de Vázquez, Río Piedras, Ediciones Huracán, 1981.

Blanco, Tomás (1985). El prejuicio racial en Puerto Rico, edición de Arcadio Díaz Quiñones, Río Piedras, Ediciones Huracán.

Casa de las Américas número 36-37, año 1966, recoge variados ensayos sobre la identidad cultural y la historia del Caribe.

Castro, María de los Angeles, y otros (1984). Los primeros pasos: una bibliografía para empezar a investigar la historia de Puerto Rico, Río Piedras, Facultad de Humanidades.

Cepero Bonilla, Raúl (1971). Azúcar y abolición, La Habana, Editorial de las Ciencias Sociales.

Cubano Iguina, Astrid (1990). El hilo en el laberinto: claves de la lucha política en Puerto Rico (siglo XIX), Río Piedras, Huracán.

Daroqui, María Julia. Las pesadillas de la historia en la narrativa puertorriqueña, Caracas, Monte Avila Editores y CELARG, 1990.

Daroqui, María Julia (1998) (Dis)locaciones. Narrativas híbridas del Caribe hispano, Valencia, Editorial de la Univesitat de Valencia. 
Depestre, René (1980). Bonjour et adieu à la négritude, París, Robert Laffont. Publicado también en La Habana, Cuadernos Casa de las Américas, Nro. 29, 1986.

Desnoes, Edmundo. "Cuba: caña y cultura", Casa de las Américas, 11.62 (1970), pp. 45-58.

Díaz Quiñones, Arcadio (1982). El almuerzo en la hierba (LLórens Torres, Palés Matos, René Marqués), Río Piedras, Ediciones Huracán.

Díaz Quiñones, Arcadio (1984). "Recordando el futuro imaginario: la escritura histórica de la decáda del treinta", Sin Nombre, San Juan, 14.3.

Díaz Quiñones, Arcadio (1993). La memoria rota, Río Piedras, Ediciones Huracán.

Díaz Quiñones, Arcadio (1997). "Isla de quimeras: Pedreira, Palés y Albizu", en: Revista de Crítica Literaria Latinoamericana, Año XXIII, Nro. 45, LimaBerkeley, 1er. semestre, pp. 229-246.

Díaz Quiñones, Arcadio (2000). El arte de bregar (ensayos), San Juan, Ediciones Callejón.

Fanon, Frantz (1952). Peau noire, masques blancs, París, Seuil.

Fernández Valledor, Roberto (2000). "La sociedad cubana y puertorriqueña de las décadas del veinte y treinta a través de su ensayística", en: Revista de Estudios Hispánicos, Río Piedras, Universidad de Puerto Rico, vol. XXVII, Núm. 2, pp. 39-49.

Figueiredo, Eurídice (1998). Construçao de identidades pós-coloniais na literatura antilhana, Niteroi, Editora Da Universidade Federal Fulmínense.

Flores, Juan (1979). Insularismo e ideología burguesa (Nueva lectura de A.S. Pedreira), Río Piedras, Ediciones Huracán, particularmente pp. 83-90.

Flores, Juan (1992). "Post-Insularismo: New Mappings of Puerto Rican Culture" en Anales del Caribe, Centro de Estudios del Caribe, Casa de las Américas, La Habana, vol. 12.

Flores, Juan (1997), "Memorias (en lenguas) rotas/Broken English Memories", en: Revista de Crítica Literaria Latinoamericana, Año XXIII, nro. 45, LimaBerkeley, 1er. Semestre; pp. 341-350.

García, Gervasio L. (1985). Historia crítica, historia sin coartadas: algunos problemas de la historia de Puerto Rico, Río Piedras, Ediciones Huracán.

García-Calderón, Myrna (1998). Lecturas desde el fragmento: escritura contemporánea e imaginario cultural en Puerto Rico, Berkeley, Latinoamericana Editores. 
Gelpí, Juan G. (1993). Literatura y paternalismo en Puerto Rico, San Juan, Editorial de la Universidad de Puerto Rico.

Gérard, Pierre Charles. El pensamiento sociopolítico moderno en el Caribe, UNAM, México, Fondo de Cultura Económica, 1982.

Glissant, Édouard (1990). Poétique de la relation, París, Gallimard.

Glissant, Édouard (1997). Le discours antillais, París, Éditions Gallimard (primera edición 1981).

Gómez Acevedo, L. y Ballesteros Gaibrois, M. (1978) Culturas indígenas de Puerto Rico, Río Piedras, Editorial Antillana.

González, José Luis (1987). El país de cuatro pisos y otros ensayos, 6a. ed., Río Piedras, Ediciones Huracán.

González, José Luis (1989). "Puerto Rico: una nueva mirada a un nuevo país", Nuevo Texto Crítico, Nro. 3, Año II, Primer semestre, pp. 59-69.

Hennesy, Alistair (ed., 1992) Intellectuals in the Twentieth-Century Caribbean/ Volume II, Unity in Variety: The Hispanic and Francophone Caribbean, London, Macmillan Caribbean, Warwick University's Caribbean Studies Series.

Hernández, Carmen Dolores (2000). "Emigración y Literatura", en: Revista de Estudios Hispánicos, Universidad de Puerto Rico, Vol. XXVII, Núm. 2, 2000.

Hulme, Peter (1986). Colonial Encounters: Europe and the Native Caribbean, 1492-1797, Londres, Methuen.

Klein, Herbert (1986). African Slavery in Latin America and the Caribbean, Ney York/Oxford, Oxford University Press.

Knight, Franklin (1978). The Caribbean: the Genesis of a Fragmented Nationalism, New York, Oxford University Press.

Lewis, Gordon (1983). Main Currents in Caribbean Thought, Baltimore, Johns Hopkins University Press.

Lienhard, Martin (1998). O mar e o mato. Histórias da escravidao (CongoAngola, Brasil, Caribe), Salvador, Universidade Federal da Bahía.

Maldonado Denis, Manuel (1969). Puerto Rico: una interpretación históricosocial, México, Siglo XXI Editores.

Marqués, René (1972). El puertorriqueño dócil. (Literatura y realidad psicológica), en: Ensayos 1953-1971, Río Piedras, Editorial Antillana, publicado originalmente en 1960.

Mathews, Thomas (1970). La política puertorriqueña y el Nuevo Trato, Río Piedras, Editorial Universitaria.

Méndez, José Luis (1982).Para una sociología de la literatura puertorriqueña, La Habana, Casa de las Américas. 
Méndez, José Luis. "La lucha cultural en Puerto Rico" en Casa de las Américas, No 123, enero-febrero de 1980.

Minc, Rose (editora, 1982). Literatures in Transition: The Many Voices of the Caribbean Area, Gaithersburg, Montclair State College \& Ediciones Hispamérica.

Mintz, Sidney W. and Price, Sally (Eds., 1985) Caribbean Contours, Baltimore, Johns Hopkins University Press.

Moreno Fraginals, Manuel (org., 1977). África en América, México, Siglo XXI.

Moreno Fraginals, Manuel (1983). La historia como arma y otros estudios sobre esclavos, ingenios y plantaciones, Barcelona, Editorial Crítica.

Moreno Fraginals, Manuel, Frank Moya Pons y Stanley L. Engerman (eds., 1985). Between Slavery and Free Labor: The Spanish-Speaking Caribbean en the Nineteenth Century, Baltimore and London, The Johns Hopkins University Press.

Navas Dávila, Gerardo (editor, 1980), Cambio y desarrollo en Puerto Rico: la trasformación ideológica del Partido Popular Democrático, Río Piedras, Editorial de la Universidad de Puerto Rico.

Nistal Moret, Benjamín (ed.) (1984). Esclavos prófugos y cimarrones: Puerto Rico, 1770-1870, San Juan, Editorial de la Universidad de Puerto Rico.

Ortega, Julio (1991). Reapropiaciones (Cultura y nueva escritura en Puerto Rico), Río Piedras, Editorial de la Universidad de Puerto Rico.

Ortiz, Fernando (1978). Contrapunteo cubano del tabaco y del azúcar, Caracas, Biblioteca Ayacucho. (Primera edición 1940).

Pedreira, Antonio S. (1970). Insularismo en: Obras de Antonio S. Pedreira, San Juan, Instituto de Cultura Puertorriqueña, p. 25 (editado originalmente en 1934).

Picó, Fernando (1979). Libertad y servidumbre en el Puerto Rico del siglo XIX, Río Piedras, Ediciones Huracán.

Picó, Fernando (1988). Historia general de Puerto Rico, Río Piedras, Ediciones Huracán, p. 209.

Pizarro, Ana (1985). "La noción de literatura latinoamericana y del Caribe como problema historiográfico", en: Pizarro, Ana (org.). La literatura latinoamericana como proceso, Buenos Aires, Centro Editor de América Latina, pp. 132-144.

Pizarro, Ana (comp.) (2002). El archipiélago de fronteras externas, Santiago, Editorial de la Universidad de Santiago de Chile, pp. 15-31.

Quintero Rivera, Ángel (1977). Conflictos de clase y política en Puerto Rico, Río Piedras, Ediciones Huracán. 
Quintero Rivera, Ángel (1988) Patricios y plebeyos: burgueses, hacendados, artesanos y obreros. Las relaciones de clase en el Puerto Rico de cambio de siglo, Río Piedras, Ediciones Huracán.

Quintero Rivera, Ángel (1988). Patricios y plebeyos: burgueses, hacendados, artesanos y obreros. Las relaciones de clase en el Puerto Rico de cambio de siglo, Río Piedras, Ediciones Huracán.

Quintero Rivera, Ángel G. (1998). Salsa, sabor y control. Sociología de la música tropical, México, Siglo XXI Editores.

Quintero Rivera, Ángel y García, Gervasio L. (1982). Desafío y solidaridad: breve historia del movimiento obrero puertorriqueño, Río Piedras, Ediciones Huracán.

Ramos Mattei, Andrés, (ed., 1982). Azúcar y esclavitud, Puerto Rico, Universidad de Puerto Rico.

Ramos Otero, Manuel (1991). "De la colonización a la culonización" (Ensayo), Cupey, Revista de la Universidad Metropolitana, Río Piedras, vol. VIII, pp. 6378.

Ramos, Julio (1996). Las paradojas de la letra, Caracas, eXcultura.

Rivera, Marcia (1992). "Ebullición del ser: los movimientos culturales puertorriqueños y la producción femenina en plástica, poesía y narrativa", ponencia leída en las I Jornadas de Arte, Literatura y Medios. Masculino/Femenino: las marcas del género, Facultad de Filosofía y Letras, UBA, 1992. (mimeo, gentileza de la autora)

Rodríguez Castro, María Elena (1987-1988). "Tradición y modernidad: el intelectual puertorriqueño ante la década del treinta", Río Piedras, Boletín del Centro de Investigaciones Históricas de la Universidad de Puerto Rico, nro. 3 , pp. 45-65.

Rodríguez Castro, María Elena,"Las casas del porvenir: nación y narración en el ensayo puertorriqueño", en: Revista Iberoamericana, números 163-64, enero-junio de 1993, pp. 33-54.

Rodríguez de Laguna, Asela (ed., 1985). Imágenes e identidades: el puertorriqueño en la literatura, Río Piedras, Edic. Huracán.

Rodríguez Vecchini, Hugo (1993). "Palés y Pedreira: la rumba y el rumbo de la historia", en: La Torre. Revista de la Universidad de puerto Rico, año VII, núms. 27-28, pp. 595-627.

Sánchez, Luis Rafael (1994). La guagua aérea, San Juan, Editorial Cultural.

Scarano, Francisco (1984).Sugar and Slavery in Puerto Rico, Madison, University of Wisconsin Press. 
Scarano, Francisco (1985). Inmigración y clases sociales en el Puerto Rico del siglo XIX, Río Piedras, Ediciones Huracán.

Scarano, Francisco (1993). Puerto Rico: cinco siglos de historia, San Juan, McGraw-Hill.

Silvestrini, Blanca G. y Luque de Sánchez, María Dolores (1987). Historia de Puerto Rico: trayectoria de un pueblo, San Juan, Cultural Puertorriqueña.

Sotomayor, Áurea María (1995). Hilo de Aracne. Literatura puertorriqueña hoy, Río Piedras, Editorial de la Universidad de Puerto Rico.

Sotomayor, Áurea María (2004). Femina Faber. Letras, música, ley, San Juan, Ediciones Callejón.

Williams, Eric. Capitalismo y esclavitud, La Habana, Editorial de Ciencias Sociales, 1975.

- NACION, NACIONALISMO, IDENTIDADES NACIONALES (selección)

Ahmad, Aijaz (1987). "Jameson's Rethoric of Otherness and the National Allegory", Social Text, No 17, vol. 6.

Anderson, Benedict. Comunidades imaginadas. Reflexiones sobre el origen y la difusión del nacionalismo, México, Fondo de Cultura Económica, 1993.

Berlin, Isaiah. (1983). "Nacionalismo: pasado olvidado y poder presente", en: Contra la corriente. Ensayos sobre historia de las ideas, México, FCE.

Bhabha, Homi (1990). Nation and Narration, Londres, Routeledge. -(2002). "Diseminación. El tiempo, el relato y los márgenes de la nación moderna", en: El lugar de la cultura, traducción de César Aira, Buenos Aires, Manantial, pp. 175-207.

Blaut, James (1987). The National Question: Decolonizing the Theory of Nationalism, London, Zed books.

Breuilly, John (1990). Nacionalismo y Estado, Barcelona, Pomares-Corredor.

Castillo, A., Muzzopappa, E., Salomone A., Urrejola, B. Y Zapata, C. (editoras, 2003). Nación, Estado y cultura en América Latina, Ediciones de la Facultad de Filosofía y Humanidades, Universidad de Chile.

Chabot, Jean Luc. (1986). Le nationalisme, París, PUF.

Chatterjee, Partha (1993). The Nation and its Fragments. Colonial and Poscolonial Histories, Princeton, Princeton University Press.

Dalmaroni, Miguel (coord., 1995) y otros, Literatura Argentina y Nacionalismo, Serie Estudios e Investigaciones No 24, Fac. de Humanidades y Cs. de la Educación, UNLP. 
Davis, Horace (1978). Towards a Marxist Theory of Nationalism, New YorkLondon, Monthly Review Press

Deane, S., Eagleton, T., Jameson, F. Y Said, E. (1990). Nationalism, Colonialism and Literature, Minneapolis, University of Minnesota Press.

Delannoi, Gil y Taguieff (1993). Teorías del nacionalismo, Barcelona, Paidós.

Fernández Bravo, Alvaro (2000, comp.). La invención de la nación. Lecturas de la identidad de Herder a Homi Bhabha, Buenos Aires, Manantial.

Geertz, Cliford (1992). La interpretación de las culturas, Barcelona, Gedisa.

Gellner, Ernest (1993). Cultura, Identidad y Política: el nacionalismo y los nuevos cambios políticos, Barcelona, Gedisa.

-(1995). Encuentros con el nacionalismo, Madrid, Alianza. -(1988). Naciones y nacionalismo, Madrid, Alianza Editorial.

Guerrero, Andrés de Blas (dir., 1999). Enciclopedia del nacionalismo, Madrid, Alianza.

Habermas, Jürgen (1989). Identidades nacionales y postnacionales, Madrid, Tecnos.

Hobsbawm, Eric J. (1983)."Introduction: Inventing Traditions"en Eric Hobsbawm and Térrence Ranger (eds.), The Invention of Traditions, cambridge University Press.

Editorial Crítica.

(1991). Naciones y nacionalismo desde 1870, Barcelona,

Kedourie, Elie. (1998) Nacionalismo, Madrid, Centro de Estudios Constitucionales.

Kohn, Hans (1994). Historia del nacionalismo, México, Fondo de Cultura Económica.

Ludmer, Josefina (1984). El género gauchesco. Un tratado sobre la patria, Buenos Aires, Sudamericana.

Munck, Ronaldo (1986). The difficult dialogue. Marxism and Nationalism, London, Zed Books.

Nairn, Tom (1979). Los nuevos nacionalismos en Europa, Barcelona, Península.

Ortega, Julio (1990). "Discurso crítico y formación nacional", en El discurso de la abundancia, Caracas, Monte Avila.

Palti, Elías (2002). La nación como problema. Los historiadores y la "cuestión nacional", Buenos Aires, Fondo de Cultura Económica. 
Recalde, José Ramón (1982). La construcción de las naciones, Madrid, Siglo $\mathrm{XXI}$.

Seton-Watson, Hugh (1977). Nations and States: An Inquiry into the Origins of Nations and the Politics of Nationalism, London, Methuen.

Smith, Anthony (1996). La identidad nacional, Madrid, Trama.

-(1976). Las teorías del nacionalismo, Madrid, Península.

Sommer, Doris (1991). Foundational Fictions: The Nacional Romances of Latin América, Berkeley, University of California Press.

Todorov, Tzvetan (1991). Nosotros y los otros: reflexión sobre la diversidad humana, México, Siglo XXI Editores.

\section{- Bibliografía general consultada}

Adorno, Theodor (1962). "El ensayo como forma", en Notas de literatura, Barcelona, Ariel (reproducido en Pensamiento de los Confines, nro. 1, segundo semestre de 1998, Buenos Aires, pp. 247-259).

Agustín de Hipona, San (1966). La ciudad de Dios, México, Porrúa.

Aínsa, Fernando (1999). La reconstrucción de la utopía, Buenos Aires, Ediciones del Sol.

Ainsa, Fernando (2004). "Construcción y demolición de los sistemas celebratorios de la historia en América Latina", en: Chibán, Alicia (Coordinadora). El archivo de la independencia y la ficción contemporánea, Salta, Universidad Nacional de Salta, pp. 9-16.

Arango, Ariel (1987). Las malas palabras, Buenos Aires, Legasa, $7^{a}$ edición.

Ariès, Philippe (2000). Morir en Occidente, Buenos Aires, Adriana Hidalgo editora.

Bachelard, Gastón (1992). La poética del espacio, Buenos Aires, FCE, 3ạ . edición.

Baczko, Bronislaw (1999).“Utopía”, en: Los imaginarios sociales. Memorias y esperanzas colectivas, Buenos Aires, Nueva Visión, pp.55-123.

Bajtín, Mijaíl M. (1974). La cultura popular en la Edad Media y el Renacimiento, Barcelona, Barral Editores.

Bajtín, Mikhail (1981). "Discourse in the Novel", en The dialogic imagination, Austin, University of Texas Press, pp. 259-422. 
Barthes, Roland (1977). "El mensaje fotográfico", en El análisis estructural, introducción y selección de Silvia Niccolini, Buenos Aires, CEAL, pp. 103-116.

Barthes, Roland (1982). Investigaciones retóricas I. La antigua retórica, Buenos Aires, Editorial Buenos Aires.

Barthes, Roland (1987). "El efecto de realidad", en: El susurro del lenguaje. Más allá de la palabra y la escritura, Buenos Aires, Paidós, pp. 179-187.

Barthes, Roland (1998). La cámara lúcida. Nota sobre la fotografía, Buenos Aires, Paidós, 5ta. edición.

Baudrillard, Jean (1993). El intercambio simbólico y la muerte, Caracas, Monte Ávila, 2a ${ }^{\mathrm{a}}$. edición.

Benjamín, Walter (1977)."Breve historia de la fotografía", Eco, t.xxxi/2 nro. 188, junio, p.155. Reproducido también en Benjamín, Walter (1989). Discursos interrumpidos I, Madrid, Taurus, pp. 61-83.

Bhabha, Homi (2002). El lugar de la cultura, Buenos Aires, Manantial.

Blanchot, Maurice (1992). El espacio literario, Apéndice 2, Buenos Aires, Paidós.

Blanchot, Maurice (1993). De Kafka a Kafka, México, Fondo de Cultura Económica.

Borges, Jorge Luis (1974). Obras completas, Buenos Aires, Emecé.

Bourdieu, Pierre (1978). Un art moyen -essai sur les usages sociaux de la photographie, París, Minuit.

Calvino, Italo (2002). Las ciudades invisibles, Madrid, Siruela, segunda edición.

Carpentier, Alejo (1974). Concierto barroco, México, Siglo XXI.

Carpentier, Alejo (1981). El reino de este mundo, en: Dos novelas, La Habana, Letras Cubanas.

Chambers, lain (1995). Migración, cultura, identidad, Buenos Aires, Amorrortu.

Chiampi, Irlemar (2000). Barroco y modernidad, México, Fondo de Cultura Económica, pp. 184-185.

Clifford, James (1992). "Travelling Cultures", en: Grossberg, Lawrence, Nelson, Cary y Treichler, Paula (eds.), Cultural Studies, Londres y Nueva York, Routledge.

Colombi, Beatriz (2004).“El triunfo de Calibán y el discurso latino", en: Viaje intelectual. Migraciones y desplazamientos en América Latina (1880-1915), Rosario, Beatriz Viterbo. 
Cornejo Polar, Antonio (1994). Escribir en el aire. Ensayo sobre la heterogeneidad socio-cultural en las literaturas andinas, Lima, Horizonte.

Cortázar, Julio (1997). "La isla a mediodía", en Todos los fuegos el fuego, Buenos Aires, Alfaguara.

De Certeau, Michel (1993). La escritura de la historia, México, Universidad Iberoamericana, 2da. edición.

De Diego, José Luis (1998). "La novela de aprendizaje en la Argentina" (primera parte), Orbis Tertius. Revista de Teoría y Crítica Literaria, Centro de Estudios de Teoría y Crítica Literaria, Facultad de Humanidades de la Universidad Nacional de La Plata, nro. 6, año III, pp. 15-40.

Derrida, Jacques (1997). Mal de archivo. Una impresión freudiana, Paco Vidarte trad., Trotta, Madrid.

Egido, Aurora (1990). "La hidra bocal. Sobre la palabra poética en el barroco.", en: Fronteras de la poesía en el barroco, Barcelona, Crítica.

Evan, David T. (1993). Sexual Citizenship. The Material Construcción of Sexualities, Londres, Routledge.

Foucault, Michel (1970). La arqueología del saber, Madrid, siglo XXI.

Freud, Sigmund (1972). Tótem y tabú y otras obras, en: Obras completas XIII, Madrid, Buenos Aires, Amorrortu, pp. 3-163.

Freud, Sigmund (1990). "Duelo y melancolía", en Obras completas, volumen 14 (1914-16), Buenos Aires, Amorrortu editores.

Freud, Sigmund (1995). Tres ensayos de teoría sexual (1901-1905), en : Obras completas, volumen VII, Buenos Aires, Amorrortu, octava reimpresión.

Freund, Gisèle (1976). La fotografía como documento social, Barcelona, Gustavo Gili.

Genette, Gerard (1989). Palimpsestos. La literatura en segundo grado, Madrid, Taurus.

González Echevarría, Roberto (1982). "El monstruo de una especie y otra", en: Co-textes, Montpellier, nro. 3, pp. 27-58.

González Echevarría, Roberto (2000). Mito y archivo. Una teoría de la narrativa latinoamericana, México, Fondo de Cultura Económica.

González Echevarría, Roberto (2001). La voz de los maestros. Escritura y autoridad en la literatura latinoamericana moderna, Madrid, Verbum.

González, Aníbal (1983). La crónica modernista hispanoamericana, Madrid, Ediciones José Porrúa Turanzas. 
Gramuglio, María Teresa (1992). "La construcción de la imagen", en: La escritura argentina, vol. Colectivo, Universidad Nacional del Litoral, Ediciones de La Cortada.

Grüner, Eduardo (2001). El sitio de la mirada. Secretos de la imagen y silencio del arte, Buenos Aires, Grupo Editorial Norma, 2001.

Gruzinski, Serge (1991). La colonización de lo imaginario. Sociedades indígenas y occidentalización en el México español. Siglos XVI-XVIII, México, FCE.

Halperín Donghi, Tulio (1988). Historia contemporánea de América Latina, Buenos Aires, Alianza Editorial, segunda edición.

Huyssen, Andreas (2002). En busca del futuro perdido. Cultura y memoria en tiempos de globalización, México, Fondo de Cultura Económica.

Jitrik, Noé (1993)."Rehabilitación de la parodia”, en: La parodia en la literatura latinoamericana, volumen colectivo coordinado por Roberto Ferro, Instituto de Literatura Hispanoamericana, Facultad de Filosofía y Letras de la Universidad de Buenos Aires, Serie Monográfica, p. 19.

Jitrik, Noé (2000). Los grados de la escritura, Buenos Aires, Manantial.

Kossoy, Boris (2001). Fotografía e historia, Buenos Aires, La Marca, Biblioteca de la mirada.

Kristeva, Julia (1997). Sol negro. Depresión y melancolía, Caracas, Monte Ávila Editores.

Lezama Lima, José (1988). "La curiosidad barroca", en: La expresión americana, Confluencias, La Habana, Letras Cubanas, pp. 229-246.

Ludmer, Josefina (1977)."Contar el cuento" en Onetti. Los procesos de construcción del relato, Buenos Aires, Sudamericana, pp. 143-185.

Marin, Louis (1994). "Une mise en signification de l'espace social: manifestation, cortège, défilé, procession”, en: De la représentation, París, Seuil-Gallimard, pp. 46-61.

Martín-Barbero, Jesús (1987). De los medios a las comunicaciones: comunicación, cultura y hegemonía, Barcelona, Ediciones Gustavo Gil.

Martín-Barbero, Jesús (2002). "Medios y cultura en el espacio latinoamericano", en: Iberoamericana, Francfort, Año II, Nueva época, junio, nro. 6, pp. 89-106.

Molloy, Sylvia (1994). "La política de la pose", en: Ludmer, Josefina (comp.). Las culturas de fin de siglo en América Latina, Rosario, Beatriz Viterbo, pp. 128-138.

Molloy, Sylvia (1996). Acto de presencia. La escritura autobiográfica en Hispanoamérica, México, Fondo de Cultura Económica. 
Molloy, Sylvia (1999). Las letras de Borges y otros ensayos, Rosario, Beatriz Viterbo.

Monsiváis, Carlos (1980). "Introducción", A ustedes les consta. Antología de la crónica en México, México, Ediciones Era, pp. 13-76.

Moraña, Mabel (ed., 2000). Nuevas perspectivas desde/sobre América Latina, Santiago de Chile, Cuarto Propio/Instituto Internacional de Literatura Iberoamericana.

Nora, Pierre (director y comp., 1998). Les lieux de mémoire, París, Gallimard.

Ortiz, Fernando (1975). Historia de una pelea cubana contra los demonios, La Habana, Editorial de Ciencias Sociales.

Pacheco, Carlos (2000). "Historiadores de papel: la metahistoria en la reciente ficción hispanoamericana", en: Canovas, Rodrigo y Mozven, Roberto (editores). Crisis, apocalipsis y utopías. Fines de siglo en la literatura latinoamericana, Santiago, Pontificia Universidad Católica.

Panesi, Jorge (2000). "Felisberto Hernández, un artista del hambre", en: Críticas, Buenos Aires, Norma, pp. 183-220.

Paz, Octavio (1991). Sor Juana Inés de la Cruz o las trampas de la fe, México, FCE.

Perlongher, Néstor (1997). "Avatares de los muchachos de la noche", en: Prosa plebeya. Ensayos 1980-1992, selección y prólogo de Christian Ferrer y Osvaldo Baigorria, Buenos Aires, Colihue.

Pizarro, Ana (organizadora, 1993). América Latina. Palabra, Literatura e Cultura, 3 volúmenes, Campinas, Editora Da Unicamp.

Pratt, Mary Louise (1997). Ojos imperiales. Literatura de viajes y transculturación (Quilmes, Universidad Nacional de Quilmes)

Prieto, Adolfo (1996). Los viajeros ingleses y la emergencia de la literatura argentina, Buenos Aires, Editorial Sudamericana.

Rama, Ángel (1984). La ciudad letrada, Montevideo, Arca, Fundación Ángel Rama.

Ramos, Julio (1989). Desencuentros de la modernidad en América Latina, México, FCE.

Rich, Adrianne (1976). Of Woman Born. Motherhood as Experience and Institution, Nueva York, W.W. Norton \& Company.

Rotker, Susana (1992). La invención de la crónica, Buenos Aires, Ediciones Letra Buena. 
Said, Edward (1985). Beginnings. Intention \& Method, Nueva York, Columbia University Press.

Said, Edward (1996), Cultura e imperialismo, Barcelona, Anagrama.

Sarduy, Severo (1987). Ensayos generales sobre el Barroco, México, FCE, 1987.

Schapochnik, Nelson (1998). "Cartòes-postais, álbuns de familia e ícones da intimidade", en: Novais, Fernando (coordinador general de la colección) y Sevcenko, Nicolau (organizador del volumen), República; da Belle Époque à Era do Rádio, História da vida privada no Brasil, vol. 3, pp. 424-512.

Schorske, Carl E. (1987). "La idea de la ciudad en el pensamiento europeo: de Voltaire a Spengler", separata de Punto de Vista nro. 30, año X, julio-oct., pp. iii-xix.

Sontag, Susan (1977). Sobre la fotografía, Buenos Aires, Sudamericana.

Sontag, Susan (1996). La enfermedad y sus metáforas y El sida y sus metáforas, Madrid, Taurus.

Todorov, Tzvetan, "Sinécdoques", en: VV.AA. (1982). Investigaciones retóricas II, Barcelona, Ediciones Buenos Aires, pp. 45-58.

Trigo, Abril (2003). "Migraciones", en: Memorias migrantes. Testimonios y ensayos sobre la diáspora uruguaya, Rosario, Beatriz Viterbo, pp. 37-62.

Walcott, Derek (1980). The Fortunate Traveller, Nueva York, Farrar \& Strauss.

Walcott, Derek (1990). Omeros, Londres, Faber and Faber. (Hay versión en castellano, corresponde a la traducción de Rivas, José Luis, Barcelona, Anagrama, 1994).

White, Hayden (1998). "La teoría de los tropos" de la "Introducción: la poética de la historia", en: Metahistoria. La imaginación histórica en la Europa del siglo $X I X$, Buenos Aires, Fondo de Cultura Económica.

Williams, Raymond (1977). The Long Revolution, Londres, Penguin. 